\title{
Formele en materiele rechtskracht : de kleren van de Keizer
}

Citation for published version (APA):

van der Linden, E. C. H. J. (1998). Formele en materiele rechtskracht : de kleren van de Keizer. [Doctoral Thesis, Maastricht University]. Sdu Uitgevers. https://doi.org/10.26481/dis.19981028el

Document status and date:

Published: 01/01/1998

DOI:

$10.26481 /$ dis. $19981028 \mathrm{el}$

Document Version:

Publisher's PDF, also known as Version of record

\section{Please check the document version of this publication:}

- A submitted manuscript is the version of the article upon submission and before peer-review. There can be important differences between the submitted version and the official published version of record.

People interested in the research are advised to contact the author for the final version of the publication, or visit the DOI to the publisher's website.

- The final author version and the galley proof are versions of the publication after peer review.

- The final published version features the final layout of the paper including the volume, issue and page numbers.

Link to publication

\footnotetext{
General rights rights.

- You may freely distribute the URL identifying the publication in the public portal. please follow below link for the End User Agreement:

www.umlib.nl/taverne-license

Take down policy

If you believe that this document breaches copyright please contact us at:

repository@maastrichtuniversity.nl

providing details and we will investigate your claim.
}

Copyright and moral rights for the publications made accessible in the public portal are retained by the authors and/or other copyright owners and it is a condition of accessing publications that users recognise and abide by the legal requirements associated with these

- Users may download and print one copy of any publication from the public portal for the purpose of private study or research.

- You may not further distribute the material or use it for any profit-making activity or commercial gain

If the publication is distributed under the terms of Article $25 \mathrm{fa}$ of the Dutch Copyright Act, indicated by the "Taverne" license above, 


\title{
Formele en materiële rechtskracht:
}

\author{
de kleren van de Keizer
}

\section{PROEFSCHRIFT}

ter verkrijging van de graad van doctor aan de Universiteit Maastricht, op gezag van de Rector Magnificus, Prof.dr. A.C. Nieuwenhuijzen Kruseman volgens het besluit van het College van Decanen, in het openbaar te verdedigen op woensdag 28 oktober 1998 om 16.00 uur

door

EVELINE CATHARINA HENRIËTTE JOHANNA VAN DER LINDEN 
Formele en materiële rechtskracht:

de kleren van de Keizer 
Promotor:

Prof.mr. A.Q.C. Tak

Beoordelingscommissie:

Prof.mr. F.A.M. Stroink (voorzitter)

Prof.mr. F.H. van der Burg (Rijkuniversiteit Leiden)

Prof.mr. N.H.M. Roos

Mr. H.J. Simon

Prof.mr. J,G. Steenbeek (Universiteit Utrecht)

1998 Sdu Uitgevers, Den Haag

Vormgeving: Andre Klijsen, villa $Y$.

Van deze studie is een handelsuitgave verschenen bij Sdu Uitgevers onder ISBN 9054091819 
Aan Elizabeth en Stan 


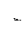




\section{Voorwoord}

Judith Herzberg schreef het prachtige gedicht dat mij er steeds aan herinnerde dat proefschriften schrijven een betrekkelijke aangelegenheid is, maar dat ik toch verder moest gaan:

Het duurt altijd langer dan je denkt ook als je denkt het zal wel langer duren dan ik denk dan durt het toch nog langer dan je denkt.

Het is altijd veel durder dan je denkt ook als je denkt het zal wel duurder worden dan ik denk dan is het toch nog duurder dan je denkt.

Het kost meer moeite dan je denkt ook als je denkt het zal veel meer moeite kosten dan ik denk dan kost het toch meer moeite dan je denkt.

Het dun veel korter dan je denkt ook als je denkt het zal wel korter duren dan ik denk dan duurl het toch nog korter dan je denkt.'

lk ben verder gegaan. En dit is mijn doel: klaarheid wil ik brengen. Helderheid is nodig in de discussie over een leerstuk dat $z 0^{\prime} n$ impact heeft op de mensen in hun samenleving.

Ja lezer, het is zo ver, u sloeg dit boek open. Voor u ligt het verslag van een studie naar de vraag: Wat is rechtskracht? Een spannende vraag en een duidelijke vraag, althans dat

1. Zie: Judith Herzberg, Liedje, in: Zoals, Amsterdam 1993, p. 27. 
dacht ik. Was rechtskracht niet immers een eigenschap van beschikkingen? Een structuurelement van het bestuursrecht? En hadden niet anderen voor mij hierover al veel beschrijvend werk gedaan? Het scheen zo. En inderdaad, anderen hadden het terrein al verkend. Ik vermoedde dat ik na afloop van de eerste twee maanden van het onderzoek wel een antwoord moest hebben op de vraag: Wat is rechtskracht?

Toch heeft deze vraag de afgelopen jaren een groot deel van mijn leven beheerst. De vraag bleek wel spannend maar allerminst duidelijk. Steeds meer bracht ik in werband met rechtskracht. Andere leerstukken werden resoluut geschrapt. $\mathrm{Al}$ was het terrein dan verkend, was dat niet steeds vanuit een andere optiek geschied? Was er geen gemeenschappelijk uitgangspunt te vinden bij al die verschillende visies? Het werd een onontwarbare knoop, weer later meende ik er toch een lijn in te zien.

Interessanter dan de vraag wat rechtskracht is, leek de vraag naar de achterliggende reden van het begrip rechtskracht. Waarom kent het bestuursrecht (binnen de publieke boom) rechtskracht? Wat is het nut ervan? Welke functie heeft het? Kan ermee worden gemanipuleerd? En zo ja, hoe wordt rechtskracht aangewend door de machthebber, door de wetgever, door het bestuursorgaan, door de rechter, door de burger? Eenmaal bij deze vragen aangekomen, besefte ik dat ik me al lang niet meer met louter een structuurelement van het bestuursrecht bezig hield, maar ook met filosofie en ethiek en de plaats van het recht daarin. De kracht van recht, leek rechtskracht nu te zijn. En daarmee kwam ik via de vraag. Waarom rechtskracht? weer terug bij de eerste vraag: Wat is rechtskracht?

Een boek schrijven is een bezigheid die je niet alleen kunt volbrengen. Van diegenen die mij daarbij hielpen will ik enkelen met name noemen.

De urenlange discussies en boekenkastsessies met mijn promotor waren steeds weer de plek waar uitdaging vorm kreeg. Als geen ander weet Twan je uit de tent te lokken door te discussiëren en je met je eigen ideeën te confronteren. Soms begeleidend, soms opponerend, soms ondersteunend en soms plagend, maar altijd prikkelend tot nader duiden van je stellingen. Het gewolg daarvan is soms grote verwarring, maar ook een zoektocht naar verdere analyse en langer doordenken van opvattingen. Die vertrouwdheid van discussie is $\mathrm{mij}$ in de loop der jaren steeds dierbaarder geworden.

Ook de leden van de beoordelingscommissie wil ik danken voor hun vruchtbare commentaar. Daar heb ik zeker mijn voordeel mee kunnen doen.

Een goed verstaander heeft maar een half woord nodig. De discussies met mijn kamergenoot waren er vaak en soms ook langdurig. Raymond en ik hebben ellkaar daardoor zeker gevormd. Dat beschouw ik als een groot goed.

Stan knipte de advertentie voor mijn aio-plaats uit en vroeg of dit iets voor mij was. Terwij! mijn oog over de advertentie ging, ervoer ik dat als een soort van déja wu. Was het toeval, of lag dit leerstuk op mij te wachten? Als altijd klaarstaande steun en toeverlaat moest mijn lief dat kennelijk al hebben geweten. Aan hem draag ik dit boek dan ook op. Ook moet ik mijn moeder noemen, wamt van haar heb ik mijn leeshonger meegekregen. Zij leerde mij niet al te gauw tevreden te zijn en de weg van mijn eigen hart te volgen in mijn zoektocht door de boeken. Liesje leerde mij lezen. Daarom draag ik dit boek ook aan haar op. 
Mijn paranymfen Marlies en Sabine zijn van die fijne vriendinnen waarbij je je altijd thuis voelt. Daardoor vormden ze het ideale stel dat zorg droeg voor dat ene duwtje in de rug. Hun vertrouwen achtte ik noodzakelijk om samen door al het gestress - of noem het feestelijkheden - heen te geraken. Zij lazen het manuscript, zij waren er en zijn er.

Wies Rayar wil ik danken voor de uitstekende vertaling van de samenvatting; het was zoals zij mij toevertrouwde - haar moeilijkste samenvatting ooit.

Nettie en Bregtje maken van de vakgroep een tweede thuis, zodat het werken alleen maar prettiger wordt. Bovendien makkten zij het manuscript op vakkundige wijze camera-ready en verzorgden zij de laatste tekstcorrectie, zodat het op tijd naar de uitgever kon.

Ten behoeve van het rechtsvergelijkende gedeelte van het onderzoek bezocht ik onder andere het Max Planck-Institut für ausländisches öffentliches Recint und Volkerrecht in Heidelberg. Meerdere bibliotheken in Duitsland werden door mij bezocht, maar tot de dames op de werkvloer van 'Max Planck' wil ik een speciaal woord van dank richten. Frau Gärttner, Frau Kraft, Frau Zimmler en Frau Zopotkova wisten met niet aflatende energie steeds weer nieuwe schatten voor mij uit het immense magazijn te toveren. Zij waren niet alleen zo hoffelijk om steeds weer vriendelijkheid, geduld en begrip op te brengen voor mijn leeshonger, maar stelden het zich met name ten doel de wetenschap en haar vele (daar aanwezige) beoefenaars in de ware zin des woords te ondersteunen.

Financiële begeleiding ontving ik van NWO, Nuffic, Stir/Swol, maar vooral van de Wetenschapscommissie van de UM.

Enfin, rechtskracht, daarover zal ik u onderhouden. De nadruk ligt daarbij op kracht, kracht van recht. De oorsprong van deze rechtskracht ligt in de kracht van civiele vonnissen. Rechtskracht is een beetje een merkwaardige kracht. Dat het hier een bijzondere kracht is, bewijzen wel de woorden van de substituut-officier van Justitie van het arrondissement Carabas:

'Er schuilt bepaaldelijk in het proza der civiele vonnissen een kracht, die aan menig advocaat en ook aan menig rechter ontsnapt.

Onze president heeft die kracht eenige jaren geleden op treffende wijze ondervonden. Zijn tweede dochterfreule Eulalie - was toen een meisje van zeventien jaar. Ze leed in hooge mate ann slapeloosheid; geen dokter kon haar genezen, gansche nachten lag ze wakende op haar bed. Het toeval wilde, dat de president eens cen concept-vonnis, dat hij juist had opgesteld, even overlas om te zien of alle zinnen goed liepen. Wiy las hardop: freule Eulalie zat dicht bij hem te borduren op de kanapee. Toen de president met voorlezen gerced was, zag hij zijn dochter languit op de kanapee liggen als een omgevallen sierpop, in diepen slap werzonken.

Sedert dien dag heeft de president cen tijdlang zijn dochter, als ze "s awonds te bed lag, een civiel wonnis voorgelezen. Hij las voor uit het Weekblad wan het Recht en thield op die wijze meteen de jurisprudentie bij."

Dat rechtskracht u voor slapeloosheid behoede!

2. Zie: G.W. vann Vierssen Trip, De gelaarsde kat, vertelling wan een merkwardige strafzatak, Ars Aequi Antiqua 1977 , p. 55. 


\section{Inhoud}

Voorwoord

vii

Inhoud

$x i$

Lijst van afkortingen

xviii

\section{Hoofdstuk 1}

Inleiding

\section{Hoofdstuk 2}

De bevoegdheid van de burgerlijke rechter en de invloed van het administratieve recht: de ontwikkeling tot Heesch-Van de Akker

2.1 Inleiding

$\begin{array}{ll}2.2 & \text { Bevoegdheid van de burgerlijke rechter }\end{array}$

$\begin{array}{ll}2.2 .1 & 19\end{array}$

2.2.2 Verklaring voor het niet ontwangen 22

2.2.3 Het niet ontvangen en de invoering van de administratieve rechtspraak 23

2.2.4 Bevoegdheid in het licht van de ontrafeling van feit, norm en gevolg

$\begin{array}{lll}2.3 & \text { Ontvankelijkheid bij de burgerlijke rechter } & 27\end{array}$

$\begin{array}{lll}2.3 .1 \quad \text { Inleiding } & 27\end{array}$

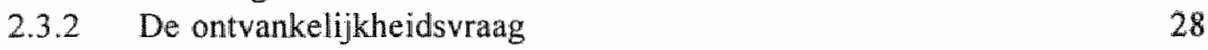

2.3.3 Ontvankelijkheid in het licht van de ontrafeling van feit en norm 33

2.4 Al dan niet zelfstandig toetsen door de burgerlijke rechter 35

$\begin{array}{lll}2.4 .1 \text { Inleiding } & 35\end{array}$

2.4.2 Heesch-Van de Akker 40

2.4.3 Toetsing in het licht van de ontrafeling van feit en norm 4.1

2.5 Tenslotte $\quad 42$

\section{Hoofdstuk 3}

Van rundveestal tot rechtsoverweging: formele rechtskracht in de zaak Heesch-Van de Akker

$3.1 \quad$ Inleiding 
3.2 Het "uitwegvergunningenstelsel', het stelsel van rechtsbescherming en Heesch-Van de Akker

3.2.1 Inleiding

3.2.2 Het stelsel van rechtsbescherming in relatie tot het "uitwegvergunningenstelsel"

3.2.3 Plaats van Heesch-Van de Akker ten opzichte van het leerstuk van het 'uitwegvergunningenstelsel'

3.2.4 Aanleiding van het arrest

3.2.5 Ontrafeling feit, norm en gevolg

3.3 De procespositie van Van de Akker in de loop van de procedure 50

$\begin{array}{ll}3.3 .1 & \text { Ontstaan van het geschil } \\ 3.3 .2 & 50\end{array}$

3.3.2 Ontrafeling feit, norm en gevolg 55

3.4 De oplossing van de Hoge Raad 55

$\begin{array}{ll}3.4 .1 & \text { De cassatiemiddelen } \\ 3.4 .2 & 55\end{array}$

$\begin{array}{ll}3.4 .2 & \text { Eerste conclusie } \\ 3.4 .3 & 56\end{array}$

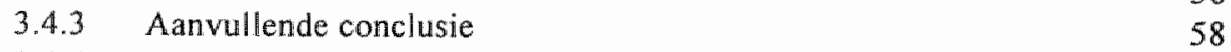

3.4.4 Het oordeel van de Hoge Raad 61

$\begin{array}{ll}3.4 .5 & \text { Ontrafeling feit, norm en gevolg } \\ \end{array}$

$\begin{array}{ll}3.5 & \text { Annotaties en andere reacties } \\ & 67\end{array}$

$\begin{array}{ll}\text { 3.5.1 Benamingen van formele rechtskracht } & 67\end{array}$

$\begin{array}{ll}3.5 .2 \text { Hoofdregel } & 67\end{array}$

$\begin{array}{ll}3.5 .3 \text { Uitzondering op de hoofdregel } & 69\end{array}$

$\begin{array}{ll}3.5 .4 & \text { Redenen voor uitzondering } \\ \end{array}$

$\begin{array}{lll}3.6 & \text { Tenslotte } & 73\end{array}$

\section{Hoofdstuk 4}

\section{Formelle rechtskracht in het publiekrecht}

4.1 Inleiding

4.2 Herkomst en oorsprong in Nederland

4.2.1 Indelen op formele gronden

4.2.2 Ontrafeling feit, norm en gevolg

4.2.3 Indelen op inhoudelijke gronden

4.2.4 Ontrufeling feit, norm en gevolg

4.3 Formele rechtskracht in een spanningsrelatie:

bestuursorgaan en administratieve rechter

4.3.1 Inleiding

4.3.2 Moment van rechtskrachtverknijging 84

4.3.3 Wachten totdat formele rechinging 86

4.3.4 Termijnen $\quad 89$

4.3.5 Formele rechtskracht doorbroken 89

4.3.6 Ontrafeling feit, norm en 91 
4.4 Rechtskracht en de strafrechter 97

4.4.1 Inleiding 97

4.4.2 Toepassing leer van de formele rechtskracht 100

4.4.3 De werhouding bestuursrecht-strafiecht en de Wet Mulder $\quad 102$

4.4.4 Nogmaals toepassing leer van de formele rechtskracht 106

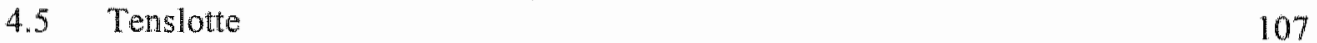

\section{Hoofdstuk 5}

De bevoegdheid van de burgerlijke rechter en de invloed wan het administratieve recht: de verdere ontwikkeling van het instrument van de formele rechtskracht

$5.1 \quad$ Inleiding

5.2 Uitzonderingen op de hoofdregel wan formele rechtskracht $\quad 110$ 5.2.1 Samenvattend $\$ 16$

5.3 De trendbreuk; overgang naar de publiekrechtelijke benadering? 117

$\begin{array}{lll}\text { 5.3.1 Inleiding } & 117\end{array}$

$\begin{array}{lll}5.3 .2 & \text { Ex tunc? } & 117\end{array}$

$\begin{array}{ll}\text { 5.3.3 Erga omnes? } & 124\end{array}$

5.4 Tenslotte

129

\section{Hoofdstuk 6}

Oorsprong, herkomst en evolutie van de begrippen formele en materiële rechtskracht in Duitsland

6.1 Inleiding

6.2 Herkomst en oorsprong in Duitsland

6.2.1 Herkomst en oorsprong van de indeling van rechtskracht in formele en materiële rechtskracht

6.2.2 Het verloop van de discussie

6.2.3 Resumé

6.3 De naoorlogse rechtskrachtdiscussie in Duitsland

6.3.1 Inleiding

139

6.3.2 'Bestandskraft' en 'Rechtskraft'

6.3.3 Conclusie

6.4 Huidige stand van zaken in Duitsland

6.4.1 Inleiding

6.4.2 Bondswetgeving

6.4.3 "Bestandskraft' in handboeken

6.4.4 "Bestandskraft" in tijdschriftartikelen

6.4.5 "Bestandskraft" in recente dissertaties 


\section{Hoofdstuk 7}

Waarvan is rechtskracht de eigenschap?

7.1 Inleiding

7.2 Wergelijkbare rechtskracht: het 'universele' element?

7.2.1 Inleiding

7.2.2 De verbindendheid is "universeel"

7.2.3 Ook het constitutieve is "universeel"

7.2.4 Voortvloeiend uit de rechtszekerheid

7.3 Onvergelijkbare rechtskracht: de verschillen

7.4 Rechtskracht en haar uiteenlopende dragers

7.4.1 Inleiding

7.4.2 De rechtskracht van een vonnis

7.4.3 Werking van uitspraken en vonnissen

7.4.4 De rechtskracht van een beschikking

7.4.5 Heeft een besluit van algemene strekking rechtskracht?

7.4.6 Heeft een wet ook 'Bestandskraft'?

7.4.7 "Bestandskraft" voor "verwaltungsrechtlicher Verträge"?

7.4.8 Rechtskracht van alle rechtshandelingen

7.4.9 Eigenschap van alle rechtsfeiten

\section{Hoofdstuk 8}

\section{Een rechtspositivistische analyse van rechtskracht}

8.1 Inleiding

8.2 Rechtskracht: gelding en/of werking?

8.2.1 Ontrafeling feit, norm en gevolg

8.2.2 Kelsen: gelding en werking, 'Sollen und Sein'

8.2.3 Kelsens rechtskracht: geldigheid als voorwaarde voor

8.3 Rechtskracht: duur van de gelding werkzaamheid (ofwel: werking door middel van gelding)

8.3.1 Inleiding

8.3.2 MerkJ: het rechtskrachtbegrip afgeleid uit het rechtsbegrip

8.3.3 Kelsens en Merkls invloed op Stellinga?

8.3.4 Kelsens en Merkls invloed op Vegting

8.4 Rechtskracht: gelding/geldigheid en werking/effectiviteit?

8.4.1 Inleiding

8.4.2 Kelsens en Merkls invloed op Steenbeek?

8.4.3 Ontrafeling feit, norm en gevolg.

8.4 .4 Betekenis van rechtskracht: gelding, werking, geldigheid
Tenslotte 


\section{Hoofdstuk 9}

De zelfproducerende formele rechtskracht; een analyse vanuit Teubners autopoietische benadering

9.1 Inleiding

9.2 De 'publiekrechtelijke wederkerige rechtsbetrekking' als reactie

9.2.1 Inleiding

9.2.2 Oorsprong van het begrip "publiekrechtelijke wederkerige rechtsbetrekking'

9.3 Een beschrijving van autopoiese

9.3.1 Autopoiese vloeit voort uit reflexief recht

9.3.2 Basisnoties

9.3.3 Autopoietische geslotenheid

9.3.4 Het recht als hypercyclus?

9.3.5 Beschrijvende en dogmatische autopoiese

9.4 De verhouding tussen het beschikkingsbegrip en rechtskracht

9.4.1 De verhouding tussen het beschikkingsbegrip en rechtskracht in het klassieke gedachtengoed

9.4.2 De traditionele verhouding tussen het beschikkingsbegrip en rechtskracht in de ogen van De Jong

9.4.3 De visie van Van Male

9.4.4 De verhouding tussen het beschikkingsbegrip en rechtskracht

9.4.5 Rechtszekerheid en rechtsbetrekking

9.5 De formele rechtskracht van beschikkingen vanuit autopoietisch

perspectief bezien in verschillende rechtsgebieden

9.5.1 Inleiding

9.5.2 Formele rechtskracht in het bestuursrecht

9.5.3 Formele rechtskracht als hypercyclus in het burgerlijke recht

9.5.4 Formele rechtskracht als Hyperzyklische Verknlipfung

$$
\text { bij de strafrechter }
$$

9.5.5 Conclusie: eigen aard van bestuursrecht, civiel recht en strafrecht

\subsection{Tenslotte}

\section{Hoofdstuk 10}

Rechtskracht als geldingswraagstuk; een analyse vanuit de transcendentale denkkritiek

10.1 Inleiding

10.2 Rechtskracht als elementair grondbegrip: rechtskracht is gelding 218

10.2.1 Inleiding

10.2.2 Betekenis rechtskracht

10.2.3 De formele kant van rechtskracht 
10.2.4 De materiele kant van rechtskracht, de rechtsbeginselen

10.2.5 Nieuw onderscheid formele en materiële rechtskracht

10.2.6 Betekenis formele en materiele rechtskracht

10.2.7 Verhouding formele en materiële rechtskracht

10.3 Rechtskracht aan de normzijde en aan de feitelijke zijde van

het rechtsaspect: ontrafeling feit en norm

10.4 Tenslotte

\section{Hoofdstuk 11}

Toetsing en de formele en de materiële rechtskracht van besluiten; een analyse vanuit het spectrale perspectief

11.1 Inleiding

11.2 Basisnoties van de spectrale kijk op het recht

11.2.1 Loskoppeling feit en gevolg

11.2.2 Toepassing op formele rechtskracht

11.3 De verbandenleer

11.3.1 Staatsverband als rechtskring

11.4 Spectraal recht als uitdrukking van de invullende rechtsleer

11.4.1 De overheid in het publiekrecht

11.4.2 De overheid - invullend - in het burgerlijk recht

11.4.3 Staatsverband in het burgerlijk recht

11.4.4 Verbandenleer en rechterlijke bevoegdheid

11.5 Toetsing bezien vanuit het spectrale perspectief

11.5.1 Inleiding

11.5.2 Toetsing: rechtmatigheids- en doelmatigheidstoetsing

11.5.3 Toetsing: ex tunc en ex nunc

11.5.4 Rechtmatigheidstoetsing ex tunc en doelmatigheidstoetsing ex nunc

11.5.5 Toetsing: abstract en concreet

11.6 Het onderscheid tussen de formele en de materiële rechtskracht vanuit het spectrale perspectief
11.6.1 De formele en de materiële rechtskracht
11.6.2 Verbandenleer en de formele en de materiële rechtskracht
11.6.3 Rechterlijke bevoegdheid en de formele en de materiële rechtskracht

11.7 Toetsing van de formele en de materiẻle rechtskracht van besluiten

11.7.1 Inleiding

11.7.2 Ex tunc/ex nunc

11.7.3 Ex tunc/ex nunc-toetsing en de burgerlijke rechter

11.7.4 Vemietigen en onverbindend verklaren tegenover buiten toepassing verklaren en buiten werking stellen 
Hoofdstuk 12

Rechtskracht: "de kleren van de Keizer"

12.1 Inleiding

12.2 De betekenissen van rechtskracht

12.3 Rechtskracht: 'de kleren van de Keizer'

12.4 Rechtskracht is erkenning

12.5 Rechtskracht is "illusie"

12.6 Rechtskracht als middel of als doel?

12.7 Conclusie

Samenvatting

Summary

Bijlage

Lijst van geraadpleegde literatuur

Jurisprudentieregister

Trefwoordenregister

316

Curriculum vitae 


\section{Lijst van gebruikte afkortingen}

$\begin{array}{ll}\text { AA } & \text { Ars Aequi } \\ \text { AB } & \text { Administratiefrechtelijke Beslissingen } \\ \text { ABR } & \text { Afdeling bestuursrechtspraak van de Raad van State } \\ \text { A-G } & \text { Advocaat General } \\ \text { AMvB } & \text { Algemene Matregel van Bestuur } \\ \text { ARSP } & \text { Archiv für Rechts- und Sozialphilosophie } \\ \text { ARRS } & \text { Afdeling rechtspraak van de Raad van State } \\ \text { AGB } & \text { Afdelingen geschillen van bestuur van de Raad van State } \\ \text { AöR } & \text { Archiv des offentliches Rechts } \\ \text { art. } & \text { artikel } \\ \text { a.w. } & \text { aangehaald werk } \\ \text { Awb } & \text { Algemene wet bestuursrecht } \\ \text { bas } & \text { besluit van algemene strekking } \\ \text { BayVBI } & \text { Bayerisches Verwaltungsblatt } \\ \text { bip } & \text { besluit in primo } \\ \text { BW } & \text { Burgerlijke Wetboek } \\ \text { CBB } & \text { College van Beroep voor het Bedrijfsleven } \\ \text { CBStufi } & \text { College van Beroep voor de Studiefinanciering } \\ \text { CRvB } & \text { Centrale Raad van Beroep } \\ \text { diss. } & \text { dissertatie } \\ \text { DoV } & \text { Die offentliche Verwaltung } \\ \text { DRiZ } & \text { Deutsche Richterzeitung } \\ \text { DVBI } & \text { Deutsches Verwaltungsblatt } \\ \text { ECRM } & \text { Europese Commissie voor de Rechten van de Mens } \\ \text { EHRM } & \text { Europees Hof voor de Rechten van de Mens } \\ \text { EK } & \text { Eerste Kamer der Staten-Generaal } \\ \text { e.v. } & \text { en volgende } \\ \text { EVRM } & \text { Europees Verdrag voor de Rechten van de Mens } \\ \text { frb } & \text { formele rechtsbestendigheid } \\ \text { frk } & \text { formele rechtskracht } \\ \text { Gst } & \text { Gemeentestem } \\ \text { GW } & \text { Grondwet } \\ \text { HR } & \text { Hoge Raad der Nederlanden } \\ \text { JA } & \text { Juristische Arbeitsblatter } \\ \text { JB } & \text { Jurisprudentie Bestuursrecht } \\ \text { jo } & \text { juncto } \\ & \end{array}$


JuS Juristische Schulung

Jura Juristische Ausbildung

$J Z \quad$ Juristenzeitung

m.nt. met noot

mrb materielle rechtsbestendigheid

mrk materiêle rechtskracht

MvT Memorie van Toelichting

NJ Nederlandse Jurisprudentie

NJB Nederlands Juristenblad

NIV Nederlandse Juristenvereniging

NJW Neue Juristische Wochenschrift

NTB Nederlands tijdschrift voor bestuursrecht

NTBR Nederlands Tijdschrift voor Burgerlijk Recht

NVwZ Neue Zeitschrift für Verwaltungsrecht

o.m. onder meer

p. pagina

Pres. President

RMThemis Rechtsgeleerd Magazijn Themis

$\mathrm{rb}$

red rechtbank

R\&R Nederlands Tijdschrift voor Rechtsfilosofie en Rechtstheorie

RvdW Rechtspraak van de Week

mbr rechtshandeling naar burgerlijk recht

Stb. Staatsblad

Stcr. Staatscourant

TK Tweede Kamer der Staten-Generaal

Tvo Tijdschrift voor Openbaar Bestuur

TwK Tijdelijke wet Kroongeschillen

VA Verwaltungsakt

VAR Vereniging voor Administratief Recht

VAWB Voorontwerp Algemene wet bestuursrecht

VBIBW Verwaltungsblatter für Baden-Württemberg

vbvb voor beroep vatbare beslissing

vgl. vergelijk

VwGO Verwaltungsgerichtsordnung

VwVfG Verwaltungsverfahrensgesetz

Vz. Voorzitter

Wet Arob Wet Administratieve rechtspraak overheidsbeschikkingen

Wet $\mathrm{BAB}$ Wet Beroep administratieve beschikkingen

WiVerw Wirtschaft und Verwaltung; Vierteljahresbeitrage zum Gewerbearchiv

ZZP Zeitschift fur die zivilistische Praxis 
. 


\section{Hoofdstuk 1}

\section{Inleiding}

De weg die juristen volgen is vaak die van literatuuronderzoek en jurisprudentieonderzoek. Dat is ook de weg die ik gevolgd heb. Het resultaat dat nu voor u ligt, is zodoende een verslag van een zwerftocht langs zowel datgene dat ik over mijn thema in de literatuur en in jurisprudentie aantrof als mijn gedachten daarover. De kennismaking met (soms zeer) verschillende ideeën over rechtskracht, geldigheid en effectiviteit bracht welhaast automatisch met zich dat ik probeerde gemeenschappelijke uitgangspunten, achtergronden of andere overeenkomsten te herkennen. Na verloop van tijd ging ik daar ook actief naar op zoek. Dat betekende een verleggen van het onderzoeksveld van bestuursrechtelijke bronnen naar ook rechtsfilosofische en rechtstheoretische bronnen. Deze heb ik (louter) geselecteerd op hun relevantie voor rechtskracht. Wanneer niet expliciet gesproken werd over het thema, wanneer analyse van het begrip niet onderwerp van studie was, werd deze literatuur buiten beschouwing gelaten. Een verhandeling over de rechtsfillosofie of rechtstheorie was immers niet de opzet van dit boek.

Daarnaast leek rechtsvergelijking een voor de hand liggende methode om eventueel nieuwe achtergronden bij het thema te vergaren. Dat hield in dat ik mij ging verdiepen in het met Nederland zo verwante Duitse rechtsstelsel. De keuze voor vergelijking met het Duitse stelsel lag voor de hand; immers had Van der Pot bij zijn introductie van het begrip in Nederland dat niet rechtstreeks aan het Duitse Rechtskraftbegrip ontleend? En omdat ook andere Nederlandse auteurs met Duitsland een vergelijking hebben gemaakt, leek vergelijking daarmee toegankelijker dan met stelsels van elders. In zijn dissertatie stelt De Jong dan ook: 'De Nederlandse stijl van wetenschapsbeoefening staat aanmerkelijk dichter bij de Duitse dan bij de Franse stijl. Dat is niet alleen het gevolg van rechtstreekse beinvloeding, maar ook het gevolg van het ontbreken van een eenvormig stelsel van administratieve rechtspraak. "1 De Jongs uitgezette sporen heb ik in dit boek gevolgd en met name wat betreft de na-oorlogse discussie - aangevuld. Tengevolge van tijdgebrek werd van rechtsvergelijking met andere landen afgezien. ${ }^{2}$ Dat is ook de reden waarom een vergelijking met het Europees recht geen aparte plaats heeft gekregen. ${ }^{3}$ Dit deel van het onderzoek werd afgesloten in de zomer van 1995.

Toch kan van rechtsvergelijking in de ware zin des woords eigenlijk geen sprake zijn wanneer niet verschillende rechtsstelsels op horizontale wijze worden vergeleken, dat wil

1. JP. de Jong, Bestuursrecht van vreemde herkomst, diss, Zwolle 1988, p. 91 .

2. Voor een vergelijking met het Franse stelsel verwijs ik naar J.P. de Jong, Bestuursrecht van vreemde herkomst, diss., Zwolle 1988 .

3. Voor een vergelijking met het gemeenschapsrecht verwijs ik naar $\mathbb{R}$. H. Lauwaars, Rechmatigheid en rechtskracht van gemeenschapsbesluiten, diss., Leiden 1970. 
zeggen naast elkaar geplaatst met thet doel de overeenkomsten en verschillen tussen de stelsels systematisch te inventariseren. En alhoewel op verschillende plaatsen naar het Duitse recht wordt werwezen heeft een dergelijke rechtsvergelijking ten aanzien van de rechtskracht niet plaatsgevonden. Het is daarom dat ik in dit boek steeds maar spreek van het opdoen van inspiratie van over de grens, van weergave van achtergronden en van een historische ontwikkeling. Voor Nederlandse beoefenaren van het bestuurstecht is het echter relevant te weten hoe de stand van zaken ten aanzien van de rechtskracht elders is. In die zin heeft de schrijver van een dissertatie een didactische opdracht. Dat is ook de reden waarom ik - in de traditie van Donner - de huidige Duitse codificaties met betrekking tot de 'Bestandskraft' en de 'Rechtskraft' van 'Verwaltungsakten' in een bijlage heb opgenomen.

En dan de 'geluiden'; hoe werd in het vak gedacht over rechtskracht? Wat was er te horen in de wandelgangen? Hoe werd het leerstuk benaderd?

De geluiden bleken zeer divers. Er waren er die het leerstuk hei liefst wilden opdoeken. Een ander zag het bestaansrecht ervan nog het meest in het kader van de discussie over de positie van derde-belanghebbenden in verband met het vertrouwensbeginsel. ${ }^{4}$ De Jong acht het begrip gecompliceerd en stelt dat de omschrijvingen van diverse schrijvers niet hebben bijgedragen aan meer helderheid: "De omschrijvingen die zijn opgesteld door diverse schrijvers kenmerken zich niet door een helder taalgebruik. Termen als 'kracht', "mogelijkheid tot het bieden van weerstand tegen", "sterke en zwakke rechtskracht', lijken in dit verband onvermijdelijk te zijn. Met dergelijke omschrijvingen is het moeilijk werken." Hij typeert rechtskracht als een structuurelement, al vindt hij tegelijkertijd dat het begrip materiële rechtskracht geen functie meer heeft en het begrip formele rechtskracht slechts dienstbaar kan zijn als denk-hulpmiddel. ${ }^{6}$ Scheltema typeert het als een mooi voorbeejd van een 'wrij lastig en in feite nutteloos leerstuk'. ${ }^{7}$ Nutteloos is het, vindt Scheltema, omdat het leerstuk (slechts) een rol speelde in de afbakening van de rechtsmacht van de administratieve en de burgerlijke rechter. Aangezien die afbakening - nu na de invoering van de eerste fasen van de reorganisatie van de rechterlijke macht - rijp is voor opdoeking
(waarbij Scheltema pleit voor eenheid van recht), hoort ook het leerstuk ter afbakening
daarvan tot het rijk der fabelen. In deze redenering van Scheltema wordt het leerstuk opgevat als zou het slechts een ontvankelijkheidsmechanisme bevatten in een verdelingsvraagstuk dat eigenlijk niet meer aan de orde zou moeten zijn. Aardig in dit verband - dat wil zeggen ter illustratie van de

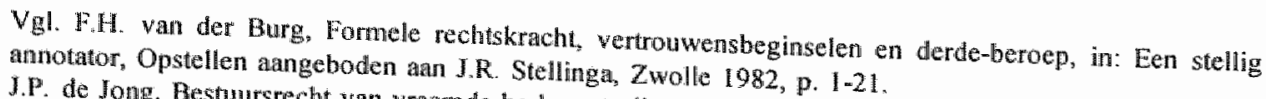

5. J.P. de Jong. Besturstecht van wroende

6. Vgl. I,P. de Jong, Bestuurstecht wan vreemde herkoms, diss, $Z$ wolle $1988, \mathrm{p} .96$.

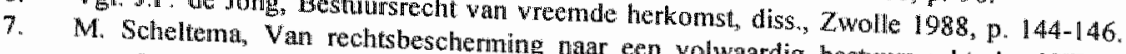
noot 2 . 
veelheid van meningen op dit punt - is dat Konijnenbelt het leerstuk beschouwt als 'een vaststaand element van onze rechtsorde' 8

Lastig was het leerstuk ook. Vragen met betrekking tot rechtskracht zijn niet eenvoudig, zo werd mij van vele zijden verteld. 'Dus jij wil over rechtskracht schrijven?, dat levert eenzaamheid op!', drukte Steenbeek mij op het hart, en hij kon het weten, zo voegde hij er aan toe, want hij had het zelf meegenaakt. Ook las ik bijvoorbeeld dat het 'een weinig geliefkoosd onderwerp' is, dat bekend staat als zeer gecompliceerd en moeilijk te doorgronden. Kortom, een onderwerp waarvoor nimmer een student 'enthousiasme kon opbrengen'." Een ander schreef: 'Het probleem van de rechtskracht is omvangrijk en moeilijk. ${ }^{10}$

Soms werd ik ook wel moe van deze opmerkingen, maar toen ik bij Erasmus las dat dit nu eenmaal een gewoonte van juristen onder elkaar is, voelde ik me weer gesterkt:

"Onder de geletterden begeeren de regtsgeleerden de eerste plaats, en niemand behagt meer zich zelven, terwijl zij aanhoudend den steen wan SISYPHUS voortwentelen, en honderden wetten in een' adern door elkander haspelen, zonder te letten waarop zij betrekking hebben, terwijl zij glossen op glossen, gevoelen op gevoelen stapeien, opdat hunne wetenschap als de moeijelijkste moge aangemerkt worden; want wat rinoejelijk is, achten zij terstond iets voortreffelijks." "I

Of moeilijk en voortreffelijk hetzelfde is, laat ik in het midden, maar vermoeiend vond ik de zinspelingen op de complexiteit vooral, omdat daarvan de suggestie kan uitgaan dat het thema wellicht ook zo moeilijk is dat we het er maar niet meer over zouden moeten hebben. Dan is het leerstuk in het verdomhoekje van de complexiteit terecht gekomen; en naast het feit dat dat een weinig begerenswaardige plaats is, lijkt mij dat daardoor ook de importantie van het leerstuk voor de praktijk van het bestuursrecht onrecht wordt aangedaan.

Ook bleek dat de vraag naar het nut van rechtskracht afhankelijk kon zijn van dogmatische uitgangspunten van rechtsgeleerden. Toen rechtskracht in ons land geïntroduceerd werd, was de eenzijdigheidsconceptie de heersende leer in het bestuursrecht. Aan het eind van de jaren tachtig was de ontwikkeling van het Nederlandse bestuursrecht zover dat men in de dogmatiek ook redeneerde vanuit het concept van de 'publiekrechtelijke wederkerige rechts-

8. W. Konijnenbelt, De administratieve rechter als schadevergoedingsrechter, preadvies Verentging voor burgerlijk recht, Lelystad 1996, p. 23, nook 72

9. Vgl. F.H. van der Burg, Formele rechtskrach, vertrouwensbeginselen en derde-beroep, in: Een stellig annotator, Opstellen aangeboden aan J.R. Stellinga, Zwolle 1982, p. 5.

10. H.D. van Wijk, Hoofdstukken wan administratief recht, Groningen/"s-Gravenhage 1968, p. 87.

11. Dit is de vertaling van P.G. Witsen Geysbeck wan Desiderius Erasmus' Lof der zotheid (Stultitie Laus 1511) Amsterdam 1828 , p. 110 ; de recentere vertaling van I.M. Vermeer-Pardoen, Utrecht 1992, p. 163 , luidt als volgt: "Onder de geleerden maken de juristen aanspraak op de belangrijkste plaats. Niemand heeft het zo met zichzelf getroffen alls zij, wanneer zij met hun sisyfusarbeid bezig zijn en aan tén stuk door honderden werten in elkaur flarsen, om het even waarover. Door de ene vakterm na de andere te spuien, wekken ze de indruk dat die wetenschap de moeilijkste van allemaal is. Want als $z$ e ergens hard voor hebben moeten werken, vinden ze meteen ook dat het om iets geweldigs gaat." 
betrekking'. Voor rechtskracht betekende dat zo zoetjesaan een stille dood. Niet alleen werd aan het nut ervan getwijfeld, sommige delen met betrekking tot het vraagstuk werden geschrapt. ${ }^{12}$ Amper een kwart eeuw daarvoor was het belang van rechtskracht nog onderstreept. ${ }^{\text {i3 }}$ Ruim een kwart eeuw weer daarvoor was het begrip in ons land geintroduceerd. ${ }^{14}$ Hoe kon in slechts een halve eeuw tijds de ster van rechtskracht zo sterk stijgen en dalen? In 1989 herhaalde Steenbeek zijn visie; hij onderstreepte het belang van rechtskracht en riep op tot meer eenheid in de discussie over het thema. ${ }^{15} \mathrm{Hij}$ leek een roepende in de woestijn.

Wat is nu de aanleiding voor dit boek? Het begrip rechtskracht en in het bijzonder de formele rechtskracht is van groot belang voor de rechtspraktijk. Niet alleen heeft de Hoge Raad vele arresten gewezen over het begrip, de uitzonderingen op formele rechtskracht en de nuances met betrekking tot de hoofdregel, ook andere rechters, met name bestuursrechters hanteren het. Dat maakt dat bestuursorganen hun activiteiten afstemmen op rechterlijke visies over rechtskracht. Ondanks vele (verschillende) beschouwingen in de literatuur blijkt deze hantering van het begrip steeds meer op problemen te stuiten. Te denken valt bijvoorbeeld aan het feit dat de rechter erkent dat wanneer bestuur en belanghebbende het met elkaar eens zijn dat er well of geen formele rechtskracht is, dat deze eenstemmigheid aanleiding kan zijn om een uitzondering op de formele rechtskracht aan te nemen. Daarmee ondergraaf je je eigen hoofdregel van formele rechtskracht. Deze situatie vraagt om. een herbezinning op de betekenis van rechtskracht. Laat ik dit toelichten.

Juristen oriënteren zich uiteindelijk op de rechtspraak en krijgen daar éen begrip van rechtskracht voor het voetlicht, namelijk formele rechtskracht als onaantastbaarheid. Hoe nu te werk te gaan? Kan men op de rechtspraak varen? Nee, want het begrip dat de rechtspraak hanteert, is niet toepasbaar door de vele uitzonderingen, nuances en verschillende meningen daar weer over; onaantastbaarheid impliceert immers het uitblijven van uitzonderingen. Wat doet men dus (ook in de rechtspraak)? Men zoekt voor alle problemen een casuîstische oplossing. Wanneer de praktijk aldus van doen heeft met casuïstiek wordt de betekenis van rechtskracht onontwarbaar en niet werkbaar. De rechtspraak moet immers voorspelbaar zijn; als de lijn (de leer of de theorie) achter de casus niet wordt gevonden, leidt dit tot willekeur. Begrijp me goed, dit is geen verwijt aan de rechter; deze heeft ook wel behoefte aan het aangeven van een lijn (de theorie achter de uitspraak), maar moet

12. Zoats we al zagen, betwijfelt De Jong in zijn "Besuursrecht wan vreernde herkomst", dissw, Zwolle 1988, het nut van de formele rechtskracht, terwijl voor nateriele rechtskracht naar zijn mening in de huidige bestuurstechtelijke realiteit geen plaats meer is. Scheltema noemde het leerstuk eveneens "nutteloos"; zie
noot. 7 . 13. Dat gebeurde door J.G. Steenbeek in diens Rechtshandeling en rechtsgevolg in het stals- en administratief
recht, diss., Assen 1958 .

14. Door C. W. wan der Pot in zijn "De vormen van het besturen" in: Nederlands Bestuurstrecht, Alphen a/d Rijn

15. In zijn 'Rechtskracht', in: NTB $89 / 8$, p. 265 e.v. 
primair de casus oplossen. Heesch-Van de Akker ${ }^{16}$ is een leerstellig arrest, een arrest dat een tipje van sluier oplicht zodat we iets van de theorie over de betekenis van rechtskracht kunnen zien. Toch kunnen we er niet mee uit de voeten, omdat er telkens uitzonderingen en/of nuances nodig zijn.

Voor de wetenschap is het niet kloppen van een theorie altijd een signaal dat de theorie moet worden overwogen. Dus gaat men zoeken bij auteurs. Men orięrteert zich op de literatuur en vindt daar allemaal verschillende visies en definities. Daardoor wordt de verwarring alleen maar groter; zo raakt de praktijk wan de regen in de drup.

Al met al wordt duidelijk dat de belangrijkste vraag van deze studie is: wat is de betekenis van de term rechtskracht, van formele en van materiële rechtskracht? Wat valt daarover nu al te zeggen? Met andere woorden, hoe is de stand van zaken met betrekking tot de vraag wat rechtskracht is, inhoudt, betekent? Een inventarisatie van betekenissen valt vanuit tweeer lei opzicht te geven: vanuit rechtsvormende kanalen en vanuit de doctrine.

In primair rechtsvormende bronnen is de betekenis van rechtskracht niet een onderwerp dat hoog op de agenda staat. De wetgever heeft geen definitie gegeven van het begrip rechtskracht, noch van de formele noch van de materiele rechtskracht. De term wordt wel expliciet gehanteerd in de MvT bij de tweede tranche van de Awb. ${ }^{17}$ Rechters hanteren de terminologie wel. Zoals aangegeven spreekt de burgerlijke rechter expliciet van formele rechtskracht (zie hierna hoofdstukken 2, 3 en 5), bestuursrechters hanteren vaak de term rechtens onaantastbaar of rechtens vaststaand (zie hierna hoofdstuk 4).

In de doctrine worden de begrippen al langer besproken. Via dit kanaal zijn de begrippen ook in ons rechtsstelsel terecht gekomen. Wat waren de ideeën over rechtskracht bij de verschillende auteurs en hoe keken zij überhaupt tegen het bestuursrecht aan? Wat waren hun dogmatische uitgangspunten en hoe werken die uit in hun betekenis van het begrip rechtskracht?

Toen in 1932 het begrip 'rechtskracht' hier te lande werd geïntroduceerd, werd het gezien als een eigenschap van beschikkingen. Hierachter ging de eenzijdigheidsconceptie van het bestuursrecht schuil. De eigenschap rechtskracht kwam uitdrukkelijk naar voren bij de vraag naar de onherroepelijkheid of onaantastbaarheid van de beschikking. Een beschilkking kon na het verstrijken van de beroepstermijn of na een onherroepelijk geworden rechterlijke uitspraak niet meer worden aangetast. Ook bij de vraag naar de mogelijkheid om beschikkingen in te trekken of te wijzigen, werd rechtskracht manifest. ${ }^{\text {s. }}$

Op die manier werden belangrijke leerstukken in verband gebracht met rechtskracht. Wat rechtskracht nu precies inhield (in een positieve definitie) bleef nog onduidelijk. Met het verschijnen van het proefschrift van Donner in 1941 werden deze leerstukken en hun verband met rechtskracht systematisch ontsloten; aldus ontstond (relatieve) duidelijkheid.

16. Vgl. HR 16 mei 1986, AB 1986,573 m.nt. FHwdB (Heesch-Van de Akker).

17. Vgl. TK, vergaderjaan 1991-1992, 22.495, nr.3, p. 93 (PG Awb 2, p. 173 en 378 e.v.).

18. Vgl. C.W. van der Pot; De wormen van het besturen, Nedettands Bestursrecln, Alphen a/d Rijn 1932, p. $2 / 4.217$. 
Donner schetste enkele karakteristieken van rechtskracht. Vanaf dit moment werd het rechtskrachtprobleem gezien als het resultat wan een voortdurend zoeken naar ewenwicht in het spanningsveld van (individuele) rechtszekerheid en (collectief) algemeen belang. Daarbij speelt tijd en met name tijdsverloop een grote rol. Rechtskracht wordt ingedeeld in formele en materièle rechtskracht en staat midden in het vraagstuk welke rechtsbescherming op welke wijze kan worden verleend aan de burger. Donner typeerde rechtskracht als enerzijds 'een buitengewone plooibaarheid en instabiliteit' en anderzijds 'een groote starheid"; beide uitersten vormen de polen die in concreto bij de rechtskracht van beschikkingen een 'ver uitgerekt kleurenprisma' opleveren. ${ }^{19}$ Het is een structuurelement van het Nederlands bestuursrecht.

Vanuit dogmatisch oogpunt veranderde het concept van eenzijdigheid in een meer wederkerige betrekking op of omstreeks 1954 . Vegting tekent hiervoor. ${ }^{20} \mathrm{Hij}$ omschrijft administratieve rechtsbetrekkingen als volgt:

\begin{abstract}
"Administratieve rechtsbetrekkingen zijn (..) wiet door het privaltrecht beheerste rechtsbetrekkingen, waarbii hetzij het tot een prestatie gerechtigde rechissubject, the tzij het tot cen prestatie verplichte dan wel beide rechtssubjecten een overheidsorgaan yormen. ${ }^{2 !}$
\end{abstract}

Maar, stelt Vegting:

Er zijn (..) ook rechtswerhoudingen tussen overheidsorganen (of door deze vertegenwoordigde overheidslichamerg) en individuen, waarop privamtrecht van toepassing is. Dezc laatste rechtsbetrekkingen duiden wij miet aan als administratieve rechtsbetrekkingen, doch als private rechtsbetrekkingen.,22

Met andere woorden, administratieve rechtsbetrekkingen belichamen de relaties van de publiekrechtelijk handelende overheid.

Die relaties worden concreet met het in het leven roepen van geldige rechtshandelingen. Rechtskracht is voor Vegting die werking van geldige rechtshandelingen waaruit administratieve rechtsbetrekkingen voortvloeien. Rechtskracht bepaalt daarmee de rechtsposities van rechtssubjecten. Een andere term voor deze werking van de rechtshandeling, voor rechtskracht, is durzaamheid van de rechtshandeling. ${ }^{23}$ Die werking is per instantie en ook voor burgers natuurlijk een andere.

Zowel Van der Pot als Donner vergeleken rechtskracht van beschikkingen met rechtskracht wan andere rechtshandelingen (met name het vonnis). Vaak werd dat gekoppeld aan een definitie van formele en van materiële rechtskracht. Aldus onderscheidden zij formele en

19. A.M. Donner, De rechtskracht van administratieve beschikkingen, diss., Alphen a/d Rijn 1941, p. 14.

20. De Jong. verwijst das ook naar. Vgl. zijn: Bestuursrecht van wreende herkomst, diss, Zwolle 1988 ,

21. W.C. Vegting, Het algenten Nederlands administratiefrecht, eerste deel, Alphen ad Rijn 1954, p. 169

22. W.G. Vegting, Het algemeen Nederlands administratieftecht, eerste deel, Alphen a/d Rijn 1954, p. 173.

23. Vgl. W. Ve.gting, Het algemeen Nederlands administratiefrecht, eerste deel, Alphen a/d Rijn 1954 ,
p. 263 . 
materiële rechtskracht op basis van een formeel criterium. Bij de vraag of er met formele of met materiele rechtskracht gerekend wordt, moest worden onderscheiden naar handelende actor. Maatgevend is daarbij de vraag jegens wie de rechtskracht zou gelden, ofwel jegens de rechter - formeie rechtskracht - ofwel jegens het beschikkinggevende orgaan materiële rechtskracht. Het proefschrift wan Steenbeek betekent een overgang, omdat hij het onderscheid (in formele en materiele rechtskracht) indeelt op basis van een inhoudelijk criterium (als eigenschap wan ofwel rechtshandeling ofwel rechtsgevolg). Steenbeek verbindt formele rechtskracht aan besluitvorming (een tunc-moment) en materiale rechts kracht aan rechtsgevolgen (een nunc-moment). ${ }^{24}$

Het jongste proefschrift dat (o.a.) rechtskracht bespreekt, is dat van De Jong. ${ }^{25} \mathrm{Hij}$ onderzoekt het rechtskrachtbegrip terwijl hij uitgaat van een rechtsbetrekkingentheorie. Daarbij geeft hij geen nieuwe, eigen definitie van rechtskracht. Hij karakteriseert het leerstuk van de rechtskracht van beschikkingen als staande:

"in de sleutel wan de rechtsverhouding tussen burger en bestuursorgaan. Dit is vooral te danken aan de ontwikkeling van de algemene beginselen wan behoorlijk bestuur. ${ }^{26}$

Wanneer De Jong ${ }^{27}$ concludeert dat er sprake is van een overgang in bestuursrechtsdogmatiek naar het denken in rechtsbetrekkingen geeft hij aan dat dit concreet neerkomt op het niet benadrukken van de rol van de beschikking (met haar rechtskracht).

'De rechtskrachtheorie is gericht op de beschikking, niet op de verhouding tussen burger en bestuursorgaan."

De rechtskracht van de beschikking kan dan eigenlijk geen zelfstandige rol (meer) spelen. Zo wordt formele rechtskracht een 'denk-hulpmiddel' en materièle rechtskracht vervult dan, als gezegd, geen functie meer. Welke zijn De Jongs argumenten? Het gebruik van de term rechtskracht is in de ogen van De Jong:

'tiet consistent (...) en (geef, EvdL) daardoor aanleiding tot verwarring (...). Hot verdient dan ook atalbeveling het gebruik van de term rechrskracht achterwege te laten indien kan worden volstawn mot ternen als kracht wan wet, werbindende kracht of rechitsgeldigheid. 2.28

Welke dienst kan het denk-hulpmiddel bieden? De Jong stelt dat het begrip formele rechtskracht in verband staat met de positie van derde-belanghebbenden, en ook in de verhouding tussen de administratieve en de burgerlijke rechter speelt het een rol. Een

24. Vg1. J,G. Steembeek, Rechtshandeling en rechtsgcvolg in het siants- en adminustratief recht, diss., Assen 1958 en J.G. Steenbeek, Rechtskracht, in: NTB 89/\% p. 265 e.v.

25. Vg. I.P. de Jong, Bestuurstecht van wreemde herkomst, diss. Zwolle 1988.

26. J.P. de Jong, Bestuursrecht wan wreende herkonst, diss, Zwolle 1988, p. 91.

27. Vgl. J.P. de Jong. Bestuurstecht van wremde herkomst, diss., Zwolle 1998, p. 141-146.

28. JP. de Jong, Bestuursrechi vary vreemde herkomst, diss . Zwolle 1988, p. 142. 
vonnis moet dan 'absoluut' (in welk opzicht, EvdL?) onaantastbaar zijn. Een beschikking kan dat niet zijn. Daarom is rechtskracht een moeilijk grijpbare term. Zowel onaantastbaarheid als flexibiliteit moeten er in zitten. Dat maakt de 'rechtskracht-idee' dan onhaalbaar:

"Het doet onvoldoende recht atan het feit dat beschikkingen een rol spelen in een dyramische rechisverhouding tussen burger en bestuursorgaan. 29

Kortom, De Jong ziet als logisch gevolg wan het niet benadrukken van de (eenzijdige) beschikking het wegdenken van rechtskracht, maar heeft daar tegelijkertijd ook moeite mee omdat hij het rechtskrachtbegrip niet helemaal uitsluit. Dan blijft rechtskracht tóch aanwezig. Hoe? Kennelijk, bij wijze van compromis, als 'denk-hulpmiddel'.

In de periode tussen 1958 en 1988 verschuift de aandacht voor het begrip van dissertaties naar handboeken en artikelen. Van Wijk, Stellinga, De Haan c.s., Ten Berge/Tak en Van der Burg bespreken het.

Van Wijk ziet rechtskracht als eigenschap van beschikkingen: 'De vraag waarom het gaat wordt door het begrip 'rechtskracht' zelf aangewezen: welke kracht heeft de beschikking, die een rechtshandeling is, tegen pogingen haar aan te tasten (...)?'30

Stellinga gaat daarentegen uit van een meer universeel rechtskrachtbegrip. Hij ziet rechtskracht als eigenschap van alle overheidshandelingen, met name: wetgeving, beschikkingen en rechtspraak. ${ }^{31}$ Deze toch enigszins afwijkende visie komt voort uit zijn benadering van het rechtsgebied. Stellinga rechtvaardigt het werschijnen van zijn handboek dan ook met de (doel)stelling dat hij 'een beeld wil geven van het administratiefrecht in zijn geheel, omvattende wetgevingsrecht, bestuursrecht, politierecht en procesrecht' en hij keert zich tegen hen die zich slechts met onderdelen van het rechtsgebied bezighouden, omdat daardoor 'helaas de blik op het geheel verwaarloosd' is. ${ }^{32}$

De Haan c.s. koppelen bespreking ervan aan de beschikking. ${ }^{33}$ Ook Ten Berge/Tak gaan uit van een koppeling van rechtskracht aan beschikking of rechterlijke uitspraak. ${ }^{34}$ Daarmee staan deze auteurs in de traditie van het denken over rechtskracht van Van der Pot, Donner, Vegting en Steenbeek. Van der Burg brengt (met name formele) rechtskracht van beschikkingen in verband met het vertrouwensbeginsel en de positie van derden. ${ }^{35}$ (Het is ten aanzien van dit punt dat De Jong later formele rechtskracht nog als denk-hulpmiddel
ziet.)

29. I. . de Jong. Bcstursrecht van veemde herkomst, diss., 2wolle 1988, p. 141.

30. H.D. wan Wijk, Hoofdstukken wan administratief recht, Groningen/s-Gravenhage 1968, $\mathrm{p} .87-88$.

31. Vgl. J.R. Stelling4, Grondtrekken wan het Nedertands Administratiefrecht., Zwolle 1951, p. 129 e.v., p. 21

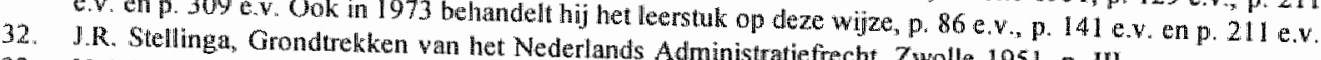

33. Vgl. P. de Ham, Th,G. Drupsteen, R. Femh handelingen en watuborgen, Deventer 1986, p. $51 \mathrm{a.v}$. Vg. A.Q.C. Tak en J.B.I.M. ten Berge, Nederlands adnunistratief procesnechu, deel 2,2 wolle $1983, p .199$

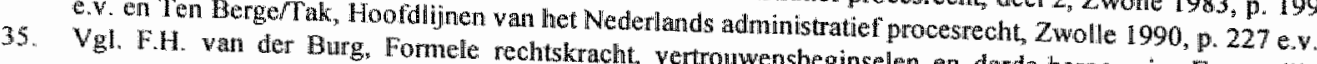
annotator, Opstellen angeboden an J.R. Stellinga, Zwolle 1982, p. $1-21$. 
Nog een woord vooraf. Arbitrair is het zeker, maar toch is, mede als gevolg van tijdgebrek en plaatsgebrek, de keuze gemaakt voor algemene beschrijvingen van rechtskracht in plaats van beschrijvingen van de rol van het begrip toegespitst op leerstukken van besturursrecht. De rechtsontwikkeling en de plaats van het thema daarin lijkt mij aan zo'n algemene beschrijwing toe te zijn. Het thema van deze studie heeft in vele leerstukken zijn eigen uitwerking. Te denken valt aan de betekenis van rechtskracht in verband met vernietiging door de rechter, vernietiging door de Kroon, spontane vernietiging, goedkeuring, schorsing, wijziging en intrekking, e.d. meer. Van een bespreking en analyse van die verschillende leerstukken en hun relatie met rechtskracht is afgezien, deels omdat deze leerstukken afzonderlijk onderwerp zijn geweest van aparte studies, ${ }^{36}$ maar ook omdat sommige leerstukken nog onderwerp kunnen zijn van zelfstandige onderzoeken. Te denken valt bijwoorbeeld aan een analyse van het verbinden van formele rechtskracht aan algemeen verbindende voorschriften en de mate waarin een rechtstreeks beroep tegen algemeen verbindende voorschriften daarbij een rol speelt. ${ }^{3 ?}$

Een beschrijving in algemene zin hoeft voor de lezer geen teleurstelling in te houden; dit boek wil immers een handreiking bieden om straks leerstukken te kunnen gaan begrijpen vanuit een meeromvattend kader. Rechtskracht beschrijven in relatie tot éen of enkele leerstukken zou alleen maar meer verwarring oproepen, omdat het de kijk op het algemene leerstuk (de betekenis van rechtskracht) vertroebelt.

De keuze voor algemene beschrijvingen van het onderwerp van deze studie betekent dat wel aandacht uit dient te gaan naar de theoretische en dogmatische achtergronden van verschillende auteurs of stromingen, die leiden tot een eigen opvatting over het begrip. Daarom wordt de betekenis van het begrip rechtskracht geanalyseerd vanuit het rechtspositivisme (hoofdstuk 8), vanuit Teubners autopoiese (systeemtheorie) in relatie tot het concept, door sommigen zelfs paradigma genoemd, van de 'wederkerige rechtsbetrekking' in het bestuursrecht (hoofdstuk 9), vanuit de transcendentale (hoofdstuk 10) en vanuit de spectrale leer (hoofdstuk 11).

In dit licht is de visie van Van der Hoeven van belang. Van der Hoeven beschouwt als kernvraag van de worming van een algemeen deel van het bestuursrecht:

36. Vgl. de yoor dit thema zo belangwekkende proefschriften van A.M. Donner, De rechtskracht van administratieve beschikkingen, Alphen a/d Rijn 1941; J.G. Steenbeek, Rechtshandeling en rechtsgevolg in het Staats- en administratief recht, Assen 1958 en J.P. de Jong, Bestuurstecht want vreemde herkomst, Zwollo 1988. Ook het handboek wan W.G. Vegting, Het algemeen Nederlands administratief rech, deel $\mathbb{1}$, Alphen afd Rijn 1954, valt ten aanzien van het thema aldus te platsen.

37. Vgl. daarover bv. het preadvies van H.G. Lubberdink en het co-referaat war E.C.M. Jurgens voor do Vereniging voor Wetgeving en Wetgevingsbeleid, Alphen a/d Rijn 1996 of het artikel van J.E.M. Polak, Rechtstreeks beroep tegen algemeen verbindende voorschriften en beleidsregels bil de bestuurstrechter: voorlopig van de baan?, in: Trema 1997/8, p. 269e. en ook Kabinetsnolitie van 13 mel 1997. TK 1996* 1997, 25 383, nr, 1 en D. Allewijn, Artikel 8:2 Awb: een voorlopig blijwende uitzondering: in: NJB $1998 / 17$, p. 787.788 . Voor een dergelijke studie lijken de dissertaties van R.M. van Malc, Rechter en bestururswetgeving, Zwolle 1988 en A.J. Bok, Rechterlijke toetsing van regelgeving, Deventer 1991 ommisbaar. Een belangrijk arrest terzake van deze materie is uiteraard HR 16 oktober $1992, A B 1993,40$ m.nt. FHwdB (Vuthop-Amsterdam). 
"Hoe is in te loop der jaren theoretisch vorn gegewen aan het probleen wan de spanning tussen enerzijds het handelende en besluftende overheidsorgan in zin dienst ten behoeve van het algemeen belang em ander zijus de bestuurde die datardoor, hetzij in zijn woordeel, hetzij, in zijn nadeel, in zijn belang wordt geraght? Deze yraag en de beantwooding daarvan staat centraal in een groot antal leerstukken van het allgemeen bestursirecht en de daarbij ingenomen standpunten. Dat geldt natuurijk in de eerste en voomaamste plaats voor de algemene beginsefen van behoorlijk bestuur, maar evenzeer woor het leerstuk van de rechtskracht van beschikkingen, woor dat van nietigheid en vernietigbaarheid, voor de betekenis van pseudo-wetgeving. de gebondenheid adn toezeggingen door de overheid gedaan, de wrihtheid die een overheidsorgaan heeft bij de keuze tussen het woigen van een privaatrechtelijke dan wel een publiekrechtelijke wog, en dergeljike meer. ${ }^{* 38}$

Daarmee volgt hij Donner die het probleem van rechtskracht immers ook zag als de belichaming van het spamningsveld tussen individueel en collectief algemeen belang. Aldus is rechtskracht de overstap tussen de door Van der Hoeven zo treffend weergegeven eerste dimensie (macht) en de derde dimensie (rechtsbescherming) van het bestuursrecht.

Vegting zocht het verband met de factor tijd en bracht de discussie daarmee in een nieuwe fase. Rechtskracht was voor hem duurzaamheid van een beschikking. ${ }^{39}$ Steenbeek borduurde daar op voort en onderscheidde naar rechtskracht op een bepaald (aflopend) moment en rechiskracht die blijvend is. De aflopende rechtskracht (de formele) koppelde hij aan het tunc-moment (van de rechtshandeling) en de blijvende rechtskracht (de materiële) verbond hij met het nunc-moment (van het rechtsgevolg). Aldus operationaliseerde hij de factor tijd in het onderscheid tussen formele en materiêle rechtskracht.

De recentste benadering van het begrip in het positieve recht heeft sterke banden met de oudere discussie, waarbij rechtskracht in een vergelijking met de rechtskracht van rechterlijke uitspraken vanuit het Duitse stelsel hier te lande werd geïntroduceerd. In de (huidige) rechtspraak is rechtskracht - en dan spreken we met name over formele rechtskracht gedefinieerd als een onatantastbaarheid voor degene die in beroep is gegaan, voor partijen, een soort van rechterlijke inter partes-onaantastbaarheid derhalve. Dat is een duidelijke definitie, maar niet de enige.

Een benadering die minder uitgaat van procesdenken ${ }_{y}$ maar daarentegen het bevoegdheidsdenken voorop stell, benadrukt de gezagsuitoefening door de overheid in de definitie van rechtskracht. Dan walt het moment van ingaan van rechtskracht al eerder te duiden, namelijk bij het afgeven van een beschikking. De (formele) rechtskracht zo opgevat is verwant aan en draagt sporen van de authenticiteit, is - met andere woorden - een geldigheidsstempel en werkt erga omnes (dat wil zeggen jegens een ieder). Dat deze benadering eveneens sporen in het geldende, positieve recht heeft, bewijst wel de regel dat het beroep in beginsel geen schorsende werking heeft. De regel komt voort uit en verklaart het respect voor de gezagsuitoefening.

38. J van der Hoeven, De drie dimensies van het bestuursrecht, Alphen a/d Rijn 1989, p. 155.

39. Vgl. W.G. Vegting, Het algemeen Nedertands administratiefrecht, deel 1, Alphen a/d Rijn 1954, p. 263. 
Terug naar de vraag: wat is betekenis van rechtskracht? Er zijn - weten we nu - vele en verschillende betekenissen van rechtskracht die heden ten dage de ronde doen. We zagen er al verschillende. Naast rechtskracht die ingaat na verloop van een termijn is er rechtskracht die er onmiddellijk na afgifte van de beschikking is. Naast onaantastbaarheid(inter partes) jegens ofwel de rechter ofwel het beschikkinggevende orgaan is er de (erga omnes) rechtskracht als geldigheidsstempel. Naast duurzaamheid is er rechtskracht van een rechishandeling (een rechtsfeit) en van een rechtsgevolg (de - gewijzigde en daardoor genormeerde - rechtssituatie). Naast rechtskracht als aanwijsbaar op enig moment (verwijzend naar een rechtsfeit) staat rechtskracht als blijvend verschijnsel (verwijzend naar de normconforme rechtssituatie).

In dit boek will ik op voorhand niet een van deze verschillende definities als de heersende en/of meest juiste vastleggen. De definitie die het meest in het geldende, positieve recht tot uitdrukking komt, is de rechterlijke onaantastbaarheid. Wanneer ik deze benadering stelselmatig zou wolgen, zou ik onrecht doen aan andere benaderingen van het begrip. Andere benaderingen - afkomstig uit de historie, de rechtsvergelijking, uit theoretische benaderingen - zijn eveneens waardevol voor een beter begrip van rechtskracht. Geen van die benaderingen is overigens naar mijn mening zaligmakend. De conclusie dat er geen duidelijkheid bestaat over de inhoud van het begrip, is zodoende het als steeds terugkerende constatering terugkerende 'Leitmotiv' van dit boek. De verschillende benaderingen wan begripsvorming en definitie van rechtskracht zullen in het boek aan de orde komen. Dat levert overigens een extra moeilijkheidsfactor op. Het naast elkaar bestaan van verschillende definities en opvattingen over de betekenis van rechtskracht impliceert immers fricties voor de lezer wanneer deze vanuit een bepaalde benadering - bewust of onbewust - tot een definitie is gekomen over rechtskracht. Wanneer bijvoorbeeld de uit het geldende recht te destilleren definitie van rechterlijke onaantastbaarheid van formele rechtskracht voor ogen wordt genomen, dan is dat nagenoeg onverenigbaar met het erga omnes-karakter dat juist in de benadering vanuit het bewoegdheidsdenken zo cruciaal is.

Vraag is daarmee inmiddels wel hoe houdbaar de in het positieve recht gehanteerde definitie van rechtskracht is. Hiervoor duidde ik op de toenemende onhoudbaarheid van het hanteren van een definitie waar de rechtspraktijk niet op kan varen. Deze onhanteerbaarheid van het begrip dient daarom te worden herijkt, mede in het licht van de andere benaderingen van het begrip (de historische, de rechtsvergelijkende, de rechtstheoretische). Een herijking van een definitie is nauwelijks volgbaar voor de lezer als die geen 'handen en voeten' krijgt. Die krijgt de lezer dan ook in de vorm van een hypothese. Daarom zal hier een hypothese van het begrip worden gesteld, die enerzijds een definitie aanreikt die 'groot' genoeg is om aan alle benaderingen te kunnen worden gespiegeld (een sleutel) en die anderzijds kan worden gehanteerd als maatstaf (als toetssteen). Deze hypothese ligt in het ontrafelen van de rechtskracht van het feit, van de norm en van het rechtsgevolg. Dit behoeft toelichting. Steeds wanneer een bevoegdheidsuitoefening plaatsvindt worden feiten en hun gevolgen met elkaar in verband gebracht. De norm heeft hiertussen een bemiddelende functie. De norm heeft zowel met het feit als met het gevolg cen relatie; daarom spreken we ook. van rechtsfeiten en rechtsgevolgen. Aan het feit is gerelateerd de 
factor tijd. Feiten zijn doorgaans aflopende gebeurtenissen. De gevolgen blijven en gaan deel uitmaken van de wereld van het recht. Daarom wordt vaak gesproken van een door de bevoegdheidsuitoefening veroorzaakte wijziging in de rechtssituatie. Deze definitie (die in feite door Steenbeek is gegeven) maakt het mogelijk om elke andere definitie of typering van rechtskracht een plaats te geven. De bestuursrechtelijke rechtshandeling kan zo worden beschouwd als het aflopende feit (een bijzonder rechtsfeit in de woorden van Steenbeek) dat blijvenddurende rechtsgevolgen in het leven roept. De rechtskracht die verbonden wordt met het feitelijke is een aanwijsbare en met een tunc-moment werbonden formele rechtskracht. De blijvende en voortdurende rechtskracht wordt met het nunc-moment verbonden en heet materielle rechtskracht. ${ }^{40}$ Dit briljante onderscheid van Steenbeek is zowel bij beschikkingen terug te zien als bij besluiten van algemene strekking als bij publiekrechtelijke overeenkomsten. Laat ik dit concreter aangeven. De beschikking waardoor het belanghebbende wordt vergund om een bouwwerk op te richten, heeft voor het bouwen een legitimerende werking doch is een aflopend iets; zeker wanneer het bouwwerk eenmaal gebouwd is "verliest de beschikking zijn (constitutieve) waarde. Het rechtsgevolg echter blijft: het bouwwerk is nog steeds legitiem opgericht; de rechtssituatie is gewijzigd. De formele rechtskracht van de beschikking is verbonden met het moment dat de beschikking in het rechitsleven kwam: vanuit het bevoegdheidsdenken is dat het moment van afgifte van de beschikking en vanuit het procesdenken het moment van het - ongebruikt - verstrijken van de beroepstermijn. De materiële rechtskracht van de beschikking is verbonden met het rechtsgevolg. Dat betekent vanuit het bevoegdheidsdenken dat wanneer na verloop van jaren het bestuur van oordeel is dat het gebouwde niet langer in overeenstemming met het recht (neergelegd in normen) kan worden geacht, dat bestuur dan door middel van een nieuwe beschikking de rechtssituatie constitutief zal wijzigen (aanschrijving, onbewoonbaarverklaring, intrekking of wijziging van de bouwvergunning). Vanuit het procesdenken is de nieuwe (constitutieve) beschikking dan noodzakelijk (waarborg).

De formele rechtskracht van een besluit van algemene strekking is in zoverre identiek aan die van de beschikking, dat deze is verbonden aan de vaststelling van dat besluit (vergelijk met kracht van wet). De materiele rechtskracht van een besluit van algemene strekking is verbonden met de inhoud van de rechtshandeling. De norm zelf kan aldus geen formele rechtskracht krijgen. Ook het besluit tot het aangaan van een overeenkomst (een gemeenschappelijke regeling) kan op deze wijze formele rechtskracht krijgen. De verbintenis die het gevolg is van het aangaan van een overeenkomst kan geen formele rechtskracht krijgen; daar betreft het weer materiele rechtskracht van de inhoud.

Het "door elkaar haspelen' van dit onderscheid is tekenend voor de discussie over de betekenis van rechtskracht. Weer een voorbeeld. De bekende discussie rond de vraag of een algemeen verbindend voorschrift formele rechtskracht moet kunnen krijgen zoals een beschikking die ook verkrijgt, wordt gekenmerkt door deze troebelheid. Het vaststellen van een algemeen verbindend voorschrift als aanwijsbaar en in de tijd aflopend moment kan

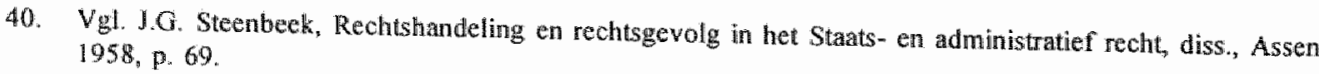


eenvoudig met de formele rechtskracht verbonden worden. De materiele rechtskracht van de inhoud (dat is een norm) kan niet aan formele rechtskracht in de zin van onherroepelijkheid of onaantastbaarheid worden verbonden. Dat is ook precies de reden waarom destijds de formele rechtskracht van algemeen werbindende voorschriften en beschikkingen niet op één lijn kon worden gesteld (waarbij argumenten als herhaalde toepasbaarheid en tekortdoen aan rechtszekerheid naar voren werden gebracht). "Het normkarakter van een algemeen verbindend voorschrift verdraagt niet dat het gekoppeld wordt aan de formele rechtskracht zoals die van de beschikking; de formele rechtskracht is immers aan het feit (dat wil zeggen de vaststelling van de regeling) gekoppeld en niet aan de norm, de inhoud, de door het rechtsgevolg vormgegeven rechtssituatie. Het normkarakter van een algemeen verbindend voorschrift kan uiteraard wel met inhoud, rechtsgevolgen en dus met materiele rechtskracht worden verbonden. Normen (inhoud van rechtshandelingen) dienen herhaald toepasbaar te zijn; rechtsbescherming is afhankelijk van een moment waarop een bepaalde inhoud rechtens vaststaat (onaantastbaar wordt). Bevoegdheidsdenken wordt bepaald door inhoud (rechtssituaties, normen) terwijl procesdenken wordt bepaald door vorm (afgifte van een besluit, beroepstermijn, het hebben van een actie).

Op dit punt wordt in de transcendentale denkkritiek een interessante nieuwe poging tot definitie van het rechtskrachtbegrip gedaan (hoofdstuk 10). De materièle rechtskracht van normen wordt daar rechtstreeks met materiele rechtsbeginselen verbonden. Daarmee is een ander punt aangesneden. In dit boek gaan sommige benaderingen wit van rechtskracht als eigenschap van normen (waarbij met name te denken valt aan een rechtspositivist als Kelsen - zie verder hoofdstuk 8 - en een transcendentalist als Van Eikema Hommes) en sommige benaderingen van rechtskracht als eigenschap van feiten. De zojuist geschetste sleutel kan ook deze spraakverwarring blootleggen.

In het twaalfde hoofdstuk tracht $i k$, als een poging tot synthese, te verbinden wat in al de benaderingen van het begrip rechtskracht overeind blijft. Dat vat ik samen in mijn eigen definitie van rechtskracht. Twee elementen staan daarin centraal. Het eerste neem ik over van Steenbeek: rechtskracht is erkenning. Het tweede kenmerk van rechtskracht is veel vluchtiger en daarom ook weer moeilijk te bevatten. De karakteristiek 'vluchtig' typeren in juridische termen komt het dichtst in de buurt wan het benoemen van rechtskracht als een fictie. Dat is dan ook wat ik in mijn eigen benadering doe. Rechtskracht is een fictie.

Ik hoop dat nu een discussie kan ontstaan, waarin over de rechtskracht van bestuursbesluiten in een breder kader wordt gesproken dan louter als ontvankelijkheidsvereiste bij de burgerlijke rechter. Niet alleen voor de burgerlijke en administratieve rechter lijkt het thema mij relevant, maar (vooral) ook voor ambtenaren en juristen in de bestuurspraktijk. Recht is maar eén aspect van het samenleven; tegelijkertijd is het geen volmaakt aspect. Door middel van een voortdurende discussie - waarin zowel proces-evaluatie als reflectie over doelstellingen een plaats hebben - kunnen we verbetering binnen het zichtveld houden.

41. Vgl. PG Awb II, MwT, p. 378 ev.; Regeringscommissaris p. 389 e.w. 
Zojuist wees ik al op de veelheid aan visies in het veld over rechtskracht. Ook in Duitsland is dat het geval. Daar leeft de rake typering van Forsthoff over de betekenis van rechtskracht als 'Labyrinhts der Meinungen' nog immer voort. De rechtskracht van bestuursbesluiten is in het Duitse recht gecodificeerd. Precieze definiëring in de wet ontbreekt ook in Duitsland, al geef de wet daar uitvoerige regelingen die expliciet gegroepeerd zijn rond die rechtskracht van bestuursbesluiten. Het belangrijkste onderscheid dat voor ons stelsel van belang is, is dat in 'Bestandskraft' en Rechtskraft'. Dit onderscheid is gerelateerd aan de fase waarin de beschikking wordt beschouwd. Vanuit de bevoegdheidsbenadering kan de beschikking worden beschouwd in de non-contentieuze fase (de besluitvormingsfase) en rechtskracht krijgt daar de naam 'Bestandskraft'. In een meer op het proces gerichte definitie (de beschikking verkeert nu in de contentieuze fase) krijgt het de naam 'Rechtskraft'.

Alleen al het brengen van klaarheid in de werschillende visies, is reden voor het schrijven van dit boek. De belangrijkste vraag die er uit voortvloeit is de vraag of er eigenlijk wel één rechtskrachtbegrip bestaat. Bestaat hết rechtskrachtbegrip eigenlijk wel? Zijn er niet meerdere rechtskrachtbegrippen, die ieder naast elkaar nadruk leggen op een bepaald aspect van rechtskracht of die ieder naast elkaar voortvloeien uit verschillende visies op het recht? Kortom, vooral de vragen wat rechtskracht is en waarom het er is, hebben mij de laatste jaren beziggehouden. Op de betekenis van rechtskracht voor de publiekrechtelijke en in het bijzonder de bestuursrechtelijke werkelijkheid wordt in het hiernavolgende dusdoende een licht geworpen.

Hoe is nu de opzet van dit Boek? Eerst ga ik in op hoe rechtskracht er eigenlijk uitziet. Heeft er ten aanzien van het begrip positieve rechtsvorming plaatsgehad? Ondat dat het meest expliciet tot uitdrukking komt in de jurisprudentie van de burgerlijke rechter beschrijf ik hoe deze ertoe gekomen is het begrip te definiëren en hoe deze het verder heeft ontwikkeld (hoofdstukken 2, 3 en 5). De burgerlijke rechter heeft de bestuursrechter als inspiratiebron gehad; de wijze waarop daar het begrip vorm wordt gegeven, bespreek ik eveneens (hoofdstuk 4). Daarbij is - als gezegd - gekozen voor een beschrijving in algemene bewoordingen in plaats van een analyse van rechtskracht en zijn relatie tot bepaalde leerstukken. Dit is de beschrijving van de historische herkomst van het begrip.

Dan volgt een beschrijving van de vreemde herkomst van het begrip; de vraag dus hoe rechtskracht van bestuursbesluiten hier te lande op deze manier vorm heeft kunnen krijgen; een vraag waarbij oorsprong en herkomst van rechtskracht centraal staat (hoofdstuk 6). Voor dit vergelijkende onderdeel van het boek heb ik mij - als gezegd - georiënteerd op het met het onze stelsel zo verwante Duitse stelsel.

Dit roept de vraag op waarvan rechtskracht eigenlijk een eigenschap is. Omdat de bron van deze (meer 'historiografische') vraag zowel in Nederlandse als in Duitse teksten ligt, moet deze vraag na een bespreking wan het begrip in het Duitse recht worden beantwoord. Rechtskracht kan, vanuit theoretisch oogpunt bezien, eigenschap zijn van ofwel enkele bijzondere rechtshandelingen, ofwel alle rechtshandelingen, ofwel van rechtsfeiten, ofwel van bloot feitelijk handelen door de overheid. En hangt de keuze voor het aanvaarden van 
rechtskracht als eigenschap van ofwel feit ofwel norm samen met de dogmatische visie op het recht van verschillende auteurs? Hoofdstuk 7 is gewijd aan de vraag waarvan rechtskracht nu eigenlijk de eigenschap is.

Dusdoende zijn we in meer 'bespiegelende' sferen gekomen, waardoor de overgang mogelijk is naar analyse van het rechtskrachtbegrip vanuit de meer theoretische en filosofische achtergronden. I $k$ heb enerzijds gekozen voor de 'traditionele' stromingen: een analyse vanuit de rechtspositiwistische benadering (hoofdstuk 8 ) naast een die meer vanuit de natuurrechtsleer opereert (transcendentalisme, hoofdstuk 10). Daarnaast wil ik de in het huidige bestuursrecht wel geduide nieuwe stroming van Teubners autopoiese als analysemodel hanteren (hoofdstuk 9). Ook de aan de Maastrichtse faculteit ontwikkelde spectrale benadering van het recht wil ik op zijn analytische mogelijkheden woor de betekenis van rechtskracht niet ongebruikt voorbij laten gaan (hoofdstuk 11).

Tenslotte wil ik mijn eigen benadering terzake van de rechtskracht uiteenzetten. Dat gebeurt in het laatste hoofdstuk. De titel van deze studie hangt daarmee samen: de kleren van de Keizer.

Het onderzoek werd afgesloten in de zomer wan 1998. 


\section{De bevoegdheid van de burgerlijke rechter en de invloed van het administratieve recht: de ontwikkeling tot Heesch-Van de Akker}

\subsection{Inleiding}

Het leerstuk van de formele rechtskracht geniet ruime belangstelling van de zijde van de civiele rechter. Tegenwoordig wordt ook wel gerept van het feuilleton van de formele rechtskracht.' Welke zijn de bronnen van het feuilleton?

In dit hoofdstuk zal getracht worden na te gaan waarom de Hoge Raad in het leerstellige arrest Heesch-Van de $A k k e r^{2}$ is gekomen tot het introduceren, dat wil zeggen het expliciet definiëren, van de formele rechtskracht van beschikkingen. Wat voor een definitie ontwikkelde de burgerlijke rechter? Het heeft er veel van weg dat de Hoge Raad in de formele rechtskracht van beschikkingen een nieuw en bevredigend instrument zag dat kon dienen als methode ter afbakening van zijn rechtsmacht met die van de bestuursrechter. Is daarin een rol weggelegd voor de factor tijd? Is formele rechtskracht gekoppeld aan de vaststelling van een beschikking, terwijl de materiële rechtskracht aan de inhoud wordt geklonken? Houdt de burgerlijke rechter rekening met deze verschillende aspecten van rechtskracht?

Formele rechtskracht werd gehanteerd als afbakeningsinstrument, en staat dan in een lange rij van instrumenten ter beslechting van het aloude dilemma. Formele rechtskracht als afbakeningsinstrument is een procestechnisch middel in een verdelingsvraagstuk dat de (grond)wetgever nimmer heeft opgelost. Afbakening van rechtsmacht geschiedt immers door de wijze van redigeren van de bevoegdheid van rechters. Daarbij moet het terrein waarbinnen de rechter competent is, worden geduid. De ontvankelijkheidswraag kont pas daama en betreft de vraag of de rechtszoekende een fout heeft gemaakt, zodat de rechter hem (ondanks zijn bevoegdheid) de toegang kan weigeren. Als de burgerlijke rechter ontvangt, zal hij bevoegd zijn. Als de burgerlijke rechter ontvangt, staat eveneens de vraag. centraal naar de mate waarin de rechter zaken waarover ook de bestuursrechter een oordeel geeft of kan geven (zelfstandig) mag toetsen. Ook die vraag weerspiegelt de afbakening van de rechtsmacht. In het dilemma van de afbakening van rechtsmacht(en) staan dus drie vragen (naar bewoegdheid, naar ontvankelijkheid en naar zelfstandige toetsing) centraal.

1. Vgl. Annotator Van der Burg onder HR 14 mei 1993, en HR 18 juni 1993, AB 1993, 503 en 504, p. 1455; A-G Koopmans bij HR 8 december 1995, CRwdW 1995, C266, p. 716 en A-G Bloembergen bij HR 11 aktober 1996, CRvdW 1996, C201, p. 692.

2. Vgl. HR 16 mei 1986, AB 1986,573 met noot F.H. wan der Burg (Heesch-Van de Akker). 
Hiema zal betoogd worden dat in het arrest Heesch-Van de Akker deze drie lijnen samenkomen. Conclusie daarvan is dat de Hoge Raad (als burgerlijke rechter) zichzelf naar de letter van zijn bevoegdheidsomschrijving nog immer bevoegd acht op terreinen waar ook de bestuursrechter actief kan zijn, maar dat hij die expliciete conclusie uit de weg gaat door gebruik te maken van het afbakeningsmiddel formele rechtskracht van beschikkingen. Aldus vat de Hoge Raad in Heesch-Van de Akker zijn rechtsmacht op zowel als bevoegdheid, als ontvankelijkheid, als toetsbaarheid, waarbij ter beslechting van de vraag hoe de rechtsmacht afgebakend wordt de beschikking (als eis, het petitum) met haar formele rechtskracht als het 'objectum litis' voorop wordt gesteld. De gerichtheid op normen van deze rechtshandeling is het niet-toetsbare voorwerp, waarover de burgerlijke rechter oordeelt geen rechtsmacht te hebben. Het niet toetsen zoals met formele rechtskracht werd geîntroduceerd betekent dat het oordeel van ofwell de administratieve rechter, ofwel van het bestuursorgaan wordt overgenomen. Dat oordeel kan zowell rechtmatigheid als onrechtmatigheid inhouden. Wanneer echter expliciet door partijen wordt aangegeven dat niet de beschikking als rechtshandeling ter beoordeling voorligt, dan kan het feit(ensubstraat) wel worden beoordeeld op conformiteit met (burgerrechtelijke) normen. Concreet betekent dit dat de burgerlijke rechter de vraag of er sprake is van een onrechtmatige daad (feitelijk handelen dat leidt tot aansprakelijkheid) dan wel beoordeelt.

Daarmee is aangegeven dat steeds wanneer de formele rechtskracht ter tafel ligt er eigenlijk sprake is van transparante lagen. Steeds gaat het om de rechtsmachtvraag. Steeds tracht de burgerlijke rechter een oplossing voor deze kwestie te zoeken en vinden; zo wordt 'niet ontvangen' een instrument en later wordt 'niet toetsen' als gevolg van de aanwezigheid van formele rechtskracht het nieuwe instrument. We zullen hierna constateren dat de rechtsmachtkwestie in eerste instantie werd opgelost met behulp van de bevoegdheidsvraag. De tweede fase van de rechtsmachtdiscussie wordt zichtbaar bij de ontvankelijkheidsvraag en de derde fase (de formele rechtskracht-fase) wordt concreet bij de toetsingsvraag. Wanneer in het hiernavolgende die toetsingsvraag aan de orde komt, is er sprake van een doorkijkje in drie lagen naar de rechtsmacht.

Drie aparte, maar met elkaar verweven rechtsmomenten spelen dus een belangrijke rol: de bevoegdheidskwestie, het ontvankelijkheidsprincipe en het - als gevolg daarvan - al of niet overgaan tot zelfstandige toetsing door de burgerlijke rechter. Langs deze drie sporen is (de vraag naar de invloed van de administratieve rechtspraak op de bevoegdheid van de burgerlijke rechter in) dit hoofdstuk opgebouwd. Voor een goed begrip zal ik ze alledrie bespreken. De daarbij voorliggende vraag luidt: welke zijn de voorlopers van het beginsel van de formele rechtskracht van beschikkingen? Via die sporen tracht ik de voorgeschiedenis van Heesch-Van de Akker in kaart te brengen. Jurisprudentie van na Heesch-Van de Akker komt in dit hoofdstuk derhalve niet ter sprake (maar in hoofdstuk 5).

Bij het zoeken naar de sporen neem ik de formulering door de Hoge Raad van het beginsel van formele rechtskracht van beschikkingen zoals die tot uitdrukking kwam in Heesch-Van de Akker tot uitgangspunt. Met die formulering en de sporen als leidraad kan de zoektocht beginnen. Die formulering is als volgt: 
3.3.1 De onder 3.1 .5 (: weergave van de oodelen van het hot, EvdL) weergegeven opzet van "s hots gedachlengang vergt wervolgens beantwoording van de door de middelen II en III an de onde gestelde verag of het hof hel prinaire betoog van de gemeente - kort gezegd: dat de betaling berust op een beschikking met formele rechtskracht herwoor 3.14 (: weergave van in rechte ingenomen standpunten, ExdL) - terecht heeft verworpen.

3.32 Deze vraag moet bewestigend worden beantwoord. Voorop noet worden gesteld dat wanneer tegen cen beschikking een met voldoende waarborgen onklede administratiefrechtelijke rechtsgang heeft opengestaan (zoals die ingevolge de Wet Arob), de burgerlijke rechter, zo deze beroepsgang niet is gebruitit, in geval de geldugheid yan de beschikking in thet woor hem gevoerde geding in geschil is, ervan dient uit to gann dat die beschikking zowel wat haar wijze wan tot stand komen als wat haar inhoud bettef in overenstemming is met de desbetreffende wettelijke woorschriften en algemene rechtsbeginselen. Dit geldt in beginsel bok dan, indien dit de burgenijke rechter ertoe zou nopen an zijin uitspraak de rechtsgeldigheid ten grondslag te leggen van een beschikking waarvan als vaststaand mag worden aangenomen dat zij, Alls daategen tijdig administratiefrechelijk beroep zou ziju ingesteld, zou zijn vernietigd. De daaraan verbonden bezwaren kumnen everwel door bijkomende onstandigheden zo klemmend warden dat op tat beginsel een uitzondering moet worden aanvaard. Of voor zuk een uitzondering plats is, hangt biggevolg af wan de bijzonderbeden van het gegeven geval. ${ }^{3}$

\subsection{Bevoegdheid van de burgerlijke rechter}

\subsubsection{Inleiding}

Welke is de omvang van de bevoegdheid van de burgerlijke rechter? Volgens sommigen is die bevoegdheid ruim. Traditioneel acht de burgerlijke rechter zich bevoegd om kennis te nemen van geschillen inzake eigendom (en andere burgerlijke rechten en schuldvorderingen) van burgers jegens de overheid. ${ }^{4}$ Gevolg daarvan is dat de rechter in beginsel zal ontvangen. De traditie van bevoegdheid van de burgerlijke rechter stamt al van voor de opkornst van het administratieve recht met zijn eigen administratieve beroepsgang(en) en/of rechtsgang(en $)^{5}$ en werd ook neergelegd in het destijds geldende art. 165 van de Grondwet (van 1815) ${ }^{6}$, hetgeen thans is geregeld in art. 112 van de Grondwet terwijl het zijn uitwerking zou vinden in de artt. 1 en/of 2 Wet R.O. Het laatste artikel is inmiddels afgeschaft. ${ }^{7}$ Volgens anderen is de bevoegdheid van de burgerlijke rechter zeer ruim. Het

3. HR 16 mei 1986, AB 1986,573 (Heesch-Van de Akker), p. 1661, linkerkolom

4. Vgl, F.A.M. Stroink. Kem van de bestuursrechusprak, "S-Oravenhage 1997, p. 46 e.k. en p. 205 e.v

5. Voor een heldere beschrijving wan afbakening vabi rechtsmacht, met name van de methode wan het recursus ad principem (opwerpen wan het conflict voor de heerser) ter oplossing van afbakeningsvragen, werwijs ik naar de dissertatie van J. Drion, Administratie contra rechter tot de intrekking van het Conflictenbesluit, "sGravenhage 1950.

6. Vg1. A.J.H.W.M. Versteeg, dic het eerste hoofustuk wan zijn dissertatie wijd aan de bevoegdheidswerdeling in onze Grondwet(ten), Verdeling wan rechtsmacht, Deventer 1987 en ook F.A.M. Stroink, Rechterlike orgarisatie en rechtspraak in beweging, Zwolle 1993 , p. 153 e. . die ingat op de nuanceverschillen van de grondwetsbepalingen; evenals J.M.H.F. Teunisen, Het burgerlijk kleed van de statat, diss, Zwolle 1996, p. $251-252$.

7. Het oude art. 2 Wet Rechterijke Organisatie is vervallen bij de wet van 16 december 1993, \$tb. 650 . 
is in deze optiek een algemene bevoegdheid. Zonderland staat aan de wieg van die visie, zoals ook door Teunissen ${ }^{3}$ en Verheij ${ }^{10}$ is aangegeven.

De rechter waakt zelf over zijn bevoegdheid. "De burgerlijke rechter beslist zelf over zijn bevoegdheid' stelt Van Angeren, en dat houdt in dat de burgerlijke rechter bepaalt 'welke invloed het bestaan van een procedure woor de administratieve rechter heeft op zijn eigen bevoegdheid". "Het destijds nog geldende artikel 2 RO gaf, evenals het thans geldende, artikel $112 \mathrm{GW}$ geen termen om aan te nemen dat de burgerlijke rechter onbevoegd zou zijn kennis te nemen van geschillen, waarover de administratieve rechter een beslissing kan geven. ${ }^{12}$ De oorsprong van deze rechterlijke activiteit kan gevonden worden bij het leerstuk wan de onrechtmatige overheidsdaad. ${ }^{13}$ Van Maanen concludeert ten aanzien van de periode tot het begin van de jaren tachtig van vorige eeuw dan ook dat de Hoge Raad een ruime opvatting van de onrechtmatige daad aanhing en ook schade-acties tegen de overheid toewees:

'Uit deze arresten mag afgeleid worden, dat de Hoge Raad in ieder geval tot in de jaren tachtig van de vorige eeuw nog een ruime opvatting van de onrechtmatige daad aanhing, ook wat betreft de aansprakelijkheid van de overheid. (...) De rechter achtte zich bevoegd, de vordering werd ontvankelijk geacht en gegrond bevonden. (...)

Gemeenschappeljik an de gevallen die ik heb gevonden is dat het vrijwel altijd ging om feitelijk owerheidshandelen in het kader van de uitvoering van specifieke door de overheid op zich genomen taken. Ook lijkt het er op dat beslissend is de vraag of eisers eigendon is aangetast door het overheidsoptreden. Op grond

8. Vgl. P. Zonderland, Het kort geding in het bijzonder tegen de overheid, Zwolle 1972, p. 156-161.

9. Vgl. J.M.H.F. Teunissen, Het burgerlijk kleed van de staat, diss., Zwolle 1996, p. 70, 97 en 280 .

10. Vgl. N. Verheij, Bevoegdheidswerdeling tussen burgerlijke en besturursrechter, preadvies nt. 50 voor de Nederlandse Vereniging woor Rechtswergelijking, Deventer 1994, p. 60.

11. J.A.M. van Angeren, De gewone rechter en de administratieve rechtsgangen, diss., Deventer 1968, p. 49.
12. Vgl. A.J.H.W.M. Versteeg, Verdeling van rechtsmacht

12. Vgl. A.J.H.W.M. Versteeg, Verdeling van rechismacht, diss., Deventer 1987, p. 10: 'De wijze waarop art. $112 \mathrm{Gw}$ is geformuleerd is de verwoording van de in de rechtspraak van de burgetlijke rechter over de bevoegdheidsverdeling tussen burgerijke en administratieve rechter gehanteerde methode: de verruinde objectum-litis-interpretatic maakt de burgerlijke rechter in theginsel ook bevoegd om van geschillen kennis te nemen, die bij cen fundamentum petendi-uitleg aan zijn kennisneming zouden zijn onttrokken." En verderop: 'Deze verschillente redacties shiten elkaar niet uit: de geschillen van art. 112 lid 1 Gw onwatten de geschillen ats bedoeld in art. 112 lid $2 \mathrm{Gw}$. Daarmee heeft de grondwetgever bereikt dat in geval ween

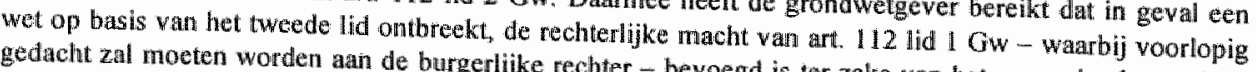
getacht zal moeten worden aain de burgerlijke rechter - bevoegd is ter zake van het voorgelegde geschil", p. 37. Dit wordt wel de grammaticale interpretatie genoemd. Vgl. ook: J. wan der Hoeven, De drie
dimensies van het bestuursrecht, Alphen a/d Rijn 1989 , p. 143 . 13. Met de constatering dat het leersituk wan de onrechtmatige overheidsdaad middenin de strijd stat on de
uiteindelijke soevereine macht, een strijd tussen rechter en wetgever/executieve, geef $J$. Drion het leerstuk
een sleutelplats in Administratie contra recher een sleutelplaats in Administratie contra rechter, diss., "S-Gravenhage 1950. J. van der Hoeven, De drie dimensies van het bestuurstecht, Alphen a/d Rijn 1989, stelt in op p. 143: 'Meestentijds oordeelde de rechter zich bevoegd van de voorgelegde vraag kennis te nemen op grond van artikel 2 van de Wet op de stalat, diss., Zwolle 1996, p. 70 en 97 . 
van art 2 RO was dan in ieder geval de burgerlijke rechter bevoegd (en de eiser ontwanketijk). Tot zover de rechispraak tot $1883^{\text {,14 }}$

Wanneer bevoegdheid in beginsel bestaat, is er ook het risico dat zaken berecht worden die de rechter helemaal niet aan zich had willen trekken. Om de omvang van zijn rechtsmacht te kunnen reguleren ontstond al snel de methode van de ntet-ontvankelijkverklaring. De breuk in de trend van bevoegd zijn en eiser ontvangen wordt door Van Maanen gekoppeld aan de arresten Vrouwe Elske en Rhedense koe wan 1896 en $1898^{15}$ :

\begin{abstract}
"Méest opvaltend in deze perode van $1883-1916$ is natuwrlijk dat schadelijdende burgers vanaf 1896 nietontvankelijk worden verklaard in hun actie tegen de overheid terzake van situaries die woor die uitspragk wèl tot ontvankelijkheid konden leiden en veelal ook gegrond werden bevonden. Met de arresten inzake de Vrowwe Elske van 1896 en de Rhedense koe van 1898 breekt de Hoge Raad met het verleden (..). Reeds in 1901 worden de scherpe kantjes van deze niet-ontvankelijkheidsdoctrine afgeslepen doordat de eiser bij de burgerlijke rechter wel ontwankelijk wordt geacht war geklangd wordt over ongeldigheid van een verordening met als gevolg een inbreuk op een eigendomsrecht van een burger. ${ }^{16}$
\end{abstract}

Aldus ondęrscheidde de burgerlijke rechter aanvankelijk niet tussen oordelen over feitelijk handelen en rechtshandelen. In dat licht is van belang dat pas in 1932 het beschikkingsbegrip hier te lande door Van der Pot werd geintroduceerd, ${ }^{17}$ zodat onderscheidingen van overheidshandelen in concrete en algemene activiteiten voor die tijd nog niet echt voor de hand lag, nog afgezien van het feit dat de burgerlijke rechter zijn oordeel over zijn bevoegdheid waarschijnlijk vooral liet afhangen van de vraag of er sprake was van de eigendom rakende gebeurtenissen. Zo hanteerde hij een perspectief vanuit de burger (en niet vanuit de overheid).

De les is duidelijk. Zo blijkt, stelt Van Maanen, 'de bevoegdheid'van de rechter nooit een obstakel te zijn geweest'. Met de aanname van de objectum litis-leer in het arrest Guldemond-Noordwijkerhout ${ }^{18}$ wordt dat nog eens op principiële wijze onderstreept: "Wel een drempel kon - aan het eind van de negentiende eeuw - de ontvankelijkheidsvraag opleveren. ${ }^{19}$ In twee geschillen (een geschil van 1907 over uitbetaling van salaris aan een onderwijzer van een 'gemeenteschool' en een geschil van 1908 over de uitbetaling van riddersoldij aan een geridderde militair), stelde de Hoge Raad deze objectum litis-leer al

14. G.E. van Maanen, De wonderbaarlijke geschiedenis van de onrechtmatige owerheidsdand in de 190 an 200 eeuw, Nijmegen 1996, p. 38-39 (cursivering Van Maanen).

15. Vgl. HR 29 mei 1896, W.6817 (Vrouwe Elske) en HR 21 april 1898, W. 7116 (Rhedense koe).

16. G.E. van Maanen, De wonderbaarlijke geschiedenis van de onrechtmatige overheidsdaad in de $19 \mathrm{e}$ en $20 \mathrm{e}$ eeuw, Nijmegen 1996, p. 52 (cursivering Van Maanen).

17. Vgl. C W. van der Pot, De wormen van het besturen, in: Nederlands Bestuursrecht, Alphen a/d Rijn 1932, p. 201 e.v.

18. Vgl. HR 31 december 1915, NJ 1916, 407.

19. G.E. van Maanen, De wonderbaaritike geschiedenis van de onrechtmatige overheidsdaad in de $19 \mathrm{e}$ en $20 \mathrm{e}$ eeuw, Nijmegen 1996, p. 55 (cursivering Van Maanen). 
eerder in werking. De Hoge Raad baseerde daar immers de bevoegdheid van de burgerlijke rechter op de door eiser ingestelde vordering. ${ }^{20}$

\title{
2.2.2 Verklaring voor het niet ontwangen
}

Vraag is waarom die ontvankelijkheidswraag een drempel kon opwerpen woor eiser. Dat heeft alles te maken met de visie die de burgerlijke rechter heeft op de vraag of en in hoeverre de burgerlijke rechter het gedrag van het bestuur (dat effecten heeft op de eigendom) mag beoordelen. Hier wordt de stelling verdedigd dat de toetsing door de burgerlijke rechter (van het handelen van de overheid via de onrechtmatige daad) verloopt van integrale toetsing (vanaf de invoering van rechtspraak door de burgerlijke rechter) naar helemaal niet toetsen (vanaf de invoering van de hoofdregel van de formele rechtskracht van beschikkingen).

\begin{abstract}
'Atrvankelijk - neergelegd in art. 165 van de Grondwet van 1815 - acht men het wolstrekt vanzelfsprekend dat de burgerlijke rechter moet kunnen oordelen als de burger aangetast wordt in zijn eigendomsrecht, ook als dat een gevolg is van owerheidshandelen. Bij het bestur ontstond irritatie over sommige rechterlijke uitspraken waarin deze het handelen wan dat bestuur kritiseerde. Dat heef toen geleid tot het Conflictenbeslüt wan $1822(\ldots)$. Uit do toepassing van het Conflictenbesluit is gebleken dat daarmee geenszins beoogd werd alle acties tegen de overheid te treffen. Waar het ging on aantasting van de eigendom van de burger was de burgerlijke rechter bevoegd en greep de Koning niet in. Slechts in die gevallen waarbij het beleid van de overheid of de effectiviteit van de administratie op het spel stond werd ingegrepen. 21
\end{abstract}

Aldus was de enige kwestie de aloude vraag of de rechter 'op de stoel van het bestuur' mag zitten; de onderscheiding van de machten.

\footnotetext{
'De verklaring moet dan zijn dat men (de Hoge Raad onder invloed van auteurs?) kennelijk wan oordeel is dat waar het gaat om een pabliekrechtelijke verplichting de (burgerlijke) rechter daar niet in mag treden. (..) is er misschien sprake wan een andere visie op de rol van de overheid tegen het einde wan de negentiende eeuw? Was het niet zo dat velen in het begin en hef midden wan de negentiende eeuw de overheid" - uiteraard met enige nuance - als niet wezenlijk verschillend zagen van burgers die schade veroorzaakten? Als het zo zou zijn dat men - bijvoorbeeld in klassiek liberale kringen - tegen het cinde van de negentiende eeuw een andere visic krijgt op de positie van de overheid, als duidelïk bóven de maatschappij staand, onderworpen aan andere regels en normen (het immiddels to volle wasdom gekomen publiekreclt), dan is de opvatting die tot uitdrukking komt in het arrest Vrouwe Elske weel beter te begrijpen: je kunt als burger de overheid niet zomaar auspreken tot schadevergoeding! 22
}

Ingebed in de op dat moment actuele discussie over al of niet invoering van administratieve rechtspraak krigt de trendbreuk van Vrouwe Elske meer kleur. De Hoge Raad heeft

20. Vgl. HR 20 december 1907, W. 8641 en HR 19 juni 1908; W. 8722

21. G.E. van Maanen, De wonderbaarlijke geschiedenis wan de onrechtmatige overheidsdaad in de $19 \mathrm{e}$ en $20 \mathrm{e}$ eeuw, Nijnegen 1996, p. 68 (cursivering Van Maanen).

22. G.E. van Manen, De wonderbarlijke geschiedenis van de onrechtmatige overheidsdaad in de 19 e en $20 \mathrm{e}$ eeuw, Nijmegen 1996, p. 69 (cursivering Van Maanen). 
zich kennelijk willen mengen in de discussie over invoering van administratieve rechtspraak:

Hel komi dan ook niet onwarschignlijk woor, dat de arresten van 1896 en 1898 , tot stand gekomen in de tijd waarim niet alleen de discussies over de iwwoeting van administratiewe rechispratk binnen de juridische wereld grote belangstelling hadden, naar ook de verwachtingen wan een spoedige invoening trvan duidelijk hoog gespannen waren, mede de weg hebben willen banen woor een duidelijke en harmonische takverdeling ussen de burgerlijke en de administratieve rechter. ${ }^{23}$

Dat het toen niet tot invoering van administratieve rechtspraak is gekonnen, veroorzaakte - in de woonden van Van der Hoeven - de infiltratie of penetratie van het burgerlijk recht in het bestururstecht. ${ }^{24}$

\subsubsection{Het niet ontvangen en de invoering van de administratieve rechtspraak}

Invoering van administratieve rechtspraak had voor de burgerlike rechter de gewenste duidelijkheid kunnen brengen inzake de omvang van zijn rechtsmacht. Vandaar dat de Hoge Raad het ontvankelijkheidsprincipe introduceerde. Doordat de invoering van administratieve rechtspraak mislukte, viel de Hoge Raad terug op zijn traditionele algemene bevoegdheid. ${ }^{25}$ Het probleem van het bepalen van de omvang van zijn rechtsmacht bleef, evenals zijn terughoudendheid ten opzichte van de andere machten:

'En het had tenslotte tot gevolg, dat het belangrijkste probleem, hoe en op welke wijze exn goede bestuursgang te verenigen med adequate rechtsbescherming, fundamenteel onopgelost bleef, 26

Tegelijkertijd stond ook vast dat een methode van recursus ad principem was uitgesloten. ${ }^{27}$ Een impasse ontstond, waarin de burgerlijke rechter weinig restte dan over te gaan tot zelfstandig toetsen. (Merk op dat met de aanname van formele rechtskracht dit is omgekeerd; nu lijkt de burgerlijke rechter dankzij aanwezigheid van bestuursrechtspraak, maar ondanks zijn bevoegdheid toch niet te willen toetsen.) De gevoeligheid bij de burgerlijke rechter voor het uitblijven van invoering van administratieve rechtspraak bleef:

23. J. van der Howen, De drue dimensies van het bestururecht, Alphen a/d Rijn 1989, p. 144.

24. Vgl. J. van der Hoeven, De drie dimensies wan hel bestuursecht, Aphen a/d kijn 1989, p. 144-145 en p. 154.

25. Vgl. J. van der Hoeven, De drie dimensies van het bestuursrecht, Alphery a/d Rijn 1989, p. 154: 'Door hen uitblijwen wart een bestwursrechtelijke rechtspraak ontstond ean waculom dat door de civiele rechtspraak moest worden gevuld.'

26. J. wan der Hoeven, De drie dimensies van het bestuurstecht, Aphen add Rijn 1989, p. 154 .

27. Het Conflictenbesluit was immers een mislukking gebleken. Vgl. I. Drion, Administratie contra rechter tol de intrekking van het Conflictenbesluit, diss., "s-Gravenhage 1950, p. 210-211: "Na enige discussie aver de motivering van thet intrckkingsbesluit, kwam dit tenslotte op 20 mei 1844 af, her Conflictenbesiluit werd ingetrokkeri (...). Door de wijziging van de artt. 1 en 88 R.O. in 1835 had de wetgever bepalid, dat aan de Hoge Raad de beslissing toekomt over de vraag, of de gewone rechterlijke macht dan wel een bijzonder college, met rechtspraak belast $(.$.$) bewoegd is van een zaak kemis te nemen."$ 
"Dit proces van civielrechteligke penetratie in het bestuurstecht verliep zeer geleidelijk. Aanvankelijk bestond bij de rechtenlijke macht kennelijk een werklaarbare schroom om overheidsorganen woor de voeten to lopen. Weliswar verklaarde de rechter zich niet onbevoegd, mals wolgde hilj de weg wan het niet-ontrankelijk verklaren. Mar die niet-ontwankeljk verklaring was alleen mogelik op grond van helt priwatrechtelijk aordeel, dat artikel $1401 \mathrm{BW}$ alleen betrekking heeft op privatrechtelijke onrechtmatigheid. Bevredigend was deze oplossing natuurlijk niet, want de terughoudendhe td bij de interpretatie vas art. 1401 BW had tot gewolg, dat kennelijk overheidsonrecht soms ongestraft kon plaatsvinden en aan het onschuldig slachtoffer de door hem geleden schade onvergoed bleef. Vandaar dat de rechter stap voor stap zijn bemoeiing uitbreidde. ${ }^{28}$

Een voorbeeld van dat expliciete terugtreden van de burgerlijke rechter voor de competentie van de administratieve geeft de Hoge Raad in 1941. De uitzondering die de regel bevestigt, wordt dan gevormd door de Ambtenarenwet, die hier wordt beschouwd als lex specialis. In ambtenarenzaken is de burgerlijke rechter dan 'met terzijde stelling van den algemeene regel van art. 2 R.O.' onbevoegd. Een dergelijk geschil is naar het oordeel van de Hoge Raad aan diens rechtsmacht onttrokken door de bepalingen van de Ambtenarenwet 1929 (oud), welke bepalingen van openbare orde zijn en waarop de rechter dan ook ambtshalve acht heeft te slaan. ${ }^{29}$

Een ander voorbeeld van die benadering van de bevoegdheid (de toepassing van de leer van het fundamentum petendi) is te zien in het geschil tussen een veiling en het bedrijfschap. Het hof had de rechtbank onbevoegd verklaard. Het middel kwam daartegen op. De volgende overweging van de Hoge Raad ten aanzien van zijn verhouding tot het Scheidsgerecht Voedselvoorziening is cruciaal:

"dat art. 13 van het Organisatiebesluit Voedselvoorziening 1941 slechts dezen uitleg toelaat, dat alle
geschitlen, weike hun oorsprong vinden in de publiekrechtelike verhouding tussen een organisatie en een
ondernemer als in het artikel bedoeld, met ontrekking aan beoordeling door den gewonem rechter in eerste
instantie door een scheidsgerectht worden beslist" 30

Aldus is de gewone rechter onbevoegd en wordt het beroep tegen deze beslissing verworpen; de beoordeling van het geschil is onttrokken aan de burgerlijke rechter en moet geschieden door het scheidsgerecht.

Weer een ander voorbeeld van onbevoegdheid, beter gezegd van het aangeven van de grenzen van de omvang van de bevoegdheid, is het in cassatie in het belang der wet gewezen Elslooêr" verkiezingsafspraak. Daar oordeelt de Hoge Raad geschillen over overeenkomsten met betrekking tot de verkiezingen als niet vallend onder art. 2 RO en omdat ook geen andere wettelijke bepaling aan de rechterlijke macht bevoegdheid verleent, komt

28. J, van der Hoeven, De drie dimensies van het bestuursrecht, Alphen a/d Rijn 1989, $p .156$.

29. Vgl. HR 13 november 1941, NJ 1942, 172 (Staat-Bonneveld). Deze visie kan ook als ongrondwettig worchen gezien, zoal beschreven werd door F.A.M. Stroink, Rechlerlijke organisatie en rechtspraak in beweging, Zwolle 1993 , p. 155 e.w. Het arrest is inwiddels achterhaald door HR 28 februari 1992, AB
1992, 301 m.nt. FHvdB (Changoe).

30. HR 24 maart 1950 , NJ 1950,662

Groenten en Fruit), $1155, \mathrm{rk}$. 
kennisneming niet aan deze toe. ${ }^{31}$ Kennelijk moet de burgerlijke rechter voor verkiezingsgeschillen uitdrukkelijk bevoegd zijn verklaard door de (grond)wetgever anders trekt hij deze rechtsmacht (deze beslechting) niet aan zich. Is de Hoge Raad de administratieve rechter hier voor geweest, in die zin, dat hij zich al conformeen aan diens (kennelijk als materieel uitsluitend ervaren) bevoegdheid nog voordat de bestuursrechter hierover expliciet zijn oordeel heeft gegeven?

Vanuit historisch perspectief kan de ontwikkeling van de administratieve rechtspraak worden beschouwd als een drietrapsraket: de eerste trap wordt gevormd door de ontwerpen Loeff, ${ }^{32}$ die het niet haalden evenals de ontwerpen $\mathrm{ODOL}^{33}$; daarna volgde de wel ingevoerde wet $\mathrm{BAB}^{34}$ en wet $\mathrm{Arob}$ - dit is de tweede trap; de derde trap wordt dan gevormd door de integratie in de rechterlijke macht en de invoering van de $\mathrm{Awb}$. Zowel in het voortraject van de invoering van de wet Arob (en niet te vergeten het achterwege blijven van invoering van het ontwerp-ODOL) als na de invoering zien we weer de rituele reidans rond bevoegd zijn en al of niet ontvangen. Zo bleef de ratio woor het instandhouden van het ontvankelijkheidsprincipe in stand.

Er waren wel verschillen. De onrechtmatige overheidsdaad ging steeds meer een eigen leven leiden - mede als gevolg van het niet aannemen van het ontwerp ODOL. De burgerlijke rechter voelde zich kennelijk steeds vrijer om zijn aanvankelijke aarzeling om overheidsoptreden te beoordelen overboord te zetten; al doende leert men, zou gezegd kunnen worden. Een verder geëwolueerd punt in deze ontwikkeling is dan ook het voor de burgerlijke rechter dagen van de burger door de overheid ter zake van onreclitmatige daad; een handelen waarbij (na de poging daartoe in Limmen-Houtkoop) ${ }^{3.5}$ de rij werd geopend in het arrest Benckiser ${ }^{36}$ en die in het arrest Kabayel ${ }^{37}$ zijn vervolg kreeg.

Een ander verschil speelt zich af rond de afbakening van de rechtsmacht ter zake van het voorwerp van het geschil bij de administratieve rechter. Met de invoering van de wet Arob werd de administratieve rechter (meer) algemeen bevoegd ter zake van de beslechting van geschillen inzake beschikkingen. Het woorwerp van rechtsingang werd daarmee tot omvang van het geschil. Aangezien de burgerlijke rechter zich traditioneel steeds bevoegd achtte

31. Vgl. HR 26 maart 1971, NJ 1971, 434 (Elslooër verkiezingsafspraak).

32. Ingediend in 1905 (TK, Bijlagen 1904-1905, Mr. 159, p. 1-64) en ingetrokken in 1937

33. De ontwerpen Onrechtmatige Daden Overheidslichamen (ODOJ) werden voorgesteld door de Commissicm De Monchy in 1950 (die adwiseerde inzake te verhoogde rechtsbescherming), maar werden nimmer behandeld.

34. De ontwerpen Beroep administratieve Beschikkingen (BAB) werden voorgesteld door de Commissie de Monchy in 1950 en ingevoerd in 1963 (Wet wan 20 juni 1963, Stb. 268); de wel BAB trad in werking op 1 januari 1964. De wet $\mathrm{BAB}$ werd gevolgd door de wet Arob (van 1 mell 1975, Stb. 284). De wet Arob is voorbereid door de commissie Wiarda (eveneens inzake werhoogde rechtsbescherming).

35. Vgl HR 9 november 1973, NJ 1974, $91 \mathrm{m.nt}$. W.F. Prins, die de term onrechtmatige daad dan ook kwalificeert alls "towerformule voor toegang bij de burgerlijke rechter".

36. Vgl HR 14 april 1989, AB 1989, 486 mnt. Kleijs-Wijnnobel.

37. Vgl HR 18 februari 1994, RvdW 1994, 58 (Staat-Kabayel). 
inzake rechtsverhoudingen die voortvloeiden uit een burgerlijk recht of sehuldvordering ${ }^{38}$ moest deze afbakening samenval en overlap opleveren. Bekend is dan ook die langjarige jurisprudentie ter zake van het bepalen of de rechter van doen heeft met een rechtshandeling naar burgerlijk recht dan wel mel een beschikking. ${ }^{34}$ De bestursrechter hanteerde aldus een afbakeningsmethode (bij de ingang) die materiëler georiênteerd was (wat is een beschikking, een rechtshandeling naar burgerlijk recht leidt immers naar de vraag wat het onderscheid tussen publiek- en privaatrecht is) dan de methode van de burger]ijke rechter (stellen geeft toegang). Zo werd de aanwezigheid van een beschikking voor de burgerlijke rechter steeds belangrijker.

\subsubsection{Bevoegdheid im het licht van de ontrafeling van feit, norm en gevolg}

De bevoegdheid van de bestuursrechter is gekoppeld aan het besluit. Het feitelijke besluit (voorheen beschikking), als uitdrukking van de publiekrechtelijke rechtsvaststelling is immers voorwerp van rechtsingang bij de bestuursrechter. Dit feit kan slechts worden vastgesteld op basis van objectieve publiekrechtelijke normen (bevoegdheid met specialiteit) en creeert als zodanig rechtsgevolgen (van objectief recht) met erga omnes-werking. Dit feit is, omdat het objectief van aard is, niet hetzelfde als een burgerlijk recht (of schuldvordering); het is immers geen subjectieve aanspraak.

De bevoegdheid van de burgerlijke rechter heeft andere verbanden met feit, norm en gevolg. Daar is de burgerrechtelijke verhouding (het recht of de plicht) het gegeven op basis waarvan de rechter zich bewoegd acht. Dit gegeven wordt beoordeeld aan normen (redelijkheid en billijkheid), zodat het gevolg een aanspraak (een subjectief recht) of een plicht (een al even subjectieve schuld) wordt.

In het kader van de werkhypothese van deze studie kan als slotsom opgemerkt worden dat de burgerlijke rechter als oorspronkelijke (en een tijd lang ook de enige) rechter door het beoordelen van de effecten wan het handelen van de overheid in het kader van een onrechtmatige daadsvraag, oordeelde over feitelijk handelen (dat effecten had op de eigendom wan burgers), maar ook over het de bevoegdheidsuitoefening, anders gezegd de 'gezagsuitoefening" of het 'typische overheidshandelen' (wanneer dat effecten had op de eigendom van burgers).

De inwoering van de administratieve rechtspraak had ook aan die praktijk een eind kunnen maken, maar deed dat echter niet. Veel duidelijkheid zou er kunnen zijn geschapen als de afbakening van de rechtsmachten van beide rechters ook langs deze scheidslijn had plaatsgevonden.

Het direct beoordelen wan normen (door zowel bestuursrechter als burgerlijke rechter) zou dan eveneens in een aparte discussie komen te staan, de discussie over de (onder)scheiding

38. Vgl. F.A.M. Stroink, Kern van de bestuursrechtspraak, 's-Gravenhage 1997, p. 208.

39. Vgl. voor een uitvoerige beschrijving hiervan de dissertatie van F.C.M.A. Michiels, De Arob-beschikking, diss., 's-Gravenhage 1987. 
van machten. In hoeverre mogen rechters immers direct (algemene en abstracte) nomen - atkomstig van regelgevers - toetsen? Een antwoord in bevestigende zin is niet vanzelfsprekend indien het primaat van de wet voorop wordt gesteld.

Terug naar de onderscheiden toetsing van feiten door beide rechters. Door aldus twee verschillende toetsingswijzen scherper te onderscheiden, zou de taakverdeling van beide rechters duidelijker zijn geworden. De verschillende aard van de toetsing zou beter zichtbaar zijn geworden. Het oordeel van de bestuurstechter houdt in dat de beschikking destijds rechtens (in)correct is afgegeven en daarmee (on)rechtmatig is (en dat objectieve feitelijke oordeel krijgt formele rechtskracht). Het oordeel van de burgerlijke houdt in dat subjectieve aanspraak wordt bevestigd.

Dat onderscheid maken in verschillende toetsingswijzen zou betekenen dat twee naast elkaar bestaande kolommen van rechtspraak elkaar hadden kunnen aanvullen; controle van overheidshandelen is immers een andere toetsing als het vaststellen van rechtshandelingen. De rechtsbescherming van de burger zou daarmee gediend zijn geweest.

Dit alles is echter niet gebeurd. Begrijpelijk worden hierdoor wel de destijds bestaande hoge verwachtingen (bij de burgerlijke rechter) van invoering van administratieve rechtspraak. Het hanteren wan het niet-ontvankelijkheidsinstrument in afwachting daarvan was een op het eerste gezicht briljante, doch technische vondst.

De burgerlijke rechter heeft zichzelf steeds ook daar bevoegd geacht waar ook de bestuursrechter actief kon zijn (en dat was hij ook naar de letter van de Grondwet). De (aanstaande) invoering van administratieve rechtspraak bracht in die opvatting geen verandering (al had dat wel gekund). Vraag is of het niet-ontvankelijkheidsinstrument wel verandering bracht in die afbakening van rechtsmachten.

\subsection{Ontvankelijkheid bij de burgerlijke rechter}

\subsubsection{Inleiding}

Het fragiele onderscheid tussen de bevoegdheid van de burgerlijke rechter en de ontvankelijkheid bij de burgerlijke rechter kent verschillende benamingen. Versteeg maakt onderscheid tussen de bevoegdheid en de ontwankelijkheid in die zin dat bevoegdheid ziet op bevoegdheid tot kennisneming van een geschil en ontvankelijkheid concentreert op bevoegdheid tot beslechting. Ontvankelijkheid vooronderstelt dan bevoegdheid. Daarmee wordt ook de vraag naar de bevoegdheid van de burgerlijke rechter een formaliteit binnen de ontvankelijkheidswraag. ${ }^{40}$

Een andere benaming komt in zicht als wordt onderscheiden in formele en materiele bevoegdheid. Dan wordt gesteld dat wanneer een vordering valt binnen de algemene omschrijving van de bevoegdheid, zoals in artikel $112 \mathrm{GW}$, de betreffende recinter formeel bevoegd is. Daarnaast is er nog de materiele bevoegdheid die in beeld komt via bijzondere bepalingen, waarbij de formele bevoegdheid opzij wordt gezet. Het dictum van (formele) 
onbevoegdheid luidde 'onbevoegd' en bij 'materiële onbevoegdheid' luidde het dictum "niet-ontvankelijk".

Hier laten we de verschillende benamingen van het onderscheid tussen bevoegdheid en ontvankelijkheid rusten en kijken we naar de werking van het ontvankelijkheidsinstrument in gevallen waar de burgerlijke rechter zich bevoegd acht (terwijl ook de bestuursrechter competent is). De ontvankelijkheid geeft dan directer inzage in de afwegingen van de afbakening van de rechtsmachten. Het betreft dan namelijk een extra laag, die aangebracht is in de rechtsmachtdiscussie. Laten we de werking van dit ontvankelijkheidsprincipe iets nader analyseren. Hoe ging dat? Welke was de rol van de bevoegdheids- alias rechtsmachtvraag hierbij? Werden feit en norm (formele en materiële rechtskracht) bij deze vraag onderscheiden? Een presentatie van jurisprudentie lijkt hier aangewezen.

\subsubsection{De ontvankelijkheidsvraag}

Laten we kijken naar de gevallen waarin de burgerlijke rechter in het kader van de vraag of hij zal ontvangen overwegingen uit over zijn bevoegdheid. Dit omdat juist deze de (voor ons interessante) gevallen zijn waarin sprake kan zijn van samenval van competentie. In het Willemse-arrest ${ }^{42}$ overwoog de Hoge Raad dat de beoordeling van het geschilpunt in het onderhavige geding was opgedragen aan de administratieve rechter. Weliswaar is de burgerlijke rechter (in zijn algemeenheid) bevoegd tot beoordeling van vorderingen uit onverschuldigde betaling, zo overwoog hij, maar zodra blijkt dat beslechting van de grond van die vordering bij uitsluiting opgedragen is aan een bijzondere rechter (rechterlijk of administratief), dan mag de gewone rechter die vordering niet beoordelen. Het hof had dan ook moeten onderzoeken of de voorliggende vraag behoort tot de rechtsmacht van de administratieve rechter. In casu is de administratieve rechter, aldus de Hoge Raad, bij uitsluiting bevoegd ten aanzien van de vaststelling door de Sociale Verzekeringsraad van premie inzake aansluiting bij de bedrijfsvereniging. Derhalve is 's hofs beslissing juist, dat het onderhavige geschil ontrokken is aan het oordeel van de burgerlijke rechter en dat deze op die grond de ingestelde vordering niet kan ontvangen 'zolang dit geschil niet door den administratieven rechter is beslecht ${ }^{4}{ }^{43}$

De aanwezigheid van een uitsluitende bevoegdheid van de administratieve rechter maakte dat de burgerlijke rechter Willemse niet mocht ontvangen, ondanks dat de vordering uit onverschuldigde betaling in beginsel tot de bevoegdheid van de burgerlijke rechter hoort.

41. Vgl. G.J. Scholten onder HR 26 jun 1964, NJ 1965,2, p. 18 (Willemse). Versteeg wergelijkt de onderscheidingen formele en materiete bevoegdheid en bevoegdheid tot kerunisneming en tot beslissing met elkat en acht zij met elkaar overeen komen. Vgl. A.J.H.W.M. Versteeg, Verdeling van rechtsmacht, diss., Deventer 1987, p. 36. Anders: N. Verheij, die dit onderscheid kenschetst als een "terminologisch problempje", terwijl hij de materiele bevoegdheid als zodanig negeert, in Bevoegdheidsverdeling hussen burgerlijke en bestursrechter, preadvies nr. 50 voor de Nederlandse Vereniging voor Rechtsvergelijking, Deventer 1994, p. 63 .

42. Vgl. HR 26 Juni 1964, NJ 1965,2 m. nt. G.l. Scholten (Willemse-Nieuwe Algemene Bedrüfsvereniging voor Ziekengeldverzekering. Kinderbijslagwerzekering en Wachtgeld- en Werkloosheidsverzekering). 
Annotator Prins concludeert 'Voor de Hoge Raad was beslissend de vraag, of de administratieve rechter zich terecht competent acht de kwestie (...) te beoordelen. (...) Het arrest doet recht wedervaren aan de plaats, welke de administratieve rechter (en ook sommige administratieve beroepsinstanties) in ons rechtsleven innemen. ${ }^{.44}$

In eem geschil tussen $N V$ Van Wijk \& Heringa en BV Bouwburean Van der Linden \& $Z$ Znen over de verkoop van een gebouwencomplex, en daarmee samenhangend het beding dat de precariorechten voor rekening zouden zijn van de koper (Van der Linden BV), speelde ook de vraag of de beoordeling van dit geschil aan de burgerlijke rechter onttrokken was. ${ }^{45}$ Zowel kantonrechter als rechtbank hadden de precario-rechten opgevat als gemeentelijke belastingen en met betrekking tot de al of niet belastingplichtigheid van ofwel de koper (Van der Linden) ofwel van beide partijen meenden zij geen oordeel te kunnen geven. Een dergelijk oordeel hoort niet in een burgerlijk geding thuis. De Hoge Raad zag dat, in afwijking van de visie wan A-Gi Ten Kate, anders. De HR onderzocht van wie de leidingen waren - de eigendom; hij achtte een oordeel hierover in casu "geenszins aan de burgerlijke rechter onttrokken, zij het dat het niet bindend is voor de ter zake bevoegde rechter in belastingzaken. ${ }^{346}$

Annotator Brunner stelt dat de handelwijze van de Hoge Raad is terug te voeren op de regel "dat de rechter, die bevoegd is t.a.v. het gevorderde, tevens bevoegd - en dus verplicht - is te oordelen over alle voorvragen die van belang zijn voor de beslissing in de zaak, ook indien die vragen niet te zijner competentie zouden staan, indien zij het voorwerp van een afzonderlijk geding waren. (...) De regel geldt niet alleen voor de burgerlijke rechter; de strafrechter, de belastingrechter en de administratieve rechter moeten zich uitlaten over voorvragen, die liggen op het terrein van het burgerlijk recht, indien dat nodig is om de zaak te beslissen. (...) Voormelde hoofdregel is wat uit het zicht geraakt door de grote praktische betekenis van de uitzondering die op de regel moet worden gemaakt woor gevallen waarin de vorm van de civiele procedure wordt gebruikt voor het omgaan of opnieuw ter discussie stellen van beslissingen van de administratieve rechter. ${ }^{347}$

Op het eerste gezicht lijkt de Hoge Raad hier af te stappen van de eerder gevolgde lijn: wat ter beoordeling van de administratieve rechter ligt, is aan het oordeel van de burgerlijke rechter ontrokken. De nuancering van dit arrest ziet op de bevoegdheid van de burgerlijke rechter om te oordelen over voorvragen, die van belang zijn voor de beslissing in

44. W.F. Prins onder HR 26 juni 1964, AA 1966, p. 211.

45. Vgl. HR 2 februari $1979, \mathrm{NJ} 1979,58 \mathrm{~m}$. nt. Brunner (NV Van Wijk \& Hering $\mathrm{AV}$ Bouwbureau Van der Linden en Zonen).

46. Vgl. HR 2 februari 1979, NJ 1979,581 m. nt. Brunner (NV Van Wijk \& Heringa-BV Van der Linden \& Zonen), p. 1946, onder 5, linkerkolom (Kir.); p. 1947, onder 5 , linkerkolom (Rb.); p. 1949, rechterkolom (conclusie); en zie: p. 1947, onder 5, rechterkolom (middel wan cassatie) en p. 1948, linkerkolom (HR).

47. HR 2 febnari 1979 , NJ 1979, 581 met noot Brunner (NV Van Wijk \& Heringa-BV Van der Linden \& Zonen), p. 1950 , onder 2 , rechterkolom. 
de zaak. ${ }^{48}$ Deze voorvragen mogen zelfs onderwerpen bevatten die, ieder afzonderlijk, door de administratieve - of een andere bij uitsluiting bevoegde - rechter beoordeeld horen te worden, want zonder beoordeling van deze voorvraag kan de burgerlijke rechter het geschil niet oplossen. Wanneer de burgerlijke rechter dergelijke voorvragen niet aan zich zou trekken, zou dat neerkomen op rechtsweigering.

Merk overigens op dat juist met het aannemen van de hoofdregel van formele rechtskracht door de Hoge Raad aan deze regel van verplichte toetsing van voorvragen een eind werd gemaakt voor wat betreft de beoordeling van beschikkingen door de burgerlijke rechter; zo bezien is Brunners" uitzondering regel geworden. Dat is des te opvallender nu de Hoge Raad in casu nog aangeeft dat zijn oordeel niet bindend is voor de bestuursrechter, terwijl met het aannemen wan de hoofdregel van formele rechtskracht de burgerlijke rechter zichzelf bindt aan het oordeel van de administratieve rechter.

In Ameland $-D e$ Boer ${ }^{49}$ denken we op het eerste gezicht te maken te hebben met een klassiek geval van het uitwegvergunningenstelsel; in zoverre lijkt deze casus sterk op HeeschFan de Akker. In casu was echter een bijdrage (in de kosten van aanleg en verbetering van een stuk openbare weg) bedongen bij overeenkomst, waarbij pas na voldoening daarvan een bouwvergunning kon worden verleend. De Boer betaalde en vordert terug. De vergoeding diende in casu (partijen zijn het daarover eens) niet betald te worden voor de bouwwergunning-plichtige bouw zelf, maar voor de vrijstelling wan de Bouwverordening om te mogen bouwen aan een weg die niet voldeed aan de eisen van die Bouwverordening. Door betaling te verlangen verzekerde de gemeente zich ervan dat de weg aangelegd zou kunnen worden. De betalingen van De Boer (en anderen die eveneens op een perceel aan die weg wilden bouwen) in een fonds creëerde voor de gemeente de financiële ruimte om (straks) een weg aan te leggen die wel zou voldoen aan de eisen van de Bouwverordening; derhalve gaat het niet, zoals in het uitwegvergunningenstelsel, om betalingen voor het recht om uit te wegen op de (aan alle eisen voldane) openbare weg..$^{50}$

Hoe zien we de gelijkenis met de casus van Heesch-Van de Akker? Indien het terugvorderen onder de Wet Arob zou zijn gevallen, met andere woorden het daarop beslissen als beschikking was (h)erkend (en de weigering tot restitutie over te gaan niet door de ARRS werd beschouwd als het weigeren om privaatrechtelijk te handelen), zou de redenering zijn opgegaan dat een administratiefrechtelijke rechtsgang had opengestaan. Die rechtsgang zou ten tijde van het oordeel in cassatie niet meer hebben opengestaan. Daardoor zou De Boer zichzelf een administratief oordeel hebben onthouden en zou de burgerlijke rechter zijn

48. Vgl. F.A.M. Stroink, Rechierijike organisatie en rechtspraak in beweging, Zwolle 1993, p. 155, die spreekt van interpreteren en toetsen. Interpretatie (beantwoorden voorvragen) mag altijd. Niet-ontwankelijkheid betekent tijdelijke onbevoegdheid wan de burgerlijke rechter.

49. Vgl. HR 11 december 1981, NJ 1983, 320 m.nt. JAB (Ameland-De Boer).

50. Of, in abstracter bewoordingen, het blijkt dat de betalingen geschiedden ter realisering wan het algemeen belang de res publica en niet als tegenprestatie voor een aanspraak op (een klein stukje van) dat algemeen bellang, die res publica. Vergelijk de beschouwingen inzake deelsubjectiviteit van burgers bij IM.H.F, Teunissen, Het burgerlijk kleed van de staat, diss., Zwolle 1996, hifdst. 6. 
uitgegaan van de rechtmatigheid van de heffing. De vordering uit onverschuldigde betaling valt echter op zichzelf onder de bevoegdheid van de burgerlijke rechter; ook de ARRS was dat oordeel toegedaan. De burgerlijke rechter diende daarom de grondslag van de onverschuldigdheid (als voorvraag) te beoordelen."

Het oordeel van de ARRS dat het weigeren om tot restitutie over te gaan kan worden beschouwd als een weigering een rechtshandeling naar burgerlijk recht te verrichten, dateert van 27 maart 1981 (Maastricht ID). In de schriftelijke aanmaning van De Boer werd aanspraak gemaakt op restitutie vanaf 10 oktober 1978 . De onverschuldigde betaling dateerde zodoende van voor het moment dat de ARRS de weigering tot restitutie kenmerkte als weigeren privaatrechtelijk te handelen. Deze weigering terug te betalen kon De Boer via de burgerlijke rechter aanvechten (al wist hij dat pas in 1981).

De oorspronkelijke bouwvergunning had hij (in die optiek die dateerde van 1981) via de administratieve rechter moeten aanvechten. Toch stond net voor deze vergunning voor De Boer geen ingang bij de administratieve rechter open (althans dat kon in 1981 geconcludeerd worden), omdat de bouwvergunning aan hem toegezonden (verlleend) werd op 24 oktober 1974. Op dat moment was de Wet Arob nog niet in werking getreden (dat geschiedde immers per I juli 1976). Het lijkt me dat de Hoge Raad voor wat betreft de mogelijkheid wan het volgen van een administratieve rechtsgang in deze casus tot eenzelfde beslissing had kunnen komen als in het (later gewezen) arrest Heesch-Van de Akker. Daar werd immers het argument van uitbreiding van de rechtsbescherming aangemerkt als een omstandigheid van het geval, die klemmend kan worden. A-G Ten Kate benadrukt dat weliswaar beroep op de gemeenteraad openstond (ex art. 51 Woningwet-oud), maar dat beroep achtte hij "een onvoldoende procesgang met rechterlijke controle om daaraan zodanige gevolgen te verbinden' ${ }^{52}$ en hij concludeert dan ook tot cassatie (ondlanks de nietontvankelijkverklaring wegens termijnoverschrijding in de administratieve procedure). De Hoge Raad gat niet op het daartoe strekkende middel in: 'Middel II richt zich tegen een overweging ten overvloede. (...) Dit middel kan dus onbesproken blijven ${ }^{153}$, zodat de kans op het aannemen van een uitzondering op de formele rechtskracht van beschikkingen in deze casus werd uitgesloten. Hier blijft de burgerlijke rechter in de ontvankelijkheidslaag, terwijl in Heesch-Van de Akker op de toetsingswraag wordt overgestapt.

Wellicht wilde de Hoge Raad in deze casus niet tot de formulering van de mogelijkheid tot het aamemen wan uitzonderingen op hoofdregel van de formele rechtskracht van beschik. kingen komen omdat de Hoge Raad dat leerstuk niet wilde uiteenzetten naar aanleiding van een obiter dictum.

Zal de burgerlijke rechter ontvangen als de beschikking helemaal niet ter discussie wordt gesteld, als met andere woorden eisers uitgaan van de (administratieve) rechtmatigheid van de beschikking en (desalniettemin) toch schadevergoeding worderen? Zal de burgerlijke

51. Tegenwoordig kan in $20^{\circ} \mathrm{n}$ situatie de bestuursfechter wia het zuiver schadebeshut worden geadieerd.

52. HR 11 december 1981, NJ 1983, 320 m.nt. JAB (Ameland-De Boer), p. 1006, linkerkolom.

53. HK 11 december 1981, NJ1983, 320 m.nt. JAB (Ameland-De Boer), p. 998, onder 7, finkerkolom. 
rechter dan ontvangen met het oog op het feit dat zijn bevoegdheid steeds is blijven bestaan? Dat was het geval in V\&D en Super Doe tegen de gemeente Groningen.

In $V \& D$-Gromingen ${ }^{54}$ wordt niet teruggevorderd wegens onverschuldigde betaling. Hier stellen $V \& D$ en Super Doe dat de gemeente een ontechtmatige daad jegens hen heeft gepleegd en vorderen zij de daardoor veroorzaakte schade. De onrechtmatige daad bestaat uit het ten onrechte verleend hebben van een (met het geldende bestemmingsplan strijdige) bouwvergunning en het ter inzage en in afschrift geven van het ter plaatse niet meer geldende bestemmingsplan. De gemeente verweerde zich door zich te beroepen op de nietontvankelijkheid van V\&D en Super Doe, omdat zij de opengestaan hebbende administratiefrechtelijke weg niet gevolgd hadden. De rechtmatigheid van beschikkingen dient, aldus de gemeente, sinds de Wet Arob is ingevoerd te worden beoordeeld door de ARRS en is derhalve aan het oordeel van de burgerlijke rechter onttrokken.

Aardig (want daarmee wordt scherp waarover zij een oordeel van de burgerlijke rechter wensen) is, dat V\&D en Super Doe stellen dat zij het met de gemeente eens zijn dat de bouwvergunning in strijd met de wet verleend was en dat de daarop volgende vernietiging door de ARRS naar hun mening terecht was en dat derhalve de bouwvergunning niet alsnog verleend kon worden. V\&D en Super Doe zijn ook van mening dat zij niet verplicht zijn beroep in te stellen tegen administratieve beschikkingen. Daarom kan de burgerlijke rechter hen ook ontvangen. ${ }^{55}$

De gemeente handhaaft daarop haar stellingen dat het gaat 'om een beschikking, waarvan uiteindelijk vast moet zijn komen te staan, dat die niet een regelmatige was, hetgeen is voorbehouden aan de hoogste administratieve rechter, zodat, indien deze niet is benaderd, een op deze onregelmatigheid gebaseerde vordering tot schadevergoeding niet kan slagen'. ${ }^{56}$

Vervolgens stelt de rechtbank dat voor de ontwankelijkheid bepalend is of V\&D en Super Doe al dan niet een uitspraak van de hoogste administratieve rechter hadden moeten uitlokken, en oordeelt dat zij dat inderdaad hadden moeten doen. 'Eiseressen kumnen niet in strijd met het aanvankelijk ingenomen standpunt de administratieve rechtsgang plotseling verlaten en op grond van een tegengesteld standpunt een civiele vordering instellen, waarvan de toewijzing mede afhankelijk is van het oordeel van de administratieve rechter,", luidt het oordeel van de rechtbank en daarop volgt de niet-ontvankelijkverklaring.

Het principale cassatiemiddel van eiseressen bevat, kort gezegd, de redenering dat het volgen van een administratieve rechtsgang geen voorwaarde is voor de ontvankelijkheid indien het een (weliswaar door de aanvrager van een bouwvergunning ingestelde) vor-

54. Vgl. HR 22 nowember 1985, AB 1986, 245 m.nt. G.A.C.M. van Ballegooij (V\&D en Super DoeGroningen).

55. Vgl. HR 22 november 1985, AB 1986, 245 m.nt. G.A.C.M. van Ballegooij (V\&D en Super DoeGroningen), p. 711 , onder 8 , linkerkolom.

56. HR 22 november 1985, AB 1986, 245 m.nt. G.A.C.M. van Ballegooij (V\&D en Super Doe-Groningen), p. 711, onder 8 , linkerkolom.

57. HR 22 november 1985, AB 1986, 245 m.nt. G.A.C.M. van Ballegooij (V\&D en Super Doe-Groningen), p. 712 , onder 11, linkerkolom. 
dering tot schadevergoeding bij de burgerlijke rechter betreft. En daarnaast de betreffende beschikking van $B$. en $W$. is onaantastbaar geworden nu niemand van de openstaande administratieve rechtsgang gebruik heeft gemaakt; deze beschikking heeft nu tegenover een ieder formele rechtskracht. De burgerlijke rechter heeft deze formele rechtskracht (onaantastbaarheid) als gegeven te aanwaarden. ${ }^{58}$

A-G Mok meent dat het principale cassatiemiddel terecht is voorgesteld: 'Eiseressen hebben inderdaad nagelaten (...) de (...) aangewezen rechtsgang (...) te volgen, maar zij hebben die beschikkingen ook niet bij de burgerlijke rechter ter discussie gesteld. Zij vragen de burgerlijke rechter integendeel van de juistheid van die beschikkingen uit te gaan. Daarbij vinden zij (...) de rechtspraak aan hun zijde, ${ }^{59}$, waarna de $A-G$ concludeert tot vernietiging van het vonnis.

De Hoge Raad geeft eiseressen in hun redeneringen gelijk: het vorderen van schadevergoeding staat los van het eventueel moeten/kunnen volgen van een administratieve weg. Pas indien de vordering een werzoek om een onrechtmatigheidsoordeel van een beschikking behelst, zal de civiele rechter tot niet-ontvankelijkheid van de eiser concluderen. ${ }^{60}$

In casu is de burgerlijke rechter derhalve bevoegd en acht eiseressen daarom ontvankelijk. Een dergelijke toetsing (van een civiele vraag) zal immers nimmer aan het oordeel van de burgerlijke rechter onttrokken kunnen zijn, lijkt de - mijns inziens terechte - redenering van de Hoge Raad.

\subsubsection{Ontvankelijkheid in hel licht wan de ontrafeling van feit en norm}

Het toepassen van de niet-ontvankelijkheidsbijl wanneer de burgerlijke rechter van oordeel was dat hij niet bevoegd was, wordt wellicht het duidelijkst met betrekking tot het al of niet beantwoorden van voorvragen. De burgerlijke rechter ging er immers toe over om niet te ontvangen wanneer dezelfde toetsing voorligt als de toetsing die door de bestuursrechter zou kunnen worden verricht. Met andere woorden, de bestuursrechter toetst de gerichtheid op rechtsgevolg van de rechtshandeling, anders gezegd de gezagsuitoefening; hij toetst de geoorloofdheid van de beoogde bevoegdheidsuitoefening en oordeelt daar met de maatstaf (on)rechtmatigheid over. Slechts deze toetsing zal/wil de burgerlijke rechter niet beoordelen (want wil zich daartoe niet bevoegd achten) en gaat over tot niet-ontvankelijk-verklaring. Aldus is er een verschuiving te zien: waar de burgerlijke rechter vór de invoering van administratieve rechtspraak wel (volledig) toetste, moet hij dat naar de letter van bevoegdheidsopdracht thans nog steeds, maar doet hij dit niet meer; hij verklaart dan eiser niet-ontvankelijk omdat hij (naar de letter van zijn bevoegdheidsopdracht) niet tot onbevoegdheid kan concluderen (al was dat wel gewenst).

58. Vgl. HR 22 nowember 1985, AB 1986, 245 m.nt. G.A.C.M. van Ballegooij (V\&D en Super Doe-Groningen), p. 712 , onder IA

59. HR 22 november 1985, AB 1986, 245 m.nt. G.A.C.M. wam Hallegooij (V\&D en Super Doe-Groningent, p. 717, onder 5.1 , linkerkolory.

60. Vgl. HR 22 november 1985, AB 1986, 245 m.nt. G.A.C.M. van Ballegooij (V\&D en Super Doe-Groningen), p. 709, onder 3.2.3, linkerkolom. 
Het beantwoorden van voorvragen (hetgeen noodzakelijk is voor beantwoording van de hoofdvraag) valt te kwalificeren als het vaststellen van feiten (ook als die liggen op terreinen waar de burgerlijke rechter niet bevoegd is). Dit vaststellen van feiten is noodzakelijk voordat tot toetsing (aan het recht) kan worden overgegaan. Het beantwoorden van voorvragen is dus niet een activiteit waarbij de rechter de inhoud van (normen in andere terreinen van) het recht beoordeelt; dan zou hij immers actief zijn op terreinen waar hij zich niet bevoegd acht en dus ook niet wil ontvangen. De voorvragen (en daarmee het 'onzekere' terrein) worden o.a. expliciet wanneer er een beschikking in het "spel' (geding) is; de grondslag van een vordering wordt immers in de beschikking gevonden en de beschikking is voorwaarde voor toegang bij de bestuursrechter. Aldus is het "beschikkingenterrein', anders gezegd het "voorvragenterrein", een soort 'schemergebied' rond al of niet bevoegdheid. De angst voor het inmengen in andermans terrein (bevoegdheid) wordt dan afgedlekt met het 'super-niet-ontvankelijkheidsinstrument': het onaantastbaar verklaren van administratieve oordelen ofwel de introductie van het niet meer toetsen van de formele rechtskracht van beschikkingen.

Dat betekent dat de burgerlijke rechter feitelijk handelen dat niet gericht is op de abjectieve gezagsuitoefening, maar op bijvoorbeeld de gedragswijze van de overheid (als onrechtmatige daad) well toetst; met andere woorden wanneer de gevolgenkant van overheidshandelen als inleidend voorwerp wordt woorgesteld, dan zal de burgerlijke rechter wel ontvangen en toetsen. De gerichtheid op rechtsgevolg (als gezagsuitoefening door de overheid) is daarbij in beginsel irrelevant - anders zou risico-aansprakelijkheid immers niet kunnen bestaan.

Het mooiste voorbeeld daarvan is uiteraard V\&D en Super Doe versus Groningen. De Hoge Raad is hier een stuk alerter dan de lagere rechters. De niet-ontvankelijkheid zal de hoogste burgerlijke rechter immers pas uitspreken, niet als een beschikking ergens "een rol' speelt, maar wel als een beschikking onrechtmatig moet worden verklaard. Daardoor moet de beschikking immers ook naar inhoud (dat wil zeggen naar beoogd rechtsgevolg) worden beoordeeld en daartoe acht de burgerlijke rechter zich niet bevoegd. Het beantwoorden van (voor)vragen rond die beschikking beschouwt hij echter als een feitelijke (en dus geoorloofde) activiteit.

Bracht het ontvankelijkheidsinstrument wel verandering aan in het feit dat de burgerlijke rechter zichzelf bevoegd achtte (ook daar waar de bestuursrechter actief kon zijn)? Nee, in de opvatting van de burgerlijke rechter over zijn bevoegdheid is niets wezenlijks veranderd door de introductie wan het ontvankelijkheidsinstrument (al had dat de potentie in zich om een wijziging in bevoegdheid op te vangen - en was daarom ook zo'n prachtig middel; thet leek technisch, maar was inhoudelijk). Overigens is het wel een vreemd instrument ter afbakening van competenties, omdat het een instrument is dat voor de afbakening van rechtsmachten de vinger wijst naar eisers, waar eigenlijk de bevoegdheidsvraag inzet is. Enfin, de vraag naar de invloed van het administratieve recht op de bevoegdheid van de burgerlijke rechter is nog steeds niet opgelost. Zou de toetsingsvraag daarin wel verandering brengen? 


\subsection{Al dan niet zelfstanding toetsen door de burgerlijke rechter}

\subsubsection{Inleiding}

In Heesch-Van de Akker mam de Hoge Raad (zoals we in het volgende hoofdstuk nog zullen zien) een uitzondering aan op de formele rechtskracht van de beschikking en ging over tot zelfstandige toetsing. Daarbij werd geconstateerd dat er sprake was 'misleiding' door het bestuursorgaan en bovendien leek de ontwikkeling van het stelsel van rechtsbescherming negatief uit te pakken voor Van de Akker. Daarom was er reden tot toetsing door de burgerlijke rechter. De vraag die hieruit te destilleren valt is, of (een vordering in) het stelsel van rechtsbescherming van invloed is op de gevallen waarin de burgerlijke rechter overgaat tot zelfstandige toetsing?

In Schellen en deuropeners ${ }^{61}$ is de kemoverweging van de Hoge Raad geconcentreerd op het middel dat, kort samengevat, inhoudt dat de burgerlijke rechter niet zelf mag toetsen of burgemeester en wethouders hun bevoegdheid te buiten zijn gegaan nu een voorziening op de gemeenteraad heeft opengestaan waarmee een administratiefrechtelijke beroepsmogelijkheid aan de aangeschrevene (NV Madorifo II) is gegeven. ${ }^{62}$ Dit middel faalt. De Hoge Raad stelt vast dat dit beroep op de gemeenteraad niet een rechtsgang is

'met zodanige wamborgen (...) onring dat zij als een bijzondere, beroep op de burgerlijken rechter uitsluitende, rechtsgang zou zijo aan te merken. ${ }^{.63}$

Met andere woorden, de civiele rechter mag wel een zelfstandig oordeel geven. Dit toetsingsrecht (in het kader van de Woningwet) van de rechter is, naar het oordeel van A-G s'Jacob, 'nimmer in twijfel getrokken. (...) Eenmaal aangenomen, dat de rechter tot toetsing bevoegd is, moet de vraag worden gesteld, hoever die bevoegdheid zich uitstrekt. ${ }^{64}$

In het bekende arrest Limmen-Houtkoop kapittelde de Hoge Raad het hof dat zijn onbevoegdheid uitsprak omdat het algemeen belang dat behartigd moet worden door het naleven van wettelike voorschriften niet valt onder de te beschermen belangen van de onrechtmatige daad. Omdat de gemeente haar vordering deed steunen op een volgens haar uit de onrechtmatige daad voortvloeiend recht (en aldus stellenderwijs aan de ontvankelijkheidseis voldeed), was volgens de Hoge Raad de bevoegdheid tot beoordeling van de burgerlijke rechter gegeven. Overigens was de Hoge Raad het materieel gezien wel met het hof eens. Daaruit zou dan een afwijzing van de vordering hebben moeten volgen, maar geen onbevoegdverklaring. ${ }^{65}$ Aldus was hier sprake van de toetsbaarheidsvraag.

61. VgI. HR 22 fcbruari 1957, NJ 1957, 310 (Scheflen en dewropeners; ook wel: Amisterdam-NV Madorifo II)

62. Vgl. HR 22 februari 1957, N1 1957, 310 (Schellen en deuropeners), p. 583, i.h.b. onder a, rechterkolom.

63. HR, 22 februari 1957, NJ 1957, 310 (Schellen en deuropenters), p. 385, linkerkolom.

64. HR 22 feoruari 1957, NJ 1957, 310 (Schellen en deuropeners), p. 385 (r.k.) en 386 (1.k).

65. Vgl. HR 9 november 1973, NJ 1974, 91 m.nt. W.F. Prins (Limmen-J.N. Houtkoop). 
De woorwaarde voor het overgaan tot toetsing zoals die in Schellem en deuropeners wordt geformuleerd, betreft de waarborgen waamee de administratieve rechtsgang is omringd. Zijn deze waarborgen zodanig, dat zij toetsing door de burgerlijke rechter zouden uitsluiten, dan zal de burgerlijke rechter niet zelfstandig toetsen. Daarmee is de vraag: wanneer sluiten de waarborgen in de administratieve rechtsgang de toetsing door de burgerlijke rechter uit; met andere woorden, in welke gevallen toetst deze rechter niet zelfstandig? Tegen de beslissing van de inspecteur voor de Scheepvaart met betrekking tot de deugdelijkheid van het schp Semper Crescendo ${ }^{66}$ (een beschikking) had belanghebbende (Willeboordse) beroep kunnen instellen bij de Voorzitter van de Raad voor de Scheepvaart, is de visie van de Hoge Raad. Dit brengt mee dat de civiele rechter (om een oordeel gevraagd inzake diezelfde weigering tot afgifte van een certificaat van deugdelijkheid) uit moet gaan wan de rechtmatigheid van de weigering tot afgifte van het certificaat wan deugdelijkheid. Met andere woorden, ondat er een administratiefrechtelijke weg was, die door belanghebbende ongebruikt is gelaten, komt de civiele rechter niet de taak toe zelfstandig op rechtmatigheid te toetsen. De omstandigheid dat er een administratiefrechtelijke weg is, maakt dat de burgerlijke rechter niet zelfstandig toetst (maar uitgaat van de rechtmatigheid van de negatieve beschikking, van het administratieve oordeel dus). Merk op dat een normatief, inhoudelijk oordeel (inzake de geoorloofdheid van het intreden van het beoogde rechtsgevolg) yan bestuurlijke zijde als gegeven (als feit) gaat fungeren voor de burgerlijke rechter.

In zijn noot maakt Stellinga de vergelijking met de Voorste Stroom-arresten:

\footnotetext{
'De stelling van de ciser: de weigering van de verlenging van het certificaat is onrechtmatig, tenzij de Stat schadevergoeding geeft, doet denken aan de Voorste-Stroomarresten. Daarin werd immers overwogen: de gedragslijn van de gemeente was volkomen gerechtvaardigd en zelfs geboden, maar, nu zij de nadelige gevolgen daarvan niet voor hagar rekening heeft genomen, heeft zij de zorgvuldigheid, die in het maatschappelijk verkeer past, niet in acht genomen. (...) Het is eiser njet gelukt de evenbedoelde stelling i.c. aanvaard te krijgen." 67
}

Daarmee geeft de Hoge Raad aan dat hij niet overgaat tot toetsing indien de vraag naar de at of niet rechtmatigheid van de beschikking voorligt, ook al is dit wegens het achterwege blijven van het aanbieden van schadevergoeding.

Merk op dat de Hoge Raad hier veel ruimte laat aan de op dat moment al enige maanden geinstalleerde Arob-rechter. De beslechting van (het vaststaan van administratieve rechtmatigheid van het besluit en de desondanks daaruit voortvloeiende) aansprakelijkheid voor schade wordt daardoor op een presenteerblaadje aan de Arob-rechter aangeboden. Pas als de administratieve rechter voor deze toetsing van bestuurscompensatie na een rechtmatige 
daad huiverig blijkt, neemt de burgerlijke rechter deze toetsing zelf (weer) in de hand (en construeert deze zaken via de onrechtmatige daad-actie: Leffers). ${ }^{6 .}$

In Loosdrechts Plassenschap-Nagtegaal en Bovelaar ${ }^{69}$ bevat het middel van cassatie een beroep op niet-ontvankelijkheid van Nagtegaal en Bavelaar, omdat de aanschrijvingen, die het Plassenschap aan hen had gericht, aan te vechten waren door gebruikmaking van de rechtsgang van de Wet Arob. (Pikant detail is daarbij dat de aanschrijvingen werden gedaan op 21 juni en 16 juli 1976 en de wet Arob, als bekend, in werking trad op 1 juli 1976.) Nagtegaal en Bavelaar zijn in kort geding opgekomen en vorderden te bevelen dat de uitvoering van de aanschrijvingen (het afbreken van tenten) diende te worden gestaakt. $\mathrm{Na}$ toewijzing van de vordering door de president verwoordt de grief in appèl het beroep op niet-ontvankelijkheid wegens het opengestaan hebben van een administratiefrechtelijke rechtsgang (in plaats van in kort geding op te komen hadden Nagtegaal en Bavelaar, aldus het Plassenschap, de Voorzitter van de ARRS in voorlopige voorziening moeten adiëren). Het hof verwerpt de grief op niet-ontvankelijkheid en bekrachtigt het vonnis van de president.

De Hoge Raad onderstreept de visie van het Plassenschap Loosdrecht in het eerste middel van cassatie. De Hoge Raad is het met het Plassenschap eens dat de Wet Arob tegen aanschrijvingen als die van het Plassenschap Loosdrecht voldoende rechtsmiddelen aan belanghebbende ter beschikking stelt. Daarbij komt dat deze rechtsgang met voldoende waarborgen is omkleed (er is een afdoende voorziening inzake spoedeisende gevallen als het onderhavige). Gevolg van deze constatering is dat belanghebbende de administratieve rechtsgang had kunnen volgen en er dus voor de civiele rechter geen plaats is voor zelfstandige toetsing ${ }^{70}$ :

\footnotetext{
'Nagtegaal en Bavelaar dienen derhalve alsnog in hun vordering niet-ontvankelijk te worden verklaard. Dit geldt mede voor zover door hen een beroep is gedaan op de aanschrijving van 21 juni 1976 en de werwijdering van Bavelaars tent op 24 juni 1976. Deze feiten hebben weliswaar plaatsgevonden vóor de inwerkingtreding van de Wet A.r.o.b. op 1 juli 1976, maar de vordering, zoals deze in hoger beroep aan de orde was, strekt slechts tot het verkrijgen van een bevel ter zake van toekomstig optreden van het Plassenschap. Voor de beoordeling van dit toekomstig optreden zijn de feiten, voorgevallen woúr do alansefrijvingen van 16 jull 1976 zonder betang, ${ }^{71}$
}

68. HR 18 januari 1991, AB 1991, 241 m.nt. FHwdB (Leffers-Staat). Inmiddels heeft de administratieve rechter de toetsing van zuivere of zelfstandige schadebesluiten expliciet aan zich getrokken. Vgl. CRWB 28 julli 1994, JB 1994/221; CBB 26 maart 1996, JB 1996/135; CBStufi 23 mei 1996, JB 1996/177; ABR 29 november $1996, \mathrm{JB} 1996 / 253$.

69. Vgl. HR 25 november 1977, AB 1978, I (Loosdrechts Plassenschap-Nagtegaal en Bavelaar).

70. Vgl. HR 25 november 1977, AB 1978, I met noot J.R. Stellinga (Loosdrechts Plassenschap- Nagtegaal en Bavelaar), p. 3, recllterkolom.

71. HR 25 november 1977, AB 1978, 1 met noot J.R. Stellinga (Loosdrechts Plassenschap-Nagtegaal en Bavelaar), p. 4, linkerkolom 
Ook hier neemt de burgerlijke rechter het (ontbreken van een) oordeel van de administratieve rechter en (de aanwezigheid wan) het oordeel van het bestuursorgaan over.

Ook A-G Berger concludeert dat spoedvoorzieningen in Arob-zaken en vol beroep op de Kroon een beroep op de burgerlijke rechter uitsluiten. De civiele rechter dient tot nietontwankelijkheid te concluderen met betrekking tot de vordering die gegrond was op de aanschrijwingen van 16 juli 1976. De administratieve weg heeft de voorkeur van de A-G, omdat deze tot wijziging in de rechtskracht van de beschikking kan leiden:

${ }^{8}$ laat de witsprak van de Pres. in K.g. de beschikking onwerlet (...). De voorzitter daarentegen schorst de bestreden beschikking, d,w,Z ontneent ath die beschikking woorlopig haar rechiskracht, zodat zij niet meer kan dienen als grondstag voor rechtsgetdige handelingen van de overheid. 72

Een ander voorbeeld biedt Bogerd. ${ }^{13} \mathrm{Hij}$ wil geen wrachtverkeer op de parkeerplaats achter zijn huis en vordert een bevel daartoe in kort geding; een samenstel van handelingen (feiten) zou aldus een onrechtmatige daad opleveren. De gemeente Hei- en Boeicop stelt zich op het standpunt dat Bogerd niet-ontvankelijk is in deze vordering, omdat hij een Arob-rechtsgang had kunnen volgen (door de vrijstellingsbeschikking c.q. aanlegvergunning voor die parkeerplaats aan te vechten). Bogerds vordering wordt door de president afgewezen. Het hof verklaart hem wel ontvankelijk, omdat het hof ervan uitgaat dat de gestelde onrechtmatige daad bestaat uit meer elementen dan alleen de beschikking en/of het bestemmingsplan en bovendien dateert van vór 1 juli 1976. Het hof meent dat Bogerds positie werd miskend en de bestemmingswijziging achter diens rug om geschiedde; dergelijk handelen acht het hof onrechtmatig. ${ }^{74} \mathrm{Na}$ een integrale beoordeling door het hof, vernietigt het hof het vonnis.

Wederom blijkt dat de Hoge Raad een beschikking in de zin van de Wet Arob niet tot zijn bevoegdheid rekent, en dus dat administratieve oordeel moet overnemen, anders gezegd de beschikking onaantastbaar acht, zodat door de civiele rechter tot niet-ontwankelijkheid van Bogerd geconcludeerd dient te worden. De formulering daarvan luidt als volgt:

\footnotetext{
"In cassatic moet erwan worden uitgegaan dat Bogerd van deze rechtsgang geen gebruik heeft gemakt en dut genoemde beschikking onawntasibasur is geworden. Bij die stand van zaken dient de burgerlike rechter ervan uit te gaan dat de 'vrjstellingsbeschikking c.q. aanlegvergunning' zowel wat haar wijze van tot stand komen als wat haar inhoud betreft in overeenstemming is met de desbetreffende wettelijke voorsehriften. ${ }^{75}$
}

Daarmee formuleert de Hoge Raad de regel die later bekend werd als de hoofdregel van het beginsel van formele rechtskracht van beschikkingen, al wordt die term hier niet expli-

72. HR 25 november 1977, AB 1978, I met noot JR. Stellinga (Plassenschap Loosdrecht-Nagtegaal en Bavelaar), p. 6 , rechterkolom.

73. Vgl. HR 4 felbruari 1983, RvdW 1983, 47 (Hei- en Boeicop-Bogerd).

74. Vgl. HR 4 felbruari 1983, RndW 1983, 47 (Hei-en Boeicop-Bogerd), p. 192, onder 3 en 4.

75. HR 4 februari 1983, RvdW 1983, 47 (Hei-en Bocicop-Bogerd), p. 191, onder 3.2, linkerkolom. 
ciet gebruikt. De Hoge Raad spreekt hier van onaantastbaarheid. Betekent dit dat voor hem onaantastbaarheid en formele rechtskracht (in latere arresten) als identiek moeten worden opgevat? Onaantastbaarheid betekent in casu dat de burgerlijke rechter geen oordeel zal geven over totstandkoming en inhoud van de beschikking in relatie tot (administratieve) wetgeving. Welke kunnen dan nog de gevolgen in het civiel recht zijn wan beschikkingen? Anders gezegd, wat is het gevolg van het niet beoordelen van de al of niet geldigheid van beschikkingen en daarmee samenhangend het (stelselmatig) uitgaan van het oordeel daarover in administrativo? Met andere woorden, de burgerlijke rechter neemt het administratieve inhoudelijke oordeel als uitgangspunt voor zijn burgerljjk oordeel; dat houdt in een gelijkschakeling van het bestuurs- en het burgerlijkrechtelijke normatieve oordeel op basis van feitelijke aanwezigheid van een administratief oordeel.

Weer een ander voorbeeld is er een tussenvonnis, waartegen de gemeente St. Oedenrode in hoger beroep en in cassatie gaat. ${ }^{76}$ Driessen had gesteld dat door de gemeente jegens haar een onrechtmatige daad was gepleegd en vorderde schadevergoeding. De onrechtmatige daad bestond er in dat de gemeente "lastgevingen", dat wil zeggen aanzeggingen (onder bedreiging van politiedwang) had uitgevaardigd. Het hof zag in de uitvaardiging van de (door de ARRS in een vergelijkbare casus vernietigde, want met de wet strijdige) lastgevingen inderdaad een onrechtmatige daad. In het tweede onderdeel van het cassatieniddel stelt de gemeente dat juist tegen deze lastgevingen de weg van adm inistratiefrechtelijke voorlopige voorziening opengestaan heeft.

De Hoge Raad is van mening dat het hof geen oordeel mocht geven 'over de vraag of beschikkingen in strijd met het recht (...) zijn genomen', omdat deze toetsing 'bij de Afd. rechtspraak berust zodat het Hof van de uitspraken van de Afd. had uit te gaan'. "De burgerlijke rechter geeft wederom blijk van zijn oordeel dat de geoorloofdheid van het intreden van het beoogde rechtsgevolg (de bevoegdheidsuitoefening) niet onder zijn bevoegdheid valt; dat acht hij een vaststaand gegeven. Ook al treedt de burgerlijke rechter niet in de beoordeling omtrent de geldigheid van een beschikking, er resten hem wel nog de vragen of er sprake is van een (civiel) onrechtmatige inhoud van een beschikking en de eventualiteit van daaruit voortvloeiende aansprakelijkheid voor schade. De gemeente draagt het risico voor onrechtmatig handhaven van beschikkingen. De aanwezigheid van een openstaande mogelijkheid tot administratieve toetsing sluit eventuele aansprakelijkheid voor civiel onrechtmatig handelen niet uit. Een onjuist besluit stelt in beginsel de schuld voor de overheid vast. Daaruit vloeit tevens voort de opvatting van de Hoge Raad dat de procedure tot woorlopige voorziening de eventuele aansprakelijkheid op grond van onrechtmatige daad niet uitsluit. ${ }^{78}$

76. Vgl. HR 24 jannani 1984, AB 1984, 399 m.nt. E.M. van Ejden (St. Oedenrode-Driessen BV en Groenwoudt BV).

77. HR 24 februari 1984, AB 1984, 399 m.nt. E.M. van Eijden (St. Oedenrode-Driessen BV), p. 1171, onder 3.5. Inkerkolom.

78. Vgl. HR 24 februari 1984, AB 1984, 399 mnt. EM. wan Eijden (St. Oedenfodto-Driessen BV), p. 1170, rechterkolom. 
lets soortgelijks is te zien in $\mathbb{K} \& D$-Groningen, waarin de omstandigheid dat tegen de beschikking beroep openstond op de Afdeling rechtspraak van de RvS (maar deze weg ongebruikt is gelaten), betekent dat de civiele rechter

"ervan zal moeten utgatin dat deze beschikking zowell wat haar wijze van tot stand komen als wat haar inhoud betreft in overeenstemming is met de desbetreffende wettelijke woorschriften. ${ }^{79}$

Daarmee zien we weer de formulering van dat wat later als hoofdregel van het beginsel van formele rechtskracht van beschikkingen wordt aangemerkt. Omdat het begrip formele rechtskracht in het cassatiemiddel expliciet wordt genoemd en de Hoge Raad daar vervolgens dezelfde uitleg bij hanteert als hier in Hei-en Boeicop-Bogerd lijkt de conclusie gerechtvaardigd dat de Hoge Raad onaantastbaarheid en formele rechtskracht als synoniemen hanteert.

De weigering om een beschikking te nemen wordt zelf ook weer als beschikking aangemerkt. Dat betekent dat de burgerlijke rechter zo'n fictieve weigering niet kan beoordelen. Een dergelijke toetsing dient te geschieden door de administratieve rechter. ${ }^{80}$ Zodoende volgt niet-ontvankelijkverklaring bij de burgerlijke rechter. Wanneer een dergelijke toetsing (door de administratieve rechter) uitgesloten is te achten wegens het algemene karakter van het besluit, dan is het nemen van het besluit voorbehouden aan het bestuur dat daarop beleid mag woeren. Het beleid van het bestuur zou wegens onredelijke belangenafweging onrechtmatig kunnen zijn. ${ }^{81}$

In het arrest Staat-Van Gelder, ${ }^{82}$ dat slechts eén week voor Heesch-Van de Akker werd gewezen, bestond de onrechtmatigheid uit het in strijd met een hoger voorschrift uitvaardigen van (dus onverbindende) voorschriften (een regeling) en het heffen van belasting op grond van die voorschriften. Het bestaan van de onverbindende regeling werd als gegeven (feit) door de burgerlijke rechter aangenomen. In zoverre lijkt dit op het aannemen en overnemen van het administratieve oordeel inzake beschikkingen door de burgerlijke rechter.

\section{4 .2 Heesch-Van de Akker}

Als we nu kijken naar de formulering van het beginsel van de formele rechtskracht wan beschikkingen door de Hoge Raad in Heesch-Van de $A k k e r^{83}$, dan vallen verschillende

79. HR 22 november 1985, AB 1986, 245, p. 708 (V\&D-Groningen).

80. Zoals geoordeeld werd door de ABR 15 januari 1998, JB 1998/51 m.nt. EvdL

81. Vgl. Hof Leewwarden 22 februari 1984, NJ 1985, 27. Anders: ABR 15 januari 1998, JB 1998/36, m.nt. Evdl, warin de grondslag van de fictieve weigering (zijnde een zelfstandig schadebesluit) bepalend is voor de bevoegdheid van de rechter; i.c. betreft de grondslag feitelijk handelen, waardoor de bestuursrechter zich (absoltut) onbevoegd acht.

82. Vgl. HR 9 mei 1986, AB 1986, 429 m.nt. F.H. van der Burg (Staat-Van Gelder NV); ook bekend als Strat-Grosheide en Kort, ondat deze laatsten optreden als curator in het faillissement van Van Gelder.

83. Vg1. HR 16 mei 1986, AB 1986,573 m.nt. FHwdB (Heesch-Van de Akker). 
zaken op. Volgens de Hoge Raad moet woorop worden gesteld dat wanneer tegen een beschikking een met voldoende waarborgen omklede rechtsgang heeft opengestaan, de burgerlijke rechter, zo deze beroepsgang niet is gebruikt, in het voor them gevoerde geding wit dient te gaan van de geldigheid van de beschikking (dan zal de rechter niet toetsen). Dit alles op straffe van niet-ontvankelijkheid. Als de burgerlijke rechter al ontvangt, kan hij toch de formeel rechtskrachtige beschikking niet (willen) toetsen. Wanneer hij niet ontvangt, kan hij van oordeel zijn dat een andere rechtsgang openstaat (of: heeft opengestaan) en dat zou kunnen betekenen dat hij zich dan niet bevoegd acht.

Daarom is de eerste vraag die in een concreet geval gesteld moet worden, de vraag of er een mogelijkheid is tot het volgen van een administratiefrechtelijke rechtsgang, die met voldoende waarborgen is omkleed. Dit is een vraag betreffende enerzijds de bevoegdheid van de rechter en anderzijds de ontvankelijkheid van de burger. Als betrokkene geen admimistratieve rechtsgang kon volgen, is de burgerlijke rechter bevoegd en zal (blijven) ontvangen. Luidt het antwoord op deze vraag daarentegen ja, dan komt een tweede afwegingsmoment in beeld: kan betrokkene worden ontwangen? Kon betrokkene immers wel een administratieve rechtsgang volgen, dan valt de niet-ontvankelijkheidsbijl(en handhaaf de burgerlijke rechter zijn bevoegdheid).

Vervolgens is de vraag of betrokkene de bestaande en met voldoende waarborgen onklede rechtsgang inderdaad heeft gebruikt? Daarmee betreden we het terrein van de toetsingsvraag. Twee mogelijkheden zijn er: betrokkene heeft de bestaande administratieve rechtsgang gevolgd en betrokkene heeft de administratieve rechtsgang niet gevolgd. Als betrokkene de voor hem openstaande administratieve rechtsgang heeft gebruikt, heeft hij een (administratief)rechterlijk oordeel over de beschikking gekregen. De burgerlijke rechter zal dat als uitgangspunt nemen. Indien hij de administratieve rechtsgang niet heeft gevolgd, zal de burgerlijke rechter niet automatisch overgaan tot zelfstandige toetsing van de geldigheid van de beschikking, maar de in administratieve termen vaststaande totstandkomingswijze en inhoud van de beschikking in principe overnemen. De daaraan ten grondslag liggende stelling is kennelijk dat (bestuursrechtelijke en aan een noment gekoppelde) geldigheid (civiele) rechtmatigheid betekent of impliceert. Met betrekking tot de hypothese van deze studie kan daarover gezegd worden dat geldigheid (die als kwalificatie of stempel wel of niet aanwezig is) is verbonden met het feit (formele rechtskracht) terwijl rechtmatigheid óók iets zegt over de inhoud (materiële rechtskuacht).

\subsubsection{Taetsing in het licht van de ontrafeling van feit en norm}

Bij de toetsingswraag wordt duidelijk dat de burgerlijke rechter (weliswaar niet expliciet, maar toch) onderscheid maakt in feit en norm. Wat gebeurt immers? De burgerlijke rechter toetst nooit de 'rechtmatigheid' van de beschikking, maar kijkt wel naar het al of niet aamnemen van de 'onaantastbaarheid' van de beschikking. Dat betekent dat de burgerlijke rechter de geldigheid van een beschikking (in de zin van de vraag naar de aanwezigheid van onaantastbaarheid of formele rechtskracht) als feitelijke (voor)vraag steeds zal beantwoorden en beoordelen. De meer inhoudelijke toetsing of de beschikking geldig behoort te zijn (in de zin van de vraag naar de aanwezigheid wan rechtmatigheid - als conclusie op de 
vraag naar geoorloofdheid van intreden van beoogd rechtsgevolg) verricht hif nimmer; daartoe acht hij zich niet bevoegd (doch aanwaardt hij de competentie van de bestuursrechter mits er voldoende waarborgen zijn in de rechtsgang voor die bestuursrechter).

De burgerlijke rechter toetst het besluit als rechtshandeling dus niet (als bloot rechtsfeit well). Expliciet is hij daarover niet (al ligt het onderscheid tussen feit en norm besloten in de wijze van afbakening van zijn rechtsmacht met die van de administratieve rechter).

Veranderde de burgerlijke rechter van opvatting over zijn bevoegdheid (ook als de bestuursrechter actief kon zijn) met of door het hanteren van de toetsingswraag als afbakeningsinstrument? Door niet te toetsen (lees: zich niet tot toetsing bevoegd te achten) neemt de burgerlijke rechter steeds meer het oordeel van de administratieve rechter of het bestuursorgaan over. Dat wil echter niet zeggen dat hij niet meer bevoegd zou zijn; daarom hanteert hij (samen met dat niet toetsen) het ontvankelijkheidsinstrument. In de aanloop naar het definitieve vestigen van de leer van de formele rechtskracht geeft de nietontvankelijkheidsverklaring steeds meer inzicht in dat overnemen van het administratieve oordeel; de formele rechtskracht van de beschikking als het onaantastbare en dus niettoetsbare deel van die beschikking vormt aldus een aanscherping van het niet-ontvankelijkheidsinstrument. Zo tracht de burgerlijke rechter de bevoegdheidsafbakening 'op te lossen'. Het is echter de vraag of het niet geven van een eigen oordeel maar het oordeel van een ander (als feit) binnenhalen en gelijkstellen met het eigen (normatieve) oordeel wel een oplossing is; worden hier geen appels met peren vergeleken? Anderzijds, nu de (grond)wetgever nog steeds geen afbakening zonder de mogelijkheid van samenval heeft gegeven, laat hij de burgerlijke rechter maar 'aanmodderen'. Omdat de burgerlijke rechter zo'n ruim geredigeerde bevoegdheid heeft, zal hij niet tot een expliciet uitspreken van zijn onbevoegdheid mogen overgaan. Waar hij voorheen er toe overging wel te oordelen (met de hem ten dienste staande burgerrechtelijke middelen), sluit de burgerlijke rechter met het aannemen van de hoofdregel van formele rechtskracht de poort en gaat over tot het niet meer zelfstandig toetsen. De beschikking als uitoefening van overheidsgezag met haar formele rechtskracht is daarbij het 'verboden' objectum litis.

\subsection{Tenslotte}

Verschillende instrumenten zijn in de loop van de geschiedenis gehanteerd ter afbakening van de rechtsmacht van de burgerlijke rechter en die van de administratieve. Het dilemma is nog immer thiet naar tevredenheid opgelost. Het bleek eveneens onmogelijk een sluitende (grond)wettelijke regeling te treffen.

Competentieconflicten illustreren dat de rechtsmacht nog steeds niet goed is afgebakend. Het eerste type van conflicten vormden de botsingen met de Koning. Het opwerpen van conflicten in een methode van recursus ad principem kon niet tot een dergelijke oplossing leiden.

Het tweede type van conflicten werd gevormd door toetsing van daden met overheidsgezag, zoals Vrowwe Elske en Rhedense Koe illustreerden. Daarbij ging het om vragen als: 
mag de rechter wetgeving controleren. De competentie bepaalde de rechter vanuit het perspectief van de burger (dit is de Guldemond-Noordwijkerhout-oplossing).

De invoering van administratieve rechtspraak leverde nieuwe problemen op, doordat de leren van het objectum litis en het fundamentum petendi tegenover elkaar kwamen te staan. Niettemin hield verhoogde rechtsbescherming de belofte in voor de burgerlijke rechter dat hij terug kon treden. De techniek van de niet-ontwankelijkverklaring was het eerste instrument dat gehanteerd werd in deze discussie. De bevoegdheid van de burgerlijke rechter bleef daarbij wel bestaan; de techniek leidde tot niet in behandeling nemen. van de zaak (niet-ontvankelijkheid betekende dan buiten behandeling laten).

De botsingen met het overheidsgezag bleven uiteraard. Een oplossing wordt gevormd door het besluit met overheidsgezag terzijde te laten. Dit is de lijn $V \& D$ en Super Doe-Gronin gen, die later in Bolsius wordt voortgezet. Een andere methode om deze conflicten het hoofd te bieden vormt de niet-toetsbaarheid ofwel de formele rechtskracht. In dat geval is de rechter bevoegd en laat hij de zaak ook niet buiten behandeling; hij doet wel degelijk uitspraak, alleen houdt die uitspraak in dat hij het oordeel van een ander overneemt (de lijn Hei-en Boeicop en St. Oedenrode-Driessen).

Zo tracht de burgerlijke rechter zijn rechtsmacht vorm te geven. Waar uiteraard ook de administratieve rechter wakt over zijn bevoegdheid, is een voortdurend spel van aantrekken en afstoten van rechtsmacht gestart op terreinen op het grensgebied van privaat en $^{-}$ publiekrecht. Steeds als duidelijk is of wordt dat de bestunrsrechter een terrein definitief afstoot, zal de burgeriijke rechter aanvullen. Is afstoting niet duidelijk, of trekt de bestuursrechter 'opeens' een terrein tot zich, dan treedt de burgerlijke rechter terug. Daartussen schrijdt de rechtsbescherming voort, waarbij waststaat dat individuele rechtszoekenden van zo'n wereld van waaierende terreinen gemakkelijk de dupe kunnen worden.

In zo'n klimaat lijkt formele rechtskracht voor de burgerlijke rechter een aantrekkelijk instrument om adequaat aanvullende rechtspraak te kunnen bieden. De formele rechtskracht, die hier wordt gehanteerd als onaantastbaarheid, lijkt zo'n adequaat instrument. Onaantastbaarheid is immers zeker en ook duidelijk (want is er of is er niet). Daarnaast bestaat de mogelijkheid om uitzonderingen aan te nemen. Naast zeker en duidelijk wordt het formele rechtskracht-instrument daardoor ook flexibel (of wellicht moet dit bij de burgerlijke rechter redelijkheid en billijkheid worden genoemd).

De formele rechtskracht van beschikkingen is de meest recente methode in het aloude afbakeningsvraagstuk. Via de band van de niet-toetsbaarheid kon de formele rechtskracht in het civiele gedachtengoed worden binnengehaald. Door de formele rechiskracht van beschikkingen aldus te beschouwen als procesrechtelijk middel leek het de belofte in zich te dragen dat het afbakeningsvraagstuk definitief kon worden opgelost. 


\section{Van rundveestal tot rechtsoverweging: formele rechtskracht in de zaak Heesch-Van de Akker}

\subsection{Inleiding}

Op 16 mei 1986 wees de Hoge Raad arrest inzake de gemeente Heesch en haar inwoner Martinus Johannes van de Akker. Het was het eerste arrest waarin de Hoge Raad de woorden 'formele rechtskracht van beschikkingen' bezigde. Op leerstellige wijze werd zijn visie met betrekking tot die formele rechtskracht van beschikkingen uiteengezet. De Hoge Raad was niet over één nacht ijs gegaan. $\mathrm{Na}$ een uitvoerige conclusie van $\mathrm{A}-\mathrm{G}$ Franx verzocht hij om een aanvullende conclusie, waarin de $A-G$ in zou gaan op de 'vraag naar de voor Van de Akker destijds opengestaan hebbende mogelijkheden voor het instellen van Arobberoep en, in verband daarmee, naar de toewijsbaarheid van zijn vordering ex art. 1395 BW. "In de tweede, aanvullende, conclusie meent de A-G dat 's hofs arrest niet in stand zal kunnen blijven wegens gegrondheid van de middelen inzake formele rechtskracht van beschikkingen. De Hoge Raad verwerpt later het beroep van de gemeente Heesch en neemt een uitzondering aan op de formele rechtskracht van de onderhavige beschikking.

Dat het een belangrijk arrest was, werd direct opgepikt. Rechtspraak van de Week publiceerde het al op 11 juni $\mathrm{i}^{2}$ en in haar aflevering van 14 juni zette het Nederlands Juristenblad het arrest in de schijnwerpers. ${ }^{3}$ Gezaghebbender publicaties konden niet uitblijven. De nestor van het hedendaagse bestuursrecht, Michiel Scheltema, schreef er een noot onder in de Nederlandse Jurisprudentie. ${ }^{4}$ De nestor van de rechtsbescherming, Van der Burg, die in het jaar daarvoor nog in Rechtsbescherming tegen de overheid ${ }^{5}$ schreef over formele rechtskracht, annoteerde het arrest in Administratiefrechtelijke Beslissingen. ${ }^{6}$ Ook Ars Aequi ${ }^{7}$ (met noot Hennekens), Bouwrecht ${ }^{8}$ (met noot Koeman) en De Gemeentestem (met

1. HR 16 mei 1986, AB 1986, 573, p. 1669 (Heesch-Van de Akker).

2. Vgl HR 16 mei 1986 , RvdW $1986,109$.

3. Vgl. HR 16 mei 1986, NJB-katern 14-6-1986, afl.24, nr. 109.

4. Wgl. HR 16 me: 1986, NJ $1986,723$.

5. Vgl. F.H. van der Burg, GJ.M. Cartigny, G. Overkleeft-Verburg, Rechtsbescherming tegen de overheid, Nijmegen 1985 .

6. Vgl. HR 16 mei 1986, AB 1986, 573.

7. Vgl. HR 16 mei 1986, AA 1986 , p. 642 .

8. Vgl. HR 16 mei 1986, Bouwrechi 1986, p. 775. 
noot Konijnenbelt) ${ }^{9}$ publiceerden de uitspraak, evenals ten Berge/Stroink ${ }^{10}$ (met noot Tak) en het prestigieuze AB-Klassiek" (met noot Ten Berge).

Laten we dat arrest en de bijbehorende conclusies eens nader bekijken. Wat was de aanleiding voor dit arrest? Hoe ontstond de rechtswraag inzake formele rechtskracht van beschikkingen" Hoe ziet de hoofdregel van formele rechtskracht van beschikkingen eruit en wanneer bestaat de mogelijkheid van uitzonderingen daarop?

Tenslotte zal ik een bloemlezing presenteren uit de literatuur, die direct naar aanleiding van dit arrest verscheen. Daaronder vat ik nadrukkelijk ook de annotaties onder het arrest in de verschillende tijdschriften.

\subsection{Het 'uitwegvergunningenstelsel', het stelsel van rechtsbescherming en Heesch-Van de Akker}

\section{2 .1 Inleiding}

Aanleiding voor het wijzen van het arrest Heesch-Van de Akker was de onvrede van Van de Akker met het zogenaamde 'uitwegvergunningenstelsel'. Dit stelsel is op zichzelf echter niet het thema van deze studie en bovendien bestaan er vele publicaties over, ${ }^{12}$ zodat ik een bespreking ervan hier terzijde laat.

De gemeente Heesch hanteerde een variant waarbij zij zich woor haar kostenverhaal baseerde op haar eigendomsrecht;, zij gaf "haar' 'uitwegvergunningenstelsel' aldus vorm. In haar APV nam de gemeente een bepaling (art. 33) op waarin geregeld werd dat het verboden was om uit te wegen op de openbare weg (a) of gebruik te maken van (b) (of veranderingen aan te brengen in) (c) een uitweg op de openbare weg zonder vergunning

9. Vgl. HR 16 mei 1986, De Gemeentestem 6842, 3.

10. Vgl. HR 16 mei $1986, \mathrm{tB} / \mathrm{S}, 1986$, Burgerlijke rechter, 3 .

11. Vgl. HIR 16 mei 1986, AB-Klassiek, Zwolle 1991, nr. 17. Dit is de eerste druk; in de derde druk van 1997 (Deventer) werd Heesch-Van de Akker opgenomen onder nr. 22, warbij latere jurisprudentie uitwoeriger werd besproken.

12. Vgl C. Oomen, Ongemotiveerde aanvallen op het uitwegvergunningenstelsel, in: Gem.st. 6404 en 6405 , nrs. 1; L. Damen, Maar het recht dat kan verkeren, in: Gem.st. 6509, mr. 1; C.J.N. Versteden, De sloop vant het uitwegvergunmingenstelsel en de exploitatieverordeningsmethode, in: Gemst. 6628 en 6629 , nrs. I evenals zijn Uitwegverguningenstelsels en financisle voorwaarden in soorten, in: Gem st. 6708, 6709 en 6710 , nrs. 1 ; . Walter de Bruijn, Terugvorderingsacties in uitwegvergunningzaken, in: Bowwrecht 1984, p. 779-789; Naschrift wan J.M.H.F. Teunissen inzake methoden wan kostenverhaal bij ARRS 11 dec. 1986 , Gem.st. 6851.10 (Waalre) J.C.E. Akkermans-Wijn, Contracten met de overheid. Een onderzoek naar de contractsvrijheid van publiekrechtelijke rechtspersonen en het toepassellike materiale recht, diss., Deventer 1989, p. $143 \mathrm{e.w}$.

13. Zo plaatst ook J.C.E. Ackermans-Wijn het stelsel, Contracten met de overheid, diss, Nijnegen 1989 , p. 143 e.v. Zo ook H.J. Simon, Publiekrecht of privaatrecht?, diss., Zwolle 1993, p. 358, die het arrest vooral bespreekt in het kader van de twee-wegenleer, maar daarbij tot de conclusie komt: "Heesch/Van de Akker zegt in deze zienswijze niet zozeer iets over de tweewegenleer, als meer over de verhouding tussen de burgerlijke rechter en diens administratieve collega's.', p. 359. 
van burgemeester en wethouders. ${ }^{34}$ Ter uitwerking van die regeling (art. 33-oud, APV Heesch) was door de gemeenteraad een Regeling vastgesteld betreffende de Ontsluiting van Particuliere Bouwterreinen (ROPB van de gemeente Heesch van 16 november 1976). De aanhef van de $R O P B$ van de gemeente Heesch luidde alls volgt:

\footnotetext{
'De ratad der gemeente Heesch;

$O$, dat art. 33 APV Heesch bepaalt dat het zonder verguning van B en W niet geoorloofd is een uitweg te maken naar een wag, die aan de gemeente in eigendom toebehoort;

dat thet wenselijk is bij de voorgenomen bebouwing wan het uit te wegen terrein, de vergunning slechts to verlenen indien en nadat tussen de aanvrager en de gemeente op privaatrechtelijke basis een overeenkonnst is gesloten tol verkrijging van een vergoeding voor door haar gemaakte of nog te maken kosten voor het bouwrijp maken van de terreinen waaroor de wergunning wordt gevratagd 1 .5
}

De artikelen van het ROPB Heesch stellen vervolgens het sluiten wan die overeenkomst verplicht voordat de vergunning wordt verleend.

Vraag is nu of deze handelwijze van de gemeente Heesch kon worden gekenschetst als rechtshandelen naar burgerlijk recht dan wel als rechtshandelen naar publiekrecht. De toegang tot de rechter is afhankelijk van deze kwalificatie. Is er sprake van een overeenkomst, dan is de burgerlijke rechter (in hoogste instantie de Hoge Raad) bevoegd. Is er sprake van een beschikking, dan kan de Afdeling rechtspraak van de Raad van State (ARRS) op basis van de wet Arob een oordeel geven. Is er sprake van rechtshandelen naar burgerlijk recht, dan kan de 'uitwegvergunning' worden gekwalificeerd als (resultaat en/of onderdeel van) een privaatrechtelijke overeenkomst. Was er, daarentegen, sprake van rechtshandelen naar publiekrecht, dan kon de 'uitwegvergunning' gekwalificeerd worden als beschikking.

\subsubsection{Het stelsel van rechtsbescherming in relatie tor het 'uitwegvergunningenstelsel'}

Ten tijde van het gebruik van het 'uitwegvergunningenstelsel' bleek de vraag of de 'uitwegvergunning' gekwalificeerd kon worden als overeenkomst of als beschikking allesbehalve eenvoudig op te lossen; de kwalificatie was noodzakelijke voorwaarde voor de ontvankelijkheid. Niet alleen bleken gemeentes en burgers voor verschillende opvattingen te pleiten, daarnaast verschilden ook de mogelijke beoordelende instanties daarover lange tijd van mening.

In eerste instantie was er de situatie waarin gemeentes de "uitwegvergunning" graag als een priwaatrechtelijke overeenkomst wilden bestempelen. Strijd met bepalingen van publiekrecht kon dan niet (snel) tot vernietiging leiden, want wanneer de 'uitwegvergunning" werd aangemerkt als overeenkomst, was de burgerlijke rechter bevoegd tot het geven van een oordeel. Publiekrechtelijke argumenten van tegenstanders van het stelsel werden door de

14. Grondslagen voor 'Litwegvergumingenstelsels' kunnen zijn een 'Bijjdrageregeling', het eigendomsrecht, een APV; vergelijk C.J.N. Versteden, Uitwegvergunmingenstelsels en finatnciele voorwarden in soorten, Giemst. $6708-6710(1982)$, p. 165 .

15. Hof "s-Hertogenbosch 7 maart 1984, Bouwrecht 1984, p. 835 r.k en ook HR 16 mei 1986, Bouwrecht 1986, p. $776, \mathrm{rk}$. 
burgerlijke rechter op tenghoudende wijze getoetst. Deze visie onderstreepte de derde kamer van de Hoge Raad in het arrest Hoogeloon (1966). ${ }^{16}$

Daartegenover stond de opvatting dat de 'uitwegvergunning' als beschikking bestempeld werd, want dan kon, als gezegd, bij de ARRS in beroep worden gegaan. Strijd met bepalingen van publiekrecht zou dan eerder worden aangenomen; de ARRS toetste de rechtmatigheid van het bestuurlijk optreden immers op minder terughoudende wijze aan o.a. de (publiekrechtelijke) wet. ${ }^{17}$

Omdat deze administratieve rechtspraak vanaf 1 juli 1976 bij de ARRS werd ondergebracht, ontstond op dat moment pas een potentieel rechtsmachtgeschil. Niet zeker was immers of de ARRS van aanvang af de 'uitwegvergunning' als beschikking zou kwalificeren (en daarmee onder haar rechtsmacht zou brengen). Met de uitspraak inzake Macsiricht I (1977) ${ }^{18}$ was dat zeker. Sindsdien werden 'aanslagen' in het kader van een 'uitwegvergunningenstelsel' gekenschetst als een beschikking. Daardoor werd de ARRS de bevoegde rechter.

Voor het terugvorderen van reeds betaalde geldbedragen in het kader van zo'n uitwegvergunningenstelsel lag het moeilijker, want het niet voldoen door gemeentes na terugvordering van een geldbedrag zag de ARRS steevast als weigeren om onverschuldigde betalingen te restitueren. Deze weigeringen dienden door de burgerlijke rechter te worden beoordeeld. ${ }^{19}$

In Heesch-Van de Akker (1986) conformeerde de Hoge Raad zich aan de opvatting van de ARRS. Vanaf dat moment waren zowel de administratieve als de civiele rechter van oordeel dat de 'uitwegvergunning' gekwalificeerd moest worden als een beschikking en dat een eventuele rechtsgang daartegen openstond bij de ARRS. Zodoende bleek de periode tussen 1976 en 1986 voor wat betreft de rechtsbescherming inzake het 'uitwegvergunningenstelsel' een 'periode van onduidelijkheid'.

\subsubsection{Plaats van Heesch-Van de Akker ten opzichte van het leerstuk van het "uitwegvergunningenstelsel"}

Op het arrest Hoogeloon uit 1966 volgde veel kritiek, zo erkent de Hoge Raad in HeeschVaw de Akker. En bovendien was na Hoogeloon bij de ARRS als vaste jurisprudentie ontstaan het afwijzen van het 'uitwegvergunningenstelsel' wegens strijd met art. 14 Wegenwet. De Afdeling had daarbij, aldus de Hoge Raad in Heesch-Van de Akker, haar oordeel gegeven dat de van burgers (op grond van een soortgelijke regeling als het ROPB

16. Vgl. HR 2 februari 1966, NJ 1966,415 m.nt. N.J. Polak.

17. HR 27 maart 1987, AB 1987, 273 m.nt. FHvdB (Ikon). Pas na Amsterdam-Ikon toetste de burgerlijke rechter immers rechistreeks atan de abbb's.

18. Vgl. ARRS I september $1977, \mathrm{AB} 1977,366$ (Maastricht 1).

19. Dat is thans wellicht anders;" vergelijke ABR 21 oktober 1996, JB $1996 / 232 \mathrm{~m} . \mathrm{nt} . \mathrm{HJS}_{\mathrm{s}}$ warin de Afdeling terugvorderingsbesluiten van bestuursorganen als gericht op rechtsgevolg oordeelt en het rechtsgevolg aan thet bestuurstechtelijke beginsel dat hetgeen onverschuldigd is betaald kan worden teruggevorderd. Dat schept eveneens ruinte om terugvordering door burgers onder de werking vam dif bestuursrechtelijke beginsel te laten vallen. 
in Heesch) gevorderde bijdrage ondanks de aanduiding privaatrechtelijk, niet berustte op een rechtshandeling naar burgerlijk recht, maar op een beschikking in de zin van de wet Arob. ${ }^{20}$ Ook deze opvatting, stelt de Hoge Raad in Heesch-Van de Akker, is vaste jurisprudentie van de Afdeling. Aldus kwam de vraag op of de Hoge Raad hier de ARRS moest volgen.

De Hoge Raad stapt af van zijn opvatting zoals neergelegd in Hoogeloon. In Heesch-Wan de Akker formuleert hij dat zo:

'3.2.2. De (..) vralag komt erop neer af met betrekking tot door de overheid ontwikkelde nitwegvergunningstelsels moet worden vastgehouden aan "Hoogeloon", dan wel de met "Maastricht l' ingexette, vaste jurisprudentie van de Afd. rechtspraak RWS moet worden gewolgd. Daarbij moet voorop worden gesteld dat het oordeel over de vraag of dergelijke uitwegwergunningensielsels rechtens aanvaardbaar zijn, typisch behoort tot die vragen tot het beantwoorden waarvan de Afd rechtspraak RvS is geroepen. Dat reeds pleit ervoor de vaste jurisprudentie van de Afd te volgen. Daar kont bij dat (...) de vraag of dergelijke uitwegvergunningenstelsels rechtens aanvardbaar zijn, al vóor "Hoogeloon" omstreden was en dat dit arrest over het algemeen is afgekeurd, terwijl ook de Kroon enige uitspraken heeft gedaan waruit kan worden afgeleid dat zij dergelijke stelsels afkeurt. ${ }^{\text {,21 }}$

Aan het 'uitwegvergunningenstelsel' als de privaatrechtelijke weg van de overeenkomst werd zodoende in Heesch-Van de Akker een einde gemakt. Niet langer werd het ontsluiten van de opembare weg buiten de in de Wegenwet neergelegde duldingsplicht van de overheid geacht. Daardoor is het vragen van een geldbedrag in strijd met art. 14 Wegenwet. In zijn arrest Heesch-Van de Akker geeft de Hoge Raad expliciet aan het oordeel van de administratieve rechter en de Kroon te volgen.

Met het wijzen van Heesch-Van de Akker, in het bijzonder het volgen van de bestuursrechter daarin, beoogde de burgerlijke rechter de rechtsbescherming van de burger uit te breiden:

"Voor een goed zicht op de mogelijkheden tot inzet door de overheid van privaatrechtelijke bevoegdheden ter behartiging van publieke belangen is de voorrang die de gewone rechter verleent aan zijn administraticve collega van cruciaal belang. Deze immers, en zeker de Afdeling rechtspraak, heeft een sterke voorkeur voor thet volgen door de owerheld van de publiekrechtelijke weg. De Afdeling kijkt door de ogen wan de burger. Voor deze is het nagenoeg steeds gunstig dat de overheid werplicht moet worden geacht tot het volgen van de publiekrechtelijke weg. Het afsnijden van de publieke weg, en de daarmee gepaard ganandle rechtsbescherming, moet in de ogen van de Afdeling dan ook een doodzonde zijn geweest. ${ }^{22}$

\subsubsection{Aanleiding van het arrest}

Concluderend kunnen we zeggen dat de discussie met betrekking tot de bevoegdheidsafbakening van de burgerlijke rechter en de bestuursrechter concreet werd doordat de bestuursirechter zijn competentie vorm gaf aan de hand van de aanwezigheid van een

20. De ARRS had dit uitgemaakt in haar uitspraak van I september 1977, AB 1977, 366 (Maastricht 1).

21. HR 16 mei $1986, \mathrm{AB} 1986,573$, p. 1660 , onder 3.2 .2 .

22. H.J. Simon, Publiekrecht of privaatrecht?, diss., Zwolle 1993, p. 359-360. 
beschikking. Het 'uitwegvergunningenstelsel' als aanleiding van het arrest illustreerde dit doordat bij dit "stelsel" de vraag voorlag of het gemeentebestuur gehandeld had met behulp van een beschikking dan wel met een overeenkomst, een rechtshandeling naar burgerlijk recht derhalve.

\subsubsection{Ontrafeling feit, norm en gevalg}

Met het volgen van de bestuursrechter nam de burgerlijke rechter ook het bestuursrechtelijke oordeel ower. Aldus werd het inhoudelijke oordeel (inzake gerichtheid op de norm, de publiekrechtelijke rechtsvaststelling) als "feit" in het burgerlijk geding binnengehaald. Dit 'feit' (weliswaar" op aanwezigheid ervan als voorvraag binnengehaald) is onaantastbaar (heeft formele rechtskracht) en gaat vervolgens fungeren als basis voor rechterlijke toetsing.

\subsection{De procespositie van Van de Akker in de loop van de procedure}

Het kon geen toeval zijn dat het geschil tussen Van de Akker en de gemeente Heesch ontstond in die "periode van onduidelijkheid' tussen 1977 en 1986. De afbakening van hun beider rechtsmacht ten aanzien van dit 'witwegvergunningenstelsel' was voor de bestuursen de burgerlijke rechter woorwerp van 'aantrekken en afstoten'. Voor zijn procespositie (en in het bijzonder voor zijn mogelijkheid tot het volgen van een rechtsgang) was voor Van de Akker bepalend met wat voor rechtsfiguur hij van doen had. Was de "uitwegvergunning' een beschikking of een overeenkomst? Was de ARRS of de burgerlijke rechter bevoegd? Gedurende de procedure werd het stelsel van rechtsbescherming gewijzigd. Daardoor moest afstemming plaatsvinden tussen de ARRS en de Hoge Raad wat betreft de mogelijkheid tot het volgen van een rechtsgang voor de ARRS. Van de Akkers procespositie in de loop van de procedure zal in het hiernavolgende worden geilllustreerd. De uiteindelijke oplossing door de Hoge Raad in zijn arrest Heesch-Van de Akker en de rol van het beginsel van formele rechtskracht van beschikkingen daarin bespreek ik in de volgende paragraaf.

\subsubsection{Ontstaan van het geschil}

Op 22 januari 1977 heeft Van de Akker een bouwvergunning aangevraagd voor een rundveestal. In antwoord daarop zond de gemeente Heesch aan Van de Akker op 13 juni 1977 een brief, waarin een akte werd bijgesloten, die al vanwege de gemeente was ondertekend. De akte hield een overeenkomst in conform de Regeling Ontsluiting Particuliere Bouwterreinen (ROPB) van Heesch, waarin Van de Akker zich verplichtte om een vergoeding te betalen voordat met de bouw zou worden aangevangen en de gemeente toestemming verleende tot het verzwaren en gebruiken van de door Van de Akker benodigde uitweg ten behoeve van de bouw van de rundveestal. In de brief van 13 juni 1977 nodigde de gemeente Van de Akker uit de overeenkomst te ondertekenen. Van de Akker liet dit desondanks achterwege, maar betaalde wel aan de gemeente de van gemeentewege vastgestelde vergoeding. 
Wat stond Van de Akker te doen? Welke rechter was bevoegd? Vanuit historisch oogpunt gezien moeten we ons afvragen wat Van de Akker diende te doen vóór invoering van de Wet Arob, wat hij diende te doen ná 1 juli 1976 (inwoering Wel Arob) en hoe de ARRS oordeelde in de periode daarna?

Vóór invoering van de Wet Arob had Van de Akker de burgerlijke rechter moeten adiëren. De Wet Arob was nog niet in werking getreden en de rechtsgang voor de Afdeling rechtspraak bestond nog niet. Via de Wet BAB konden 'uitwegvergunningen', die afkomstig waren van gemeentes (lagere overheden) niet aan de Kroon worden voorgelegd. Louter 'uitwegvergunningen' op centraal (rijks-)niveau (en die waren er niet ${ }^{23}$ ) konden via de route van de Wet $B A B$ aan een (publiekrechtelijk) rechtmatigheidsoordeel worden onderworpen.

Overigens had de Kroon (in administratief beroep) wel al haar oordeel gegeven met betrekking tot het "uitwegvergunningenstelsel'. De Kroon had het stelsel, overigens op andere gronden dan op strijd met de Wegenwet, steeds afgewezen. ${ }^{24}$

Ná invoering van de Wet Arob (vanaf 1 juli 1976) stond voor de ARRS nog niet vast dat het bij de 'uitwegvergunning" inderdaad om een beschikking ging. Er was immers een aanduiding 'privaatrechtelijk' en dat zou kunnen betekenen dat de ARRS inderdaad van doen had met een rechtshandeling naar burgerlijk recht. In dat geval was de civiele rechter bevoegd en zou men op de voet van de Hoogeloon-redenering bij de burgerlijke rechter terecht kunnen.

In 1977 kwam het oordeel van de ARRS. Voortaan konden burgers die wilden opkomen tegen aanslagen naar aanleiding van de 'uitwegvergunning' bij de ARRS terecht. In haar uitspraak van 1 september 1977 (Maastricht I) kwam de ARRS tot dat oordeel. Voor de procespositie van Van Akker wil dat zeggen, dat vanaf 1 september 1977 duidelijk was dat hij tegen een aanslag terzake van de 'uitwegvergunning' kon opkomen bij de ARRS, met andere woorden na 1 september 1977 had Van de Akker een administratieve rechtsgang kunnen volgen. Helaas was op 1 september 1977 de beroepstermijn tegen de - nu als beschikking gekwalificeerde - brief van 13 juni 1977 verlopen (4 weken). Van de Akker had echter al uit eigen beweging voldaan en vorderde dat bedrag wegens onverschuldigde betaling terug. Ingewikkelder was daarom dat pas in 1986 de Hoge Raad (in Heesch-Van de Akker) uitmaakte dat hij de opvatting van de ARRS overnam, dat wil zeggen de "uitwegvergunning" gekwalificeerd als beschikking en daaruit volgend de rechtsmacht van de ARRS erkende.

23. "Uitwegvergunningen' op rijksniveau zijn wellicht denkbaar op basis van het Rijkswegenreglement, maar voorzower mij bekend nooit door de Kroon beoordeeld in het kader van de Wet BAB.

24. Vgl. KB 29 oktober 1969, Stb. 488, AB 1970, p. 43 (Nijmegen I) en KB 29 oktober 1975, Stb. 600 , Bouwrecht 1976, p. 25 (Soest) warbij de Kroon spontaan vernietigde. In KB 20 januari 1971, AB 1971, 153 (Njijmegen IIy vernietigde de Kroon nadat de raad in beroep was gekomen tegen de onthouding wan de goedkeuring van de bouwvergumning wegens strijd met art. 48 (oude) Woningwet. 
Nu kan gesteld worden dat Van de Akker in beroep had kunnen gaan bij de ARRS tegen het schrijven van 13 juni 1977 , omdat deze brief angemerkt kon worden als een beschikking. Moeilijkheid was echter dat het kwalificeren van de brief van 13 juni 1977 als beschikking in een soortgelijk geval pas door de ARRS geschiedde op 1 september 1977. Op dat moment was evenwel de termijn woor het indienen van bezwaar en het instellen wan beroep bij de ARRS verlopen. Kortom, het volgen van de administratieve weg was toen onmogelijk geworden. De 'uitwegvergunning', alias de als overeenkomst vermomde beschikking, had (zo stelde de gemeente later voor de rechtbank, het hof en de Hoge Raad) formele rechtskracht gekregen, al werd die term pas daarna door de Hoge Raad aan het verschijnsel gehecht. Al met al had Van de Akker daardoor in redelijkheid geen administratieve rechtsgang kunnen volgen, een voor betrokkene pijnlijke zaak; in HeeschVan de Akker concludeert de Hoge Raad dan ook dat Van de Akker op dit punt geen verwijt treft:

¿... dat het in de - wóor I sept. 1977 gelegen - periode waarin ingevolge art. 6 ROPB voor Van de Akker beroep tegen de in het schrijven van de gemeente van 13 juni 1977 verscholen beschikking openstond, bepaald geenszins voor de hand lag een dergelijk beroep mogelijk te achten. Dat Van de Akker zulk cen beroep achterwege heeft gelaten, walt wem dewalve niet aan te rekenen., 25

Het volgen van de administratiefrechtelijke weg lag, volgens de Hoge Raad, bepaald niet voor de hand. Van de Akker volgde de civiele route. Maar was de zaak wel zo overzichtelijk, kon Van de Akker niet via een andere brief nog een administratieve rechtsgang volgen? Laten we nog eens naar de feiten kijken.

Bij brief van 31 oktober 1979 verzoekt Van de Akker de gemeente om restitutie van de betalde geldsom. De gemeente Heesch wijst bij schrijven van 13 november 1979 dat verzoek af. Bij exploot van 27 november 1979 heeft Van de Akker de gemeente gedagvaard voor de rechtbank Den Bosch. De gemeente verweert zich. De rechtbank wijst Van de Akkers vordering toe bij vonnis van 24 september 1982. De gemeente stelt hoger beroep in. Het hof bekrachtigt bij arrest van 7 maart 1984 het vonnis van de rechtbank. De gemeente gaat in cassatie.

Van de Akker kon dan wel niet verweten worden dat hij niet in beroep gegaan was tegen de beschikking van 13 juni 1977 , lag dat ook zo voor de afwijzing van het verzoek om restitutie van de betaalde geldsom van 13 november 1979 ? De restitutie werd door de Arob-rechter beschouwd als rechtshandeling naar burgerlijk recht, zodat daar geen bijzondere rechtsgang tegen openstond. Eenmaal bij de Hoge Raad aangekomen (in 1986), bleek dat, door het conformeren aan de administratieve opvatting, Van de Akker ten tijde van het verzoek om restitutie en de daarop volgende afwijzing (in 1979) wellicht de administratieve weg (via de ARRS) had moeten volgen. Daar was een grondslag voor restitutie inmiddels immers te halen. Uit de door de ARRS in Maastricht I ingezette rechtspraak kon namelijk, aldus de Hoge Raad in Heesch-Van de Akker, worden afgeleid, dat 'deze juris- 
prudentie voor degenen die bij de Afd. met succes tegen 'heffing' van een bijdrage zijn opgekomen, ten gevolge heeft gehad dat zij deze bijdrage, zo zij reeds was voldaan, terugbetaald hebben gekregen.' De Hoge Raad geeff in Heesch-Van de Akker aan dat het opmerking verdient dat sommige gemeentes, als gevolg van Maastricht I, "vrijwillig" waren overgegaan 'tot terugbetaling van alle in het kader daarvan 'geheven' bedragen." 26 Kon Van de Akker in 1979 weten dat hij zodoende die administratieve rechtsgang had moeten volgen? De terugbetaling van bijdragen aan burgers in het kader van het 'uitwegverguminingenstelsel' was echter door de ARRS in Moastricht II (1981) gekwalificeerd als rechtshandeling naar burgerlijk recht. ${ }^{27}$ Dat zou betekenen dat de afwijzing van 13 nowember 1979 Van de Akker naar de burgerlijke rechter dwong. De Hoge Raad schetst in Heesch-Van de Akker deze verklaring als het door Van de Akker in rechte ingenomen standpunt:

\begin{abstract}
"Op de (..) geschetste achtergrond heeft Van de Akker zich (...) beroepen ter verklaring waarom hij zich, ma de hiervoor (...) bedoelde weigering van de gemeente, tot de burgerlijke rechter heeft gewend met de onder. werpelijke vordering die ertoe strekt dat de gemeente zal worden weroordeeld tot terugbetaling van hel hiervoor (...) genoende bedrag, dat hij haar, naar hij heeft gesteld, op grond wan een wegens sind met art. 14 Wegenwet nietige overeenkomst, en bijgevolg onverschuldigd heef betaad. 28
\end{abstract}

De Hoge Raad vervolgt dan met een weergave van het verweer daartegen door de gemeente. Weliswaar was de betaling geschied in het kader van een overeenkomst, maar ingewolge de jurisprudentie van de ARRS moest de gemeente dat zien als een beschikking in de zin wan de Wet Arob. Primair betoogde de gemeente dat nu Van de Akker heeft verzuimd tegen die beschikking de administratiefrechtelijke rechtsgang te volgen, dat daaruit volgt dat

'de burgeriijke rechter ervan moet uitgaan dat die beschikking zowal wat haar wijze van totstandkoning, als wat haar inhoud betreft in overeenstemming is met de desbetreffende wettelijke voorschuiften en deswege moet aannemen dat de op deze beschikking berustende betaling niet onverschuldigd is. ${ }^{2}$ t9

In zijn beoordeling van het verweer komt de Hoge Raad hier op terug.

Overigens kan - bij wijze wan terzijde - naar aanleiding hiervan de wragg gesteld worden of de brief van 31 oktober 1979 als verzoek on een zalfstandig schadebesiuit formele rechtskracht kan krijgen en in hict vertengde daarvant: kan een zelfstandig schadebesluit nu - naar de huidige stand wan het positieve rechformele rechtskracht krijgen? Doordat de aarovragg door belanghebbende is geschied, kan cen zeilstandig schadebesluit (bijwoorbeeld een weigering) worden afgegeven, zodat dit na verloop van de beroepstermijn formele rechtskracht kan krijgen. Dat żou dan betekenen dat de toegang tot de burgerlijke rechter is afgesneden, daar waar artikel $8: 73$ Awb aan belanghebbenden de keuze laat bij welke rechter zij in beroep kunnen gaan. In de 5 e tranche van de Awb moet de wetgever deze incongruentie meenemen. Een argument

26. HR 16 nei 1986, AB 1986,573 (Heesch-Van de Akker), p. 1659, rechterkolom, onder $3.1 .3 \mathrm{c}$.

27. Vgl. ARRS 27 maart 1981, AB 1981,323 (Maastricht II).

28. HR 16 mei 1986, AB 1986,573 (Heesch-Van de Akker), p. 1659-1660, onder 31.4.

29. HR 16 mei 1986, AB 1986, 573, (Heesch-Van de Akker), p. 1660, linkerkolom, onder 3.1.4. 
tegen het adrnemen wan formele rechitskrach bij zelfstandige schadebesluiten is dat deze kunnen worden beschouwd als behept met cen (feitelijk) inter parte-karakter (egalite) en dat zou zich niet verdagen met her (nomatiove) erga omnes-karakter van de formele rechtsktacht (zoals bestursorganen dat aan constitutieve besilutiten meegeven).

Terug naar de vraag: kon Van de Akker weten dat hij in 1979 een administratieve rechtsgang had kumen volgen? Hijzelf stelde dat hij dat niet had kunnen weten en daartoe beriep hij zich op een uitspraak van de ARRS (Macastricht II). De gemeente verweert zich in Heesch-Van de Akker daartegen met de stelling dat de overeenkomst gekwalificeerd moet worden als beschikking en dat Van de Akker daarom de administratieve route had moeten nemen. Het primaire verweer wan de gemeente is gebaseerd op 'jurisprudentie van de Afd. rechtspraak". Dat roept de vraag op of het primaire verweer gebaseerd is op Maastricht I of op Maastricht II? Enfin, de gemeente beriep zich op nog een ander verweer. Het subsidiaire verweer van de gemeente beschrijft de Hoge Raad als het vertrouwen door de gemeente op de met Hoogeloon ingezette lijn in de jurisprudentie. De Hoge Raad geeft vervolgens aan dat zowel rechtbank als hof de vordering van Van de Akker hebben toegewezen en dat de redenering die daartoe heeft geleid erop neerkomt dat het

\footnotetext{
'te dezen nitet ter zake doet of de rechtshandeling op grond waarvan Van de Akker de (...) betaling aan de. gemeente heeft verricht, wordt gekwallificeerd als een privatrechtelijke overeenkomst dan wel als een publiekrechtelijke beschikking in de zin van de Wet Arob. Indien de rechtshandeling - zoals het hof primair meent - te dezen behoort te worden gekwalificeerd als een privaatrechtelijke overeenkomst dan is de betalïng onverschuldigd omdat deze overeenkonst wegens strijd met art. 14. Wegenwet nietig is (...). Indien die rechtshandeling - zoals het hof subsidiair aaneemt - moet worden gekwalificeerd als een beschikking in de zin van de Wet Arob, dan is de betaling eveneens onverschuldigd amdat er onder de bijzondere omstandigheden van het gegeven geval evan mag en moet worden uitgegaan dat deze beschikking die is gegeven krachtens een wegens strija met de wet onverbindende regeling, ook zelf wegens strijd met de wet rechiskracht ontbect. ${ }^{30}$
}

Merk op dat in deze redenering de grondslag van de onverschuldigdheid van de betaling als die zou berusten op een beschikking wel degelijk werd getoetst.

Enfin, wat daar ook van zij, de kwalificatie van de 'uitwegvergunning" als overeenkomst dan wel als beschikking van de afwijzing van de restitutie in de brief van 13 november 1979 is door het hof als niet doorslaggevend beoordeeld als verweer. En het vertrouwen op de jurisprudentie van de Hoge Raad in Hoogeloom staat aan de toewijzing van Van de Akkers vordering niet in de weg, stelt het hof aldus de Hoge Raad. Het oordeel van de Hoge Raad daarna is bekend; hij volgt de opvatting van de ARRS (toetst dus niet zelf) en acht het bedingen van een geldsom voor het recht van uitweg door een gemeente in strijd met art. 14 Wegenwet. Dat de Hoge Raad zich conformeert aan het oordeel van de ARRS betekent dat het hof terecht kon constateren dat de afwijzing tot terugbetaling in strijd was met de Wegenwet. ${ }^{31}$

30. HR 16 mei 1986, AB 1986, 573 (Heesch-Van de Akker), p. 1660, onder 3.1.5.

31. Vgl. HR 16 meil 1986, AB 1986,573 (Heesch-Van de Akker), p 1660, einde r.o. 3.2.2. 
Met deze laatste constatering zijn we beland bij de oplossing van de Hoge Raad over de formele rechtskracht van beschikkingen.

\subsubsection{Ontrafeling feit, nom en gevolg}

Achter het gevecht tussen beschikking of overeenkomst (rechtshandeling naar burgerlijk recht) ging de afbakening van rechtsmacht schuil. In geval van een beschikking nam de burgerlijke rechter het oordeel van de bestuursrechter over en ging hij niet over tot zelfstandig toetsen (dit is de lijn Hei-en Boeicop en St. Oederyrode-Driessen zoals in het vorige hoofdstuk tot uitdrukking kwam). In geval van een rechtshandeling naar burgerlijk recht ging hij wel over tot ontvangen en toetsen (dit is de lijn $V d D$ en Super Doe-Groningen zoals in het vorige hoofdstuk tot uitdrukking kwam). In Heesch-Van de Akker komen deze twee lijnen samen en dus wordt de voorafgaande jurisprudentie bevestigd. De volgende paragraaf illustreert dit.

Waarom is de formeel rechtskrachtige beschikking voor de burgerlijke rechter onantastbaar? Waarom toetst hij de gerichtheid op de norm, de publiekrechtelijke rechtsvaststelling, de rechtshandeling als rechtshandeling, niet? Een verklaring kan zijn dat dit, de gerichtheid op de norm, een normatief, objectief, oordeel behelst. De burgerlijke rechter is niet gewoon op die wijze te toetsen (en acht zich daartoe ook niet geroepen); niet voor niets zegt hij vaak zelf dat de wetgever voor dit oordeel een terzake meer deskundig geachte specifieke rechter heeft aangewezen. Het binnenhalen wan het bestuursrechtelijke cordeel, anders gezegd het overnemen vam het oordeel in administrativo inzake de formele rechtskracht van de beschikking, maakt het mogelijk om dat normatieve oordeel verpakt als 'feit' binnen te halen; vandaar dat dit 'feit' onaantastbaar moet zijn.

\subsection{De oplossing van de Hoge Raad}

In deze paragraaf wordt het arrest van de Hoge Raad inzake Heesch wersus Van de Akker stap voor stap gevolgd en well (in het bijzonder) met betrekking tot de rechtsvraag inzake de formele rechtskracht van beschikkingen.

\subsubsection{De cassatiemiddelen}

De gemeente Heesch stelt schending van het recht en/of verzuim van vormen, hetgeen wordt gestoeld op vier middelen van cassatie.

Het eerste middel richt zich tegen de uit art. 14 Wegenwet volgende duldingsplicht voor de overheid en dat die zich zou uitstrekken tot het recht om te mogen uitwegen. Het verlangen van een betaling is daarmee niet in strijd en 's hofs visie daaromtrent is onjuist en/ of onbegrijpelijk. ${ }^{32}$

Het tweede middel concentreert op 's hofs beslissing dat betald zou zijn op grond van een privaatrechtelijke overeenkomst en dat deze overeenkomst nietig is wegens strijd met de 
wet, waardoor de betaling onverschuldigd is en door Van de Akker teruggevorderd kan worden. Het middel betoogt dat het hof heeft miskend dat de grondslag van de betaling niet een overeenkomst, doch een (inmiddels rechtens onaantastbare) beschikking betreft; de overeenkomst was immers een voorwaarde voor de beschikking. Daarnaast miskent het hof dat tegen de beschikking cen administratieve rechtsgang heeft opengestaan, die door Van de Akker niet is gebruikt, waardoor de beschikking onaantastbaar is geworden. ${ }^{33}$

Het derde middel beoogt de onverbindendheid van de ROPB aan te vallen. De redenering daarvoor luidt dat 's Hofs overweging dat beide partijen het eens zijn over de onverbindendheid van de ROPB onjuist is, althans onbegrijpelijk. De gemeente acht het systeem wan de ROPB nog steeds rechtens juist. De beschikking die is gebaseerd op de ROPB is (inmiddels) rechtens onaantastbaargeworden. Het is een open vraag tot welke uitspraak de administratieve rechter zou zijn gekomen, want er is nu eenmaal niet vernietigd en Van de Akker heeft de administratieve rechtsgang niet gevolgd. Het op basis van de uitkomst van die open wraag terug moeten betalen is een onjuist, althans onbegrijpelijk oordeel van het hof, omdat het hof daarmee de onaantastbaarheid van de beschikking miskent. ${ }^{34}$

Het vierde middel strekt ten betoge dat de gemeente in goed vertrouwen op de jurisprudentie van de Hoge Raad (Hoogeloon) had mogen afgaan. De gemeente had op de validiteit van Hoogeloon mogen afgaan, omdat zij dat deed voordat de ARRS met andere rechtsopvattingen kwam, Van de Akker geen bezwaar had gemaakt en heeft betald, en ook de redelijkheid en billijkheid in verband met de rechtszekerheid meebrengen dat terugvordering niet meer geldend gemaakt kan worden. Gewijzigde rechtspraak heeft geen terugwerkende kracht. 's Hofs rechtsopvatting dat de geldigheid van een bepaalde rechtsfiguur niet slechts voor na die verandering gestelde handelingen zou gelden en dat daarvan slechts in bijzondere omstandigheden kan worden afgeweken, is in strijd met het recht en/of onjuist en/of onbegrijpelijk. ${ }^{35}$

\subsubsection{Eerste conclusie}

Advocaat-Generaal Franx concludeert op 6 december 1985. Nadat de A-G de feiten en het verloop van de procedure heeft geschetst, geeft hij een analyse van de opbouw van het bestreden arrest. Daarna geeft de A-G aan dat hij zich 'drastisch' zal beperken. Aangezien de A-G het vierde middel gegrond acht, kan bespreking van het eerste en het tweede middel achterwege bliiven. Ook het derde middel kan volgens hem niet tot cassatie leiden. ${ }^{36}$ De gegrondheid van het vierde middel, zo stelt de A-G "brengt mee dat de rechtsgrond van de litigieuze betaling door Van de Akker moet worden beoordeeld naar de ten tijde van die betaling bestaande rechtsopvattingen. Het hof gaat er, veronderstellenderwijs en met juistheid, van uit dat er toen een geldige rechtsgrond woor de betaling bestond, gelet op het

33. Vgl. HR 16 mei 1986, Ni 1986, 723. (Heesch-Van de Akker), p. 2732-2733.

34. Vgl. HR 16 mei 1986, NI 1986, 723 (Heesch-Van de Akker), p. 2733.

35. Vgl. HR 16 mei 1986, NJ 1986, 723 (Heesch-Van de Akker), p. 2734.

36. Vgl. HR 16 mei 1986, NJ 1986,723 (Heesch-Van de Akker), p. 2736, linkerkolom, onder 3. 
Hoogeloon-arrest. Uit de structuur van het bestreden arrest (r.o. 2.1-4.1) blijkt dat het hof die rechtsgrond heeft getoetst aan de naderhand veranderde rechtsopvattingen."37

Aldus is het vierde cassatiemiddel geconcentreerd op de vraag naar het verschil in ex tuncen ex numc-toetsing door de burgerlijke rechter en de invloed van wijziging van rechtspraak op het rechtmatigheidsoordeel. Ter beantwoording van deze vraag start de $A-G$ een uitwoerige bespreking met als centrale stelling: gewijzigde rechtspraak heeft geen terugwerkende kracht. Ondat de A-G het vierde middel gegrond acht, moet tot vernietiging van "s hofs arrest worden geconcludeerd. De $A-G$ ondersteunt deze conclusie als volgt:

\begin{abstract}
"Al aangenomen dat de regels wan het Hoogeloon-arrest zijn vervangen door de gewijzigde rechtsopvatimgen blijkend uit de jurisprudentie van de Afd. rechtspraak, mi. moet het er, net het hof, voor worden gehouden dat die wijziging van recht is ingetreden nadat Van de Akker de thans door hem als onverschuldigd gekwalificeerde betaling aan de gemeente heeft werricht, en dat die techtswijziging wer terugwerk in dier woege dat die betaling achteraf alsnog als onverschuldigd zou hebben te gelden., 3 s
\end{abstract}

De A-G ziet geen ruimte voor een regel in het Nederlandse geldende recht als zou wijziging van rechtspraak in beginsel terugwerkende kracht hebben. Art. 4 Wet $A B$, o.a. inhoudende een verbod van terugwerkende kracht van wetgeving, is "daarom i,c. niet, althans niet rechistreeks, van toepassing. ${ }^{39} \mathrm{Nu}$ de $\mathrm{A}-\mathrm{G}$ geen ruimte ziet voor in beginsel terugwerkende kracht van gewijzigde rechtspraak benadrukt hij daarmee dat de gemeente voor een voldongen feit werd gesteld:

"uit het vorenstande volgt tevens, dat de jurisprudentie van de Afd. rechtspraak van 1 sept. 1977 an later, waabij werd afgeweken van de Hoogeloon-regel, niet terugwerkt ten aanzien wan wớr die datum verrichte "Hoogeloon-handelingen".

Zulks klent temeer mu het hier gaat om een voldongen feit. De gemeente had de litigieuze betaling van Wan de Akker, steunend op de met hem gesloten overeenkomst, reeds ontvangen toen de rechispraak inzake de rechsgeldigheid van die transactie zich wijzigde. ${ }^{40}$

Terugkomen op voldongen feiten door aan nieuwe regels terugwerkende kracht te verlenen, kan de goedkeuring van de A-G miet wegdragen. Immers, een feit kan wel relevant zijm in het kader van de beantwoording van de vraag naar toepasselijklieid van een norm, zo lijkt de redenering, maar datzelfde feit is niet maatgevend wanneer de norm reeds is toegepast. De vraag naar toepasselijkheid is op een bepaald moment (en toen ook correct) geschied. Daarna heeft de nom wijziging ondervonden (door verandering van rechtspraak, die rechtsvormend was). Aldus onderscheidt de $A-G$ in casu feit en norm.

37. HR 16 mei 1986, NJ 1986, 723 (Heesch-Van de Akker), p. 2736, linkerkolom, onder 3.

38. HR 16 mei 1986, NJ1986,723 (Heesch-Van de Akker), p. 2736, rechterkolom, onder 4.

39. Vgl. HR 16 mei 1986, NJ 1986, 723. (Heesch-Van de Akker), p. 2737-2739, onder de nummers $\$$ (eind) tot en met 9 .

40. HR 16 mei 1986, NJ 1986, 723 (Heesch-Van de Akker), p. 2740, linkerkolom, onder 10. 


\title{
3.4.3 Aanvullende conclusie
}

Op 28 februari 1986 komt een aanvullende conclusie. Deze conclusie doet de A-G na een verzoek daartoe van de Hoge Raad. De eerste conclusie behandelde slechts het vierde cassatiemiddel. In de aanvullende conclusie gaat de A-G in:

'op de in de middelen ll en lin aan de orde gestelde vraag naar de woor Van de Akker destijds opengestaan hebbende mogelijkheden voor het instellen van Arob-beroep en, in verband daarmee, naar de toewijsbaarheid wan zijn vordering ex art. $1395 \mathrm{BW}^{.4}$

We komen nu bij de vraag hoe de A-G de rechtsvraag inzake formele rechtskracht schetst en wat daarop zijn antwoord is. Hij vat eerst de te bespreken middelen samen:

'De middelen II en III zijn gericht tegen ro. 4.1 van 's hof arrest en komen neer op de klacht dat uit het sub 2 en 3 overwogene de nietigheid van de "privaatrechtelijke overeenkomst" tussen pp. en de toewijsbaarheid van Van de Akkers condictio indebiti wiet voortvloeien. ${ }^{42}$

Daarna komt hij tot een meer operationele vraag in zijn analyse:

\begin{abstract}
"Was de brief d.d. 13 jumi 1977 van $B$ en W aan Van de Akker een besclikking in de zin de Wet Arob waaricgen Arob-beroep opensiond, zoals onderdeel 2 van middel II zegt? Het onderdeel werbindt daaraan de gevolgtrekking, dat nu Van de Akker van de Arob-rechtsgang geen gebruik heefi gemaakt, die beschikking onaantastbaar is geworden en de burgerlijke rechter bij zijn oordeel over de verschuldigdheid van de betaling van de rechtsgeldigheid van bedoelde beschikking behoort wit te gaan. ${ }^{\circ 4}$
\end{abstract}

Het tweede middel doet aldus een beroep op de rechter om de beschikking niet te toetsen. Dit is een belangrijke vraag in de aanvullende conclusie, zo stelt de $A-G$ impliciet, want het antwoord bepaalt of er gecasseerd kan worden of niet. Hij zegt het zo:

\footnotetext{
'Tot cassatie kan zulks echter niet leiden indien geoordeeld moet worden dat de in middel II besloten materiste klacht, dat het hof van de onaantastbaarheid van de 'beschikking' d.d. 13 juni 1977 en daarmee van de rechisgeldigheid wan de dakrop gebaseerde overeenkomst tussen $\mathrm{pp}$. had moeten uitgaan, niet gegrond is.
}

De A-G beantwoordt het beroep op niet toetsing negatief, want hij is van mening dat een vordering uit onverschuldigde betaling door de burgerlijke rechter dient te worden beoordeeld. Hij is de bevoegde rechter. De A-G onderstreept deze stelling door eerder gedane conclusies voor de Hoge Raad aan te halen, alsmede annotaties en jurisprudentie. Hij zegi:

41. HR 16 mei 1986, NI 1986, 723 (Heesch-Van de Akker), p. 2741, linkerkolon, onder 1 .

42. HR 16 mei 1986, NJ 1986, 723 (Heesch-Van de Akker), p. 2741, linkerkolom, onder $\mathbb{I}$.

43. HR 16 mei 1986, WJ 1986,723 (Heesch-Van de Akker), p. 2741, linkerkolom, onder 2.

44. HR 15 mei 1986, NJ 1986, 723 (Heesch-Van de Akker), p. 2741, rechterkolom, onder 2. 
'Eun vordering ati amerschuldigde betaling (art. 1395 lid $\mathbb{1}$ BW) als de onderhavige moet woor de gewone, burgerlyhe rechter worden gebracht. Een dergelijke vordering (...) is een 'rechtshandeling naar burgerlik rechit $^{* 45}$

Daarmee geeft de A-G zijn (impliciete) opvatting dat in casu niet geconcludeerd kan worden tot aanwezigheid van een beschikking (die dan tot het niet toetsen zou moeten leiden), maar stelt hij de civiele rechtsingang voorop.

Maar er is meer onder de zon. Naast de vraag naar de bevoegdheid van de burgerlijke rechter, onderscheidt de $\mathrm{A}-\mathrm{G}$ de vraag naar zelfstandige toetsing door de burgerlijke rechter. Deze vragen staan aldus naast elkaar; tot hoever reikt de bevoegdheid van de burgerlijke rechter?

"Een andere kwestie is echter of de burgerlijke rechter, die moet oondelen over een condictio indebiti, bewoegd is tot wolledige toetsing van de gestelde onverschuldigdheid wan de betaling.

Indien beantwoording van de vraag of de betaling al dan niet verschuldigd was (een toereikende rechisgrond had), mede affangt van de geldigheid van een 'beschikking' in de zin van art. 2 Weit Arob en de bevoegde administratieve rechter over die geldigheid een beslissing heeft gegevem, dan is de burgerlijike rechter aan die beslissing gebonden. Indien de belanghebbende wan de beschikbare Arob-rechtsgang geen gebruik heeft gemaakt, is de burgerlijke rechter aan de geldigheid, de rechtmatigheid van de beschikking gebonden. *6

De rechtsmacht van de burgerlijke rechter reikt niet ver als de rechtsgrond in het bestuursrecht ligt: de burgerlijke rechter neemt het administratieve oordeel (van bestuursrechter of van bestuursorgaan) over.

Daarbij valt het een en ander op. Geldigheid en rechtmatigheid van beschikkingen worden daarbij gelijkgesteld (als onaantastbaarheid). Aldus maakt de A-G geen onderscheid in feitelijke en normatieve, inhoudelijke eigenschappen van de beschikkingen.

Overigens zijn de druiven zuur, aldus de $\mathrm{A}-\mathrm{G}$ :

\footnotetext{
'Opgemerkt zij dat de hier besproken onaantastbaarheid wan een beschikking in cen civicle procedure het effect heeft van rectulsbescherming wan de overheid tegen de burger. De rechisbescherming tegew de overheid is hier in haar tegendeel komen te verkeren. Dat kome in de onderhavige zaak dan ook duidelijk tot uiting. As de brief d. 13 juni 1977 rechtens als een onaantastbare Arob-beschikking heeft to gelden, dan is daarmee het lot van Van de Akkers condictio indebiti (..) bezegeld. De administratieve rechter biedt misschien een betere bescherming tegen de overheid, mar men moet er, vergelijkenderwijs, als particulier wel als de kippen bij zijn. ${ }^{47}$
}

Dan gaat de A-G over tot een bespreking van het derde middel. Daarbij komt hij tot een belangrijke overweging. Bij zijn stelling dat het derde middel en in het bijzonder de onderdelen 3 en 4 terecht zijn voorgesteld, komt hij op de formele rechtskracht van de beschikking. Hij stelt het zo:

45. HR 16 mei 1986, NJ 1986, 723. (Heesch-Van de Akker), p. 2741, rechterkotom, onder 3.

46. HR 16 mei 1986, NJ 1986,723 (Heesch-Van de Akker), p. 2741, rechterkolom, onder 4.

47. HR 16 mei 1986, NJ 1986,723 (Heesch-Van de Akker), p. 2742, linkerkolom, onder 4. 


\begin{abstract}
'De geneente heeft steeds atangevoerd dat de "beschikking' d.d. 13 juni 1977 , waarop vollgens haar de betaling door Van de Akker beruste, onaantastbaar is geworden doordat laatstgenoemde datartegen niet binnen de weftelijk voorgeschreven termijn Arob-beroep heef ingesteld. Aldus heeft de gemeente zich beroepen op de formele rechrskrach wan die beschikking. Met name ait haar pleitnota in hoger beroep blijkt van een sterke nadruk op dat aspect, wajap trowwens de gemeente mede haar stelling dat Van de Akker niet onverschuldigd heeft betald, fundeerde. In r.0. 5.6 heeft het hof het beroep op die formele rechtskracht verworpen on "redenen van proceseconomie". Hiertegen kormen de middelonderdelen III.3 (slot) een III.4. natar het mij toeschijnt, terecht op. De formele rechtskracht van cen niet in Arob-beroep aangevallen en daardoor onherroepelijk geworden Arob-beschikking berust mede op het rechtszekerheidsbeginsel. Na hat verstrijken warl de beroepstermign kan geen Arob-beroep meer worden ingesteld. Alle betrokkenen hebben daardoor de zekerheid verkregen dat de beschikking in stand blift, althans niet meer in Arob-beroep kan worden vernietigd. Dat is niet alleen voor de belanghebbende particulier maar ook voor de betrokken besturursinstantie van grote betekenis, met het oog op het in de toekomst woor gelijksoortige gevallen te voeren beleid en de financiele consequenties darwan. Het gaat niet aan om jaren na dato en beschikking, op de rechisgeldigheid waaryan reeds lang is en mocht worden wertrouwd, alsnog aan te tasten en van haar effecten te berowen Jangs een daarwoor thiet in de eerste plaats gegeven weg, we wen een gewone civiele procedure. ${ }^{28}$
\end{abstract}

De druiven mogen dan wel zuur zijn, maar dat hindert niet nu formele rechtskracht niet voor miets bestaat; de rechtszekerheid is ermee gediend. Echter, zo stelt de A-G, de gegrondheid van middel III hangt af van middel II, "waarin wordt geponeerd dat voor Van de Akker een Arob-rechtsgang beschikbaar was."49 Daarmee wordt opnieuw de kwestie van de bevoegdheid aangeroerd. In geval van jurisdictieconflicten, zo luidt zijn oplossing, moet de Hoge Raad de Arob-jurisprudentie zoveel mogelijk volgen. ${ }^{50}$ Vervolgens komt hij terug op de vraag of de gemeente een (inmiddels onaantastbare) beschikking heeft genomen, met andere woorden of middel II gegrond is.

De A-G bespreekt zeer uitvoerig de vraag welk rechtskarakter toekomt aan de brief met bijlage van 13 juni 1977. In het vervolg duidt hij deze brief aan als 'de brief'. De brief van 13 november 1979 (afwijzing verzoek om restitutie) wordt niet naar rechtskarakter geanalyseerd. Kortom, aan de orde is de wraag welk het rechtskarakter is van "de brief"?

"In dit werband zij opgemerkt, dat een besluit een meervoudig karakter kan hebben; het kan zowel een "beschikking' zijn als een 'rechtshandeling naar burgerlijk recht', een en ander in de zin van art. 2 Arob. 31

'De brief' bevat verschillende rechtsmomenten tegelijk, stelt de $A-G$, en wel de volgende:

'a. Eem aambod tot het slluiten van een overeenkomst met een bepalde inhoud $(\ldots)$.

b. Het tor kennis van Van de Akker brengen wan een beshit tot:

1 s het s.twiten wan bedoelde overecnkomst met hem, en tot

48. HR 16 mei 1986, N. 1986,723 (Heesch-Van de Akker), p. 2743, linkerkolom, onder 7.

49. HR 16 mei 1986, NJ 1986, 723 (Heesch-Van de Akker), p. 2743, linkerkolom, onder 8.

50. Vgi. HR 16 mei 1986, NJ 1986,723 (Heesch-Van de Akker), p. 2743, rechterkolom, onder 9.

51. HR 16 mei 1986, NJ 1986,723 (Heesch-Van de Akker), p. 2744, linkerkolom, onder 11. Merk overigens op dat de tekst van art. 2 Arob deze conclusie nu juist witsloot. Lid 2 lwidde immers: Geen beschikking in de zin van deze wet is: a. (..); b. en rechtshandeling naar burgerlijk recht. Vgl. ook: Jo. Steenbeek, Wet Arob, 's-Gravenhage 1976, p. 59-62. 
$2^{\circ}$ weigering van de gevraggde verguning onder een voorwarde, te weten dat Van de Akker niot zou instenunen met het sluiten van die overeenkomst. (..)

Zou men slechts letten op het onder a bedoelde aambod, dan zou daarin een rechtshandeling naar burgerlik reckt en geen 'arobabele' beschikking gezien mogen worden. (...)

Betrekt men hierbij element $b-1^{\circ}$, thet besluit van de gemeente tot het angaan van een overeenkomsi met

Van de Akker, dan is het antwoord op de vratag: arobabele beschikking? minder tenwoudig." ${ }^{2}$

Dan volgt een uitwoerige uiteenzetting van voors en tegens woor het aannemen van een beschikkings-rechtskarakter voor het gestelde onder b-1 $1^{\circ}$, en volgt tenslotte de conclusie:

'ik neig tot de opvatting dat in de brief vam 13 juni 1977 een "enzijdige oplegging krachtens (de gemeentelike) bijdrageregeling" besloten ligt en mitsdien een beschikking in de zin van art. 2 Wet Arob., ${ }^{3,3}$

\title{
En iets verderop stelt hij:
}

\begin{abstract}
"Zolang de overeenkomst niet gesloten is blijft de arobabele beschikking een arobabele beschikking, ook al wordt de instemming van de belanghebbende, in de vorm van die overeenkomst, verlangd. Van de Akker had voor het bereiken van zijn doel, het verkrijgen van een bouwwergunning, geen andere optie: hij "moest" de hem aangeboden overeenkomst shiten, wilde hij niet afzien van de bouwvergunning. Het 'aanbod" was daardoor een vorm van bestuursdwang (...). Hier is, zoals Van de Akker wooral in hoger beroep met veet nadruk heef betoogd, sprake van een 'heffing' net zoals in de zaken Maastricht 1 etc.

Derhallwe ben ik wan mening dat in de meerbedoelde brief $d . d .13$ juni 1977 twee onderling samenhangende

Arob-beschikkingen besloten lagen (...):

$1^{\circ}$ een besluit tot het sluiten van de overeenkomst, en

$2^{\circ}$ een besluit inhoudende een voorwaardelijke weigering van de gevraagde bouwvergunning. 94
\end{abstract}

Kennelijk is het bestaan van het dwangkarakter (hij 'moest' de overeenkomst well sluiten) doorslaggevend voor het aannemen van thet beschikkingskarakter door de A-G. Na nog aangegeven te hebben dat hij van mening is dat de jurisprudentie van de ARRS inderdaad aanleiding geeft tot twijfel, gaat de A-G over tot zijn eigenlijke conclusie. Onderdeel 2 van het tweede middel acht hij gegrond en zo kan geconcludeerd worden tot vernietiging van 's hofs arrest en verwijzing naar een ander hof. ${ }^{55}$

\subsubsection{Het oordeel van de Hoge Raad}

De Hoge Raad bespreekt alle vier de middelen van cassatie. Het eerste middel redt het niet. En passant heeft de Hoge Raad in zijn beoordeling van het eerste middel aangegeven dat hij aan de met Hoogeloon ingezette jurisprudentie niet langer vasthoud, maar de jurisprudentie wan de administratieve rechter op dit punt zal volgen. ${ }^{36}$

52. HR 16 mei 1986, NJ 1986, 723 (Heesch-Van de Akker), p. 2744, onder 11.

53. HR 16 mei 1986, NJ 1986,723 (Heesch-Van de Akker), p. 2745, rechterkolom, onder 14.

54. HR 16 mei 1986, NJ 1986,723 (Heesch-Van de Akker), p. 2746, linkerkolom, onder 14.

55. Vigl. HR 16 mei 1986, NI 1986, 723 (Heesch-Van de Akker), p. 2746, onder 15 en 16.

56. Vgl. HR 16 mei 1986, AB 1986, 573 (Heesch-Varn de Akker). p. 1660-1661, onder 3.2, in het bijzonder 3.2 .2 (einde), $32.3,3.2 .4$ en 3.2 .5 . 
In r.o. 3.3 gaat de Hoge Raad over tot beantwoording van de middelen II en III. Eerst geeft hij kont de in de middelen gestelde vraag weer. Daarna wolgen de overwegingen, waarin de hoofdregel van en de uitzondering op het beginsel van formele rechtskracht van beschikkingen worden uiteengezet. Deze overwegingen van de Hoge Raad luiden:

\begin{abstract}
"3.3.1 De onder 3.1.5 (: weergave van de oordelen van het hof, EvdL) weergegeven opzet van 's hofs gedachtengang vergl vervolgens beantwoording van de door de middelen li en lfl aan de orde gestelde wraag of het hof het primaire betoog van de gemeente - kort gezegd: dat de betaling berust op een beschikking met formele rechtskracht hervoor 3.1.4 (: weergave wan in rechte ingenonen standpunten, EvdL) - terecht heeft verworpen.

3.3.2 Deze vraag moet bewestigend worden beantwoord. Voorop moet worden gesteld dat wanneer tegen een beschikking een met voldoende wataborgen omiklede administratiefrechtelijke rechtsgang heeft opengestaan (zods die ingewolge de Wet Arob), de burgerlijke rechter, zo deze beroepsgarg niet is gebruikt, in geval de geldigheid van de beschilking in het voor hem gevoerde geding in geschil is, ervan dient wit te gaan dat die beschikking zowel wat hatr wijze van tot stand komen als wat haar inhoud betreft in overeenstemming is met de desbetreffende wettelijke voorschriften en algemene rechtsbeginselen. Dit geldt in beginsel óok dan, indien dit de burgerlijke rechter ertoe zou nopen aan zijn uitspraak de rechtsgeldigheid ten grondslag te leggen van een beschikking waarvan als vaststaand mag worden aangenomen dat zij, alls daartegen tijdig administratiefrechtelijk beroep zou zijn ingesteld, zou zijn vernjetigd. De daaraan verbonden bezwaren kunnen evenwel door bijkomende omstandigheden zo klemmend worden dat op dat beginsel een uitzondering moet worden aanvatud. Of woor zullk een uitzondering plaats is, hargt bijgevolg af van de bijzonder* heden wan het gegeven geval. ${ }^{57}$
\end{abstract}

Met deze overweging hanteert de Hoge Raad voor het eerst expliciet het begrip formele rechtskracht van beschikkingen in navolging van de A-G. Hij doet dat in de weergave van de door de middelen voorgestelde wraag (in r.o. 3.3.1). Vervolgens zet hij uitvoerig uiteen wat onder die formele rechtskracht van de beschikking moet worden verstaan: een beschikking waartegen niet in een administratieve rechtsgang in beroep is gekomen, krijgt formele rechtskracht; dat wil zeggen zal niet door de burgerlijke rechter aan een zelfstandige toetsing worden onderworpen. De burgerlijke rechter gaat dan uit van de rechtsgeldigheid van de beschikking ten aanzien van zowel de totstandkomingswijze (feitelijk) als de inhoud (normatief). Zo onderstreept hij de door de A-G voorgestelde zienswijze ten aanzien van de formele rechtskracht wan beschikkingen: de aanwezigheid van een beschikking leidt tot onaantastbaarheid en dus mag de burgerlijke rechter niet toetsen. Anders echter dan de A-G concludeert, ziet de Hoge Raad vervolgens geen ruimte voor vernietiging van 's hofs arrest. Hij breidt de aangeboden visie met betrekking tot de formele rechtskracht van beschikkingen uit tot enerzijds een hoofdregel (die ook de A-G had geschetst) en anderzijds de mogelijkheid tot het aannemen van uitzonderingen (zodat de mogelijkheid wordt geopend om toch te toetsen).

De Hoge Raad geeft de reikwijdte (grenzen) van de formele rechtskracht van beschikkingen aan: 'dit geldt in beginsel ook dan ...", maar 'De daaraan verbonden bezwaren kunnen zo klemmend worden dat op dat beginsel een uitzondering moet worden gemaakt'.

57. HR 16 mei 1986, AB 1986,573 (Heesch-Van de Akker), p. 1661, linkerkolom. 
Afhankelijk van de omstandigheden wan het geval kan de formele rechtskracht van beschikkingen te strikt uitpakken, maar de mogelijkheid van de uitzondering bestaat. Daarmee is een hardheidsclausule ingebouwd. Ik vermoed dat de overwegingen van de A-G dat de rechtsbescherming van de burger tegen de overheid hier in haar tegendeel kan komen te verkeren - dat wil zeggen als rechtsbescherming tegen de burger - de Hoge Raad daarbij parten speelde. Kennelijk is de Hoge Raad het met de stellingname van de A-G eens geweest en heeft hij daarop de uitzonderingsmogelijklheid gecreeerd.

Het overgaan tot niet toetsen (aannemen hoofdregel formele rechtskracht) moet de Hoge Raad wel combineren met de mogelijkheid tot het maken van uitzonderingen. Immers, het niet toetsen (omdat hij zich niet bevoegd acht) komt in strijd met de onvang van zijn bevoegdheid (naar de letter van de GW). De mogelijkheid tot het aannemen van uitzonderingen is zo bezien een hardheidsclausule die door de (algemene) bevoegdheid van de burgerlijke rechter wordt gevorderd. Ook een rechter, die de efficiëntie vooropzet, verliest de (volledigheid van) rechtsbescherming niet uit het oog. De aanwezigheid van een (feitelijk) oordeel inzake een beschikking hoeft dus niet in alle gevallen te leiden tot het overnemen van het bestuursrechtelijke oordeel of niet toetsing daarvan.

En passant benoent de Hoge Raad de (hoofdregel van) formele rechtskracht van beschikkingen als een beginsel: "op dat beginsel een uitzondering moet worden gemaakt". Dat is des te merkwaardiger waar dat 'beginsel' eerder geformuleerd werd als een regel (een afbakeningsrege().

Ten aanzien van de uitzonderingen op de hoofdregel van de formele rechtskracht van beschikkingen constateert de Hoge Raad eerst dat er een mogelijkheid van het aannemen van een uitzondering op de hoofdregel van formele rechtskracht van beschikkingen bestaat, immers:

'De daaraan werbonden bezwaren kunnen evenwel door bijkomende omstandigheden zo klemmend worden dat op dat beginsel een uitzondering moet worden aanwaard. Of voor zulk een uitzondering plaats is, hangt bijgevolg af van de bijzonderheden van het gegeven geval.'

Afhankelijk van de bijzonderheden van een concreet geval bestaat er de mogelijkheid tot het aannemen van zo'n uitzondering op de hoofdregel van de formele rechtskracht van beschikkingen. Welke bijzonderheden kunnen in een concreet geval leiden tot het aannemen van zo'n uitzondering op de formele rechtskracht van beschikkingen? Naar aanleiding daarvan gaat de Hoge Raad zeer uitvoerig in op de omstandigheden zoals die geschetst werden door rechtbank en hof. Omwille van de volledigheid neem ik deze passage integraal over:

"In dit verband moet er in de eerste plaats op worden gewezen dat in gevallen als het onderhavige alleea daarom moet worden aangenomen dat (mede) sprake is van een beschikking waartegen destijds beroep heeft opengestaan ingevolge de Wet Arob, omdat de Afd. rechtspraak RvS - ongetwijfeld ten einde de rechtsbescherming van de betrokken burgers witt te breiden - in het kader van haar hiervoor in 3.1 .3 sub $\mathrm{c}$ en $d$ (weergave van de achtergronden van het geschil, ExdL) bedoelde rechtspraak bereid is gebleken in de rechishandeling waarop betalingen als de litigieuze berusten, ondanks haar duidelijk privaatrechtelijke gedaante, (mede) een beschikking in de zin van de genoemde wet te ontwaren. Uit de op dil punt op "Maas- 
tricht I' (1 sept 1977) en de daarop wolgende uitspraken van de Afd. witgeoefende kritick mag echter worden afgeteid dat het in de - v6or \ sept. 1977 gelegen - periode waarin ingevolge art. 6 ROPB voor Van de Akker tegen de in hel schrijven van de gemente van 13 jun 1977 verscholen beschikking openswond, bepalald geenszins voor de hand lag een dergelijk beroep mogeligk te achten. Dat Van de Akker zulk een beroep acherwege heeft gelaten, valt hem derhalye niet aan te rekenen. Datar komt bij dat, zoals de Rb. het treffend heeft geformuleerd (r.o. 17), 'overduidelik (blikt) dat de gemeente (. ) al het mogelijke heeft gedaan om aan haar liandellen tegenover Van de Akker het karakter te geven van een avereenkomst naar burgerlijk recht". Blijkens zijn r.o. 4.3 en 4.4 heeft ook het hof dit punt van belang geoordeeld: in deze overwegingen ligt besloten dat het hof daarom primair van mening was dat de rechtshandeling op grond warvan de litigieuze betaling is verricht, behoort te worden beschouwd als een privaatrechtelijke overeenkomst, omdat het de gemeerite, nu zij de ROPB - gelijk blijkt wit de door het hof in r.0. 4.3 opgesomde omstandigheden - "principteel en doordacht heeft opgezet en uitgewerkt" als een regeling van privaatrech telijke aard ingevolge welke betalingen als te dezen gedaan, berusten op, immers worden verricht ter voldoening aan een met haar als eigenaar gestloten, witdrukkelijk glls privaatrechtelik betitelde overeenkomst. niet meer vrijstaat thans, in deze procedure woor de burgerlike rechter, aan Van de Akker tegen te wetpen dat zijn betaling ( in wezen ${ }^{2}$ ) berust op, immers is verticht ter voldoening aan een publiekrechtelijke "heffing", een beschikking in de zin wan de Wet Arob.

Deze argumentatie van het hof speort met de gedachte dat de hiervoor onder 3.1 .3 (: weergave achtergronden van het geschil, EvdL) geschetste jurisprudentie van de Afd. rechtspraak ertoe strckt de rechtsbescherming van borgers die met een uitwegvergumingenstelsel als het onderhavige worden geconfronteerd, uit te breiden. Vóór die jurisprudentie konden zulke burgers, wanneer zij de wettigheid van de van hen in dit kader gevergde betaling wilden betwisten, deze binnen de door de Wel van 31 okt. 1924, Stb. $482^{58}$ getrokken grenzen - woor de burgerlike rechter als onverschuldigd terugvorderen. Bedoelde jurisprudentie leidt, voor zover nodig, bók tolt terugbetaling wan reeds betalde bijdragen, maar stelt betrokkenen bovendien en vooral in staat zich reeds op voorhand tegen het vergen van zulk een bujdrage tic verweren. Van deze uitbreiding van de rechtsbescherming kunnen zij echter slechts profiteren indien en zolang voor hen tegen de desbetreffende heffing nog administratieffechtelijk beroep openstaat. Voor degenen voor wie dat niet meer het geval is - omdat zij, misleid door het burgerrechtelijk uiterlijk van het stelsel, die mogedijkheid wan beroep niet tijdig hebben onderkend -, zou die jurisprudentie - indien het primaire standpunt van de gemeente als juist zou moeten worden aanvaard - neerkomen op een vermindering van de rechtsbeschurmung, aangezien $z$ ij dan immers, hoewel uit die jurisprudentie onmiskenbaar voortwloeit dat betalingen als de onderhavige valn hen in strijd met de wet zijn "geheven', deze niet meer voor de burgerlijke rechter als onverschuldigd betaald kunnen terugvorderen, ook niet binnen de door voormelde wet getrokken grenzen.

Tenslotte dient ${ }_{\text {p }}$ als in dit kader van belang, te worden opgemerkt dat de in de eerste alinea van deze overweging (3.3.2: vaststelling regels inzake formele rechtskracht wan beschikkingen, EvdL) vooropgestelde regels mede ertoe strekt (strekken, EwdL) te wookomen dat de burgerlijke rechter inzake vragen waarover ook de administratieve rechter tot oordelen is geroepen. tot een ander oordeel komt dan deze. Dit gevar Areigt als te dezen wordt afgeweken wan die regel niet: zowel Van de Akker als $R$ b. en hof hebben zich

58. De wet wan 31 oktober 1924, Stb. 482, houdende voorschriften nopens de werjaring van geldvorderingen ten laste van het Rijk, de provincièn, de gemeenten en de waterschappen, veenschappen en veenpolders bevatte in artikel 1 een regeling waaril afwijking wan de verjaringstermijn van het $B W$ werd woorgeschreven. De afwijking resulteerde in een verjaringstermijn van vijf jaren. Deze wet is ingetrokken bij wet van 25 oktober 1989 , Stb. 490 (Invoeringswet Boeken 3,5 en 6 nieuw $\mathrm{BW}$, ach tste gedeelte), Artikel XVI, p. 20. Overigens verjaren rechtsvorderingen uit onverschuldigde betaling onder huidig recht door werloop van een termijn wan in beginsel vijf jaren mits de schuldeiser bekend is met zowel het bestaan van de vordering als met de persoon van de ontvanger, ingevolge art. 3:309 BW. In andere gevallen verjaart deze vordering 20 jaar ma verloop van zijn ontstuan. Vgl. Jac. Hijma en MM. Olthof, Compendium van het Nederlands vermogensrecht, Leidraad voor het nieuwe BW, Deventer 1996, nr. 96, p. 63-64. 
immers geconformeerd an de hiervoor onder 3.1 .3 (weergave achtergronden van het geschil, EvdL) be* doellde vaste jurisprudentie wan de Afd. rechtspralak en, gelijk hiervoor onder 3.22 (: beoordeling eerste middel met betrekking tot het volgen wan de met Maastricht I ingezette jurisprodientie, EvdL) overwogen. hebben zij dat terecht gedaan.

De voorgaande omstandigheden wettigen in onderling werband en sanenhang de slotson dat, indien de rechtshandeling op grond waarvan Van de Akker de onder 3.1 .2 (: weergave feêten, Eval) bedoelde betaling aan de gemeente heeft verricht, wordt gekwalificeerd als een beschikking in de zin van de Wet Arob, de omstandigheid dai Van de Akker heefl verzuimd gebruik te maken van de beroepsmogelijkheden welke die wet hem dan bood, de burgerlijke rechter niet erwan behoen te weerhouden zelf te oordelen dat deze beschikking, als in strijd met de wet genomen, niet als rechisgeldige titel wan betaling kan worden aangermerkt. ${ }^{9} 50^{\circ}$

Een drietal omstandigheden op grond waarvan in dit geval een uitzondering moet worden aangenomen worden door de Hoge Raad met name genoemd. De eerste omstandigheid springt het meest in het oog: de wens om de rechtsbescherming te verlenen (en zelfs uit te breiden). Niet alleen de ARRS wilde in de ogen van de Hoge Raad rechtsbescherming verlenen: 'ongetwijfeld ten einde de rechtsbescherming van betrokken burgers uit te breiden', ook de Hoge Raad wenst zulks: 'de in de eerste alinea van deze overweging (3.3.2) vooropgestelde regels mede ertoe strekt te voorkomen dat de burgerlijke rechter inzake vragen waarover ook de administratieve rechter tot oordelen is geroepen, tot een ander oordeel komt dan deze. Dit gevaar dreigt als te dezen wordt afgeweken van die regel niet'. Daarbij neemt de Hoge Raad de gedachtengang van het hof over: 'Deze argumentatie van het hof spoort met de gedachte dat de hiervoor onder 3.1 .3 geschetste jurisprudentie van de Afd. rechtspraak ertoe strekt de rechtsbescherming van burgers die met een uitwegvergunningenstelsel als het onderhavige worden geconfronteerd, uit te breiden'. Vóor het in het leven roepen van de ARRS konden burgers bij de burgerlijke rechter terecht. Nu zij bij de ARRS een uitgebreidere rechtsbescherming kunnen verwachten (mits zij op tijd die rechtsgang volgden), moet voor Van de Akker een soortgelijke kans gecreëerd worden.

De tweede omstandigheid is dat onduidelijkheid over de te volgen rechtsgang niet voor risico van de rechtszoekende mag komen, zeker nu: 'bepaald geenszins voor de hand lag een dergelijk beroep mogelijk te achten. Dat Van de Akker zulk een beroep achterwege heeft gelaten, valt hem derhallve niet aan te rekenen".

Daamaast, als derde omstandigheid, wordt de gemeente verweten dat zij - naar het haar uitkomt - goochelt met het rechtskarakter van de rechtshandeling. Dat is niet kies. De Hoge Raad citeert hier het standpunt van de rechtbank dat hij 'treffend' geformuleerd acht: "dat de gemeente (...) al het mogelijke heeft gedaan om aan haar handelen tegenover Van de Akker het karakter te geven van een overeenkomst naar burgerlijk recht'.

De conclusie van dat alles is dan ook dat de Hoge Raad oordeelt dat de middelen inzake het onverkort vasthouden aan de formele rechtskracht van de beschikking van 13 juni 1977 falen: 
' $\mathrm{Nu}$, gelijk hiervour onder 3.1 .5 is gebleken, ook het hof tot deze slotsom is gekomen, falen de middelen II en III, wat er ook zij wan de toor het hof yoor zinn oordeel bijgebrachte gronden. ${ }^{\text {s. }}$

Daarna gaat de Hoge Raad over tot een beoordeling van het vierde middel: het goed vertrouwen op Hoogeloon door de gemeente. Kon dat vertrouwen 'goed', dat wil zeggen gerechtvaardigd zijn? Dat kon in het midden blijven volgens de Hoge Raad:

\begin{abstract}
"In "s hofs r.o. 3.4 ligt besloten dat naar 's hofs oordeel te dezen "goed", dat wil zeggen gerechtwaardigd vertrouwen geen sprake is, ondat de gemeente er niet op mocht vertrouwen dat de HR bij $z$ ijn in dat arrest neergelegde opvatting zon blijwen en nog minder dat deze opvatting door de Afd. rechtspraak RvS, als deze zich ooit over uitwegvergunningenstelsels als in "Hoogeloon" alan de orde zou moeten uitspreken, zou worden gevolgd. (...) In het midden kan bljwen onder welke omstandigheden vertrouwen dat de hoogste rechter bij cen bepaalde rechtsopwatting zal blijven volharden, bescherming verdient. Uit hetgeen (...) is overwogen volgt (...) dat het hof in elk geval heeft geoordeeld dat woor wat betreft 'Hoogeloon' voor zulk een vertrotwen geen grond was.

Overigens faalt onderdeel 1 van het middel ook indien wèl van 'goed vertrowwen' van de genneente zou moeten worden uitgegaan; aan de toewijzing wan deze vordering uit onverschuldigde betaling staat niet in de weg de enkele omstandigheid dat de gemeente die de betaling bedong en ontving, meende en mocht menen dat zij daartoe gerechtigd was; evenmin staat daaraari in de weg dat Van de Akker de gevraagde betaling heeft verricht zonder tegen het vragen daarvan bezwaar te maker. ${ }^{\text {6) }}$
\end{abstract}

Tenslotte komt de Hoge Raad tot het dictum. De Hoge Raad verwerpt het beroep. Geen van de middelen heeft uiteindelijk tot cassatie kunnen leiden. De gemeente wordt veroordeeld tot de kosten van het geding in cassatie.

\title{
3.4.5 Ontrafeling feit, norm en gevolg
}

De hoofdregel van formele rechtskracht zoals de Hoge Raad die heeft geformuleerd bevestigt de geschetste lijn van het overnemen van het oordeel zoals dat in het bestuursrecht tot stand is gekomen; aldus wordt aan de afbakening van rechtsmacht vorm gegeven. De hoofdregel betekent dat wordt uitgegaan van de rechtmatigheid (naar totstandkoming en natir inhoud) van het bestuursrechtelijke oordeel. Zo vermijdt de burgerlijke rechter dat hij dat bestuursrechtelijke oordeel moet geven. Maar slechts daar waar de mogelijkheid bestaat dat de burgerlijke rechter treedt in die bestuursrechtelijke rechtsuitleg, haakt hij af. Zo voorkomt de burgerlijke rechter dat hij treedt in de beoordeling die hij aan de bestuursrechter voorbehouden acht.

Uitzonderingen op de hoofdregel houden toetsing door de burgerlijke rechter in; wat en waardoor beoordeelt hij nu wel? Nu formele rechtskracht onaantastbaarheid van het bestuursrechtelijke oordeel betekent, zal de rechtmatigheid van het - resterende - feitelijk handelen wel steeds beoordeeld worden door de burgerlijke rechter. Toetsen kan de burgerlijke rechter in die situatie wel, omdat de gerichtheid op rechtsgevolg van de beschikking (de publiekrechtelijke rechtsvaststelling) in die gevallen niet aan de orde is en de

60. HR 16 mei 1986, AB 1986,573 (Heesch-Van de Akker), p. 1662, linkerkolom, onder 3.3.3.

61. HR 1.6 mei 1986, AB 1986, 573 (Heesch-Van de Akker), p. 1662, onder 3.4.2. 
beschikking louter als feit, als gegeven een rol speelt. Eigenlijk wordt er in die situatie dus ook niet getoetst, althans niet aan nomen van publiekrecht, maar worden - slechts - 'feiten' op hun feitelijk karakter beoordeeld.

\subsection{Annotaties en andere reacties}

In deze paragraaf bespreek ik reacties op het arrest voorzover die verband houden met de hoofdregel van formele rechtskracht en de mogelijke uitzonderingen daarop.

Overigens kwamen ook andere (en ook daarmee verband houdende) thema's terug in de commentaren. Daarbij valt te denken aan: het verlaten van het standpunt in Hoogeloon en het volgen van de administratieve rechter; het daaruit weer voortvloeiende vraagstuk wat nou 'typisch' behoort tot het terrein van de (bestuurs- en burgerlijke)rechter (en kennelijk dus de al of niet aanwezigheid van een eigen aard van rechterlijke activiteit en/of rechtsgebied); verlaten tweewegenleer; terugwerkende kracht van rechtspraak en ook de consequenties van dit arrest voor andere zaken, bijvoorbeeld terugvordering van heffingen en belastingen.

\subsubsection{Benamingen van formele rechtskracht}

Onder welke benamingen wordt het 'beginsel' van formele rechtskracht van beschikkingen besproken?

Scheltema bespreekt het beginsel van de formele rechtskracht van beschikkingen onder de vlag van de rechtsgeldigheid van de beschikking waartegen geen beroep is ingesteld ${ }^{62}$ Van der Burg stelt formele rechtskracht op éen lijn met onaantastbaarheid. Het standpunt van de Hoge Raad kan zijn instemming tegemoet zien; het is een juridische techniek. 'De onaantastbaarheid of formele rechtskracht is slechts een juridische techniek voor het goed functioneren van de administratieve rechtspraak, maar niet een absoluut beginsel' ${ }^{63}$

Ten Berge spreekt van het 'basisbeginsel van de formele rechtskracht'. ${ }^{64}$

\subsubsection{Hoofdregel}

Wat wordt gezegd over de hoofdregel van formele rechtskracht van beschikkingen? Wat zijn de achtergronden ervan en zijn er nieuwe elementen?

Volgens Koeman konden 'Rechtbank, Hof noch Hoge Raad het over hun hart verkrijgen Van de Akker weg te sturen, omdat hij had nagelaten (...) beroep in te stellen' ${ }^{65}$ Kenne-

62. Vgl. Annotator M. Scheltema onder HR 16 mei 1986, NJ 1986, 723, p. 2748, onder 5 .

63. Annotator F.H. valn der Burg onder HR 16 mei 1986, AB 1986, 573 (Heesch-Van de Akker), p. 1677. rechterkolom, onder 6 .

64. Vgl. Annotator J.B.J.M. ten Berge onder HR 16 meil 1986 (Heesch-Van de Akker), AB-Klassiek, Deventer 1997, in het bijzonder p. 192, onder 4 .

65. Annotator N.S.J. Koeman onder HR 16 mei 1986, Bouwrecht 1986 (Heesch-Van de Akker), p. 781, rechterkolom, onder 2 . 
lijk is het toepassen van de hoofdregel te hard. Hennekens stelt dat de Hoge Raad alle registers opentrekt bij de bespreking van de middelen $\mathrm{H}$ en $\mathrm{III}^{66}$

Scheltema geeft aan dat de hoofdregel steunt op twee overwegingen: "het belang van de rechtszekerheid dat er niet langdurig twijfel blijft bestaan omtrent de rechtsgeldigheid van een beschikking', en het 'voorkomen dat de burgerlijke rechter inzake vragen waarover de administratieve rechter tot oordelen is geroepen, tot een ander oordeel komt dan deze'. ${ }^{37}$ Daarbij constateert Scheltema dat de hoofdregel in vergelijking met de daarvoor tot dusverre gebruikte formulering een uitbreiding heeft ondergaan. Over de formulering door de Hoge Raad dat de burgerlijke rechter ervan dient uit gaan 'dat die beschikking zowel wat haar wijze van totstandkoming als wat haar inhoud betreft in overeenstemming is met de desbetreffende wettelijke woorschriften en algemene rechtsbeginselen', zegt Scheltema: 'De toevoeging 'en algemene rechtsbeginselen' is nieuw. Zij bevestigt m.i. dat de HR de burgerlijke rechter gebonden acht aan het oordeel dat in de administratiefrechtelijke procedure tot stand is gekomen, inclusief het oordeel over de algemene beginselen van behoorlijk bestuur'. ${ }^{68}$

Ook Tak geeft aan dat het arrest ten aanzien van de formele rechtskracht nieuwe elementen bevat, het 'opent twee nieuwe gezichtspunten. In de eerste plaats wordt als beginsel vooropgesteld dat de "formele rechtskracht" ook kan worden ingeroepen als eigenlijk moet worden aangenomen dat de beschikking vicieus was. In de tweede plaats is juist voor die gevallen een eerste bres geslagen in de leer: uitzonderingen blijken dan mogelijk'. ${ }^{\text {a' }}$ Ten Berge benadrukt dat de Hoge Raad vrije forumkeuze tussen ARRS en burgerlijke rechter niet moet toestaan:

\footnotetext{
'Een dergelijke forumkeuze is niet toelaatbaar, omdat zij afbreuk doet aan het gezag wan de rechtspraak en een bedreiging vormt voor de eenheid van het recht. Dit gevaar weegt voor de Hoge Raad zo zwaar, dat hij het basisbeginsel van de formele rechtskracht ondubbelzinnig strak formuleert". ${ }^{70}$
}

Hennekens spreekt van het rechtspolitieke karakter van het arrest met betrekking tot de vraag welke rechter bevoegd is een oordeel te geven inzake het 'uitwegvergunningenstelsel'. Hennekens schetst dit als een: 'apodictisch uitgangspunt", dat niet wordt gemotiveerd.

66. Vgl. Annotator H.Ph J.A.M. Hennekens onder HR 16 mei 1986, AA 1986 (Heesclim-Van de Akker), p. 645 , rechterkolom, onder 3 .

67. Annotator M. Scheltema onder HR 16 mei 1986, NJ 1986, 723 (Heesch-Van de Akker), p. 2748, linkerkolom, onder 5 .

68. Annotator M. Scheltema onder HR 16 mei 1986, NJ 1986, 723 (Heesch-Van de Akker). p. 2748, rechterkolom, onder 6 .

69. Annotator A.Q.C. Tak onder HR 16 mei 1986, HB/S 1986, Burgerlijke rechter, 3 (Heesch-Van de Akker》, p. 21 , onder 4 .

70. Annotator J.B.J.M. ten Berge onder HR 16 mei 1986 (Heesch-Van de Akker), AB-Klassiek, Deventer 1992 p. 192 , onder 4 . 
"De wet Arob roept de Afdelling rechtspraak RWS tot het beoordelen van de reohtmatigheid van baschikhingen, doch niet wan stelsels, welke dat ook moge zijn. (..) Het in het geding zijnde uitwegyergunningstelsel was nied op rechtsgevolg gericht, doch een samenstel van regels wan uhteenlopend juridisch karakter - publiek-zowel als privaatrechelijk - welke in onderlinge sannenhang leidden wot cen bepaald gemeentelijk bele id inzake werhal wan grondkosten. ${ }^{\text {?! }}$

\subsubsection{Vitzondering op de hoofdregel}

Hoe wordt de mogelijkheid tot het aannemen van een uitzondering op de hoofdregel van formele rechtskracht van beschikkingen besproken?

Een uitzondering op de algemene regel wordt gemaakt in het arresit, stelt Scheltema, maar dit gebeurt

"nadat eerst is gesteld dat de hoofdregel blijft gelden, ook wanneer dit tot gevolg heeft dat de burgerlijke rechter moet uitgaan van de rechtsgeldigheid van cen beschikking die zeker zou zijn vernietigd wanneer daartegen tijdig beroep zou zijn ingesteld. Maar de daar aan verbonden bezwaren kunnen door bijkomende omstandigheden zo 'klemmend' worden, dat een uitzondering moet worden aanvaard. $k 2$

Ten Berge signaleert dat door het aannemen van de mogelijkixeid tot het maken van uitzonderingen op de hoofdregel het 'aanvullende karakter van de burgerlijke rechtspraak' opnieuw tot uiting komt. $^{73}$

\subsubsection{Redenen voor uitzondering}

Welke redenen voor het aannemen van een uitzondering in het onderhavige geval worden besproken?

Konijnenbelt ziet Heesch-Van de Akker als afwijkende jurisprudentie: "Thans volsta ik met erop te wijzen dat de omstandigheden van dit geval zó bijzonder waren dat men zich niet te veel moet voorstellen van de uitzondering die de Hoge Raad hier heeft toegelaten op het beginsel dat het niet gebruiken van een met voldoende waarborgen omklede administratieve rechtsgang tegen een beschikking in civilis het onweerlegbare vermoeden oplevert dat de beschikking in alle opzichten rechtsgeldig is. ${ }^{2 / 4}$

Naar het oordeel van Scheltema waren er in casu twee omstandigheden die leidden tot het aannemen van een uitzondering op de hoofdregel, te weten het nauwelijks kunnen 'ontwaren' var een beschikking in de brief van de gemeente en als tweede dat de jurispru-

71. Annotator H.PhJ.A.M. Hennekens onder HR 16 mei 1986, A.A 1986 (Heesch-Van de Akker), p. 644, linkerkolom, onder 1 .

72. Ammotator M. Scheltema onder HR 16 mei 1986, NJ 1986, 723 (Heesch-Van de Akker), p. 2748, rechterkolom, onder 7 .

73. Annotator J.D.M. ten Berge onder HR 16 mei 1986 (Heesch-Van de Akker), AB-Klassick, Deventer 1997, p. 193, onder 5 .

74. Annotator W. Konjinenbelt onder HR 16 mei 1986, De Gem.st 6842,3, p. 343 , onder 2 
dentie van de ARRS ertoe strekt de rechtsbescherming inzake de 'uitwegvergunningen' uit te breiden. ${ }^{75}$ Op dit laatste punt heeft hij kritiek:

'Dit tweede punt kan mi. als bijzondere omstandigheid geen zelstandige betekenis hebben. Heel in het algemeen geldt immers, dat de invoering var administratieve rechtsbescherming - steeds bedoeld om de positic wan de Justifibelen te versterken - gepaard gaal met het negatieve effect, dal men na het verstrijken van de beroepstermin in beginsel aan de rechtsgeldigheid van een beschikking vast zit. (...) Uitbreiding wan de rechtsbescherming heef steeds een ketrijde voor hen, die niet snel genoeg in beroep (kunnen) gaan. Aangezien uitbreiding van wechtbescheming niet moet leiden tot het tegendeel daarvan zou hat gewenst zijn on voor die gevallen, waarin men niet kats vergen dat de justitiabele (tijdig) in beroep gaat, een woorziening te treffen orn aan dat negatieve effect te ontkomen. Die voorziening kan bestaan in het toestaan dat de benadeelde zich in exn latere procedure woor de burgerlijke rechter toch nog op het gebrek kan beroepen. Daarvoor kiest de Hel in dit arrest.

Gezien de grote bezwaren, die daaraan zijn verbonden (...) komt die oplossing echter alleen in aanmerking indien langs administrat Heftechteligke weg onvoldoende woorzieningen op dit punt bestaan. "76

Daarop redeneert Scheltema door; hij trekt de omstandigheden van de casus weer naar de witzonderingen in zijn algemeenheid en komt dusdoende terug bij de eerdere vraag betreffende de mogelijkheid tot het aannemen van een uitzondering op de hoofdregel. In het bestuursrecht, stelt hij, zijn er twee mogelijkheden 'om lets te doen tegen een beschikking, waarvan de beroepstermijn is verstreken". Dat zijn enerzijds een beroep doen op verschoonbare termijnoverschrijding ${ }^{77}$ en anderzijds het bestuursorgaan om intrekking van de beschikking vragen. ${ }^{78}$ Wanneer dat verzoek om intrekking wordt geweigerd, is dat een beschikking en is een beroep daartegen ontwankelijk. ${ }^{79}$ De ARRS oordeelde in Maastricht II echter:

'de weigering tot terugbetaling van de heffing woor een uitwegvergunning een weigening tot hef verrichten wan cen rechtshandeling naar burgerlijk recht (...). M.i. had de Afd., indien niet om terugbetaling, naar om

75. Vgl. ook N.S.J. Koeman onder HR 16 mei 1986, Bouwrecht 1986 (Heesch Van de Akker), p. 781-782, die als weede argument van de Hoge Rasd zag dat hij betang hechtte aan de opstelling van de gemeente Scheltema specificeert zijn tweede argument 'uitbreiding van de rechtsbescherming' onder andere daarmee. Overigens brengt ook Koeman beide aspecten wan dit argunent naar voren en heeft ook Koeman kritiek op dat laatste onderdeel van het argument, ondat de gestelde vermindering van de rechtsbescherming niet overtuigend is, immers ondat "de competentie van de Afdeling rechtsprak en die van de gewone rechter conmunicerende vaten zijn”, p. 782, linkerkolom, onder 3. Ten Berge rafelt de twee punten wan Scheltema uiteen tot vier hoofdoverwegingen, waarwan er twee naar zijn zeggen tevems onderling samenhang vertonen ('schoolvoorbeelden wan gebrek aan fair play", p. 196); vergelijk AB-Klassiek, Deventer 1997, p. 193-194, onder 5 . Ook Hemekens bespreeki deze vier "bijzonderheden', A. 1986, p. 645 e.v., onder 3.

76. Annotator M. Sclieltema onder HR 16 mei 1986, NI 1986, 723 (Heesch-Varu de Akker), p. 2748-2749, onder $\%$.

77. Thans artikel 6:11 Awb.

78. Thans artikel $4: 6$ Awb.

79. Artikel 4:6 Awb voorzict thans in deze mogelijkheid. Oak HJ. Simon bespreekt artikel 4:6 Awb als zodanig: Stratsburg bezien vanuit het Nederlandse bestuurstecht, JB 1997/261, p. $1170-1171$. 
intrelkking wan de beschikking waarbïj de heffing was opgelegd was gevragad, het beroep ontwankelijk kumnen (of zelfs moeter) oordelen.

Daamee snijdt Scheltema een interessant punt aan. Al eerder stipte ik aan dat een onderscheid gemaakt kan worden in een beroepsgang tegen de brief van 13 juni 1.977 en daarnaast wellicht tegen de brief van 13 november 1979 . Geen van de oordelende rechters ging hierop in, terwijl het formele rechtskracht-verweer weliswaar werd gevoerd bij de brief van 13 november 1979 (waar dat zo op zijn plaats lijkt bij de brief van 13 juni 1977) en de oordelende rechters dit verweer beoordelen als ware het gevoerd tegen de brief van 13 juni 1977. Scheltema bespreekt hiermee de (in casu niet gevolgde) administratiefrechtelijke, alternatieve, route die eveneens had kunnen leiden tot een oordeel van de ARRS. Verklaarbaar is nu ook het opeens uiterst felle verweer van de gemeente dat die administratieve rechtsgang in casu nu eenmaal niet gevolgd was en er dus in casu nu eenmaal geen oordeel van de administratieve rechter was gegeven; het administratiefrechtelijke oordeel is "een open vraag'. Conclusie van Scheltema is (naar mijn mening terecht) dan ook: 'Daarom moest de gewone rechter wel een oplossing zoeken'. ${ }^{2}$ Overigens kan hier worden geconcludeerd dat de burgerlijke rechter beperkt wordt in het doorbreken van de formele rechtskracht (door het aannemen van een uitzondering) door de toepassing van de mogelijkheid van artikel $4: 6 \mathrm{Awb}$; hetzelfde geldt voor het aannemen van verschoonbaarheid van termijnoverschrijding (artikel 6:11 Awb), herziening (in de zin van titel 8.4 van de $\mathrm{Awb}$ ) of het terugkomen van door" de bestuursrechter. Overigens kan de burgerlijke rechter in zo'n geval bindend verwijzen naar de bestuursrechter (ingevolge artikel 96a Burgerlijke Rechtsvordering) en hoeft hij geen uitzondering op de formele rechtskracht aan te nemen. ${ }^{83}$

Als voorwaarde woor het aannemen van een uitzondering op de formele rechtskracht van beschikkingen had Scheltema gesteld dat er langs de "administratiefrechtelijke weg onvoldoende voorzieningen op dit punt' bestaan. Dat betekent dat 'moet vaststaan dat geen van deze beide (hiervoor genoemde, EvdL) administratiefrechtelijke mogelijkheden openstaat: ${ }^{84}$ Aansluitend gaat hij over tot het inventariseren in zijn algemeenheid van voorwaarden voor het aannemen van een uitzondering.

\footnotetext{
'Men kan op grond van de gevallen die zich in de jurisprudentie hebben voorgedaan en gezien de beper'kingen van de bestuursrechtelijke mogelijkheden aan de volgende bijzondere onstandigheden denkan.

a. De justitiabele is niet in beroep gegan omdat hij niet wist en ook niet behoefde te weten dat dit kon. Men kan op grond van dit arrest aan twee soorten van redenen daarvoor denkent
}

80. Annotator M. Scheltema onder HR 16 mei 1986, NJ 1986,723 (Heesch-Van de Akker), p. 2749, onder 8

81. Vgl. het verweer zoals dat verwoord is in het derde cassatiemiddel in $\mathrm{HR} 16$ mei 1986, N1 1986, 723 (Heesch-Van de Akker), p. 2733.

82. Annotator M. Scheitema onder HR 16 meil 1986, NJ 1986, 723 (Heesch-Van de Akker), p. 2749, rechterkolom, onder 8.

83. Vgl. ook: Toel. Tweede NvW, PG Awb 2, p. 466 e.Y.

84. Annotator M. Scheltema onder HR 16 mei 1986, NJ 1986, 723, (Heesch-Van de Akker), p. 2749, rechterkolom, onder 9 . 
a1. Het lag juridisch 'geenzzins voor de thand' on een beroep mogelijk te achten. (..)

22. Er kwarn nog bij, dat de geneente zelf alles had gedaan on de indruk te vermiden dat het om een beschikking zou gaan. Zij kon zich daarom later niet meer op het standpunt stellen dat - nu het toch een besehikking bleek te zijn - deze rechtens onaantastbaar was geworden ondat niet tijdig beroep was ingesteld.

(...)

b. Door de wederpartij wordt niet betwist dat de beschikking in strijd met het recht is (...).

c. Men verlangt niet zozeer vernietiging van de gebrekkige beschilking, mar vitsluitend schadevergoeding. Aangezien de adwinistratiefrechtelijke rechtsbescherming gericht is op vernietiging, kan men daar dit resultat niet (goed) bereiken. Nu de HR niet meer strikt uitgaat wan de regel dat cen beschikking, waartegen een openstaande beropsmogelijkheid niet is gebruikt, voor de burgerlijke rechter als rechtsgeldig moet worden aangemerkt, kan ook hier misschien een reden voor het aannemen van een uitzondering bestaan. ${ }^{85}$

Merk op dlat de Hoge Raad overigens samen met de introductie van het overgaan tot niet toetsen (de hoofdregel) de mogelijkheid crecert dat partijen het op een akkoordje kunnen gooien inzake de al of niet aanwezigheid van de formele rechtskracht van de beschikking (b); variant c. staat in de V\&D en Super Doe-Groningen-traditie terwijl de varianten onder a. liggen in de sfeer dat belanghebbende "er niks aan kon doen", zodat niet-ontvankelijkheid hem niet tegengeworpen mag worden (risico moet voor de overheid komen). Tenslotte stelt Scheltema dat de Hoge Raad door het aannemen van een uitzondering op de hoofdregel het bestuursrecht onder druk houdt, want:

bestatk geen mogelijkheid om op te komen tegen en beschikking met een ernstig gebrek, waartegen men redelikkerwijs niet tijdig beroep heeft kunnen instellen, dan kan men het onder omstandigheden bij de burgerlijke rechter proberen":

Dat vereist bezinning van de administratiefrechtelijke rechtsbescherming, want bv. het terugbrengen van de verjaringstermijn voor geldvorderingen bij de overheid ( 5 jaar) tot de Arob-beroepstermijn ( 30 dagen) is vanuit civiel perspectief 'een absurd korte periode?. ${ }^{87}$ Het maken van veel uitzonderingen op een strakke hoofdregel zou daarentegen (zeker indien er verschillende belanghebbenden zijn) leiden tot een verstoring van het geldende stelsel van administratiefrechtelijke rechtsbescherming, stelt Scheltema. De oplossing ligt in een verbetering van het intrekkingenstelsel binnen het bestuursrecht, ${ }^{8 \%}$ waarbij eventuele bezwaren daartegen bij geldvorderingen minder groot zijn, omdat daar doorgaans geen derde-belanghebbenden bij betrokken zijn in tegenstelling tot andere gevallen: "Te

85. Annotator M. Salneltema onder HR 16 mei 1986, NJ 1986, 723 (Heesch-Van de Akker), p. 2749-2750, onder 9.

86. Annotator M. Scheltema onder HR 16 mei 1986, NJ 1986, 723 (Heesch-Van de Akker), p. 2750, linkerkolorn, onder 10.

87. Annotator M. Scheltema onder HR 16 mei 1986, NJ 1986, 223 (Heesch-Van de Akker), p. 2750, linkerko$10 m_{,}$onder 10.

88. Daarin komt het kabinet hem tegemoet. In het kabinetsstandpunt over de Evaluatie van de Awb wordt beloofd dak nader onderzoek naar de toepassing van de artt. 6:18 en 6:19 Awb zall worden getntameerd. Vgl TK 1997-1998, 25600 VI, nr.46, p. 39. 
werwachten is daarom dat de HR daar het bestuursrecht iets meer onder druk zal houden dan buiten dat gebied". ${ }^{89}$

Koeman vindt het nog maar de vraag of de Hoge Raad wel de aangewezen instantie is om voor hen die tussen wal en schip dreigen te vallen de methode van de dubbele competentie te accepteren.

'Alternatief zou nitteraard zijn een soepeler opstelling van de Afdeling in dergelijke gevallen, bijv. door te laat ingestelde beroepen in verband met gewijzigde jurisprudentie toch $(\ldots)$ ontvankeljk to achten, danwel wijziging in de jurisprudentie als nowm te erkennen dat tot een nieuwe beschikking kan leidern ${ }^{\text {, }}$.

\subsection{Tenslotte}

Een vermoeden van de visie van de Hoge Raad in deze zaak heb ik wel, al blijft het naturlijk altijd koffiedik kijken als het geheim van raadkamer in het geding is. Zo denk ik, dat de Hoge Raad de kans met beide handen heeft willen aanpakken om uitgebreid arrest te wijzen over de formele rechtskracht van beschikkingen. Als dat namelijk niet het geval was, droeg de eerste conclusie voldoende materiaal in zich om in de zaak een beslissing te geven. Maar nee, de Hoge Raad vroeg een aanvullende conclusie en ging nagenoeg voorbij aan het vierde cassatiemiddel. De Hoge Raad wilde een aanvullende conclusie met betrekking tot de formele rechtskracht van beschikkingen en ging daar vervolgens in het arrest uitvoerig op in. De Hoge Raad sloeg geen acht op weigeringen tot restitutie en het rechtskarakter van die figuur, hij ging in op de "moeilijk te ontwaren beschikking' waartegen geen administratiefrechtelijke rechtsgang was gevolgd. En terwijl de Hoge Raad dat deed ontwikkelde hij het systeem dat op de hoofdregel het aannemen van een uitzondering mogelijk is en gaf hij inzicht in de gevallen waarin van zo"n uitzondering sprake kon zijn. Daarbij nam hij het begrip expliciet over en merkte het aan als beginsel. Kortom, de Hoge Raad nam de gelegenheid te baat om zowel ten aanzien van de hoofdregel als ten aanzien van de uitzonderingen op de hoofdregel van de formele rechtskracht van beschikkingen zijn oordeel leerstellig te geven. Aldus ging hij ertoe over om zijn bevoegdheid minimaal vorm te geven door enerzijds over te stappen op het niet toetsen en het overnemen wan het administratieve oordeel (hoofdregel) en anderzijds openen wan de (bescheiden) mogelijkheid om uitzonderingen aan te nemen. De verwachting die hiermee gewekt wordt, is dat de rechtspraktijk op zoek zal gaan naar de grenzen (de reikwijdte) van de uitzondering. Daar waar hij sprak van overeenstemming met de wet en beginselen van de beschikking 'zowel wat haar wijze van tot stand komen als wat haar inhoud betreft" onderscheidde de Hoge Raad feit en norm op het eerste gezicht niet, terwijl hij dat bij de ontwikkeling van hoofdregel en de mogelijkheid tot het aannemen van een uitzondering daarop wel deed. Kortom, de Hoge Raad wilde - en daarin schuilt naar mijn mening het

89. Annotator M. Scheltema onder HR 16 mei 1986, NJ 1986, 723 (Heesch-Van de Akker), p. 2750, rechterkolom, onder 10 .

90. Annotator N.SJ. Koeman onder HR 16 mei 1986, Bouwrecht 1986 (Heeschm Van de Akker), p. 782, rechterkolom, onder 3 . 
belang van het arrest - leerstellig en rechtsvormend de formele rechtskracht van beschikkingen als onaantastbaarheid introduceren ter afbakening van zijn rechtsmacht met die van de bestuursrechter. 


\section{Formele rechtskracht in het publiekrecht}

\subsection{Inleiding}

In het vorige hoofdstuk zagen we dat de burgerlijke rechter formelle rechtskracht definieerde als onaantastbaarheid. Waar haalde hij dat begrip vandaan? Deed hij inspiratie op bij de bestuursrechter? Hoe wordt er daar met (formele) rechtskracht omgegaan? We zullen zien dat de bestuursrechter voorop zal stellen dat formele rechtskracht relewant is voor de korte beroepstermijnen; hoofdregel is hier vooral: ná - ongebruikt - verloop van de beroepstermijn verkrijgt de beschikking formele rechtskracht. Niet alleen de bestuursrechter handelt zo, ook de doctrine bevestigt deze regel. Rechtskracht vervult op die manier de basis van 'de constructie van het bestuursrecht en het bestuursprocesrecht; het wordt daarom wel een structuurelement genoemd. Zo zijn sinds hun introductie de formele en de materiele rechtskracht in de doctrine van ons bestuursrecht tot algemene leerstukken van het bestuursrecht verworden.

Rechtskracht wordt doorgaans als complex gekenschetst. De rechtskracht als eigenschap van besluiten is wellicht mede daarom zo moeilijk te bevatten ondat ook die besluiten zo velerlei van aard zijn. Zo werkt de rechtskracht van repeterende besluiten anders dan die van besluiten die onderdeel uitmaken van grote projecten.' Sommige besluiten vergunnen dat bepaalde personen handelingen kunnen verrichten of dat die handelingen namens hen geschieden, bijwoorbeeld dat in bepaalde lokaliteiten alcoholhoudende dranken worden verstrekt. Andere besluiten vergunnen dat bepaalde terreinen een bestemming krijgen, van bestemming wijzigen, aangewezen, be- of verbouwd kunnen worden. Weer andere besluiten zien op de wijze waarop inrichtingen worden geëxploiteerd of trachten bepaald gedrag. te sturen of illegale situaties te herstellen door middel van handhavingsinstrumenten. Op al die gebieden van het bestuursrecht kan worden gesproken van de formele en de materiële rechtskracht van bestuursbesluiten en hun gevolgen, al is het traditie dat wel expliciet van formele, maar zelden of nooit expliciet van materiesle rechtskracht wordt gerept.

1. Een definitie van de term groot project is moelijk te geven. Kenmerkend is dat het gaat om cen maatschappelijke activiteit waarvoor meer dan exn besluit nodig is. Bowendien betreft laet activiteiten van nationaal belang. Vaak treedt de overheid op als (mede)initiatiefnemer. De vereiste besluiten zijn wak ook verschillend van rechtskarakter. Stroink stelt dan ook dat het begrip juridisch niet sluitend is te definisren. Vgl. F.A.M. Stroink, Complexe besluitworming: en opgave voor burger, bestum en rechter, VAR preadvies 120, Alphen a/d Rijn 1998, p. 77. Eeri meer bestuurskundige benadering geeft. J.A. de Bruijn e.a., Grote projecten, Beshitworming \& management, Aphen add Rijn 1996. 
In al die gewallen kan de hypothese van deze studie de helpende hand bieden doordat zij een verklaring geeft. Vragen naar het loskoppelen van de rechtshandeling en het rechtsgevolg en de rol van normen daarbij, zullen dan steeds worden gesteld. De door de rechter gegeven oplossingen voor problemen met deze situaties worden eveneens besproken. Formele rechtskracht reserveren we - in het licht van de hypothese - voor de rechtshandeling en de materiele rechtskracht voor het rechtsgevolg. Zo wordt de formelle rechtskracht zichtbaar op een tunc-moment en de materiele op een nunc-moment.

Voordat deze vragen en oplossingen echter aan bod kunnen komen, dienen we ons echter af te vragen waar dat rechtskrachtbegrip nu eigenlijk vandaan komt. Wat is de oorsprong, welke de herkomst ervan? Daarna houden we ons bezig met de vraag hoe de verdere ontwikkeling van het begrip was. Op die manier kan de thistorische achtergrond van het rechtskrachtbegrip hier te lande geînventariseerd worden.

Vervolgens wordt ingegaan op de rechtskracht zoals de administratieve rechter deze hanteert. Hoe gaat hij met formele rechtskracht om? Is er een verschil tussen de bestuursrechterlijke en de burgerrechterlijke benadering van rechtskracht.

Nog een opmerking vooraf, bij wijze van "waarschuwing". Juist omdat de formele rechtskracht hier nimmer is gecodificeerd zijn de sporen ervan moeilijk te achterhalen. De formele rechtskracht bestaat aldus in een soort van 'schemergebied' van het bestuursrecht. Enerzijds kan worden gezocht in de doctrine en anderzijds kan bekeken worden hoe de bestuursrechter ermee omgaat. Daarbij is opvallend dat de term weinig of niet expliciet wordt gebruikt. Toch hanteren rechters rechtskracht wel degelijk. Eigenlijk kan in elke uitspraak wel een element of elementen van het leerstuk worden gevonden. Wat ik bedoel aan te geven is daarmee dat het 'zien' van formele rechtskracht vooral een manier van kijken naar het recht betekent. Door met dat 'formele rechtskracht-vizier' het rechtsgebied te bekijken, worden de sporen helder, soms zelfs expliciet zichtbaar. Tegelijkertijd weten we dat de rechter incidenteel, dat wil zeggen slechts indien belanghebbenden hem dat vragen, uitspraak doet; de jurisprudentie is geen stelselmatig handboek, geeft geen gestructureerde hoofdlijnen. Voor een bespreking van de formele rechtskracht is dat moeilijk, voornamelijk voor wat betreft de sellectie van uitspraken en de zeggingskracht van overwegingen. In de inleiding van dit boek ben ik daarop al ingegaan. Dit hoofdstuk geeft u daarom veeleer een impressie van de formele rechtskracht in het bestuursrecht en de leerstukken waarin het zijn rol speelt dan dat u onweerlegbaar 'bewijs' van die aanwezigheid zult aantreffen. Aldus 'gewaarschuwd' kunnen we overgaan tot de bespreking ervan.

\subsection{Herkomst en oorsprong in Nederland}

Zoals De Jong op overtuigende wijze heeft uiteengezet, heeft Van der Pot zijn rechtskrachtbegrip gebaseerd op de ideeên zoals die tot uitdrukking kwamen bij Kormann, Flleiner en Jellinek (en ook bij Jeze) en daarnaast bij codificatiebewegingen: 
"Vati der Pot heeft zich vernoedelijk op Fleiner, Jellinek en de Verwaltwngsrechtsordnung fur Wurttenberg georienteerd:"

Daarbij wordt steeds de link naar het civiele procesrecht gelegd:

"Volgens zijn eigen verklaring zoekt hij aansluiting bij het spraakgebruik wan burgerlijk recht en burgerlijk procesrecht, zo lijkt hef tenminste. De term rechtskracht was in Van der Pots tijd (anders dan nu het geval is) een equivalent voor kracht en gezag van gewijsde. ${ }^{3}$

\subsubsection{Indelen op formele gronden}

Zowel Van der Pot als Donner hanteerden een formeel criterium op basis waarvan zij formele en materiele rechtskracht indeelden. Maatgevend was voor hen welk orgaan de beschikking trachtte aan te tasten. De formele rechtskracht van de beschikking kan in dit concept (althans zolang die nog niet gevestigd is) worden aangetast door alle andere actoren dan het (oorspronkelijke) beschikkingnemende orgaan. De materiële rechtskracht kan aangetast worden door het (oorspronkelijke) beschikkingnemende orgaan. De betekenis, de definitie of het synoniem van formele rechtskracht wordt dan al gauw onaantastbararheid, onaanvechtbaarheid, onherroepelijkheid; materiële rechtskracht leidt dan naar intrekkings-, en wijzigingsvraagstukken.

Van der Pot zag formele rechtskracht als geldigheid of onaantastbaarheid na ommekomst van een beroepstermijn en materiële rechtskracht als intrekbaarheid en wijziging van de beschikking:

"De wraag naar de rechiskracht eener beschikking kan ook nog in anderen zin worden gesteld, in deze zin namelijk, of een beschikking door het bestuursorgaan, dat haar gaf, gewijzigd of ingetrokken kan worden en of er dus reden kan zijn, dat een belanghebbende on die wijziging of intrekking verzoekt. Men noemt dit well de materieele rechtskracht in tegenstelling tot de formeele, wellike zooeven ter sprake kwam. ${ }^{34}$

\section{Bij Donner is formele rechtskracht:}

'het geheel van de werkingen, welke zonder meer voortvloeien wit het feit, dat de recthtshandeling bestatst, de materieele als hel geheel van de werkingen, welke van den inhoud der redtshandeling afhankelijk zijin. (..) Tegenover de formeele rechtskracht stat de matericele. Vooral het overheidsorgaan "dat de beschikking zelve heeft genomen en er dientengevolge min of neer boven stat, behoeft zeker niet zonder neer door het feit, dat er is beschikt, te zijn gebounden."

In een interview in 1985 stelt Donner dat formele en materiële rechtskracht beter aangeduid kunnen worden met de termen vernietigbaarheid en intrekbaarheid.

2. J.P. de Jong, Bestutrsrecht van vreemde herkontst, diss., Zwolle 1988, p. 120.

3. J.P. de Jong, Bestuursrecht van vreemde herkomst, diss., Zwolle 1988, p. 98 .

4. C.W. van der Pot, De vormen van het besturen, in: Nederlandsch Bestuurstecht, Alphen a/d Rijm 1932 , p. 215 .

5. A.M. Domner, De rechtskracht wan administratiewe beschikkingen, diss., Alphen a/d Rijn 1941, p. 17-18. 
'Die rechtskracht werd onderscheiden in formele en materiele recintskracht (...). De zaak zou beter over het voeticht gekomen zijn als cenwoudig was gesproken wer vemietigbaarheid en intrekbarheid van beschikkingen. ${ }^{\circ 6}$

Ook Van Wijk, Stellinga, Van der Burg/Cartigny, De Haan/Drupsteen/Fernhout, De Jong en Konjinenbelt/Van Male gingen van dit uitgangspunt uit.

Van Wijk stelt ten aanzien van de formele en materiële rechtskracht van beschikkingen:

"Het is duidelijk daf de fomele rechtskracht afhankelijk is in de earste plaats van de vraag of er nog beroep tegen de beschikking openstaat."

en:

"Het probleem van de materiele rechtskracht van de beschikking komt met dat van de formele slechts in zovere overeen, dat het in beide gevallen gat om de vrag of de beschikking aantastbaar is. Bij de materiele rechtskracht gat het echter niet om het ongedaan maken wan de beschikking ex tunc, met in principe al haar gevolgen ook woor het verteden; neen, de beschikking blijft voor het werieden geaccepteerd (...). Vraag is nu of de beschikking nu kan worden ingetrokken met werking ex nunc, alleen woor de toekonst (...) Gaat het bij de formele rechtskracht praktisch steeds om aantasting door hoger gezag dan hetwelk de beschikking gar, of door een rechterlijke instantie die tot exen oordeel geroepen is, bij de materiele rechtskracht gaat het vrijwel steeds on aantasting door het gezag dat de beschikking heeft gegeven."

Wanneer Stellinga de formele rechtskracht van de beschikking bespreekt, constateert hij:

"De beschikking, waartegeri geen enkel rechtsmiddel als hierbedoeld openstaat of welke geen enkel woorafgaand tiat van hogerhand behoeft, zal aanstonds bij haa inwerkingtreding formele rechiskrachi verkrijgen, en degene, tegen wie zij is gericht, is er derhalve dadelijk door gebonden, ${ }^{\text {.8 }}$

Niet uit het oog moet worden verloren dat Stellinga dit schreef in een tijd dat er nog geen algemene administratieve rechtspraak tot ontwikkeling was gekomen; vanuit de opvatting dat in zo'n situatie het handelen van het bestuursorgaan maatgevend is voor het intreden van de formele rechtskracht is hij van mening dat afwezigheid van rechtsmiddelen leidt tot direct intreden van de formele rechtskracht. Daarna gaat hij in op het enige rechtsmiddel dat belanghebbenden nog soelaas kan bieden, "waarbij vooral moet worden gedacht aan het vernietigingsrecht." Ook, stelt hij, komt het voor 'dat een beschikking een rol speelt in een geding voor de burgerlijke rechter'.

De materiele rechtskracht definieert Stellinga als de vraag, "of een beschikking al dan niet gehandhaafd moet of kan blijven, waarbij zowel het algemeen belang als de belangen van de overige partijen bij de zaak een rol spelen." Daarmee geeft hij de belangenafweging

6. A.M. Donner, De rechtskracht van administratieve beschikkingen, in: Ars Acqui 1985, p. 678 .

7. H.D. van Wijk, Hoofdstukken van administratief recht, Groningen/"s-Gravenhage 1968, p. 88 en 90-91.

8. J.R. Stellingat, Grondtrekken van het Nederlands Administratiefrecht, Zwolle 1973, p. 150-151.

9. J.R. Stellinga, Grondtrekken van het Nederlands Administratiefrecht, Zwolle 1973, p. 146. 
door het bestuursorgaan bij wijziging of intrekking weer. Kortom: "Het instellen van beroep raakt het punt van de rechtsgeldigheid en van de formele rechtskracht, terwijl het hier gaat over de materiële rechtskracht, m.a.w. over de vraag of een beschikking naar haar aard, wettelijke regeling e.d. al dan niet voor intrekking (of wijziging) in aanmerking kan komen. ${ }^{30}$

In de Stellinga-bundel vraagt Van der Burg aandacht voor het feit dat het leerstuk van de formele rechtskracht of onaantastbaarheid nooit goed wan de grond is gekomen, omdat er geen algemene mogelijkheid was de beschikkingen aan te vechten bij de administratieve rechter. Van der Burg verwacht dat dit met de invoering van de Wet Arob anders zou worden. De formele rechtskracht brengt hij eveneens in verband met vertrouwensbeginselen en het derde-beroep. Hij legt daarbij nadruk op de verbinding tussen formele rechtskracht en kracht van gewijsde zoals die in de literatuur wordt gemaakt, waarbij de verschillen tussen het civiele vonnis en de administratieve beschikking worden beklemtoond."

Van der Burg/Cartigny stellen de complementariteit van formele rechtskracht (onaantasbaarheid in de zin van niet meer te vernietigen) en exceptie van onwettigheid (on-geldigheid van een overheidshandeling) aan de orde. Daarbij definiëren zij formele rechtskracht als de kracht die een beschikking heeft "wanneer een daartegen ingesteld beroep in hoogste instantie ongegrond is verklaard of de termijnen voor het instellen van bezwaar en beroep ongebruikt zijn verstreken. ${ }^{12}$

Het begrip materiële rechtskracht wordt door Van der Burg/Cartigny niet expliciet gehanteerd. Er wordt gesproken over een andere vorm van rechtskracht, waarbij aan de orde is 'de vraag of een eenmal gegeven beschikking - al dan niet met terugwerkende kracht kan worden ingetrokken door het orgaan dat de beschikking heeft gegeven. ${ }^{13}$

De Haan/Drupsteen/Fernhout zien formele rechtskracht als de mate waarin een beschikking 'bestand is tegen aantasting door de direct belanghebbende, door derden-belanghebbenden, door de rechter, door een hoger bestuursorgaan, terwijl materiële rechtskracht is 'de mogelijkheid van intrekking of wijziging van een beschikking. ${ }^{1 / 4}$

De Jong concludeert dat formele rechtskracht gezien kan worden als denk-hulpmiddel en dat materiële rechtskracht maar helemaal niet meer gebruikt hoeft te worden. Daarmee plaatst hij zichzelf in de stroming die indeelt op formele gronden. Het denk-hulpmiddel

10. IR, Stellinga, Gronditrekken van het Nederlands Administratiefrecht, Zwolle 1973, p. 148.

11. Vgl. F.H. van der Burg, Formele rechtskracht, vertrouwensbeginselen en derde-beroep, in: Een stellig annotaior, Zwolle 1982, p. 19-20.

12. F.H. van der Durg, G.I.M. Cartigny, G. Overkleefl-Verburg, Rechtsbescherming tegen de overheid, Nijmegen 1985 , p. 180.

13. F.H. van der Burg, G.JM. Cartigny, G. Overkleeft-Verburg, Rechtsbescherming tegen de overheid, Nijmegen 1985, p. 175 .

14. P. de Haan, Th.G. Drupsteen, R. Fernhout, Bestuursrecht in de sociale rechtsstaat, deel 2, Bestuurshandelingen en warborgen, Deventer 1986, p. 51 . 
(formele rechtskracht) kan zijn diensten immers bewijzen ten aanzien van het derdenberoep en in de verhouding tussem beschikking, administratieve en civiele rechter:

"Zowel in het geval van do verhouding tussen het derdenberoep en de aangerechten (lees: aangevochten, EwdL) beschikking, alls in de verhouding tussen beschikking, adninistratieve beroepsgang en de positie wan de burgerligke rechter heeft het begrip formele rechtskracht nog een onderscheidende werking. In deze gevallen kan dit begrip cen zinvolle functie verwullen. ${ }^{15}$

Het begrip materiële rechtskracht vervult geen functie meer, want:

'Als de vratg naar de materidle rechtskracht wordt beschouwd als de vraag naar de binding van het bestuus aan de rechtsgewolgen van beschikkingen, dat (bedoeld wordt: dan, EvdL) zal het wraagstuk van de materidte rechtskracht zich voomamelijk voordoen bij de intrekking (of wijziging) van beschikkingen." ${ }^{16}$

Ook Konijnenbelt/Van Male ${ }^{17}$ passen in deze stroming. In de oudere drukken bespraken zij rechtskracht enerzijds bij intrekking en wijziging (die in plaats traden van een aparte bespreking van materièle rechtskracht) en anderzijds bij ontwankelijkheid (waarbij de formele rechtskracht een plaats wond). In de editie van hun "Hoofdstukken" van 1994 wordt rechtskracht in de gedaante van formele rechtskracht besproken bij de ontvankelijkheidsvraagstukken. De meest recente editie van 1997 sluit daar weer bij aan. De formele rechtskracht wordt bij de ontvankelijkheid besproken en bij de verhouding burgerlijke rechter en niet-gevolgde rechtsgang. Daar komt ook de recentere jurisprudentie aan bod. ${ }^{18}$ Daarmee is de eenzijdige gedaante van rechtskracht in dit handboek geduid. Materiêle rechtskracht wordt niet meer genoemd.

\subsubsection{Ontrafeling feit, now en gevolg}

Over het algemeen betekent formele rechtskracht voor deze auteurs dus onaantastbaarheid en materielle rechtskracht weerstand tegen intrekking en/of wijziging. Dit definitiepaar is het eerste dat in het bestuursrecht opkwam. De door de burgerlijke rechter gehanteerde formele rechtskracht-onaantastbaarheidkan zodoende gebaseerd zijn op deze in het bestuursrecht gehanteerde.

Dit begrip onaantastbaar lijkt nogal statisch, alsof de beschikking onveranderbare situaties in het rechtsleven roept. Dit probleem werd al door Donner onderkend; hij hanteerde daarom als uitersten op een lijn de moeilijk hanteerbare termen starheid en plooibaarheid met betrekking tot rechtskracht. Een bestuursorgaan moet wrij zijn om - weer - wijzigingen aan te brengen in de rechtssituatie (die door de oorspronkelijke beschikking is gecreëerd)

15. J.P. de Jong. Bestuursreclit van vreemde herkonst, diss, Zwolle 1988 , p. 146.

16. J.P. de Jong, Bestuursrecht van vreende herkomst, diss, Zwolle 1988 , p. 146.

17. Vgl. H.D. van Wijk, W. Konjinenbelt, R.M. van Male, Hoofdstukken van administratief recht, Utrecht 1994, m.n. p. 607 .

18. Vgl. H.D. van Wijk, W. Konijnenbelt, R.M. van Male, Hoofdstukken van administratief recht, "s-Gravenhage 1997, p. 601, p. $678-689$, p. $716-717$. 
maar anderzijds heeft de openbare dienst belang bij duidelijkheid en dus moet een rechtssituatie aanwijsbaar vaststaan.

De vraag moet dan ook anders gesteld worden: van wat is formele rechtskracht onaantastbaarheid? En ook: materiële rechtskracht is intrekking en/of wijziging, maar wat wordt er ingetrokken of gewijzigd? Als vanuit het perspectief van het bovenstaande auteurs hierop antwoord geven, dan zal dat zeker luiden onaantastbaarheid, intrekking of wijziging van het besluit (de beschikking). Zo bezien worden de zaken vertroebeld voor het voetlicht gebracht, immers een besluit als op enig moment vastgestelde gezagsuitoefening is zeker statisch en onaantastbaar, maar de gevolgen die dat besluit heeft bewerkstelligd zijn lang zo onaantastbaar niet. Donner voelde intuittief wel aan dat de materiële rechtskracht (van rechtsgevolgen) zichtbaar wordt bij intrekking en wijziging en aldus onderscheidde Donner feit en gevolg in de zin van de hypothese van deze studie: starheid is verbonden met een aanwijsbaar moment, terwijl plooibaarheid leidt tot aantasting van de rechtsgevolgen, de rechtssituatie - bijvoorbeeld op basis van actuele maatstaven.

\subsubsection{Indelen op inhoudelijke gronden}

Zoals we nog zullen zien baseerde Vegting zijn rechtskrachttheorie op het gedachtengoed van Merkl (die vaak als leerling van Kelsen wordt beschreven; zie hoofdstuk 8).

\footnotetext{
"Afgezien wan de Kelsiaanse beperking van het positiewe recht tot de wet, tot de grondnorm en de daarop gebaseerde normen, biedt het begrip rechtskracht in de door Merkl ontwikkelde zin, een bruikbaar uitgangs.punt voor de benadering wan de vraagstukken, die betrekking hebben op de vragg, welke omstandigheden een ongestoorde en duurzame gelding van rechtshandelimgen - voor ons doel uiteraard beperkt tot de administratieve beschikkingen - kurnen aantasten. ${ }^{19}$
}

Naast de wet als bron wan recht erkent Vegting ook andere bronnen: wilsuiting, beginselen. De omvang van de rechtskracht van beschikkingen is afhankelijk van het positieve recht. Omdat de belangrijkste bron van het positieve recht (de wet) geen regeling geeft met betrekking tot de rechtskracht van administratieve beschikkingen, tracht Vegting een dergelijke regeling af te leiden uit de plaats van de beschikking in het geheel van het recht.

'Zo moeten uit de overige regellen met betrekking tot een bepaalde beschikking en wit de plaats, welke een beschilking inneemt in het geheel wan het recht, de voor hatar geldende regelen van rechiskracht worden opgespoord. 20

Vegting gaat vervolgens uit van de rechtskracht van geldige en gebrekkige (onregelmatige) beschikkingen omdat voor hem gelding logisch vooraf gaat aan rechtskracht.

19. W.G. Vegting, Het algemeen Nederlands administratiefrecht, deel 1, Alphen ard Rijn 1954, p. 269.

20. W.G. Vegting, Het algemeen Nederlands administratisfrecht, deel 1, Alphen a/d Rijn 1954, p. 271. 
'Eer eerste onderscheid, dat gemaakt moet worden nussen de beschikkingen met betrekking tot hun rechtskracht, is dat tussen gebrekkige en regelmatige, rechtsgeldige, beschikkingen."

Pas daarna valt er volgens Vegting te onderscheiden naar de formele en de materiele rechtskracht van de (gebrekkige of de rechtsgeldige) beschikking. De formele rechtskracht blijft niet beperkt tot aantasting door de belanghebbende (zoals Merkl dat ziet, aldus Vegting). Materiele rechtskracht is ruimer dan binding louter ten opzichte van de beschikkinggever:

\begin{abstract}
"Wel is er aanleiding on niet, zoals Merkl doet, slechts als een aantasting van de formele rechtskracht te zien de atantasting der beschikking na beroep door de belanghebbende. Ook andere gevallen van vernietiging ener beschikking, gellijk ook die gevallen, warin op andere wijze duidelijk blijkt wan een ontkennen van de betekenis van de beschikking voor het recht, dienen in dit verband te worden bezien. En bij de materiele rechtskracht dient niet alleen de mogelijkheid van veranderng ener beschikking door een gelijksoortige beschikking to worden besproken "mar behoort ook in beschouwing te worden genomen in hoever de inthoud wan cen beschikking ook anderen dan de auteur in hun bewegingsvrijheid belemmert. ${ }^{22}$
\end{abstract}

Definities van formele en materiële rechtskracht wijken vervolgens af van de tot dan toe gehanteerde:

'Onder de fornele rechtskracht wan een rechtshandeling verstaan wij dan de kracht, die zich verzelten kan tegen een opzettelijk ongedaan maken van de rechtshandeling of algemener tegen een handelen, dat iedere werking in rechte beoogt te weerstaan.

Van materite rechtskrachi spreken wij, wanneer het er om gaat de spreiding aan te geven van de werking ener rechtshandeling. Een spreiding in tijd en naar personen, wier handelen door bestaan en inhoud der rechishandeling wordt beänvloed. ${ }^{.23}$

Aldus geeft Vegting weer dat formele rechtskracht is verbonden met het (juridische) bestaan (het zijn of de ontologische existentie ${ }^{24}$ ) van de beschikking en materiêle rechtskracht met de invloeden die die beschikking heeft op de werkelijkheid. Vegting zegt het niet expliciet, maar tussen zijn regels in is te lezen dat formele rechtskracht aan het al of niet bestaan van de beschikking wordt gekoppeld, terwijl materiele rechtskracht wordt vastgeknoopt aan de rechtsgevolgen. Iets later maakt Steenbeek dit onderscheid scherper. Vegting kiest nog voor indeling van formele en materiële rechtskracht naar handelende actor (de traditionele indeling op formele grondslag), maar rekt die indeling tegelijkertijd zodanig op dat hij niet zonder meer nog in de eerste stroming past. Formele rechiskracht geeft dan in essentie de anti-aantastingsweerstand weer, terwijl materiele rechtskracht concentreert op de gevolgen wan de rechtshandeling ten aanzien van (direct en derde-)

21. W.G. Vegting, Het algemeen Nederlands administratiefrecht, deel 1, Alphen a/d Rijn 1954, p. 27》-272.

22. W.G. Vegting, Het algemeen Nederlands administratiefrecht, deel 1, Alphen a/d Rijn 1954, p. 269-270.

23. W.G. Vegting, Het algemeen Nederlands administratiefrecht, deel 1, Alphen a/d Rijn 1954, p. 270-271.

24. Vgl, ook R. Marcic, Merkls ontologische Theorie der Rechtskraft, ein vergessenes, doch hochst aktuelles Lehrsttuck aus des Jubilars Gesamtwerk, in: Festschrift fur Adolf Merkl, Imboden e.a., Minchen-Salzburg 1970, S. $223-247$. 
belanghebbenden. Ook de erkenning dat de basis van rechtskracht ligt in de rechtsorde (waarbij Vegting leunt op de rechtspositivistische invloed van Merkl) wordt bij Steenbeek expliciet.

Steenbeek gaat uit van een materieel, inhoudelijk criterium dat bepalend is voor het onderscheid in formele rechtskracht en materiële rechtskracht. Niet is bepalend wie handelt, maar de totstandkoming en het rechtsgevolg van de rechtshandeling geven inhoud aan de begrippen. De (aflopende) rechtshandeling is drager van formele rechtskracht en materiêle rechtskracht wordt gekoppeld aan het (blijvende) rechtsgevolg:

\footnotetext{
"Met het worenstaande is aangeduid, welke verschillen bestaan tussen de kracht van het rechtsverschijnsel: de rechtshandeling, en die wan het rechtsverschijnsel: de rechtsgevolgem, de rechtssituatie. Beide soorten wan kracht betreffen, zoals gezegd, kracht in rechte, dus rechtskracht. Wij kennen de rechtskracht van de rechtshandeling en die van de rechtsgewolgen.

Nu overweegt bij de rechtshandeling het formele aspect. De in de rechtshandeling uitgedrukte wilsinhoud moet verklaard worden op zulk een wijze, dat de rechtsorde deze verklaring als relevant kan aanmerken, en dat eist cen formelle aanpak, hoe weinig formeel de rechtshandeling somtijds ook moge zijn.

De rechisgevolgen echter dragen een ander karakter, de rechtshandeling wordt verricht om in de wereld van het recht een mutatie aan te brengen en is daarmede op een naterieel doel gericht hoezear dit woel als rechtsdoel een abstract karakter draagt.

Er zou daarom weel woor te zeggen zijn het in de rechtsliteratuur veelwuldig gebruikte begrip "formele rechtskracht" te reserveren voor de kracht van de rechtshandeling, terwijl dan de evenzo bekende "materiële rechiskracht ${ }^{*}$ zou kunnern worden gebruikt om de kracht van de rechtsgevolgen aan te duiden. Een voorstel als dit kan moeilijk misplaatst worden genoemd waar over de inhoud van deze rechtskrachibegrippen zo weinig eensgezindheid heerst. 25
}

En later:

"Formele rechtskracht is in deze benadering een ondersteuning van de noodzaak dat een overheidsbesluit als zodanig respect verdient en slechts op bepalde wijze en (vaak) slechts binnen een bepaalde tijd door bepaalde overheidsorganen op grond wan bepaalde argumenten die op de tunc-situatie slaan en die tot strekking hebben dat dat beshüt onjuist was, kan worden aangetast. (...) Materiele rechtskracht stewnt daventegen het rechtsgevolg dat door hat besluit van de owerheid is gegeven. Dat recht moet eveneens. wordien beschermd want (ook) daaraan mag de eis van stabiliteil worden gesteld. ${ }^{26}$

\subsubsection{Ontrafeling feit, norm en gevolg}

Concluderend luidt de tweede definitie van rechtskracht die in het bestuursrecht de ronde doet die van Vegting: duurzaamheid verbonden met juridisch bestaan (formele rechtskracht) en verbonden met - in tijd en naar personen gespreide - effecten (materiële rechtskracht).

25. J.G. Steenbeek, tRechtshandeling en rechtsgevolg in het Staats- en administratieff recht, diss, Assen 1958 , p. 69 .

26. J.G. Steenbeek, Rechtskracht in: NTB 1989/8, p. 267 
De derde betekenis - van Steenbeek - definieert formele rechtskracht op een - aflopend moment (eigenschap van de rechtshandeling) en materiële rechtskracht als blijvend (eigenschap wan het rechtsgewolg). Feit en gevolg worden aldus expliciet onderscheiden; deze tweedeling in formele en materiële rechtskracht houdt rekening met de verschillende actoren die in het publiekrecht kunnen handelen, maar ook met de factoren tijd en plaats. Feit en gevolg krijgen invulling als vorm en inhoud. Dat deze inhoud (de gevolgen dus) genormeerd wordt door het recht (de bemiddelende functie van normen tussen werkelijkheid en rechtswerkelijkheid) blijft bij Steenbeek onderbelicht.

Het lijkt overigens onwarschijnlijk dat de burgerlijke rechter een van deze betekenissen van formele rechtskracht als inspiratiebron heeft gebruikt voor zijn eigen definitie van formele rechtskracht als synoniem met onaantastbaarheid.

\subsection{Formele rechtskracht in een spanningsrelatie: bestuursorgaan en administratieve rechter}

\subsubsection{Inleiding}

Formele rechtskracht vindt zijn rechtvaardiging in het rechtszekerheidsbeginsell. Duidelijk en voorzienbaar moet voor belanghebbende zijn wanneer de beschikking vast staat. De beschikking is als laatste en meest concrete stap het instrument dat de rechtssituatie wijzigt of, met andere woorden, de publiekrechtelijke rechtssituatie normeert. Een wijziging in de rechtssituatie is daarmee steeds objectief en tot een ieder gericht, heeft met andere woorden erga omnes-werking. De rechtssituatie of de inhoud van de gewijzigde rechtssituatie moet dan ook voor ieder kenbaar zijn voordat men er aan gebonden wordt. De voortgang van de openbare samenleving eist dat dat binnen afzienbare tijd gebeurt. Door instelling van korte beroepstermijnen is dat ook het geval.

Tegelijkertijd moeten bestuursorganen in hun uitoefening van het algemeen belang kunnen 'spelen' met bevoegdheden; het al of niet afgeven van beschikkingen, het wijzigen of intrekken van beschikkingen moet met een zekere flexibiliteit kunnen plaatsvinden. Vandaar dat de rechtskracht wan beschikkingen, die voor belanghebbenden een duidelijke starheid kan vertonen, voor bestuursorganen een meer flexibele omvang moet hebben. In zo'n situatie staan twee kenmerken van rechtskracht tegenover elkaar. Dan staan enerzijds de erga omnes-werking (die voortwloeit uit de rechtszekerheid) en anderzijds de uitvoering of concretisering van het collectieve algemeen belang (die object is van bevoegdheidsuitoefening door bestuursorganen) tegenover elkaar in een spanningsrelatie.

Het bestaan wan een bevoegdheid verleent aan actoren (bestuursorganen) de potentie om rechtskracht aan een rechtshandeling mee te geven. ${ }^{27}$ Rechtskracht is zodoende steeds

27. Ontbreekt de bevougdheid, dan zal in beginsel ook de rechtskracht ontbreken: 'De Afdeling rechtspraak is vam oordeel dat het beshuit van de geneenteraad (...) tot delegatie (...) rechtskracht mist. In de WRO is deze bevoegdheid (...) uitdrukkelijk toegekend aau de gemeenteraad. In deze noch in enige andere wet kan een grondslag worden gevonden voor de overdracht van deze bevoegdheid aan thet college. Zie: ARRS 16 
verbonden aan de bevoegdheidsuitoefening. Daardoor ontstaat de situatie dat de bevoegdheidsuitoefening enerzijds (als publiekrechtelijk handelen) objectief is, gericht jegens allen (erga omnes) en anderzijds (als feitelijk handelen) subjectief is, individuen raakt in hun belang (inter partes).

Dit als uitgangspunt nemende kijken we naar de formele rechtskracht van beschikkingen in het administratief recht; duidelijk zal inmiddels zijn dat een onderscheid aangebracht moet worden in perspectief (van bestuursorganen, van rechters, van burgers). Vanuit het perspectief van het bestuursorgaan staat immers de objectieve gezagsuitoefening altijd voorop; vanuit het perspectief van de rechter de subjectieve bevoegdheidsuitoefening en het belang van individuen. De admimistratieve rechter heeft het helemaal moeilijk: hij verkeert in een 'dubbele' positie; enerzijds wil hij - als rechter immers - individuele rechtsbescherming verlenen (ingevolge de doelstelling van de Algemene wet bestuursrecht) en anderzijds handhaaft hij het objectieve recht (want zijn rechtsmacht is - ook in de Awb - op besluiten betrokken en vereist een algemene belangenafweging, die kan leiden tot vernietiging). De (materiële) rechtszekerheid gebiedt dat belanghebbenden mogen vertrouwen op beschikkingen met formele rechtskracht. ${ }^{28}$ De (formele) rechtszekerheid gebiedt dat er duidelijkheid is ten aanzien van beschikkingen met formele rechtskracht. ${ }^{29}$ Zoals hiema uitvoerig naar voren zal komen, zijn de meer specifieke eisen, die aldus uit de rechtszekerheid voortvloeien, derhalve korte beroepstermijnen, de aanwezigheid van hardheidsclausules als verschoning van termijnoverschrijding, het verbod van terugwerkende kracht van besluiten. ${ }^{30}$ De rechter is bevoegd tot vernietiging. De vernietiging werkt terug tot het moment tunc en beslaat - in beginsel - alle rechtsgevolgen. Een boeiende vraag die daaruit voortvloeit is de vraag naar het voorwerp van de vernietiging; wat wordt vernietigd: de rechtsgevolgen of de rechtshandeling? Want kan niet ook bij de vernietiging een of alle rechtsgevolgen in stand worden gellaten (de vernietiging aldus gedekt verklaard) en in het verlengde daarvan kan de beschikking worden herzien? Wat heeft formele rechtskracht: het rechtsgevolg of de rechtshandeling? En, hoe te handelen als de formele rechtskracht (achteraf beschouwd) helemaal niet intreedt?

oktober 1992, AB 1993, $328 \mathrm{mnt}$. PwB, p. 934. Soms éist de rechtszeker rheid dat ondanks de oubevoegdheid de formete rachtskracht in stand blijft; vergelijk. CR B I jun 1989, AB 1989, 436 m.nt. MH.

28. Vgl. P. de Haan, Th.G. Drupsteen, R. Fernhout, Bestutrsrecht in de sociale rechtsstat, deel I, Deventer 1996, p. 108: "Dat het gegeven woord bindt geldt in civiellechtelijke rechesbetrelkkingen alls uitgangspunt. Voor het totstandkomen van een rechtshandeling en voor het vaststeflen van de inhoud daarvan is naast de geopenbaarde wil ook het opgewekte vertrouwen bepalend (..) In publickrechtelijke rechtswerhoudingen kan opgewekt wertrouwen eveneens to binding leiden, malar deze binding moet wel passen in de kaders van het publieke recht.'

29. Vgl. P. de Haan, Th.G. Drupsteen, R. Fernhout, Bestuursrecht in de sociale rechtsstaat, deel 1, Deventer 1996, p. 121-122 en daar genoemde literatuur.

30. Vgl. P. de Haan, Th.G. Drupsteen, R. Fernhout, Bestuursirecht in de sociale rechtsstaat, deel 1, Deventer 1996, p. 109-110 en daar genoemde literatuur. 


\subsubsection{Moment wan rechtskrachtverkrijging}

Wanneer, dat wil zeggen op welke dag, gaat formele rechtskracht in? Ten aanzien van deze vraag spelen twee benaderingen voortdurend door elkaar. Theoretisch gezien kan de beschikking fomele rechtskracht verkrijgen ofwel na een correcte afkondiging door het bestuursorgaan ofwel na ongebruikt verlopen van de beroepstermijn ofwel na verloop van de (gehele) bestuursrechtelijke procedure. Daartussen kunnen in beginsel maanden, zoniet jaren liggen. Vraag is daarmee welk het moment is van de afronding van de competente rechtsvorming. Wanneer het bestuursrecht in een procesrechtelijk vertoog wordt opgevat (het rechtsbeschermingsdenken), zal de formele rechtskracht pas kunnen aanvangen aan het eind van de administratiefrechtelijke procedure of, bij ongebruikt verstrijken van de beroepstermijn, aan het einde van die beroepstermijn. In benaderingen van het bestuursrecht die primair uitgaan van de bevoegdheidsuitoefening (het bevoegdheids- of besluitvormingsdenken) zal het moment van verkrijging van de formele rechtskracht bij het begin van die procedure liggen. ${ }^{31}$ Daarop is als uitzondering te bedenken dat de formele rechtskracht van de bevoegdheidsuitoefening nog niet perfect is zolang de bestuursrechtsgang nog niet volledig is doorlopen. Aldus zal op moment I van onderstaand schema de formele rechtskracht zijn ingetreden wanneer men uitgaat van de bevoegdheidsuitoefening. Dit geldt dan als vaststaand moment, tenzij de uitzondering (uitoefening nog niet perfect) wordt aangenomen, omdat in dat geval het moment van rechtskrachtverkrijging ligt op moment 2. De uitzondering (uitoefening nog niet perfect) valt dan samen met het moment van rechtskrachtverkrijging in het Procesrechtelijke uitgangspunt. Ondertussen kan een civiele procedure starten; dat geschiedt dan op enig moment $y$.

Schematisch gezien:

1 2 (administratieve procedure)

y................. (civiele procedure)

Op moment 1 wordt de beschikking genomen (moment van rechtskrachtverkrijging vanuit het bevoegdheidsdenken). Op moment 2 is de bestuursrechtelijke procedure volledig door-

31. Overigens blijt de levensgrote vraag staan of er al sprake is wan - jets als - formele rechtskracht vóor het moment van beshuitvorming. Daarbij doel ik - in een vergelijking met het civiel recht - op Plas-Valburgachtige situaties (HR 18 juni 1982, NJ 1983, 723 m.nt. CJHB). Er is wel iets, maar wat is dat dan? Vertrouwen speelt hier een rol in de zin wan warom zouden we intrekken of wijzigen. Ook speelt hier de acius contrarius. Kennelijk zou datgene wat hier is onschreven kunnen worden als een soort van vermoeden wan rechtmatigheid, waar belanghebbenden en bestuurders op afgaan. Steenbeek heeft het in zijn dissertatie Rechtshandeling en rechtsgevolg in het Staats- en administratief recht, Assen 1958, p. 50-51. over de "latente aanwezigheid" van rechtsgevolgen. In feite betreft deze problematiek een apart dissertatieonderwerp, waaryoor naar mijn mening inzicht in het Duitse begrip Bestandskraft ons waarschijnlijk verder kan helpen. 
lopen (moment van rechtskrachtverkrijging vanuit het procesrechtsdenken). Op moment y start (wellicht) de civiele rechtsgang.

Bij de start van een civiele rechtsgang ligt de vraag voor of het besluit (al) formele rechtskracht heeft. Wanneer de formele rechtskracht wordt beschouwd vanuit de bevoegdheidsbenadering kan ten tijde van de start van de civiele procedure de formele rechtskracht als bestaand worden vastgesteld. Dat geeft richting aan de wijze waarop de civiele rechter zich onthoudt van toetsing of de mate warin de beschikking invloed uitoefent op het civiele oordeel. Vanuit de procesrechtsbenadering kan de formele rechtskracht wellicht moeilijker als bestaand worden vastgesteld; formele rechtskracht wordt dan bezien als een instrument in een procesmiddelenstelsel. Aanwezigheid van formele rechtskracht is dan voorwaarde voor het weigeren van toegang; afwezigheid of onduidelijkheid over aanwezigheid van formele rechtskracht leiden dan tot niet-ontvankelijkheid of opschorten van de toegang bij de burgerlijke rechter door toepassing te geven aan artikel $96 \mathrm{a} \mathrm{R}$.

De burgerlijke rechter heeft de formele rechtskracht vanuit dat rechtsbeschermingsdenken binnengehaald als instrument ter afbakening van zijn rechtsmacht met die van de bestuursrechter. Hij kwam daartoe ondat de formele rechtskracht het ideale toetsingsinstrument leek dat recht kon doen aan gerechtvaardigde eisen van rechtsbescherming (naast de hoofdregel stond immers de hardheidsclausule van de uitzondering). Wanneer het individu een verwijt te maken valt, zal niet licht tot een uitzondering op de formele rechtskracht worden besloten; zo werd de formele rechtskracht ingepast in een systeem dat uitgaat van de subjectieve posities van partijen. Doordat het de betekenis had van onaantastbaarheid, kon het functioneren als een geobjectiveerde toetssteen van die subjectieve partijposities; aanwezigheid van onaantastbaarheid betekent dan immers dat het individu niets meer bij de burgerlijke rechter heeft te zoeken.

In het publiekrecht overheerst vanouds de benadering vanuit het bevoegdheildsdenken, omdat dit primair het handhaven van het objectieve recht weerspiegeld. Dat denken gaat niet alleen uit van de bevoegdheidsuitoefening door een bevoegde rechtsvormer, maar knoopt daar eveneens de erga omnes-werking van besluiten aan vast. Op die wijze is het publiekrecht objectief van aard. Het rechtsbeschermingsdenken in het publiekrecht is met name zichtbaar wanneer de rechter de formele rechtskracht van besiuiten doorbreekt (met een beroep op de rechtszekerheid). De president en de rechtbank Den Haag oordeelden aldus dat de formele rechtskracht van een beschikking niet aan betrokkene kon worden tegengeworpen; zo kan de formele rechtskracht worden doorbroken. ${ }^{12}$

Wanneer is er mu dat moment van rechtskrachtwerkrijging, aldus de rechter? Het moment van werkrijging van formele rechtskracht is dan daar wanneer de "formaliteiten" zijn vervuld. 'Formaliteiten' zijn dan bevoegdheidsuitoefening door een bevoegd orgaan mef inachtneming van vereiste stappen. De regel dat het beroep op de administratieve rechter (op

32. Vgl. President en rechtbank Den Maag, zittinghoudend te Haarlem 21 november 1997, JB 1997/292 m.nt EvdL. 
zichzelf) geen schorsende werking heeft, bevestigt deze stelling alleen maar. ${ }^{33}$ Vraag is hierbij of het moment van rechtskrachtverkrijging ligt voor het moment van bekendmaking of dat de bekendmaking deel uitmaakt van de formaliteiten voor rechtskrachtverkrijging. Daarna, dat will zeggen logischerwijze na het moment van rechtskrachtverkrijging, is er hett moment wan inwerkingtreding. In werking treden kan een besluit pas nadat het is bekendgemaakt: $^{34}$

"Het vaststellingsbeshuit is niet overenkomstig het bepaalde in artikel 3.42 van de Awb bekend genalakt, zodat, gelet op antikel 3.40 wan die wet, moet worden geoordeeld dat de rechtsgevolgen (..) nog niet zijn ingetreden. 35

Wanneer ook maar enige twijfel rijst over de bekendmaking dan ligt het risico daarvoor bij het bestuursorgaan:

"Daarbij laat de rechtbank wegen dat verweepder zelf er toe kan bijdragen dat er geen twijfel behoeft te bestaan of eem betrokkene al dan niet door de verzekeringsdeskundige ter zake correct en wolledig wordt geinformeerd, door in situaties als deze niet te wolstaar met een mondelinge mededeling, maar een bewijs van hersteldyerklaring te verstrekken waarop de bepalingen zijn vermeld die betrokkene in acht moet nemen bij het verzock een voor beroep vatbaar besluit te treffen. Door dit na te haten heeft verweerder in casu zelf - een deel van - de thans ontstante onduidelijkheid gecrederd. De gevolgen daarvan dienen niet voor rekening van eiser te komen. (...) Daaraan voegt de rechtbank toe dat (...), gelet op de hoofdregel van artikel $3: 40$ van de Awb (...), de werking wan dal besluit zal moeten worden opgeschort tot het tijdstip waarop dit beslut is bekend gemaakt." 36

Bekendmaking is zodoende een vereiste formaliteit naast het verlopen van de beroepstermijn. ${ }^{37}$ Vanuit de stelling dat de formele rechtskracht voortvloeit uit de rechtszekerheid is dat ook alleszins logisch; cen belanghebbende kan niet aan een wijziging van de rechtssituatie worden gebonden indien hij daarvan geen weet heeft. Bekendmaking van beschikkingen vloeit aldus rechtstreeks voort uit de eis van het beginsel van lex certa.

Daarnaast zijn er andere te vervullen formaliteiten, die afhankelijk zijn van de omstandigheden van het geval. Een merkwaardige casus vormt de volgende inzake goedkeuring. De strekking daarvan lijkt wel dat indien goedkeuring is vereist, daar zonder geen rechtskrachtig plan kan ontstaan. De datum van goedkeuring van een planherziening, diende volgens de ARRS "als de datum van rechtskrachtverkrijging van dit plan (...) te gelden's\&, hetgeen betekent dat rechtskrachtverkrijging en goedkeuring op hetzelfde moment plaatsvinden. Dat is daarom onlogisch omdat goedkeuring in feite werkt als een soort van sllag-

33. Vgl. artikel 6:16 Awb.

34. Vgl. CBB 10 november 1994, B $1994 / 317$, p. 854, r.k.: "Vooropgesteld moet ook hier worden dat de aanvang van de bezwaartermijn niet afhangt van de dag van mededeling, maar van de dag van bekendmaking."

35. Pres. Rb. Zutphen 27 december 1994, JB 1995/35 m.nt. MAH, p. 119, l.k.

36. Rb. Rotterdam 18 april 1994, JB 1994/118, p. 302-303.

37. Zie ook: HJ. Simon, die benadrukt dat bekendmaking moet geschieden op de voorgeschreven wijze: De Hoge Raad, de Awb en de toegang tot de rechter, in: JB 1996/123, p. 500.

38. ARRS 7 april 1990, AB 1991, $122 \mathrm{~m}$.nt. PwB, p. 357, r.k. 
boom (toezicht) ná het geldig nemen van een besluit. ${ }^{39} \mathrm{Zo}$ bezien is goedkeuring een formaliteit voor inwerkingtreding, maar niet een formaliteit voor rechtskrachtverlening.

\subsubsection{Wachien totdat formele rechtskracht intreedt}

Voor het intreden van formele rechtskracht is sinds jaar en dag het verlopen van een termijn vereist. Soms zijn ook andere formaliteiten vereist. Zijn deze formaliteiten niet vervuld, dan heet het besluit niet op rechtsgeldige wijze tot stand te zijn gekomen. ${ }^{\text {to }}$ In het Rapport Abar sprak men dan ook van 'De fasen, welke de beschikking doorloopt, voordat het beoogde rechtsgevolg intreedt" ${ }^{41}$ In de drie daar onderscheiden fasen worden vele van deze formaliteiten geinventariseerd. In een meer specifiekere benadering is dat ook hetgeen Van Driell deed ten aanzien van de ministerièle verordening ${ }^{42}$ en Steenbeek ten aanzien van rechtshandelingen. ${ }^{413}$

In de verschenen handboeken wordt steeds uitgegaan van de regel dat een besluit pas rechtskracht verkrijgt na verloop van de beroepstermijn en na vervulling van de formalitei$\operatorname{ten}^{44}$

\subsubsection{Termijnen}

Wanneer de beroepstermijn is werlopen is het besluit formeel rechtskrachtig en kan dan - in beginsel - niet meer worden aangevochten. ${ }^{45}$ Zo was de in een brief vervatte anticumulatiebeslissing rechtens onaantastbaar, omdat geen voor beroep vatbare beslissing (vbwb) werd aangevraagd. ${ }^{46}$ Aan besluiten (tot het vaststellen van theffingen of weigerin-

39. Vgl art. 3:40 Awb en art. 1025 Awb.

40. In het uiterste geval heet het besluit dan nietig te zijn; vergalijk D. van der Wel, Administratiefrechtelijke nulliteiten, diss., Amhem 1951 en F.W. ter Spill en A.Q.C. Tak, Onwetmatig bestuur, preadvies VAR, Alphen a/d Rijn 1981.

41. Vgl. Rapport Algemene bepalingen van administratief recht, Alphen a/d Rijn 1973, p. 68 e. .: $^{\text {ik }}$ ikeb woor dexe windplaats gebruik gemakt van de uitgave van 1980, warin aar het bewerkte origineel van 1973 een supplement uit 1976 is toegewoegd. In de meest recente, overigens wan opzet gefueel van de vorige druk verschillende, wijfde druk van 1984 wordt aandacht besteed aan het ontstaan van rechtsktricht in par. 6.2 , p. 206 e.v. i.ll.b. p. 209.210.

42. Vgl. JMC. van Driel, De ministeriele verordening, diss., Zwolle 1956 , ihb pardV, p. $66 \mathrm{c.v}$

43. Vgl. J.G. Steenbeek, Rechtshandeling en rechtsgevolg in het Stats-en administratice recht, diss., Assen 1958

44. Vgl. o.a. J.R. Stellinga, Grondtrekken van het Nederlands Administratiefrecht, p. 86 e.w., $14 \|$ e.v. en $21 \|$ e.v, A.M. Donner, Nederlands bestuursrecht, Algemeen deel, Alphen a/d Rijn 1987, p. 260 e., "H.D. van Wijk, W. Konijnenbelt, R.M. van Male, Hoofdstukken van administraticf recht, Utrecht 1994, p. 608 ; P. Nicolal, B.K. Olvier, L.J.A. Damen, H. Troostwijk, Bestuursiecht, Amsterdam 1994, p. 369e.v.; Th. Holterman, Constanten in het publiekrecht, Zwolle 1995, p. 94 c.v.; A.Q.C. Tak, Hoofdlijnen wan het Nederlands bestuursprocesrecht, Zwolle 1995, p. 226-227; H.J. Simon, Handleiding Awb-praktijk, "s-Gravenhage 1995, p. 100 e.\%.

45. Vgl. autt. 6:7, 6:8, 6:l1 Awb en ook HI. Simon, Handleiding Awb-praktijk, "s-Gravenhage 1995, p. $157-167$.

46. Vgl. Rb. Breda 27 februari 1996, Nieuwsbrief Awb/Justcx. 1996,203 (ongepubliceerd). 
gen op heffingsbesluiten terug te komen) waartegen geen beroep is ingesteld, komt derhalve formele rechtskracht toe. "Indien belanghebbende niet de hem ten dienste staande rechtsmiddelen heeft aangewend, dient het besluit als rechtens onaantastbaar te gelden. ${ }^{\text {s }}$ Wanneer een beschikking onherroepelijk is, staat zij niet meer ter beoordeling aan de rechter en naleving kan dan - in beginsel - worden afgedwongen: 'De Afdeling geschillen overweegt dat, nu voorschrift 4 aan een onherroepelijke vergunning is verbonden, de inhoud van dit voorschrift niet ter beoordeling staat en behoudens in het geval het evident in strijd is met art. 13 Hinderwet, de naleving daarvan kan worden afgedwongen. ${ }^{, 49}$

Een nieuwe termijnbepaling in een nader besluit kan niet leiden tot omzeiling van de formele rechtskracht van het eerdere besluit: 'Niet kan immers worden aanvaard dat degene die een beroepsmogelijkheid tegen een besluit onbenut heeft gelaten, door voorziening te wragen tegen een nader besluit, waarbij hem onder verwijzing naar dat eerdere besluit een nieuwe termijn wordt gegeven om an thet gestelde in het eerdere besiluit uitvoering te geven, zou kunnen bereiken dat het op grond van de wet Arob ingediende bezwaarscinrift tegen het nadere besluit zou worden beoordeeld als ware dit gericht tegen de eerdere, in rechte onaantastbaar geworden beschikking., ${ }^{\text {s0 }}$ Aldus bakent de formele rechtskracht van de beschikking ook de omvang van het geschil af.

Dat men na geprocedeerd te hebben bij de bestuursrechter eventueel ook nog kan procederen bij de burgerlijke rechter (bv. in verband met schadevergoeding) doet aan de onherroepelijkheid vam de beschikking niet af. ${ }^{\text {sl }}$

Als de beroepstermijn eenmaal is verstreken heeft het besluit formele rechtskracht, ook als aan het besluit gebreken kleven (die alls het aangevochten was tot vernietiging hadden moeten leiden). ${ }^{52}$ De wraag is echter of er eigenlijk wel een besluit kan ontstaan ingeval van absolute onbevoegdheid. Problematisch is, dat wanneer een besluit absoluut onbevoegdelijk tot stand is gekomen en niemand er tegen in beroep komt, het wel in het rechtsleven gaat functioneren als ware het aanwezig. In feite hebben we het dan niet over de rechtshandeling, maar over (rechts)gevolgen. Ingeval van absolute onbevoegdheid, zit het wel bevoegde orgaan stil (althans heeft niet gereageerd op het onbevoegdelijk handelen). Om $z o$ 'n situatie te legaliseren wil de rechter de onbevoegdheid doorgaans helen met het oog op de (wenselijke) instandhouding van inmiddels ontstane gevolgen. Zo bezien lopen tuncen nunc-momenten weer volledig door elkaar heen. De Centrale Raad van Beroep handelde aldus inzake een - naar later blijkt - onbewoegd genomen besluit tot aanstelling van een ambtenaar (waarop eiser de ontslagaanzegging baseert):

"Nu diat beshuil destijds niet door gedaagde is aangevochten doch zondermeer is geaccepteerd en pp. zich er jarenlang naar hebben gedragen is de $\mathbb{R}$ ad owereenkomstig constante jurisprudentie van oordeel dat onder

47. Vgl, V2. CBB 8 nowember 1990, AB 1991.289.

48. Vgl. Vz. ARRS 8 maant 1991, AB 1992, 167

49. AGB 22 april 1993, AB 1993, 387, p. 1099-1100 m.nt. FM.

50. V: ARRS 13 januari 1993, AB 1993, 236.

51. Vgl. AGB 20 december 1991, AB 1992, 294 m.nt. FM.

52. Zo ook W. Duk en P. Nicolar, Nitiliteiten in het bestuursrecht, in: RM Themis 1993, p. 7. 
deze omstandigheden het beginsel der rechtszekerheid dient mee te brengen dat gedaagde ook rechtens ats ambenaar van gemeentepolitie wordt aangemerkt. Genoemd beginsel staat er eveneens atn in de weg dat aan gedaagde (...) alsnog de status wan ambtenaar wan gemeentepollite word ontnomen door hem met terugwerkende kracht wanaf die aanstelling aan te merken ais ambtenaar in de zin van het Algemeen Rijksanbtenarenreglenient. ${ }^{53}$

Merkwaardig is overigens dat de rechter zich laat leiden door beginselen (i.c. de rechtszekerheid) ter heling van de onbevoegdheid. Dat is daarom vreemd omdat beginselen, in tegenstelling tot bevoegdheden, geen causa zijn wan rechtshandelingen. Annotator Hennekens wijst erop dat in deze casus de materiële rechtszekerheid naast de formele rechtszekerheid staat: 'Deze benadering stemt overeen met de algemeen in rechte geldende, dat een niet aangevochten besluit na ommekomst van de beroepstermijn formele rechtskracht heeft, zelfs wanneer het naar inhoud in strijd is met het recht (...). De ene rechtszekerheid zet dus de andere rechtszekerheid niet opzij, zij bestaan naast elkaar. ${ }^{34}$

\subsubsection{Formele rechtskracht doorbroken}

Vergunningen die rechtskracht hebben verkregen zijn niet absoluut onaantastbaar. ${ }^{55}$ Het is daardoor een uiterst relatieve eigenschap van beschikkingen. De formele rechtskracht van een beschikking kan op vele wijzen worden "doorbroken". Doorbreken is eigenlijk geen zuivere aanduiding, omdat vaak het wijzigen van rechtsgevolgen voor ogen staat, terwijl een oordeel wordt gegeven over de rechtshandeling. Doorbreken in de letterlijke zin slaat op het een streep trekken door de rechtshandeling; dat moet dan steeds ex tunc geschieden, omdat de rechtshandeling destijds in het rechtsleven kwam. Van een dergelijke doorbreking is slechts af en toe sprake: bijvoorbeeld bij de intrekking ex tunc van een besluit, Veel vaker is er sprake van naast elkaar staande wensen: het besluit is dan weliswaar en of het er blijft is dan niet relevant, maar heeft men veeleer de wijziging van rechtsgevolgen op het oog. In het gangbare taalgebruik wordt dan toch vaak gesproken van 'doorbreking van formele rechtskracht' van besluiten. Dat is het geval bij verschoonbaarheid van de termijnoverschrijding ${ }^{56}$, wijziging of intrekking door het bestuursorgaan, ${ }^{57}$ terugkomen op de beschikking dow een bestuursorgaan ${ }^{58}$ of door de rechter ${ }^{54}$, gehele of gedeeltelijke vernietiging. ${ }^{60}$ Laten we deze situaties nu iets preciezer bekijken.

53. CRWB I juni 1989, AB 1989,436 m.nt. HH, p. 1283, I.k

54. CRvB 1 juni $1989, \mathrm{AB} 1989,436 \mathrm{mnt} . \mathrm{HH}, \mathrm{p}$. $\| 284$, onder 3

55. Vgl. Vz. ARRS 12 aktober 1990, AB 1991, 120 m.nt. PvB en Rb. "s-Hertogenbosch 23 november 1995 , JB $1996 / 28$ mint. Eval en RS.

56. Vgil. art 6:11 Awb.

57. Vgl. arti 6:18 en 6:19 Awb.

58. Vgl. ard. 4:6 Awb.

59. Vgl thtel $8.4 \mathrm{Awb}$, herziening.

60. Vgl art. $8: 72 \mathrm{Awb}$. 
Wanneer er sprake is van verschoonbaarheid van de termijnoverschrijding wordt de beroepstermijn gerekt. Dit staat middenin de spanningsrelatie van bevoegdheidsdenken en procesrechtsdenken, ondat het de toegang tot de rechter betreft. Het rapport ABAR beschreef dit: "Al springt de redelijkheid van het aanvarden van souplesse ingevall van te verontschuldigen overschrijding van de beroepstermijn (...) in het oog, de keerzijde van de medaille verdient eveneens de aandacht. Hoezeer het ook tegenover appellant gerechtvaardigd kan zijn, dat zijn na het verstrijken van de beroepstermijn ingesteld beroep ontvankelijk wordt verklaard, het is in bepaalde gevallen heel goed mogelijk dat andere belangen bij het aanvaarden van een overschrijding van de beroepstermijn in het gedrang komen. ${ }^{\text {,5i }}$ Omdat het een uizzondering op ontvankelijkheidsvereisten betreft, zal er doorgaans pas toepassing aan worden gegeven wanneer belanghebbende geen werwijt kan worden gemaakt; voor het overige ondergraaft het het bestur (dat zijn legitimatie immers primair in zijn bevoegdheid zoekt en niet bij de rechter). Betrokkene dient zelf aannemelijk te maken dat er een grond is die tot verschoonbaarheid kan leiden; de belastingrechter formuleerde dit aldus:

\begin{abstract}
'Zoals de Hoge Raad in zijn arrest van 22 juli 1988, BNB 1988/292, heett overwogen, is, ingeval de belastingplichtige an wie een verhoging is opgelegd, stelt dat de termijnoverschrijding aan een hen niet toc te waken omstandigheid is te wijten, terwijl omtrent de juistheid van die stelling in rechte geen zekerheid valt te verkriggen, eerbiediging van zjn techt op toegang tot de rechter niet gewaarborgd wanneer die onzekerheid voor zijn risico wordt gebracht, en kan de nict-ontwankelinkheid alsdan slechts worden witgesproken indien de onjusistheid van deze stelling wordt bewezen. ${ }^{262}$
\end{abstract}

Niet alleen belanghebbenden kunnen fouten maken, die verschoonbaarheid opleveren; zo ook bestuursorganen. Te denken valt aan fouten bij de bekendmaking, de doorzending, foutieve adressering. ${ }^{63}$

Wanneer aan het bestuursorgaan wordt verzocht om het 'besluit' te wijzigen of om erop terug te komen, is er dus al een afwijzing; het verzoek betreft een herhaalde aanvraag. ${ }^{64}$ Belanghebbende is het dan niet eens met de rechtsgevolgen, terwijl het bestuursorgaan zich op het standpunt stelt al een besluit genomen te hebben. Zo'n herhaalde aanvraag hoeft alleen dan in behandeling worden genomen indien er nieuwe feiten en omstandigheden ex tunc (nova) worden gesteld; de bevoegdheid om terug te komen op (dat wil zeggen door wijziging of intrekking van) rechtens onaantastbare besluiten kan ook worden aangenomen indien niet van nova is gebleken. ${ }^{65}$ De formeel rechtskrachtige beschikking als verwijzend

61. Rapport ABAR, Alphen a/d Rijn 1980, p. 332.

62. Hoge Raad 27 manart 1996, JB 1996/124 m.nt. HJS.

63. Voor een overzichtelijke beschrijwing van de jurisprudentie werwijs ik naar H.J. Simon, Handboek bestuurs(proces)recht volgens de Awb, 's-Grawenhage 1997, p. 246-248.

64. Vgl. ook H.I. Simon, Handboek besturs(proces)recht wolgens de Awb, "s-Gravenhage 1997, p. 172 a.w.

65. Vgl CRvB 28 novenber $1995, \mathrm{JB} 1996 / 33$. 
naar een tunc-moment blijft bestaan, maar de daardoor ontstane rechtsgevolgen worden ex nunc gewijzigd op basis van destijds onbekende argumenten.

All lijkt de situatie wan de herhaalde aanwraag sterk op herziening; ze moeten toch van elkaar worden onderscheiden. Herziening geschiedt immers door de rechter en ex tunc. ${ }^{66}$ Waarschijnlijk is, dat het bestuur zich meer zal laten leiden door beleidsmatige overwegingen dan de rechter. Er bestaan verschillen tussen de hoogste bestuursrechters met betrekking tot de wijze van toetsing van de nova. Overigens lijkt het aannemelijk dat deze verschillen verklaard worden door de al dan niet aanwezigheid van derde-belanghebbenden ${ }^{67}$ het is in overeenstemming met eisen van rechiszekerheid als de formele rechtskracht van een beschikking overeind blijft als ook derden daarop konden en mochten vertrouwen. ${ }^{68}$

Door wijziging van een beschikking kunnen rechtsgevolgen (of de voor belanghebbenden relevante rechtssituatie) veranderen van geoorloofd in ongeoorloofd en vice versa. Wijziging is verandering aanbrengen ex nunc. Intrekking geschiedt ex tunc en brengt dus veranderingen aan in de rechtshandeling zelf in de zin van terugnemen. ${ }^{69}$

De totstandkomingsgeschiedenis van wettelijke bepalingen kan uitwijzen dat het beschikkingverlenende orgaan tevens bevoegd is tot wijziging of intrekking ${ }^{70}$ van die beschikking, ook als die rechtens onaantastbaar is geworden. Dat werd expliciet bepaald voor enkele bepalingen van de Ontgrondingenwet: "Voorts kunnen deze bepalingen tevens betrekking hebben op wijziging of intrekking van vergunningen of daaraan verbonden voorwaarden, die rechtskracht hebben verkregen. ${ }^{71}$

Het overgaan tot herziening (van de gevolgen - ex nunc) is (wederom om redenen van rechtszekerheid) niet steeds mogelijk, maar aan voorwaarden (aanwezigheid van nova - ex tunc) gebonden. Opvallend is het uitblijven van het onderscheiden naar rechtshandeling (ex tunc) en rechtsgevolg (ex nunc):

"Indien verweerder bij nader inzien tot het inzicht komt dat een door hem gewomen besluit zich niat: verdragat met algemeen verbindende voorscliriften statit het hem in beginsel vrij, zo hij hictoe al niet verplicht is, een zodianig besluit ongedaan te maken. (...) Dit is slecthts anders wanneer verweerder door terug te komen op zijn eerder onjuist besluit handelt in strijd met de beginselen vary behoorlijk besturar door bijwoorbeld bij het nieuwe besluit te handelen in stijo met rechtens te respecteren verwachtingen of andere gerechrwardigde belangen van betrokkene. ${ }^{* 72}$

66. Vgl. titel 8.4 Awb.

67. Vgl. CRvB 14 meil 1996, JB 1996/142 m.nt EvdL.

68. Vgl. ook: CRVB 14 mei 1996, JB 1996/142 mn.m. EvdL en daar genoemdle jurisprudentie.

69. Vgl. ook de VAR-preadviezen, nr. LXXIV van M. Scheltema en W. Konijnenbelt, De rechtsverwerkimg in het administratieve recht, Gironingen 1975.

70. Vgl. Rb. Roermond 30 novernber 1995, JB 1996/4 m.nt. EvdL.

71. AGB 8 april 1991, AB 1991, 426 m.nt. PJS, p. 1164.

72. CBB 12 september 1990, AB 1991,441, p. 1216 . 
En ook:

"Verweerder heeft er terecht op gewezen dat de Afdeling eerder als haar oordeel heeft uitgesproken dat niet onder alte omsilandigheden aar werweerder de bevougdheid kan worden ontzegd om een beschikking tot werlening van subsidie te herzien (..). Daaraan heeft de Afdeling evenwel telkens toegevoegd dat dit zijn begremzing vindt in de algemene beginselen wan behoorlijk bestuur, met name het beginsel van de rechtszekerheid. (...) De Afdeling is wan oordeel dat in strijd met het rechtszekerheidsbeginsel wordt gehandeld indien $z o$ een herzieningsbeschikking, die immers genonen is, althans geacht moet worden genomen te zijn nat een volledige en wus voltoolde heroverweging, nadien wederon wordt gewijzigd. Is de desbetreffende herzieningsbeschikking naar achteraf blijkt, onjuist, dan komt dit voor rekening van het betrokken overheidsorgain. ${ }^{7 y}$

Nieuwe argumenten leveren nog geen nieuwe feiten (nova) op. In zo'n geval blijft de beschikking met haar formele rechtskracht in stand.

Vernietiging "doorbreekt" de formele rechtskracht van een beschikking, omdat deze geschiedt met terugwerkende kracht ex tunc en woor alle rechtsgevolgen. ${ }^{95}$ Het spreekt vanzelf dat bij de vraag of er vermietigd moet worden onderscheid gemaakt moet worden tussen begunstigende en belastende beschikkingen. Dit moet scherp in het oog worden gehouden, omdat vernietiging anders uitpakt in geval. van het vernietiging van een verleende uitkering als bij de vemietiging van de intrekking van die uitkering.

Bij de vernietiging van het "besluit" kan de rechter rechtsgevolgen in stand laten; niet alle" rechtsgevolgen hoeven dan ex tunc uit het rechtsleven te verdwijnen. Wanneer het wenselijk lijkt om rechtsgevolgen (ex nunc) te laten bestaan, kan het instituut van de gedektverklaring van een ventetiging zijn mut bewijzen. ${ }^{76}$ Redenen van proceseconomische aard naast oog hebben woor de feitelijke gevolgen van besluiten zijn de achtergronden van de wetgever voor instandhouding van de mogelijkheid van de gedektverklaring van een vernietiging. ${ }^{77}$ De rechter gaat onder meer over tot gedektverklaring van een nietigheid indien er redenen van algemeen belang voor zijn aan te voeren. ${ }^{78}$

"Uit hot worenstathde blijkt, dat heit ontslag mocht worden verleend en dat het enige gebrek, dat aan dit besluit kleeft. de ingangsdatum betref. Zoals reeds meermalen in soorgelijke gevallen acht de Raad deze omstandigheden voldoende redenen wan algemeen belang gelegen de nietigheid voor gedekt te verklaren met ingang wan een datum de aan de opzegtermijn recht doet. ${ }^{79}$

73. ARRS 2 september 1991, AB 1992,77, p. 198.

74. Voll. CBStuli 2 januari 1995, JB $1995 / 38$.

75. Vgl. Rb. Rotterdam 27 mai 1997, JB $1997 / 185$ m.nt. EvdL en rectificatie in afl. 11, p. 834.

76. Vgl art 8:72, derde lid Awb.

77. Vgl. Mvi, PGi Awb 2, p. 470.

78. Vgl. ook: H.3. Simon, Handboek bestuars(proces)recht volgens de Awb, 's-Gravenhage 1997, p. 325 en datar genoemde jurisprudentic.

79. CRvB 6 december 1990, AB 1991, 150 m.nt. HH, p. 42.1 en ook CRvB 14 mei 1992, AB 1992, 420 m.nt. $\mathrm{HH}$ 
Aan een gedektverklaring kan schadevergoeding worden verbonden. ${ }^{80}$ Indien de gedektverklaring van de nietigheid niet doorgaat (rechtsgevolgen), blijft de 'formele rechtskracht van het besluit' staan. ${ }^{81}$

\section{Ook door middel wan het door de rechter terugkomen van een bindende beslissing kan de} 'formele rechtskracht' worden 'doorbroken'. Waarschijnlijk is dat ook hierbij het wijzigen wan rechtsgevolgen het meest voorzit, al zit daarbij het "onaantastbare besluit" in de weg. Terugkomen van door de rechter is een discretionaire bevoegdheid: 'Van een onherroepelijk geworden besluit behoeft in principe niet te worden teruggekomen. Hier geldt het beginsel van de formele rechtskracht. ${ }^{, 82}$ En ook:

'Zoals de Raad (..) heeft owerwogen, is gedaagdes beslissing (...) rechtens onaantastbaar geworden. De bestreden beslissing betreft derhalve de uitoefening van gedaagdes bevoegdheid ten gunste van cen bellanghebbende terug te komen van een rechtens onaantastbaar geworden beslissing. Deze bevoegdheid is discretionair wan aard. Dit betekent dat de beroepsrechter slechts ter becordeling staat of wan zo"n beslissing gezegd moet worden dat gedaagde daartoe bij afweging van alle in aanmerking te nemen belangen in redelijkheid niet heeft kunnen geraken, dan wel daarbij anderszins in strijd heeft gehandeld met enig algemeen beginsel van behoorlijk bestuur, ${ }^{3} 3$

\section{En eveneens:}

'De Raad merkt hier nog eens op dat de hier aan de orde zijnde bewoegdheid van eiser om ten voordele van de bellanghebbende terug te komen wan een rechtens onaantastbaar geworden beslissing, varn discretionaire aard is. (...) Evenals de Raad in zijn hierwór genoemde uitspraak (...) heeft overwogen, is de Raad ook thans van oordeel dat het bestuur van een bedrijfsvereniging bij het aanhouden van de hiervór gereleveerde gedragslijn een binnen het raam van zijn evenbedoelde discretionaire bevoegdheid passende beleidsregel hanteert die zeker niet als onaanvaardbaar is te beschouwen. ${ }^{84}$

\section{En ook nog:}

'Het bestreden beslunit moet worden gekarakteriseerd als een weigering terug te komen op zijn in rechte onaantastbaar geworden besluit van 26 april 1988. Aan de orde is (...) de wraag of verweerder bij het bestreden besluit in strijd met het recht heeft geweigerd om op zijn besluit van 26 april 1988 utug te komen. Nu in her algemeen woor de administratie geen verplichting bestabt on (...) op onaantastbaar geworden besluiten terug te komen.

\section{En tenslotte:}

80. Vgl. CRvB 31 januari 1991, AB 1991, $291 \mathrm{~m}$.nt. HH.

81. Hetgeen blijkt wit CRwB 9 februari $1989, \mathrm{AB} 1989,209$ m.nt. HH.

82. W.P.F. de Bruijn onder CRvB 28 november 1995 , Gem.st. 7039 , nr. 7 , p. 508

83. CRvB 13 juli 1988, AB 1988, 465 m.nt. JHS, p. 1356 en wergelijk ook CRvB 2 mantt 1993, AB 1993, 421 an CRvB 21 april 1994, $A B 1994,476 \mathrm{~m}$.ni HH.

84. CRWB 10 februari 1988, AB 1988,299 m.nt JHS, p. 874 .

35. CBB 16 maart 1990, AB 1990, 362, p. 1099-1100. 
"Met de eerste rechter is de Raad wan oordeel dat het thans bestreden besluit een wergering is orn terug te komen wan eerder genomen rechtens vaststaande besluiten van eiser irzake het toekennen van reiskostenvergoedingen aan gedaagde. Zouls de Raad eerder heeft overwogen dient een dergelijke weigering te worden gederbiedigd tenzif aan dat eerdere beslut dusdanige gebreken kleven dan wel zich dusdanige omstandigheden hebben voorgedaan dat het administratief orgaan in redelighthe id niet had mogen weigeren het eerdere besluiti ongedaan te naken." 86

Het terugkomen van wordt wel geconstrueerd als herziening: "De Raad merkt nog op het voor de hand te zien liggen dat gedaagde bij het voorbereiden en nemen van een nadere beslissing mede eiseresses hiervoor gemarkeerde wens (...) betrekt, dit dan in het kader van zijn bevoegdheid tot 'herziening' van een beslissing ten voordele van de belanghebbende. ${ }^{37}$

Wanneer is er sprake van rechtsverwerking, anders gezegd ontgelding door onbruik? Zou de formele rechtskracht van besluiten eveneens 'doorbroken' kunnen worden door rechtsverwerking? Eigenlijk is dit niet correct gesteld, omdat er in strikte zin geen sprake kan zijn van 'doorbreking' van de formele rechtskracht (ex tunc) als de mogelijkheid tot het gebruik maken van (de inhoud, de gevolgen van) het besluit door 'natuurlijk' verloop van tijd zou verdwijnen. De vraag is daarmee of rechtsverwerking in het publiekrecht eigenlijk wel kan. In feite hebben we het ook niet over rechtsverwerking, maar over bevoegdheidsverwerking (de oorspronkelijke civielrechtelijke rechtsverwerking als aanspraakverwerking is immers vanuit publiekrechtelijk oogpunt een aberratie $)$ Logischer lijkt daarom dat de rechtssituatie gewijzigd wordt door nieuw (constitutief) handelen. In die zin begrijp ik ook de Centrale Raad van Beroep:

\footnotetext{
'Reeds eerder heeft de raad geoordeeld (...) dat het doen van een verzoek om terug te komen van een rechtens ondantastbaar geworden beslissing on tot een gunstiger resultaat te komen op zichzelf niet aan tijd gebonden is. Anders dan de eerste rechter, is de rad wan oordeel dat aard en strekking van de sociale-verzekeringswetgeving zich verzetten tegen het aannemen van rechtsverwerking. ${ }^{88}$
}

\subsubsection{Ontrafeling feit, norm en gevolg}

Zoals in het voorgaande hoofdstuk is gebleken, kan de invoering van het beginsel van de formele rechtskracht van beschikkingen door de burgerlijke rechter worden beschouwd als het binnenhalen van een instrument ter afbakening van rechtsmachten. Daarbij werd - zoals hier duidelijk is geworden - de formele rechtskracht aanvankelijk vooral benaderd wanuit het procesdenken (als instrument in een rechtsmiddelenstelsel). Deze betekenis was in het bestuursprocesrecht eveneens herkenbaar, al werd daar doorgaans van een rechtens vaststaand besluit of onherroepelijkheid van een besluit gesproken. Daarnaast is echter

86. CRwB 2 mei 1991, AB 1992, 22 m.nt. HH, p. 63-64 en vergelijk ook CRvB 27 april 1992, AB 1992, 688 nu.nit. HH.

87. CRWB 4 december 1987, AB 1988, 298 mnt. JHS, p. 872 .

88. CRvB 10 juni 1992, AB 1992, 570 m.nt. WASD, p. 1630. 
gebleven de betekenis van rechtskracht in het bevoegdheidsdenken: de eigenschap van beschikkingen als uitdrukking van de publiekrechtelijke gezagsuitoefening met erga omneswerking. Twee verschillende betekenissen (beter gezegd karakteristieken) van rechtskracht staan dan echter tegenover elkaar: onaantastbaarheid aan de rechtshandeling-kant (procesdenken) en erga omnes-werking aan de gevolg-kant (bevoegdheidsdenken).

\subsection{Rechtskracht en de strafrechter}

\subsubsection{Inleiding}

Welke is de betekenis van formele rechtskracht bij de strafrechter; welke betekenis hanteert hij? Is er verschil tussen de betekenis van formele rechtskracht bij de strafrechter en bij de burgerlijke rechter? Hoe zit het met formele rechtskracht door de bestuursrechter inzake besluiten ingevolge de Wet Mulder, de Wet administratiefrechtelijke handhaving verkeersvoorschriften (WAHV); de hoogste bestuursrechter in deze gedingen is immers de strafkamer van de Hoge Raad? Zou de betekenis van formele rechtskracht in deze Mulderzaken vergelijkbaar kunnen zijn met de betekenis van formele rechtskracht in strafzaken? De vraag naar de betekenis van formele rechtskracht heeft in het strafrecht oude papieren; Cluysenaer besprak hem in 1970 , terwijl hij de eigen verantwoordelijkheid van de strafrechter ten aanzien van de toetsing van beschikkingen benadrukte.

'Is er nu ook parallelliteit tussen de toetsing door de burgerlijke rechter en de toetsing door de strafrechter in die zin, dat de strafrechter zich evenals de burgerlijke rechter van deze toetsing heeft te onthouden in alle gevallen ${ }_{\text {, warin }}$ voor verdachte beroep op een administratieve "rechter" open heeft gestan? (...) Voor een parallelliteit tussen de toetsing van administratiewe beschikkingen door de burgerlijke rechter en door de strafrechter bestaat m.i. geen reden. Integendeel. Een zodanige parallelliteit is $\mathrm{m}$.i. in strijd met het werschil tussen beider taak. (...) Het overnemen van het systeem van de burgerlijke rechter zou tot de consequentie leiden, dat de strafrechter zich van toetsing moet onthouden indien de verdachte (voor whe beroep op een administratieve rechter open stond) op deze onrechtmatigheid een beroep doet, doch dat hij wel tot deze toetsing moet overgaan indien het O.M. (woor wie dit beroep als regel niet openstaat) op deze onrechtmatigheid een beroep doet (...). Doch dit komt mij voor geheel in strijd te zijn met het stelsel van ons strafprocesrecht (..) Het standpunt leidt ook tot inconsequenties: a. In alle gevallen, waarin voor verdachte geen beroep op een administratieve rechter open stond, stond voor hem ex ant. $1401 \mathrm{~B}$ W. beroep open op de burgenlijke rechter. Waarom hem nu in het strafproces wel ten beroep op de onrechtmatigheid van de beschilk. king te ontzegzen in de gevallen, waarin woor hem beroep op een adwinistratieve rechter open stond en niet in alle andere gevallen, waarin woor hem dus beroep op de burgerllyke rechter open stond" $b$. In de gevallen, warin de strafbaarheid wan het feit niet afhangt van de geldigheid ener administratieve beschikking doch van de geldigheid ener overeenkomst (of privatuechtelijke beschikking) toetst de strafrechter de geldigheid (...) zulks niettegenstaande de onstandigheid, dat woor verdachte m.b.t. de rechtsgeldigheid deze overeenkomst uiteraard beroep op de burgenlijke rechter open stond. Ook een beroep op het, door het verstrijkem van de beroepstermijn, "in kracht wan gewijsde' zijn gegaan en dardoor "rechtens onaantastbaar" geworden zijn van de beschikking gaat mi. nuet op. De hier besproken wrag is juist de vraag of (en in hoewerre) de beschikking door het verstrijken van de beroepstermijn "rechtens onaantastbaar" wordt. Ik meen 
dan ook, dat de strafrechter gehouden is om steeds als eén der partijen een beroep op de onrechtmatigheid dur beschikking doet en ook ambishowe de rechtmatigheid der beschikking te onderzoekem. 8 ?

Al komen Cluysenaer's overwegingen begrijpelijk voor, de rechtspraak was - ook al in die tijd - een stuk diverser. ${ }^{90}$ Soms gaat de strafrechter over tot zelfstandige toetsing van (de grondslag van) een beschikking, soms niet. We zien hier dus een verschil met de burgerlijke rechter. Wanneer de burgerlijke rechter conform de hoofdregel van formele rechtskracht handelt, betekent dat immers dat hij overgaat tot het afzien van zelfstandig toetsen van de gerichtheid op normen van een beschikking. Zo neemt hij het bestuursrechtelijke oordeel inzake de beschikking over. De strafrechter neemt, als gezegd, niet altijd het bestuurstechtelijke oordeel over. Zo overwoog de Hoge Raad ten aanzien wan een vergunning met een "nietige" voorwaarde

\begin{abstract}
'dat de $\mathrm{Rb}$. het verweer dat die wergunning was verleend onder een voorwaarde die nietig was, voor het overige ter zijde kon stellen, alangezien voorwa arden, in strijd met art. 18 , eerste lid, Keurenwet alan een wergunning verbonden, niet van rechtswege nietig zijn, doch overeenkomstig het bepaalde in het tweede lid van evengenoemd artikel kumen worden wernietigd overemkomstig de regels omtrent de vernietiging van besluiten van de besturen van waterschappen, veenschappen of veenpolders gesteld of te stellen, zodat de $\mathrm{Rb}$. woor wat dit punt betreft kon wolstaan met te overwegen, dat woor rekw. cen aan redelijke eisen woldoende administratieve rechtsgang openstond. ${ }^{*} 1$
\end{abstract}

Het beroep wordt verworpen, zodat de strafrechter duidelijk maakt, dat een vergunning weliswaar gebrekkig kan zijn, maar zulks geen rechtvaardiging vormt voor (strafrechtelijk) verwijtbaar handelen. Een oordeel over al of niet geldigheid van de (grondslag van de) vergunning is voorbehouden aan de (redelijke) administratieve wegen, die daarvoor geeigend zijn; de strafrechter treedt niet in die beoordeling. ${ }^{92}$

In andere gevallen gaat de strafrechter wel over tot zelfstandige toetsing van de (grondslag van de) beschikking. De nietigheid van een vergunning moet i.c. voor verdachte leiden tot strafbaarheid nu de verlening van de vergunning voor de verdachte een zo onmiskenbare

89. J.L.H. Cluysenaer, De toetsing van administratieve beschikkingen door de strafrechter, in: NJB 1970 , p. 1002-1004.

90. Voorzower ik theb kunnen nagaan heeft het arrest van de HR van 5 december 1904 (W.8152; Scheveningse pier) de oudste papieren met batrekking to dit leerstuk. Strekking daarwan was dat handelen zonder de woorwatarden bij een vergunning in acht te nemen strafbaarheid oplevert. De vergunning om concerten en andere vermakelijkheden op het wandethoofd te geven was immers afgegeven onder voorwaarde dat cr gen behendigheidsspelen zoals het jeu de poule Europeeme personelle zouden worden geexploiteerd.

91. HR 23 november 1965, NJ 1966, 331 m.nt. Van Berckel.

92. Dat was eveneens het geval in HR 28 november 1967 , NJ 1968, 143 (Weertse cafehouder) waar de Hoge Rat overwoog, p. 558: "dat de strafrechter niet vermag te treden in een beoordeling of de intrekking van het verlof terecht is geschied, nu de Drankwet met betrekking tot deze intrekking een administratieve procedure kent'. In Rb. Dordrecht 28 januari 1966, NJ 1968, 156 (Heukelemse hinderwetoventreder)' owerwoog de rechtbank, p. 570 : $^{\circ} \mathrm{O}$ dat de $\mathrm{Rb}$., om dit verweer te kunnen beoordelen, de strekking van de onderhavige voorwarde zou moeten toetsen aan de Hinderwet; $O$. dat zodanige toetsing de Rechter echter niet vrijstaat en hij de verbindendheid van de onderhavige voorwaarde zal moeten aanvaarden'. 
wetsschending opleverde dat hij had moeten begrijpen dat de vergunning niet afgegeven had mogen worden, ook al mocht hij in zijn algemeenheid vertrouwen op de rechtsgeldig. heid van de vergunning. ${ }^{93}$ Aldus treedt de strafrechter in een beoordeling van (de nietigheid van) een beschikking. Veroordeling (zonder strafoplegging) blijft in stand. Hier wordt een burger verweten dat hij had kunnen weten dat een vergunning onwettig was; dat oordeel was immers 'voor iedereen duidelijk' aldus de strafrechter. Annotator Van der Burg kritiseert dit terecht en noemt de zaak 'curieus'. Het oordeel van de strafrechter over het ontbreken van rechtskracht aan een beschikking leidt in een andere zaak tot ontslag van rechtsvervolging. ${ }^{95}$ Annotator Van der Burg concludeert dan ook: "Noch de $A-G$, noch de HR zeggen dat de beschikking van de hoofdcommissaris onaantastbaar is geworden, ondat daartegen geen Arob-beroep meer openstaat. De strafkamer van de HR volgt op dit punt een andere aanpak dan de civiele kamer. ${ }^{96}$

lets ingewikkelder ligt het in weer een andere casus; de rechtbank moet een voorvraag beoordelen. Daar oordeelt de rechtbank naar het oordeel van de Hoge Raad terecht dat de ontheffing niet rechtsgeldig is, zodat het bewijs (vanuit strafrechtelijk oogpunt) rond is. De Hoge Raad zegt het zo: 'De Rb. heeft echter kennelijk geoordeeld en (...) ook kunnen oordelen dat de door Wildering verleende ontheffing niet als rechtsgeldig kon worden aangemerkt, aangezien zij op een valse grondslag berustte' en verderop: 'dat de havenmeester de gegeven ontheffing niet heeft ingetrokken (...) bracht immers niet mede dat de ontheffing alsnog rechtsgeldig werd' en zodoende 'heeft de $\mathrm{Rb}$. op grond van de inhoud wan de gebezigde bewijsmiddelen bewezen kunnen achten, dat sprake is geweest van een verboden gedraging'. ${ }^{97}$ De rechtbank treedt hier in een beoordeling van de (valse) grondslag van de beschikking, zodanig dat wordt vastgesteld dat de ontheffing niet rechtsgeldig is en daardoor kan tot strafbaarheid worden geconcludeerd. De administratieve niet-rechtsgeldigheid heeft dusdoende strafrechtelijke rechtsgevolgen. (Overigens dient vermeld dat de onderhavige beschikking op het moment van het plegen van het strafrechtelijk laakbaar handelen (al wordt dat pas achteraf vastgesteld) nog geen formele rechtskracht kan hebben, aangezien de voor een administratieve gang tegen de ontheffing vereiste beroepstermijn niet was verlopen.)

Overigens blijkt uit het voorgaande wel dat onderscheiden moet worden naar voorwerp van toetsing door de strafrechter en wijze van toetsing door de strafiechter en de invloed van beschikkingen daarop.

93. Vgl. HR 13 november 1984, AB 1985, $361 \mathrm{~m}$.nt. FHUdB (Camperen in Domburg).

94. Zo stelt thij: 'Het merkwaardige is nu dat in deze literatuur enerzijds de woorden "voor iedereen duidelijk" worden gebruikt, terwijl anderzijds voorbeelden van "aperte' onbevoegdheid worden gegeven die voor leken niet zondermeer duidelijk zijn. Daar komt in dit geval nog bij dat de gemeenteijke bemoeienis met het kamperen sterk gekenmerkt wordt door gedogen en semilegaliteit.' Zie: Annotator Van der Burg onder HR 13 november 1984, AB 1985,361 (Camperen in Domburg), p. 908

95. Vgl. HR 14 juni $1985, \mathrm{AB} 1986,106$ m.nt. FHvdB.

96. Annotator Van der Burg onder HR 11 juni 1985, AB 1986, 106, p. 302.

97. HR 10 februari 1987, NJ 1987, $662 \mathrm{~mm}$.nt. "थH, p. $2290-2291$. 
Wat betreft het voorwerp van toetsing door de strafrechter is duidelijk dat de strafrechter altijd strafwaardig handelen van burgers beoordeelt, ofwel als zij handelen conform een beschikking (dan staat de vraag naar de vrijwarende werking wan de beschikking centraal), ofwel in strijd met een beschikking, ofwel in strijd met een vergunningsvoorwaarde ofwel zonder beschikking. Wanneer de verdachte in strijd met een beschikking, in strijd met een voorwaarde of zonder beschikking handelt, ligt de vraag voor wat de invloed is van deze beschikking (en de eventuele administratieve rechtsgang daartegen) voor de strafrechter; met andere woorden, waarop toetst de strafrechter dan, waarmee mag hij rekening houden? Toetst hij op strijd met de wet dan zal verdachtes verweer vooral een beroep inhouden op een exceptie van onwettigheid. Toetst hij op strijd met beginselen dan is de vraag welke beginselen voor hem maatgevend zijn (abbb's of strafrechtelijke, doorgaans gecodificeerde, beginselen). Daar doorheen speelt ook de vraag naar de positie van derde-belanghebbenden. Immers, indien een beschikking niet wordt aangevochten (om welke reden dan ook) verkrijgt deze formele rechtskracht; de derde heeft bij de strafrechter geen ingang om de beschikking getoetst te krijgen. De strafrechter houdt geen rekening met de belangen van de derde.

Duidelijkheid over onze vraag naar de betekenis van formele rechtskracht bij de strafrechter is er dus allerminst. ${ }^{98}$ Een definitie van formele rechtskracht door de strafrechter is dan ook nauwelijks te geven. Wel kan geconcludeerd worden dat de strafrechter, nu hij soms wel toetst, in ieder geval niet de betekenis onaantastbaar aan de formele rechtskracht van beschikkingen hecht, zoals de burgerlijke rechter dat wel is gaan doen. Van der Burg, Cartigny stellen dan ook: 'Daarbij moet men zich bewust zijn dat over de rechtskracht van beschikkingen tegenover de strafrechter nog weinig duidelijkheid bestaat. ${ }^{999}$

Onder invloed van het expliciet benoemen van formele rechtskracht door de burgerlijke rechter is het thema weer meer in de strafrechtelijke publieke belangstelling komen te staan. Ook de vraag naar de betekenis van formele rechtskracht bij de strafrechter ontmoette daardoor weer een nieuwe impuls. Nu zijn er voorstanders van gelijkschakeling van de formele rechtskracht in de zin van onaantastbaarheid zoals de burgerlijke rechter die definieerde met de formele rechtskracht die de strafrechter nu kennelijk opeens ook hanteert; kortom, de leer van de formele rechtskracht van de burgerlijke rechter vindt toepassing doo" de strafrechter.

\subsubsection{Toepassing leer van de formele rechtskracht}

Buruma en Daalder zien het vraagstuk heel anders dan Cluysenaer. Kan de leer van de formele rechtskracht, zo vragen Buruma en Daalder zich af, in het strafrecht worden toegepast? 'Het is verleidelijk om van formele rechtskracht in het strafrecht uit te gaan op grond van dezelfde redenering als door de burgerlijke rechter is gevolgd: waarom zou de

98. Vgl. "De jurisprudentie wan de stratrechter is op dit punt niet eenduidig. ' in: L.E.M. Hendriks, Techniek en normstelling in het milliekstrafrecht, diss., Zwolle 1994, p. 68.

99. F.H. van der Burg, G.I.M. Cartigny, G. Overkleef-Verburg, Rechtsbescherming tegen de overheid, Nijmegen 1985 , p. 180. 
strafrechter het gesloten bestuursrechtelijk stelsel kunnen openbreken, terwijl de burgerlijke rechter dat niet mag?' Maar, er kan 'tegen het aannemen van formele rechtskracht worden ingebracht dat de strafrechter - anders dan de civiele rechter - uit de aard wan het strafrecht niet zonder meer gebonden mag zijn aan een besluik van een bestuursorgaan'. En daarom geven zij 'er de voorkeur aan in concreto te bezien welke gevolgen de formele rechtskracht in het strafrecht heeft in verschillende gevallen. ${ }^{100}$ Waarom Buruma en Daalder kiezen voor de casuïstiek laten zijzelf in het midden; in ieder geval willen ze de principiëler discussie over de eigen aard van de verschillende rechtsgebieden uit de weg gaan.

De gevalsbeschrijving door Buruma en Daalder volgt aan de hand van verschillende fasen in het bestuurlijke besluitvormingsproces. Conclusie daarvan is - niet geheel toevallig dat de formele rechtskracht ook voor de strafrechter overeind hoort te blijven:

\begin{abstract}
"Tegen de leer kan principieel in stelling worden gebracht, dat het uit de aard wan het strafrecht niet kan zijn toegestaan dat de strafrechter of het OM altijd is gebonden aam bestuursbeshiten. Dat zullen wij ook geenszins betwisten. Maar wij willen uit dat principide argument niet de conclusie trekken dat de strafrechter bestuursbesluiten alls zodanig op hun waarde moet beoordelen of dat de officier van justitie zich wan bestuursbesluiten niets hoeft aan te trekken. De strafrechter onderscheidt zich wan de bestursrechter ondat hij (in de hoofdzaak) niet treedt in de beoordeling wan besturrsbesluiten, naar het handelen van de burger beoordeelt. Dat stelt bijzondere eisen aan hem, al was het maar dat hij nog scherper dan de andere rechters naast het gemene techt oog moet hebben voor wat vanwege de bijzondere onstandigheden van het geval billijk is. Hij hoeft immers niet - zoals de civiele rechiter - een verdelingsvaagstuk op te lossen, waarbij er schade is die een wan twee partijen zal moeten dragen. Hij hoett ook niet - zoals de besturursrechter - te beoordelen of de overheid ten opxichte wan een van betrokken partijen de ondergrenzen van het recht heeft overschreden. Hij moet éen partij opzettelijk leed toevoegen en zal daarbij meewegen of de overheid ten opzichte van die ene betrokken partij correct heeft gehandeld. Niet voor niets gaat het er nief alleen on te bepalen of het feit gepleegd en strafbar is, maar ook of de dader strafbaar is (art. 350 Sv). Het hoeft daarom niet tegen het rechtsgevoel in te gaan als de straffechter de leer van de formele rechtskracht toepast en hij het een strafbaar feit acht om in strijd met een later vernietigde bestuursbeslissing te handelen. Er zijn immers andere wegen om te bewerkstelligen dat de verdachte van dit strafbare feit niet wordt bezwaard met een strafsanctie." 101
\end{abstract}

En zo wordt billijkheid - niet principieel natuurlijk - een nieuwe strafrechtelijke categorie, terwijl voor het overige - ook voor de strafrechter - de deur voor het overnemen van de burgerlijke formele rechtskracht - wagenwijd - wordt opengezet. ${ }^{102}$ Hendriks kenschetst deze hele gang van zaken als 'opmerkelijk":

100. Y. Buruma en EJ. Daalder, Formele rechtskracht in het strafrecht, in: RM Themis 1994/7, p. 32 1-323.

101. Y. Buruma en E.J. Daalder, Formele rechtskracht in het strafrecht, in: RM Themis 1994/7, p. 333-334.

102. De door Buruma en Daalder genuanceerder weergegeven conclusie wordt enigszins verkort door Rogier, walar hij - onder verwijzing naar Buruma en Daalder - stelt: "Ook de strafrechler kan cen bestuursbesluit dat formele rechtskracht heeft gekregen niet op zijn waarde toetsen." Zie: L.J.J. Rogier, De Algemene wet bestuarsrecht en strafrecht, Deventer 1995, p. 109. Stroink is genuanceerder. Hij stelt dat ook al is de strafrechter gebonden aan het rechmatigheidsoordeel van de administratieve rechier, er woor de strafrechter "nog wel een belangrijke rol kan zijn weggelegd indien thet besturstbesitut interpretatie behoeft." Zie: F.A.M. Stroink, Rechterlijke organisatie en rechtspraak in beweging, Zwolle 1993, p. 153 . 
De heersende opvatting (..) is dat de strafrechter de bevoegdheid toekomt de nechtrnatigheid van beschilkking te toetsen, ook, indien door de verdachte tegen de betreffende beschikking niet is opgekomen in een admimstratieve rechtsgang. (...) De ratio voor dit standpunt kan worden gevonden in de omstandigheid anders - indien de strafrechter de toetsingsbevoegdheid niet zou toekomen - een verdachte zou (kunnem) worden veroordeeld op grond wan een overtreding van een woorschrift dat in strijd is met het objectieve. materide recht. 102

Wanneer de strafrechter uitgaat van de rechtmatigheid van de beschikking, omdat deze formele rechtskracht heeft, heeft dit "tot gevolg dat iemand kan worden veroordeeld op grond van een overtreding van een (vergunning)voorschrift dat in strijd is met het recht, zelfs als het om die reden door de administratieve rechter is vernietigd. Ook dit wind ik op zijn zachtst gezegd opmerkelijk.

\subsubsection{De verhouding bestuursrecht-strafrecht en de Wet Mulder}

Echte veranderingen ontstonden met de invoering van de wet Mulder in 1989. ${ }^{105}$ In deze wet, waarin de strafrechtellike handhaving werd omgebouwd tot een bestuursrechtelijke handhaving, bleef de strafkamer van de Hoge Raad de hoogste bevoegde rechter. ${ }^{106}$ Daardoor is het de vraag of de strafrechter hier zijn strafrechtelijke kleed wel heeft afgelegd. De worsteling met de (verschillen tussen de) werschillende rechtsgebieden en de toepassing van de leer van de formele rechtskracht als 'ei van Columbus' daarvoor, kan worden geïllustreerd aan de hand van uitspraken van Scheltema:

"Evenals in het vorige arrest gaat het om de vraag of de formele rechtsknacht doorbroken moet worden (...). Evenals bij het beroep (...) moet dit probleem in de eerste plaats in het besturursecht worden opgelost. (..) De taak van de burgerlijke rechter geat niet verder dan te controleren (...). De stratkamer van de Hoge Raad koos een vergelijkbare benadering (...). Het ging daar eveneens om de doorbreking van de formele rechtskracht."

En ook:

"De steeds grotere verwevenheid wan het recht komt ondermeer tot nitdrukking in thet feit dat de strafkamer wan de Hoge Rad met meer besturstechtelijke vragen geconfronteerd wordt dan wroeger het geval was. In

103. Annotator Hendriks onder HR 11 januari 1994, M en R 1994, afl.7/8, 10r. 85, p. 237.

104. Arnotator Hendriks onder HR 11 januari 1994, M en R 1994, all, $7 / 8$, nu. 85, p. 239.

105. De Wet administratie frechtelike handhawing verkeerswoorschiften, Stb. 1990, 435.

106. Vgel. ook annotator Scheltema onder IRR 8 jult 1992, NJ 1993, 180, p. 619: "In dit (..) arrest over de WAHV maakl de Hoge Kaad duidelijk dat hij het administratiefrechteljke karakter van de wet serieus wil nemen. Als meri eenmaal kiest voor de administratiefrechtelijke weg "dan moet men ook consequent zijn. (..) De algemene benadering van de Hoge Rand is duidelijk: procedurele leemtes in de WAHV moeter worden opgelost aan de hand van het administratieve prosesrecht. Alle delen wan het recht dreigen hier doorheen te gaan topen: vervanging van strafrechtelijke handhaving door bestuursrechtelijke sancties, bij ofe uitwoering waarvan nog weer civielrechtelijke regels van stal werden gehaald. Dit word inderdaad te verwartend."

107. Annotator Soheltena onder HR 23 oktober 1992, NJ 1993, 640, p. 2600.2601. 
dit nummer (van de NJ, EvdL) is een wiental uitspraken van de strafkamer opgenomen die op het terrein van thet bestursecht liggen, en gedeeltelik ook werband houden met de bestuurstechtelijke jurisprudentie van de burgerlijgke kamer. ${ }^{.108}$

Met de invoering van de Wet Mulder worden strafrechtelijke gedragingen via een bestuursprocesrechtelijke route afgehandeld. In het klassieke strafrecht is het zo dat een strafrechtelijke gedraging door de strafrechter 'ex tunc' (op het moment van de gedraging) wordt getoetst aan normen van datzelfde moment. Formele rechtskracht ligt daar nog voor, omdat de verdachte conform de eerdere vergunning handelt en daardoor een beroep op vrijwaring of exceptie van onwettigheid doet.

Met de Wet Mulder is er eerst een strafrechtelijke gedraging, waama een beschikking volgt, die formele rechtskracht kan krijgen. De rechtspraak hierover vat ik samen onder 'vroege arresten'. Het kan ingewikkelder worden wanneer er voorafgaand aan de Mulderbeschikking en het strafwaardig handelen nog een ander bestuursbesluit is, dat weer een rol speelt voor de formele rechtskracht van de Mulder-beschikking. Hier ga ik op in onder de noemer 'latere arresten'.

In de "vroege" arresten van de Hoge Raad inzake de wet Mulder komt steeds naar voren dat de strafkamer aansluit bij de wijze van toetsing en de procedureregels zoals die in het bestuursrecht al sinds jaar en dag bestaan. Wanneer de overtreder een sanctie opgelegd krijgt en daartegen niet in beroep gaat, wordt de beschikking onherroepelijk. ${ }^{109}$ Een ander voorbeeld: inzake een overschrijding wan de beroepstermijn, waarbij betrokkene aangeeft dat hij de beschikking niet heeft ontwangen, staat de strafkamer voor hef probleem dat hij niet de weg naar de rechter wil afsnijden, terwijl toch geen rechtsmiddel is ingesteld. Dan zal de rechter moeten onderzoeken of betrokkene de beschikking al dan niet heeft ontvangen en indien hij hem niet heeft ontvangen, kan zij ook niet onherroepelijk zijn geworden. In dat geval zal de rechter beslissen dat doorzending van het bezwaarschrift moet plaatsvinden, zodat de officier van justitie alsnog op het bezwaar kan beslissen, ${ }^{110}$ Wanneer betrokkene is verhuisd en dat niet heeft doorgegeven aan de Rijksdienst voor het Wegverkeer mag het niet ontvangen hebben van de beschikking door de onjuiste adressering niet voor zijn risico komen. Als betrokkene stilzit, kan dus niet worden uitgegaan van de onherroepelijkheid van de beschikking; er is immers geen wettelijke meldingsplicht. ${ }^{\text {"I }}$ In de 'vroege' arresten betekent formele rechtskracht zoiets ats onherroepelijkheid, een woor bestuursrechter bekende term. In de 'latere' arresten verandert het beeld, waarschijnlijk onder invloed van de jurisprudentie van de burgerlijke rechter, waarin formele rechtskracht veelvuldig voor het voetlicht komt. De toepassing van de leer van de formele rechtskracht van beschikkingen zoals de burgerlijke rechter ermee omgaat wordt steeds prominenter. Zo ook bv, in een cassatiemiddel, waar wordt ingegaan op de uitleg van vergunningsvoorwaarden. Daarover is een administratieve uitspraak gedaan; er dus een eerder

108. Annotator Scheltema onder HR 21 mman 1995, NJ 1995, 694.

109. Vgl. HR \& juli 1992, NJ 1993, 180 m.nt. MS.

110. Vgl. HR 10 november 1992, MI 1993, 181 m.nt. MS

111. Vgl. HR 15 juli 1993, NJ 1994, 524 m.nt. C. 
bestuursrechtelijk oordeel dat een rol kan spelen bij de zaak van de Mulder-beschikking. Vraag is nu, aldus het cassatiemiddel, of deze administratiefrechterlijke witspraak bindend is voor de strafkamer (let wel, dat is hier een andere bestuursrechter!). Bekende voordelen van dergelijke binding worden in het cassatiemiddel opgesomd: voor de beoordeling van de rechtmatigheid van een beschikking (en dus ook voor de uitleg van vergunningsvoorwaarder) is de administratieve rechter (bedoeld wordt: de primair oordelende administratieve rechter) de "best geplaatste rechter'; daarnaast is van groot belang het systeem van eenheid van de rechtsorde. "II In de conclusie trekt de A-G Van Dorst dan ook expliciet de vergelijking met het arrest van de eerste kamer inzake Heesch-Van de Akker met het stellen van de vraag/verzuchting: "Maar er moet natuurlijk wel iets zijn waaraan de nietadministratieve rechter zich kan conformeren." In casu ging het immers om zaken van feitelijke aard (interpretatie van vergunningsvoorschriften), en 'omdat over uniformiteit van rechterlijke waarderingen van feitelijke aard slechts kan worden gesproken in termen van wenselijkheid zonder dat een rechtsregel valt aan te wijzen welke die uniformiteit gebiedend voorschrijft, faalt het middel.'"13 De strafkamer van de Hoge Raad neemt vervolgens deze conclusie over. Aldus wordt volgens de annotator weliswaar de hoofdregel van de formele rechtskracht onderschreven, al kan die in casu niet worden toegepast:

\begin{abstract}
"Het recht kent cen aantal regels on tegenstrijdigheden in vitspraken van rechters te vemijden. De leer van het gezag van gewijsde dient dit doel, mar kon hier geen toepassing vinden. De regel van de formele rechiskraeht, oniwikkeld door de burgenlijke rechter (...), heet dezelfde achtergrond. Het gevolg is cen sterke binding van de burgerlijke en de strafrechter aan de oordelen wan de bestuursrechter. Maar hier viel met de gedachte van de formele rechtskracht niet te werken. Daarvoor is immers nodig dat aansluitmg gevonden kan worden bij een eerdere uitspraak van de bestuurstechter. Dat is mogelijk wanneer het gaat om de rechtsgeldigheid wan bestuiten." 14
\end{abstract}

Vervolgens wordt de leer van de formele rechtskracht door de strafkamer met zoveel woorden omarmd:

'Ingevolge het bepaalde in art. 26, derde lid, WAHV zal het verzet tegen de tenuitwoerlegging van een dwangbewel niet gericht kumen zijn tegen de beschikking watbij een administratieve sanctie is opgelegd. Aan die bepaling ligt thet beginsel ten grondsag dat tegen de oplegging van de administratieve sanctie cen net warborgen omklede rechtsgang heeft opengestan en dat, ingewal deze rechtsgang niet is gebruikt, de rechler die in de verzetsprocedure heeft te oordelen over de gegrondheid van de tenuitwoerleggiring van een dwangbevel, ervan kan, en moet, uitgaan dat de inleidende beschikking zowel wat halar wijze van tot stand komen als wat haar inhoud betreft in overeenstemming is met de desbetreffende wettelijke voorschriften en adgernene rechtsbeginseten. De aan di beginsél verbonden bezwaren kunnen evenwel door bijkomende omstandigheden zo klemmend worden dat hierop, gezien de bijzonderheden van thet gegeven geval, een uitzondering moet worden aanvaard (...). Van zodanige uitzondering kan met aame sprake zijn wanneer een betrokkene uit verklaringen en gedragingen van de overheid in redelijkheid heef mogen afleiden dat de bij de inleidende beschikking opgelegde sanctie niet zou worden geeffectueerd. Weliswaar heeft de Kanton-

112. Vgl Cassatieniddel bij HR 23 mei 1995, NJ 1995, 695 m.nt. MS, p. 3467-3468.

113. A-G Van Dorst bij HR 23 mei 1995, NJ 1995, 695 m.nt. MS, p. 3469.

114. Annotator Scheltema onder HR 23 mei 1995, N.I 1.995, 695, p. 3471 . 
rechter (...) niet miskend dat een zodanige uitzondering zich kan voordoen waardoor de formele rechtskracht van de inleidende beschikking wordt doorbroken. Maar tègen de achtergrond van het gespecificeerde verweer van de betrokkene (...) is het oordeel van de Kantonrechter ontoereikend gemotiveerd. Immers, woor het aamemen van een uitzondering op de formele rechtskracht in een geval als het onderhavige is reeds woldoende dat de betrokkene uit gedragingen en verklaringen war de overheid (de polthe) heeft begrepen en in redelijkheid het ervoor mocht houden dat de beschikking, houdende de sanctie, op een vergissing berustte en zou worden ingetrokken."115

\title{
Volgt vernietiging van de beschikking. Scheltema stemt daar van harte mee in:
}

\begin{abstract}
"Deze uitspraak van de strafkamer geeft adn dat de Hoge Raad street naar cen zo zorgwuldig mogelijke afstemming van de jurisprudentie op de verschillende rechtsgebieden. Hier geeft de strafkamer de leer van de formele rechtskracht wan beslluiten van bestuursorganen op dezelfide wijze vorm als de burgerlijke kamer dat doet (..) In ant. 26, derde lid, WAHW is bepaald dat het werzet niet gericht kan zijn tegen de beslissing waarbij de administratieve sanctie werd opgelegd. Dit is in overeenstemming met de leer wan de formele rechtskracht, die impliceen dat de burger bij het openstaan van een behoorlijke bestuarsrechteligke rechtsweg daarin zijn bezwaren naar voren moet brengen. Doet hij dat niet, dan kan hij in een andere rechtsgang. niet meer het standpunt innemen dat het besluit van het bestuur onjuist was. Interessant is overigens dat de leer wan de formele rechtskracht is ontwikkeld woor een goede takverdeling tussen wee rechters: bestuursrechter en burgerlijke rechter. In de WAHV-zaken verwullen kantonrechter en strafkamer Hoge Raad beide functies (...). Het ligt echter in de lijn wan deze uitspraak te veronderstellen dat ook in andere gevalien de strafrechter de leer van de formele rechtskracht zal volgen. Men denke aan de vervolging van ienand die luandelt in strijd met voorschriften van een vergunning. Verweert de verdachte zich met de stelling dat het voorschrift in strijd met de wet is opgenomen, en dus nietig is, dan zal dat verweer afstuiten op de formele rechsskracht wan de vergunning. Hiermee zou een vraagstuk, dat in het verleden tot de nodige onzekerheid aanleiding heeft gegeven, opgelost zijn." 116
\end{abstract}

De stelling van Scheltema dat de strafrechter 'ook' in andere gevallen de leer van de formele rechtskracht zal gaan toepassen, is merkwaardig, omdat het in casu weliswaar de strafkamer doch als bestuursrechter betrof.

De remmen gaan pas echt los als de HR overweegt dat het verzet tegen een dwangbevel niet gericht kan zijn

"aegen de inleidende beschikking ondat daartegen een met woldoende waaborgen omklecle rechisgang heeft opengestaan en, als die niet is benut, de rechter in de verzetsprocedure ervan kan en moet uitgaan dat de inl. besch. zowell vwb de totstandkoming als de inh. efm de wettelijke bep ${ }^{4} n$ en algennene rechubbeginselen is. De aan dit beginsel verbonden bezwaren kunnen door bijkomende omstand'n zo klemmend worden dat hilerop, gezien de bijzonderheden wan het gewal, een uitz. moet worden gemaalki (HR NJ 86.723). Daarvan kan sprake zijn als de betrokkene uit verkl'n en gedragingen van de overheid in redelijkheid heeft moegen afteiden dat ten onrechte een sanctie is opgelegd, zodat hij ervan mocht witgaan dat de sanctio niet zou worden geeffectueerd. 117

I15. HR 6 juni 1995, NJ 1995, 696 m.nt. MS, p. 3473.

116. Annotator Scheltema onder MR 6 juni 1995 , NJ 1995,696, p. 3473-3474.

117. HR 20 juni 1995, DD 1995, 397. Zo ook HR 13 februari 1996, DD 1996, 206. 
Vervolgens wordt wegens strijd met de (ongeschreven) algemene beginselen van behoorlijk bestuur een inbreuk op de formele rechtskracht van beschikkingen toegestaan. Scheltema:

"De Mulderwoete word" doos de officier van justitie opgelegd. Dit besluit had hier fomele rechtskracht gekregen doordat daartegen geen beroep op de rechter was ingesteld. Indien een besluit formele rechuskracht heeft, kan de onjuistheid ervan mist meer bij een rechter wonden staande gehouden dan had men maar warn de special daarvoor bestemde rechtgang gebruk moeten maken. Daaron zal de burgerlijke rechter een dergeljik besluit in en ciwele procedure niet als een onrechtratige daad kunnen beschouwen. Om dezelfde reden zal die rechter (...) wan de rechisgeldigheid van die beschikking uitgaan. (...) Het arrest volgt hiermee ook consequent het system van aanvultende rechtsbescherming, dat de gewone rechter biedt bij het ontw breken van woldoende techtsbescherming in het bestursrecht. ${ }^{11:}$

\subsubsection{Nagmaals toepassing leer van de formele rechtskracht}

De heersende opvatting is toch dat de strafrechter zijn zelfstandige bevoegdheid om te toetsen in beginsel moet uitoefenen, omdat sanctietoepassing zonder geldige of verbindende rechtsgrond niet het uitgangspunt van het strafrecht kan zijn. ${ }^{119}$

Wel is er communis opinio over het bewaken van rechtseenheid waar de strafrechter de bestuursrechter zou kunnen volgen. Hendriks stelt:

'Wel gaan de meeste auturs er wan uit dat de strafrechter zich heeft te conformeren aan het oorded van zijn bestuursrechtelijke collega; heeft deze zich reeds over de rechtmatigheid van een beschikking uitgelaten (...) dan gaat het niet aan da de strafrechter daar ook nog eens zijn eigen oordeel over velt. De administratieve rechier is immers bij utstek geschikt om over de rechtmatigheid wan beschikkingen te oordelen."

En:

'De rechtszekerheid is er nier mee gediend, wanneer meerdere rechters zich verschillend (kunnen) uitlaten." 21

De Hoge Raad stelt dat

"het Hof hesf vooropgesteld dat in beginsel van de rechtmatigheid van de vergunning dient te worden wittgegaan, nu deze kemelijk niet is bestreden in de datartow openstaande rechtsgang. (...) Dit oordeel geeft niet blijk van een onjuiste rechtsopvatting. ${ }^{\$ 22}$

118. Annotator Scheltema onder HR 17 juli 1995, NJ 1995, 697.

119. In dezelfde zin LEM. Hendriks, Techniek en normstelling in het milieustrafrecht, diss., Zwolle 1994 , p. 70 .

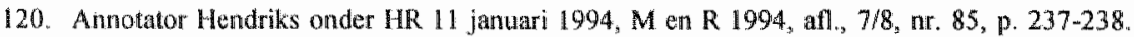

121. L.E.M. Hendriks, Techniek en normstelling in het milieustrafrecht, diss., Zwolle 1994, p. 70

122. HR 11 januari 1994, M en R 1994, af. $7 / 8$, nr. 85 m.nt. Hendriks, p. 236. 


\begin{abstract}
'Omdat een zekere antonomic van de strafrechter te prefereren valt - reeds ondat het niet steeds uitgesloten kan worden dat de administratieve rechter andere belangen afweegt dan die welke in het strafrecht een rol spelen - zou de fornele rechtskracht in stratzaken, dunkt mij, net onvorwardelijk behoren te gelden. Anderzijds moet worden voorkomen dat (rechts)punten die aan de hand van dezelfde matstaven worden gefoetst, tot uiteenlopende oordelen leiden. De rechtseenheid zou daardoor in het gedrang kunnen ko. men.
\end{abstract}

Hier komt naar mijn idee toch de principiele kant van toepassing van (burgerrechtelijke) formele rechtskracht door de strafrechter om de hoek, all wilden Buruma en Daalder deze discussie vermijden. In feite gaat het om rechtseenheid. Het is naar mijn mening echter de vraag of met die rechtseenheid de nadruk moet worden gelet op rechtseenheid zoals Scheltema de Hoge Raad toedicht of op rechtseenheid, waarbij verscheidenheid van gelijkwaardige doch anders-geaarde rechtsgebieden naast elkaar wordt geplaatst.

\title{
4.5 Tenslotte
}

In het publiekrecht staan twee benaderingen van de formele rechtskracht naast elkaar; enerzijds de benadering die de bevoegdheidsuitoefening beschouwt als objectieve handeling (de publiekrechtelijke rechtsvaststelling door een bestuursorgaan, gericht op het creëren van normconforme rechtsgevolgen) en anderzijds de benadering die de bevoegdheidsuitoefening beschouwt als subjectieve handeling (de door het besluit gecreèerde rechtsgevolgen die een burger feitelijk in zijn individuele belang kunnen raken).

De eerste benadering betekent dat primair wordt uitgegaan van de bevoegdheidsuitoefening door de competente rechtswormende instantie, het bestuursorgaan. Daarbij betekent formele rechtskracht dan die eigenschap van besluiten, die maakt dat het besluit geldig kan worden geacht en waardoor direct-belanghebbenden en derde-belanghebbenden worden gebonden aan de inhoud van het besluit; de formele rechtskracht impliceert een erga omnes-werking. Die bindling aan het besluit geldt eveneens voor het bestuur met dien verstande dat de inhoud van de rechtshandeling (de rechtsgevolgen - de materiële rechtskracht) flexibeler in het rechtsleven staat; het bestuursorgaan zal de bestaande rechtssituatie met het oog op het algemeen belang altijd kunnen aanpassen. Het oorspronkelijke besluit met formele rechtskracht doet daaraan niet af. De rechter heeft ook in deze benadering een rol waar hij het objectieve recht handhaaft; hij kan de formele rechtskracht van een besluit als uitgangspunt nemen of ingeval van afwezigheid ervan dat vaststellen.

Daarnaast staat de benadering waarin de betekenis van formele rechtskracht wordt bepaald wanuit het procesdenken; dan betekent formele rechtskracht primair individueel bepaalde onaantastbaarheid, een op een bepaald moment vaststaande eigenschap van besluiten, waarop de rechtsbescherming is gebaseerd. Deze onaantastbaarheid heeft dan inter parteswerking. Het is deze definitie van formele rechtskracht die de burgerlijke rechter als

123. A-G wan Dorst bij HR 27 juni 1995, NJ 1995, 722, p. 3657. 
inspiratiebron kan hebben gediend voor zijn definitie in het afbakeningsvraagstuk van rechtsmachten. De burgerlijke rechter heeft daarbij aansluiting gezocht bij het ingaan van formele rechtskracht nádat de beroepstermijn verlopen is, want ook dan geldt: indien er formele rechtskracht is, leidt dit tot niet-ontwankelijkheid.

Conclusie van dit alles is dat we moeten constateren dat de formele rechtskracht in het publiekrecht een uiterst relatieve betekenis heef. Een uiterst relatieve betekenis is niet hetzelfde als geen betekenis. Het betekent niet dat de formele rechtskracht er niet is, of dat die er niet zou moeten zijn. Het betekent wel dat bestuursorganen en bestuursrechters op verschillende wijze met formele rechtskracht omgaan. Voor bestuursorganen staat daarbij flexibiliteit voorop; zij focussen op de rechtsgevolgen, de materiële rechtskracht, waardoor zij de relativiteit van de betekenis van formele rechtskracht van het besluit - althans voor zichzelf - onderstrepen. Voor de binding van de burgers is formele rechtskracht effectief. Deze nuancering tussen strakke binding van de burger en relatieve binding voor zichzelf biedt bestuursorganen juist de hele attractie van rechtskracht. Tegelijkertijd is rechtsbescherming tegen eenmaal genomen besluiten een betrekkelijke waarborg tegen bestuursmacht. Ook bestuursorganen willen echter zeker zijn dat een eenmaal genomen besluit vaststaat. Dat verklaart eveneens waarom bestuursorganen in procedures wel eens het rechtskarakter van bepaalde handelingen als besluiten (met formele rechtskracht) willen duiden. Daarmee betreden we het terrein van. de uitzonderingen op de hoofdregel van formele rechtskracht zoals door de burgerlijke rechter werd mogelijk gemaakt.

De door de strafrechter gehanteerde definitie van formele rechtskracht is allerminst duidelijk, al is er een beweging die ijwert voor gelijkstelling van de formele rechtskracht (zoals de burgerlijke rechter die hanteert) met die van de strafkamer (in Mulder-zaken) en eveneens in strafzaken. 


\section{De bevoegdheid van de burgerlijke rechter en de invloed van het administratieve recht: de verdere ontwikkeling van het instrument van de formele rechtskracht}

\subsection{Inleiding}

In een woortdurend spel van aantrekken en afstoten van rechtsmacht over terreinen die liggen op het grensgebied van publiek- en privaatrecht, blijf de bevoegdheid van de burgerlijke rechter als achterwacht actueel. Het beginsel van de formele rechtskracht bracht daarin geen verandering. Wel ging de burgerlijke rechter ertoe over om niet meer zelfstandig te toetsen als er een (met voldoende waarborgen omklede) administratieve rechtsgang gevolgd had kunnen worden. Dat niet meer toetsen kwam enerzijds tot uitdrukking in het overnemen van het oordeel van een bestuursrechter en anderzijds (als $z 0^{\prime} \mathrm{n}$ oordeel niet voorhanden was) in het overnemen van het oordeel van het bestuursorgaan. De betekenis wan formele rechtskracht is in deze optiek hetzelfde als of synoniem net onaantastbaarheid; deze onaantastbaarheid houdt tevens een rechtmatigheidsoordeel in.

De belangrijke vragen die hierdoor ontstaan, dat wil zeggen die ontstaan als de burgerlijke rechter formele rechtskracht aanneemt en overgaat tot hel overnemen van het bestuurstechtelijke oordeel, zijn of hij dat bestuursrechtelijke oordeel compleet overneemt (1) en of hij daamee ook wel hetzelfde overneemt (2)?

De eerste vraag leidt naar de omvang van formele rechtskracht en in het bijzonder naar de uitzonderingen op formele rechtskracht. De uitzonderingsmogelijkheid op de hoofdregel van formele rechtskracht fungeert als een hardheidsclausule. Dat past geheel in de alomvattende traditie van bevoegdheid van de burgerlijke rechter. Na Heesch-Van de Akker zien we dam ook een lijn in de jurisprudentie met verschillende pogingen om eern uitzondering aangenomen te krijgen. Vragen die daarbij gesteld kunnen worden zijn: lheeft de Hoge Raad deze uitzonderingen limitatief gesteld of is de opsomming eerder enumeratief te noemen; dat wil zeggen van enuntiatieve aard (zijn er steeds nieuwe uitzonderingen mogelijk)? In de eerste paragraf wordt dit uitgezocht.

Nadat de uitzonderingsmogelijkheid enigszins in beeld gekomen is, kijken we naar de hoofdregel; dan komt de tweede hierboven gestelde vraag in beeld. Als de burgerlijke rechter het bestuursrechtelijke rechtmatigheidsoordeel bindend overneemt, in hoeverre doet hij dat en neemt hij dan wel hetzelfde over? Het bestuursrechtelijke oordeel houdt in ieder geval in een oordeel over een rechtssituatie ex tunc (feit), dat objectief van aard is (norm) en dat erga omnes-werking heeft (gevolg). Neemt de burgerlije rechter deze "publiekrechtelijke benadering" over? In de tweede paragraaf gaan we hier naar op zoek; het: vermoeden is dat de burgerlijke rechter soms wel en soms ook niet uitgaat van deze "publiek- 
rechtelijke benadering'. De burgerlijke rechter in zijn gewone (burgerrechtelijke) benadering toetst immers een feitelijk handelen ex nunc aan normen als redelijkheid en billijkheid en dat oordeel krijgt een inter partes-werking (gevolg).

\title{
5.2 Uitzonderingen op de hoofdregel van formele rechtskracht
}

Uitzonderingen op de hoofdregel van formele rechtskracht zijn mogelijk; in zo'n geval zal de burgerlijke rechter - desondanks - toch ontvangen en toetsen. Het antwoord op de vraag wanneer een uitzondering aangenomen kan worden, is gegeven in Heesch-Van de Akker:

\begin{abstract}
"Woorop moet worden gesteld dat wamneer tegen een beschikking een (...) administratiefrechtelijke rechtsgang heeft opengestaan, $(\ldots)$, de burgerlijke rechter, $(\ldots)$, erwan dient uit te gan dat die beschikking zowel wat haar wijze van tot stand komen als wat haar inhoud betreft in overeenstemming is met de desbetreffende wettelijke voorschriften en algemene rechtsbeginselen. Dit geldt in beginsel bok dan, indien dit de burgerlijke rechter ertoe zow nopen aan zijn nitspraak de rechtsgeldigheid ten grondslag te leggen van een beschikking waarwan als vaststaand mag worden aangenomen dat zij, àls daartegen thijg administratiefrechtelijk beroep zou zijn gesteld, zou zijn vernietigd. De daaraan verbonden bezwaren kumen evenwel door bijkomende omstandigheden zo klemmend worden dat op dat beginsel cen uitzondering moet wotden aanvaard. Of voor zulk een uitzondering plaats is, hangt bijgevolg af van de bijzonderheden van het gegeven geval."
\end{abstract}

Toch roept deze overweging van de Hoge Raad vragen op. Waarnaar verwijst het woord 'daaraan'? Wanneer zijn bezwaren 'klemmend'; welke omstandigheden zijn 'bijkomend'? Welke - op het geval betrokken - 'bijzonderheden' staan de Hoge Raad voor de ogen? Laten we deze vragen iets nauwkeuriger bekijken.

Waarop slaat het woord 'daaraan'? Verwijst dat naar de zin ervoor? Dat zou betekenen dat er slechts sprake zou kunnen zijn van het aannemen van uitzonderingen op de hoofdregel, indien vast zou staan dat geen administratieve rechtsgang is gevolgd en tegelijkertijd dat als die rechtsgang wel gevolgd zou zijn de beschikking zou zijn vernietigd. Of zou 'daaraan' slaan op de hoofdregel van formele rechtskracht van beschikkingen (vergelijk in dat verband ook het verderop gestelde 'dat beginsel')? In deze variant zou er in veel meer gevallen bezwaren kunnen zijn ontstaan die zo klemmend worden, dat het aannemen van een uitzondering tot de mogelijkheden behoort. Een presentatie van de jurisprudentie lijkt hier aangewezen.

Ook voor een antwoord op de vraag wat moet worden verstaan onder "klemmend" lijkt inventarisatie van 'klemmende bezwaren' in de jurisprudentie de aangewezen weg. Dat kan eveneens licht werpen op de vraag welke omstandigheden "bijkomend" zouden zijn. De 'bijkomende omstandigheden' zijn immers voorwaarde voor het aannemen van 'klemmende bezwaren'. In ieder geval lijken de 'bijzonderheden' en de 'bijkomende omstandighe-

1. HR 16 mei 1986, AB 1986,573 m.nt. FHvdB (Heesch-Van de Akker), r.o.3.3.2, p. 16611 1.k. 
den' te kunnen sporen. Door te spreken van 'bijzonderheden van het geval' geeft de Hoge Raad inmers aan dat hij de vraag of er sprake is van een uitzondering op de formele rechtskracht casuistisch benadert. Dat betekent dat al geconcludeerd kan worden dat de uitzonderingen niet limitatief worden benaderd.

In Heesch-Van de Akker werd een uitzondering op de formele rechtskracht aangenomen. Deze uitzondering stoelde op een aantal 'omstandigheden'; welke? Voorop werd gesteld door de Hoge Raad dat de bedoeling van de wet Arob was om de rechtsbescherming uit te breiden. Daarmee in verband werd als eerste omstandigheid vastgesteld dat het geenszins voor de hand lag in dit geval dat beroep op de ARRS mogelijk te achten. Ten tweede viel het Van de Akker (in verband met het eerste punt) niet aan te rekenen dat hij het volgen van die beroepsgang achterwege had gelaten. Daar kwam bij - het derde punt - dat de gemeente enerzijds al het mogelijke had gedaan om haar handelen een civielrechtelijk karakter te geven, terwijl anderzijds (later) dat (uitdrukkelijk door de gemeente als overeenkomst aangemerkt) handelen door dezelfde gemeente als een inmiddels formeel rechtskrachtige beschikking werd bestempeld. Voor hen die, misleid voor het burgerrechtelijk uiterlijk van de beschikking niet de administratiefrechtelijke procedure hadden doorlopen, zou daarom de beoogde uitbreiding van de rechtsbescherming neerkomen op een vermindering van rechtsbescherming. Het laatste en vierde punt was dat gevaar voor overlap in rechtsmacht met de administratieve rechter in casu niet bestond nu partijen zich conformeerden aan het rechtsoordeel van de ARRS. Slotsom is dat de Hoge Raad de beschikking zelf beoordeelde als zijnde niet een rechtsgeldige titel van betaling.

In $H$ ot $A I R^{2}$ wordt een andere poging gedaan om een uitzondering aangenomen te krijgen op de hoofdregel van het beginsel van formele rechtskracht van beschikkingen. Welke omstandigheden of bijzonderheden had Hot AIR aangevoerd?

Allereerst stelt Hot AIR dat een administratieve rechtsgang haar zin en belang verliest wanneer belanghebbende op een andere wijze van de betrokken overheid het door hem beoogde resultaat weet te verkrijgen. Daarbij is irrelevant of die overheid vrijwillig (door intrekking van de beschikking) dan wel onvrijwillig (door veroordeling in kort geding) tot dat resultaat komt. Dan mag het niet verder volgen van een administratieve weg (Hot AIR trok het bezwaarschrift in), die haar zin en belang heeft verloren, niet tot de conclusie leiden dat uitgegaan moet worden van de rechtmatigheid van de destijds bestreden beschikking.

De stelling van Hot komt er eigenlijk op neer dat zij aangeeft dat wanneer zij in situatie A berust dat niet wil zeggen dat zij dat ook doet in situatie B (en dat de formele rechtskracht weliswaar in situatie A geen rol speelde, maar daarom in situatie B nog niet aan Hot kan worden tegengeworpen); kortom, de stelling wan Hot is dat procesbelang en materieel belang niet hetzelfde zijn. 
De poging van Hot om een uitzondering aangenomen te krijgen, strandt in de overweging van de Hoge Raad dat er geen reden is die ruimte te geven. De Hoge Raad gaat niet mee in de redenering van Hot; wanneer een bezwaarschrift wordt ingetrokken doe je afstand van een rechtsoordeel. In zo'n geval gaat de burgerlijke rechter uit van de formele rechtskracht van de niet meer bestreden beschikking en deze wordt geacht in overeenstemming te zijn met de wettelijke voorschriften en algemene rechtsbeginselen. De A-G stelt dan ook: 'De zaak lijkt mij dat HOT in 1983 een 'deal' met de RLD is aangegaan en daar later spijt van heeft gekregen. ${ }^{3}$ De Hoge Raad twijfelt of de gestelde omstandigheden eigenlijk wel cen feitelijke grondslag hebben en concludeert dat zich hier niet het geval voordoet 'dat de burger en het overheidslichaam het erover eens zijn dat de door het lichaam gegeven beschikking onrechtmatig is. Kennelijk zou een dergelijke situatie eveneens tot het aannemen van een uitzondering kunnen leiden. ${ }^{5}$

In Ekro-Staat ${ }^{6}$ werd een uitzondering aangenomen. Ook hier misleidde de Staat de burger, doordat wederom de grote wisseltruc van rechtshandeling naar burgerlijk recht tot beschikking werd toegepast. Als bijzondere omstandigheid werd dan ook gezien dat de Staat door jarenlang handelen in een groot aantal procedures het vertrouwen gewekt heeft dat nimmer een beschikking voorlag. Daar kwam bij dat Ekro nu voor het eerst met dat beschikkingskarakter werd geconfronteerd en dus de Staat van dat jarenlange beleid is afgeweken. Ten dercle kwam vast te staan dat er een ondoorzichtige situatie bestaat terzake van de mogelijkheden van bezwaar en beroep in keurloonzaken.

In zijn annotatie stelt Damen dat met het aannemen van deze uitzondering de stemmen verstommen die de mogelijkheid van een uitzondering in Heesch-Van de Akker hadden bestempeld als een ontsnappingsclausule "pour besoin de la cause'. Aldus valt Ekro-Staat te zien als een bevestiging van Heesch-Van de Akker.

In Lanser-Haarlemmermeer is er geen sprake van omstandigheden die een uitzondering rechtvaardigen. Het betrof een zaak over schadevergoeding op grond wan onrechtmatig uitgeoefende bestuursdwang (onmogelijk maken van detailhandel). De gemeente had - na een vernietiging van de beslissing op een bezwaarschrift door de administratieve rechter - alsnog een beslissing op het bezwaarschrift inzake de bestuursdwang moeten nemen, maar dai niet gedaan. De termijn voor het nemen van zo'n beslissing verliep. Deze zgn. fictieve weigering zou formele rechtskracht hebben gekregen, doordat daartegen geen rechtsmiddel was aangewend. Weer later deelde de gemeente Lanser mee dat de voortzetting van de

3. A-G Mok onder HR 26 februari 1988, AB 1989, 80, nu.nt. F.A. van Bakelen (Hot AlR-Staal), p. 239.

4. HR 26 februari 1988, AB 1989, 80, m.nt. F.A. wan Bakelen (Hot AIR-Staat), p. 242. Merk op dat de HR hier spreekt van een beschikkingnemend overheidshichaam.

5. Dit pordeel van de HR wordt in dezelfde zin opgevat door annotator Scheltema onder dit arrest in NJ 1989, 528 , p. $19421 \mathrm{k}$.

6. Vgl. HR 11 nowember 1988, AB 1989, $81 \mathrm{~m} . n$. FHydB (Ekro BV Vee- en Vleeshandel-Staat)

7. Vgl. L.J.A. Damen in Gem.st. 6875, no. $2, \mathrm{p} .155, \mathrm{m.k}$.

8. Vgl. HR 13 november 1992, NJ 1993,639 n.m. MS (Lanser BV-Haarlemmermeer). 
detailhandel gedoogd werd. In de onderhavige procedure wil de gemeente deze gedoogbeschikking doen lijken als de beslissing op het bezwaar. Zo krijgt belanghebbende - wanuit materieel-bestuursrechtelijk oogpunt - wat hij wilde. Hij gaat tegen deze brief niet in bezwaar, zodat ook hiervan vaststaat dat - als deze brief als beschikking zou zijn aangemerkt - deze formele rechtskracht had gekregen. Voor schadevergoeding probeerde Lanser het bij de burgerlijke rechter. Die oordeelde de gedoogbeschikking niet een beslissing op het bezwaarschrift dat thans formele rechtskracht heeft gekregen en zag dus geen aanleiding tot het aannemen van een uitzondering op de formele rechtskracht. De fictieve weigering als beslissing op bezwaar had wel formele rechtskracht.

De Hoge Raad acht dit geen onbegrijpelijke rechtsopvatting. Daardoor staat de rechtmatigheid van de negatieve beslissing voor de burgerlijke rechter vast. Had de burgerlijke rechter ten aanzien wan de fictieve weigering wel een uitzondering op de formele rechtskracht aangenomen, dan zou daarmee de onrechtmatigheid van de bestuursdwang hebben vastgestaan en was de gemeente aansprakelijk geweest. A-G Koopmans concludeert: 'Voor een zelfstandig oordeel wan de burgerlijke rechter is slechts plaats in individuele gevallen, waarin de belanghebbende door toedoen van het overheidsorgaan een onrecht is aangedaan dat onevenredig groot is in verhouding tot het belang om, terwille van de cohesie van de rechtsorde, de bestaande competentieverdelingen te eerbiedigen. ${ }^{\text {.9 }}$ Kortom, jammer maar helaas voor Lanser.

De burgerlijke rechter gaat standaard uit van de rechtmatigheid van een bestuursbesluit als dat besluit formele rechtskracht heeft. Dat doet de burgerlijke rechter vanuit rechtsbeschermingsmotieven. Op het eerste gezicht lijkt dat heel nobel. De casus van Lanser BV-Haarlemmermeer illustreert echter dat het genuanceerder zou zijn als onderscheid gemaakt zou worden tussen begunstigende en belastende beschikkingen. Een standaard-toekenning van het predikaat rechtmatig kan immers zeer verschillend uitpakken voor de belanghebbende.

De Hoge Raad wijst terug in Aruba-Playa Liquor $N V^{10}$ met de overweging dat het Gemeenschappelijk Hof van Justitie van de Nederlandse Antillen en Aruba zich moet verdiepen in Playa's betoog dat als gevolg van aan Aruba toe te rekenen omstandigheden Playa geen beroep heeft ingesteld. Wanneer belanghebbende niet kan worden aangerekend dat hij niet in beroep is gegaan, is dat reden om een uitzondering aan te nemen. Terecht is, zo luidt de redenering van de Hoge Raad, een beroep op het aannemen van een uitzondering gedaan, maar de gestelde omstandigheden zijn naar het oordeel van de Hoge Raad voor die aanname onvoldoende.

De gestelde omstandigheden zijn drieërlei. Ten eerste mag als vaststaand aangenomen worden dat tot terugbetaling van de betaalde accijnzen zou worden overgegaan; ten tweede hoeven de voor consumptieartikelen (i.c. bier) verschuldigde accijnzen niet betald te

9. AO Koopmans bjj HR 13 november 1992, NJ 1993, 639 mnt MS (Lanser BV-Haarlemmmemeer), p. $2589,1 \mathrm{k}$.

10. Vgl. HR 14 mei 1993, AB 1993,503 m.nt FHvdB onder 504 (Het Land Aruba-Playa Liquor \& Botling Company NV). 
worden indien de artikelen blijken niet voor consumptie geschikt te zijn. Dat is niet door Aruba weersproken. En ten derde staat daardoor vast dat er geen sprake is van een beleidswijziging. Aangezien het om een aanzienlijk belang gaat, gaat het Gemeenschappelijk Hof van Justitie van de Nederlandse Antillen en Aruba over tot het aamnemen van een uitzondering. In zijn aanvullende conclusie verstaat $A-G$ Mok het verzoek van de Hoge Raad tot deze aanvullende conclusie aldus dat de Hoge Raad 'rekening houdt met de mogelijkheid dat het beginsel van de formele rechtskracht hier wel doorbroken zou kunnen worden'." Na terugwijzing oordeelt het Gemeenschappelijk Hof van Justitie van de Nederlandse Antillen en Aruba dat een klemmende reden aanwezig is om 'af te wijken van het beginsel dat een door de overheid genomen beschikking waartegen een met voldoende waarborgen ornklede administratiefrechtelijke rechtsgang open heeft gestaan formele rechtskracht heeft. Niet kan worden aanvaard dat de overheid, die hier een ondoorzichtige en onduidelijke situatie heeft geschapen (...) thans met succes het verweer zou kunnen voeren dat Playa niet ontvankelijk zou moeten worden verklaard nu zij geen beroep heeft ingesteld tegen de beschikking"12

Tot nog toe heeft de Hoge Raad slechts uitzonderingen aangenomen wanneer er sprake was van misleiding door de overheid. Pas in 1993, zeven jaar na Heesch-Van de Akker komt daar een tweede categorie uitzondering bij. In Hot Air kondigde hij al aan dat overeenstemming tussen partijen een uitzondering kon opleveren, ${ }^{13}$ maar pas in St. Oedenrode-wan Aerle $e^{14}$ was het zover. Partijen waren thet erover eens dat de beschikking onrechtmatig was. Voor die eenstemmigheid is voldoende dat de burger zich op het standpunt stelt dat er sprake is van onrechtmatigheild en hij uit verklaringen en gedragingen van overheidszijde begrijpt en redelijkerwijze mag begrijpen dat de overheid de onrechtmatigheid erkent. Daardoor bestaat er geen geschil dat voor beslissing door een administratieve rechter in aanmerking komt. Omdat hier, in tegenstelling tot in de zaak Hot AIR, partijen het wel met elkaar eens waren, wordt het intrekken van het beroep in de administratieve procedure Van Aerle niet verweten.

Het aannemen van deze uitzondering kan als een ommekeer worden gekenschetst, omdat de Hoge Raad de positie van derden hier volledig uit het oog verliest. De rechtsgeldigheid van elke wergunning is beroepbaar gemaakt (als partijen het er maar over eens zijn). Deze

11. AwG Mok bij HR 14 mei 1993, AB 1993, 503 (Arubamplaya Liquor) p. 1444, 1.

12. Het Gemeenschappelijk Hof van Justitie van de Nederlandse Antilten en Aruba 21 september 1993, Burgerlijke Zaken 1993, no. 280.

13. Het hof Den Hang ging ertoe over om deze uitzondering aan te nemen in het geschil tussen EKOM BV en Rotterdam (Hof" "s-Gravenhage 23 februari 1989, NJ 1990, 595); partijen waren het erover eens dat de onderhawige belastingaanslag als in strijd met het recht diende te worden aangemerkt. Pikant is dat het hof stelt dat geen (derde)belangen die met recht een beroep zouden kunnen doen op de rechtszekerheid worden geschaad door het aannemen van deze uitzondering.

14. Vgl. HR 18 juni 1993, AB 1993, 504 m.nt. FHwdB (St. Oedenrode-Van Aerle) 
uitzondering is wel vergeleken met de 'grote leugen' zoals die in het oude echtscheidingsw recht lange tijd heeft bestaan. ${ }^{\text {s }}$

Geen uitzondering werd aangenomen in Kruit en Warrink-Zuidwolde. ${ }^{16}$ Waarschijnlijk is dat de Hoge Raadl met deze casus het stelsel wan uitzonderingen niet nog verder heeft willen oprekken. Hoe ziet de casus eruit? Kruit en Warrink kopen een stuk grond van de gemeente Zuidwolde. Ze spreken af dat de omzetbelasting die de gemeente wel zou moeten betalen wordt doorberekend aan de kopers. Later bedenken Kruat en Warrink dat de gemeente helemaal geen omzetbelasting had hoeven betalen. Dan is het echter al te laat. De gemeente heeft de belasting namelijk al op eigen aangifte betaald en heeft daartegen (uiteraard) geen rechtsmiddel ingesteld. Daardoor heeft de eigen aangifte formele rechtskracht gekregen en staat de verschuldigdheid van de betaling vast. In tegenstelling tot $A-G$ Mok, die van oordeel was dat deze casus aanleiding gaf tot het aannemen van een uitzondering op de formele rechtskracht, laat de Hoge Raad het aannemen van een uitzondering op formele rechtskracht in het midden (zodat de hoofdregel van formele rechtskracht blijft staan). Er was immers een met voldoende waarborgen omklede rechtsgang, zo redeneert de Hoge Raad. Addertje onder het gras is natuurlijk dat de met voldoende waarborgen omklede rechtsgang weliswaar voor de gemeente had opengestaan, maar niet voor Kruit en Warrink. Vanuit rechtvaardigheidsoogpunt lijkt het vasthouden aan de hoofdregel bij afwezigheid van het kunnen volgen van een rechtsgang wat erg zuur. Vandaar dat de A-G in zijn pleidooi voor het aannemen van een uitzondering het heeft over: "het voordeel dat onrecht wordt voorkomen'." Het feit dat geen bijkomende omstandigheden zijn gesteld acht de A-G niet van belang nu de discussies tussen partijen Kruit c.s. hiertoe geen aanleiding hadden gegeven en het beginsel wan de formele rechtskracht pas in cassatie ten tonele werd gevoerd. Omdat de uitleg van een overeenkomst een feitelijke kwestie is, rest de Hoge Raad weinig meer dan te oordelen dat "s hofs oordeel niet onbegrijpelijk is; dat is des te opmerkelijk omdat de Hoge Raad in deze casus ook had kunnen terugwijzen zoals in Playa Liquor-A muba. Dan zou ook beter zicht zijn ontstaan op de in cassatie uitgebleven bijkomende omstandigheden. In de volgende paragraaf kom ik terug op de hier aangesneden problematiek.

Ook Schut-Utrecht bleek geen geval te zijn dat dwingt tot het maken van een uitzondering. De vennootschap onder firma Schut ontving dwangsombeschikkingen en dwangbevelen wegens overtreding van vergunningvoorschriften. Daarna volgt een aanzegging bestuursdwang, ook weer inzake diezelfde overtredingen. Slechts tegen deze beschikking wordt beroep ingesteld en gedeeltelijk gegrond bevonden. Ook bezwaren tegen de niet aangevochten beschikkingen worden daarbij gegrond bevonden. In de verzetprocedure tegen de dwangbevelen wordt uitgegaan van de rechtsgeldigheid van deze laatste beschikkingen;

15. Vgl. A.Q.C. Tak, De overheid in het burgerlijk recht, "s-Gravenhage 1997, p. 157.

16. Vgl HR 15 nowember 1996, JB 1997/21 m.nt. EvdL. (Kruit en Warrink-Zuidwolde).

17. A-G Mok bij HR 15 novernber 1996, JB 1997/21 m.nt. EvidL (Kruit en Warrink-Zuidwolde), p. 75. 
zij hebben immers formele rechtskracht gekregen, omdat zij niet in rechte zijn aangevochten. 'Het Hof heeft terecht geoordeeld dat zich hier niet een geval voordoet dat dwingt tot het maken van een uitzondering op de regel dat de burgerlijke rechter ook dan de rechtsgeldigheid van een beschikking van een bestuursorgaan aan zijn uitspraak ten grondslag dient te leggen, indien als vaststaand kan worden angenomen dat die beschikking zou zijn vernietigd, wanneer daartegen tijdig bij de bestuursrechter zou zijn opgekomen. De vraag of er in een situatie als hier aan de orde is, reden is de beschikking in te trekken, te wijzigen of te herzien, staat slechts ter beoordeling aan de bestuursrechter. ${ }^{18}$

\subsubsection{Samenvattend}

Het is tijd voor een tussenconclusie. Uitzonderingen worden aangenomen ingeval van aanwezigheid van door bijzondere omstandigheden ontstane klemmende bezwaren tegen het vasthouden aan de hoofdregel. Zulke omstandigheden zijn er indien er sprake is van "misleiding' door de overheid (waardoor belanghebbende niet kan worden aangerekend dat hij niet in beroep is gegaan). Tot die eerste mogelijkheid van een uitzondering kwam de Hoge Raad in Heesch-Van de Akker en Ekro; er werd op aangestuurd in Aruba-Playa Liquor, waar het Gemeenschappelijk Hof diezelfde conclusie trok.

De tweede variant die klemmende bezwaren oplevert, was zijdelings aan de orde in Hot AIR-Staat, maar leidde tot succes in St. Oedenrode-Van Aerle, nadat het hof de Hoge Raad was voorgegaan in EKOM-Rotterdam. Deze uitzondering wordt aangenomen als partijen het met elkaar eens zijn over de status van het voorwerp van geschil; er is met andere woorden eenstemmigheid tussen partijen over de onrechtmatigheid.

De uitzonderingen zijn aan elkaar tegengesteld. De eerste uitzondering, misleiding door de overheid, staat in het teken van het perfectioneren, het vervolmaken, het nóg beter tot zijn recht laten komen van de administratieve rechtsbescherming. Deze uitzondering is immers aan de orde in geval van hiaten in de administratieve rechtsbescherming. Deze uitzondering bevestigt daarmee het systeem van de administratieve rechtsbescherming.

De tweede uitzondering, partijen zijn het met elkaar eens, staat in het teken van de wilsovereenstemming. Hoe verhoudt deze uitzondering zich met een systeem waarin rechtmatigheidsoordelen in objectieve zin, dat wil zeggen ook buiten partijen om, wordt uitgesproken? Hoe zit het met een derde die niet partij is? Dat komt allemaal aan de orde in de volgende paragraaf.

Conclusie is derhalve dat het aan het begin van deze paragraaf geciteerde 'daaraan' wellicht in beginsel slechts verwees naar situaties waarbij werd afgezien van een administratieve rechtsgang waarin de beschikking zou zijn vernietigd, maar thans ook slaat op de hoofdregel. Het oordeel van het Gemeenschappelijk Hof van Justitie van de Nederlandse Antillen en Aruba laat hierover eveneens geen twijfel mogelijk.

18. HR 5 september 1997, RvdW 1997, 164 C (vof Schut-Provincie Utrecht), p. $10091 \mathrm{k}$. 
Opvallend is eveneens dat steeds vaker uitzonderingen aan de orde zijn; enerzijds zal de rechtspraktijk weliswaar de uitzondering "ontdekt" hebben en er daarom vaker op aansturen, anderzijds wordt door met name de tweede uitzonderingsvariant (eenstemmigheid tussen partijen) juist doordat partijen nu zelf het rechtskarakter van besluiten kunnen afspreken de eigen hoofdregel ondergraven. Er is dus een groei in uitzonderingen; ${ }^{19}$ de hier besproken arresten illustreren die verdichting in tijd eveneens. Dat leidt tot onrust in de rechtspraktijk. ${ }^{20}$

\subsection{De trendbreuk: overgang naar de publiekrechtelijke benadering?}

\subsubsection{Inleiding}

In hoeverre valt het bestuursrechtelijke rechtmatigheidsoordeel samen met dat van de burgerlijke rechter? Zoals al bleek kunnen er problemen ontstaan. Als het rechtmatigheidscordeel alleen tussen partijen geldt, kan het nog wel worden aangehouden, maar als ook niet partijen aan datzelfde oordeel worden gehouden ligt dat wellicht anders.

Voor alle duidelijkheid: het rechtmatigheidsoordeel in het bestuursrecht is ex tunc (feit), objectief (norm) en heeft erga omnes-werking (gevolg). Vraag is nu of de burgerlijke rechter (die normaal ex nunc, subjectief en inter partes oordeelt) nu ook dat besturursrecltelijke oorcleel ex tunc, objectief en erga omnes overneemt? Gaat de burgerlijke rechter over op een "publiekrechtelijke benadering"?

Hiema zal ik eerst jurisprudentie bespreken terzake van het overnemen van het rechtmatigheidsoordeel op een bepaald moment. Dan gaat het over de vraag of de burgerlijke rechter het bestuursrechtelijke oordeel ex tunc overneemt. Daarna bespreek ik de vraag of het overnemen van het bestuursrechtelijke oordeel door de burgerlijke rechter ook met erga omnes-werking geschiedt.

\subsubsection{Extunc?}

Gaat de burgerlijke rechter uit wan het rechtmatigheidsoordeel van de bestuursrechter ex tunc? Gaat hij niet veeleer uit van het bestuursrechtelijke oordeel op het moment dat hij gevraagd wordt er zelf een oordeel over te geven? Concreet gesteld en tocgepast op Heesch-Van de Akker houdt deze vraag het volgende in: gaat de burgerlijke rechter uit van de rechtsgeldigheid van de brief van 13 juni 1977 op diezelfde 13 juni 1977 of gaat hij uit van de rechtsgeldigheid van deze brief op 16 mei 1986 ? Wanneer hij uitgaat van rechtmatigheid op 16 mei 1986 dan neemt hij ex nunc over. In feite neemt hij dan het bestuursrechtelijke oordeel NIET over, want er is nooit een bestuursrechtelijk oordeel geweest op 16 mei 1986.

19. Ook B.J. Schueler concludeen dat zeker niet witgesloten is dat in de jurisprudentie in de toekomst nog andere uhitzonderingen worden anvaard; in: Schadevergoeding onder de Algemene wet bestursrecht, Dewenter 1997, p. 46.

20. Een conclusie waartoe oiok E.C.G. Okhuizen komt; De leer wan de formele rechiskracht en de nasleep van het St. Oedenrode-arrest: een uitgemaakte zaak?, in: Weekblad. Fiscaal Rechi 1997/6271, p. 1769. 
Laat ik eerst illustreren dat de burgerlijke rechter zo'n bestuursrechtelijk oordeel overneemt. Wat neemt de burgerlijke rechter over? Rechtmatigheid? Hoe handelt de burgerlijke rechter als er formele rechtskracht wordt geconstateerd? Geeft de burgerlijke rechter aan dat als een besluit niet wordt aangevochten of in beroep in stand houdt (met andere woorden in bestuursrechtelijke termen rechtrnatig geacht wordt), hij dat dan beschouwt als rechtmatig in de zin van het BW? ${ }^{21}$ In ieder geval is het zo dat een beschikking die in een bestuursrechtelijke procedure in stand blijft, haar rechtskracht behoudt. ${ }^{22}$

De reactie van de burgerlijke rechter ten aanzien van deze vraag is natuurlijk moeilijk te achterhalen, omdat de burgerlijke rechter als hij van oordeel is dat er sprake is wan formele rechiskracht niet zelfstandig toetst. $Z$ ou hij dan toch expliciet overwegen dat formele rechtskracht en rechtmatigheid in de zin van het BW hetzelfde zijn? Soms vermijdt de burgerlijke rechter om dit oordeel te expliciteren; dat gebeurde in het bekende Bolsius-arrest. Bij het openstaan van twee rechtsgangen kan de burgerlijke rechter de beschikking terzijde laten en feitelijk handelen als onrechtmatig in de zin van het BW aanmerken. ${ }^{23}$

In gevallen waarbij geen uirzondering op de formele rechtskracht wordt aangenomen, kunnen we wellicht zien of de burgerlijke rechter het formeel rechtskrachtige besluit (of rechterlijke oordeel) overneemt in de $z$ in van rechtmatig handelen naar BW-maatstaven (of als expliciet oordeel dat er geen onrechtmatige daad in de zin van het BW is). In dit verband is de overweging in Hot $A I R$ van bellang: 'Tegen deze achtergrond is er geen reden voor een geval als door het onderdeel bedoeld een uitzondering op dat beginsel te aanvaarden en de burgerlijke rechter bevoegd te achten (kort gezegd) de rechtmatigheid van de betrokken beschikking te beoordelen. "24 Hier gaat hij dus niet over tot kwalificatie. In Lanser-Haarlemmermeer overweegt de Hoge Raad: 'de aanschrijving formelle rechtskracht heeft gekregen, zodat de burgerlijke rechter in beginsel van haar rechtmatigheid heeft uit te gaan' ${ }^{25}$ Welke onrechtmatigheid dat is, is evenwel onduidelijk.

Overigens kan het aannemen van formele rechtskracht omdat er niet is vernietigd en het als gevolg daarvan niet aannemen van een onrechtmatige daad onbevredigend zijn, zoals in het geval van $A$ harchi. ${ }^{26}$ In $20^{\prime} n$ situatie kan een adwocaat beter feitelijke gedragingen als onrechtmatig voorstellen dan aansturen op een wijziging wan het formele-rechtskracht-isgelijk-aan-civiele-(niet-on)rechtmatigheid-beleid van de burgerlijke rechter.

21. Dit is een conclusie die wak wordt getrokken. Zo stelt Schueler: "De rechtsgeldigheid van een nietvernietigd besluit, wartegen bestuursrechtelijke rechtsbescherning heeft opengestaan, wordt in beginsel aangenomen." in: Scluadewergoeding onder de Algemene wet bestuursredut, Deventer 1997, p. 34.

22. Vgl. HR 2 jun 1995, AB 1995, $542 \mathrm{mnt}$. ThGD (Aharchi-Bedrijfswereniging Tabak).

23. Vgl. HR 2 tebruari 1990, AB 1990, 223 m.nt. G.P. Kleijn (Staat-Bolsius), later bevestigd in HR 7 oktober 1994, AB 1996, 125 m.nt. B.J.G. Roozendal (Staat-Van Benten).

24. HR 26 februari 1988, AB 1989, 80 m.nt. F.A. van Bakelen (Hot Air BV-Stat), p. 242, I.k.

25. HR 13 novenber 1992 . NJ 1993, 639 m.nt. MS (Lanser BV-Harlemmemeer), p. 2590, 1.k.

26. Zie ook de stellingen van annotator ThGD onder HR 2 juni 1995, AB 1995, 542 (Aharchi-Bedrijfswereniging Tabak). 
De formele rechtskracht van een $\mathrm{KB}$ (in beroep gegeven) is kennelijk sterker dan die van een beschikking, want eerder 'rechtmatig' voor de burgerlijke rechter. A-G Mok stelt uitdrukkelijk de formele rechtskracht van KB's aan de orde. Die is niet hetzelfde als de formele rechtskracht van beschikkingen, zodat de burgerlijke rechter hier ook anders heeft te handelen:

'Onderdeel 2 bestrijd de passage (..) war het hof zegt dat aan het KB (..) formele rachiskracht toekomt. Die formulering is hier inderdaad niet de meest voor de hand liggende. De uitdrukking "Vonnele rechlskrachi" pleegt in dit verband gebruikt te worden voor onaantastbaar geworden beschikkingen. Daarmee wordt dan aarge* duid dat de rechtmatigheid daarvan dan - in beginsel - voot de burgerlijke rechter niet meer ter discussie staat. Daarom gaat het hier niet. Het hof heef met de uithukking willen aangeven dat het gedeelte wan het door de raad van Nistelrode vastgestelde bestemmingsplan, waarvan de Kroon goedkeuring had onthouden, daarmee definitief van de baan was. Er bestaat wel een parallel met het begrip formele rechtskracht, zoals dat doorgaans wordt geharteerd, dat van een nieuwe toetsing door de burgerlijke rechter van het desbetreffende (gedeelle van) een door de Kroon niet goedgekeurd bestemmingsplan geen sprake kan zijn."27

Hoe dit ook zij, in Den Haag-Aral typeert de burgerlijke rechter het KB dat formeel rechtskrachtig is als in beginsel 'juist':

\begin{abstract}
"Nu het bij dat beroep gaat on een administratiefrechtelijke beroepsgang die in de zin van de regel wan (intern) Nederlands recht die woor dat geval de positie wan de burgerlijke recthter nader bepalt - met voldoende waarborgen is omkleed, brengt die regel mee dat, wamneer de Kroon op dat beroep uitspraak heef gedaan, aan die uitspraak in een geding als het onderhavige woor de burgerlijke rechter in beginsel zgn. formele rechtskracht toekomt, dat wil zeggen dat de burgerlijke rechter het oordeel van do Kroon in beginsel zondermeer alls juist heeft te aanvaarden. ${ }^{28}$
\end{abstract}

Later neemt de rechtbank Assen de Aral-redenering van de Hoge Raad letterlijk over in een geschil tussen de Stichting anti-wuilverbranding Drenthe en de Staat. Geconcludeerd wordt dat geen nieuwe beoordeling door de burgerlijke rechter zal plaatsvinden nadat het Kroonberoep is doorlopen:

"In casu heett de Kroon zijin oordeel gegeven. Nu het Kroonberoep naar intern Nederlands recht ecn met voldoende walaborgen omklede rechtsgang is, heeft het oordeel van de Kroon formele rechtskracht en moet de burgerijke rechter untgaan van de juistheid van dit oordeel. (..) Hieraan kunnen echter voor de onderhavige procedure geen gevolgtrekkingen worden verbonden, nu dit beginisel volgens vaste jurisprudente doorbroken wordt indien de belanghebbende zich kan beroepen op artikel 6 EVRM. ${ }^{29}$

In Kaveka-Apeldoorn betekent de formele rechtskracht (van het goedkeuringsbesluit van GS wanneer daartegen een beroep op de Kroon heeft opengestaan) dat in beginsel ervan moet worden uitgegaan dat dat besluit conform wet en rechtsbeginselen is tot stand gekomen.

27. AG Mok bij HR 19 oktober 1990, NJ 1994, I38 m,nt. MS Noord-Brabant-Stichting Brabantse Milieufedteratie), p. $540, r . k$. (cursivering Mol).

28. HR 6 februari 1987, AB 1987, $272 \mathrm{~mm}$. FHvdB (Den Haag-Aral) p. 804-805.

29. Rb. Assen 19 april 1994, NJ 1995, 36 (Stichting anti-wuilverbranding Drenthe-Staat), p. 146\%147. 
Deze regel berust op een taakverdeling "waarbij als uitgangspunt heeft te gelden dat ten aanzien wan overheidsbesluiten de beslissing omtrent de vraag of het besluit jegens belanghebbende als onrechtmatig moet worden aangemerkt, in een administratiefrechtelijke procedure wordt genomen. Hieruit vloeit woort dat degene die de administratiefrechtelijke procedure niet heeft gebruikt, zich niet op de onrechtmatigheid van het besluit kan beroepen. ${ }^{30}$

Laten we die onrechtmatigheid nader bekijken. Hoe kwalificeert de burgerlijke rechter als er geen formele rechtskracht wan de beschikking wordt geconstateerd? Zo werd een beschikking ingetrokken omdat het bestuur haar onjüst achtte; deze beschikking heeft geen formele rechtskracht meer en de burgerlijke rechter gaat dan uit van de 'onjuistheid' ervan: 'Veeleer behoort een burgerlijke rechter in een zodanig geval bij zijn beoordeling van een vordering als de onderhavige de onjuistheid van de beslissing tot uitgangspunt te nemen. ${ }^{31}$ Een ex tunc uit het rechtsleven verdwenen beschikking kan ex nunc ook niet meer formeel rechtskrachtig zijn; dan is zij kennelijk 'onjuist'.

Geeft de burgerlijke rechter aan dat hij, als hij een bestuursrechtelijk besluit (inhoudende bijvoorbeeld een vernietiging van een vergunning) overneemt, dat beschouwt als een onrechtmatige daad in de zin van het $B W$ ?

Bekend zijn in dit geval de overwegingen in Van Gog-Nederweert:

"Indlen een overheidslichaam een onrechtmatige daad pleegt door een beschikking te nemen en te handhaven die naderhand door de rechter wordt wemietigd (...) is daarmede de schuld var hel owerheidslichaam in beginsel gegeven. ${ }^{32}$

Eveneens onrechtmatig in de zin van het BW wordt geacht het in strijd met de wet een bouwvergunning weigeren:

"In geval een gemeente een onrechmatige daad pleegt door in strijd met de wet - zoals is vastgesteld door de $A f d$, rechtspraak $\mathrm{RwS}$ - te weigeren een bouwwerguning te verlenen ${ }^{13}$

De spiegel van formele rechtskracht is al even strikt als de formele rechtskracht zelf: in geval van vernjetiging is er (BW-)onrechtmatigheid.

Het antwoord op de vraag of de burgerlijke rechter het bestuursrechtelijke oordeel, inhoudende onrechtmatigheid van een beschikking, kwalificeert als een burgerrechtelijke onrechtmatige daad is bevestigend. Daarbij conformeert de burgerlijke rechter zich volledig aan het administratieve oordeel. De bedoeling is dat op die manier de competenties van beide rechters worden afgebakend en dat rechtsonzekerheid wordt voorkomen. Zodoende neemt

30. HR 19 juni $1998, \mathrm{NB} 1998 / 27$, nr. $128 \mathrm{C}$. p. 1202

31. HR 8 decenber 1995,3 B 1996160 m.nt. EvdL (Bedrijfsvereniging Metal-Heijboer).

32. HX 31 mei 1991 , AB 1992, 290 (Van Gog-Nederweert), p. 855, r.k.; dit werd bevestigd in HR 1 jull 1993 , NJ 1995,150 m.nt. CJHB (Staat-NCB).

33. HR 30 januari 1987, AB 1988, 43 m.nt. PvB (Gebr. Nibourg BV-Zuidwolde), p. 90 r.k. 
de burgerlijke rechter een historisch gegeven (een bestuursrechtelijk ex tunc oordeel) tot uitgangspunt van zijn kwalificatie op het moment van uitspraak.

Eveneens in deze lijn wordt gesteld door de Hoge Raad in Talma Rustoord-Friesland, dat de burgerlijke rechter pas mag oordelen over de schadevergoeding als de onrechtmatigheid in een procedure voor de Kroon is vastgesteld. In het arrest werd de formele rechtskracht van een $\mathrm{KB}$ in stelling gebracht. Uit de leer wan de formele rechtskracht wloeit voort dat de verjaringstermijn pas gaat lopen op het moment dat het besluit in administratieve termen onrechtmatig is verklaard. De civiele rechter zal aldus niet terugtreden maar wachten op bestuursrechtelijke 'zekerheid' bij schadevergoedingsvorderingen na een Kroonuitspraak: "De in de rechtspraak ontwikkelde (...) taakverdeling tussen enerzijds de burgerlijke rechter, anderzijds de administratieve rechter respectievelijk (voor wat de periode vóór de inwerkingtreding van de Tijdelijke wet Kroongeschillen betreft) de Kroon, brengt mee dat de burgerlijke rechter een vordering tot schadevergoeding, gebaseerd op onrechtmatigheid van een beschikking waartegen een administratieve rechtsgang openstond, in beginsel slechts kan toewijzen indien en nadat die rechtsgang is gevolgd en daarbij is beslist dat de beschikking onrechtmatig is., ${ }^{34}$ In zijn arrest Zuidhorn-Erven Staal wordt deze lijn bevestigd. ${ }^{35}$

De burgerlijke rechter gaat wel over tot zelfstandige toetsing van een onrechtmatigheidsvraag over werkzaamheden (feitelijk handelen) op basis van een anticipatieve aanlegvergunning (ten aanzien waarvan een Kroonbesluit goedkeuring onthield aan het bestemmingsplan). Laten we dit concreter bezien; hoe zag deze casus er uit? De provincie NoordBrabant wilde een weg aanleggen in Nistelrode. Het bestemmingsplan staat dat niet toe zodat overgegaan wordt tor anticipatie. Een nieuw bestemmingsplan wordt voorbereid en de gemeente geeft een antïcipatieve aanlegvergunning af. De provincie verleent een verklaring van geen bezwaar ten behoeve van de bestemmingsplanwijziging (kortom, ook ten behoeve van zichzelf). De Kroon onthoudt goedkeuring aan het nieuwe bestemmingsplam. De grondslag van de aanlegvergunning is daarmee tenietgedaan. De Milieufederatie is tegen deze plannen en vecht elk punt aan bij de administratieve rechter. Daarbij stuit de Milieufederatie op de ex tunc-toetsing. Schorsingsverzoeken worden dusdoende steeds afgewezen. Uiteindelijk start zij een civiele procedure.

De burgerlijke rechter toetst de rechtmatigheid van het feitelijk handelen (de werkzaamheden) ex nunc en daarmee speelt het vraagstuk van de vrijwarende werking (van in dit geval de beschikking ondanks het oordeel van de Kroon). Het aloude vraagstuk van de vrijwarende werking, gecombineerd met de ex tunc-toetsing in het administratief recht en de ex nunc-toetsing in het civiele recht, maakt de omvang van de formele rechtskracht enigszins vaag; dat betekent dat de burgerlijke rechter - vanuit zijn visie van verlenen van

34. HR 28 oktober 1994, NJ 1995, $139 \mathrm{m.nt}$. MS (Stichting Wooncentrum Talma Rustoond-Provincie Friesland), p. $594,1 \mathrm{k}$.

35. Vgl HR is maart 1996, AB 1996, $243 \mathrm{~m}$.nt. ThGD (Gemeente Zuidhom-Erven Andries Staal). 
rechtsbescherming - tot toetsing overgaat. Het gat dat tussen beide toetsingsmethoden valt, is echter niet te dichten met de formele rechtskracht, want die hangt nu eenmaal vast aan het formele moment (van besluitneming of het verlopen van beroepstermijnen) en riet aan de feitelijke gevolgen die door dat formele moment als rechtsgevolg zijn geëcarteerd. De burgerlijke rechter rest dan ook niets anders dan te constateren dat de formele rechtskracht vastzit aan de formele momenten en overgaan tot toetsing en afweging van belangen:

\begin{abstract}
"Het hof heeft o.m. tol uitgangspunt genomen (...) dat het koninklijk besluit de aanlegvergunning niet doet vervallen of - met andere woorden - dat de vergunning ook na het koninklijk besluir haar rechtskracht behoudt en voorts dat de houder in beginsel de vrigheid heeft overeenkomstig de vergunning te handelen zonder dat or sprake is wan onrechtmatigheid. Deze uitgangspunten (...) zinin juist. (..)

Wels waar belowdt de aawlegvergumning (...) ook na een afwijkend oordeel van de Kroon haar rechtskracht. Maar bij de beantwoording van de vraag of de houder van de aarlegvergunning in redelijkheid kan oordelen dat de werkzaamheden kumen worden woortgezet nadal goedkeuring aan het bestemmingsplan, voorzover betrekking hebbende op die werkzaamheden, is onthouden, vormt het oordeel wan de Kroon - zoals ook het hof kaarbijkelijk tot uitdrukking hetft willen brengen - een gewichtige, zij het ook niet beslissende factor.

(..)

Het vorenstaande neemt niet weg dat de burgerlijke rechter, wanneer zijn oordeel over het voortzetten van de werkzaamheden wordt gevraagd, niet alleen zal moeten letten op de uitspraak van de Kroon en de doon de Kroon wetrichte belangenafweging, maar ook op de andere betrokken belangen en de verdere onstandigheden van het geval, zoals die zign ten tijde van het voortzenten van de werkzaamheden. Daarbij zal hij in beginsel een eigen oordeel omtrent de onrechtmatigheid moeten geven. ${ }^{36}$
\end{abstract}

Met andere woorden, de burgerlike rechter toetst hier iets anders dan datgene dat voorwerp was van de bestuursrechtelijke procedure. Van samenval in de eigenlijke zin des woords is daarom geen sprake. Dat wordt ook erkend met de zinsnede: "kon de burgerlijke rechter de rechtmatigheid van de aanleg gaan beoordelen, ook al beslist de administratieve rechter over de rechtmatigheid van de vergunning, ${ }^{17}$ Beseft moet worden dat de vergunningverlener niet bevoegd is tot het geven van een oordeel omtrent de civielrechtelijke rechtmatigheid (en dat dus met het geven van de vergunning ook niet geeft).

Soms weet de burgerlijke rechter niet of hij nu wel formele rechtskracht moet aannemen of juist niet; in dat geval ziet hij geen ijkpunt in het oorspronkelijke bestuursbesluit, omdat er een administratieve rechtsgang loopt. In het vorige hoofdstuk is een schema opgenomen; daar wordt nu weer naar verwezen. De vraag die hier immers voorligt, is of de burgerlijke rechter op moment y moet uitgaan van formele rechtskracht (een ex tunc-oordeel van ofwel het bestuursorgaan, moment 1, ofwel de bestuursrechter, moment 2). Dat moment 2 kan in voorlopige voorziening of in de bodemprocedure zijn gegeven. Anders gezegd, te verwachten is dat de burgerlijke rechter zich bij de vraag of er sprake is van formele rechtskracht primair orienteert op de aanwezigheid van een bestuursbesluit, vervolgens op

36. HR 19 oktober 1990, NI 1994, 138 m.nt. MS (Noord-Brabant-Stichting Brabantse Milieufederatie), p. 543; het arrest is ook bekend als wegomlegging Nistelrode.

37. Annotator Scheltema onder HR 19 oktober 1990, NJ 1994, 138 Noord-Brabant-Stichting Brabantse Milieufederatie), p. $544,1 . \mathrm{k}$. 
de aanwezigheid van een uitspraak van een bestuursrechter, ofwel de uitspraak in voorlopige voorziening, ofwel de uitspraak in de gewone procedure.

Een merkwaardige zaak is het geschil tussen Smit en de Staat. ${ }^{38}$ De Staat vordert van Smit terugbetaling van een teveel en dus in zoverre onverschuldigd betaald bedrag. Tegen het terugvorderingsbesluit gaat Smit in administratieve rechte. Wegens termijnoverschrijding wordt hij niet-ontvankelijk verklaard; hij gaat in hoger beroep. Ondertussen is de Staat de civiele procedure gestart. Het bestuursrechtelijke hoger beroep had nog geen uitsluitsel gegeven op het moment dat de civiele zaak hangende was. Heeft het terugvorderingsbesluit in zo'n situatie formele rechtskracht en dient de burgerlijke rechter dus uit te gaan van de juistheid van het besluit? De Hoge Raad oordeelde dat de hoofdregel van de formele rechtskracht ook geldt

'in gevall gebruik is gemaakt wan een administratiefrechtelijke rechtsgang (...), in welk geval de burgerlijke rechter van de geldigheid van het besluit dient uit te gaan, zolang het niet is vernietigd.

Hic behoeft niet te worden ingegaan op de vraag of, en zo ja voor wetke rechter hangende de administratiefrechtelijke rechtsgang opschorting van de uitvoering van het besluit kan worden verlangd tot in die rechtsgang onherroepelijk is beslist. Wel verdient aantekening dat de eisen wan een behoorlijke rechtspleging kunnen mebrengen dat de burgerijke rechter, teneinde mogelijk tegenstrijdige beslissingen te voorkomen, zijn uitsprak aanhoudt totdat zodanige onherroepelijke beslissing is verkregen; daartoe zal met name grond bestaan ingeval te werwachten valt dat bij die bestissing het besituit zal worden verinietigd. De burgerlijke rechter kan ook, in plats wan zijn uitspraak aan te houden, die uitspraak doen onder voorwarde wan de vitkonst wan de administratiefrechtelijke rechtsgang.

In een geval als het onderhavige (...) bestat voor het aanhouden door de burgerlijke rechter slechts grond indien te verwachten vali dat de administratieve appelrechter een niet-ontvankelijkwerklaring van het beroep wegens termijnoverschrijding achterwege zal laten op grond dat redelijkerwijs niet $k$ an worden geoordeeld dat de wederpartij van het bestuursorgaan in verzuin is geweest, en dat hij het besluit zal vernietigen. Smit heeft echter (...) niet gesteld dat te werwachten viel dat de ambtenarenrechter (...) het terugvorderingsbesluit zou veruictigen. 39

Hier had de burgerlijke rechter kunnen afgaan op de formele rechtskracht van het bestuursbesluit, maar vindt dat kennelijk niet doorslaggevend.

Wel wordt afgegaan op de formele rechtskracht van het bestuursbesluit in het geschil van de gebroeders Kakkenberg. ${ }^{40}$ Het betreft een hoog oplopende ruzie inzake een afspraak omtrent het gebruik van een schuur op het perceel wan broer Henk voor een autoreparatiebedrijf van broer Tonnie. De vraag spitst zich toe op de invloed van een bij de administratieve rechter aanhangig zijnde procedure. Onzeker is (op dat moment voor de burgerlijke rechter) of de administratieve rechter de beschikking - inhoudende het bevel tot staking van het met het bestemmingsplan strijdige gebruik - zou vernietigen. Dan gaat de Hoge Raad (onder verwijzing naar Smit-Staat) wit van de formele rechtskracht van de beschikking en gaat over tot verwijzing. "Na verwijzing zal onder ogen moeten worden gezien of en in hoeverre, zo omtrent de strijd met het bestemmingsplan een onherroepelijke beslis-

38. Vgl. HR 7 april 1995, AB 1995, $441 \mathrm{~m} . n t$. ThGD onder 542 (Smit-Statat).

39. HR 7 april 1995, AB 1995, 541 mnt. ThOD onder 542 (Smit-Staat), p. 1629.1630.

40. Vgl HR 21 april 1995, NJ 1995, 437 (Kakkenberg-Kakkenberg). 
sing is gevallen, deze omstandigheid van belang is voor beantwoording van de vraag of de overeenkomst kan worden opgezegd." ${ }^{* 1}$

De oplossing van dit soort van situaties, waarbij vooral het voorkomen van overlap drijfveer lijkt te zijn, is gegeven in art. 96a Rv. De wet codificeerde in art. 96a Rv de regel dat wanneer niet-ontwankelijkheid de burger niet kon worden verweten omdat de toegang tot de administratieve rechtsgang onduidelijk was, hij alsnog ontvankelijk is bij de bestuurs. rechter; een bijkomende en dwingende reden voor verschoonbaarheid van de termijnoverschrijding. ${ }^{42}$ Naast het aannemen wan een witzondering op de formele rechtskracht kon nu ook dwingend de toegang bij de administratieve rechter bevolen worden. Aanhouding van de beslissing in een civiele procedure totdat de formele rechtskracht van een besluit is ingetreden, is een andere oplossing. ${ }^{43}$

\subsubsection{Erga omnes?}

Wanneer de burgerlijke rechter een onrechtmatige daad kwalificeert dan geldt die beslissing voor partijen, heeft met andere woorden inter partes-werking als gewolg. Een formeel rechtskrachtig besluit heeft echter erga ommes-werking. Het onderscheid komt in beeld wanneer er sprake is van derden. Geldt het formeel rechtskrachtige besluit bij de burgerlijke rechter jegens allen of jegens partijen? ${ }^{44}$ Geldt het overgenomen onrechtmatigheidsoordeel bij de burgerlijke rechter jegens allen of jegens partijen?

Eerst maar het besluit zelf; hierna kom ik op het overgenomen onrechtmatigheidsoordeel terug. In een geschil over aansprakelijkheid na een ongeval speelt de formele rechtskracht van een beschikking inzake WAO. De bedrijfsvereniging vordert de betaling van kosten voor de WAO-uitkering. In zijn conclusie gaat Bloembergen in op de vraag of de formele rechtskracht van een beschikking ook werkzaam is jegens derden. In beginsel is daarvan geen sprake stelt Bloembergen, maar

\footnotetext{
'Waarom heef de beschikking in ons geval dan wel rechtskracht tegen een derde, namelijk de WAM-verzekeraar die in de procedure voor de sociale verzekeraar niet kan optreden? Mijn antwoord is dat er in ons geval bij wijze varn uitzondering plaats is voor rechtskracht tegen een derde, omdat zulks voor de WAMverzekeraar (...) nict tot onaanwatrdbaan resultaat leidt wanwege het civiele plafond (...). En, zo voeg ik toe, dat resultat is ook in hoge mate wenselijk, ondat aldus dubbele procedures en tegenstrijdige beslissingen worden vermeden' 'ts
}

41. HR 21 april 1995, NJ 1995, 437 (Kakkenberg-Kakkenberg), p. 2080, r.k

42. Een voorbeeld van de toepassing evvan biedt $\mathbb{R} b$. 's-Gravenhage 16 november 1994 , JB $1994 / 311$ m.nt. Evdl.

43. Vgl Rb. Utrecht 24 augustus 1994, JB $1995 / 3$ m.nt. Exid en ook Pres. Rb. Utrecht 14 juni 1994, JB $1996 / 23$ m.nt. Evol.

44. Vgl bijwoorbedd deze overweging uit Kavekat-Apeldoon: 'de valag of het jegens belanghebbende alls onrechtmatig moet worden aangemerkt", HR 19 juni 1998, NJB 1998/27, nr. 128C, p. 1202 (mijn: cursivering).

45. A-G Bloembergen bil HR 23 februari 1990, NJ 1991, 574 m.nt. CHB (Centraal Beheer Schadeverzekering-Bedrijfsvereniging woor de Metalnijverheid), p. $2397,1 \mathrm{~K}$. 
Omdat partijen niets witdrukkelijk hebben gesteld ten aanzien wan de leer van de formele rechtskracht, gaat de Hoge Raad daar dan ook niet expliciet op in. Dat gebeurt wel in een later arrest. Heeft een beschikking eenmaal formele rechtskracht gekregen, dan staat dat ook vast jegens derden, zo stelt de Hoge Raad, maar dan moeten ze wel een rechtsgang hebben kunnen benutten:

\begin{abstract}
"Wanneer anderen dan degene, tegen wie en beschikking is gericht, het rechens vereiste beimg hebber on gebruik te kunnen maken wan een met voldoende waarborgen onklede administrateve rechisgang, brengt de wenselijkheid wan een doelmatige taakverdeling ais vorenbedoeld mee dat ook ten aanzien van hen in beginsel dient te worden uitgegaan van de formele rechtskracht van de beschikking indien zij die reclitsgang niet hebben benut. ${ }^{46}$
\end{abstract}

Soms lijkt het alsof de Hoge Raad van deze lijn afstapt. Dat is bijvoorbeeld het geval in Dircks c.s.-Peters-Dircks. De kinderen Dircks hebben ruzie met hun zusje Johanna. Het betreft een erfrechtelijke kwestie, waarbij een vergunning voor de exploitatie van een tankstation en een gezamenlijke vennootschap onder firma tussen vader en Johanna Dircks de stiekeme inzet zijn. Vader Dircks en zijn jongste dochter Johanna runnen een tankstation, uiteraard zodanig dat Johanna in de loop der jaren het merendeel van de taken op zich neemt. De zaken die daarmee verband houden zijn goed geregeld in een vennootschap onder firma, waarbij in de loop der jaren de aktes zijn aangepast voor wat betreft de verdeelsleutel van de winsten. In zijn testament heeft vader zijn dochter Johanna eveneens goed bedacht want de overige kinderen zullen voor $1 / 8$ delen in zijn vermogen, terwijl Johanna voor $3 / 8$ recht heeft op de nalatenschap. Dat betekent dat Johanna de waarde van het tankstation op vaders sterfdag voor $5 / 8$ zal moeten uitkeren aan haar broers en zusters. Daartussendoor loopt nog het dispuut over de vergunning voor de exploitatie van het tankstation. Oorspronkelijk was deze gericht aan vader. In de loop der jaren heeft Johanna steeds op basis van deze vergunning kunnen werken, omdat de vergunning was ingebracht in de vennootschap. Na het overlijden van pa verzoeken de overige kinderen om de vergunning op naam te stellen van Avanti BV, waarin zij zouden participeren. Johanna deelt niet mee in Avanti en vreest het verlies van 'haar" vergunning. De vergunning wordt daarna uitdrukkelijk op naam van alle kinderen gesteld. Johanna eist nu verklaring voor recht dat zij met uitsluiting van de overige erfgenamen wordt aangemerkt 'als houdster van de publiekrechtelijke en de privaatrechtelijke vergunning, "4

Vraag is hier natuurlijk of een vergunning wel een vermogensrecht is; met andere woorden kan een vergunning wel voorwerp zijn van eigendom? Het antwoord op die vraag is simpelweg nee, maar de burgerlijke rechter twijfelt kennelijk, want het hof wijst de vorderingen toe. Dat is vanuit zijn standpunt ook niet zo heel vreemd, papieren vertegenwoordigen immers in het privaatrecht al gauw een bepaalde waarde en kunnen daarmee inzet zijn van geschillen. Vergunningen echter zijn geen voorwerp van eigendom, omdat ze

46. HR 8 september 1995, JB 1995/249 (Budinovski en Pejkowski-Utrecht), p. 897, r.k.

47. Vgl de conclusie van A-G Koopmans bij HR 16 mei 1997, JB 1997/148 mit. HJS (Dircks c.s.-PetersDircks), p. 668. 
gerichi zijn op een bepaalde rechtssituatie, in dit geval het perceel watarop het tankstation staat en dat onder de door vergunning gestelde voorwaarden kan worden geëxploiteerd. Voor de vergunningverlening is daarbij irrelevant wie dat tankstation zal gaan exploiteren, als het maar gebeurt onder de voorwaarden van de vergunning en met een vergunning. Het us ook daarom dat Rijkswaterstaat - de ruzie tussen de kinderen waarschijnlijk ook meer dan beu - de vergunning gericht heeft aan alle erfgenamen. Bovendien, zo stelt ook het middel van de kinderen, heeft de vergunning met deze "tenaamstelling aan allen' formele rechtskracht gekregen, zodat de burgerlijke rechter zich met deze discussie niet meer mag bemoeien. 'Dit betoog', zo overweegt de Hoge Raad, 'gaat uit van een verkeerde lezing van het bestreden arrest en faalt derhalve reeds wegens gebrek aan feitelijke grondslag. Het Hof heeft niet de formele rechtskracht miskend van de besluiten waarbij de vergunningen zijn verleend, maar heeft zijn beslissing op een gedachtengang gegrond die deze formele rechtskracht niet raakt'. Annotator Simon stelt daaromtrent dat het betoog van de Hoge Raad erop neerkomt dat de formele rechtskracht van de vergunning 'niet kan afdoen aan de privaatrechtelijke verhoudingen zoals deze voortvloeien uit het verblijvensbeding. (...) In een dergelijke situatie geldt, in elk geval voor de verhouding tussen 'burgers' onderling dat privaatrecht gaat voor publiekrecht.' elkaar staan wan beide rechtsgebieden, maar vergelijkt vooral appels en peren met elkaar. Laten we nog eens precies lezen: een vergunning met formele rechtskracht raakt niet de privaatrechtelijke verhoudingen, stelt de Hoge Raad (naar mijn mening terecht) en dat is nu eenmaal iets anders als de stelling dat de verguming niet afdoet aan het privaatrecht, zoals Simon beweert. De woordkeus 'niet raken aan' veronderstelt immers twee naast elkaar staande verhoudingen, terwijl de woorden 'niet afdoen aan' een hierarchie veronderstellen.

Soms is de beschikking 'zoek' (of non-existent, zoals eiser in casu stelt), maar toch worden schriftelijke stukken later nog verzonden; is er dan toch werking jegens derden? In Sprangers-Staat ${ }^{50}$ is de beschikking te laat genomen en dus onbevoegd, althans zo stelt de cessionaris. Hoe ziet de casus er uit? Twee vennootschappen ontvangen een negatieve voorlopige aanslag in de vennootschapsbelasting. De vorderingen op de Ontvanger der directe belastingen, dan wel de Staat worden gecedeerd aan Sprangers tot zekerheid van de betaling van een vordering uit aanneming van werk. Ter verdere afwikkeling doen de vennootschappen schriftelijk aangifte, waarbij belastbare bedragen van nihil zijn opgegeven en aanspraak wordt gemaakt op de investeringsbijdragen. Vervolgens gaan de vennootschappen failliet. Er volgt een gesprek tussen de belastinginspecteur en gemachtigde van de vennootschappen. Daaruit volgt eerst een mondelinge mededeling aan de gemachtigde van de vennootschappen (dat het er op gehouden moet worden dat de aanslag op nihil was vastgesteld) en dat betekent dat de schriftelijke beschikkingen imhouden dat

48. HR 16 mei 1997, JB $1997 / 148$ m.nL. HJS (Dircks c.s.-Peters-Dircks), p. 672-673

49. Annotator Simon onder HR 16 mei 1997, JB 1997/148 (Dircks c.s.-Peters-Dircks), p. 675.

50. Vgl. HR 27 mei 1994, RvdW 1994, 121 C (Sprangers-Staat). 
'geen aanslag' wordt opgelegd. Dat betekent dat Sprangers te maken heeft met een 'lege' cessie. Na de mondelinge beschikkingen wordt door hem dan ook (prematuur) bezwaar gemaakt. Ondertussen verloopt de wettelijke termijn voor het nemen van een aanslag, aldus gemachtigde van de vennootschappen, zodat er geen beschikking is totstandgekomen. Omdat er geen aanvraag tot een aanslag is gedaan, kan ook niet sprake zijn van een fictieve aanslag; er is dus geen schriftelijk besluit van de Ontvanger. Sprangers stelt daarom een civiele vordering in. Dan pas volgen gedagtekende stukken inhoudende de schriftelijke beschikking dat geen aanslag wordt opgelegd (6 juli 1984). Na een gesprek handhaaft de inspecteur deze beschikking. In de daarna actuele, onherroepelijk geworden, fiscale procedure wordt de mondelinge beschikking vernietigd (want er is geen aanslag opgelegd), terwijl het prematuur bezwaar niet-ontvankelijk wordt verklaard (want er is geen beschikking). Aldus werden de besluiten van de inspecteur door Sprangers nonexistent (de mondelinge beschikking is door de vernietiging non-existent geworden en het bezwaar daartegen was eveneens een niet bestaande beschikking) geacht in de civiele procedure; de rechtbank heeft ze aangemerkt als bestaande beschikkingen met formele rechtskracht. Het hof heeft dit vonnis bekrachtigd.

In de nog lopende civiele procedure staat de vraag centraal of de beschikkingen van 6 juli 1984 formele rechtskracht hebben, zodat de burgerlijke rechter geen taak meer heeft. Welbewust heeft Sprangers geen gebruik gemaakt van de administratieve rechtsgang (ondat ook deze beschikkingen non-existent waren in zijn visie, behoefde hij ze niet aan te vechten). Well was al (prematuur) bezwaar ingediend tegen de mondelinge mededeling, maar een herhaald bezwaar tegen de schriftelijke stukken is achterwege gebleven. De schriftelijke stukken hielden in Sprangers optiek niet meer in dan een bevestiging van de (mondelinge) mededeling.

De Hoge Raad conformeert zich aan de opvatting van de belastingrechter dat de mondelinge beschikking geen beschikking was en dat pas de beschikkingen van 6 juli 1984 als zodanig zijn aan te merken.

"Het vorenoverwogeme brengt mede dat de Rechtbank en het Hof terecht hebben aangenomen dat de burgerlijke rechter in dit geding ervan nnoet uitgaan dat de beschikkingen van 6 julli 1984 zowel wat de wijze van tot stand komen als wat de inhoud betreft in overeenstemming zijn met de desbetreffonde wettelijke voorschriften en algemene rechtsbeginselen. Daarbij zijn beide colleges kennelijk en terecht ervan uitgeganan dat deze formele rechtskracht eveneens to gelden heeft ten anzien van Sprangers in haar hoedanigheid van cessionaris. (... )

In deze grief heeft Sprangers aangevoerd dat in thet onderhavige geval aanleiding bestaat om een uit zondering te maken op het beginsel dat aan de beschikkingen van 5 juli 1984 formele rechiskracht toekomt. (...) Het Hof heeft (...) geoordecld dat, zo al ervan moet worden vitgegaan dat de Stat onrechtmatig heeft gehandeld door niet binnen drie jaren een aanslag op te leggen dan wei een beschikking (...) te geven, zulks niet een omstandigheid is, die tot een dergelijke uitzondering dwingt. Dit oordeel is juist.

Voor zover het middel aldus moet worden begrepen dat het tevens aanvoent dat plaats is woor een afwijking van het beginsel van formele rechtskracht, omdat de Inspecteur de gemachtigde 'op het werkeerde been heef gezet' door (...) mede te delen dat het er maar voor moest worden gehouden dat de aanslag op rihil was vastgesteld, faalt het eveneens. Ook indien dit het geval was, is zulks immers irrellevant in het licht van de onstandigheid diat de vennootschappen (...) ter terechtzitting, van de belastingrechter in de gelegenheid zijn 
gesteld ook de beschikkingen wan 6 juli 1984 in hum beroep te betrekken, doch welbewust darvan hebben afgezien. ${ }^{* 51}$

De formele rechtskracht van de belastingbeschikkingen van 6 juli 1984 geldt dus ook jegens de cessionaris Sprangers. Dat betekent dat Hoge Raad hier impliciet aanneemt dat de formele rechtskracht werkt ten opzichte van derden. De direct-belanghebbende kan zodoende afzien van het wolgen van een administratieve rechtsgang (omdat dat wellicht goed uitkomt) terwijl de derde-belanghebbende bij de burgerlijke rechter het deksel van de formele rechtskracht op de neus krijgt.

Geldt het overgenomen onrechtmatigheidsoordeel jegens allen of jegens partijen, luidt de tweede vraag die hier aan de orde moet komen. Deze vraag kan worden benaderd aan de hand van de geschillen die schuil gaan in het arrest Gebr. Nibourg BV-gemeente Zuidwolde. ${ }^{32}$ De feiten eerst maar. Niet alleen Nibourg BV had een aanvraag voor een bouwvergunning gedaan, maar ook Stok BV. Nadat de aanvraag van Stok BV was geweigerd verkocht zij aan Nibourg BV, die eveneens een weigering tegemoet konden zien. Nibourg BV ging in beroep en deze weigering werd vernietigd. Dat oordeel werd door de burgerlijke rechter overgenomen en aangemerkt als onrechtmatige daad. Jegens Stok BV is de gemeente echter niet aansprakelijk uit onrechtmatige daad, omdat deze onrechtmatigheid afstuit op de formele rechtskracht van de weigering.

\footnotetext{
'De enkele ornstandigheid dat Stok de beroepsgang tegen de weigeringsbeschikking triet heeft gebruilkt ondat zij van mening was daartoe een goede grond te hebben, is niet voldoende om een uitzondering te maken op het beginsel dat de burgerlijke rechter, zo een met voldoende waarborgen omklede rechisgang tegen een beschikking niet is gebruikt, ervan dien uit te gaan dat die beschikking zowel wat haar wijze van tot stand komen als wat hat inhoud betreft in overeenstemming is met de desbetreftende wettelijke voorschriften en algemene rechisbeginselen. 5 .
}

Het verkrijgen van formele rechtskracht leidt hier dus tot uitsluiting wan aansprakelijkheid. Had de vordering van Nibourg BV tot onrechtmatigheid geleid op basis van feitelijk handelen, dan was de gemeente ook aansprakelijk geweest jegens Stok BV.

Het onrechtmatigheidsoordeel van de burgerlijke rechter heeft hier zodoende inter parteswerking, want het is meer dan duidelijk dat de weigering ten aanzien van hetzelfde perceel naar bestuursrechtelijke maatstaven zowell voor Nibourg BV als voor Stok BV gelijkelijk in strijd met de wet gegeven is. Dat oordeel van de bestuursrechter is erga omnes gegeven, zodat hier als conclusie kan luiden dat de burgerlijke rechter niet hetzelfde oordeel overneemt.

51. HR 27 mei 1994, RwdW 1994, 121 C (5prangers-Statat), p. 668-669.

52. Vgl. HR 30 januari 1987, AB 1988, 43 m.nt PvB (Gebr. Nibourg BV-Zuidwolde).

53. HR 30 januari 1987, AB 1988, 43 m.nt PvB (Gebr. Nibourg BV-Zuidwolde), p. 911 lk 


\subsection{Tenslotte}

Aan het begin van dit hoofdstuk werden twee vragen gesteld, namelijk of de burgerlijke rechter als hij het bestuursrechtelijke oordeel overneemt dat compleet overneemt, en als hij het overneemt, of hij dan hetzelfde oordeel overneemt. Beide vragen moeten ontkennend worden beantwoord.

De burgerlijke rechter opende de mogelijkheid tot het aannemen wan uitzonderingen op de formele rechtskracht samen met het definiëren van de formele rechtskracht-regel. Twee typen uitzonderingen komen voor: enerzijds wordt een uitzondering aangenomen indien er sprake is van misleiding door de overheid en anderzijds kan een uitzondering worden aangenomen als partijen het samen eens zijn. De eerste vorm van uitzondering bevestigt het systeem van de administratieve rechtsbescherming; de tweede variant ondergraaft dat. Door immers als overheid met een partij afspraken te maken over het rechtskarakter van het voorwerp van geschil, kunnen derden buiten de boot vallen.

Wanneer de burgerlijke rechter het bestuursrechtelijke oordeel overneemt, is dat niet hetzelfde oordeel. De burgerlijke rechter kiest (en dat is terecht) immers steevast voor het verbinden van inter partes-werking (gevolg) aan zijn uitspraken. Ook wordt het oordeel dat bij de burgerlijke rechter een rol speelt (vanuit bestuursrechtelijk oogpunt een ex tunc gegeven) pas actueel op het moment dat de burgerlijke rechter wordt geadieerd, dus ex nunc. Daarmee stelt de burgerlijke rechter een historisch gegeven centraal voor een kwalificatie (een normatief oordeel) nu. Zo bezien neemt de burgerlijke rechter NIETS over, want over dat ex nunc-moment heeft noch het bestuursorgaan noch de bestuursrechter ooit een oordeel gegeven.

Conclusie van dit alles is, dat de burgerlijke rechter appels en peren gelijkschakelt, terwijl de formele rechtskracht van beschikkingen niet het adequate instrument is om rechtsmacht af te bakenen of toetsingswijzen op elkaar af te stemmen. Beter zou het zijn als de burgerlijke rechter dat expliciet had gemaakt; dan zou ook de wetgever de noodzaak van een werkelijk adequate afbakeningswijze eerder aannemen.

De zojuist door middel van een selectie uit de jurisprudentie geschetste rol van het beginsel van de formele rechtskracht van beschikkingen in de afbakening van de rechtsmacht van de bestuurs- en de burgerlijke rechter geeft inzage in enkele duidelijke uitgangspunten. De burgerlijke rechter stelt zich steeds op het standpunt dat hij rechtsbescherming zall verlenen indien daarvoor ruimte is; hij is steeds aanvullend bezig. Daarbij valt op dat een lichte voorkeur bestaat om de zaak vanuit het perspectief van de 'zwakkere' te benaderen en om naar het resultaat toe te rekenen. Drupsteen karakteriseerde het als volgt:

"Het nast elkaar bestaan van civicle en adminstraticwe rechigangen maakt ons rechisstelsel ingewikkeld. (..) De jurisprudentie van de Hoge Raad is naar mijn mening thelder en consequent. Ze laat zich verklaren uit twee elementen; een gegeven en en regel. Het gegeven is dat de wetgever tegen een groot aantal overheidsbesluiten administratieve voorzieningen in thet leven heeft geroepen. Deze administratieve beroepsmogelijkheden bieden bij uitstek de mogelijkheid om her omstreden overheidsbesluit ter toetsing aan een deskundige instantie woor te leggen. Kenmerkend voor deze administratieve voarzieningen is dat ze maar gedurende een beperkte periode openstaan. Wanneer de beroepstermijn is verstreken, is geen beroep meer 
mogelijk. Beroepstermijnen gelden over het gehele terrein wan de administratieve rechtsbescherming tegen de overheid met het oog op de rechtszekerheid. Na een bepalde periode noeten zowel de betrokken burgers, als het betrokken owemeidsorgaan er vanuht kunnen gaan dat een genomen beshuit rechtsgeldig is. Het besluit heef dan formele rechtskracht gekregen.

De regel is dat de burgerlike rechter een wordering tegen een overheidsbesluit nietwontwankelijk werklaart, wamneer tegen dit overheidsbeshit een administratieve voorziening openstat of heef opengestaan. Deze regel is niet gebaseerd op een weltelijke bepaling. Ze vloeit voort uit het bestaan van administratieve voorzituingen. Zou de burgerlijke rechter deze regel niet hanteren, dan zou het voor een burger mogelijk zijn om rechtstreeks een vordering tegen cen overheidsbesluit in te stellen. De met het oog op de rechisbescherming ingestelde administratieve voorzieningen zouden daarmee hun betekenis verliezen. Ditzelfde geldt voor de regeling wan de beroepstermijn. Een schadevergoedingsactie bij de burgerlijke rechter kan inmers worden ingesteld waineer er schade wordt onderwonden als gevolg wan een onrechtmatige daad. Dit kan het geval zijm geruime tijd nadat het overheidsbesluit is genomen. $\$ 4$

Het gegeven is duidelijk, de regel wellicht iets minder helder. Vraag blüft of de door de burgerlijke rechter stelselmatig gekozen en gehanteerde regel van formele rechtskracht voor de afbakening van de rechtsmacht van de civiele en de administratieve rechter inderdaad de meest toepasselijke regel is.

In dit verband moet de verzuchting van A-G Koopmans met betrekking tot de effectiviteit van de rechtsbescherming worden aangehaald: "Wij zouden er eens over moeten denken naar welk stelsel van rechtsbescherming wij eigenlijk toe willen. ${ }^{35}$

54. Th.G. Drupsteen, Frank Bolsius: administratieve en civiele rechtsgang, in: AA 1990, 7/8, p. 461 .

55. A-G Koopmans bij HR 18 december 1992, NJ 1994, 139 m.nt. MS (Kuunders-Stichting Natuur en millieu), p. $56 \mathrm{j}$, r.k. 


\section{Oorsprong, herkomst en evolutie van de begrippen formele en materiële rechtskracht in Duitsland}

\subsection{Inleiding}

Om inzicht te krijgen in 'de stand van zaken' met betrekking tot formele en materiële rechtskracht, wordt hier ingegaan op de vraag waar de begrippen vandaan komen, welke is de oorsprong en de herkomst ervan? Wat is de ratio van deze begrippen? Vanuit verschillende gezichtspunten kan dit onderzocht worden. Zo ligt een historische benadering evenzeer voor de hand als een rechtsvergelijkende; de geschiedenis van de begrippen wijst immers naar Duitse en Franse bronnen."

We zullen zien dat de beide begrippen in Nederland zijn geïntroduceerd op basis van het Duitse, civielrechtelijke, Rechtskraftbegrip. De Jong inwentariseerde de bronnen hierwan en ik heb de door hem uitgezette sporen gevolgd. Vanaf de introductie in Nederland is er hier een eigen ontwikkeling. In dit hoofdstuk wordt ingegaan op het vervolg van de, inmiddels zeer van hier verschillende, rechtskrachtdiscussie in het na-oorlogse Duitsland; hierover repte De Jong immers niet. Deze Duitse discussie resulteerde in (nog) verfijnder begrippen en uiteindelijk ook in (bonds)wetgeving.

Tenslotte nog een opmerking. Het is mogelijk dat deze analyse onvoldoende recht doet aan de opvattingen van geleerden die onder een andere beïnvloedingslijn hebben gestaan (met name het Franse recht) zoals Van der Burg of Konijnenbelt en eveneens, maar in mindere mate, De Jong.

\subsection{Herkomst en oorsprong in Duitsland}

6.21 Herkomst en oorsprong van de indeling wan rechiskrach in formele en materiele rechtskracht

In de hedendaagse Duitse literatuur wordt keer op keer geconstateerd dat de indeling in formele rechtskracht en materiële rechtskracht voortkomt uit de indeling in het civiel procesrecht van kracht en gezag wan gewijsde van vonnissen. Die discussie speelde in Duitsland met name aan het eind van de vorige eeuw. De namen van Bernatzik ${ }^{2}$, Mayer ${ }^{3}$

1. De Jong bespreekt dit uitwoerig. Hij werwijst o.a. naar Jeze, Alibert en Delbez, maar geeft ook atan dat van directe beïnvloeding uit Franse bronnen minder nadrukkelijk sprake is. Vgl. J.P. de Jong, Besiuurstecht van wreemde herkomst, diss., Zwolle $1988, p 91$ en 132 e.v.

2. Vgl. E. Bernatzik, Rechtsprechung und materielle Rechiskraft, Neudruck der Ausgabe Wien 1886 , Aalen 1964, die alls eerste Duitse auteur de term rechiskracht hanteerde. 
en Tezner zijn hiermee verbonden; zij legden via hun Rechtskraftbegrip een werbinding met administratieve rechtspraak. Donner verwees naar de discussie in zijn proefschrift. De Jong beschreef haar in zijn dissertatie. ${ }^{6}$

Soms kent de onderzoeker de wens om verder in de geschiedenis terug te gaan. Dat is precies wat Bernatzik (1886) deed. Hij maakte zichtbaar dat en waarom rechtskracht in het publiekrecht in het Romeinse recht niet te herkennen is:

\begin{abstract}
"Aus der rechtlich vollich unbesclyrankten Macht der romischen Magistrate, die ihren tieferen Grund in dem gatnzlichen Aufgehen der Person und Interessen des eimzelnen Butgers im Staatsinteresse findet, folgt mit Notwendigkeit, das das im romischen Privatrecht zu hoher technischer Vollendung gelangte Institut der materiellen Rechtskraft im offentlichen Recht nicht zur Entwicklung kommen konnte. (..)

Es ist daher begrefflich dass uber die materielle Rechtskraft im offentichen Recht in den Rechtsquellen Nichts zu finden ist."
\end{abstract}

Ontwikkeling van het rechtskrachtinstituut in het publiekrecht is aldus afhankelijk van het aan banden leggen van overheidsmacht. Pas wanaf de opkomst wan het rechtsstaatconcept (als resultaat van machtenscheiding) is het vraagstuk dan ook voonwerp wan studie en debat. ${ }^{8}$ Deze wetenschap is belangrijk, want Bernatzik leert ons daardoor dat rechtskracht er pas is als er ook bevoegdheden zijn; zo wordt rechtskracht als eigenschap aan bevoegdheden verbonden. Bernatzik constateert dan ook als eerste rechtskrachtverschijnselen: de eenzijdige (dwangmatige) uitwoering van de door een bevoegd orgaan opgelegde maatregel in het publiekrecht en de privaatrechtelijke uitwoerbaarheid van de rechterlijke bevelen (de administratieve rechtspraak moest vanzelfsprekend nog tot ontwikkeling komen).

\footnotetext{
"Was bisher eine gesetzliche Regeling fand, war nur die Zwangsvollstreckung behördlicher Administratiwakte. Diese ist historisch uberall die erste Form gewesen, in welcher sich die rechtlichen Wirkungen slaatlicher Jurisdiktion geaussert haben. Man kann denselben Entwickelungsgang, (...) im Privatrecht,
}

3. Vgl. O. Mayer, Zur Lehre von der materiellen Rechtskiaft in Verwaltungssachen, in: Archiv des offentlichen Rechts, 1907, S. 1-71.

4. Vg1. Tozner, Das Rechtskraftproblem im Verwaltungsrechte, een verhandeling in drie delen, in: Verwaltungsarchiv 1911 , S. 128-166 en $442-485$ en 1912 , S. 102-138.

5. Vgl. A.M. Donner, De rechtskracht wan administratieve beschikkingen, diss., Alphen a/d Rijn 1941, p. 15.

6. Vgl. J.P. de Jong: "Het begin wan het Rechtskraftebat' in: Bestuurstecht wan vreemde herkomst, diss., Zwolle 1988, p. $117 \mathrm{e} . \%$.

7. E. Bernatzik, Rechisprechung und materielle Rechtskraft, Neudruck der Ausgabe Wien 1886, Aalen 1964, S. 97.

8. Vgl in deze zelfde zin $\mathrm{H}$. Hemmrich in de inleiding van zijn dissertatie: 'Da nur in einem wohlgeordneten Rechtsstaat, wo die Kompetenzen des Staates gegenuber den Untertanen genau won einander abgegrenz: sind, von einer eigentichen Rechtskraft der verwaltungsgerichtlichen Entscheidungen gesprochen werden kann...", in: Die Rechtskraft der verwaltungsgerichtichen Entscheidungen und der Verwaltungsakte, diss., Koln 1929, S. 12 
speziell im römischen, ziemlich genau verfolgen. Auch im römischen Recht gab es ursprunglich nur die wollstreckburkeit richtlicher Befele."

De discussie over het rechtskrachtbegrip begint, zoals Bernatzik aangeef, bij het begrip 'materielle Rechtskraft'. Moest een 'litis finiri oportet' aan de rechtspraak (van priester, later koning en rechter) ontbreken, "so wäre er zwecklos. ${ }^{.10}$ Eenzelfde materiële rechtskracht als de civiele uitspraak moest ook de administratieve uitspraak hebben, vond Bernatzik. Het vraagstuk van de 'materielle Rechtskraft' in het publiekrecht kont zodoende voort uit de rechtspraak in civilibus.

"Mit diesem Schritt nach vorwarts sehen wir uns aber sofort auch in die Lage versetzl, die materielle Rechtskraft nicht mehr auf das Gebiet Privatrechts beschranken zu konnen. Denn die Rechtsprechung in affertlichen Recht (und dass es eine solche gibt und geben muss, glaube ich nachgewiesen zu haben) nuss wid jede Rechtsprechung Erzielung möglichster Rechtssicherheit und okononisches Gebahren mit den Kartten der rechtsprechenden Organe zum Zwecke haben. 11

Later, in 1907, nuanceert Mayer. Hij stelt dat rechtskracht de eigenschap is van het gerechtelijke oordeel, het 'Urteil'. Mayer laadt daardoor de - in de ogen wan Bernatzik - verdenking op zich dat rechtskracht ook de eigenschap van een beslissing van een bestuursorgaan kon zijn, dat immers bevoegd is tot (ook) het afgeven van een oordeel. Mayer bevestigt dat niet, maar twijfelt wel. Hij stelt het aldus:

'Die Rechtskraft nehmen wir wahr an unserem gerichtichen Urteill als eine diesem zukonmende EigenSchaft. Und zwar ist sie eine ihm ausschliesslich zukommende Eigenschalt, dh. sile findet sich zwar nicht notwendig bei jedem Urteil, findel sich aber jedenfalls bei keimer anderen Art von Rechtsakt als bei dieser. Insofern ist sie eire das Urteil auszeichende Eigenschaft.

Um uns die verschiedene Eigenschafen des Urteils zu vergegenwartigen, werden wir naturgemass vor allem die Bedeutung ins Auge fassen, welche es hat auf seinem ursprünglichen Boden, in Zivill- und Strafprozess." 12

In zijn bekende Handboek Deutsches Verwaltungsrecht uit 1924 is Mayer iets explicieter:

'Der Verwaltungsakt kann, auch ohne ungultig zu sein, aufgehoben, sbgeandert oder sonst beeintrachtigt werden durch neue Verwaltungsakte. Solange nichts dergleichen uber ihn gekommen isti, ubt er die bindende Kraft des obrigkeitlichen Einzelaktes, wie das rechtskaftige Urteil Er bestimm fur den. Uber welchen er ergeht, was dieser soll and darf: 13

9. E. Bernalzik, Rechtsprechung und materielle Rechiskraft, Neudruck der Ausgabe Wien 1886, Aalen 1964,

S. 1 lli.

10. E. Bernatzilk, Rechtsprechung und materielle Rechtskraft, Neudruck der Ausgabe Wien 1886, Aaten 1964, S. 112 .

11. E. Bernatzik, Rechisprechung und materielle Rechtskraft, Neudruck der Ausgabe Wien 1886, Aalen 1964, S. 113 .

12. O. Mayer, Zur Lelvre von der materiellen Rechtskaft in Verwaltungssachen, im: Archiv flu offentliches Recht 1907, S. 19.

13. O. Mayer, Deutsches Verwaltungstecht, Erster band, Munchen und Leipzig 1924, S 96. 
En tegelijkertijd, verderop:

'Das Wort Rechtskrafti wird mannigfach verwendet, um die wirksamkeit von willenserklarungen auf dem Boden des rechtes zu bezeichnen. Und zwar handell es sich dabei - wenn auch dazwischen einmal von rechtskaftigen Vertugen oder Testamenten geredet wird-wesentlich wh obrigkeitliche Willenserklänngen: Rechtskaft won Gesetzen, Verordnungen, Gemeindebeschtissen, Enteignungsaussprilchen, Polizeiverfügungen. Sein scharfes wissenschaftiches Geprage hat der Begriff aber erst erhalten in Zusammenhang des ProxeBrechis, in der Lehre won der res judicata, dem rechtskiaftigen Unteil. Damit alle in haben wir es: zu tun; alle andere Verwending des Wortes geht uns nichts an."14

Tezner (1911) breidt de eigenschap rechtskracht expliciet uit over "Verwaltungsakte", al doet hij dat via een omweg: hij geeft zijn mening over wat Bernatzik bedoeld zou hebben:

Bernatzik war (...) der erste, der mit ener nicht zu uberbietenden Entschiedenheit die Rechtskraft des Verwalungsakts als eine auch die Verwaltung dauend bindende Kraft bestimmte. ${ }^{35}$

Zeker is dat Tezner daarmee Bernatziks woorden niet letterlijk heeft aangehaald, maar zijn eigen opvatting in Bernatziks woorden leest, omdat Bernatzik in 1886 (het moment waarop Bernatzik over rechtskracht schreef) het begrip Verwaltungsakt (dat weer van de hand vant Mayer afkomstig is) niet als dusdanig hanteerde. Bematzik sprak van 'Entscheidungen" of "Verfugungen', waarvan louter de eerste (als rechterlijk besluit aan het 'Urteil" verwant) de eigenschap rechtskracht konden bezitten. Hier zit de logica die Mayer blootlegt': de 'Entscheidung ${ }^{*}$ is constitutief, bewat een rechtsvormend oordeel en dat is de kern waar rechtskracht aan wastgeknoopt wordt. ${ }^{16}$

"Die juristische Konstruktion, die damit gemeint ist, kommt zum Ausdruck in der alten Formel: res judicata jus facit. Die materielle Rechtskraft ist "die Eigenschaft des Urteils, Recht zu schaffen". Sie ist die "zautoritatiwe normierende Gesetzesanwendung'. Das Urteil wirkt durch diese seine normierende Kraft fur Einzelfafle ahnlich wie das Gesetz allgemeinar wirkt. "Die staatlich rechtsbestimmende Kraft' ist es, was das Urteil 'mil dem Gesetze gemein hat'. Das rechtskraftige Urteil wind geradezu als "lex specialis' bezeichnet."17

14. O. Mayer, Deutsches Verwaltungsrecht, Erster Band, Munchen und Leipzig 1924, S. 162.

15. F. Tezner, Das Rechtskrafiproblem im Verwaltungsrechte, in: Verwaltungsarchiv 1911, S. 132

16. Vgl. de dethitic van Bernatzik: 'Der Begriff der 'Entscheidung' ist auf allen Rechtsgebieten einer wnd dersebe. Jede Entscheidung besteht aus einem Schlusse, und da jeder llogische Schluss seine Pramissen haben muss, so wird die Frage nach der bindenden Kraft dieser Prämissen mit dem Momente entstehen, da die materielte Rechtskraft der Entscheidung selbst entsteht. ${ }^{2}$ E. Bernatzik, Rechisprechung und materielle Rechtskraft. Neudruck der Ausgabe Wien 1886, Aalen 1964, S. 154.

17. O. Mayer, Zur Lehre won der materiellen Rechtskraft in Verwaltungssachen, in: Archiv fur offentliches Recht, 1907, S. 22. 


\section{2 .2 Het verloop van de discussie}

Begin deze eeuw verandert de discussie, aldus De Jong. Daarmee is de naam van Kormann ${ }^{18}$ gemoeid; Fleiner ${ }^{19}$ en Jellinek ${ }^{20}$ bleven bij de oudere uitgangspunten. Ook werden er al pogingen tot codificatie van het bestuursrecht voorbereid.

Het begrip 'Verwaltungsakt' had inmiddels zijn plaats veroverd en stond tegenover het 'Urteil" (als rechterlijke beslissing). Mayer trok een parallel met de Franse 'acte administratif' en voegde de verschillende benamingen ('Verfügungen", 'Entscheidungen') samen tot de 'Verwaltungsakt".

Kormanm, de schematicus, zag in 1910 'Rechtskraft' expliciet als eigenschap van alle publiekrechtelijke rechtshandelingen ('rechtsgeschäftiche Staatsakte'). Kormann onderscheidde een 'vierfachen Begriff des Verwaltungsakts". Naast de "Verwaltungsakt in weitesten Sinn' noemde hij de 'Verwaltungsakt im weiteren Sinn", die zichtbaar wordt wanneer van het uitgebreidste begrip de privaatrechtelijke en de "rein tatsăchlichen Akte" worden afgescheiden. De derde categorie is die van de "Verwaltungsakt im engeren oder eigentlichen Sinn'. Deze categorie wordt gevormd door de 'rechtsgeschäftliche Verwaltungsakt' (rechtshandelingen met beoogd rechtsgevolg) die is ontstaan door afzondering van de 'Rechtshandlungen' (rechtshandelingen zonder beoogd rechtsgevolg) uit het wijdere begrip. Tenslotte is er de categorie van de 'Verwaltungsakt im engsten Sinn', het begrip zoals dat door Mayer wordt gebruikt, aldus Kormann. ${ }^{22}$ De eerste categorie is zozeer vervluchtigd dat het begrip zinloos is. De tweede categorie is een verzamelbegrip en heeft weinig praktische betekenis. Het vierde begrip kan Kormann niet bekoren:

'Umgekelurt kann ich aber anch dem Begriff im engsten Sinn, dem Mayerischen Verwaltungsakt, keinen allzugroben Wert beimessen, weill er aus dem Zusammenhang gleichartiger Erscheinungen herausgerissen und dadurch der Moglichkeit einer Enklärung durch diese entzogen ist." ${ }^{23}$

Zadoende is het begrip van de 'Verwaltungsakt im eigentlichen Sinn' verdere studie waard, stelt Kormann en hij ontwikkelde een rechtskrachttheorie in oppositie op 0.a. Ber-

18. Vgl K. Kormann, System der rechtsgeschafulichen Staatsatiten, Verwaltungus- und prozeBrechthiche Untersuchungen zum alfgemeinen Teil des offentlichen Rechts, Berlin 1910; hier werd gebruik gemalkt wan de Manuldruck uit 1925.

19. Vgl. F. Fleiner, Institutionen des Deutschen Verwaltungstechts, 8.Aufl., Tubingen 1928.

20. Vgl. W. Jellinek, Gesetz, Gesetzesanwendung und Zweckmassigkeitserwägung, Tabingen 1913.

21. Vgl de definitie van Mayer zelf: "Die Rechtseinrichtung, die das bewirkt, ist der Verwalungsalu, ein der Verwaltung zugehörger obrigkeithcher Ausspruch, der dem Untertanen im Einzelfall bestimmt, was fur ihn Rechtensi sein soll.' in: O. Mayer, Deutsches Verwaltungsrecht, Erster Band, Milnchen und Leipzig 1924" S. 93 Wanneer Mayer spreekt van het 'gerichtliche Unteil', dan ziet hij dit als het vorgibeld wan de 'Verwaltungsakt' (S. 93); wanneer hij spreekt van 'Verfugungen' dan worden deze gezien als "polizeilich" (S. 97), "Entscheidungen" als 'richterlich" (S. 99-100). Zie ook: J.P. de Jong, Bestuursrecht van vreemde herkomst, diss, Zwolle 1988 , p. 36-39.

22. Vgl. K. Kormann, System der rechtgeschafthchen Staatsakte, Berlin 1910, S. 26

23. K. Kormann, System der rechisgeschaftichen Statsakte, Berlin 1910, S. 27. 
natzik en Tezner, die hij als exponenten van 'das alte System' ${ }^{24}$ ziet. Aan zijn rechtskrachtheorie hechtte hij een uitwoerige nulliteitenleer.

Achteraf kunnen we vaststellen dat het Verwaltungsakt-begrip van Mayer het heersende is geworden. Tegelijkertijd is rechtskracht steeds duidelijker (tegen de visie van Mayer in) gelabeld als eigenschap wan het constitutieve element (het 'Urteil') en zo sluipt het het bestuursrecht binnen. Gesteld kan worden dat Kormann de wegbereider is geweest voor de opening van de discussie in deze richting. Door onderscheid te maken in de rechtskracht van 'Rechtsgeschäft' en 'Rechtshandlung' en de afwijzing van het 'alte System", verbreedde hij de toepassing van rechtskracht. Kormann had veel verwarring (die overigens pas later is ontstaan) kunnen voorkomen door aan zijn 'Rechtskraft-begrip een nieuwe term, een nieuwe naam te verbinden; dan was immers zichtbaar geworden dat er verschil is in rechtskracht van rechterlijke uitspraken en van beschikkingen. Hij deed dit niet, zodat de discussie na hem steeds met beide elementen verband bleef houden. Wat men dan precies op het oog heeft (elementen van rechterlijk handelen of van besiuurlijk handelen) en de relatie daarvan met rechtskracht, is in zo'n debat steeds schimmig.

De discussie in Duitsland spitst zich daarna toe op de vraag welke besluiten (dat constitutieve element in zich dragen en daardoor) rechtskracht hebben. Kormann is de mening toegedaan dat zowel 'Entscheidungen' als 'Verfugungen' constitutief kunnen zign, en hij bestrijdt 'der strengsten Scheidung' die Bernatzik aan zijn theorie ten grondslag legt. ${ }^{25}$

Beetschen (1923) beschouwt de 'Verfugung' als eenzijdige wilsverklaring van overheidswege voor het concrete geval: 'Die Verwaltungsverfugung ist demnach eine einseitige, obrigkeitliche Willenserklärung für einen konkreten Einzelfall. ${ }^{26}$ Rechtskracht is daarbij een tweeledige eigenschap, die zowel op verbindendheid als op onveranderlijkheid ziet.

\footnotetext{
Jeder rechtsgeschaftliche Staatsakt ist eine Anwendung abstrakter Rechtsnormen erfolgende staatliche Willensbetsigung an einem Einzeltatbestand. (..)

Oberall, wo cine soliche Konstellation auftrit, besteht Gelegentheit zu einem eigenartigen Zusammenwirken zweier verschiedener Bündungen des stattlichen Willens, - der Verbindlichkeit einerseits und der Unanderlichkeit andererseits. Eine Synthese dieser zwei Bindangen in eadem re ergibt als Wirkung materielle Rechiskratt." 27
}

24. Alhowwel Kormann afziet van een uitwoerige bespreking van zijn kritiek op andere systemen, moeien zij het averigens allen ontgelden. Hier is het echter van belang zijn eigen systeem te volgen.

25. Vgli. K. Kortuan, System der rechisgeschaftichen Staatsakte, Berlin 1910, S. 73.

26. B. Beetschen, Die materielle Rechtskraft der Verwaltungsverfügungen unter Bericksichtigung der bundesrechtlichen Praxis, Zurich 1923, S. 15.

27. B. Betsehen, Die materielle Rechtskifft der Verwaltungsverfugungen unter Berucksichigung der bundesrechtlichen Praxis, Zurich 1923, S. 23. 
Coester (1927) benadrukt de zienswijze van Mayer ${ }^{28}$ Rechtskracht ziet Coester als een werking van de Staatsakt. Rechtskracht is daarbij een Inhaltswirkung.

"Von einem Staalsakt geht in zweifacher Weise Wirkung aus: einmal wom Staatsaktinlaalt, sodann won der Staatsakttatsache. Die beiden großen Gruppen von Inhaltswirkung sind, wie noch zu zeigen sein wird, die Verbindlichkeit und die materielle Rechtskraft, ihnen steht gegenuber die Gruppe der sog. "Tatbestandswirkungen', dil.h. der Folgen, die der Gesetzgeber an die Staatsakututsache kulpft. ${ }^{29}$

Fleiner (1928) beschouwt rechtskracht als een eigenschap van beschikkingen (Staatsakten, daaronder vallen bij hem 'Entscheidungen' en 'Verfugungen"), ${ }^{30}$ al ziet hij nadrukkelijk de Verfingung als de constitutieve, eenzijdige beschikking.

Hemmrich (1929) benadrukt het bestaan van rechtskracht van "Verwaltungsakte" (dat wil zeggen 'Entscheidungen' en 'Verfügungen') en ziet de oorsprong van de eigenschap in de rechtszekerheid:

"Aus vorstehenden Ausführungen lässt sich m. E in Interesse der Rechtssicherheit nur der Schluss ziehen, dass man die Rechtskraft der verwaltungsgerichtlichen Entscheidungen anerkennen muss. Man brauchut nicht einmal soweit zu gehen, wie es Bernatzik (...) wut, undem er die Rechtssicherheit geradezu fur den Zweck der ganzen Rechtssprechung erklärt. Er ist der Autor des Satzes, "dab die Rechiskraft Anwendung des Gesetzes der Kausalitat auf dem Gebieit der Rechtsprechung ist". ${ }^{31}$

Daarbij wordt, in nawolging van Mayer, de rechtskracht van de 'Entscheidungen' direct afgeleid van de civiele 'Unteile", terwijl Hemmrich ten aanzien van de rechtskracht van 'Verfugungen' de formele rechtskracht aanneemt, maar twijfelt over de materiële rechtskracht. ${ }^{32}$

Jellinek (1948) benadwukt dat het Verwaltungsakt-begrip van Mayer te eng is (zeker wanneer daarmee tot uitdrukking gebracht moet worden dat in elke 'Verwaltungsakt' 'das Urteilsmåßige' tot uitdrukking komt) en spreekt zijn voorkeur uit woor het begrip 'Staatsakt'. Maar tegelijkertijd geeft hij aan dat het spraakgebruik zeker voor wat betreft het onderdeel 'Hoheitsakte' wel steeds van Mayers definitie uitgaat. De belangrijkste vraag ziet Jellinek echter als de wraag naar de 'Kraft des Verwaltungsaktes'. De Verwaltungsakt is behept met "mindestens die Vermutung der RechtmäBigkeit und Gultigkeit'. "Wat betekent dan die (on)geldigheid bij Jellinek:

28. Vgl. R. Coester, Die Rechiskraft der Staatsakte, Múnchen und Leipzigg 1927, \$. 32-33.

29. R. Coester, Die Rechtskraft der Staatsakte, Munchen uind Leipzig 1927, S. 34.

30. Vgl. F. Fleiner, Institutionen des Deutschen Verwaltungstechis, 8.Aull., Tubingen 1928, S. 180-214

31. H.Hemmrich, Die Rechtskraft der verwaltungsgerichthchen Entscheidungen und der Verwaltungsakte, diss., Koln 1929, S. 64.

32. Vgl. H.Hemmrich, Die Rechtskrat der verwaltungsrechtlichen Entscheidungen tund der Werwalungsakte, diss., Koln 1929, 5. 81184, insb. 83.

33. W. Jellinek, Verwaltungsrecht, 3. Aun. Offenburg $1948, \$, 246$. 
Unter Gutigkeit eines Verwaitungsaktes versteht man dessen unbedingte Wirksamkeit. Dies ist der Fall bein fehlerlos zustande gakommenen Verwaltungsakt und dem vielleicht bedauerlichen, aber in der Verwaltungsrechswissenschaft nun einmal eingeburgerten Sprachgebrauch nicht einfach soviel wie nicht unbedingte Wirksamkeit. Sowohl der sehlechthin unwirksame als auch der bedingt umwirksame Venwalturngsakt ist also 'ungthlig'. (...)

Die Hauptunterscheidung der Ungultigkeit ist die in Unwirksa mkeit einerseits, Anfechtbarkeit, Widerruflichlueit andererstits.

Unwirksamkeit ist die von sich aus bestehende Unbeachlichkeit eines Verwaltungsaktes. (..) Innerhalb der Unwirksamkeit kan man wieder Starkegrade unterscheiden. (...)

Anfechbarkeit bedeutet in Gegensatze zum privatrechtlichen Sprachgebrauch nichteinfach Unwirksamwerden eines Verwaltungsakts auf eine Anfechtungserklarumg hin, sondern die Pflicht einer Behörde zur Aufheburig eines dem einzelnen ungunstigen Verwaltungsaktes auf dessen Antrag. In einem weiteren. Sinne nernt man schon die Moglichkei, eine Behörde zur Prufung eines Verwaltungsakts zu zwingen in der Erwartung, er werde ihn aufheben, Anfechtbarkeit des Aktes.

Widerruflichkeit endlich ist die Moglichkeit der Zurucknahme eines Aktes, vor allem eines begunstigenden Akfes gegen den Willen des Begunstigten..34

Omdat Jellinek een voorkeur heeft voor het hanteren van de term 'Staatsakt' in plaats van "Verwaltungsakt" kan hij ten aanzien van gevolgen tot verdere onderscheidingen komen:

\begin{abstract}
'Da laBt sich zundehst als Erfahrungssatz aussprechen, dab' Unwirksamkeit die typische Fehlerfolge bei der Verordnung und der statutarischen Worschrift ist, wahrend Gesetzwidrigkeiten beim Erlasse von Verwaltungsakten meist nur deren Anfechtbarkeit oder" Widerruflichkeit zur Folge haben. Der grund hierfur liegt in der Losgelostheit der Verordnung und statutarischen Vorschrift der Wirklichkeit. Der gesetzwidrigen Verordnung und statutarischen Vorschrift steht die Mangelhaftigkeit auf der Stirn geschrieben, den gesetzwidrigen Verwaltungsakt deckt vielfacly ein möglicher Tatbestand. $\$ 5$
\end{abstract}

De 'Kraft des Verwaltungsaktes' bespreekt Jellinek uitdrukkelijk naast de 'Rechtskraft des Urteils', alhoewel hiij dat ook weer koppelt aan het Urteils-element van Verfugungen. Zo houdt ook hij het onderscheid van Mayer in stand.

\title{
6.2.3 Resumé
}

Resumerend kan een aantal kenmerken en onderscheidingen van de start van de discussie in Duitsland worden aangegeven. De discussie start bij het begrip 'materielle Rechtskraft' en ziet dat als eigenschap van rechterlijke vomissen. Vervolgens wordt scherp dat de eigenschap is vastgeknoopt aan het element 'Urteil' van die vonnissen. Daarmee is de theoretische overgang naar een eigenschap van ook besluiten van bestuursorganen gezet, ondat ook deze de potentie kunnen hebben om oordelen te geven. De discussie spitst zich dan toe op de vraag welke beslissingen van bestuursorganen dat constitutieve element, dat 'Urteil', bevatten. Dat 'Urteil' is bij de verschillende typen beschikkingen anders; sommigen zien dat 'Urteil' bij 'Verfugungen', anderen bij 'Entscheidungen', weer anderen helemaal niet of juist bij beide.

34. W. Jellinek, Verwaltungsrecht, 3. Anfl, Offenburg 1948, S. 262.

35. W. Jellinek, Verwaltungsrecht, 3. Aul1, Offenburg 1948, S. 262-263. 
Wat houdt dat element 'Urteill' dan eigenlijk in? Het is een procesrechtelijk verschijnsel dat pregnant tot uitdrukking komt bij uitspraken. Als je de beschikking ziet als een publiekrechtelijke rechtsvaststelling, dan bevat deze ook dat element 'Urteil'. Dat nu is precies wat Kormann op het oog had toen hij 'Rechtskraft' als eigenschap van alle publiekrechtelijke rechtshandelingen duidde.

Het begin van de discussie in Duitsland, in het bijzonder de vergelijking vonnis en beschikking en het zoeken naar het element 'Urteil', is verkenmender en wellicht dogmatischer van aard dan de latere discussie inzake welk type beschikking dat 'Urteil' (en daarmee ook rechtskracht) zou bevatten.

\subsection{De na-oorlogse rechtskrachtdiscussie in Duitsland}

\subsection{Inleiding}

De na-oorlogse rechtskrachtdiscussie in Duitsland is niet stil blijven staan. De vraag of rechtskracht aangenomen moet worden als eigenschap van beschikkingen is inmiddels naar de achtergrond gedrukt. De begripsvinding wordt verfijnder, genuanceerder.

Vanaf 1956 makt Wolff het belangrijke onderscheid tussen "Rechtskraft" en 'Bestandskraft". Uiteindelijk is men ertoe overgegaan om regels met betrekking tot de "Rechtskraft' en de "Bestandskraft von Verwaltungsakten" in de (bonds)wetgeving neer te lleggen (zie bijlage).

\subsection{2 'Bestandskraft' en 'Rechtskraft'}

Jellinek zag, als gezegd, verschillen in de rechtsgevolgen van de verschillende beschikkingen, doordat hij de 'Staatsakt' als uitgangspunt nam van zijn analyse. Zo inspireerde hij Wolff die uitging van het verschil in feitelijke en rechtswerkelijkheid en onderscheidde in 'Tatsache', 'Tatbestand' en 'Rechtsfolgen'. Elke normering wordt gekenmerkt door de bekende drieslag: er zijn feiten, deze moeten voldoen aan bepaalde voorwaarden, zodat een rechisgevolg kan intreden. Waarom moeten ze voldoen aan de voorwaarden? Ondat de norm dat aangeeft. Kort gezegd zijn dan de feiten 'Tatsachen', de voorwaarden of toepassingscondities het "Tatbestand" en de rechtsgevolgen de 'Rechtsfolgen'. Daaraan verbond Wolff in 1956 een nieuw onderscheid: dat van de 'Rechtskraft' en de 'Bestandskraft van Verwaltungsakten". Dit behoeft toelichting.

'Tatsachen' zijn feitelijke omstandigheden, die zowel buiten de menselijke wil om gelegen kunnen zijn, als er binnen kunnen vallen, als gecombineerd kunnen woorkomen. Deze comm binatie (de mens als veroorzaker van feiten) levert handelingen op. Ook in deze handelingen wordt weer onderscheid gemaakt, want er zijn zowel die handelingen waaraan rechtsgevolgen worden vastgeknoopt ongeacht de will van degene die handelle ("Rechtshandlungen') als ook die waaraan beoogd rechtsgevolg wordt vastgeknoopt ('Rechtsgeschäfte', die wij in Nederland als rechtshandelingen aanmerken). De "Rechtsgeschäfte" kunnen dan weer 'Privathandlungen', 'Zivilhandlungen' en 'hoheitliche Handlungen' omvatten.

Het 'Tatbestand' bestaat in de feitelijke werkelijkheid. Rechtsgevolgen worden door het objectieve recht vastgelegd. Het objectieve recht koppelt aan die feitelijke toestand of 
omstandigheid (dat is het 'Tatbestand") de rechtsgevolgen. Het 'Tatbestand' bestaat daarom u it verschillende feitelijke omstandigheden: de 'Tatbestandmomenten'. Voorzover de 'Tatbestandmomente" geen invloed uitoefenen op de rechtsgevolgen, heten ze "leerlaufend". Voorzover de rechtsgevolgen afhangen van de feitelijke omstandigheden, heet het 'Tatbestand' 'rechtsfolgbegrindend', maar 'Die Tatbestandmomente sind rechtsfolgbedingend, insofern sie für den Eintritt der Rechtsfolge zwar notwendig aber nicht hinreichend sind. Wenn zwar nicht die RechtmäBigkeit aber die Wirksamkeit der Rechtsfolge von ihnen abhångt, werden sie 'Wirksamkeitsvoraussetzungen' genannt". ${ }^{36}$

'Verwaltungsakte' zijn in de visie van Wolff concrete (want op een individueel 'Sachverhalt" betrekking hebbende), extern werkende (omdat ze 'Gewaltverhältnisse' regelen), op het 'hoheitliche Verwaltungsrecht' gebaseerde (en daarmee uitvloeiselen van de wet) "Verwaltungs-Rechtshandlungen'. Wanneer 'Verwaltungsakte' zich richten op alle door het concrete 'Sachverhalt' bestemde subjecten, heten zij 'Allgemeinverfigungen' en wanneer "Verwaltungsakte" speciaal, dat wil zeggen gericht zijn tot een enkel subject, dan heten zij "Verfugungen, Entscheidungen, gestaltende Verwaltungsakte" ${ }^{37} \mathrm{Zij}$ zijn nimmer privaatrechtelijk, maar ook niet echte 'öffentlichen Rechtsgeschäften'. De reden daarvoor is dat de 'Verwaltungsakt', aldus Wolff, deels

\footnotetext{
"eine Institution des Verwalungswerfahrensrechtes ist. Das hat es nathe gelegt, ihn mit Otto Mayer in die Paraltele zum richterdichen Unteil zu rucken. Dadurch aber wird sein Bild im entgegengesetzten Sinne verzert. Zwar ist auch der Verwaltungsakt ein Staatsakt, der einen konkreten Einzelfall rechtsanwendend regelt. Er (...) gedeiht daher auch nur ausnahmsweise zur Rechtskraft und unterliegt stets gerichtlicher Nachprufung hinsichttich seiner RechtmaBagkeit. ${ }^{38}$
}

De vergelijking met de 'Rechtskraft' van vonnissen zoals Mayer die heeft blootgelegd wordt nu, aldus Wolff, verklaarbaar. 'Rechtskraft' kan immers worden onderscheiden als kracht en gezag van gewijsde van vonnissen. Voor beschikkingen van organen geldt, aldus Wolff, dat zij slechts kracht kemen (zonder gezag) en daarom in de Mayeriaanse traditie met 'Rechiskraft' werden behept. Beschikkingen kennen alleen kracht, omdat zij voortkomen uit een besluitvormingstraject. Gezag ontbreekt omdat ze steeds nog door rechters moeten kunnen worden getoetst.

Maar Wolff zegt meer, want door de "Verwaltungsakt' als 'Staatsakt' nog eens te benadrukken, geeft hij expliciet aan dat de rechtskracht ervan aan de bevoegdheid is verbonden. Al noemt hij Bernatzik hier dan niet expliciet, hij brengt wel beide lijnen (bevoegdheid en proces) bij elkaar, terwijl hij ze zorgvuldig onderscheidt. Daarom kon Wolff aan dit onderscheid het begrippenpaar 'Bestandkraft' en 'Rechtskraft' geven. Zo doet hij wat Kormann naliet.

Hoe geeft Wolff de nieuwe termen hun plaats? Onder het hoofdstuk 'Gultigkeit und Fehlerhaftigkeit' (geldigheid en gebrekkigheid) plaatst Wolff de 'Wirksamkeit' en 'Recht-

36. Vgl. H.J. Wolf, Venwalturigstecht 1, 1. Aufl, 1956, \$. 148-150

37. H.J. Wolf, Verwaltungsrecht I, 1. Auff 1956 , S. 194.

38. H. Wolf, Verwaltungsrecht I, 1. Aufl. 1956, S. 195. 
mäßigkeit" van de 'Verwaltungsakten', terwijl onder 'Geltungskraft' de 'Rechtskraft und Bestandskraft" van "Verwaltungsakten' wordt aangegeven. Wameer Wolff ingaat op de vergelijkbaarheid van 'Verwaltungsakten' met rechterlijke 'Urteilen' komt hij te spreken over de 'Rechtskraft". Daamaast is er de 'Bestandskraft', die past bij de 'Verwaltungsakte' in de non-contentieuze fase. Wolff creëert dusdoende een tweetrapsraket: 'Rechtskraft' is geînspireerd op de contentieuze aspecten en 'Bestandskraft' kent een non-contentieuze basis.

Concreet: bij ons zouden we in hoofdstuk 1 tot en met 5 van de Awb spreken van 'Bestandskraft" en zodra het contentieuze procesrecht aan de orde is, dus als de bezwaarfase een aanvang neemt (hoofdstukken 6,7 en 8 van de Awb), van 'Rechtskraft'.

Samenvattend is dan (met betrekking tot de formele en de materiele aspecten) geldigheid na verloop van de beroepstermijn (in de zin van onaantastbaarheid) 'formelie Rechtskraft". Onaanvechtbaarheid voor derden en - als uitzondering - weerstand tegen intrekking door het beschikkingnemende orgaan is 'formelle Bestandskraft'. Daarnaast is de vastliggende inhoud in het gelijke geval 'materielle Rechtskraft' en niet-herzienbaarheid of het daartoe slechts overgaan pas na aanwezigheid van nova of wijziging van de onderliggende regeling 'materielle Bestandskraft'. Wolff zegt het als volgt:

\footnotetext{
'Versteht man unter formeller Rechtskraft nichts anderers, als dab ein Staatsakt mit ordentlichen Rechtsmifteln nicht mehr angegriffen werden kann, dann gelangen auch die Verwaltungsakte zu formeller Rechtskraft - wenigstens sofern sie nicht etwa von vornherein michtig sind. (...)

Diester prozeBrechticher Begriff der formeller Rechtskraft ist jedoch fur das nicht-prozessuale Verwaltungsrecht wenig geeignet. Er setzt nämlich stillschweigend voraus, daß eine Wiederanfnahme nur auf Antrag in besonderem Verfahtren möglich ist. Die Zurlicknahme eines Verwaltangsaktes wurch die erlassende Behörde mit Wirkung ex tunc ist dagegen - mit oder ohne Antrag des Betrofienen - mitunter mbiglich. Deshalb empfiehlt es sich, mindestens fur den verwaltungsrechtlichen Bereich, den Begriff der formellen Rechtskraft enger za fassen, indem marn in ihn auch die Festigkeit (Endgulltigkeit) des (auch mangethaften) Verwaltungsaktes im formellen Sinne gegenuber der erlassenden Behorde sowie auch gegenuber eined Wiederaufnahme des Verfahrens durch diese einbegreift. (...)

Ist der Verwaltungsakt zwar unanfechtbar und von Dritten zu respektieren, von der erlassenden Behorde aber, obzwar nur ausnahmsweise, durch newen Verwaltungsakt mit Wirkung ex tunc zurucknehmbar, so kani man won seiner formellen Bestandskraft (Unanfechtbarkeit) sprechen. (..)

Unter materieller Rechtskraft versteht man (u.a.) die Maßgeblichkeit des Inhalies eines kombreten Stuatsaktes derart, dab auch in einem newen Verfahren nicht mehr in einem anderen Sinne entschieden werden kan, und zwar auch dan nicht, wenn die getroffene Entscheidung mangelhaft, unrichtig oder unzweckmabig watr. (...)

Wie Urteile, so komnen auch Verwaltungsakte nur insoweit materiell rechtskaftig werden, wie sie formell rechiskräftig geworden sind. Die formell nur bestandsmabig gewordenen Verwaltungsakle können daher auch materiell nur bestandskrafige werden. (...) Der Begriff der materiellen Bestandskraft druckt aus; das sie das kann (- die Behorde muß 3 einen fortwirkenden Verwaltungsakt erst beseitigen, EvdL) und, wenn hinreichende Grunde worliegen, sich auch ohne einen der Abanderungsklage entsprechende Antrag in Widerspruch sebzen darf mit einer froher getroffenen Regelung. (...)

Die materiele Bestandskraft deckt zwar eine falsche Beurteilung eines Sachverhaltes, nicht aber die Beurteilung eines Sachverhaltes, der nicht (mehr) vorliegt. (...)
} 
Die materielle Bestandskraft endet jedoch darn, wenn Tatsachen entfallen sind, die den Verwaltungsakt begrundet baben oder wenn Tatsachen eintreten, angesichts deren der Fortbestand des Inhalts des Verwaltungsaktes nicht melur rechumabig ist. ${ }^{\text {s39 }}$

\subsubsection{Conclusie}

Het onderscheid van Wolff is zeer belangwekkend en kan ook van betekenis zijn woor de Nederlandse rechtspraktijk. Zo onderscheidde ik all tussen de verschillende benaderingen van forme le rechtskracht. Het bevoegdheidsdenken werd naast het procesrechtelijke denken geplaatst. Het bewoegdheidsdenken komt tot uitdrukking in het door Wolff zo treffend geanalyseerde begrip 'Bestandskraft', terwijl het procesrechtelijke denken dan aanknoopt bij het begrip 'Rechtskraft'. Het zichtbaar maken en benoemen van dit onderscheid door Wolff (voor de Duitse situatie) maakt het makkelijker om datzelfde verschijnsel ook in Nederland beter te kunnen 'zien'; wij kennen immers geen met de 'Bestandskraft' vergelijkbaar begrip. Toch bestaat ook wel dat bevoegdheidsdenken en zou er dus ook hier voor 'Bestandskraft' plaats zijn; hier wreekt zich derhalve het gebrek aan een adequate term en wil ik een Nederlands equivalent 'rechtsbestendigheid' voorstellen. Daar kom ik later op terug.

Zodra we een procesrechtelijke bril op hebben, dan spreken we wan 'Rechtskraft'. Bij ons spreken we dan vaak van formele rechtskracht. De associatie van het begrip 'Rechtskraft' als een procesrechtelijk verschijnsel ('Urteil') is uiteraard een inter partes-eigenschap. De daar tegenowerstaande "Bestandskraft' moet dan inderdaad erga omnes zijn. Daaraan is verbonden het verschil in controle en rechtsbescherming.

De in Nederland bekende definitie van formele rechtskracht als rechtens vaststaand (bestuursrechter) of als 'inter partes onaantastbaarheid' (burgerlijke rechter) is vergelijkbaar met het hier geduide 'formelle Rechtskraft'. Het vaststaan van een besluit voor het bestuursorgaan, de onherroepelijkheid voor het bestuursorgaan van het besluit met erga omnes-werking (omdat het besluit eenmaal is genomen) is 'formelle Bestandskraft'. Wanneer artikel 4:6 Awb (herhalde aanvraag) in beeld kont en het in wezen gaat om de vraag of een bestuursorgaan ex tunc een foutieve beoordeling gaat dekken, dan hebben we het over 'materielle Bestandskraft'. Het ne bis in idem of (bij uitspraken van toepassing) gezag van gewijsde, waarbij we ook de precedentwerking bij de rechter voor ogen hebben, betreft dan de 'materielle Rechtskraft'.

\subsection{Huidige stand wan zaken in Duitsland}

\subsubsection{Inleiding}

Met betrekking tot de huidige stand van zaken ten aanzien van de 'Bestandskraft' van beschikkingen in Duitsland wil ik volstaan met een beknopte weergave aan de hand van handboeken, tijdschriftartikelen en dissertaties. De van toepassing zijnde (bonds) wetgeving zal worden opgenomen in een bijlage. De meer positiefrechtelijke discussies lijken voor 
ons -- want te zeer verwijderd van ons eigen stelsel - minder interessant. Een integrale inventarisatie en bespreking laat ik daarom achterwege. De vraag naar de houdbaarheid wan Wolffs onderscheid wil ik wel nagaan aan de hand van een illustratie van meningen bij de diverse auteurs.

\subsubsection{Bondswetgeving}

In het Duitse geldende recht is inmiddels de term Bestandskraft in een Bondswet, het Verwaltungsverfahrensgesetz ( VwVfG), vastgelegd. In het derde deel van deze wett (over de 'Verwaltungsakt') is het tweede hoofdstuk gereserveerd voor de 'Bestandskraft des Verwaltungsaktes' ( $\$$ 43-52). Ter illustratie wil ik aangeven dat onderwerpen als de 'Wirksamkeit des Verwaltungsaktes', 'Nichtigkeir des Verwaltungsaktes', 'Heilung von Verfahrens- und Formfehler', 'Folgen von Verfahrens- und Formfehler', 'Umdeutung eines fehlerhaften Verwaltungsaktes', 'Rucknahme eines rechtswidrigen Verwaltungsaktes', 'Widerruf eines rechtmäßigen Verwaltungsaktes', 'Rücknahme und Widerruf im Rechtsbehelfsverfahren', "Wiederaufgreifen des Verfahrens en Rückgabe von Urkunden und Sachen" daar zijn geregeld. ${ }^{40}$

'Rechtskraft' van 'Urteile' is geregeld in $\$ 121$ van de Verwaltungsgerichtsordnung (VwGO), hetgeen eveneens in de bijlage is opgenomen.

Deze codificatie heeft ook weer kritiek ontmoet, want:

\footnotetext{
"Seitdem eine gesetzliche Regelung der Bestandskraft won Verwaltungsakten geschaffen worken ist, sind" netue Fragen aufgetaucht. ${ }^{41}$
}

Deze vragen zijn aanleiding tot positiefrechtelijke discussies. Daarnaast zijn er de meer theoretische (politiek-dogmatische) discussies over de vraag of het onderscheid van Wolff in stand moet blijven. De meningen hierover lopen - zoals hierna geillustreerd wordt zeer" uiteen. Eên conclusie kan echter wel worden getrokken: de verschillen tussen 'Rechtskraft' en 'Bestandskraft' zijn toch wel van zodanige aard dat de terminologie gescheiden is gebleven.

Daarop is ook wel kritiek geuit. Het begrip zou nooit en te nimmer, ook niet door de wetgever, zijn gedefinieerd. Dat zou een en ander "schillernd" maken: ${ }^{42}$

Wenige Begrife des Algemeinen Verwallungsrechts sind so schillernd und werden in so unterschiedlichen Sim verstanden wie del Begriff der "Bestandskraft' von Verwaltungsakten. (...)

40. Voor een witvoerige beschrijving van de totstandkoming van deze regels wil ik verwijzen nar W. Klappstein, Rechtseinheit und Rechtswielfalt im Verwaltungsrecht, Dargestellt am Be ispiel der Bestandskraft won Verwaltungsakten nach dem Algemeinen und dem Besonderen Verwaltungsrecht, Inang.-Diss, Heidelberg 1994.

41. W.-R. Schenke, Probleme der Bestandskraft von Verwaltungsakten, in: Die offentliche Verwaltung, 1983, Hen 8, S. 320.

42. Dit woord betekent zotets als 'wan kleur veranderen'; verialing ervan zou wellicht het beste tot uitdrukking kummen komen met ons woord "kameleontisch". 
Auch das VwVG des Bundes und de entsprechenden Verwaltungsverfahrensgesetze der Lander, van denen man vielleicht insoweit eine Klarung erwarten băte konnen, haben hier keine Klarheit gebrach, sondem cher zu weiterer Verwirtung beigetragen. In dem mit 'Bestandskraft des Werwaltungsaktes' diberschriebenen Abschnitt des VwVfO-gleiches gilt fur die ent-sprechende Abschnitte der Verwaltungsverfahrensgesetze der Länder w finden sich Regelungen unterschiedlichster Art (..), jedoch keine Definition oder auch nur nathere Umschreibung dessen, was. unter 'Bestandskraft' eines Verwaltungsakts zu verstehen ist. Der Gesetzgeber verwendet dabei offensichtich den Begriff der Bestandskraft in einem "ganz allgemeinen umd deshalb unscharfen', untechnischen Sinn, so dab auch aus einer naheren Prufung der einzelnen Regelungen der 43 ff. VwVfG insoweit keine naheren Ekenntrisse zu gewinnen sind, was der Gesetzgeber unter Bestandskraft versteht oder was allgemein darunter zu versteheth ist. ${ }^{43}$

In ieder geval wordt de discussie over de temen sinds Forsthoff met 'ein Labyrinths der Meinungen' aangeduid. ${ }^{44}$

\subsection{3 'Bestandkraft" in handboeken}

Om te bezien welke omschrijving of definitie van 'Bestandskraft' wordt gehanteerd in Duitse handboeken heb ik gebruik gemaakt van Achterberg, Bull, Erichsen, Faber, Klein, Mayer/Kopp, Maurer, Wallerath en Wollf/Bachof.

Achterberg plaatst de 'Bestandkraft' in de paragraaf over de 'Selbstkontrolle durch die Verwaltung'. Rond het thema 'Aufhebung von Verwaltungsakten' wordt de 'Bestandkraft' besproken naast de 'Bindungswirkung'. Achterberg onderscheidt dan naast 'Rechtskraft' de 'Bestandskraft' en ook 'Bindungskraft', waarbij deze laatste 'Bindungskraft' dan duidt op het door het bestuursorgaan zelf opheffen van een beschikking.

'Dice Rechtskraft betrifft gerichtliche Entscheidungen. (...) Die Bestandskraft betrift demgegenibber behördlicher Maßnahmen. Im Iormellen Sinue bedeutet sie, daß ein Verwaltungsakt nicht metur angefochten werden kann. (...) Mit der materielle Rechtskraft ist die Bestandskraft in materiellen Sinne wergleichbar. Auch sie tritt mit der Endgütigkeil der Maßnahme aufgrund formeller Bestandskraft ein. Sie bedeutet, daB die Beteiligten des Verwaltungsverfahrens an den Inhalt eines (möglicherweise fehterhaften, nicht dagegen nichtigen) Verwaltungsakts gebunden sind, ohne dab das Verwalltangsgericht - anders als die Verwaltungs. behorde durch Erlats eines Zweilbescheids - noch eine Anderung der Rechtslage herbeifuhren könnte. Die Bindungskaraft betrift die Selbstaufhebung eines Verwalungsakts durch die Behorde. In formellen Sinne besagt sie, dab ein soleher durch die enlassende oder ibbergeordnete Behorde nicht mehr aufgehoben werden katn, weil die im Verwaltungsrecht entwickelten Grundsatze tuber die Selbstaufhebung nicht eingreifen. (...) Die Bindungskaft in materiellen Sinne bedeutet ebenso wie die materielle Bestandskraft, dab die Beteiligten an den Inhalt des Verwalungsakts gebunden sind. (..) Von der Bindungskraft ist die Bindungswirkung von Verwaltungsakien zu unterscheiden, aufgrund deren Gerichte und Behorden die Tatsachen hinnehmen mussen, daB ein Verwaltungsakt erlassen ist, falls sie nicht selbst zu seiner Aufhebung berechtigt sind. Neben der Bindungswirkung gibt es die Tatbestandswirkung und die Feststellungswirkung. (...) Von

43. F. Kopp, Die Bestandskraft von Verwaltungsakten, in: Deutsches Verwaltungsblatt 15-4-1983, S. 392, die ervoor pleit on het door Wolf in 1956 ingevoerde verschil in terminologie, tussen 'Rechtskraft' en "Bestandskratt", maar weer te laten varen en louter nog wan 'Rechtskraft' - ook van "Verwaltungsakten" te spreken.

44. Vgl. E. Fossthoff, Lehrbuch des Verwaltungsrechts $1,1966, \mathrm{~S}, 246$. 
der Bindungswirkung ist die Verbindlichkeit zu unterscheiden: Sie bedeutet nicht Bindung enthes anderen Staatsorgans, sondern solche des Betroffenen an den Verwaltungsakt. Prinzipiell besteht Verbindlichkeit gegenuber dem Adressaten des Verwaltungsakts, doch kommen auch Drittwirkungen gegenuber anderen Rechissubjekten vor. (...) Um die Durchbrechung der Bestandskraft des Verwaltungsakts handelt es sich bei seiner Aufhebung. Deren Unterfalle sind die Rihcknahme und der Widerruf? ${ }^{45}$

Bull plaatst 'Bestandskraft' in een paragraaf inzake 'Wirksamkeit, Nichtigkeit und Auf* hebbarkeit von Verwaltungsakten". In het onderdeel inzake de "Bedeutung der Wirksamkeit und Bestandskraft des Verwaltungsaktes' is hij iets specifieker:

"LäBt der Adressat bzw. Betroffene (hier derjenige, dem der VA bekanntgegeben worden ist) diese Frist werstreichen, ohne Widerspruch zu erheben (oder - in besonderen Fallen - sogleich KJage zu erheben), so wird der VA unanfechtbar (bestandskraftig). Unanfechtbarkeit oder Bestandskraft bedeutet, dab derjenige, gegenuber dem sie eintritt, keinen Rechtsbehelf mehr gegen den VA zur Verfugung hat. (...) Verwaltungsakte werden bestandskraftig, Unteile rechiskraffig. 46

Erichsen plaatst 'Bestandskraft' in het bekende De Gruyter Lehrbuch in het hoofdstuk over 'Verwaltungsverfahren'. In een paragraaf over 'Die Entscheidung' is een onderdeel opgenomen inzake de 'Bestandskraft'. Onder het kopje 'Bestandskraft oder Rechtskraft?' wordt gesteld dat enerzijds beide termen goed onderscheiden moeten worden, omdat het rechterlijk proces en het bestuurlijk proces verschillend van karakter zijn, terwijl anderzijds beide termen ook in de rechtszekerheid hun bron vinden en in zoverre aan elkaar verwant zijn.

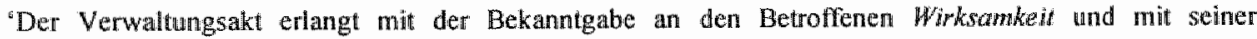
Unanfechtbarkeit Bestandskraft. Die prinzipielle Verschiedenartigkeit des Verwaltungsverfallirens und des gerichtlichen Verfahrens laßBt es nicht zu, die prozeßrechtlichen Regeln wber die Rechtskraft gerichticher Entscheidungen auf die Entscheidungs- und Bindungswitkung von Verwaltungsaktera zu ubertragen. Welchen Inhalt und welche Tragweite die einem Verwaltungsakt zukommende 'Beständigkeit' (Bestandskraft) hat, muß in Abgrenzung won der materiellen Rechtskraft gerichticher Entscheidungen im Verwaltungsrecht selbstandig bestimmt werden. (...) Der Gegenstand und die rechtliche Tragweite der Bestandskraft eines Verwaltungsaktes lassen sich nicht eimheidich for alle Rechtsgebiete und fur alle Arten von Verwaltungsakten beurteilen. Nur insofern als die Verbindlichkeit des Venwaltungsaktes hinsichtlich seines Entscheidungsgegenstandes kraft Unanfechtbarkeit eintritt, in ihren Voraussetzuingen verfahrensrechtlich bedingt und zuletzt in dem allgemeinen rechtsstaatlichen Prinzip der Rechtssicherheit begrundet ist, kann man von einer "Wesensverwandtschaft" der Bestandskraft yon Verwaltungsakten und der formellen Rechtskraft von gerichtlichen Entscheidungen sprechen. Dawon abgesehen beschrankt sich die Paralellitut darauf, da $B$ in beiden Fullen mit staatlicher Autoritat umkleidete Akte vorliegen, die selbststandige und nicht ohne weiteres wieder zu beseitigende Wirkungen fur die Beteilgten haben. (...) Die alls Bestandskraft bezeichnete Moßgeblichkeit der Entscheidung lindert den Betroffenen daran, etwaige Fohler des Verwaltungsaktes gettend zu machen und eine Änderung des Verwaltungsaktes oder eine neue Entscheidung in der Sache zu verlangen, wenn sich die dern Verwaltungsakt zugrunde liegende Sach- und Rechtlage nicht gedndert hat. (...) Die als Bestandskraft bezeichnete Entscheidungs- und Bindungswirkung des Verwaltungsaktes fur die

45. N. Achterberg, Allgemeines Verwaltungsrecht, Heidelberg 1986, S. 592-594.

46. H.P. Bull, Aligemeines Verwaltungsrecht, Heidelberg, z.j, S. 222-223. 
Behorde und die Beteiligten ist zu unterscheiden won der Bindungswirkung, die ein Verwaltungsakt in Gestait der Tabestamdswimkang und der Fegtstellwgswirkung fur andere Behörden haben kann." ${ }^{*}$

Faber bespreekt 'Bestandskraft' onder de 'Wirksamkeit belastender Verwaltungsakte' en ook onder de 'Wirksamkeit begünstigender Verwaltungsakte', 'Bestandskraft' heef een zwakkere werking dan het procesrechtelijke "Rechtskraft'. Eerst maar zijn stellingen over de belastende beschikkingen:

\begin{abstract}
"Wirksame Verwaltungsakte setzen Rechtsbehelysfristen in Lauf (...). Die Ablauf der Rechtsbehelfsfrist fuhn zur Unanfechtbarkeit; in Gegensatz zum gerichtlichen Urteil sprechen wir sicht won formeller Rechtskraft, sondern von formeller Bestandskraft. Die schwächere Wirkung der Bestandskraft aubert sich u.a. darin, dab Behơden wele Verwaltungsakte worn Amts wegen aufheben können ( 48 Abs. 1, 49 VwVFG); Gerichte dagegen sind an ithe Urteile schon vor Eintritt der formellen Rechtskraft gebunden (8 318 ZPO). Die Bestandskraft selbst ist keine unmittelbare Rechisfolge der Wirksankeit (sondern des Ablaufs einer Frist), setzt aber die Wirksankeit voraus. Ebenso verhalt es sich mit der Vollziehbarkeit. Verwaltungsakte sind in der Regel vollziehbar, wenn sie unarfechtbar sind (formelle Bestandskraft erlangt haben), fur sofort vollziehbar erklyrt werden oder wenn durch Bundesgestetz die aufschiebende Wirkung von Rechtsmitteln ausgeschlossen ist ( 6 Abs. IVwVG, $\$ 80 \mathrm{Abs} .2 \mathrm{Nr} 3$ VwGO); die Wirksamkeit ist dabei aber immer vorausgesetz; nichtige Verwaltungsakte diurfen nicht vollzogen werden. ${ }^{4: 8}$
\end{abstract}

En ten aanzien van de begunstigende beschikkingen sluit hij aan bij zijn stellingen inzake belastende beschikkingen. ${ }^{49}$

Klein plaatst 'Bestandskraft' in een paragraaf inzake 'Aufhebung und Änderung eines Verwaltungsaktes' en stelt daar dat hij met name twijfelt of er ruimte is voor 'materielle Bestandskraft'; procesrecht en materieel recht moeten daarbij uit elkaar gehouden worden.

\begin{abstract}
'Auch einen bestandskraftig gewordenen. Verwalnungsakt kann die Behörde bei entsprechender Ermáchtigung zugunsten oder zu Lasten des Betroffenen auf dessen Antrag oder von Amts wegen andern. a) Hat der Gutachter zu prilfen, ob und inwieweit die Authebung oder Anderung eines Verwaltungsaktes reclntmaiBig ist, so praft er damit, ob und inwieweit eine Durchbrechung von dessen Bestandskraft rechtmathig ist. Fur den in der Literatur wie auch in Gerichisentscheidungen bekiagenswert "schillemden" Bestandskraftbegriff, der htufig durch Unablinderlichkeit, Selbsibindung. Mabgeblichkeit und anders ersetzt wird (Kopp) (...), hat auch das VwVtG nicht Klathe it geschaffen. Keine Zweifel gibt es mehr, daß Verwaltungsakte in forntelle Destandskraft erwachsen, sobald die Rechtsbeheltsfristen abgelaufen oder die fur die konkrete Verwaltungsentscheidung gegebenen Rechtsbehelfe erschopft sind (...). Zweifelhaft hingegen bleibt, ab der Verwal. tungsakt - wie im Schritum verteten - nach formeller auch in materielle Bestandskraft (..), im Sinne einer voll ausgebildeten, Behörde und Betroffene gleichermaben bindenden Wirkung erwachsen kann. (...) b) Ob und inwieweit eine Durchbrechung der so unissenen Bestandskraft durch Anderung, oder durch deren starkste form, die Aufhebung, eines Verwaltungsaktes in Verwaltungswerfahren rechtmaBig ist, wird der Gutachter systematisch werfohrenswechtich nach der Zultssigkeit ein abgeschlossenes Verwaltungsverfahren wieder aufgreifen und materielrechtich nach den Voraussetzungen fir die Aufhebung eines Verwaltungsaktes prufen und darlegen. Wegen des engen Zusammenhanges von Verwaltungswerfahrensrecht
\end{abstract}

47. H.-U. Erichsen, Algemeines Verwaltungsrecht, Berlin/New York, 1995, S. 490-492.

48. H. Faber, Verwaltungsrecht, Tubingen 1995, S. 190-191.

49. Vgl. H. Falleer, Verwaltungsrecht, Tubingen 1995, S. 254. 
und materielem Verwaltungsrecht hat das VwVfO diesen Komplex einheitlich in die Vorschriften der $\$$ bis 52 einbezogen. ${ }^{50}$

In de paragraaf met de titel 'Der Verwaltungsakt" bespreken Moyer/Kopp de 'Wirksamkeit, Bestandskraft, Tatbestand- und Feststellungswirkung von VAen'. In een procesrechtelijke visie komt bij hen vooral tot uitdrukking dat beroepstermijnen het aanvechten van overheidshandelen ordenen; 'Rechtskraft' van 'Urteile' is in zoverre vergelijkbaar met de 'Bestandskraft' van beschikkingen.

'In Interesse der Effektivität staatlichen Handeins wie anch der Rechtssicherheit und des Rechtsfriedens ist dem Birger die Moglichkeit einer Anfechtung von VAem, die er fur fehlerhaft hatt und durch die er sich in seinen Rechten verletat fohl, nicht zeitlich unbegrenzt eroffnet, sondern an bestimmte Fristen und sonstige Voraussetzungen gebunden (...). Nach Ablauf dieser Fristen bzw nach rechiskrafliger Abweisung ciner gerichtlichen Klage gegen den VA erlangt den VA eune der Rechtskraft gerichtlicher Urteile wergleichbare formelle und iV damit id auch materielle Bestandskraft (...). Die Verwaltuing und auch die Betroffenen wissen dann, woran sie sind und konnen ihre weiteren Dispositionen entsprechend treffen, ${ }^{51}$

Mowrer plaatst de 'Bestandskraft' in het deel over 'Das Verwaltungshandeln: Der Verwaltungsakt' in de paragraaf 'Bestandskraft, Rücknahme und Widerruf von Verwaltungsakten'. Hij stelt dat 'Bestandskraft' als begrip omstreden is. De wetgever heeft het dan ook niet gedefinieerd. De achtergrond van 'Bestandskraft' is wel duidelijk: beschikkingen moeten immers verbindend en duurzaam zijn. Er zijn verschillen met het procesrechtelijke 'Rechtskraft", hetgeen de term goed aangeeft; dat wordt het beste zichtbaar bij de 'materielle Bestandskraft'.

'Der Begriff'Bestandskraft, der in der Literatur und Rechtsprechung haufig anftaucht und zuweilen geradezai als festes. Rechtsinstitut erscheint, ist mehrdeutig und umstritten. Das VwVfG hat zur KHarung nicht beigetragen. Die "Bestandskraft des Verwaltungsaktes' erscheint zwar in der Öberschrift vor $\$ \$ 43$ ff. In den folgenden Regelungen wird sie aber nicht năher bestimm, nicht einmal mehr erwahnt. Aus dem lnhalt dieser Regelungen laft sich lediglich entnehmen, daßB die Bestandskraft im Bezugsfeld won Wirksamkeit und Aufhebbarkeit von Verwaltungsalkten liegt. Der die Bestandskfaft tragende Grundgedanke ist allerdings allgemein anerkannt: der Verwaltungsakt soll als hoheilliche Regelung verbindich und dawerhaft sein, er soll Rechisbestundigkeit erhalten. Das ergibt sich bereits aus dem Regelungscharakter des Verwaltungssakis; denn eine Regelung, die zur beliebigen Disposition stunde, wăre sinnwidrig und wertlos. Das ergibt sich ferner aus der spezifischen Klarstellungs- und Stabilisierungs funktion des Verwalungsakts, die ihrerseits in der Rechtssicherheif güundet. Der Ausdruck "Bestandskraft" ist offensichtich in Anlehnung an den prozessualen Begriff Rechtskraft entwickelt worden, soll aber - wie die Wortbildung 'Bestands'-kraft zeigt - doch auch die Distanz zum ProzeBrech dokumentieren. (..) Formelle Bestandskraft bedleutet Unanfechbarkeit. Sie besagt, daB der Verwal tungsakt nicht oder nicht mehr mit den ordentlichen Rechtsmilteln (Widerspruch, Anfechungsklage) angefochten werden kann. Sie entspricht somit der formellen Rechtskraft des Prozelbrechts. (...) Den eigentichen Streitpunkt bildet die materielle Besitandskraft. Hier lassen sich auch keine eindeutigen

50. K.H. Klein, Gutachten und Unteil im Verwaltungsprozeb und Verwaltungsgerichtlichen Normmenkontrollwerfahren, Munchen 1987, S. 136-138.

51. F. Mayer, F. Kopp, Allgemeines Verwaltungsrecht, Stuttgart-Munchen-Hannover 1985, S. 200. 
Parallen zum Prozebrecht finden. Die materielle Bestandskraft kann sowohl mit der Bindungswirkung als auch mit der beschrainkten Authebbarkeit des Verwalungsakt in Zusanmenhang gebracht werden. ${ }^{.52}$

Ook Wallerath plaatst 'Bestandskraft' in het deel inzake het 'Verwaltungshandeln'. In een paragraaf inzake 'Die Bestandskraft des Verwaltungsaktes' wergelijkt hij deze met de 'Rechtskraft':

\begin{abstract}
'Die dem Verwalungsakt zukommende besondere 'Bestandskraft' hat - insoweit ubeteinstimmend mit der 'Rechtskraft' des gertchtlichen Urteils - eine zweifache Auspragung: Die 'forme lle' Bestandskraft des Verwaltungsaktes bedeutet, dal der Verwaltungsakt mit einem formlichen Rechtsbehelf oder einem Rechtsmittel nicht mehr angefochten werden kann; sie ist damit gleichbedeutend mit der "Unanfechtbarkeit" des: Verwaltungsaktes. Die 'materielle' Bestandskraft des Verwaltungsaktes umfaBt einmal den Aspekt der Inhalthichen "Verbindlichkeit" der Entscheidung für die Beteiligten. Sie entspricht insofern die Wirksamke it des Verwaltungsakites, die nicht erst mit seiner Unanfechtbarkeit sondern bereits mit der Bekanntgabe des Verwaltungsaktes eintritt. Zum anderen ist der Frage der 'materiellen' Bestandskraft die Grundsatze der nachröglichen Abänderbarkeit der getroffenen Entscheidung durch die Behörde zuzuordnen. Die materielle Bestandskrat des: Verwaltungsaktes kennzeichnet damit den Charakter des Verwaltungsaktes als einer hoheitlichen Regelung, die fur die Dauer seines Bestandes eine bestimmte Rechtsfolge zwischer den Betelligten verbindlich festlegt, aber von der Behörde unter gewissen Voraussetzungen wieder abgeăndert werden kann. ${ }^{53}$
\end{abstract}

Wolff Bachof tenslotte wijden in het hoofdstuk inzake 'Der Verwaltungsakt' een paragraaf aan 'Rechtskraft, Bestandskraft und Bindungswirkung von Verwaltungsakten'. Daar blijft het in 1956 gemaakte onderscheid in stand. De 'Bestandskraft' is het probleem dat is ontstatan uit een spanningsrelatie tussen veranderingsbehoefte en rechtszekerheid; een kenschets die ons na Donners typering van het rechtskrachtprobleem vertrouwd in de oren klinkt. Mede daarom is het oordeel van Wolff/Bachof over de plaats van het leerstuk ook zo interessant:

"In diesem noch naher zu erorternden Spannungsverhältnis zwischen Anderungsbedurftichkeit und Rechitssicherheit steht die Problematik, die heute meist unter dem begriff Bestandskraft von Verwaltungsakteri erortert wird. Dabei wird Bestandskraft mit Abstrichen als werwaltungs-, abgaben- und sozialrechtlicher Parallelbegriff zur Rechtskraft des Prozebrechts verstanden, der sich mit der Frage befaBt, unter welchen Umstunden ein Verwaltungsakt zuriekgenommen oder widerrufen werden darf oder muß ${ }^{54}$

\title{
6.4.4 "Bestandskraft" in tijdschrifiartiketen
}

Voor een beschrijving van het Bestandskraft-begrip zoals dat in tijdschriftartikelen tot uitdrukking komt, heb ik gebruik gemaakt van de teksten van Baring, Sauer, Knöpfle, Erichsen und Knoke, Ipsen, Kollmann en Randak.

52. H. Maurer, Allgemeines Verwaltungsrecht, Munchen 1994, S. 251-253.

53. M. Wallerath, Allgemeines Verwaltungstecht, Stegburg 1985, S. 200.

54. H. Wollto.Bachof, Verwaltungsrecht 1, Minchen 1994, S. 717 
Baring schrijft over 'Die Rechtskraft der Verwaltungsakte' nog voordat het onderscheid tussen 'Rechtskraft' en 'Bestandskraft' door Wolff werd gemaakt. Hij onderscheidt wel formele en materiële rechtskracht als de 'äußere, formelle Rechtskraft' (Unanfechtbarkeit) en de "innere, materielle Rechtskraft" (Verbindlichkeit).

\title{
Sower begint zijn bijdrage met de stelling: 'Die Frage nach der Bestandskraft von Verwal-
} tungsakten ist seit je umstritten und bis heute ungelöst.. ${ }^{56}$ Hij plaatst het leerstuk in het licht van de 'Rücknahmeproblematik' en stelt dat de formele 'Bestandskraft' met de formele 'Rechtskraft' vergelijkbaar is.

\begin{abstract}
"Betrachter man die rechtichen Wirkungen des Verwaltungsakts, so erhell auf Anhieb, dab sich eine formelle Rechtsbeständigkeit in Sinne der Unanfechubarkeit auch in diesem Bereich zeigt. Sie eignet einem Verwaltungsakt, soweit er nicht nichtig ist, immer dann, wenn er mit ordentlichen Rechtsmitteln nicht mehr angegriffen werden kann. Die in der verwaltungsrechtlichen Literatur und Judikatur als formelie Bestandskraft bezeichnete Wirkung ist also mit der formellen Rechtskraft gerichtlicher Entscheidungen durchaus vergleichbar, ${ }^{57}$
\end{abstract}

En ook:

"Wenm hier indes die Bezeichnung materielle Bestandskraft vorgeschlagen wird" so soll damit lediglich die Feststellung ihren nominellen Ausdruck erfahren, dab beim unanfechtbaren belasienden Verwaltungsakt die Korrekturanfalligkeit, d.h. der Katalog won Prufungsgrtinden, bei deren Vorliegen ein Anspruch auf erneute Sachprufung gegeben ist, angesichts des hier oft anzutreffenden summarischen Verfahrens gröBer sein mußB alls im prozessualen Wiederaufnahmerecht; dies andert nichts an der strukturellen Gleichheit beider Rechtsinstitute. Hat die formelle Bestandskraft von Verwaltungsakten in der als konkrettisierende Ausgestaltung des Rechtssicherheitsprinzips zu verstehenden materiellen Bestandskraft ihr Korrelat gefunden, so liegt nichts nather, als zur Lösung der Rilcknahmeproblematik die entscheidenden Anregungen aus dem prozessualen Rechtskraftsystem bzw. insbesondere Whederaufnahmerecht zu holen. ${ }^{58}$

Kröpfle beschrijft eerst de definities van anderen om dan vast te stellen dat het wenselijk zou zijn om meer helderheid in het onderscheid te hebben. Hij doet een poging door 'Rechtskraft" als procesrechtelijk instituut inter partes (subjectief) te duiden en "Bestandskraft" als typisch bestuurlijk fenomeen.

'Das Ergebnis dieser Tour d'Horizon laft es wunschenswert erseheinen, zu groberer begrifficher und klassifikatorischer Klarheit und Ubereinstimmung zu gelangen. Dem Versuch, einen schritt in diese Richtung zu gehen, sei vorausgestell, daB die Institute der gerichtlichen Urieilen zulkommenden materiellem Rechtskraft und einer Bestandskrafi von Vemwaltwngsaken keine rechtiche Grundlage einer generellen, die Gerichtstbar* kell und Verwaltung verbindlichen Respektierungsplicht hoheitlicher Akte zu bilden wermogen, weil sie hinsichtlich des betroffenen Personenkreises ('in subjektiver Hinsicht') engen Grenzen unterliegen: Fur die materielle Rechuskraft ergibt sich dies schon aus ihrem Wesen als einer Einrichtung des Prozebrechts, die,

55. Vgl. Baring, Die 'Rechtskraft' der Verwaltungsakte, in: NJW 1952/28, \$. 1073-1076.

56. H. Sauer, Die Bestandskraft won Verwaltungsakten, in: DoV 1971/5, S. 1.50.

57. H. Sauter, Die Bestandskraft von Verwaltungsakten, in: DOV 1971/5, S. 152.

58. H. Sauer, Die Bestandskraft von Verwaltungsakten, in: DOV 1971/5, S. 157. 
abgesehen von Fallen der Rechtskrafterstreckung auf Dritte, Wirkungen nur fur die Parteien des betrefienden Verfahroms zeitigt. - Entsprechendes gilt fur die 'Bestandskraft' bestimmter Arten von Venwalungsakten. Ahnlich der Wirkung der materiellen Rechtskraft hindert die Verfahrensbeteiligte Betroffene und die erlassende Behorde daran, sich uber die getroffene Entscheidung hinwegzusetzen und den ihr zugrundeliegenden Lebenssactiverhalt bei unveranderter Sach- und Rechtslage zum Gegenstand emeuter Prafung und Regelung $2 u$ machen. ${ }^{30}$

\title{
Erichsen und Knoke geven aan dat er geen onduidelijkheden bestaan over de 'formelle' varianten 'Bestandskraft' en 'Rechtskraft', maar wel bij de 'materielle'.
}

\begin{abstract}
"Die als Bestandskraft bezeichnete Rechtsbestandigkeit won Verwaltungsakten labst sich in eine formelle und eine materielle Bestandskraft unterteilen. Die formelle Bestandskraft wird allgeme in, ohne dal hier noch terminologische Unklatheiten bestehen, mit der Unanfechtbarkeit des Verwaltungsakts gleichgestetzt. Sie entspricht der formellen Rechtskraft gerichtlicher Entscheidungen und bedeutet daher, das ein Verwaltungsrechit nicht mehr mit den ordentlichen Rechtsbehelfen (Widerspruch, Anfechtungs-, Verpflichtumgsklage) in dern dafur vorgesehenen Verfahren angegriffen werden kann. (..) Eine allgemein anerkannte, verfestigte Definition der materiellen Bestandskraft findet sich weder in der Rechtsprechung noch in der Rechtsliehre. Insoweit hat sich an dem schon won Forshoff beklagten, seit jeher bestehenden 'Labyrinth der Meinungen' bis heute wenig geândert Zuweilen wird die materielle Bestandskraft mit der MaBgeblichkeit der in dem Verwallungsakt getroffenen Regelung gleichgestetzt, mitunter wird sie auf die inhalltiche Gelung des Verwaltungsikts bezogen. Wieder andere begreifen materielle Bestandskraft als: (Rechts-)Bestandigkeit, wobei z.T. Unabänderbarkeit oder inhalitiche Unabanderlichkeit gefordert wird. Ferner wird die materielle Bestandskraft auch als (naterielle) Bindungswirkung bezeichnet, ohne daB allerdings Art, Ausmafs und Zuordnungssubjekt dieser Bindung immer deutlich werden. ${ }^{60}$
\end{abstract}

Ipsen probeert in de veelheid aan termen met betrekking tot de rechtskracht van beschikkingen duidelijkheid te scheppen.

\footnotetext{
"Statt des vielzitierten 'Labyrinths der Meinungeg" erwartet uns vorerst ein Gestrupp der Begriffe. Bei Durchsicht der Literatur finden sich rund zwei Dutzend verschiedener Begriffe, die in irgendeiner Weise auf den Bestand des Verwaltungsakts abzielen: So ist von Bindung, Geltungskraft, Bestandskrat, Rechtsbestundigkeit, Bindungswirkung, Tatbestands- und Feststellungswirkung, von Verbindlichkeit, materieller Bestandskraf, Unanfechlbarkeit, Unangreifbarkeit, Mabgebłlichkeit und inhalticher Geltung ebenso die Rede whe von Unatbinderbarkeit, inhaltlicher Unabanderlichkeit, naterietler Bindungswirkung, Gettungsanspruch, materieller Reehtskralt pradjudizieller Wirkung, Prajudizialitat, Selbstbindung und Bindungskraft die Rede. Diaze geradezu babylonisch zu nemende Sprachverwirrung erschwert fraglos den Konsens, denn nur selten wird definiert, welche Bedeutung den einzelnen Degriff beizumessen ist. Ob man dem Verwalungsakt aber "Maldgeblichket", materielle Bestandskaft' oder Rechtskraft zuspricht, bleibt worerst eine folgenlose begriffliche Operation, dic erst Gewicht gewinnt, wenn die unterschiedliche Bedeutung der Begriffe und also der Unterschied in den Rechtsfolgen deutlich geworden sind
}

59. F. Knöphle, 'Tathestands-' und 'Feststellungswirkung' als Grundlage der Verbindlichkeit von gerichtlichen Entscheidungen wnd Verwaltungsakten in: Bay. Verw. BI. 1982/8, \$. 227-228.

60. H.U. Erichsen und U. Knoke, Bestandskraft von Verwaltungsakten, in: NZTV 1983/4, S. 186-187

61. J. Ipsen, Verbindlichkeit, Bestandskraft und Bindungswirkung von Verwaltungsakten; Versuch einer begriflichen Klarung, in: Die Verwaltung 1984, S. 170. 
In feite gaat het volgens Ipsen om oplossing van problemen die de wetgever heef laten liggen, met op name op het gebied 'der Tatbestände und Rechtsfolgen, also des rechtlichen Sollens' en zegt hij verderop 'die Begriffe zielen gemeinsam darauf ab. daß Hoheitsakte irgendwann fur irgendwen rechtlich verbindlich sind. ${ }^{62}$ En zegt hij: "An dieser Stelle zeigt sich erneut, warum begrifflich zwischen Wirksamkeit und Verbindlichkeit unterschieden werden muß. ${ }^{163}$ Daarnaast is hij van mening: 'Der Verwaltungsakt gilt insofern nicht nur "unter partes", sondern erheischt als Hobeitsakt allseitige Anerkennung. ". Een definitie van 'Bestandskraft' als erga omnes-eigenschap geeft hij eveneens:

\begin{abstract}
'Bestandskraft ist die allseitige, verfahrensbeschrankte Verbindlichkeit von Verwaltungsakten. 1. Formelle" und "materielle Beskandskrafi?: In Schriftum wird die "formelle" Bestandskraft mit der Unanfechtbarkeit eimes Verwalthngsaktes gleichgesetzt, wăhrend die "materielle" Bestandskraft bedeuten soll, daß der Verwaltungsakt fur die Beteiligten verbindlich oder malsgeblich ist. (...) Nun Mat sïh mit dem Begriffspaar 'formell" und materiell' muhelos so etwas wie eine äulere, die Form betreffende, und eine innere, den Inhalt erfassende Verbindlichkeit assozijeren. (...) Legt man den Regelfall, in dem Rucknahme oder Widerruf ausgeschlossen sind, zugnunde, so wird der Verwaltungsakt mit Ablauf der Rechtsbehelfsfrist allseitig werbindich. Das aber bedeuter nichts anderes, als daß er fur Beteiligte tund Dritte imhallich werbindlich ist. Es ist nicht einzusehen, wie hier noch Raum fur eine Differenzierung nach form und Inlaalt bleiben soll. In der "Tat stelt sich das Gegensatzpaar von 'formeller' und 'materieller' Bestandskraft als begriflichos Fossil heraws, das zivilprozessualen Ursprungs und von der Verwaltungsdogmatik konserviert worden ist. (...) In der Flat unterschiedlicher Begrifnichkeit erscheint es geradezu als eine Insel der Gemeinsamkeit, daß Unanfechbarkeit und formelle Bestandskraft des Verwaltungsaktes gleichgestetzt werden. Dieser synonyme Gebrauch geht auf die ziwilprozessuale Teminologie zuruck. (..) Die werwaltungsrechtiche Terminologit betont mit dem Begriff der 'Bestandskraft' also einerseits die Unterschiede zwischen Verwaltungsakt und Urteil, sucht aber mit dem Atribut "formel" wiederum die Parallele zum Prozebrecht. (..) Unsere bisherigen Oberlegungen geben Raum fur einen der gesetzlichen Terminologie angenaherten Gebrauch des Begriffs 'Bestandskraft". Da sich die Attribute 'formell' und "materiell" als Relikte einer dberholten Rechtskraftheorie erwiesen haben, die einseitige Verbindlichkeit gegenuber Adressaten und Drittbetroflenen aber priziser durch den Begriff 'Unanfechtbarkeit' ausgedruckt wird, JäBt sich der Begriff der Bestandskraft fur allseitige Verbindlichke it des Verwaltungsaktes reservieren. Erst in dieser Bedeutung gewinnt der Bestandskraftibegriff eigenen Konturen und wird dem Rechtskraftbegriff vergleichbar. ${ }^{\text {t65 }}$
\end{abstract}

Kollmann bespreekt voornamelijk de werking van beschikkingen. Hij benadrukt het onderscheid tussen 'Bindungswirkung', "Tatbestandswirkung' en 'Feststellungswirkung" .

62. J. Ipsen, Verbindlichkeit, Bestandskraft und Bindungswirking won Verwaitungsakteri, Versuch einer begrifflichen Klarung, in: Die Verwaltung 1984 , S. 171.

63. J. Ipsen, Verbindlichkeit, Bestandskraft und Bindungswirkung von Verwaltungsakten, Versuch einer begrifflichen Klatrung, in: Die Verwaltung 1984, S. 174.

64. I. Ipsen, Verbindlichkeit, Bestandskraft und Bindungswirkung von Verwaltungsakten, Versuch einer begrifflichen Klarung, in: Die Verwaltung 1984, S. 176.

65. I. Ipsen, Verbindlichkeit, Bestandskraft und Bindungswirkung won Verwaltungsakten, Versuch einer begrifflichen Klarung, in: Die Verwaltung 1984, S. 178-184.

66. Vgl. A. Kollmann, Zur Bindungswirkung von Verwaltungsakten, in: DOV 1990/5, S. 189-197. 
'Aus dem zum Begriff der matertellen Bestandskiaft bestehenden 'Labyrinth der Meinungen' labt sich ein Verstundnis herauskristallsieren, das an den prozeBrechtlichen Begriff der materiellen Rechtskraft der Uiteile angelehnt ist und die materielle Bestandskraft als ein mit der formellen Bestandskraf eintretendes Abweichungyverbot sieht Nach diesen Verstandnis uritt mithin dic materielle Bestandskraft eines Verwaltungsaktes gleichzeitig mít seiner formellen Bestandskraft ein, also sobald der Verwaltungsakt unanfechtbar geworden ist. Wern nun mehrere Rechtstager von einem Verwaltungsakt betroften sind, laufen die Anfechtungsfristen ihnen gegenuber nicht urbedingt gleichzeitig ab (etwa weil der Verwaltungsakt ihner zu unterschiedichen Zeitpumkten Bekanntgegeben worden ist). Dann stellt sich die Frage, ob es eline relative Be* standskafh (beschrankt auf jeweils diejenigen, gegenuber denen Unanfechbarkeit eingetreten ist) gibt oder ob die materielle Bestandskraft immer die allseitige Unanfechtbarkeit woraussetzt (absolute Bestands(knofit. ${ }^{.67}$

\section{4 .5 'Bestandskraft' in recente dissertaties}

Voor een beschrijwing van het Bestandskraft-begrip in de recente dissertaties en een enkele habilitatie heb ik gebruik gemaakt van de teksten van Krause, Domke en Bronnenmeyer.

Krause bespreekt de 'Bestandskraft und Rechtskraft des Verwaltungsakts' in zijn habilitatie inzake 'Rechtsformen des Verwaltungshandelns' bij het onderdeel inzake de functie van de handelingsvormen.

'Fomelle Bestandsktafit oder formelle Rechtskraft heiBt Unanfechtbarkeit einer Entscheidung im dafir vorgesehenen formlichen Rechtsschutzverfahren. ${ }^{68}$

\section{En verderop:}

"Die Bindung des konstitutiven Verwalturggakts ist nicht an eine besondere Verbindlichkeit des Aktes im Sinne einer materiellen Rechts- oder Bestandskraft geknupft, sondern folgt aus der Bindung an Gesetz und Recht. Gibt das Gesetz einem Verwaltungsakt die gestaltende Kraft nicht, erlangt er sie auch nicht infolge einer Rechts-ader Bestandskraft. Wuthend es die materielle Rechnskraft verbietet, den Entscheidungsimhalt - und zwar nach Eintritt der Unanfechibarkeit - in Frage zu stellen, begint die Bindung des wirksamen Verwalungsakts war die Gerichte, den Burger und andere Behorden bereits mit dessen ErlaB. ${ }^{69}$

Domke karakteriseert 'formelle Bestandskraft' als 'Unanfechtbarkeit' ${ }^{70}$ Ten aanzien wan de 'materielle Bestandskraft' stelt zij dat deze 'seit jeher umstritten' is."

67. M. Randak, Bindungswirkung wou Verwaltungsakten, in: JuS 1992/, S. 34.

68. P. Krause, Rechtsformen des Verwaltungsharndelns, Hab. Schrift, Berlin 1974, S. 179.

69. P. Krause, Rechtstormen des Verwatungshandelns, Hab.Schrift, Berlin 1974, S. 183.

70. Vg. U. Domke, Rechtsfragen der Bestandskraft won Verwaltungsakten, Inaug. Diss, Mannheim 1989, S. 6.

71. U. Domke, Reçhtsfragen der Bestandskraft von Verwaltungsakten, Inaug.-Diss., Mannheim 1989, S. 18. 
Ook Bromnenmeyer definieert de 'formelle Bestandskraft' als 'Unanfechtbarkeit', terwijl hij de "materielle Bestandskraft" typeert als een "vieldiskutiertes Thema des allgemeinen Verwaltungsrechts' en ook zegt hij daarover:

"Unklar ist insbesondere thre begriffliche Deutung" ?

\subsection{Tenslotte}

Twee discussiepunten zijn tot op heden overeind gebleven. Als eerste de oude discussie van Bernatzik en Mayer, waarbij 'Rechtskraft' werd ontwikkeld uit het civiele procesrecht. Zo ontstond het idee om het te verbinden met het constitutieve moment van rechtsvaststelling en kon het getransporteerd worden naar het bestuursrecht. Mayer tekende voor het duiden van deze overgang, terwijl Tezner en Kormann deze visie definitief vestigden door de conclusie te trekken. Daaraan wooraf ging het door Bernatzik geduide en belangrijke besef dat rechtskracht in het bestuursrecht altijd aan bevoegdheden verbonden moet worden.

Daarnaast - als tweede punt - het nieuwe begrippenpaar van Wolff. Het onderscheid 'Bestandskraft' en Rechtskraft' legt het bevoegdheidsdenken en het procesdenken bloot. Wolff kon dat onderscheid maken doordat hij feit, norm en gevolg uiteenrafelde (een benadering die in dit boek eveneens is gevolgd). Wolff is daardoor eigenlijk de Steenbeek van Duitsland, met dien verstande dat Steenbeek niet zo expliciet het verschil in bestuur en proces (bevoegdheid leidt tot het begrip 'Bestandskraft' en procesrecht leidt tot het begrip 'Rechtskraft') maakte.

Resumerend kan gesteld worden dat de beschrijving van 'Bestandskraft' en 'Rechtskraft' als begrippenpaar expliciet nuanceert naar onderscheidingen die we in het Nederlandse recht wellicht ook wel kennen. Als gezegd kan het begrip formele rechtskracht in de zin wan inter partes onaantastbaarheid zoals de Nederlandse burgerlijke rechter dat heeft ontwikkeld goed vergeleken worden met het Duitse begrip 'formelle Rechtskraft'. Daarmee is meteen de beperktheid van het Nederlandse begrip aangetoond; er is immers meer onder de zon dat dit facet van rechtskracht. Deze procesrechtelijke benadering wordt in Duitsland over het algemeen ook aangehangen. Een equivalent voor 'Bestandskraft' kennen we in Nederland niet; het is daarom dat ik daarvoor de term rechtsbestendigheid voorstel.

Een ander punt is het belangrijke verschil tussen 'Bestandskraft' en 'Rechtskraft'. De 'Bestandskraft' wordt duidelijk als 'allseitig' gezien. Dat betekent dat bij de 'Bestandskraft' de erga omnes-werking wordt benadrukt. Daarnaast wordt de inter partes-werking benadrukt bij de 'Rechtskraft' (wooral Ipsen zegt dit expliciet). Dat lijkt vanuit de historie logisch verklaarbaar. De inter partes-werking werd immers steeds vastgeknoopt aan vonnissen, waarvan de 'Rechtskraft' in een procestechtelijke benadering als begrip werd afgeleid (vergelijk Mayer). De erga omnes-werking is meer verwant aan de objectieve

72. H. Bronnesmeyer, Die Widerruf rechtmaBiger begunstigender Verwallungsakte nach 89 VwVFG, Berlin 1994 , S. 205. 
bestuurlijke benadering, die vanuit het bevaegdheidsdenken (het uitoefenen van bevoegdheden) is ontstaan.

Het bestuurlijke bevoegdheidsdenken is veel moeilijker grijpbaar woor auteurs. Dat zie je met name bij de 'materielle Bestandskraft', want daar haken de meeste schrijvers af (het lijkt erop dat Maurer en Ipsen de uitzonderingen zijn die deze regel bevestigen). Kennelijk is Wolff daar toch ook het moeilijkst te volgen. De indruk bestaat dat wanneer auteurs niet goed met dit begrip van Wolff kunnen omgaan, of wanneer het onderscheid of de bedoeling daarvan niet goed te zien is, dat het dan wordt verworpen of overbodig wordt verklaard. In ieder geval kan geconcludeerd worden dat de theorievorming na Wolff niet verder is gekomen.

Laten we de termen nog eens op een rijtje zetten. 'Bestandskraft " en 'Rechtskraft' staan dan naast elkaar met allebei een formele en een materielle variant. De Duitse termen kennen nu ook een Nederlands equivalent: 'formelle' en 'materielle Bestandskraft' worden formele en materiële rechtsbestendigheid; 'formelle' en 'materielle Rechtskraft' worden formele en materiële rechtskracht. Dit behoeft toelichting.

Het breekpunt tussen rechtsbestendigheid en rechtskracht ligt bij de aanvang van de bezwaarfase. Vóór dat moment spreken we van rechtsbestendigheid; daarná van rechtskracht. De fase van rechtsbestendigheid is de fase tot de contentieuze fase. De bekendmaking van het besluit speelt in deze fase ook nog een rol, omdat de bekendmaking niet jegens elke belanghebbende op dezelfde wijze (noch op hetzelfde moment) hoeft te geschieden. De fase van de rechtskracht begint met de contentieuze fase, die in beginsel minimaal de beroepstermijn beslaat, maar ook jarenlang kan duren.

Formele rechtsbestendigheid ('formelle Bestandskraft') ontstaat op het moment van het officieel nemen van het besluit; het is het moment waarop de overheid het geldigheidsstempel aan het besluit meegeeft. Dat moment van formele rechtsbestendigheid hebben wordt gerespecteerd. Het tenietdoen ervan (ex tunc) komt in drie gevallen voor: 1. het exceptionele opheffen ex tunc door het bestuur zelf (als buitengewoon rechtsmiddel); 2 . in spontane vernietiging en 3 . door een bestuursrechtelijke vernietigingsuitspraak.

Materiele rechtsbestendigheid ("materielle Bestandskraft") is dan het vermogen (of de potentie) om het formeel rechtsbestendige besluit actief rechtsgevolgen in het rechtsleven te laten creëren. Het is op een nunc-moment betrokken.

Formele rechtskracht ('formelle Rechtskraft') is de rechtsbestendigheid in rechte; in bezwaar en in beroep. Het is de procesrechtelijke onaantastbaarheid die ingaat na het onbenut verstrijken van de beroepstermijn en op een tunc-moment is betrokken. Alle ontvankelijkheidskwesties hebben hier mee van doen.

Materiële rechtskracht ('materielle Rechtskraft') is dan het vermogen (of de potentie) die in het proces moet worden alangenomen, dat dit besluit op rechtens correcte wijze rechtsgevolgen in het leven heeft geroepen. 


\section{Hoofdstuk 7}

\section{Waarvan is rechtskracht de eigenschap?}

\section{$7.1 \quad$ Inleiding}

Inmiddels weten we dat rechtskracht een eigenschap is. Ook weten we dat de aard van die rechtskracht verschillend wordt gezien; zo wordt rechtskracht wel gedefunieerd als inter partes-onaantastbaarheid, als rechtens vaststaand en ook als erga omnes-werking van besluiten. De aard van de eigenschap is in het voorgaande hoofdstuk aan de orde geweest. In dit hoofdstuk zal centraal staan van wat, dat wil zeggen van welke rechtsfiguur, rechtskracht een eigenschap is; met andere woorden welke de drager is van rechtskracht.

Op de vraag waarvan rechtskracht de eigenschap is, bestaan verschillende visies. De meningen lopen zozeer uiteen dat sommigen stellen dat rechtskracht de eigenschap is van alle rechtshandelingen, terwijl anderen daarentegen spreken van de rechtskracht van eén bepaalde rechtshandeling: van het vonnis of van de beschikking. Weer een andere opvatting is dat rechtskracht de eigenschap zou zijn van alle rechtsfeiten (waar de rechtshandelingen dan ook weer onder vallen). Hoe wordt aan die verschillende (en uiteenlopende) meningen vorm gegeven? Doorgaans wordt rechtskracht echter gezien als de eigenschap wan beschikkingen; zo werd de eigenschap althans in een vergelijking met de rechtskracht van (civiele) vonnissen in ons land geïntroduceerd. Met de inwerkingtreding van de Awb valt niet (alleen) de beschikking als meest centrale figuur onder de aandacht van bestuursrechtjuristen, nu is die aandacht verlegd naar het besluit. Dat besluit houdt ook de traditionele beschikking in, maar eveneens besluiten van algemene strekking (bas - niet zijnde algemeen verbindende woorschriften, avv) vallen er onder. De vraag die daarmee opgeworpen wordt, luidt of rechtskracht nu ook als eigenschap van dat besluit kan worden beschouwd in tegenstelling tot eigenschap van (alleen) de beschikking. En hebben ook specifieke bas, wetten (wel awv), rechtskracht? Is rechtskracht eigenlijk wel de eigenschap van alleen rechtshandelingen of toch eerder van rechtsfeiten? Dit zijn de vragen die we hier gaan onderzoeken.

Werd in het voorgaande vooral de vreemde herkomst van het rechtskrachtbegripbeschreven, nu kies ik voor een 'historiografische' insteek: hoe hebben beschrijvers van rechtskracht getracht het begrip te duiden. Bij Kormann zagen we dat rechtskracht als eigenschap werd gezien van alle publiekrechtelijke rechtshandelingen; hij zag kennelijk vergelijkbare, "universele", elementen. Zo werd rechtskracht als eigenschap van alle rechtshandelingen vermengd over de mogelijke dragers. Bij Wolff daarentegen gaat het weer uiteen en worden de onvergelijkbare elementen, de verschillen, weer naar voren gehaald. 
In het vorige hoofdstuk is well de stelling verdedigd dat het constitutieve element doorslaggevend is voor het aannemen van rechtskracht. Zou dit constitutieve element lets "universeels" vertegenwoordigen (zoals met name Erichsen en Mayer/Kopp uitdrukkelijk stellen), zodat verklaarbaar is dat rechtskracht een eigenschap is van vonnissen én beschikkingen (en van alle overheidsbesluiten)? De introductie van het rechtskrachtbegrip in Nederland is in ieder geval langs deze lijn gelopen; kennelijk is de vergelijkbaarheid op dit punt het duidelijkst. Zo wordt in ieder geval wel de civielrechtelijke oorsprong wan het begrip werklaarbaar, althans begrijpelijk. Hebben privaatrechtelijke rechtshandelingen dan ook rechtskracht? of is de rechtskracht van de beschikking anders, doordat het in het publiekrecht gaat om het objectieve constitutieve element?

Daarmee kom ik op een ander onderscheid, dat eveneens in Duitsland (met name door lpsen) werd gemaakt, het onderscheid in de 'allseitige' rechtskracht van 'beschikkingen', die nog in de besluitvormingsfase (nog vóor de contentieuze fase) verkeren ('Bestandskraft' of rechtsbestendigheid) en in de 'inter partes'-rechtskracht van beschikkingen die al in de contentieuze fase zijn beland ('Rechtskraft' of rechtskracht). Is er onderscheid tussen deze "allseifige' rechtsbestendigheid (de 'Bestandskraft' met erga omnes-werking, als voortkomend uit een bevoegdheidsbenadering van het bestuursrecht) en de meer relationele rechtskracht (de 'Rechtskraft' met inter partes-werking als voortkomend uit een procesrechtelijke benadering van het bestuursrecht)?

En daarop weer doordenkend, heeft dit onderscheid in rechtsbestendigheid ("Bestandskraft') en reclutskracht ("Rechtskraft') te maken met de plaats of de functie van de drager van de rechtskracht? Zou de plaats die rechtshandelingen hebben in de rechtsstaat een verklaring kunnen verlenen voor eventuele verschillen in de rechtskracht van de verschillende typen rechtshandelingen? Zijn er verschillen in de rechtskracht van rechtshandelingen van de onderscheiden delen van de trias politica? Welke verschillen zouden door de functies van de onderscheiden machten veroorzaakt kunnen worden? Moet geconcludeerd worden dat rechtskracht de eigenschap is van rechtsfeiten of rechtshandelingenuit één bepaalde functie?

Nog een woord vooraf. In dit hoofdstuk zullen Nederlandse en Duitse bijdragen door elkaar heenlopen. Dat leest waarschijnlijk niet zo heel gemakkelijk, maar daarover valt te zeggen dat het hier nu eenmaal niet anders kan. Dat komt omdat in dit hoofdstuk een vraag wordt besproken, die juist ook door de bestudering van de beide stelsels actueel werd. Het feit dat hier ook Duitse literatuur aan de orde komt, is doorslaggevend geweest om dit hoofdstuk te plaatsen ma de bestudering van de vreetnde herkomst van het begrip.

\subsection{Vergelijkbare rechtsliracht: het 'universele' element?}

\subsubsection{Inleiding}

Is de rechtskracht van het vonnis vergelijkbaar met die van de beschikking? Waarin of waardoor komen ze overeen? Wat is dat vergelijkbare 'universele' element? Wat houdt het in? Waar komt het vandaan? Welke verklaringen worden ervoor gegeven? Is het constitu- 
tieve element 'universeel', of toch de verbindendheid van de rechtsfiguren? Is het 'universele' gelegen in de relatie met het rechtszekerheidsbeginsel?

\subsubsection{De verbindendheid is "universeel"}

Een verklaring voor vergelijkbaarheid van de rechtskracht van vonnissen en beschikkingen is dat het "universele" element bestaat uit de verbindendheid van de rechtsfiguren. In die zin zou de vergelijkbaarheid schuilen in het feit dat rechtshandelingen, en dus ook beschikkingen en rechterlijke uitspraken, zijn behept met enigerlei soort van bindende kracht. Wat is de oorzaak van die bindende kracht? Moeten we denken aan de binding zoals in het beginsel "pacta sunt servanda'? Verbintenissen ontstaan inderdaad uit overeenkomst, maar ook uit de wet (rechtstreeks of uit de strekking van de wet). Verbindendheid vloeit dan woort uit het gegeven woord of uit de wet. Dat is een belangrijke constatering, omdat bij publiekrechtelijke rechtshandelingen dat gegeven woord wegvalt en de verbindendheid uit de wet resteert. In het publiekrecht is er immers geen 'wil' al wordt dit vaak vereenzelvigd met het hebben van een bevoegdheid.'

Daarmee is inmiddels wel aangegeven dat verbindendheid als 'universeel' element rechts kracht vergelijkbaarmaakt. Bernatzik benadrukte dat er pas van rechtskracht sprake kan zijn als er bevoegdheden zijn (die hij verbindt met de intrede van het concept van de rechtsstaat). Vergelijkbaar met de rechtskracht van een rechterlijke uitspraak (die voortvloeit uit de behoefte aan binding door het gegeven woord van het vrije individu) wordt de rechtskracht van beschikkingen dan omdat deze voortvloeit uit de bevoegdheid(suitoefening), die steunt op de wet. In zoverre lijkt verbindendheid te worden verbonden met de potentie om constitutief te kunnen opereren.

\subsubsection{Ook het constitutieve is 'universeel'}

Naast de potentie om constitutieve rechtshandelingen te kunnen verrichten, is er dat constitutieve element zelf. Het 'universele' element, dat maakt dat de rechtskracht van beschikkingen en uitspraken vergelijkbaar is, wordt dan veroorzaakt door het constitutieve element. Zowel bij rechter ijke uitspraken als bij beschikkingen is dit constitutieve element te zien. Deze verklaring heeft oude papieren en gaat terug tot de stelling dat het zogenaande 'Urteil' rechtskracht had; een stelling waarvoor Mayer als eerste tekende.

\subsubsection{Voorwloeiend uit de rechtszekerheid}

Erichsen geeft aan dat het vergelijkbare en 'universele." element van zowell beschikkingen als uitspraken van rechters voortvloeit uit de verbindendheid en het algemene rechtsstatelijke beginsel van de rechtszekerheid. Alleen als dat verband scherp is, kan verwantschap tussen de formele rechtskracht van beschikking en rechterlijke uitspraak worden gezien. Daarnaast

1. Ik zou woor deze "wil", die ik beschouw als rechtsdoelgerichtheid de term specialiteit willen reserweren. 
hebben rechtsfiguren kenmerken van overheidsautoriteit en daaruit komt woor beide een eigen effectiviteit voort.

'Der Gegenstand und die rectutliche Tragweite der Bestandskraft eines Verwaltungsaktes lassen sich nicht einheitlich fur alle Rechtsgebiete und fur alle Arten won Verwalhungsakten beurteilen. Nur insofern als die Verbindlichkeit des Verwaitungsaktes hinsichtich seines Entscheidungsgegenstandes kraft Unamfechbarkeit cintrit, in ihren Voraussetzungen verfahrensrechtich bedingt und zuletzt in dem alligemeinen rechtsstaatlichen Prinzip der Rechtssicherheit begrandet ist, kann man von einer 'Wesensverwandtschaft' der Bestandskraft von Verwaltungsakten und der formellen Rechtskraft von gerichtlichen Entscheidungen sprechen. Davon abgesehen beschrankt sich die Paralellitat darawf daß in beiden Fallen mit staatlicher Autoritat umkleidete Akte worliegen, die selbststindige und nicht ohne weiteres wieder zu beseitigende Wirkungen fur die Beteiligten habent: 2

Ten aanzien van juist deze 'Bestandskraft' benadrukt Kopp het belang van duidelijkheid bij overheidshandelingen; deze eis van duidelijkheid komt ook voort uit de rechtsstatelijke rechtszekerheid en is aan het moment van vaststellen van de overheidsrechtshandeling ('Hoheitsakt') verbonden:

\begin{abstract}
'An der Bestandskraft won Verwaltungsakten besteht ein vergleichbares rechtsstaatliches, in der Rechtssicherheit begrthdetes Interesie. Zwar ist es nach der Verfassungsordnung des Grundgesetzes vorrangig Sache der Gerichte, die Rechisordnung durch die letztwerbindliche feststellung dessen, was im konkreten Fall Rechtens ist, zu sichern. Das Erfordemis der Rechtssicherheit gilt indes nicht minder in anderen Wirkungsbereichen der Rechtsordnung und insbesondere in Vorfeld der moglichen Betassung der Gerichte. Dieses Erfordernis gebietes sa auch, daB uberall dort, wo Akte mit dem Anspruch rechtlicher Verbindlichkeit gesetzt werden, den Betroffenen moglichst schnell Gewißheit aber das fur sie Verbindliche zuteil werde. (..) Gibt die Rechtsordoung der Verwaltungsbehorde die Moglichkeit, durch Hoheitsakt fur ihren Bereich das im Einzelfall rechtlich Verbindliche festzustellen, zu begrunden oder zu verandern, so besteht auch ein verfassungsrechtliches Interesse daran, seine Bestandskraft herbeizufuhren. Dieser Bestandskraft des Verwaltungsakts kommt, wenn auch auf anderer Ebene, vergleichbare Bedeutung zu wie der Rechtskraft der gerichtlichen Entscheidung."
\end{abstract}

\title{
7.3 Onvergelijkbare rechtskracht: de verschillen
}

Maar er zijn ook verschillen. Zouden die verband houden met de plaats die de verschillende typen rechtshandelingen hebben in het staatsbestel? Zijn de verschillen in de rechtskracht van rechtshandelingen te verklaren uit de verschillende functies, uit de trias? Welke verschillen in de rechtskracht van rechtshandelingen zouden door de machtenscheiding veroorzaakt kunnen worden? Moeten we concluderen dat rechtskracht de eigenschap is van rechtshandelingen uit één bepaalde functie: uit wetgeving of rechtspraak of bestuur? Deze vraag werd eerder al gesteld door Beseler:

'Verwaltungsakt und Richterspruch sind nach Begriff, Wesen und Wirkungen gegenuberzustellen. Auf Grund der sich dann ergebenden Gemue insamkeiten und Unterscheidungen ist festzustellen, ob die Voraussetzungen

2. H.-U. Erichsen, Algemeines Verwaltungsrecht, Berlin/New York 1995, \$, 490

3. F. Kopp. Die Bestandskraft won Verwaltungsakten, in: Deutsches Verwaltungsblatt $15-4-1983,5.393$ 
dafur gegeben sind, diejenigen Eigerschaften und Wirkungen der Verwaltungsakte, die sich als denen entsprechend herausgestellt haben, die man im Prozebrecht mit dem Namen Rechtskmat belegt hat zu benennen..

Hoe zinvol is de vraag naar het verband met de trias? De trias wordt in Nederland wel eens als een achterhaald, een beetje belegen instituut beschouwd. In die visie zou het onderscheid maken in de verschillende functies (die met elkaar het machtsevenwicht vormen) en met name het kritiseren van de rechterlijke functie (omdat deze niet democratisch gelegitimeerd is) niet alleen door de tijd achterhaald zijn, maar bovenal te ongenuanceerd. De interventiestaat heeft immers geleid tot (over)regulering en dat leidt op zijn beurt weer tot een enorme toename van geschillen. De rechter kan in zo"n samenleving nou eenmaal niet anders dan springen in het gat dat de wetgever en het bestuur hebben laten liggen. Op die manier zou het probleemoplossend vermogen van de klassieke drieslag worden overschat. ${ }^{5}$

Daartegen valt het een en ander in te brengen. Met name het argument van het verschil in competenties is in dit verband van belang. Juist omdat er verschillen zijn in competenties, dienen de onderscheiden machten deze competenties ook te respecteren. ${ }^{6}$

Enfin, het verband met de trias wordt hier wel verkend. Een verklaring voor het onderscheid in rechtskracht van de uitspraak en de beschikking wordt in Duitsland eveneens gezocht in de achterliggende functie van die rechtshandeling. Zo wordt het verband gelegd tussen de plaats die de rechtshandeling heeft in de trias en de aard van de rechtskracht ervan.

\footnotetext{
'Zu bedenken ist jedoch, daB sich Verwaltungsakt und Urteil hinsichtich ilhrer Funktion und det Ausgestaltung des Entscheidungsverfarens wesentlich voneinander unterscheiden und diese Andersartigkeit auch die unterschiedliche Bindung gegentber dem erlassenden Organ erklart. Auch verkennt die genannte Ansicht, daf die unterschiedliche Wirkung durch die verschiedenen Begriffe 'Bestandskraft' und 'Rechtskraft' zum Ausdruck gebracht wird. Es bestehen daher keine bedenken, die formelle Bestandskraft mit der formellen Rechtskraft gerichtlicher Enischeidungen gleichzusetzen.,
}

Een aantal factoren veroorzaakt verschil in de rechtskracht van vonnis, uitspraak, beschikking in de besluitvormingsfase, beschikking in de contentieuze fase, besluit van algemene strekking en wet. Deze factoren worden aangeduid als antinomieên: de benadering van het bevoegdheidsdenken (executieve) tegenover die van het procesdenken (rechtspraak), de rechtsbestendigheid ('Bestandskraft') tegenover de rechtskracht ('Rechtskraft'), de erga omnes-werking versus de inter partes-werking. Ook wordt hier wel gerept van de karakterisering van de rechtssituatie en/of de rechtsverhouding als objectief dan wel als subjectief:

Laten we deze factoren beschouwen aan de hand van de verschillende rechtsfiguren. Om dat te doen, zal het werstandig zijn aan te sluiten bij de wijze van onderscheiden zoals dat in

4. H. F, Beseler, Die Rechtskraft der Verwaltungsakte, diss., Munster 1960, $\mathrm{s}, 16$.

5. Vgl. o.4. de typering van M. de Werd, Bestuur in geding, in: JB 1997/280, p. 1262 e.v.

6. Vgl. R. Schlossels, Bestuur in geding, in: JB 1997/280, $\mathbb{P} .1261$.

7. U. Domke, Rechtsfragen der Bestandskraft won Verwaltungsakten, diss., Mannheim 1989, S. 15-16. 
Duitsland tot uitdrukking komt in het begrippenpaar 'Bestandskraft' en 'Rechtskraft'. In de door Wolff gekozen benadering wordt onderscheid gemaakt tussen enerzijds bevoegdheidsdenken (rechtsbestendigheid of 'Bestandskraft') en anderzijds procesdenken (rechtskracht of 'Rechtskraft'). Steenbeek ontrafelt het feit (de formele variant, die er op een bepaald, aflopend tunc-moment is), nom en gevolg (de materielle variant, die er steeds is, blijft en daarom op een nunc-moment is betrokken). De koppeling van deze benaderingen is de benadering die in deze studie steeds is gevolgd. Vanuit deze systematische benaderingswijze kunnen de rechtsbestendigheid en de rechtskracht van elke rechtsfiguur worden geanalyseerd. Dat is tot op heden in Nederland niet gebeurd.

\subsection{Rechtskracht en haar uiteenlopende dragers}

\subsubsection{Inleiding}

In deze paragraaf worden de rechtsbestendigheid en de rechtskracht bij de verschillende rechtsfiguren onder de loep genomen. Daarbij zal de aandacht uitgaan naar wat de verschillende (Nederlandse en Duitse) geleerden ten aanzien van die rechtskracht beschrijven. Door zowel Nederlandse als Duitse auteurs naast elkaar te plaatsen, hoop ik een verdieping te kunnen bieden van de verklaringen voor ons 'Leitmotiv', dat will zeggen voor de vele betekenissen van rechtskracht, voor de vele benaderingen van het begrip, die naast elkaar bestaan.

\section{4 .2 De rechtskracht van een vonnis}

De eerste discussie over rechtskracht werd, als gezegd, gevoerd over het begrip 'materielle Rechtskraft'. Het was een eigenschap van vonnissen, die tot uitdrukking kwam in een element van vonnissen, het zogenaamde 'Urteil'. Moyer beschreef deze rechtskracht als eerste.

Toen Van der Pot de vraag opwierp of aan beschikkingen dezelfde rechtskracht toe dient te komen als aan het (civiel)rechterlijk vonnis, ging hij er impliciet van uit dat dat vonnis kennelijk materieel rechtskrachtig was. Als de beschikking rechtskracht zou hebben, zoals het rechterlijk wonnis, was dat dan wel dezelfde rechtskracht?

\footnotetext{
'Anders dan het rechterlijk vonnis beef de beschikking van een bestumrsorgaan in beginsel geen materieele rechtskacht. Een benoeming kan ingetrokken, een wergunming opgezegd, een subsidie ongedaan gemaakt worden, natuurlijk voor zoover niet uitdrukkelijk ten gunste van den betrokkene een subjectief recht is gevestigd.
}

En als de beschikking dan geen materiële rechtskracht heeft, blijft slechts de formele rechtskiracht over.

8. C.W. van der Pot, De vormen van het besturen, in: Nederlands Bestuursrecht, Alphen wd Rijn 1932, p. 215. 
Later beantwoord Donner de door Van der Pot opgeworpen vraag, of vonnissen en beschikkingen dezelfde rechtskracht dragen, negatief. Eerst constateert hij dat de term rechtskracht van toepassing wordt geacht op rechterlijke vonnissen:

${ }^{4} H e t$ woord rechiskracht is den Nederlandschen jurist niet onbekend. (...) Soms ook gebruikt men dezen tern wanmeer men het gezag van gewijsde van rechterlijke uitspraken op thet oog heef',

maar, zo stelt hij, de rechtskracht van rechterlijke vonnissen is 'slechts een modaliteit' van het totale rechtskrachtbegrip:

'De rechiskracht, welke thet rechterlijk vonnis eigen is, wordt gezag van gewijsde genoend. Niets echter rechtvaardigt de werabsoluteering van de darmee aangeduide werkingen voor het geheele rechtskracht" verschijnsel. 10

Rechtskracht (destijds materieel genoemd) als eigenschap van het vonnis is een eigenschap met inter partes-werking. Dit vonnis bevat een 'Urteil'. In deze discussie (waarin de vraag naar vergelijkbaarheid van de rechtskracht van vonnis en beschikking wordt gesteld) wordt gezocht naar wergelijkbare elementen van rechtsbestendigheid en rechtskracht. Dit vergelijkbare element wordt gevonden in het 'Urteil', omdat ook bestuurlijke rechtsvaststellingen een oordeel inhouden.

\subsubsection{Werking van uitspraken en vomissen}

In het verlengde van de rechtskracht van het vonnis ligt de vraag of uitspraken van bestuursrechters vergelijkbaar zijn met civiele vonnissen. Met name ten aanzien van hun verbindende kracht verschillen civiele vonnissen van administratieve uitspraken. Uitspraken van bestuursrechters hebben (afgeleid van de beschikking) wellicht ook werking erga omnes. Bij civiele vonnissen wordt de rechtskracht van de uitspraak primair gekoppeld aan partijen. Bij de bestuursrechterlijke uitspraak is de beschikking (of: het besluit) datgene dat de omvang van het geschil bepaalt, in tegenstelling tot de rechtsbetrekking tussen partijen. Dat brengt een andere binding van de uitspraak met zich.

'De bindende kracht van de uitspraak in het administratief procesrecht is van een gehed andere orde dan die van vonnissen in het burgerijk procesrecht. Hebben vonnissen in het burgerlijk procesrecht in principe alleen bindende kracht tussen partijen, in hei administratief procesrecht moet worden aangenomen, dat uitspraken als publiektechtelike rechtsbeslissing algemene werking hebben, ten aanzien van iedetien ("erga ommes. ${ }^{*} \cdot 1$

9. A.M. Donner, De rechtskracht van administratieve beschikkingen, diss., Alphen a/d Rijn 1941, 13.

10. A.M. Donner, De rechtskracht van administratieve beschikkingen, diss., Alphen add Rijn 1941, p. 15.

11. A.Q.C. Tak, J.B.J.M. ten Berge, Nederlands administratief procesrecht, deel 2, Zwolle 1983, p. 241 en in de druk wan 1995. p. $406-407$. 
En in dezelfde zin:

'Omalat de procedure zich richt op een bepaald besluit, kan men concluderen dat de rechterlijke uitspraak eem definitef oondel geft over de rechtmatigheid van dat besluit, niet alleen ten opzichte wan partijen, maar ten opzichte van een ieder. Dit lijkt zeker in de rede te liggen, indien de rechter tot een vernietiging wal het aangewallen besluit komt." 12

Hier moet de rechtsvaststelling worden onderscheiden van de werking van de uitspraak of het vonnis tussen partijen. Als declaratoir, bekendmaking van het definitief door de rechter als rechtens gekenschetste, is uiteraard elke uitspraak gericht op een ieder; de inhoud echter is verschillend. Zal de burgerlijke rechter vaststellen wat rechtens is tussen partijen (inter partes) , zo oordeelt de bestuursrechter over het objectieve besluit met erga omnes-werking. Aldus is de uitspraak van de bestuursrechter met de executieve functie (bevoegdheidsdenken) verbonden, terwijl dat voor de uitspraak van de burgerlijke rechter niet het geval is; daar is (enkel) de rechtspraak-functie (het procesdenken) van toepassing.

Het is eveneens van belang om onderscheid te maken tussen de rechtskracht van een bodemuitspraak en een tussenuitspraak; de tussenuitspraak heeft doorgaans (vooral) betrekking op datgene wat tussen partijen rechtens is, terwijl de bodemuitspraak zeker ook dat oordeel over het beshit behelst. ${ }^{13}$

\title{
7.4.4 De rechtskacht van een beschikking
}

Donner reserveerde de term rechtskracht voor administratieve beschikkingen:

\begin{abstract}
"Van de beschikking gaan bepaalde werkingen uit welke de rechtsgenooten, daaronder ook de overheid, beperken in de mogelijheid ten wolle van hum bevoegdheden gebruik te maken of die bewoegdheden geheel uit te scinakelen. Deze werkingen hebben dus op het rechtsverkeer een zekeren verstarrenden of consolideerenden invloed. Van de mate van die werking hangt het nu af, of en onder welke omstandigheden de beschikking haar rechisgelding verhiest. Dezen weerstand nu duiden wij aan met den term rechtskracht."
\end{abstract}

Een recentere auteur in deze benadering is Ten Berge, die de formele rechtskracht van beschikkingen uitwoerig bespreekt, ${ }^{15}$ maar daarnaast ook stelt dat uitspraken van de bestuursrechter formele rechtskracht hebben. ${ }^{16}$

12. M. Scheltema en H.G. Lubberdink, Administratieve vechtsgangen, Algemeen deel, Hoofdstuk 7, p. 7. 1-5; overigens zijn zij van mening dat de rechtskracht van de uitspraak zich niet verder moet uitstrekken dan tot de partien bij die uisprak.

13. Vgl. ook mijn Enige opmerkingen omtrent de betekenis en rechtskracht van bestuursrechtelijke uitspraken naar anteiding van CRvB 26 jun 1997, JB 1997219 in: JB 1997210 en daar genoemde literafuur on jurisprudentie en ook ABR 15 september 1997, JB $1997 / 252$ m.nt. EvdL.

14. A.M. Donner, De rechtskracht van administratieve beschikkingen, diss., Alphen a/d Rijn 1941, p. 14

15. Vgl. J.B.J.M. ten Berge, Bescherming tegen de overheid, Zwolle 1995, p.342 e.v.

16. Vgl. J.B.M. ten Berge, Bescheming tegen de overheid, Zwolle 1995, p.198. 
Ook in ander recent werk wordt rechtskracht als eigenschap toegedicht aan beschikkingen; o.a. Van Wijk/Konijnenbelt/Van Male ${ }^{17}$, Nicolail/Olivier/Damen/Troostwijk ${ }^{18}$, Allewijn $^{19}$, Mok en Tjittes ${ }^{20}$.

In Duitsland tekende Tezner als eerste voor deze benadering van rechtskracht als toekomend aan "Verwaltungsakte".

Als gezegd is de beschikking drager van rechtsbestendigheid (bevoegdheidsbenadering) naast rechtskracht (procesrechtelijke benadering). Zowel de formele als de materiële varianten komen voor. Pas in 1965 werd het onderscheid in 'Bestandskraft' (rechtsbestendigheid) en 'Rechtskraft' (rechtskracht) in Duitsland gemaakt, het geen verklaart waarom Donner nog zo'n moeite had met het begrippenpaar formele rechtskracht-materiële rechtskracht, hetgeen hij later duidde als vernietigbaarheid-intrekbaarheid. Hij verkoos dit laatste begrippenpaar in 1985 boven het eerdere, omdat hij het abstractieniveau van het met eerdere paar verbonden onderzoek te hoog vond. Het begrippenpaar vernietigbaarheid-intrekbaarheid zou thet probleem beter voor het voetlicht kunnen brengen. ${ }^{21}$

\subsubsection{Heeft een besluit wan algemene strekking rechtskracht?}

Sinds de invoering van de Awb in 1994 kan de vraag gesteld worden of ook een besluit van algemene strekking (bas, niet zijnde een algemeen verbindend voorschrift, aww) drager is wan formele rechtskracht. Die vraag is (nog) niet expliciet gesteld in Nederlandse literatuur all wordt wel de rechtskracht van algemeen verbindende voorschriften (avv) besproken wanneer het (juist wel of juist niet) vervallen van artikel $8: 2 \mathrm{Awb}$ aan de orde is ${ }^{22}$ Daarover later meer.

De rechter liet zich inmiddels wel al uit over de rechtskracht van bas. De rechtskracht van bas is in de visie van de rechtbank Utrecht minder absoluut dan die van beschikkingen. Dat heeft te maken met de mate van duidelijkheid van deze rechtshandelingen. De rechtbank onderscheidde een soort glijdende schaal in de mate van (on)duidelijkheid van een besluit. Is een besluit onduidelijker dan is er meer onzekerheid ten aanzien van de rechtskracht ervan. Deze onzekerheid is doorslaggevend voor de vraag of aan het besluit formele rechtskracht kan worden verbonden. ${ }^{23}$ Zo bezien is de rechtszekerheid het richtsnoer voor de anvaarding van formele rechtskracht bij besluiten van algemene strekking: afhankelijk van de mate

17. Vgl. H.D. van Wijk, W. Konijnenbelt, R.M. varn Male, Hoofdstukken wan administratief rech, 'S-Gruvenhage 1997 , p. 601 e.v, p. 680-689, p. 716.

18. Vgl. P. Nicolai, B.K. Oliwier, I.C. van der Vhies, L.J.A. Damen, B.J. Schmeler, Bestuurstecht, Amsterdam 1997, p. 200 , 334 en p. 733 e.w.

19. Vgl D. Allewiin, Het nicuwe bestuursprocesrech, VAR-geschrift 112 , preadvies, Alphen a/d Rijn 1994, p. $73,74,76,80$ e.wen 94 , die niet expliciet verwijst naar de HR (Heesch-Yan de Akker).

20. Vgl. M.R. Mok en R.P.I.L. Tijtes, Formele rechtskracht en overheidsananspakelijkheid, in: RMThemis 1995 , p. $383-404$.

21. Vgl Interview met A.M. Donner, Ars Aequi 1985/12, p. 678.

22. Vgl. PG Awb 2, p. 378 en p. 385 e.w.

23. Vgl. Rechtbank Utrecht 10 mei 1996, JB 1996/195 mat EvdL. 
van concreetheid (dan wel onduidelijkheid) kan de formele rechtskracht van besluiten van algemene strekking een absoluter (dan wel aantastbaarder) karakter krijgen. In de woorden van de rechtbank:

\begin{abstract}
"De rechbank is derhalve van oordeel dat het Besluit moet worden beschouwd als een beslluit wan algemene strekking niet zijnde een algemeen werbindend voorschrift, zodat daartegen woor belanghebbenden rechtstreeks bezwatr en beroep openstond.

Formele rechsskrach wan het Besluit

Vagtstagt dat tegen het Besluit binnen de gestelde termijn door belanghebberden geen rechtsmiddwen zijn aangewend. (...) Uit het woorgaande blijkt allereerst dat de grens tussen algemeen verbindende voorschriften en woor beroep vatbarie besluiten van algemene strekking niet altijd scherp te trekken is aangezien er een soort glijdende schaal bestaat naar de mate watrin de uitwerking van een besluit in concreto ond uidelijker is. Deze onzeketheid maakt het naar het oordeel van de rechtbank reeds onwenselijk om aan het verstrijken van de beroepstermijn het ingrijpende gevolg te verbinden dat de rechtmatigheid van een dergelijk beshit niet meer ter discussile kan staan. (...) De rechtbank kan verweerder gelet op het worenstaande niet volgen in het standpunt dat de verbindendheid van het Besłait niet meer ter discussie kan worden gesteld omdat het recthtens onaantastbaar is geworden. ${ }^{34}$
\end{abstract}

De rechtbank verwart hier het duidelijk en aanwijsbare moment van vaststelling van het bas met de inhoud daarvan. Bovendien identificeert zij de inhoud van het bas met de inhoud van het algemeen verbindend voorschrift (avv).

Overigens is het moment waarop een bas genomen wordt in dezelfde zin vatbaar voor formele rechtsbestendigheid als de beschikking. Wanneer de bezwaarfase een aanvang neemt, komt de (formele) rechtskracht van het bas in beeld. De materiële rechtsbestendigheid en rechtskracht van bas en beschikking behelzen uiteraard een wereld van verschil; dit hangt samen met de functie van deze dragers (in relatie tot de trias).

De rechtbank onderstreept weliswaar dat het bas in casu formele rechtskracht heeft gekregen (er zijn immers geen rechtsmiddelen aangewend), maar vindt niet dat de inhoud ervan daarmee in rechte vaststaat.

\title{
7.4.6 Heeft een wet ook 'Bestandskraft'?
}

Maurer wroeg zich af of algemeen verbindende voorschriften, regelingen ook drager kunnen zijn van rechtsbestendigheid. Deze regelingen zijn bij Maurer dan met name 'Satzungen' en dat zijn o.a. gemeentelijke verordeningen, die aanwechtbaarzijn. Ze komen met name voor als bestemmingsplannen en stadswernieuwingsplannen, die als algemeen verbindend voorschrift gezien worden, maar daarnaast zijn ze er ook in thun algemeenheid. Overigens latat Maurer de rechtsbestendigheid ingaan na het werloop van de beroepstermijn (normaliter wordt dan van rechtskracht gesproken).

24. Rb. Utrecht 10 mei 1996, JB 1996/195 m.nt. ExdL, p. 819-820 en ook Rb. Zutphen 19 december 1997, JB $1998 / 45$ m.nt Evdl. 
Der Vergleich mit den Verwaltungsakt, der mach Ablauf der Anfechtungsfristen Bestandskraft erlangt, liegt nahe. In den Gesetzesmaterial ien sowie in der Literatur und Rechtsprechung wird dementsprechend auch won der 'Bestandskraft' der Satzungen gesprochen." 25

Maurer beantwoort deze vraag tweeledig; er zijn overeenkomsten en in zoverre kunnen "Satzungen" inderdaad 'Bestandskraft' hebben, mar er zijn ook verschillen waarbij 'Bestandskraft' voor 'Satzungen' niet in de rede ligt:

\begin{abstract}
Ebenso wie Verwaltungsakte konnen auch Satzungen nach ungenutztem Ablauf einer bestimmten Fist nicht mehr in Frage gestellt, sondern mussen als rechtlich gegeben hingenommen werden. Insofern mag man von der Bestandskraft von Satzungen sprechen.

Im ibrigen bestehen aber doch erhebliche Unterschiede in mehracher Hinsicht. Sie sollen im folgenden zusammengestellt werden. (...)

1. Unterschiede bestehen bereits bezighlich des rechtsdogmatischen Ausgangspunktes. Die Bestandskraft won Verwallungsakten knüpft an die materiell-rechtliche Rechtswirksanukeit von Verwaltungsakten an und sichert sie endgulltig ab. Die "Bestandskraft" der Satzung beruht dagegen darauf, daß bestimmte Rechtsverletzungen verfahrensrechtlich nicht mehr gettend gemacht und beriokssichtigt werden konnen. ${ }^{26}$
\end{abstract}

Maurer somt nog zes andere verschilpunten op ten aanzien van de rechtskracht van de beschikking en regeling. (De vergelijking gaat overigens op verschillende punten mank door de vele verschillen met de Nederlandse situatie, waar geen mogelijkheden bestaan tot rechtstreekse aanvechting van algemeen verbindende voorschriften ('Normenkontrollverfahren') bij de bestuursrechter en ook het algemene uitgangspunt van de 'Individualrechtsschutz' (rechtsbescherming van de individuele belangen van de burger) van het rechtssysteem is in Nederland anders uitgewerkt.)

De vraag roept wellicht de meeste verwarring op doordat impliciet de vraag naar het aannemen van formele rechtskracht bij normen wordt gesteld. In tegenstelling tot beschikkingen gaat het bij algemeen verbindende voorschriften (avv) om dle rechtsbestendigheid en de rechtskracht van een norm. Dat maakt nogal verschil. ${ }^{27}$ Rechtskracht aannemen voor regelingen in zijn algemeenheid (afkomstig van de Länder) wordt dan ook zeer betwijfeld:

"Auch die zustimmenden oder ablehnenden Stimmen in der Literatur befassen sich fasl durchweg mit dem Bebautugsplan. Die Begrundungen zu den landesrechtlichen Regelungen beziehen sich zwar auf die Satzungen im allgemeinen, sind aber pauschal und undifferenziert, $z$.T, sogar aberst fraglich. ${ }^{2 B 29}$

25. H. Maurer, Bestandskraft fur Satzungen?, in: Wege zum Rechtsstaat, Festschrift fhir Otho Bachof zum 70 . Geburtstag, Munchen 1984, S. 219.

26. H. Maurer, Bestandskraft fur Satzungen?, in: Wege zum Rechtsstaat, Festschrift fur Otio Bachof zum 70 Geburtstag, Munchen 1984, S. 234-235.

27. Ook in Nederland worden vaak 'norm'-argumenten gehanteerd tegen het aannemen van formele rechtskracht bij awv; vergelijk: POA Awb 2, p. 378 ev.

28. H. Maurer, Bestandskraft fur Satzungen?, in: Festschrift fur Otto Bachof zum 70. Geburtstag. Manchen 1984, S. 241. 
Het feitelijke moment van afkondiging van de wet kan gemakkelijk formele rechtsbestendigheid krijgen: ${ }_{s}^{30}$ het bewijs is de bekendmaking ervan op de woorgeschreven wijze (bijvoorbeeld plaatsing in het Staatsblad bij wetten in formele zin). Formele rechtskracht is voor de meeste regelingen uitgesloten daar zij niet rechtstreeks bij de bestuursrechter kunnen worden aangevochten. Dat hangt samen met de plats van wetgeving ten opzichte van rechtspraak in onze constitutionele ordening en daardoor eveneens met hun materielle rechtskracht; in Nederland is men er immers nog steeds niet wan overtuigd dat rechters wijzigingen kunnen aanbrengen in de werking van regelingen; dat bewijze wel het verbod van constitutionele toetsing. ${ }^{3}$ De materiële rechtsbestendigheid kan de wetgever zelf (naar believen) wijzigen.

\subsection{7 'Bestandskraft' voor 'verwaltungsrechlicher Ferträge??}

Omdat de wetgever 'Bestandskraft' in het Verwaltungsverfahrengesetzheeft opgenomen en de toelaatbaarheid van "verwaltungsrechtlicher Verträge" (bestuursrechtelijke overeenkomsten) ${ }^{32}$ al uitwoerig bediscussieerd werd, onderzoekt Büchner of dit "partnerschaftliches (Vertragliches) Handeln' ook met 'Bestandskraft' behept is. De toelaatbaarheid van 'verwaltungsrechtliche Verträge' wordt verder niet meer door Büchner besproken.

29. Overigens geeft Maurer aan dat het "Bebaungsplan' als "Satzung" een merkwaardige rechtsfiguur is; onduidelijk is of het cen beschikking, een regeling of een nieuwe derde figuur is: 'Der Bebauungsplan wird nach $\$ 10$ BBauG "als Salzung erlassen", er unterscheidet sich aber gleichwohl in verschiedener Hinsicht von den typischen Satzungen. Die Frage, ob der Bebaungsplan seiner Rechtsmatur nach Rechtsnorm oder Verwaltungsakt oder ein tertium ist, war vor Erlab des Bundesbaugesetzes (...) heftig umstritten. (...) Der Gesetzgeber (...) hat damit aber die Streitfrage rechtsdogmatisch nicht entschieden', in: H. Maurer, Bestandskraft fur Satzungen?, in: Wege zum Rechtsstaat, Festschrift für Otto Bachof zum 70. Geburistag, Munchen 1984, 5. 238 .

30. Dat teit stat er overigens niet an in de weg on de norm te bcoordelen; zo passeerde de ABR het onherrocpelijk worden van ecn bestemmingsplanwoorschrift in ABR 21 juli 1997, Gem.st. 7078, nr. 8 met illustrat leve noot van I.M.H. Teunissen (Niedorp).

31. Dat was ook het probleem warvoor de kort geding fechter zich gesteld zag in Pres. Rb. Assen 11 decemher 1997, Gem.st. 7076, nr. 5 m.nt. HH (Eelde). De formele rechtskracht werd an de beschikking verbonden (bestursswang), maar nit an het avw (APV-bepalingen); dat leven de moeilijkhid op dat een rechter in kort geding wetgewing onrechtmatig (uiteraard in de zin van het BW) zou moeten gatan verkitren. Wast die onrecktmatigheid tewens onverbindendheid van de regeling moet inhouden, deinst de rechter terug.

32. De definitie dic Buchner geef, luidt alswolgt: 'Ein verwaltungsrechlicher Vertrag liegt vor, wenn mehrere Rechissubjekte durch einander entsprechende Bffentlichrechtliche Willenserklarungen nichthoheitlicher Art Rechte und Pllichten auf den: gebiet des Verwaltungsrechts begrunden, aufheben oder andern', Die Bestandskiant warwaltungsrechthicher Vertage, Dusseldorf 1979, S. 7. Vgl ook Teil IV van het VwWG over het Offenthich-rechtlicher Vertrag. Nist uit het oog moet worden verloren dat in Duitsland niet het besluit rechsingang vornt bij de administratieve rechter, maar het belang van de burger. Dit belang krijgt vorm door middel van zogenaamde 'offentlichrechtliche Rechte oder Pflichten'; een verschijnsel dat wij] in Nederland niet kennen, maar dat met het Duitse uitgangspunt van 'Individualrechtsschutz' overeenstemt. 
"So fuhrte die wachsende Bedeutung ofentich-fechticher Vertrage wohl allmallich zu einer starkeren Beaching der Probleme der Bestandskraft und Bindingsdauer der Vertuge., ${ }^{33}$

Dat met de vraag naar de rechtskracht van bestuursrechtelijke overeenkomsten eigenlijk ook de vraag naar de afdwingbaarheid van die overeenkomsten wordt gesteld, beseft Büchner terdege wanneer hij stelt:

\begin{abstract}
'Unter Verwendung der im Vertragsrecht gebrauchlichen termini technici ist unter Bestandskraft verwallungsrechtlicher Verträge die Wirksamkeit, rechtsbeständigkeit und Verbindlichkeit solcher Vertrage für dic Vertragspartner zu verstehen. Diese Begriffe werden meist synonym verwandt. Mann sollte indes streng genommen nicht won der Bestandskraft verwaltungstechtlicher Vertraghe, sondern nur von der vorgenannten Wirksamkeit bzw. Verbindlichkeit verwaltungsrechtlicher Vertrige sprechen. (...) Der Terminus Bestandskraft ist der Lehre vom Verwaltungsakt entlehnt und seinem Inhalt tach den prozebiechnischen Instituten der formellem Rechtskraft (...) und der Entscheidungsbindung (...) vergleichabar. Verwaltungsrechtliche Vertrage werden aber weder im obigen Sinne formell rechtskräftig, noch kann man von eitner so gearteten Enischeidungsbindung sprechen. ${ }^{34}$
\end{abstract}

Kortom, eigenlijk is de terminologie niet zuiver, maar daarom beveelt Buchner de term 'Bestandskraft verwaltungsrechtlicher Verträge' wel als geschikte werktitel aan, temeer daar het vraagstuk onder dit steekwoord bekend is.

Wanneer hij overgaat tot de bespreking van de (on-) vergelijkbaarheid van "Vertragswirksamkeit' en de 'Bestandskraft von Verwaltungsakte' komt Büchner tot een falsificatie.

'Ein: Ubernahme der Bestandskraft von Verwaltungsakten auf verwaltungsrechtliche Vertratge und damit ein AnalogieschluB erscheint jedoch nur dann moglich, wenn rechtsăhnliche Tatbestande vonliegen. ${ }^{35}$

Vervolgens analyseert hij de kenmerken van de 'Verwaltungsakt" en concludeert:

'Diese vorgenannten Grundsatze Wassen sich indes nichl auf den werwatungsrechtlichen Vertrag ubertragen, da dieser in keinem Fall ein hoheitliches Rechtsgeschaft darstellt. Der verwaltungstechtichen Vertrag ist vielmehr ein hoheitsfreies zweiseifiges Rechtsgeschaft 36

En tenslotte concludeert Büchner:

'A iss dem Wesen des Vertrages und der aufgezeigten Verschiedenartigkeit von Vertrag und Verwaltungsakt ergibt sich aber, daB es un zwei unvergleichbare Groben handelt. Daraus folgt somit aluch zwingend, dall (...) kein 'Bindungsgleichwert' abgeleitet werden kann. (..) Im abrigen whrde sich bei einem Analogieschiub und der Annalmme einer Bindungsgle ichthe it won verwaltungsrechthichern Vertrag und Verwaltungsakt diw Frage aufdringen, ob das Rechtsinstitur des verwaltungs rechtichen Vertrag dann noch die Bezeichnung "Vertrag" verdient, denn er unterschiede sich nicht mehr wesentlich won eimem Verwaltungsakt. (...) Die Lehre von der Bestandskraft verwaltungsrechtlicher Vertsage ubersieht oder ignoriert somit, dab Venwaltungsakte und

33. Vg!. V. Buchner, Die Bestandskraft verwaltungsrechticher Vertrage, Dusseldorf 1979, S. $1-5$.

34. V. Buchner, Die Bestandskraft werwaltungsrechticher Vertrage, Dusseldorf 1979, \$. 14-15.

35. V. Buchner, Die Bestandskraft verwalungsrechtlicher Vertrage, Dusseldorf 1979, S. 90.

36. V. Buchner, Die Bestandskraft verwaltungsrechtlicher Vertrage, Dusseldorf 1979, S. 95. 
werwaltungsrechthche Vertrage vom Wesen her zwei nicht vergleichbare Gestaltungsformen sind, deren Ruchtsregeln nicht einfach untereinander ausgetaucht werden konnen. ${ }^{37}$

Valt het nog voor te stellen dat een overeenkomst wanneer die op enig moment is vastgesteld formele rechtsbestendigheid verkrijgt, zeker is daarbij ook dat de inhoud van de overeenkomst (de verbintenis) materieel rechtsbestendig wordt. Dat deze materiêle rechtsbestendigheid onvergelijkbaar is met de materiële rechtsbestendigheid van de beschikking wordt scherp wanneer ook hier weer het bevoegdheidsdenken (beschikking is een objectief besluit met erga ornnes-werking) tegenover het procesdenken (de verbintenis levert subjectieve rechten en plichten op) wordt geplaatst.

\subsubsection{Rechtskracht wan alle rechtshandelingen}

Rechtskracht wordt ook wel gezien als eigenschap van alle rechtshandelingen, dus als eigenschap van zowel wet, vonnis, overeenkomst of privaatrechtelijke handeling en beschikking. Donner signaleert deze visie, ondanks dat hijzelf kiest voor een andere definitie. Daarbij legt hij het verband met codificaties:

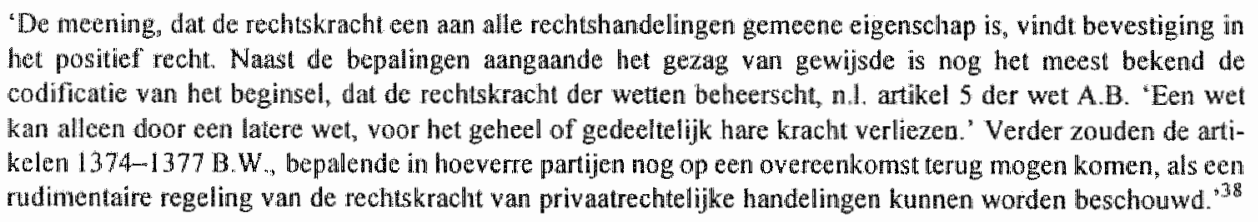

Stellinga legt het verband met de systematiek:

"Hier wreekt zich in het bijzonder, dat men cen figum als de rechtskracht niet over de gehele lijn heeft bezien. Zij is jarenlang alleen bij de rechispraak bezien (gezag van gewijsde!); eerst in de laatste jaren besteedt men ook aandacht an de rechtskracht bij de bestuurshandel ingen. Toch is dit nog onvolkomen: men zal slechts dan tot het ware karakter wan de rechtskracht kunnen doordringen als men haar ziet als algemeen probleen. 30

Steenbeek ziet rechtskracht van alle rechtshandetingen vanuit het uitgangspunt van de positileve rechtsorde. ${ }^{40}$ De grondslag is steeds de rechtshandeling en of dat nu een wet of een beschikking is, doet, vanuit principieel oogpunt, niet terzake:

37. V. Buchner, Die Bestandskraft verwalungstechticher Vertrage, Dusseldorf 1979, \$. 101-103.

38. A.M. Donner, De rechtskracht van administratieve beschikkingen, diss., Alphen a/d Rijn 1941, p. 16.

39. I.R. Stellinga, Grondtrekken van het Nederlands Administratiefrecht, Twolle 1973, p. 89-90; in zijn eerste editie van 1951 wordt dit citaat op p. 129 nog aangevuld: "... een algemeen probleem, optredende bij alle Overheidsverrichtingen" en vergelijk ook zijn Systematische Staatsrechtsstudie, diesrede voor de Rijksbelastingacademie te Rotterdam 16 oktober 1946, "s-Gravenhage 1946, p. 16.

40. Vgl, J.G. Steenbeek, Rechtshandeling en rechtsgevolg in het Staats- en administratief recht, diss., Assen 1958, th.b. p. 13 en zijn Rechtskracht, in: NTB 1989/8, p. 265-268. 
In mijn benadering kan de vraag van het bestaan van formele rechtskracht in principe ook worden gesteld bij andere besluiten zoals die walarbij een plan of een regeling is gegeven. Het lijkt mij vreend de rechtskrachivragg te beperken tot beschikkingen $(\ldots) .41$

Deze benadering, waarin rechtskracht de eigenschap is van alle rechtshandelingen, is in Duitsland door Kormann onderzocht. Dat hier door Nederlandse auteurs dan ook alleen van rechtskracht wordt gesproken, is verklaarbaar omdat zij nog niet bekend waren met het onderscheid in 'Bestandskraft' en 'Rechtskraft' zoals dat in Duitsland vanaf 1956 werd gemaakt.

Zo bezien is de spanningsverhouding (plooibaarheid en starheid) zoals Donner die ziet, verbonden aan dit onderscheid. De plooibaarheid wordt zichtbaar bij de materiele rechtsbestendigheid, die door het bestuursorgaan op elk nunc-moment kan worden gewijzigd (evenals het veel minder voorkomende intrekken van de formele rechtsbestendigheid ex tunc), terwijl de starheid zichtbaar is bij de formele rechtskracht, want het in rechte waststaan van die beschikking onderstreept de formele rechtsbestendigheid.

\subsection{Eigenschap van alle rechtsfeiten}

Of alle rechtsfeiten drager zijn van rechtskracht is een vrag die Stellinga zich aldus afvroeg:

'De vraag kan gesteld worden, of bij de politie-maatregelen ook sprake kan zijn van enige rechtskracht. Wat dit punt betreft bedenke men ook weer, dat de politie-maatregelen in de regel geen rechtshandelingen zijth, doch materiête daden. Dit moet als vanzelf meebrengen, dat er voor rechtskracht eigenlijk geen plaats is. Anders dan de rechtshandeling heef namelijk de materiele daad een onniddellijke feitelijke werking, zodat er over haar formele reclutskracht, haar bindende kracht niet behoeft te worden gedacht. (...)

Een uitzondering op deze regel kan aanwezig zijn in de gevallen, waarin tegen een politie-matregel administratief beroep openstaal, zoals volgens. art. 28 Hinderwet tegen een kennisgeving door $B$. en W. wan een voorgenamen sluiting en tegen cen mededeling van een verrichte sluiting. 42

Aldus neemt Stellinga aan dat er (slechts) sprake is van (formele) rechtskracht van rechtsfeiten, wanneer daartegen administratief beroep openstaat (dit zijn overigens - naar huidige maatstaven - steeds rechtshandelingen). Rechtsfeiten waartegen geen beroep openstaat, kennen alleen een feitelijke werking (en die is niet hetzelfde als formele rechtskracht). Rechtsfeiten (politie-maatregelen) hebben in zijn optiek nimmer materiële rechtskracht.

Maar meer dan zich afvragen of rechtsfeiten formele rechtskracht kunnen hebben, is dit wat Stellinga doet eigenlijk niet. Steenbeek trekt de lijn explicieter. Hij is immers - terecht - van

41. J.G. Steenbeek, Rechtskracht, in: NTB 1989/8, p. 267 en ook: "Wamner echter wordt aangenomen, gelijk in deze studie gebeurt, dat de rechtskracht is de kracht welke een bepaald rechtsverschinnsel kan opbrengen en dat in beginsel elk rechtsversehijnsel juist omdat het een rechtsverschijnsel is, rechtskracht heef (...), dan is als conclusie gegeven, dat elk overheidsbesluit (formele) rechiskracht heeth, zoals ook elke rechterlijke witspraak formele rechtskracht heeft, in: Rechtshandeling en rechtsgevolg in het Staats- en administratief recht, diss.; Assen 1958, p. 70.

42. IR. Stellinga, Grondtrekken van het Wederiands Administratiefrecht, Zwolle 1973, p. 179 
mening dat rechtshandelingen bijzondere rechtsfeiten zijn. Daaraan verbindt hij zijn indeling in formele en materiele rechtskracht. Dat is immers de reden waarom hij steeds spreekt van rechtshandeling en rechtsgevolg in het staats- en administratief recht.

Wolff hanteert dat onderscheid in aflopend moment (feit) en door de norm daaraan verbonden (blijvend) gevolg eveneens. Steenbeek had van dit in 1956 verschenen gedachtengoed van Wolff gebruik kunnen maken, maar het is duidelijk dat hij dat niet heeft gedaan. De overeenkomst tussen beide geleerden ten aanzien van de ontrafeling van feit en gevolg is echter treffend.

\subsection{Tenslotte}

Het belang van rechtskracht zit hem in het waarborgen van rechtsbeginselen, zoals rechiszekerheid, vertrouwen, duidelijkheid en voorzienbaarheid. Daarmee geeft het begrip de witwerking van legaliteit (gebondenheid aan het recht) en legitimiteit (op het geconcretiseerde en daarmee voor rechtssubjecten meest acceptabele niveau) weer. Rechtskracht moet herkenbaar zijn. De aloude koppeling van rechtskracht aan een concrete constituerende rechtsfiguur lijkt daarom zo gek nog niet.

Uit het voorgaande kan de conclusie getrokken worden dat rechtskracht een eigenschap is. Nagenoeg alle auteurs, die in de pen klommen met betrekking tot rechtskracht, zagen rechtskracht als eigenschap. Waar Van der Pot de rechtskracht van het vonnis vergeleek met de rechtskracht van beschikkingen, liet Donner het bij de rechtskracht van beschikkingen. Steenbeek sluit bij Donner aan terwijl Stellinga de rechtskracht onderscheidt als eigenschap van daden van wetgeving, rechtspraak, politie en besturur.

Een daarvan afwijkend standpunt wordt ingenomen door De Jong en Van Male. De Jong ziet rechtskracht nog als denk-hulpmiddel, maar Van Male ziet al helemaal geen eigenschap meer. Dat rechtskracht "vastzit' aan een beschikking of rechtshandeling van overheidswege of enige constituerende rechtsfiguur, is een kwestie van logica. Het is logisch om rechtskracht te verbinden aan een concrete rechtsfiguur, omdat:

\footnotetext{
"... het oogenblik, warop de wet wordt afgekondigd en het vonnis wordt uitgesproken niet op zichzelf staat, mar veel eerder exu pun vormt in een geheele reeks wan gebeuntenissen.

Dat eene punt is chter wan essenticel belang, het is de spil warom alles draait, daarop richt zich de woorbereiding en daarvan gnat de uitwoering ait. Dit hangt samen met het feit dat de stat een rechisinstelling is, die leeft en zich beweegt in rechtsvormen. De procedure van voorbereiding moge zich wijzigen, de uitwoering moge veranderen, nergens is het moment weg te denken, warop de ontwerpen en plannen overgaan in de rechtswerkelikheid en wh het geldend recht deell gaan uitmaken. 43
}

Rechtskracht is geen zelfstandige rechtsfiguur, geen rechtsfiguur op zichzelf, geen zelfstandig juridisch verschijnsel. Rechtskracht is een eigenschap. ${ }^{44}$

43. A.M. Donner, De rechtskracht van administratieve beschikkingen, diss., Alphen a/d Rijn 1941, p. 4.

44. Voorzover eigenschappen ook als 'rechtsfiguur' kunnen worden gedefinieerd, ligt dit uiteraard anders. Dat is echer hier niet het gewal. 
Wat wordt zichtbaar als de hypothese van deze studie wordt gehanteerd als maatstaf voor de verschillen in rechtsbestendigheiden rechtskracht van 'wet', bas, beschikking in besluitwormingsfase of in contentieuze fase, uitspraak, vonnis of overeenkomst tussen besturuorganen? Laten we de verschillen bezien vanuit de ontrafeling van feit, norm en gevolg.

Het eerste dat opvalt is dat bij de vraag of aan 'wetten' (algemeen verbindende voorschriften) rechtskracht toekomt in feite de vraag gesteld wordt of normen drager kunnen zïn van rechtskracht; dat is opvallend omdat in deze studie formele rechtskracht steeds werd gezien als eigenschap van feiten, terwijl materiële rechtskracht eigenschap van gevolgen is. Normen verlenen aan feiten weliswaar hun gevolgen, of beter gezegd bemiddelen bij het verlenen van (dan rechts)gevolgen aan feiten, maar zijn zelf niet drager van rechtskracht.

Bij deze en andere besluiten van algemene strekking (bundel beschikkingen, plan, beleidsregel) ligt de vraag, of zij drager kunnen zijn van rechtskracht, wel open zodra het feit en het gevolg in beeld komen; dan is de norm niet de drager van rechtskracht. Steeds zal dan gekeken kunnen worden naar het feitelijke moment (vaststelling van een 'wet', beschikking, plan, beleidsregel is een aanwijsbaar moment), waaraan formele rechtsbestendigheid gemakkelijk kan worden verbonden. Hetzelfde geldt voor de overeenkomst tussen bestuursorganen; wanneer het moment wan vaststelling van het contract als aanwijsbaar en aflopend feitelijk moment formele rechtsbestendigheidverlangt, zal de inhoud, de rechtsgevolgen (dat wil zeggen de verbintenis) materiële rechtsbestendigheid verlangen.

De uitspraak van de administratieve rechter en het vonnis van een burgerlijke rechter zijn beide te beschouwen als een rechtsfeit; in zoverre kunnen zij beide formele rechtskracht hebben. Het gevolg van beide rechterlijke uitspraken (administratief zowel als burgerlijk) is binding van partijen aan die uitspraak; deze binding is voorwerp van materiële rechtskracht (want het rechtsgevolg van het feitelijke doen van de rechterlijke uitspraak). De uitspraak van de administratieve rechter is echter ex tunc gegeven ten aanzien van een objectiefrechtelijk besluit en in zoverre bevat zij dus niet alleen de subjectieve inter partes bindende rechtsgevolgen van een rechterlijke uitspraak, maar ook een objectief en dus erga omnes bindend oordeel.

De rechtsbestendigheid van iedere beschikking vóor de contentieuze fase (de rechtsbestendigheid of 'Bestandskraft') wordt eveneens gekenmerkt door deze objectieve erga omneswerking, terwijl de rechtskracht in de contentieuze fase (de rechtskracht of 'Rechtskraft') juist de inter partes-werking benadrukt.

Als conclusie kan gelden dat er grote verwarring, onduidelijkheid, heerst in de discussie over welke rechtsfiguren als dragers van welke eigenschap aangemerkt kunnen worden. Dat komt doordat steeds met een andere bril naar het probleem wordt gekeken. Als men zich bewust is met welke bril er gekeken wordt, is het heel goed mogelijk om met de verschillende begrippen (formele en materiële rechtsbestendigheid en formele en materie le rechtskracht) om te kunnen springen. 



\section{Hoofdstuk 8}

\section{Een rechtspositivistische analyse van rechtskracht}

\subsection{Inleiding}

Verschillende auteurs, die over de betekenis van rechtskracht, formele rechtskracht en materiële rechtskracht schrewen, baseerden zich op Kelsen en Merkl. Vegting deed dat expliciet.' Steenbeek is niet zo expliciet, maar hij neemt wel uitdrukkelijk de positieve rechtsorde als uitgangspunt van elke studie aan. ${ }^{2}$ Zo kwam ik ertoe om het rechtskrachtbegrip te analyseren vanuit de theorie van de rechtspositivisten. Door zich te baseren op (of te laten inspireren door) de rechtspositivisten werd een belangrijke theoretische basis gelegd onder het rechtskrachtbegrip. Kreeg het begrip daardoor ook een specifieke betekenis? Laten we kijken waartoe de analyses van Kelsen en Merkl leidden, met name hoe het door hen gehanteerde rechtskrachtbegrip zich verhoudt tot de in deze studie gehanteerde toetsingsmaatstaf van feit, norm en gevolg. Zo zullen we zien welke hun invloed op het Nederlandse rechtskrachtbegrip was.

\subsection{Rechtskracht: gelding en/of werking?}

Kelsen onderscheidt juridische beweging en stilstand in zijn Reine Rechtslehre. Hij noemt dat 'Rechtsstatik' en 'Rechtsdynamik'; zij wormen de basis voor zijn theorie en daarbinnen maakt hij verdere onderscheidingen. Binnen de 'Rechtsdynamik' zijn er twee principes: het statische en het dynamische principe. Samen vormen zij het systeem waarop de gelding van normen gebaseerd is en dat samenkomt in de (vooronderstelde) 'Grundnorm".

Die Grundrom ist die geneinsame Quelle fur die Geltung aller zu einer und derselben Ordnung gehorigen Normen, ibr gemeinsamer Geltungsgrund. (..) Diese Grundnorm ist $e^{3}$, die die Einheit einer Vielheit von Normen konstituiert, indem sue den Grand fur die Geltung aller zu dieser Ordnumg gehowigen Normen darstelle: ${ }^{* 3}$

Wat houden die principes (binmen de 'Rechtsdynamik') in?

Het statische principe is een logisch subsumptie-principe: uit een hogere norm wordt een lagere afgeleid.

'Die Normen einer Ordnung des ersten Typus (het statische principe, Evdli.) gelten, das heibt: das von ihnen bestinme Verhalten der Menschen wird als gesollt angesehen kraft thres Jnhaltes: well thre Geltung auf eine

1. Vgl. W.G. Vegting, Het algemeen Nederlands administratiefrecht, deel I, Alphen a/d Rijn 1954, p. $268-269$.

2. Vgl. J.G. Steenbeck, Rechtshandeling en rechtsgewolg in het Stats-en administratief recht, diss, Assen en Arrithem 1.958, p. 32.

3. H. Kelsen, Reine Rechislehre, Wien 1960, p. 197. 
Norm zurbckgefuht werden karn, unter deren Inhadr sich der Inhallt der die Ordrung bildenden Normen als dass Besondere unter das Allgemeine subsumieren labt. So konnen z. B. die Nomen: man soll vicht ligetn, man soll nich betrigen (...) aus eimer Norm abgele itet werden, die Wahrhaftigkeit gebietet."

Het dynamische principe is het woortbrengende, producerende principe: de 'Grundnorm' bevat een bepaalde (morele) inhoud, die in de afgeleide normen voorondersteld wordt en gelegitimeerd is, omdat zij uit de 'Grundnorm' is afgeleid. Het dynamische principe heeft een enigszins concentrisch karakter.

'Der dynarnische Typus ist dadurch gekennzeichnet, dab die vorausgesetzte Grundnorm wichts anderes beinhaltet als die Einsetzung eines nommerzeugenden Tatbestandes, die Ermushtigung einer normsetzenden Autoritat oder - was dasselbe bedeutet - eine Regel, die bestimmt, wie die generellen und individuellen Normen der auf dieser Grundnorm beruhenden Ordnung erzeugt werden sollen. (...) Eine Norm gelhort zu einer auf einer solchen Grundnorm beruhenden Ordnung, weil sie auf die durch die Grundnorm bestimmte Weige erzeugt tst - und nicht, weil sie einen bestimmten Inhatt hat. Der Grundnorm liefert nur den Geltungsgrund, nicht aber auch den Inhalt der dieses System bildenden Nomen." ${ }^{\text {st }}$

Via het dynamische principe komt de gelding van normen naar voren. De logische afleiding van de ene norm uit de andere komt voort uit het statische principe. De inhoud van normen wordt door het statische principe afleidbaar (niet bepaald), de gelding staat vast omdat de norm op de daarvoor vaststaande wijze uit de vooronderstelde 'Grundnorm' voortkomt. De vorm van de norm staat los van de inhoud. 'Darum und nur darum gehört sie zu der Rechtsordnung, deren Normen dieser Grundnorm gemäß erzeugt sind. Daher kann jeder beliebige Inhalt Recht sein. ${ }^{6}$

Aldus bevat Kelsens Reine Rechtslehre een systeem waarbij uit de 'Grundnorm" de gelding (niet de inhoud) van concrete rechtsnormen afgeleid kan worden. Deze vaststelling door Kelsen wordt belangrijk geacht: 'Daarmee heeft Kelsen de belangrijke waarheid onderstreept, dat de gelding der rechtsnorm afhankelijk is van het dynamisch rechtsvormingsproces. ${ }^{7}$ Maar tegelijkertijd kritiseert Van Eikema Hommes hem, want "Kelsen heeft met zijn leer van het dynamische principe in het recht de verticale rechtsdynamiek op het oog. Maar hij maakt haar volkomen los van de relatief-constante, materiële rechtsbeginselen." Datarover meer in hoofdstuk 10.

\subsubsection{Ontrafeling feit, norm en gevolg}

Opvallend is dat recht en rechtsnormen bij Kelsen wolledig samenvallen. De aan elkaar verbonden normenhierrarchie vormt een logisch opgebouwd normenstelsel. Dat normenstelsel is de rechtsorde, het objectieve recht. Aangezien de rechtsorde een logische ordening van

4. H. Kelsen, Reine Rechtslehre, Wien 1960, p. 198.

5. H. Kelsen, Reine Rechtslehre, Wien 1960, p. 199-200.

6. H. Kelsen, Reine Rechtslehre, Wien 1960, p. 201.

7. H.J. van Eikema Hommes, De elementaire grondbegrippen der rechtswetenschap, Deventer 1972, p. 148 .

8. H.J. wan Eikema Hommes, De elementaire grondbegrippen der rechtswetenschap, Deventer 1972, p. 148. 
de structuur wan het stelsel weergeeft, is Kelsens rechtsopvatting te kenschetsen als een opvatting over het recht in objectieve zin. Het recht in subjectieve zin (de subjectieve rechten en plichten van personen) wordt door hem in de rechtsnormen ingelezen of anders gezegd, omvat. Dat betekent dat ook het recht in subjectieve zin tot de normenhierarchie hoort. Juist ten aanzien van dit onderscheid zall het spectrale perspectief - zoals we nog zullen zien in hoofdstuk 11 - kritiek leveren, omdat daar het onderscheid tussen norm en feit steeds in die zin (objectief versus subjectief) wordt gemaakt.

Overigens is de 'Grundnorm' een transcendentaal-logischevooronderstelling. Bewust wordt erkend dat de 'Grundnom' voorondersteld is en dat daarin de gelding van de dwangorde culmineert. Zodoende is de "Grundnorm" geen product van vrije bevinding, maar ondat het geheel aan objectieve rechtsnormen een uiterste grondslag moet hebben, is de "Grundnorm" deze transcendentaal-logische vooronderstelling. ${ }^{10}$ Juist op dit punt is de vergelijking met de transcendentale denkkritiek gemakkelijk; al culmineert alle transcendentale denkkritiek in het geloof en is het Archimedisch punt daar het religieuze godsbesef, iets waarvan de zuivere rechtsleer op grond van formeel-logische argumenten, in het bijzonder dat recht door mensen vastgesteld en gepositiveerd is, ontbloot is. Zo bezien ontpopt de "Grundnorm" zich als het product van de tovenaarsleerling; weliswaar door mensen gemaakt, maar norm der normen, het eeuwige en oneindige, steen der wijzen; kortom, de creatie van het goud.

\subsubsection{Kelsen: gelding en werking, 'Sollen und Sein'}

Een norm is voor Kelsen geldig als hij gepositiveerd is. Daarmee wordt de norm gerekend tot de wereld van het 'Sollen' in tegenstelling tot het 'Sein' van de natuurlijke werkelijkheid. De werking (de effectiviteit, werkzaamheid) van de norm behoort tot het 'Sein', is met andere woorden een 'Seintatsache'. Door deze vaststelling is door Kelsen de wraag opgeworpen welke de verhouding is tussen gelding (geldigheid) als een 'Sollen' en werking (effectiviteit) als een 'Sein'.

"Eine positivistische Rechtstheorie ist wor der Aufgabe gestellt, zwischen zwei Extremen, die beide unhaltbar sind, den richigen Mittelweg zu finden. Das eine extrem ist die These, daß zwischen Geltung als einen Sollen und Wirksamkeit als cinem Sein uberhaupt keine Beziehung bestelat, daf die Geltung des Rechts won seiner Wirksamkeit völlig abhangig ist. Das andere Extrem ist die These, dab die Geltung des Rechts mit seiner Wirksamkeit idertisch ist."11

Niet verloochend kan worden, vervolgt Kelsen, dat een rechtsorde in zijn geheel niet haar gelding verliest als een enkele rechtsnorm zijn gelding verliest. Daarom bestaat er een verhouding fussen gelding (geldigheid) en werking (effectiviteit), tussen "Sollen' en "Sein". Ook kan niet ontkend worden dat er rechtsnormen zijn die, ofschoon ze gelden, niet werkzaam zijn. Gelding (geldigheid) en werking (effectiviteit) zijn derhalve niet identiek.

9. Vgl. H. Kelsen, Reine Rechtslelore, Wien 1960, S. 194-195.

10. Wgl. H. Kelsen, Reine Rechtslehre, Wien 1960, S. 204-209.

11. H. Kelsen, Reine Rechtsllehre, Wien 1960, p. 215. 
'Die von Reine Rechtslehre worgeschlagene Losung des Problems ist: ( ..) Die Normen einer positiven Rechisordnung gelten, wedl die die Grundregel threr Erzeugung bildende Grundnorm als gultig vorausgesetz wird, aicht weil sie wirksam sind; aber sie gelten nur, wenn, das heiBt nut solange als diese Rechitsordnumg wirksam ist. (..) Eine Rechtsordnung verliert aber nicht dadurch ithe Geltung, dab eine einzelne Rechtsnorm ihre Wirksamkeit verliert (...) Eine Rechtsordnung wird als gultig angesehen, wenn ihre Normen im großen whol ganzen wirksan sind, das heiBt tatsachlich befolgt und angewendet werden. ${ }^{12}$

Kortom, omdat de rechtsorde gebaseerd is op de als geldig wooronderstelde 'Grundnorm" en op basis van die 'Grundnorm' werkzaam, effectief is, gelden de normen van de positieve rechtsorde. De normen wan de positieve rechtsorde gelden en werken daarbij zolang als de positieve rechtsorde geldt en werkt. Gelding (geldigheid) gaat derhalve aan werking (effectiviteit) vooraf, ondanks dat zij elkaar weronderstellen.

'Da die Wirksamkeit einer Norm darin besteht, dalb sie im groben und ganzen tatsächlich be folgt und wem nicht befolgt, im großen und gamzen angewendet wird, ihre Geltumg aber darin, dab sie befolgt oder wenn nicht befolgt angewendet werden soll, muB die Geitung won der Wirksamkeit der Norm als ein Sollen von einem Sein geschieden werden. ${ }^{* 3}$

\subsubsection{Kelsens rechtskracht: geldigheid als voorwaarde voor werkzaamheid (ofwel: werking door middel van gelding)}

De constantie van rechtsnormen die Kelsen ziet als gevolg van de samenwerking van het statische en het dynamische principe wordt opgevat als gelding van rechtsnormen. Deze geldige rechtsnormen werken; werking (effectiviteit) kan staan voor de rechtskracht van rechtsnormen. Kelsen ziet gelding (geldigheid) als voortspruitend uit een systeem dat samenkomt in de (met eeuwige gelding beklede) 'Grundnorm'. Door middel van een subsumptie-principe (het statische principe) wordt de lagere norm uit een hogere afgeleid. Door middel van een producerend principe (het dynamische principe) wordt een bepaalde (morele) inhoud afgeleid uit de 'Grundnorm'. Daardoor ontstaat een systeem dat elke inhoud tot recht kan afleiden/maken. De gelding (geldigheid) van rechtsnormen is derhalve afhankelijk van de rechtsdynamiek, een dynamisch rechtsvormingsproces.

We hebben gezien dat gelding (geldigheid) in de visie van Kelsen afhankelijk is van het dynamisch rechtsvormingsproces. Tevens beschouwt Kelsen gelding (geldigheid) als een normatief-juridische entiteit: een 'Sollen'. Werkzaamheid(effectiviteit) acht hij-als voortkomend uit een feitelijk substraat - een 'Seintatsache'. 'Sollen' en 'Sein' zijn met elkaar verbonden. "Wirksamheit ist eine Bedingung der Geltung, aber ist nicht diese Geltung selbst." Gelling (geldigheid) voert zodoende terug tot de 'Grundnorm', werking (effectiviteit) niet. Omdat juridisch correcte werkzaamheid gelding veronderstelt, kan de betekenis van Kelsens rechtskrachtbegrip worden gezien als werkzaamheid(door middel van

12. H. Kelsen, Reine Rechtslehre, Wien 1960, p. 218-219.

13. Zie het postum uitgegeven: H. Kelsen, Algemeine Theorie der Wormen, Wien 1979, S. 112.

14t. H. Kelsen, Reine Reclutslehre, Wien 1960, p. 220. 
gelding). De niet-werkzame norm verliest immers ook haar gelding (geldigheid). ${ }^{15}$ Gelding en werkzaamheid vallen in Kelsens wisie ook wel samen met de tweedeling recht en macht. ${ }^{16}$ Werkzaamheid of rechtskracht is aldus het feitelijk opvolgen en/of toepassen van een norm. Daarmee is tevens aangegeven dat rechtskracht in Kelsens visie steeds relatief (niet absoluut) is. ${ }^{17}$

\subsection{Rechtskracht: duur van de gelding}

\subsubsection{Inleiding}

Merkls rechtskrachtbegrip, dat inhoudt dat hij rechtskracht voomamelijk ziet als werking of werkzaamheid door middel van gelding, is afgeleid van Kelsens rechtskrachtbegrip (al baseert hij zich eveneens op Bernatzik). ${ }^{18}$ Merkl onderscheidt, net als Kelsen, gelding naast rechtskracht-werkzaamheid. Bij rechtskracht concentreert hij dan niet zozeer op het werkzame aspect (dat dan rechtskracht zou zijn), maar benadrukt hij de duur van de gelding (en dat definieert hij als rechtskracht). Vanuit de 'Ursprungnorm' (die altijd en overal geldt) ontstaan afgeleide normen: Grondwet, wetten, enz. Rechtskracht is de vraag naar de duur van de gelding van de afgeleide normen. Elk rechtsverschijnsel is, in die optiek, een norm en kan daarmee drager zijn van rechtskracht. Elke 'Staatsakt' kan rechtskracht hebben. Hoe zegt Merkl het zelf?

"Nicht die Geltung schlechthin, wohl aber die Geltungsdauer won Rechtlichem ist fur uns problematisch. Sie ist das hiemit erklarte Hauptproblem dieser Abhandlung. Wir machen nun die Beobachtung, daß die bisherige Jurisprudenz unter dem Titel der 'Rechtskraft' (...) die Frage der Gelingsdauer von Rechtserscheinungen aufgeworfen hat. Diese Geptlogenheit juristischer Terminologie veranlaBt uns und rechifertigt es zugieich, das soeben aufgerollte Problem der Geltungsidauer won Rechtlichem ebenfalls als Problem der Rechtskraft anzusprechen. (...) Also nennen auch wir unsere Frage nach der Geltungsdawer von Rechtserscheinungen die Frage nach deren Rechtskraft. Und unter der Rechtskraft selbst wollen wir die spezifische Geltungsdauer von Rechtlichem verstehen. ${ }^{19}$

En later zegt hij:

'Das Problem der Rechtskraft ist das Problem der Geltung von Rechtserscheinungen in der Zeit, genauer': das Problem der Geltungsdauer oder der zeitlichen Grenzen won Rechtserseheinungen. Unter Rechtskraft wersieht die Rechiswissenschaft (n..) die Eigenschaft gewisser Statsakte, wonach sie durch Akte gleicher Art entweden unter allen Umständen oder nur unter gewissen Umständen unabanderbar sind. (...) Als formelle Rechtskraft

15. Zo stelt ook HJ. van Eikema Honmes wast dat Kelsen de gelding van de rechtsorde afhankelijk maakt wan de werking van rechtsregels; De elementaire grondbegrippen der rechtswetenschap , Deventer 1972, p. 148 en: 'Und Kelsen macht auf antinomische Weise die normative Geltung von der faktischen Wirksamkeit, abhăngig' in: Sein und Sollen im Erfahrungsbereich des Rechts, in: ARSP 1970/6, S. 174.

16. Vgl. H. Kelsen, Reine Rechislehre, Wien 1960, S. 220-221.

17. Vgl ook het postum uitgegewen: H. Kelsen, Allgemeine Theorie der Normen, Wien 1979, S. 88.

18. Niet woor niets draggt A. Merkl zijn Die Lehre von der Rechiskraft entwickelt auss dem Reclitsbegriff, Wien 1923 aan zijn (Bematzks) nagedachtenis op.

19. A. Merkl, Die Lehre von der Rechtskraft entwickelt aus dem Rechtsbegriff, Wien 1923, S. 177 . 
gillt die Unabanderlichkeit eines Statsaktes auf grund des Abringens eines privaten interessenten; das bedeutet soviel wie Unanfechbarkeit. Die materielle Rechtskraft wird kurz als die allseitige Unabanderlichkeit eines Aktes gekennzeichnet. ${ }^{20}$

\subsubsection{Merkl: het rechtskrachtbegrip afgeleid wit het rechtsbegrip}

Het rechtskrachtbegrip wordt door Merkl afgeleid uit het rechtsbegrip. De 'Grundnorm' is de basis van elk rechtsverschijnsel en is zelf onveranderlijk, universeel. Een rechtsorde is en blijft onveranderlijk. Zelfs als afgeleide normen (van eenzelfde niveau -'Stufe'-) veranderen, blijft de rechtsorde als geheel gelden en blijft in die zin onveranderd. Enkel de "Grundnorm" is uiteindelijk onveranderlijk en heeft de geldingsduur van de eeuwigheid:

"Die rechtiche Ursprungnom, die das Fundament des ganzen Rechtsgebadudes darstellt, ist allein von unbedingler Geltung und hat infolgedessen won Rechts wegen unbegrenzte sowie unbegrenzbare Geltungsdauer. Sie erhebt den Anspruch auf Ewigkeit, teilt das Schicksal der gesamten Rechtswelt, deren Urgrund sie abgibt, und kanu von Rechts wegen nicht aus dieser Rechtswelt geschaffen werden. ${ }^{2 \sharp}$

De eerste, uit deze onveranderlijkheid van de 'Grundnorm' afgeleide, these van Merkls theorie luidt: 'Rechtliches gilt insolange, als nicht im Bereich bedingender Rechtserscheinungen aufscheinende Voraussetzungen für das Außergeltungtreten bedingter Rechtserscheinungen erfid It sind. ${ }^{22}$ Rechtskracht is zodoende steeds een eigenschap en dus van alle rechtsverschijningen.

Met betrekking tot de verhouding van rechtskracht tot het rechtssysteem (de vraag naar waarvan rechtskracht eigenschap is) stelt Merkl zijn tweede these: "daß die als Eigenschaft von Rechtlichem bestimmte Rechtskraft eine Eigenschaft unterschiedslos aller Rechtsnormen ist. ${ }^{, 23}$ Maar vooral wan belang voor het systeemdenken in het recht is Kelsens dynamisch rechtsvormingsproces of subsumptiesysteem, dat door Merkl de naam van 'Stufentheorie' heeft meegekregen, waarin alle rechtsnormen uiteindelijk zijn terug te voeren op de 'Grundnorm' of 'Ursprungnorm'. Rechtskracht moet in dat licht benaderd, geanalyseerd worden.

"Insotern ist dic Stufentheorie, wie schon Kelsen festgestellt hat, die erste bewulte Anwendung des den Juristen bislang fast fremd gebliebenen Systemgedankens auf die Welt der Rechtserscheinungen. Sind nun die Rechtsnomen - gleich welcher Rechtsform - gleichwertige Realisierungen der Rechtsidee, so fallt jeder Grund weg, sie in bezug aut dic Rechtskraftproblematik gesondert zu behandeln; zunachts schon das Problem der Rechtskraft wur in einzelne ausgewathlte Akte zu stellen, sodann die Rechtskraft je nach dem Akte oder wenigstens dem Rechtsgebiete, bezuglich dessen Problem gestellt wird, verschieden zu definieren und endlich - Konsequent nur in der Inkonsequenz - das Problem olne Rucksicht auf andere Telle des Rechisganzen oder gar aull dieses selbst derart za lösen, daß sich was sich heute Lehre von der Rechrskraft nennt, mosaikartig alus Teilerkenntnissen summiert, die von einem von Rechtserscheinung wechselden, wenn auch gleich

20. A. Merkl, Allgemeines Verwaltungsrecht, Wien und Berlin 1927, p. 201.

21. A. Merkt, Die Lehre von der Rechtskraft entwickelt aus dem Rechtsbegriff, Wien 1923, S. 178.

22. A. Merkl, Die Lehre von der Rechtskraft entwickelt aus den Rechtsbegriff, Wien 1923, S. 180.

23. A. Merkl; Die Lehre von der Rechtskraft entwickelt aus dent Rechtsbegriff, Wien 1923, S. 181 . 
benannten Gegemstande 'Rechtskraft' gewonnen sein wollen und dabei trotz einer minutiösen, unfruchbaren, auf einzelne Rechtsphänomene aufgewendeten Kleinarbeit doch nich die Sumne der Rechtstornten erschopfen, beziglich deren das. Problem der Rechiskraft aufgegeben isi. (...) Diese ganze kalsuistische Behandlung des Rechtskraftproblemes in der herschenden Lehre mit dem bezeichnenden Ergebnisse (..) werliert durch die als Voraussetzung einer revidienten Rechtskaftheorie versuchte Revision der Rechtsformensystematik jede Unterlage. (..) Die verhaltuismaBige Komplizitat des von der Sufentheorie erơffuneten Bildes der Rechtsordnung hat hingegen eine aufföllige Primitivität der Lehre von der Rechtskraft zur Konsequenz. Wenn Rechtskraft uberhaupt die Eigenschaft won Rechtichem ist, dann ist sie Eigenschatt aller Rechisnormen, welche Form immer das positive Recht für die Realisierungen der Rechisidee erfinden mag. (..) Bei allen positiviechtlichen Abweichungen in der Geltungsdauer der einzelnen Rechtsnormen ist es, rechtstheoretisch gesehen, doch die gle iche Rechtskraft, deren alle Rechtsnormen nicht blo B fihig, sondern auch teilhatig sind. ${ }^{24}$

De afgeleide normen zijn in die zin hetzelfde dat zij pas veranderbaar zijn als de rechtsorde (dat will zeggen het positiewe recht) de mogelijkheid heeft gecreeerd dat deze nomen veranderd kunnen worden. Dat betekent dat rechtsnomen in zekere zin onveranderlijk zijn. De onveranderlijkheid van de rechtsnormen als afhankelijk van de rechtsorde is zodoende relatief.

\begin{abstract}
"Wemn die Rechtskraft in Anlehnung an die herrschende Lehre als spezifische Gelungsdauer wan RechtVichem (...) bestimmt, und diese spezifische Geltungsdaver in Abweichung von der herrschenden Lehre dahin präzisiert wurde, dab eine Rechtserscheinung, im besonderen eine Rechtsnorm insolange gette, als nicht die im Bereich bedingender Rechtsnormen aufgesteltten Voraussetzungen für ihn AuDergeltungureten erfullt sind, so bedeutet dies eine gewisse Unveranderlichkeit der Rechtsnorm: eine Unverânderlichkeit, die allerdings dadurch bedingt ist, daB sich nichi aus höheren Rechtsnomen eine Abănderungsmöglichkeit ergibt, und eine Unveränderlichlkeit nur gegendber solchen Rechtsnormen, die nicht nit der Fahigkeit der Abanderung ausgestattet sind. In der Begrenzung dieser bedingter und relativen Unveranderlichkeit liegt der auffalligste Unterschied der hier versuchten von der ublichen Bestimmung der Rechtskraft. ${ }^{25}$
\end{abstract}

\title{
En verderop:
}

"Die Bestimmung der Rechtskraft als spezilischen Geltungsdauer von Rechtlichem mochte als Trivialitat er" scheinen, die im Vergleiche mil dem hochentwicketten Stande der heutigen Rechiskraftehre als Ruckschritt dunken mubte. Die weitere Bestimmung dieser spezifischen Geitungsdauer alls relative Unveranderlichkeit hat der Formulierung erst einen Sinn gegeben, die sie der herrschenden Lehre methr, als man auf den ersten Blick annehmen mochte, angenthert hat. In der besonderen Bestimmung des Grades der Relativitar dleser Unveränderlichkeit, in der Erkenntnis, daß das Recht in allen seinen Fonmen unveranderlich ist, soweit nicht die Anderungsmoglichkeit rechtlich ausdrlicklich gesetzt ist, besteht die radikale Abkehr won allen uberkommenen Vorstellungen. Die obige Definition der Rechtskraft duldet an diesem Zielpunkte des Gedinkenganges die Variation: Rechtskraft ist die Eigenschaft aller Rechtsnormen, dab sic - vorbehaldichi positivrechtlich gesetzter Abanderungsmöglichkeiten - grundsutzlich unabanderlich, oder anders ausgedrtickt, dats sie in Konsequenz der allseitigen Universalitat des Rechtes zeitlich unendlich gelten - wiederum vorbehallich der Fainigkeit des positiven Rechltes, diese grundsatzliche Unendichkeit zu ciner unendlich variablen Endlichkeit zu begrenzen. ${ }^{26}$

24. A. Merkl, Die Lehre von der Rechtskraft entwickelt aus dem Rechisbegriff, Wien 1923, $\$ .223-228$.

25. A. Merkl. Die Lehre von der Rechtskraft entwickelt aus dem Rechtsbegriff, Wien 1923, 5. 229.

26. A. Merkl, Die Lehre von der Rechiskraft entwickeit aus dem Rechtsbegriff, Wien 1923, S. 243-244. 
Aldus is rechtskracht als eigenschap van rechtsnormen de grens van het onveranderlijke, het oneindige, het onbegrensde, het eeuwige.

Merkl hanteert bij zijn analyse louter logische maatstaven. Als de rechtsorde als geheel een eeuwigheidsaanspraak heeft en rechtsnormen logischerwijze daarvan afgeleide onveranderlijkheid moeten hebben, dat is immers hun rechtskracht, dan spreekt vanzelf dat eveneens beweeglijkheid wan individuele rechtsnormen noodzakelijk is. Dat betekent dat veranderlijkheid als andere kant van de medaille van onveranderlijkheid steeds in de eigenschap rechtskracht aanwezig is.

\begin{abstract}
'Die Losung des Problems der Rechukraft der Verwaltungsakte liegt meines Erachtens in der Lostung des Problems der Geltungsdauer von Rechtsakten uberhaupt. Hat man erkannt, daß gewisse Arten von Verwaltungsakten, und zwar alle im weiteren: Sïne konstitutiven, rechtsbegrandenden Akte, Rechtssabze enthalten, so ust es selbstverstandlich, daß diese Gruppe won Verwaltungsakten mit allen anderen Rechtsakten Geltungsgebiet und Geitungsdauer gemeinsam hat, und bedonfte die Annahme, dabs sich Verwaltungsakte von anderen Rechtsaktern in bezug auf Geltungsgebiet und Geltungsdauer unterschieden, einer besonderen Rechts fertigung. (...) Aber kommt einer Rechtsordnung dberhaupt jenes Minimum an Wirkung zu, setzt sie sich in dem Mabe durch, daB man sie uberhaupt als geltendes Recht anspricht, so mub sie auch insoweit, als sie ilhr ortliches und zeilliches Gelungsbereich offenbar tberspannt, als geltend angesehen werden. (...) Jeder einzelne Rechtssatz gilt im Zweifel so lange wie die gesamte Rechtsordmung. Erwunscht ist aber selbstwerstandlich nur eine moglichst lange Geltungsdauer der Rechtsordnung - nicht jedoch kann die zeitliche Unbegranztheit jedes einzelnen Rechtssatzes erwinscht sein. Die Rechtsordnung tritt zwar mit dem Anspruch der Ewigkeit wie mit dem Anspruch der Souveranitat anfi, sie will aber eine Ordnung mit wechseldem, das bedeutet zugleich auch mit zeitlich begrenztem Inhalt sein. Um dies zu sein, muß das positive Recht die jeden Rechtssatz innewohnende Unendlichikeit zu einer irgendwie starr oder beweglich bemessenen Endlichke it begrenzen. ${ }^{\text {"27 }}$
\end{abstract}

In het onderscheid tussen formele en materiële rechtskracht benadrukt Merkl dan ook de noodzaak wan zowel veranderlijkheid als onveranderlijkheid.

'Die derart in ihrem Wesen bestimmte formelle und materielle Rechtskraft bedeuten zwei bestimmte Grade (relativer) Abanderbarkeit und (relativer) Unabänderbarkeit von Rechtsnormen, und zwar die formelle Rechtskraft einen verhalunismäBig höheren Grad von Abänderbarkeit als die materielle Rechtskraft, diese einen verhaltuismabig thoheren Grad von Unabinderbarkeit als jene. 2 st

Waar Kelsen onderscheid maakt in gelding (geldigheid) en werking (effectiviteit; die als rechtskracht werd benadrukt), zien we bij Merkl de verhouding tussen gelding en rechtskracht als toegespitst op de vraag naar de duur van de gelding. Merkl schiet naar mijn mening door. Bij Kelsen herken ik nog enigszins een nuance. De morele inhoud van rechtsnormen is daar immers niet afwezig, maar voorondersteld in de 'Grundnorm'. Het dynamische principe (producerende principe) maakt de gelding van afgeleide vormen mogelijk. Daarmee is een wijziging van de inhoud van de 'Grundnorm' niet onmogelijk. Bij Merkl is dat verband nagenoeg afwezig. Daar is de 'Grundnorm' eeuwig (geldt oneindig) en onveranderlijk (niet te wijzigen gelding; de inhoud is begtensd in zijn onbegrensdheid). Zo

27. A. Merkl, Allgemeines Verwaltungsrecht, Wien und Berlin 1927, p. 208-210.

28. A. Merkl, Die Lehre von der Rechiskraft entwickelt aus dem Rechtsbegriff, Wien 1923, S. 274. 
bezien heeft het dynamische principe geen creatieve rol meer. Principielle onveranderlijkheid van het recht en zo mogelijk de rechtsorde is daarvan het gevolg. Dat lijkt onaanvaardbaar. Weliswaar is enige mate van onveranderlijkheid van rechtsnormen in een samenleving wenselijk (zelfs noodzakelijk), maar tegelijkertijd moet er ook de mogelijkheid zijn tot aanpassing aan nieuwe omstandigheden. Merkl erkent dat slechts voor individuele 'Rechtssatze"; daar moeten zowel 'Unendlichkeit" als 'Endlichkeit' begrensd zijn. De voortdurende zoektocht naar evenwicht kan worden geduid met de spanning tussen individuele rechtszekerheid en vervulling wan het algemeen belang; in dat licht plaatste Donner het rechtskrachtprobleem: "Is de onveranderlijkheid der beschikking een rechtsbelang van de eerste orde, haar veranderlijkheid is het niet minder' ${ }^{29}$

\subsubsection{Kelsens en Merkls invloed op Stellinga?}

Elke norm kan rechtskracht hebben, is de stelling van de rechtspositivisten. Merkl zegt dat rechtskracht de specifieke gellingsduur is van rechtsverschijnselen in welke vorm het positieve recht ze dan ook gerealiseerd heeft, dus van alle normen in 'Staatsakten". De oplossing van het probleem van de rechtskracht van beschikkingen ligt volgens Merkl in de oplossing 'van de rechtskracht van 'Rechtsakten uberhaupt', omdat deze de rechtsregels bevatten. Elke gewone 'Rechtsakt' die normen bevat, geldt - in theorie - zolang als de rechtsorde als geheel geldt. De rechtsorde mag dan wel eeuwige aanspraak hebben, de individuele rechtsregels zijn in tijd en territoir begrensd (gepositiveerd) en hun duurzaamtheid is rechtskracht. Rechtskracht van beschikkingen is dusdoende ontwikkeld en afgeleid uit het rechtsbegrip, uit de rechtskracht van normen zelf. In de Nederlandse literatuur geeft Stellinga aan deze stelling als eerste uiting. Rechtskracht benadert hij in zijn Grondtrekken van het Nederlands administratief recht van 1951 als eigenschap van zowel wetgeving, beschikkingen, rechtspraak als materiële daden (feitelijk handelen). ${ }^{30}$ Dat feiten en normen door Stellinga dusdoende niet worden gescheiden neemt niet weg dat met het constateren van samenval van zijn benadering met die van Kelsen en Merkl geenszins vaststaat dat hij daadwerkelijk door hen is beïnvloed. Stellinga is het weliswaar niet met Merkl eens, ${ }^{31}$ maar verwijst vervolgens wel instemmend naar Merkl waarbij hij de rechtskracht van normen zoal's Merkl die beschrijft, duidt als een algemene beschrijving van rechtskracht. ${ }^{\text {tz }}$ Opvallend is daarentegen wel zijn stelling dat rechtsgeldigheid een voorwaarde is voor rechtskracht. Rechtsgeldigheid wordt als oordeel geduid, war rechtskracht de werking betreft; ${ }^{33}$ dat komt immers overeen met Kelsens beschouwingen. Juist over Kelsen is

29. A.M. Donner, De rechtskracht van administratieve beschikkingen, diss., Alphen a/d Rijn 1941, p. 20.

30. Vgl. J.R. Stellinga, De grondtrekken van thet Nederlands administraticf recht, Zwolle 1951.

31. Vgl. zijn opmerking: "Van de opvatting van Merkl is hier uityoerig meldirig gemaakt (...). Dat wil echter niet zeggen, dat men het met deze schrijver eens kan zijn." im: Grondtrekken van het Nederlands adrministratiefrecht, Zwolle 1951 , p. 136.

32. Vgl. I.R. Stellinga, De grondtrekken van het Nederlands administratiefrecht, Zwolle 1951, p. 135 en op p. 136: "Verdienstelijk is zijn zienswijze, dat de rechtskracht als universeel probleem moet worden gezien."

33. Vgl. IR. Stellinga, Gronderekken van het Nederlandis administratiefrecht, Zwolle 1951, p. 131 . 
Stellinga echter uitgesproken kritisch, omdat deze geen rekening houdt met het feit dat de rechtsnormen fungeren binnen werschillende functies (wetgeving, bestuur, rechtspraak), hetgeen bepalend is voor hun rechtskracht. ${ }^{34}$

\subsubsection{Kelsens en Merkls invloed op Vegting}

Voor Vegting ligt dit anders; hij noemt Kelsen en Merkl immers expliciet als inspiratiebron. Vegting neemt de indeling in gelding en rechtskracht over ${ }^{35}$ In die zin is hij beînvloed door Kelsen. Daarbij valt op dat Vegting gelding van recht weergeeft vanuit een statische beschouwing en rechtskracht gebruikt vanuit een dynamische beschouwing. ${ }^{36}$ Daardoor ligt de parallel met Kelsens statische principe en dynamische principe voor de hand. Vanuit die statische beschouwing van het recht is zijn indeling van regelmatige en gebrekkige beschikkingen verklaarbaar. Regelmatige beschikkingen zijn immers rechtsgeldig. Een dynamische beschouwing brengt rechtskracht in beeld: de anti-aantastingspotentie.

Vegting verwijst steeds naar Merkl. Kennelijk vat hij rechtskracht, de anti-aantastingspotentie, op als een soort van werking die de geldigheidsduur van rechtsnormen betreft (rechtskracht is dan temporele werking). Merkl noemt geldingsgebied (territoriale werking) steeds naast geldingsduur. De vraag naar de duur van de gelding van rechtsverschijnselen, zoals Merkl dat ziet, acht Vegting een bruikbaar uitgangspunt voor de benadering van vraagstukken met betrekking tot aantasting van beschikkingen. Rechtskracht is voor hem, evenals voor Merkl, een eigenschap van iedere rechtshandeling, waarvan de omvang afhankelijk is van het positieve recht. ${ }^{37}$

\subsection{Rechtskracht: gelding/geldigheid en werküng/effectiviteit?}

\subsubsection{Inleiding}

Recht is voor Steenbeek het objectieve recht (dat is het positieve recht) en het geheel aan subjectieve rechten in een samenleving. In zijn eigen woorden is een rechtsorde: 'dat het recht in zijn algemene betekenis (het objectieve recht, de [objectieve] rechtsorde) regeling ten doel heeft van onderlinge betrekkingen der mensen in de menselijke samenleving, maar dat ook tot het 'recht' gerekend moeten worden de subjectieve rechtsbetrekkingen. Een totaalbeeld van de rechtswereld is slechts te krijgen, wanneer men zowel de objectieve als de subjectieve rechtsbetrekkingen beschouwt en deze samen als een alomvattend complex ziet. ${ }^{3 R}$ Rechtskracht is erkenning door de rechtsorde: "Het zijn van een deel van de rechtsorde valt daarmede samen met het hebben van geldigheid of gelding en impliceert het

34. Vgl. JR. Stellinga, Grondtrekken var het Nederlands administratiefrecht, Zwolle 1951, p. 136 en 138.

35. Vgl. W.G. Vegting, Het algemeen Nederlands administratiefrecht, Alphen a/d Kijn 1954, deel 1, p. 262 e.w

36. Vgl. W.G. Vegting, Het algemeen Nederlands administratiefrecht, deel 1, Alphen a/d Rijn 1954, p. 270.

37. Vgl. W.G. Vegting, Het algeneen Nederlands administratiefrecht, deel $\mathbb{1}$, Alphen a/d Rijn 1954 , m.n. p. $268-272$.

38. J,G. Steenbeek, Rechtshandeling en rechtsgevolg in het Statis- en administratief recht, diss., Assen en Arohem 1958, p. 13. 
vermogen, deze geldigheid of gelding althans enigszins te handhaven. 'Recht zijn' betekent daram tevens "rechtskracht hebben"."39

\title{
8.4.2 Kelsens en Merkls invloed op Steenbeek?
}

Steenbeek redeneert vanuit de geldige rechtsorde. Erkenning door de rechtsorde is rechtskracht: omdat de rechtsorde als geheel geldt, moet ook de daarin bestaande rechtshandeling (als bijzonder rechtsfeit) rechtskracht hebben. Dusdoende heeft ook Steenbeek - net als Merkl - zijn rechtskrachtbegrip ontwikkeld en afgeleid uit zijn rechts-orde-begrip. of hij door Kelsen en Merkl is beïnvloed is daarmee nog niet wastgesteld. Steenbeek's stelling dat rechtskracht erkenning (van het zijn van recht) door de rechtsorde is, geeft ook Merkl aan:

\begin{abstract}
"die eigentumliche 'Kraft' des Rechtes ist die spezifische rechtliche Geltung. Dab dem Rechte Rechtskraft eigen ist, worde demnach nichts anderes bedeuten als dab es in der fur diese Normkategorie eigentumlichen Art, also rechtlich, gilt. Das Urteil, mit dem dem Rechte in seiner Totalitat oder einer Teilerscheinung des Rechtes Rechtskraft nachgesagt wird, spricht also, wenn man es den Wortsinne nach wurdigt, nur die Tautologie aus, daßs Recht Recht ist. ${ }^{*} 0$
\end{abstract}

Steenbeek wijkt ook af van Kelsen en Merkl. Bij hem is de vorm van de rechtsvorming (het rechtsfeit of de rechtshandeling), een aflopend en feitelijk iets; dit noemt hij formele rechtskracht. De rechtsgevolgen zijn blijwend; zij brengen een mutatie aan in de wereld van het recht en zijn daarmee 'op een materieel doel gericht', aldus Steenbeek. Bovendien stelt hij nadrukkelijk dat er geen verschil is in gelding en werking, in werken en gelden; gelding en werken zijn voor hem identiek (zodat we de term gelding maar beter kunnen opdoeken). Steenbeek onderscheidt wel tussen gelding en geldigheid:

\footnotetext{
'Het begrip 'gelding' is als zodanig actief van aard; het wijst niet in de eerste plaats op een kwaliteit, maar meer op een actie. Wanneer mer zegt, dat iets geldt, betekent dit, dat men zich aan dat 'iets' moet storen, dat men dat moet erkennen. Als recht geldt, wil dit zeggen, dat men zich aan dat recht moet storen, dat het functioneert en deel is van de actieve rechtsorde.

'Werken' en 'gelden' dekken elkaar daarmede, wanncer wij-bij de rechishandeling - de legitimerende werking als oneigenlijke werking buiten beschouwing laten. Recht, dat geldt, werkt, is in werking, en recht dat niet geldt, werkt niet, is niet in werking, en omgekeerd. Indien wij ook de oneigenlijke werking van de legitimatie er bij willen betrekken en willen bijiven vergelijken met de gelding blijkt dat wij in gelijke zin ook het begrip 'geiding' oneigenlijk kannen bezigen, zodai wij dan kunnen spreken van de gelding als legitimatie. Daarmede is de parallel tussen de begrippen volledig.

Dit oneigenlijke gebruik van het begrip "gelding" kunnen wil echter ook wel misten, want de Nederlandse tal kent het begrip: geldig; dit is meer geschikt om met de oneigenlijke werking te worden vergeleken, omdat het meer op de kwaliteit betrekking heeft dan op de actie.

Wij komen er dan toe het begrip "gelden" te reserveren woor het actieve werken van de rechtshandeling (= het veroorzaken van rechtsgevolgen) en voor het begrip "geldig zijn' een bestemming te zoeken in de sfeer wan
}

39. J.G. Steenbeek, Rechtshandeling en rechtsgevolg in het Stats- en administratief recht, diss:, Assen en Arnhem 1958, p. 66 .

40. A. Merkl, Die Lehre won der Rechtskraft entwickelt aus dem Rechtsbegriff, Wien $1923,5,171$ 
de legitimatie. Dat geldigheid met legitimerende functie kan worden geidentificeerd is daarmede nog niet gezegd. 'Geldig zijn' is in de cerste plaats een zaak van waardering, terwijl 'legitimatie" in de eerste plaats een zaak is van werklarend aanwijzen van de historische bron. (..)

Vergelijken wij vervolgens gelding en geldigheid, dan komen wij tot de volgende witkomst. De geldigheid wan de rechtshandeling kan eveneens op elk moment in de toekomst actueel worden gesteld, ondat zij betrekking heeft op het waarderen van het vermogen van de rechtshandeling als bron wan rechtsgewolgen te hebben gefungeerd. (..)

Uit sen en ander bilkt wel, dat de legitimerende functie van de rechtshandeling en de geldigheid dier recheshandeling, al zijn zij dan nüet identiek, toch voortdurend en onverbrekelijk met elkaar zijn verbonden. Het kan daarom, meen ik, geen overwegend bezwaar ontmoeten bij de rechtshandeling het begrip "geldigheid" te gebruken in nauw verband met de legitimerende functie. Als de geldigheid kan worden volgehouden, is daamede de legitimatie wan de gepretendeerde rechtsgewolgen wan die rechtshandeling gegewen.

(...)

Bif de rechtsgevolgen, teweeggebracht door de rechtshandeling, staat het, valak duurzame, actieve element op de woorgrond. De rechtsgevolgen wormen als zodanig een nieuwe rechtssituatie, die door de rechtsgenoten moet worden gerespecteerd. (..)

De rechtssituatie alls zodanig nu heeflt geen andere pretentie, dan dat zij als situatie erkend wil worden en dat men zich daarnalar moet gedragen. Zij werkt, zoals elke norm werkt, nadat deze eenmaall tot norm is verheven. (...) Zij werkt doordat zij werbindt, zich doet gelden.

Daarom lijkt het actief geaarde begrip 'gelding' bijzonder geschikt voot de aanduiding van deze actieve werking wan de rechtsigevolgen, van de rechtssituatie. ${ }^{41}$

Het belangrijkste verschil van Steenbeek met Kelsen is dat Kelsen gelding (geldigheid) en werkzaamheid (effectiviteit) expliciet van elkaar loskoppelt - ze moeten als een 'Sollen' (gelding) en als een 'Sein' (werkzaamheid) gescheiden worden - terwijl Steenbeek juist de overlap van gelding en werking benadrukt. Daarbij hanteren beide het dynamische principe van het rechtsvormingsproces (al doet Steenbeek dat niet zo expliciet - hij heeft het over gelding als actief van aard of over oneigenlijk gebruik van de term gelding).

Steenbeek's stellingen komen ook in meer abstracte zin erg dicht in de buurt van transcendentalistische stellingen:

'Esi ist die Korrelation von Norm und Tatbestand innerhalb des Rechtsaspekts, die fordert, daß Rechtsnormen nicht nur von Rechisfornem entworfen und erlassen werden, sondern dab sie in einen Prozeb der fortschreitenden Rechtsbildung und Rechtsverfeinerung aufgenommen werden. (.) Rechtsgeltung und Rechtseffekivitat hthgen in der Tat auts engste zusammen, ja, sie sind m.E. identisch. Rechtsnormen konnen fnur geltew, wenn sie effettiv die Rechtsbestunde regelm und werten. (...) Mam kann im dynamischen Rechtsbildungsprozeb zwischen einer horizontalen und eimer vericalen Rechtsdynamik unterscheiden. (...) Bieide. horizontate und venticale Rechtsdynamik, hangen unlosbar zusammen. Beide sind fundamentale Bedingungen (condiviones sine atra novi) der Geltung und Effektivitat des Rechts. Der dynamische Rechtsbildungsproze [h kann sich aber nur mittels rechticher Wiliensbildungen der kompetenten Rachisorganen vollziehen. Diese Willensbildungen sind aber konkrete faktische Geschehnisse. ${ }^{42}$

41. J.G. Steenbeek, Rechtshandeling en rechtsgevolg in het Staats- en administratief recht, diss., Assen 1958 , p. $62 \cdot 64$.

42. HJ. Hommes, Sein und Sollen im Erfahrungsbereich des Rechts, in: ARSP 1970/6, S. 175. 
Maar ook hier valt op dat gesproken wordt van rechtsnormen, waar Steenbeek rechtskracht ziet als eigenschap van rechtsfeiten.

\subsubsection{Ontrafeling feit, norm en gevolg}

Voor de betekenis van rechtskracht bij Kelsen is het onderscheid 'Sein' en 'Sollen' van belang. Normen behoren tot de wereld van het 'Sollen' net zoals dat het geval is voor gelding (geldigheid). Werking (effectiviteit) daarentegen is een kwestie van 'Sein'. Wanneer" nu de betekenis van rechtskracht bij Kelsen kan worden gedefinieerd als werking door middel van gelding, dan is rechtskracht een feitelijk gegeven dat alleen kan bestaan doordat er een normatieve achtergrond is. Dit lijkt - prima facie - sterk op de door Steenbeek gehanteerde definitie: rechtskracht is erkenning door de rechtsorde.

Toch is dit merkwaardig, omdat Kelsen steeds spreekt van werkzaamheid van normen (waar Steenbeek rechtskracht van rechtsfeiten definieert als erkenning door de rechtsorde). Dat impliceert dat Kelsens rechtskracht alleen maar als definitie kan worden gehanteerd in de zin van werking van de rechtsorde door middel van de gelding ervan; dan immers is het een feitelijk gegeven. Daarmee is blootgelegd dat zowel feit en norm ontrafeld moeten worden op het niveau van rechtsorde (stelsel, systeem) als op het vlak van de (individuele) norm. Juist daarover zegt Kelsen weinig, in tegenstelling tot auteurs die hem als inspiratiebron noemen.

Steenbeeks onderscheid in geldigheid en gelding benadrukt dit, omdat geldigheid als kwalificatie (van legitimatie) van een rechtsfeit (rechtshandeling) op een bepaald moment een feitelijke constatering is, terwijl gelding als gekoppeld aan de rechtsgevolgen blijwend actief is en daarmee illustreert dat normen feiten juridisch doen gelden en aldus aan erkenning vorm geven.

Merkls rechtskrachtbegrip, duurzaamheid (of temporele werking), is eveneens eigenschap van alle normen. Vegting neemt dat over waar hij rechtskracht ziet als eigenschap van alle rechtshandelingen, waarbij hij gemakshalve "alle rechtshandelingen" duidt als "alle beschikkingen':

'Afgezien van de Kelsenianse beperking van het positieve recht tot de wet, tot de grondnorm ende darop gebaseerde normen, biedt het begrip rechtskracht in de door Merkl ontwikkelde zin, enen bruikbaar uitgangspunt woor de benadering van de vraagstukken, die betrekking hebben op de vrata, welke omstandigheden een ongestoorde en duturame gelding van rechtshandelingen - voor ons doel uiteraard beperkt tot de gidmünistrat tieve beschikkingen - kunnen aantasten. ${ }^{43}$

Daarbij lijken rechtshandelingen (beschikkingen) eveneens als normen te worden opgevat. Vanuit de hypothese wan dit boek is dit opvallend, omdat feit en norm dusdoende niet worden gescheiden. Naast het feitelijk vaststellen van een beschikkingen is er immers de met de norm verbonden inhoud, waardoor het rechtsgevolg wordt bewerkstelligd. Is de rechtshandeling identiek met de norm, dan wordt het feitelijk vaststellen van de rechtshan- 
deling miskend. Wordt de rechtshandeling opgevat als rechtsfeit, dan wordt de relatie met de norm gedxpliciteerd.

\subsubsection{Betekenis van rechtskrach: gelding, werking, geldigheid}

Resumerend kan onderscheid gemaakt worden naar gelding en werking als entiteiten die verbonden zijn met het dynamische principe (actief zijn van aard) en geldigheid alls betrokken op het statische principe. Gelding en werking staan in verband met het voortbrengende, producerende principe (dynamische principe). Geldigheid is het gevolg van het logische subsumptie-principe (statische principe). Beide principes analyseerde Kelsen als deel uitmakend van 'Rechtsdynamik'. Daarmee zijn zowel. stilstand van het recht als beweging van het recht door Kelsen relatief opgevat.

Rechtskracht als erkenning door de rechtsorde of als afgeleid en ontwikikeld uit de rechtsorde kent daardoor naar mijn mening vier specifieke aspecten: gelding, werking, geldigheid en effectiviteit. Ik ga hier beknopt in op deze vier kenmerkende verschijningsvormen van rechtskracht.

Geldigheid zie ik als de statische of constante formele rechtskracht; of zoals Steenbeek dat onderscheidt datgene dat is veroorzaakt en dat afloopt. Geldigheid treedt in na vervulling van voorwaarden (zoals bv. afkomstig zijn van een bevoegd orgaan en na de voorgeschreven formaliteiten in acht genomen te hebben).

Gelding is dan datgene dat blijvend is en voortdurend bestaat; dit is wat Vegting duurzaamheid noemt. Dit is de dynamische kant van de rechtsgevolgen, het bestaan van een (gewijzigde) rechtssituatie.

Effectiviteit is de statische of constante kant van de rechtsgevolgen; het is het kunnen constateren of vaststellen dat een effect geldig bestaat. Effectiviteit heeft geldigheid als juridische causa nodig. Effectiviteit is naar mijn mening wat Vegting noemt de pretentie van elke rechtshandeling voor recht betekenis te hebben.

Werking is dan dat voortdurend daadwerkelijk effecten gesorteerd worden. Het is enerzijds de dynamische kant van effectiviteit. Anderzijds zijn er effecten die niet verbonden zijn met een gelarge causa; deze zun bijvoorbeeld niet bedoeld en toch gewoonweg aanwezig. Deze effecten kunnen en dienen soms gelegaliseerd, geldig gemaakt te worden; met andere woorden wanneer erkenning als zijnde geldig plaatsvindt, zullen gelding en effectiviteit deel zijn van de rechtshandeling. Dat is precies wat er gebeurt als bijvoorbeeld de rechter declaratoir de status van een rechtshandeling vaststelt. Ten aanzien van werking kwam Steenbeek niet rond; dit is wat hij de latent-heid van rechtsgevolgen noemt.

\subsection{Tenslotte}

De rechtspositivisten beschouwen de structuur van een rechtsstelsel louter op formeellogische wijze. Het systeem van de 'reine Rechtslehre' valt aldus te beschouwen als de grammatica van een rechtsstelsel. Een rechtsstelsel heef logica als bouw-basis nodig; in die zin is het een noodzakelijk systeem. Gelede normstelling en hiërarchie van normen als concretiseringen van de "Stufenbau" zijn niet meer weg te denken in westerse (staats)- 
rechtsstelsels. Maar, er zijn ook bezwaren tegen de "reine Rechtslehre" in te brengen. Het meest genoemde, en meest bezwaarlijke element van de theorie is ongetwijfeld dat het stelsel 'inhoudsloos' is, in die zin dat elke gewenste inhoud via het subsumptie-principe tot recht kan verworden. Kelsen zegt zelf dat 'jeder beliebige Inhalt Recht sein kann'. Dat is onbevredigend, want al is in Kelsens optiek de 'Grundnorm' dan wel niet inhoudsloos, de techniek van het recht maakt inhoudsloosheid wel degelijk mogelijk..4 Merkl trekt die lijn dan ook door naar in beginsel onveranderlijkheid van het recht, van een rechtsstelsel, juist omdat het is betrokken op een universele en eeuwig onveranderlijke 'Grundnorm'.

De conclusie moet zijn: wanneer Vegting en Steenbeek leunen op of geünspireerd zijn door dit rechtspositivistische stelsel, waartegen bezwaren zijn in te brengen (inhoud is irrelevant; elke inhoud kan recht zijn), is het voor de hand liggend dat deze kritiek aanzwelt. Vanuit die aanzwellende kritiek is een nieuwe theorie opgekomen, die andere paradigmata dan het louter formeel-logische perspectief voor het bestuursrecht naar voren wilde schuiven. Dan hebben we het over het betrekkelijk nieuwe, jonge paradigma van de wederkerige rechtsbetrekking in het bestuursrecht, gebaseerd wellicht op de theorie van de autopoiese. In het volgende hoofdstuk zal ik de formele rechtskracht vanuit deze autopoietische benadering analyseren.

44. In het verlengde daarvan ligt het kritiekpunt van de transcendentate methode dat de formeel-logische benadering eem aspect van de rechtswerkelijkheid. zow verabsoluteren, wardoor cen gemankeerde en eenzijdige anallyse natar voren komt. Zie verder hoofdstuk 10 . 



\section{De zelfproducerende formele rechtskracht; een analyse vanuit Teubners autopoietische benadering}

\subsection{Inleiding}

De 'wederkerige rechtsbetrekking' in het bestuursrecht kan worden beschouwd en geanalyseerd als voortvloeiend uit de theorie van de autopoiese van het recht. Het concept (door sommigen zelfs genoemd paradigma) van de wederkerige rechtsbetrekking is ontstaan als reactie op al bestaande dogmatiek. Hierop ga ik in de eerste paragraaf in.

Ook een theorie van autopoiese van het recht is een reactieve theorie: de theorie stelt zichzelf voor als de derde rechtsfilosofische theorie - dat wil zeggen naast het rechtspositivisme en de natuurrechtsleer - maar in ieder geval als de nieuwe grote rechtsfilosofische theorie waarmee het recht verklaard wordt.

"In the contemporary dilemmatic schism between formal analytical theories of law and more empiricallybased legal sociology, legal autopoitesis appears (...) as a kind of 'Columbus' egg'. Legal autopoiests is at the same time post-Kelsen and post-sociological. Both the internal viewpoint of the Kelsenian tradition which has been unable to account for differences between legal systems, and the critical project that inspired the extemal wiewpoint of legal sociology are in deep crisis today. In this historical situation of legal thought, autopoiesis is emerging as an ambitious attempt to reconcile the antagonistic views. Autopoiesis transcends and conserwes at the same time the split between pure theory and sociology. The view of law as a selfreproductive system of communication, the legal act as the element of the legal system, the combination of normative closure and cognitive openness - these features of autopoiesis give it a chance (...) to overcome the contemporary crisis in legal theory and sociology. ${ }^{1}$

In het Nederlandse bestuursrecht wordt Gunther Teubners naam steevast verbonden aan deze autopoiesis; ${ }^{2}$ zijn naam staat aldus aan de basis van de autopoiese als de belangrijkste beschrijver ervan. Deze autopoiese als theorie wan het recht kent een hoge mate aan eigen jargon. Vaak wordt gebruik gemaakt van specifieke terminologie. Als daarvan gebruik wordt gemaakt, geschiedt dat op een wijze waarbij de betekenis(sen) bij de lezer steeds bekend worden verondersteld. De termen worden dan nauwelijks op een directe manier toegelicht. Kortom, het gebruik van het eigen jargon wordt gekenmerkt door een hoge mate aan impliciet taalgebruik.

1. G. Teubner, Introduction to Autopoietic Law, in: Autopoietic Law: A New Approach to Law and Socjety, Berlin and New York 1988, p. 4.

2. Vgl. H. Stout en J. Stoop, Het falen van de wet, Een inleiding tot het autopoietisch denken van Ounther Teubner, in: Regelmaga 1991-1, p. 3; N.J.H. Huls en H.D. Stout (red.), Reflecties op reflexief recht, Zwolle 1992 
In dit hoofdstuk will ik trachten om de formele rechtskracht te analyseren vanuit dit autopoietisch perspectief. Daartoe zal ik een korte beschrijving geven van de belangrijkste analytische elementen van de theorie om dat vervolgens met de beschrijving van de formele rechtskracht samen te brengen. Tenslotte wordt twijfel geuit en kritiek geleverd. Voordat het zover is, will ik eerst het concept van de 'wederkerige rechtsbetrekking' uiteenzetten.

\title{
9.2 De "publiekrechtelijke wederkerige rechtsbetrekking" als reactie
}

\subsection{Inleiding}

Vanuit de gedachte dat eenzijdig overheidsoptreden de rechtsbescherming van de burger niet op ideale wijze kan behartigen (het bestuur zou dan namelijk boven de burger staan), ontwikkelde zich het denken in 'publiekrechtelijke wederkerige rechtsbetrekkingen'. De Jong geeft als volgt zijn commentaar op eenzijdig bestuur:

\begin{abstract}
"De ontwilkkeling van de algemene beginselen wan behoorlijk bestuur door de administratieve rachtspraak theeft echter duidelijk gemaakt dat deze visie niet meer kan worden volgehouden. Hoewel de aard van het beschikkings-begrip met zich meebrengt dat een element van eenzijdigheid nooit helemaal uit dat begrip kan worden gemist, is het eenzijdig karakter van het beschikkingsbegrip door de ontwikkeling van de algemene beginselen van behoorlijk bestuur naar de achtergrond gedrongen.

Doordat in de jurisprudentie eisen worden gesteld aan de motivering en aan de zorgyuldige voorbereiding van beschikkingen, wordt duidelijk dat de beschikking niet meer als bestuurshandeling op zichzelf beschouwd moet worden. De beschikking is ingebed in een rechtsbetrekking die zich tussen burger en bestuursorgaan ontwikkelt. Bestuursorganen moeten rekening houden met de standpunten van de burger en de betrokken belangen tegen elkaar afwegen, woordat zij tot het geven van een beschikking overgatan. De burger zal echter ook het zijne er toe bij moeten dragen dat het bestuursorgaan in staat wordt gesteld de rechtens juiste beslissing te nemen. Ook op de burger rusten in dit verband informatie- en medewerkingsplichten. Dit spreekt wellicht nog het meest in die gewallen warin er sprake is van duurbeschikkingen: beschikkingen waarvan de werking zich uitstrekt ower een langere periode. In die gevallen zijn de betrokken belangen voor de burger meestal gewichtiger dan bij beschikkingen die gericht zijn op eenmalig handelen. ${ }^{.3}$
\end{abstract}

Wat houdt die "publiekrechtelijke wederkerige rechtsbetrekking" eigenlijk in? Waarop berust het denken in termen van een 'publiekrechtelijke wederkerige rechtsbetrekking'?

\subsubsection{Oorsprong van het begrip 'publiekrechtelijke wederkerige rechsbetrekking'}

Het begrip wederkerige rechtsbetrekking werd officieel geöntroduceerd in januari 1987.4 Door opname van het concept in de Memorie van Toelichting bij de eerste tranche van de

3. J.P. de Jong, Bestuursrecht van vreemde herkomst, diss., Zwolle 1988, p. 71 .

4. Dat was per 19 januari 1987 ter gelegenheid van het aanbieden van het Voorontwerp van de Wet houdende algenene regels van bestuursrecht $(A w b)$ door de Commissie Wetgewing algemene regels van bestumrsrecht (waarvan de Vz. M. Scheltema was en de vice-vz. E.M.H. Hirsch Ballin), Staatsuitgeverij, Den Hagg 1987, p. 23-25. Ten aanzien van de gedachtenworming loopt een spoor tussen Hirsch Ballin en J.P. de Jong, die (op 29 september 1988 an de KUB) promoveerde op zijn proefschrift Bestuursrecht van vreemde herkomst (Zwolle 1988), waarbij Hirsch Ballin optrad als promotor 
$A w b^{5}$ krijgt het impact. De nieuwe benadering wordt gepresenteerd als de leidraad van het wetsontwerp. De 'wederkerige rechtsbetrekking' is daar een kenschets van de verhouding tussen bestuur en burger. Bestuur en burger staan tot elkaar in een betrekking en dat is een wederkerige relatie.

Hirsch Ballin beschrijft in 1989 het wederkerige karakter van het bestuursrecht en komt daarbij tot de volgende drie kenmerken. ${ }^{5}$

Ten eerste bindt de overheid niet alleen de burgers, zij is zelf in haar hele besluitvorming gebonden aan het recht. Dat is wederkerigheid. In de woorden van Hirsch Ballin:

"kan de karakterisering wan het bestuursrecht als "wederkerig" duidelijk naken dat ook de overheid in hasar hele besluitvorming aan het recht is gebonden.'

Ten aanzien van de beoordeling van de situatie (de feiten) op basis waarvan de overheid een beslissing moet geven is er ook sprake van wederkerigheid. De algemene beginselen van behoorlijk bestuur waken over deze situatie. Als het bestuur rekening moet houden met de belangen van de burger, is de burger belast met het verlenen van medewerking aan het bestuur (advisering, inspraak- en hoorprocedures). Zo wordt

"de communicatie tussen bestuur en burger terecht als kenmerk van de zo opgevatte wederkerigheid genoemd.' (cursiwering HB)

Als derde punt geeft Hirsch Ballin een pregnant kenmerk van de wederkerigheid. Deze zegt namelijk:

"ook tets over dat waartoe de burger - afgezien wan de als uitkomst van het besluitwormingsproces mogelijk gan de betrokkene op grond van wettelijke voorschriften op te leggen verplichtingen - jegens bestuursorganen gehouden is."

Wederkerig bestuursrecht is het resultaat van wederkerig constitutioneel recht, aldus Hirsch Ballin. Wederkerig bestuursrecht is namelijk een uitvloeisel van een contract van de overheid met de burger. De 'wederkerige rechtsbetrekking" staat middenin het

"denkmodel van het maatschappelijk contract, en het is die wederkerigheid implicerends, fundamentele constitutionele beslissing die aok de wederkerigheid in het bestuursrecht voortbrengt."

De 'rechtsbetrekking' wordt door Hirsch Ballin begrepen in de zin van de "als kenmerk van een rechtsstatelijk bestuursrecht toegelichte "wederkerigheid" waarbij "het bestursrecht wordt begrepen als ordening van bestuursrechtelijke rechtsbetrekkingen'. ${ }^{8}$ Op die wijze

5. Dat was per 17 juli 1989. De verantwoordelijke minister (van Justitie) destijds was E.M.H. Hirsch Ballin Vgl. TK 1988-1989,21.221, nr. I (Koninklijke boodschap), p. I en wr.3 (MvT), p. 13.

6. Vgl EM.H. Hirsch Ballin, Wederkerig bestursirecht in: RM Themis 1989/1, p. 2-3.

7. E.M.H. Hirsch Ballin, Wederkerig bestuursrecht in: RM Themis $1989 / 1$, p. 4.

8. E.M.H. Hirsch Ballin, Wederkerig bestuursrecht, in: RM Themis 1989/1, p. 3. 
staat het begrip wederkerige rechtsbetrekking voor door het recht gedefinieerde relaties tussen overheid en burger. Door middel van dit rechtsbetrekking-begrip wordt het mogelijk de samenleving te beheersen, te controleren. Voorgeschiedenis, beslissingsmoment en nageschiedenis van besluiten zijn dan een continu ontwikkelingsproces van de 'rechtsbetrekking".

Gribnau stelt dat met het als uitgangspunt aannemen van het rechtsbetrekking-paradigma in het denken over bestuursrecht afstand wordt genomen van het top down-denken.

\begin{abstract}
'Alfa en omega van het bestuursrecht is derhatwe niet meer een overheid die de door het legaliteitsbeginsel ingekaderde bewoegdlineid heeft burgers te beperken in de uttoefening wan hun rechten en vrijheden, met andere woorden de burgers op basis van een wettelijke grondslag - eernzijdig - te binden."
\end{abstract}

De overheid is het kennelijk niet toegestaan eenzijdig burgers te binden. Anderzijds hebben burgers ook verplichtingen, alhoewel het feit dat er wederzijds rechten en plichten zijn niet impliceert 'dat deze als het ware symmetrisch verdeeld zijn, dat het recht beide partijen evenweel rechten en plichten toekent." 10

Ook Van Male analyseert de beide elementen van het concept. Het element rechtsbetrekking wordt opgevat als een permanente rechtswerhouding tussen overheid en burger, waarbij de rechtspositie van enige deelnemer niet meer bepaald wordt door een vanwege de overheid vastgestelde rechtshandeling.

'Het thematiseren van de verhoudingen tussen subjecten als permanente - - door dynamiek bepaalde - rechtsverhoudingen kan verhelderen dat de toepassing van het recht niet alleen afhankelijk kan worden gesteld van een min of meer toevallige woorafgaande constituerende rechtshandeling. "11

Het element wederkerig duidt volgens Van Male niet op een ruilkarakter:

"Met wexterkerigheid van de rechtsbetrekking is stellig niet bedoeld dat burger en bestuur over en weer vrijelijk verbintenissen zouden kumnen scheppen met betrekking tot het algeneen belang. ${ }^{12}$

9. II.M. Gribnau, De wederkerige rechtsbetrekking als nieuw paradigma?, in: R\&R 1993/2, P. $91-92$ met erratum in R\&R $1993 / 3$, p. 244.

10. J.L.M. Gribnau, De wederkerige rechtsbetrekking als nieww paradignna? in: R\&R 1993/2, p. 92 , cursivering van Gribnau met erratum in R\&R 1993/3, p. 244. Tjuttes stelt dat te verwachten valt "dat de wederkerige relatie tussen bestuun en burger zich verder zal ontwikkelen naar meer verplichtingen van de burger jegens het bestuur' in: R.P.J.L. Tjuttes, Herbezinning op de grondslagen van de overheidsaansprakellifkheld, preadvies Vereniging voor burgerlijk recht, Lelystad 1996, p. 53 .

11. R.M. van Male, Onvoltooid recht, Over rechtsbetrekking, bestuursreclnt en bestuursprocesrecht, oratie EUR 1993, Zwolle 1993, p. 16.

12. R.M. wan Male, Onvoltooid recht, oratie, Zwolle 1993, p. 17. 
Houdt wederkerigheid dus niet in een vorm van omkeerbaarheid van het aangaan wan rechtsbetrekkingen, het betekent wel dat "het bestuur gebonden is aan de beginselen van behoorlijk bestuur. ${ }^{183}$

Maar, stelt Van Male, het ruilkarakter is dan weliswaar niet bedoeld (niet expliciet), het ligt wel enigszins opgesloten in de rechtsbetrekking. Welke verplichtingen heeft de burger, vraagt Van Male zich af, als het bestuur de algemene beginselen van behoorlijk bestuur in acht zal nemen? Welnu, het is zo dat "de burger zich ervan bewust moet zijn dat hij met het bestuur in een wederkerige rechtsbetrekking staat. ${ }^{\prime 4}$ De burger dient zijn inzichten en belangen op een daarvoor geschikte wijze naar voren te brengen. Hij heeft m.a.w. een zorgplicht, is de conclusie van Van Male, en hij vraagt zich af hoever die zorgplicht gaat en waarop die berust.

Kortom, de 'publiekrechtelijke wederkerige rechtsbetrekking' wordt gekenmerkt als een continue relatie tussen bestuur en burger waarbij de overheid aan het recht is gebonden, het bestuur de algemene beginselen van behoorlijk bestuur in acht dient te nemen en op de burger een medewerkingsplicht (zorgplicht) rust. De 'publiekrechtelijke wederkerige rechtsbetrekking' is als paradigma kunnen ontstaan uit de grote vlucht die de algemene beginselen van behoorlijk bestuur in het bestuursrecht (met name in de jurisprudentie) hebben genomen en zou volgens sommigen een uitvloeisel zijn van een maatschappelijk contract tussen overheid en burger. De 'publiekrechtelijke wederkerige rechtsbetrekking' is het duidelijkst waarneembaar in het geval van duurbeschikkingen.

Het maatschappelijk contract is in het fundament van deze wederkerigheid vooral een model van voortdurend onderhandelen tussen staat en burger. Dit interactionisme kenmerkt zich door het ideaal van de flexibiliteit. Het interactionisme zou een zichzelf producerend recht bewerkstelligen.

\subsection{Een beschrijving van autopoiese}

De oorsprong van de autopoiese ligt, zo wordt well beweerd, in het falen van wetgeving. De vertaling van autopoiese als zelfproductie kent de biologie als bron. Recht wordt gezien als subsysteem van de werkelijkheid. Problemen wan buiten het juridische subsysteem ('noise') worden vertaald in systeem-eigen termen. Zo worden algemene problemen naar juridische problemen vertaald. De juridische oplossingen brengen aldus variaties aan op de juridische systemen. Zo produceert het juridisch subsysteem zichzelf. ${ }^{15}$

13. R.M. van Male, Onvoltooid rech, oratie, 2 wolle 1993 , p. 18.

14. R.M. van Male, Onvoltooid recht, oratie, Zwolle 1993, p. 18.

15. Vgl. H. Stout en J. Stoop, Het falen van de wet Een inleiding tot het autopoietisch denken van Gunther Teubner, Regelmat 1991-1, p. 3 . 


\title{
9.3.1 Autopoiese vloeit voort wit reflexief recht
}

Autopoiese vloeit voort uit reflexief recht, dat op zijn beurt een reactie is op het falende recht van de verzorgingsstaat:

\begin{abstract}
"Toen Teubner (..) zün idee van teflextef recht introduceerde, omschreef hij reflexief recht als 'a new evolutionary stage of law", een stadium dat gezien kan worden als "an emerging but as yet unrealized possibility". Het idee wan een evolwtionaire, historische ontwikkeling van het recht is derhalve cruciaal voor een juist begrip van reflexief recht. De belanigrijkste stadia wan dat proces wan rechtsontwikkeling zijn volgens Teubner de volgende. De klassieke 19 eeuwse opwattingen van recht en stat staan model voor een rechistype dat kan worden aangemerkt als formeel-rationeel. (...) In de loop wan de $20 \mathrm{e}$ eeuw hebben echter maatschappelijke ontwikkelingen de beperkingen wan het formeel-rationele recht aan het daglicht gebracht, hetgeen zelfs heef geteid tot een algemeen arkende crisis van formele rationaliteit. Uit deze crisis is een nieuw type van inhoudelijk rationeel recht ontstaan, dat wil zeggen recht dat typisch als een insirument voor doelbewuste maatschappelijke interventie wordt gebruikt door de verzorgende-regulatieve staat en zijn bureaucratiedn. (..) De crisis van de moderne verzorgingsstaat heeft echter de inherente tekortkomingen van inhoudelijk rationeel recht geopentaard, sterker nog, heeft dat recht zelf in cen diepe crisis gestort. In de stofwolken van die crisis zijn thans contouren zichtbaar van weer een nieuw type recht, een recht dat geheel wordt gekenmerks door 'reflexieve rationaliteit'. (...) Reflexief recht mikt noch op de "autonomic' die hoog in het waandel staat wan formeel recht, noch op de 'regulering' waar inhoudelijk recht het van moet hebben, marar zookt in plaats daarvan naar "gereguleerde autonomie". (...) Dexe korte schets moge voldoende zijn om duidelijk te maken dat het idee van reflexief recht in feite alleen maar begrepen kan worden in termen vam tegenstelling tot modem, instnumenteel, intervenierend, regulatief, doelgericht, inhoudelijk recht. (...) De tern autopoiese is pas kortgeleden opgekomen vanuit de biologie (de onmisbare namen zijn hier die van Maturana en Varela), vervolgens overgewaaid naar de sociale wetenschappen (de belangrijkste context is die van Luhmann) on ten slotte geîntroduceerd in de rechtsweterischappen. Wat dit laatste betreft heeft geen auteur mér invloed gehad dan Teubner zelf. Zijn geschrifteh van de afgelopen jaren (...) kunnen worden gelezen als een uitvoerig pleidooi voor de relevantie van autopoiese voor de theorie en praktijk van het recht. (...) Dat ook de kern wan rechtsautopoiese bestaat uit de principiele afwijzing van het moderne, inhoudelijke, intervenierende recht. 16
\end{abstract}

Reflexief en autopoietisch recht zijn aldus ontstaan als reactie en in oppositie op het recht wan de sociale verzorgingsstaat. Ten aanzien van het bestuursrecht werd de autopoietische benadering zichtbaar door de introductie van de wederkerige rechtsbetrekking als nieuw paradigma voor het bestuursrecht. Met name het kenmerk "the legal act as the element of the legal system', zoals dat in ons bestuursrecht zo treffend werd herkend door Hirsch Ballin (wederkerig constitutioneel recht leidt tot wederkerig bestuursrecht) en Van Male (in zijn oratie Onvoltooid recht) werd door mij kritisch bejegend. ${ }^{17}$

\subsubsection{Basisnoties}

"What is autopoiesis? An autopoietie system produces and reproduces its own elements by the interaction of its elements. (...) Autopoietic systems are not only identified in biology as cells and organisms, but they can also be identified as social systems (interaction, organization, society), on the basis of meaning. The basic

16. P.C.M. wan Seters, Dilemma's van modern beleidsrecht, in: N.J.H. Huls en H.D. Stout, Reflecties op reflexief recht, 2 wolle 1992 , p. 34-37.

17. Vgl. mujn bijjarage in: Eenzijdig en wederkerig?, Deventer 1995, p. 191-223. 
element of a social system is communication - not the human being. Communication as the unity of utterance, information and understanding constitutes social systems by recursively reproducing communicaw tion. $\times 1.8$

Basisnoties van de theorie van autopoiese zijn zelfproductie van het positieve recht, de ontkenning van voorzienbaarheid (en daarmee negatie van het ideaal van rechtszekerheiden determineerbaarheid), de circulaire structuur in de geschiedenis van het recht en de paradox van zelfreferentie. ${ }^{19}$ Laten we deze basisnoties nader beschouwen.

Zelfproductie betekent dat het positief recht zichzelf produceert: 'Positives Recht ist selbstproduziertes Recht - nicht nur im Sinne eines von Menschenhand gemachten Rechts, sondern im Sinne eines durch Recht hergestellten Rechts. ${ }^{20}$

Recht is niet voorzienbaar, stelt Teubner, en dus falen ook de idealen van rechtszekerheiden determineerbaarheid. "Recht ist vergangenheitsabhängig, aber nicht voraussagbar. Die Unbestimmtheit des Rechts hinge danach unmittelbar mit seiner Autononie zusammen. ${ }^{21}$ In de meer geconcretiseerde uitwerking van de autopoietische benadering in het bestuursrecht, in het bijzonder in het denken over de wederkerige rechtsbetrekking in het bestuursrecht, is deze negatie van het ideaal van de rechtszekerheid in verband gebracht met het algemenere falen van de wet en uitgewerkt als een pleidooi tot afschaffing of verzwakking van de werking van het legaliteitsbeginsel. ${ }^{22}$

Veranderingen in het subsysteem geschieden via systeem-interne variaties en zijn zodoende circulair; regels zijn gebaseerd op hogere regels en weer hogere regels, maar de bron van de hoogste regel valt samen met de laagste. ${ }^{23}$

De paradox van de zelfreferentie is goed zichtbaar - aldus Teubner - in het voorbeeld van de staat als juridische persoon: 'wonach sich der Staat als juristische Person wie einst Münchhausen am eigenen Schopfe aus dem Sumpf ziehen muß, indem die Staat als Fiktion sich selbst fingiert. ${ }^{24}$ Men kan zich afvragen of dat eigenlijk wel het geval is dat de staat ons zo 'overkomt' als hier wordt geschetst. ${ }^{25}$ In ieder geval heeft die staat wanneer die eemmaal uit het niets is komen opdoemen, in Teubners visie, algemene, universele en eeuwigdurende pretenties. Universele aanspraken op goed of fout, recht of onrecht komen in de problemen, 'nein, dann setzt ihr eigener Universalitătitsanspruch sie unter den Zwang, sich auch auf sich selbst anzuwenden. Und in diesem Moment tauchen die "paradoxes of self-

18. O. Teubnet, Introduction to Autopoietic Law, in: Autopoictic Law: A New Approach to Law and Society, Berlin and New York 1988, p. 3.

19. Vgl. G. Teubner, Recht als autopoietisches System, Frankfuhrt an Main 1989, S. 8-11

20. G. Teubner, Recht als autopoietisches System, Frankfurht am Main 1989, S. 8.

21. G. Teubner, Recht als autopoietisches System, Frankfuht am Main 1989, 5. 8-9.

22. Vgl. M. Scheltema in de reeks 'Het juridisch tekort', Van rechtsbescherming maar een wolwardig bestuwts recht, in: NJB 1996/33, p. 1355-1361.

23. Vgl. G. Teubner, Recht als autopoietisches System, Frankfirht am Main 1989, S. 9.

24. G. Teubner, Recht als atutopoietisches System, Frankfuhrt am Main 1989, S. 11.

25. In mijn optiek is de staat viet zomaar uit het niets ontstaan, maar in de loop der geschisdenis ontstaan uit onze behoefte aan een "dienende" owerheid; met andere woorden, de stau is er omdat wij (met $z$ "n allen) dat gewild hebben. 
reference" auf." Zelfreferenties, paradoxen en antinomieèn zijn er vele soorten in het recht, stelt Teubner en hij noemt er werschillende.

\begin{abstract}
"Bekannt sind die großen paradoxen Fragen der Auberkraftseoung des Rechts durch Widerstandsrecht und Staatsraison; , die paradoxe Schopfung des Rechts durch die Gewalt der Revolution (...); das schon angesprochene Paradox der Normenhierarchie; das Munchhausen-Trilemma der Normbegrundung. ${ }^{27}$
\end{abstract}

Het recht is circulair opgebouwd, want zelfreferentieel. Daardoor wordt de totale onzekerheid van het recht getransformeerd in een relatieve zekerheid van het recht:

\begin{abstract}
"Worauf die Autopoiese-Theorie letztlich hinausiufut, ist der Zusammenhang folgender Elemente: Selbsireferenz - Paradox - Unbestimmthe í - Stabilinat durch Eigen-Values. Das Rechtssystem grindet sich mit der Anwendung seiner Unterscheidung Recht/Unrecht auf einen selbstreferentiellen Zirkel. Dieser furht unweigerlich in die Situation der "Tautologie und des Paradoxes und damit in eine fundamentale Unbestimmtheit des Rechts. Bei dieser Unbestimmtheit muB man aber nicht stehen bleiben, noch mulb man wor ihr zuruckweichen. Denn es existieren praktischen Lossungen des paradoxinduzierten Unbestimmtheitsproblems. Der Schllussel liegt in der "Entparadoxierung von Paradoxien", in der 'kreativen Verwendung von Paradoxien, in der Transformation unendicher in endliche Informationslasten, in der Überfuhrung unbestimmbarer Komplexitut in bestimmbare Komplexitat". 28
\end{abstract}

\title{
9.3.3 Autopoietische geslotenheid
}

Daarnaast is het van belang om autopoietische systemen te zien als informatief open en operationeel gesloten. 'Het begrip autopoiese is de hoeksteen van een nieuw paradigma in de algemene systeem theorie dat beoogt de oude theorieern van 'gesloten' en 'open' systemen op een hoger niveau te integreren. ${ }^{529}$ Informatief open moeten systemen zijn om flexibel en intern variaties te kunnen creëren. Operatief geslloten moet het systeem zijn om de eigen eenheid en identiteit te bewaren; op die manier zijn zij op zichzelf betrokken. ${ }^{30}$ Dat betekent dat "men geen systeem-interne veranderingen teweeg kan brengen door systeemexterne voorwaarden. ${ }^{319}$ Pas dan kunnen zelfbeschouwing ('Selbstbeobachtung') en zelfbeschrijving ('Selbstbeschreibung') plaatsvinden. Deze kunnen via zelfopbouw ('Selbstorganisation" en 'Selbststeuerung') en zelfreflectie('Selbstreflexion') leiden tot zelfproductie ('Selbstproduktion'). ${ }^{32}$

In een meer concrete visie, luiden openheid en geslotenheid als volgt:

26. G. Teubuer, Recht als autopoictisches System. Frankfuhrt am Main 1989, S. 10-11.

27. O. Teubner, Recht als autopoietisches System, Frankfurht am Main 1989, S. 11.

28. G. Teubner, Recht als autopoietisches System, Frankfuhrt am Main 1989, S. 18-19.

29. P.C.M. van Sefers, Dilemma's van modern beleidsrecht, in: N.J.H. Huls en H.D. Stout, Reflecties op reflexief recht, Zwolle 1992 , p. 36 .

30. Vgl. G. Teubner, Recht als autopoietisches System, Frankfurht am Main 1989, S. 21-28.

31. H. Stout en J. Stoop, Het falen wan de wet, Een inleiding tot het autopoietisch denken van Gunther Teubnem, in: Regelmat 199:-1, p. 4, I.k.

32. Vgl. G. Teubner, Recht als autopoietisches System, Frankfuhrt an Main 1989, S. 28-35. 
"Volgens Teubner is het rechtssystem cognitief open, maar operationeel gesloten: het recht neemt wel waw wat er in de matschappij gebeurt (openheid), waar interpreteert dat in haar eigen termen. Hetzelffe geldt omgekeerd woor de manier waanop de maatschappij de rechitssignalen interpteteert. (..) De geslotenheid vian het rechtssysteem is een barriere voor de sturende potentic van instrumentele wetgeving. Veel politiek wenselijk geachte matschappelijke veranderingen komen niet tot stand ondat het bestaande recht het probleem selectief waarneemt, waardoor de verandering 'juridisch niet kan'.

\title{
9.3.4 Het recht als hypercycius?
}

Teubner vraagt zich af of het recht een autopoietisch systeem is, dat wil zeggen:

'Ein System also, das seine Elemente aus dem Netzwerk seiner Elemente produziert? - Die Antwort ist ein

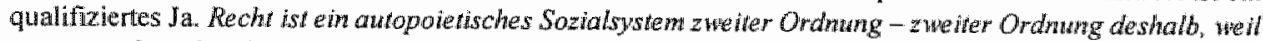
es gegenüber der Gesellschaft als autopoietischem System erster Ordnumg eine eigenstänalge operative Geschlossenheit gewinnt, insofern as seine Systemkomponenten selbstreferentiel konstituiert und diese in einem Hyperzykitus miteinander verkmipfit. ${ }^{.34}$

Dat roept de behoefte naar een beschrijving van de hypercyclus op. Daarvoor is het -- aldus Teubner - noodzakelijk om zelfbeschouwing ('Selbstbeobachtung') en zelfproductie ('Selbstproduktion') goed te onderscheiden. Zichzelf bekijken en analyseren is immers wat anders dan zichzelf te creëren. Zelfproductie is mogelijk in een systeem dat de constitutie van elementen op elkaar heeft afgestemd. Anders gezegd:

\begin{abstract}
"auf der Basis selbstreferentieller Zirkel der Systemkomponenten kamn ein selbstreproduktiver Hyperzykhus wart dann entstehen, wenn die zyklisch organisienten Systemkomponenten miteinander verkettet werdem. Um es auf eine Formel zu bringen: Gesellschaftiche Teilsysteme gewinnen an Autonomie, wenn im Subsystem die Systemkomponenten (Element, Struktur, ProzeB, Identitat, Grenze, Unwelt, Leistung, Funktion) selbstreferentiell definiert sind ( $=$ Selbstbeobachung), wenn zusttzlich diese Selbst-beobachtungen im System operativ verwendet werden (= Selbstkonstifution) und wenn schlieblich in einem Hyperzyklus die selbstkonstituierten Systemkomponenten als einander wechselseitig produzierend miteinander verkettet werden ( Antopoiesis). ${ }^{.35}$
\end{abstract}

De hypercyclus wordt steeds in verband gebracht met de autonomie van een rechtsstelsel, met de autonomisering van het recht.

'Die Autonomisierung des Rechtssystems verlafuf, wendet man die Konstruktion des Hyperzyklus versuclisweise auf das Recht an, in drei Phasen. In der Phase eines "gesellschaflich diffusen Rechts" sind Elemente, Strukturen, Prozesse und Grenzen des Reclitsdiskurses mit denen der allgemeinen gesellschaftichen Konmunikation identisch oder jedenfalls heteronom von gesellschafticher Kommunikation bestimntt; die Phase eines "teilautonomen Rechts" setat ein, wenn der Rechtsdiskurs beginnth, seine Systemkomponenten

33. N.J.H. Huls, Reflexieve en autopoietssche tendensen in de wetgevingspraktijk, in: N.J.H. Huls en H.D Stout, Reflecties op reflexief recht, Zwolle 1992, p. 46-47.

34. G. Teubner, Recht als attopoietisches System, Frankfuhrt am Main 1989, \$. 36

35. G. Teubner, Recht als autopoietisches System, Frankfuhrt am Main 1989, S. 44. 
selbst zu definieren und operativ zu verwenden; von der Bhase eines 'autopoietischen Rechts' kann man erst spreche $H_{i}$ wen die Systemkomponenten des, Rechtssystems hyperzyklisch miteinander verkettet werden. "36

De drie fasen noemt Teubner de "Stufen der Autonomie des Rechtes", waarbij de hypercyclus in de laatste fase uiteindelijk alle systeemcomponenten met elkaar verbindt ("verknupft'). Van een discussie in en over elementen van het rechtssysteem als basis-'Stufe" verloopt de ontwikkeling via een abstracter en zelfreferentieel (circulair) systeem naar het autopoietische systeem van hypercyclische verbindingen.

Er is ook een iets concretere omschrijving van de hypercyclus.

'Een ander begrip uit Teubners theorie is de hypercyclus. Zelfireferentie is nog maar een eerste stap op weg naar autopoiese, warwoor nodig is dat componenten uit het systeem geelusterd worden. Een autopoietisch systeem bouwt zichzelf uit door eindeloos nieuwe variaties op zijn eigen structuur te genereren. De nieuw gevormde coubinaties leidden weer tot nieuw recht etcetera. (...) De toegenomen aandacht voor schending van mensenrechtenverdragen kan ook gezien worden als een juridische hypercyclus. De imterne dynamiek van thet recht heet schending van het Verdrag van Rome geproduceerd. Daar is geen politieke druk van buiten voor nodig geweest. Niemand zal toch durven vollhouden dat schending van mensenrechten de laatste 20 jaar explosief is toegenomen en de eerste 20 jaar na de Tweede Wereldoorlog niet of nauwelijks voorkwam. Het recht construeert cen nicuwe werkelijkheid die het de maatschappil voorhoudt; ook de Nederlandse regering blijkt mensenrechten te schenden. ${ }^{377}$

Het steeds opnieuw en uit zichzelf (zelfreferentieel) verbinden van elementen uit een rechtssysteem met elkaar is dan de constituerende activiteit die hypercyclus wordt genoemd. Tot hypercyclische verbinding ('hyperzyklische Verknüpfung') wordt het wanneer een tweede verbindingslaag systeemelementen produceert, waardoor de eerste, andere systeemcomponenten terugtreden. Kort gezegd, hypercyclus staat voor enkelvoudig verbinden van systeemelementen. Hypercyclische verbinding is de verbinding van elementen en componenten, die al door de hypercyclus verbonden waren. Een voorbeeld:

"Auch der Rechtsbegriff des Prozesses muB in einer Weise konstituiert sein, daß er auf Rechtshandlungen einerseils, Rechtsmomen andererseits Bezug nimmt. Schaut man genauer hin, so wird weder der Rechtsprozefs noch die Rechtsdogmatik mit den anderen Systemkomponenten direk werknopft, sondern nur mit deren Relationierung. Verfahena und Dogmatik sind hyperzyklische Relationienungen der Relationierung won Norm und Entscheidung, dic auf diese Weise dite Setbstproduktion des Rechts steuern." ${ }^{38}$

Het grote verschil met Kelsens 'reine Rechtslehre', waarin uitgegaam wordt van een lineair rechtvormingsproces, is de concentrische (circulaire) opbouw bij de autopoietische methode. Ook het afleidings- of substmptie-principe dat steeds de 'Grundnorm' als voorondersteld

36. O. Teubner, Recht als autopoietisches System, Franktuht am Main 1989, S. 49.

37. N.H. Huls, Reflexieve en autopoietische tendensen in de wetgewingspraktijk, in: N.J.H. Huls en H.D. Stout, Refiecties op reflexief recht, Zwolle 1992, p. $50-51$.

38. O. Teubner, Recht als autopoietisches System, Frankfuht am Main 1989, S. 56. Voor een concreter voorbeld verwijs ik naar N.J.H. Huls, Reflexieve en autopoietische tendensen in de wetgevingspraktijk, in: N.J.H. HuLs en H.D. Stout, Reflecties op reflextef recht, Zwolle $1992, p, 52$ 
uitgangspunt neemt, is eruit, omdat in de autopoietische methode het rechtssysteem zelf - of elementen uit thet rechtssysteem zelf - het rechtswormingsproces initieert/ initieren. 'Circularity replaces extra-legal foundations of law as does Kelsens fictitious Grundnorm. ${ }^{39}$ Overeenkomst in beide theorieern is uiteraard het dynarnische karakter van het rechtsvormingsproces.

\subsubsection{Beschrijvende en dogmarische autopoiese}

Autopoiese is ambitieus; het is geintroduceerd als nieuwe visie met nieuwe mogelijkheden ter oplossing van problemen. Zo zal, stelt Teubner: "binnen het abstracte kader van Hret autopoietisch recht aan te geven zijn wat de betekenis van de verschillende juridische vormen van overheidsinterventie is. ${ }^{40}$ Autopoiese is zowel analytisch als normatief; zo kan de theorie aangewend worden voor zowel beschouwing als voor strategie. 'De normatieve betekenis van autopoiese schuilt in de mogelijkheid de theorie te gebruiken als interne theorie van het recht. In dit geval is de rechtstheorie (...) een theorie binnem het recht; het recht kjjkt naar zichzelf en construeert een rechtstheorie. En op die manier deelt de rechtstheorie de normatieve uitgangspunten van het hele juridische discours. ${ }^{4 t}$

Met betrekking tot de analyse en toepassing wan de theorie op de rechtswerkelijkheid is Teubner ook weer voorzichtig; er is verschil in het ontwikkelen van een theorie en de aanwending of operationalisering daarvan in de praktijk. Dit laat zich het beste illustreren aan de hand van de antwoorden die Teubner gaf op vragen in een interview:

\footnotetext{
"In her rapport "Rechtshandhaving' komt de Wetenschappellyke Raad woor het Regeringsbeleid" (hiema te moemen: WRR) tor de conchusie dar de ordening:wetgeving (bujwoorbeeld de milieu- en de volksgezordheidlswetgewingl met een aanial problemen kampt.

Rechisnormen waaradn de overheid en de burger zijn gebonden, zijn minder dwidelijk, sams zelfs regenstrijdig. en worden instrumenteel toegepast. Hierdoor meewt de rechtszekerheid af. Het normatieve gehate stiwuleer berekend gedrag bij burgers. Door de ineenwloeing van de parriculieve en publieke sector raken algemene/opentare en privebelangen vermengd. Wij denken dar deze conchusies wel in wh theoric zijn in te passen.

De WrR beweeld in dit werband onder andere adw het nomatieve gehalle wan formetle beleidswetgeving te wergroren. Een andere aambeveling behelst de vergroting wan de rol van de formete wetgever bij de raget. gewng die vandwoorwaarden stell aan her maatschappelijk verkeer. Foor delen wan de wilieumergeving kan de overheid zich ertae beperken de essentie wan het gewenste bescherningswineau aan fe geven, warna belanghe bbenden zelf voor de wiwerking van de technische standaduden zorgen. Dit wardt geconditoweerde zelfregulering genoemd. Deze gecondinoneerde zelfregulering heef tal doel de publith belangen wh evenwichtige krachiswerhoudingen nussen de betrokken belanghebbenden velfig te whellew. benkt U dat deze aambeveling zou kwnnen werken? En waar ligl dan de grens tussen het gewenste bescherningsnivean en de rechnische winwerking?
}

39. G. Teubner, Introduction to Autopoietic Law, in: Autopoietic Law: A New Approach to Law and Society, Berlin and New York 1988, p. 4.

40. Aldus $G$. Teubner in het wraggesprek met H. Stout en J. Stoop, Autopoiese an de Maas, ofwel: instrumentele wetgeving reddeloos verdronken, in: Regelmat 1991-1, p. $5,1 / k$.

41. H. Stout en J. Stoop, Autopoiese aan de Maas, ofwel: instnumentele whetgeving reddeloos verdronken, in: Regelmatit $1.991-1$, p. 5 r.k. 
Ik heb eigenlijk geen antwoord op deze wrag. Ik zou overigers voorzichtig zijn met een theorie die meent op alle vragen een pasklaar antwoord te hebben, dat is zoiets als de katholieke kerk.

Denkt u niel dat de WRR dezelfde problenen signaleeri als w in ww theorie? Dat de WRR woor onderwerpen die in uw theorie aan de arde kowen praktisch toepassingen suggereert? Daam ligt natuurlijk het problem het operarioneel maken wan w wheorie.

Ik denk niet dat het een kwestie is van deductie. Ik denk dat we dan zouden moeten spreken van een creatief misverstand. De én ontwikkelt een theorie en de ander heeft ideean. Uit beide worden elementen gehaald die aansppreken en dan wanneer de praktig $k$ om richtijnen vragt ... Een dergelijke simpele afleiding bestaat nilet. Dat is wat ik bedoel met een creatief misverstand. ${ }^{42}$

\section{En tegelijkertijd ook:}

'Autopoiesis proposes, as a new and promising research strategy, to identify circular relationships within the: legal system and to analyze the ir internal dynamics and their external interactions. What has been done so farr in this field seeris to be marginal. 43

\section{En ook:}

"Auf die Diskussion, welche politische Funktionen die Theorie der Autopoiese hat, mochte ich mich nicht eintassen. Wer kann worweg entscheiden, welches politisches Lager welche Version won Autopoiese auf wellche Weise instrumentalisiert? (...) Wie hatuhg greift auch hier eine Ideologiekritik, die hinter dem $\mathbb{R}$ uhcken einer Theoric deren politische Funktionen aufdeckt, zu kurz. Sie unterschätzt gleichermaBen die Autonomie des theoretischen und die des politischen Diskurses sowie deren komplizierten Vermittlungen. Vielmehr mochte ich versuchen, das Verhalunis von Rechtsantopoiese und Gesellschaftsteuerung zu analysieren. ${ }^{44}$

Maar zoals vaak het geval is, is de creator van een theorie veel bescheidener ten aanzien van de operationele mogelijkheden en onmogelijkheden ervan, dan - sommige van - zijn navolgers. Daarnaast zijn er signalen waarbij men zich afwraagt of autopoiese wel werkt. Naast deze zelfmaakbaarheid of het autopoietisch vermogen van het recht is er steeds externe sturing nodig; tegelijkertijd wordt de invloed van sturing weer betwijfeld:

"Darom ontwikkelt men onder invloed wan de autopoietische systeemleer wel voorstellen om de overheid afstandelijker op te besturen systemen te laten inwerken. Vooral verwacht men dan veel heil wan het aansluiting zoeken bij het zelffegulerende vermogen van een systeen. De wetgever zou daar ruimte voor moeten biedorn en slechts de randwoorwaten woor zelfregulering moeten opleggen. (...) Het is de vraag of deze nieuwe wetgevingsstrategie ook succesvol kan zijn als autopoiese werkelijk de zelfstandigheid bezit die de theorie nameemt. In do prakijk zijn er nog weinig woorbeelden van op langere termijn suocesvol gebleken wettelik geconditioneterde xelfregulering

De attopoietische benadering van het recht bestaat nog pas kort en heeft voor veel controverse gezorgd. Toch is wanuit dit standpunt een interessante externe kritiek op ordening door het recht te horen. Vooral wetgevers

42. H. Stout en J. Stoop, Autopoiese aan de Maas, ofwel: instrumentele wetgeving reddeloos verdronken?, an: Regelmati $1991-1$, p. 9 l.k.

43. O. Teubner, Introduction to Autopoietic Law, in: Autopoietic Law: A New Approach to Law and Society, Berlin and New York 1988, p. 1.

44. G. Teubner, Recht als autopoietisches System, Frankfuht am Main 1989, S. 81-82. 
worden aangemaand bescheiden verwachtingen te hebben van de mate waarin de maatschappij liaar matonome rechtssysteem kan sturen. ${ }^{, 5}$

De verhouding tussen beschrijving wan het recht in autopoietische termen en het volgen van een autopoietische strategie (als uitvloeisel van normatieve autopoiese) is niet vanzelfsprekend. Teubner is uiterst bescheiden op dit punt; hij betwijfelt het normatieve karakter van autopoiese. In ons land en ten aanzien van het bestuursrecht kan de autopoietische benadering geîntroduceerd zijn door middel van het concept van de "wederkerige rechtsbetrekking'. Dit concept zou dan de belichaming zijn van de autopoietische strategie. Naast overeenkomsten met de autopoietische theorie (verwijzingen naar Teubner), bestaan er echter ook twijfels (met name op het vlak van de concretisering van autopoiese in "wederkerige rechtsbetrekking', die zelf immers ook niet concreet wordt voorgesteld). Naast bijval ${ }^{46}$ ontmoette het nieuwe rechtsbetrekkingen-paradigma kritiek. ${ }^{47}$ Inmiddels lijkt een meerderheid der vakgenoten zich te hebben uitgesproken tegen de 'wederkerige rechtsbetrekking', zodat het als nieuw paradigma een zachte dood gestorven lijkt. ${ }^{48}$ De normatieve (strategische) mogelijkheden van de autopoiese lijken daarmee voor ons thema (rechtskracht) uitgeput. Laten we de beschrijvende analyse verder volgen.

\subsection{De verhouding tussen het beschikkingsbegrip en rechtskracht}

Er bestaat als gevolg van het denken in rechtsbetrekkingen werschil van opvatting tussen De Jong en oudere auteurs over het belang van het denken in termen van rechtskracht. De Jong, die de aanwezigheid van een 'subjectiveringstendens' in het bestuursrecht vooropstelt, betwijfelt het belang van het denken in termen van rechtskracht. Welke is de invloed van het concept van de 'wederkerige rechtsbetrekking' op de vraag of de term rechtskracht acceptabel is? Om deze vraag te kunnen beantwoorden, wordt bezien weike de verhouding is tussen rechtskracht en het beschikkingsbegrip bij de verschillende auteurs.

45. W. Witteveen, De geordende wereld wan het recht, Amsterdarn 1996, p. 415-416.

46. Vgl. EM.H. Hirsch Ballin, Wederkerig bestumrsrecht, in: RM Themis 1989, 1, p. 1-4 en JL.M. Gribnaw. De wederkerige rechisbetrekking als nieuw paradigma?, in: R\&R 1993, jrg. 22, afl. 2, p. 90 e.w.

47. Vgl. F.A.M. Stroink, Boekbeschouwing over C.P.J. Goorden Rechtsbevoegdheid in het besturrsrecht, in: NTB 1990, p. 295 e.v; L.J.A. Damen, Bestaat de Awb-mens?, in: Aantrekkelijke gedachten beschoiwingen over de Algemene wet bestuursrecht, JL. Boxum e.a. (red), Deventer 1993, p. 109 130; F.A.M. Stroink, Algemeen bestuursredt, Zwolle 1996, p. 13-16 en P. de Haan, Th.G. Drupsteen en R. Fernhout, Bestuursrecht in de sociale techtsstaat, deel $\mathbb{l}$, Deventer 1996, p. $24-36$.

48. $\mathrm{Vgl}$. 'Door anderen is inmiddels voldoende aangetoond dat de "theorie" over de "wederkerige rechtsbetrekking' vitgaat van een onhelder en onwerkzaam concept en wan beginselen, die goed beschowwd, in strijd komen met de fundamentele uitgangspunten wan het Nederlandse bestuurstecht. De wederkerigheidsnotie past ook in onze visie nadr essentie niet op de bestursrechtelijke relatie tussen bestuur en burger ondat het bestuur geen subject is met eigen rechten en belangen ten dus zijn positie naar zjin aavd nien verwisselbaar is met die van de burger als rechtsgenoot in de bestuursrechteligke relatie." in: $P$. Nicolai, B.K. Olivier, I.C. van der Vlies, L.J.A. Damen, B.J. Schueler, Bestuurstecht, Amsiterdam 1997, p. 7. 


\subsection{De verhouding tussen het beschikkingsbegripen rechtskracht in het klassieke gedach- tengoed}

Zoals we al zagen heeft Van der Pot het begrip rechtskracht in ons land geîntroduceerd tegelijkertijd met het beschikkingsbegrip, dat hij belangrijker achtte. In zijn optiek is rechtskracht een eigenschap van beschikkingen. Van der Pot vergeleek deze eigenschap met de rechtskracht van het vonnis, dat niet meer aantastbaar is. ${ }^{49}$

Voor Van der Pot stond voorop dat beschikkingen eenzijdig van karakter zijn:

".. de eenzijdige rechtshandelingen der bestuursorganen, waarvoor is als algemeene benaming het woord. 'beschikking' zal bezigen."

Dit had alles te maken met de plaats die hij het besturen en daamee het bestuursrecht gaf:

'Bestuurswarkzaamheid is (...) de werkzamheid, die zich in haar aard wan wetgeven onderscheidt en ook niet is rechtspraak (...). Bij de ontleding der bestuurswerkzaamheid houden wij ons aan dit matericele kenmerk. ${ }^{511}$

De Jong ${ }^{52}$ concludeert dat Van der Pot zich liet inspireren door met name Duitse bronnen, waaronder F. Fleiner en W. Jellinek, maar ook door de Fransman G. Jèze. Ook, stelt De Jong, is het beschikkingsbegrip van Van der Pot:

'I. een idee dlat niet los wan zijn rechtsstatelike context kan worden gezien; het verwijst naar de idee van machtenscheiding en thet onderscheid tussen algemeen-abstracte en concreet-individuele handelingen.

2. op beslissende punten, te weten het beschikkingsbegrip zelf en zijn juridische gewolgen (met name geldigheidseisen') beïnvloed door buitenlandse bronnen. ${ }^{.53}$

Kortom, beschikkingen werden door Van der Pot gezien als sluitstuk van de bestuursrechtelijke besluitvorming. De beschikking is daarin het logisch eindpunt, immers de meest concrete rechtsfiguur van de overheid naar de onderdaan toe. Later werd dit verschijnsed door Van Wijk gekenschetst als gelede normstelling (al was de beschikking in de visie van Van Wijk geen norm). ${ }^{54}$

49. Wgl. C.W. van der Pot, De vormen wan het besturen, in: Nederlands Bestuursrecht, Alphen a/d Rijn 1932. p. 214.

50. C.W. van der Pot, De vormen wan het besturen, in: Nederlands Bestuursrecht, Alphen a/d Rijn 1932 , p. 204.

51. C.W. wan der Pot, De vormen wan het besturen, in: Nederlands Bestunisrecht, Alphen a/d Rijn 1932 p. 201 .

52. Vgl, Jif. de Jong, Bestuurstecht van vreende herkomst, diss, Zwolle 1988, p. $21-22$.

53. I.P. de Jong, Besturursrecht van vreemde herkonst, diss., Zwolle 1988 , p. 22

54. Vgl. HD. van Wijk, Hoofdstukken van administratief recht, Groningen's-Gravenhage 1968, p. 40-42 en p. 55-59. Van Wijk onderscheidde scherp tussen wetgeving (door normstelling, altijd cen abstracte aangelegentheid) en uitvoeting/bestuur (een concrete angelegenheid). Wanneer uitvoering gepaard gaat met het opsitellen van beleidssregels is dat in beginsel veralgemenisering van de potentie fot concrete 
In Nederland wordt een dergelijke opvatting over bestuursrecht aangegeven met de Duitse term Hoheitsverwaltung. ${ }^{55}$

Niet alleen Van der Pot ging uit van (een visie over het karakter van bestuursrecht die te kenschetsen valt als) trias-denken, ook voor Donner stond dit buiten kijf. Hij zegt dat als volgt:

'De staat is naar zijn aard een rechtsinstituut. Niet slechts spelen de staatsorganen een leidende rot bij de rechtsyorming, maar zij voeren al hunne werkzaamhe den in den weg van het recht wit en elk hunner handelingen wordt in het keurslijf der rechtsvormen geregen.

Die handelingen zijn van allerlei soort; volgt men de trias politica dan kan men er al anstonds drie verschillende calegorieern in onderscheiden: de handelingen wan den wetgevenden, van rechtsprekenden en van bestuurlijken aard. Elk van die groepen heeft zijn eigen kenmerken (..... ${ }^{56}$

Donner zag rechtskracht als een eigenschap van beschikkingen. Die rechtskracht van beschikkingen was voor hem een andere dan kracht en gezag van gewijsde van rechterlijke vonnissen. De door Van der Pot opgeworpen vraag of aan beschikkingen een soortgelijke rechtskracht toekomt als aan rechterlijke vonnissen, beantwoordde Donner daamee negatief. Het hanteren van de term rechtskracht wanneer gezag van gewijsde van rechterlijke uitspraken wordt bedoeld, vond hij onjuist. Omdat de van bestuursorganen afkomstige rechtshandelingen verschillen van vonnissen, is hun rechtskracht een andere. Zo betoogde hij dat:

"gezag van gewijsde, het moge dan met de rechtskracht nauw verwant zijn, toch slechts een modaliteit daarwan vormt. De rechtskracht welke het rechterlijk wonnis eigen is, wordt gezag van gewijsde genoemd. ${ }^{57}$

Donner wordt vaak genoemd als auteur van de eerste verschijningsvormen van de "wederkerige rechtsbetrekking'. Dat maakt het interessant om hem hier nog nader aan het woord te laten over datgene waarop het concept als reactie is ontstaan: met name staat en staatsrecht, triasdenken, de noodzaak van wederkerig staatsrecht, beschikkingen en de rechtskracht daarvan. In zijn oratie Bestendig en wederkerig gaat Donner in op het verband wan staat en staatsrecht. ${ }^{58}$ Een samenleving heeft behoefte aan bestendigheid van hatar staatsinstellingen. De noodzaak van wederkerigheid formuleert hij als:

handelingen, die kan leiden tot abstracties (dam zijn het normen en dus wetgeving) of tof concrete handelingen (dan zijn het beschikkingen, dus uitwoering). Een term alls bestuurswetgeving (zoals geintroduceerd door R.M. van Male in zijn dissertatie Rechter en bestuurswetgeving, Zwolle 1988 , en sindsdien gemeengoed) is in de visie van Van Wijk onbestatanbar.

55. De term komt ook in een letterlijke "vertaling" in het Nederlands woor; vergelijk het "foogheidsbestuur" van J.L.M. Gribnau in zijn: De wederkerige rechtsbetrekking als nieuw paradigma?, K\&R 1993, jrg. 22, anl. 2 , p. 90 .

56. A.M. Donner, De rechtskracht van administratieve beschikkingen, diss., Alphen a/d Rjin 1941, p. 1.

57. A.M. Donner, De rechtskracht van administratiewe beschikkingen, diss., Alphen a/d Rijn 1941, p. 15

58. Vgl. AM. Donner, Bestendig en wederkerig, oratie RUG, Zwolle 1979 
'de ars sum cargue tribuend, de kunst om ieder het zine te geven, om de rechter en plichten van de enen te doen corresponderen met die van de anderen. ${ }^{59}$

Bestendigheid en wederkerigheid staan nimmer los van elkaar. Een samenleving moet rust en orde brengen en bewaren opdat er vrede zal zijn. Dat is in het (collectieve) algemeen belang. Dergelijke bestendigheid is afhankelijk van wederkerigheid:

\begin{abstract}
"Voor bestendigheid is in het bijzonder een flinke dosis wederkerigheid noodzakelijk. De macht wan overheden moet lot bevoegdheid, $d$, w z tot rechtens omsehreven, bepaalde en verplichtende macht worden, zodat er ean beroep op kan worden gedaan en er werweer tegen kan worden gewoerd. Everzo moeten ook de plichten en rechten van de statitsdelen en van de burger worden omschreven, zodat dus het bestaan van staatsen rechtsinstellingen een houvast en steun wordt in zijn samenleven en samenwerken met anderen. Just het handhaven van dat element wan wederterigheid wormt vooral de zin van het stalsrecht. ${ }^{60}$
\end{abstract}

De bestendigheid staat in Donners ogen voor machtsuitoefening en die moet gecontroleerd worden. Zo bezien is wederkerigheid het waarborgen van o.a. rechtsbescherming. Dat bestendigheid en wederkerigheid in een voortdurend spanningsveld tegenover elkaar staan, is daarmee duidelijk. ${ }^{\prime \prime}$

Onderwerping aan wet en overheid is pas mogelijk als bevoegdheden van wet en overheid bepaald en omschreven zijn, als hun uitoefening geregeld en met waarborgen omkleed is, want dan:

"is er pas in réchte een statat, nl. een verband waarin de wederkerige betrekkingen tussen owerheid en burgers ais rechtsbetrekkingen met rechtsgewolgen worden erkend en zo met stelligheid en een vooruitzicht op bestendigheid bekleed. ${ }^{62}$

In zijn Algemeen deel van het Nederlands bestuursrecht hanteert Donner de term rechtsbetrekking als vormgever van de relatie tussen bestuur en burger. ${ }^{63}$ Daarbij bestaat de rechtsbetrekking bij de gratie van de beschikking (als eenzijdige rechtsbetrekking) en de overeenkomst (als tweezijdige rechtsbetrekking). Die beschikking heeft rechtskracht. Een uitvoerige geldigheids- en nulliteitenleer is eraan gehecht. Hier is dle 'rechtsbetrekking' dus allerminst een continu bestaand iets dat de relatie tussen bestuur en burger beheerst, maar wordt middels een besluit in het leven geroepen.

59. A.M. Donner, Bestendig en wederkering, over het verband van staat en staatsrecht, oratie RUG, Zwolle 1979, p. 10 (cursivering van Donner).

60. A.M. Donner, Bestendig en wederkering, over het verband van staat en staatsrecht, aratie RUG, Zwolle 1979, p. 13.

61. Vgl. A.M. Donner, Bestendig en wederkering, ower het werband wan staat en staatsrecht, oratie $\mathbb{R U G}$, Zwollie 1979, p. 15.

62. A.M. Donner, Bestendig en wederkering, over het verband van staat en staatsrecht, oratie RUG, Zwolle 1979, p. 15

63. VgI. A M. Domner, Nederlands besturursrecht, Algemeen deel, Alphen a/d Rijn 1987, p. 210 e.v. 
In zijn Algemeen deel van 1974 hanteert Donner nog de terminologie 'De burger in de rechisbeschikking met het bestuur' in de inhoudsopgave, terwijl in de hoofdtekst de burger in de rechtsbetrekking staat met het bestuur. ${ }^{64}$ Kenmerkend voor die rechtsbetrekking acht Donner dat haar oorzaak ligt in objectief recht en dat zij niet omkeerbaar is. Rechtsbetrekkingen spelen zich volgens Donner af binnen een verband dat steeds aanwezig is. ${ }^{65}$ De rechtsbetrekking zelf is zodoende voor Donner ook in 1974 niet een steeds aanwezig conti-. nuim tussen burger en bestuur, alhoewel hij een dergelijk verband wel (h)erkent.

Donners wederkerigheid bestaat uit de rechtsbescherming van de burger tegen dat door het bestuur (eenzijdig) genomen besluit. Daarbij worden niet de (rechten of) plichten, maar de waarborgen voor de burger benadrukt. De rechtsbetrekking in Donners optiek is geformuleerd als rechts-betrekking, juist omdat het kanaliseren van machtsuitoefening de betrekking tot een juridische maakt.

Vegting ontkent noch negeert in de door hem onderscheiden administratieve rechtsbetrekkingen rechtskracht als verschijnsel. Hij gaat uitvoerig in op de rechtskracht van beschikkingen in het hoofdstuk over de administratieve rechtsbetrekkingen naar haar ontstaansbron. ${ }^{66}$ Beschikkingen worden gekenmerkt als ontstaansbron van rechtsbetrekkingen, terwijl enige mate van rechtskracht steeds aan die beschikking moet toekomen, wil zij geldig zijn. Het bezit van enige rechtskracht is een eis die aan de beschikking wordt gesteld; heeft zij geen (of te weinig) rechtskracht, dan is zij gebrekkig en zodoende nietig of vernietigbaar. Vegtings rechtsbetrekking is een door middel van een besluit vanwege het bestuur in het leven geroepen relatie.

Ook Steenbeek acht voor rechtskracht vereist dat er een besluitvormings-moment aanwijsbaar is. Pas daama kan dat besluit geldige rechtsgevolgen in het leven roepen. Beschikken is wereist voor het in het leven roepen van rechtsgevolgen ${ }^{67}$ In 1989 herhaalt hij dit principe, waarbij hij ook weer beschikken (het tunc-moment) koppelt aan formele rechtskracht en de rechtsgevolgen (het nunc-moment) koppelt aan materiële rechtskracht:

Als men nu het begrip formele rechtskracht koppelt aan dat beschikken (beschikken is dus altijd op een tuncmoment, achteraf gezien) en de materiêle rechtskracht koppelt aan de rechtsgevolgen van dit beschikken krijgt men m.j. een duidelijk beeld. ${ }^{6}$

64. Vgl. A.M. Domner, Nederlands Bestursrecht, Algemeen deel, Alphen a/d Rijn 1974, p.x en 238; is de typelout hier de vader wan de gedachie?

65. Vgl. A.M. Donner, Nederlands Bestuursrecht, Agemeen deel, Alphen a/d Rijn 1974, p. $221-222$.

66. Vg. W.G. Vegting, Het algemeen Nederlands administratiefrecht, eerste deel, Alphen a/d Rijn 1954, p. 218 c..

67. Vg. JG. Steenbeek, Rechtshandeing en rechtsgevolg in het staats. en administratiefrecht, diss., Assen 1958.

68. J.G. Steenbeek, Rechiskracht, in: NTB 1989/8, p. 266. 


\subsubsection{De traditionele verhouding tussen het beschikkingsbegrip en rechtskracht in de ogen van De Jong}

Het denken vanuit de 'wederkerige rechtsbetrekking' is geformuleerd in oppositie met het klassieke triasdenken, dat traditionele, rechtsstatelijke principes op de voorgrond plaatst. In dat oude denken is de beschikking, zoals we al gezien hebben, eenzijdig van karakter. De Jong kenschetst de traditionele eenzijdigheid van het overheidsbestuur als volgt:

Dit (...) pastite ook in de opwatting dat het bestuur met naast maar boven de burger stond. Het bestuur gaf cenzijdig een beschikking af en de burger had deze, wameer de beschikking in overeenstemming met de geldende voorschriften gegewen was te gehoorzamen. De fase wan totstandkoming van de beschikking kwam hierbij in thet gehtel niet aan de orde. De besturstheorie concentreert zich bij de behandeling van het leerstuk beschikking volledig op die handeling zelf, en de uitwerking ervan. Bevoegdheidswaagstukken, nulliteitenleer en rechtskracht kunmen worden beschouwd als woorbeelden van die uitwerking wan het beschikkingsbegrip. ${ }^{69}$

Met de rechtskracht die een beschikking eigen is, wordt gesuggereerd dat het bestuursorgaan de rechtspositie van partijen kan vaststellen. De Jong zegt dan ook:

\footnotetext{
'Achter het begrip rechtskracht schuilt de verhouding tussen enerzijds de administratieve beslüttvorming (besluitworming door bestursorganen) en anderzijds de positie van de burger, de hogere toezichthoudende bestuursorganen, de administratieve beroepsorganen en de administratieve en burgerlijke rechter.

Het gaat op het terrein varn de rechiskracht dus om de vraag wie uiteindelijk bevoegd is de rechtsbetrekking ussen burger en bestursorgan bindend vast te stellen. 70
}

Daarna vervolgt hij zijn uiteenzetting over de verhouding van het beschikkingsbegrip en de rechtskracht daarvan met de mededeling dat in het hedendaagse bestuursrecht de feiten anders liggen dan in de tijd van Van der Pot. De algemene beginselen van behoorlijk bestuur fungeren in die ontwikkeling als katalysator:

"Het feit dat de algemene beginselen van behoorlijk bestuur op dit terrein (het terrein van de rechtskracht, watabij het er on gaat welke actor uiteindelijk bevoegd is bindend de rechtsbetrekking wast te stellen, (EvdL) een belangrijke rol zijn gaan spelen, heeft ook hier voor veranderingen gezorgd.

Het begrip rechiskracht lijkt daardoor een andere rol te gaan spelen. ${ }^{71}$

Welke andere rol moet dat dan zijn? Het begrip rechtskracht heeft, doordat het verbonden is aan het beschikkingsbegrip, kennelijk geen zelfstandige plaats (meer) in de Nederlandse bestuursrechtstheorie. Dat is althans De Jongs conclusie. ${ }^{72}$

69. J.P. de Jong, Bestuurstecht van vreemde herkomst, diss., Zwolle 1988, p. 70-7ll.

70. J.P. de Jong, Bestuurstecht wan vreemde herkomst, diss., Zwolle 1988 , p. 5.

71. J.P. de Jong, Bestuursrecht van vreemde herkomst, diss., Zwolle 1988 , p. 5.

72. $V_{g l}$ I..$P$. de Jong, Bestuursrecht van vreemde herkomst, diss., Zwolle 1988, p. 5, 91, 140-147. 
Kortom, in het wederkerige rechtsbetrekking-paradigma speelt thet beschikkingsbegrip geen of hoogstens een ondergeschikte rol. Dan is het logisch dat in die optiek ook de rechtskracht van beschikkingen niet wordt benadrukt.

\subsubsection{De visie van Van Male}

In zijn oratie 'Onvoltooid recht' vestigt ook Van Male de aandacht op bet feit dat vanuit de wederkerige rechtsbetrekking geen nadruk wordt gelegd op de beschikking (met haar rechtskracht), maar op het ontwikkelingsproces tussen burger en bestuur. Waar De Jong nog ¿wijfelt aan de mogelijkheid van een zelfstandige betekenis voor rechtskracht terwijl de overheid in een dynamische relatie staat met haar burgers, gaat Van Male verder. Rechtsbetrekkingen worden naar zijn mening niet door middel van een voorafgaande constituerende rechtsfiguur in het leven geroepen. Waar die constituerende rechtsfiguur er niet is, lijkt toch rechtskracht (impliciet) helemaal overboord gezet. Het is volgens Van Male zo dat:

'... tussen (rechts)personen en colleges die tot het bestuur behoren en andere rechtssubjecten betrekkingen bestaan die ten volle beheerst worden door het geschreven en ongeschreven recht (...). Deze betrekkingen zijn onvoltooid omdat de (rechts)normen die partijen over en weer in acht moeten nemen, geen statisch gegeven zijjn. (...)

In verband hiermee acht ik het onjuist te stellen dat de rechtsbetrekking door een wet, beschikking of overeenkomst tot stand worden gebracht. Zij bestaan steeds daar waar subjecten met elkaar samenleven en zijn naar haar aard onvoltooid. ${ }^{73}$

En ook:

"In deze benadering verschijnt de wet, de algemene maatregel van bestuur of de beschikking niet als de bron wan cen rechtsbetrekking, maar als de bron van rechtsnormen die aan de reeds tussen partijen geldende rechtsnormen worden toegevoegd. Feitelijke gebeurtenissen, of feitelijke handelingen, kunnen de inhoud van de rechtsbetrekking dus niet veranderen. Het betekent echter niet dat het geven wan toestemming, of het doen van een belofte door cen bestuursorgaan rechtens irrelevant zou zijn. Het wekken van gerechtvaardigde verwachtingen is wel degelijk relewant, zij het niet uit zichzelf, maar, naar ik meen, witsluitend uit hoofde van het tussen partijen geldende vertrouwensbeginsel, dat daaraan gevolgen verbindt. ${ }^{74}$

\subsubsection{De verhouding tussen het beschikkingsbegrip en rechtskracht}

Uit het voorgaande kan in jeder geval geconstateerd worden dat rechtskracht in de klassieke visie beschouwd wordt als een eigenschap van een bestuursrechtelijke handeling. Van der Pot en Donner koppelen rechtskracht uitdrukkelijk aan de beschikking, terwijl Steenbeek spreekt van rechtskrachtals eigenschap van een rechtshandeling. In tegenstelling tot De Jong (en eigenlijk ook Van Male) erkennen de overige schrijvers het belang van rechtskracht: ze gebruiken het begrip; ze hebben het begrip nodig.

73. R.M. van Male, Onvoltooid recht, oratie EUR, Zwolle 1993, p. 22.

74. R.M. van Male, Onvoltooid recht, oratie EUR, Zwolle 1993, p. 17 . 
Kortom, geconcludeerd kan worden dat in de klassieke opvatting rechtskracht 'vastzit' aan de beschikking/rechtshandeling. Wanneer de beschikking niet wordt benadrukt (zoals gebruikelijk is te denken binnen het rechtsbetrekking-paradigma), is het logisch dat rechtskracht geen betekenis meer heeft. Rechtskracht is in die optiek een fossiel. Er bestaat derhalve een groot verschil in opvatting over rechtskracht bij De Jong en zijn voorgangers. War De Jong betwijfelt of rechtskracht nog een zelfstandige rol kan spellen in de betrekking tussen burger en overheid, gaat Van Male nog een stap verder. Hij verwerpt dat rechtskracht (als immers aan een constituerende rechtsfiguur vastgeklonken) bestaat; althans concreet aanwijsbaar als constituerende rechtsfiguur hoeft een vormgever (bv. wet, beschikking) van de inhoud van de rechtsbetrekking niet te zijn. Hoe de burger dan moet weten waar hij 'aan toe' is, blijft in het ongewisse.

Overigens wordt ook in de klassieke opvatting (h)erkend dat er een groot, breed, algemeen verband bestaat tussen bestuur en burger (vergelijk Donner) en wordt dat verband gekarakteriseerd als het staatsverband van een democratische rechtsstaat waar alle burgers deel van uitmaken. Dit verband is echter een ander verband dan de contimue relatie tussen bestuur en burger die het rechtsbetrekking-paradigma voor ogen staat.

Kortom rechtskracht en wederkerige rechtsbetrekking sluiten elkaar uit. De mogelijke keuzes zijn dan ofwel (uitgaan van het concept en) het afschaffen van rechtskracht(De Jong, Van Male), ofwel (rechtskracht aannemen en) het afschaffen van het concept (vooralsnog mijn opvatting). Overigens lijkt het onvoorstelbaar dat Van Male of Hirsch Ballin zal ontkennen dat er (definitieve) besluiten zijn. Daarmee wordt geillustreerd dat het concept van de wederkerige rechtsbetrekking als abstracte theorie weliswaar in hun gedachten leeft, maar in een concrete uitwerking niet. De conclusie dat rechtskracht en "wederkerige rechtsbetrekking' elkaar uitsluiten zouden zij waarschijnlijk niet nemen. Aldus lijkt het paradugma in een ver van de realiteit verwijderd vacuum te leven.

\subsubsection{Rechtszekerheiden rechtsbetrekking}

Als gezegd lijkt er incongruentie te bestaan in het hanteren van autopoiese als abstracte theorie en de uitwerking in concreto. Beschrijwing in autopoietische termen is rationeler dan het hanteren van de theorie vanuit normatief (strategisch) oogpunt. Rechtskracht heeft in een geconcretiseerde beschrijving wan 'wederkerige rechtsbetrekking' geen rol. Rechtskracht is ontstaan als eis van rechtszekerheid. Op welke wijze wordt in de autopoiese dan aan die rechtszekerheid vorm gegeven?

Redenerend vanuit de autopoietische theorie kan gesteld worden dat autopoietische geslotenheid rechtszekerheid biedt doordat het gesloten gebied een eigen autonomie kent. In zoverre is autopoietische rechtszekerheid (systeem-rechtszekerheid) een relatieve waarborg (want afluankelijk van de abstractie systeem). Zelfproductie geschiedt langs de lijnen van processen en procedures. Zou rechtszekerheid aldus gewaarborgd zijn in een procesmatige selting? 


\subsection{De formele rechtskracht van beschikkingen vanuit autopoietisch perspectief bezien in verschillende rechtsgebieden}

\subsubsection{Inleiding}

De fomele rechtskracht van beschikkingen ${ }^{75}$ is in ons land steeds als bestuursrechtelijk leerstuk bestudeerd. Al had de wetgever als erkend rechtsvormer het leerstuk nimmer expliciet en/of leerstellig benaderd, voor het bestuur was en is het realiteit. In zijn arrest Heesch-Van de Akker was de Hoge Raad - eveneens als erkend rechtsvormer - wel leerstellig en introduceerde de formele rechtskracht van beschikkingen nu (in het privaatrecht) als afbakeningsmechanisme in de verdeling van rechtsmacht van burgerlijke en administratieve rechtspraak. Valt deze benadering te verklaren vanuit de autopoietische theorie?

De hypercyclus als ijkpunt van autopoietische beschrijving kan hier wellicht dienst doen. Dan wordt formele rechtskracht als verschijnsel geanalyseerd in de systemen van het bestuursrecht, het civiele recht en het strafrecht. Hiertegen zou men wellicht kunnen inbrengen dat deze rechtsgebieden deelsystemen van het recht zijn, die geen onderlinge geslotenheid kennen en als zodanig niet vergelijkbaar zijn van de autopoietische geslotenheid van recht met bijwoorbeeld systemen als economie of biologie. Het antwoord op deze stelling is afhankelijk van welke definitie van een systeem wordt gehanteerd. Als we het volstrekt acceptabel vinden om verschillende rechtsstelsels als systemen naast elkaar te beschouwingen (rechtsvergelijking), dan is er veel voor te zeggen ook rechtsgebieden te zien als object van interne vergelijking, met andere woorden als zelfstandige (sub)systemen.

\subsubsection{Formele rechtskracht in het bestuursrecht}

Sinds jaar en dag werkrijgt in een positiefrechtelijke opvatting een beschikking formele rechtskracht na verloop van de beroepstermijn, indien de beroepsgang niet is gebruikt, of, indien de beroepsgang wel wordt gebruikt, na het volledig doorlopen daarvan. De ratio daarvan ligt in de rechtszekerheid. Het bestuur moet snel duidelijkheid hebben inzake de status en de betekenis van een besluit. Ook voor burgers is het in het belang van de rechtszekerheid indien zij snel weten waar ze aan toe zijn. De administratieve rechter hanteert do formele rechtskracht in die zin dat een formeel rechtskrachtig besluit onaantastbaar is voor ieder (behalve het beschikkingnemende orgaan), of ook wel dat het onherroepelijk is of in rechte vaststaat. Beroepstermijnen zijn fataal en kort onwille van diezelfde rechtszekerheid en voorzienbaarheid.

Formele rechtskracht van beschikkingen (besluiten) is van belang omdat beschikkingen constitutief zijn voor de rechtssituatie. Door een besluit kan ten aanzien van een persoon of goed de rechtssituatie aangepast worden aan de actuele situatie. Dat is de ratio van vele aanvragen voor beschikkingen.

75. Omdat in het actieve rechisvormende deel van het bestumrstecht met name de term formele rechtskrachit wordt gehanteerd, ga ik hier daarvan wit. 
$B i j$ verschillende typen besluiten kan de formele rechtskracht andere effecten hebben. Zo verliezen rechtvaststellende, aflopende beschikkingen met formele rechtskracht na verloop van tijd hun constitutieve betekenis (zij zijn er als verwijzingsmogelijkheid naar de llegitimiteit van de gewijzigde rechtssituatie, maar hebben geen afzonderlijke constitutieve betekenis meer). Denk bijwoorbeeld aan de bouwvergunning onder tijdsbepaling voor de bouw van een woning. Na verloop van tijd, als de woning is gebouwd, verliest de bouwvergunning als constitutieve beschikking betekenis. (Slechts de declaratoire betekenis blijft, namelijk als verwijzing dat het bouwwerk legaal gebouwd is.) Zijn er aanpassingen vereist, dan is vaak en nieuwe constitutieve beschikking noodzakelijk (bijvoorbeeld een nieuwe bouwvergunning woor een aanbouw aan de inmiddels gebouwde woning). Duurbeschikkingen daarentegen wereisen vaak een nieuw formeel moment waarop constitutief wordt vastgesteld dat de rechtssituatie gewijzigd wordt (vergelijk intrekkings- of terugworderingsbesluiten).

In beginsel is het bestuur volledig toegerust om op enig moment de dan noodzakelijke en vanuit specialiteit ook - mogelijke rechtssituatie te creëren. De rechter heeft in deze een controlerende functie; hij dient daarbij diezelfde eisen van rechtszekerheid in acht te nemen. Wanneer de beschikking conform de wet gegeven of geweigerd moet worden en het bestuur heeft zulks niet gedaan, dan kan de rechter inspringen en de rechtssituatie in overeenstemming met het recht brengen (vernietigen of zelf in de zaak voorzien). Zijn er nova dan is het instituut van de herziening de mogelijkheid om de rechter te laten corrigeren. Ook door middel van de gedektverklaring van nietigheid kan de rechter corrigerend optreden. Weliswaar erkent het positieve bestuursrecht niet expliciet de mogelijkheid tot het uitspreken van een declaratoir door de administratieve rechter, ${ }^{76}$ maar dit moet worden afgeleid uit taak en functie van de rechter in het bijzonder daar waar (ook) hij de rechtszekerheid moet dienen door vast te stellen wat inhoud en omvang van een rechtens relevante (rechts)situatie is. Uit zijn bedrijvigheid kan de administratieve rechter deze bevoegdheid tot het geven van een declaratoire uitspraak afleiden. ${ }^{77}$ Door uit te spreken welke rechtssituatie rechtens vast staat, doet hij niets anders dan de orntrekken van de formele rechtskracht van die situatie vastleggen. Daaraan kan behoefte zijn, indien het bestuur (om welke reden dan ook) zich niet wan deze taak heeft gekweten of heeft kunnen kwijten.

76. Weliswar overwoog de regering de mogelijkheid van een declaratoire uitsprak op te nemen in de uitsprakencktalogus van art. $8.72 \mathrm{Awb}$, maar ging daar niet daadwerkelijk toe over. Vgl. Nader Rapport, PG Awb 2, p. 469 en MvT, PG Awb 2, p. 472 en daar genoemde jurisprudentie. Ook Simon noemt op dit punt interesšnte jurisprudentie. Vgl zijn Handleiding Awb-praktijk, Den Haag 1995, p. 282-283 en zijin Handboek bestuurs(proces)recht wolgens de Awb, Den Haag 1997, p. 321. Zie ook: J.M.H.F. Teunissen, Bestuurlijk oordeel als rechtshandeling, in: Gem.st. 7077, nr. 1, p. 309-315.

77. Zoals ook de President van de rechtbank Amsterdam op 2 februari 1996, JB 1996/145, nint. EvoL deed; ondanks dat de Awb niet expliciet de mogelijkheid opent tot het geven van een declaratoire uitspraak en de wetsgeschiedenis uitgatat wan cen gesloten stelsel van dicta, oordeelde de president, staat dat "niet in de weg an het doen van een witsprakk als hier bedoeld'. De rol van de rechter ten aanzien van zaken alls deze is zo overwoog de president - dat hij hier een grote verantwoordelijkheid heeft en hem een actieve rol is toebedeewld. 
Nu kan zo'n snel intredende formele rechtskracht op zichzelf ook well problemen creëren. Bekend is de situatie dat een beschikking wordt afgegeven die met een fout is behept. Zowel bestuursorgaan als belanghebbende(n)zien dat - om verschillende redenen - over het hoofd. Er wordt - wederom om betrokkenen moverende redenen - geen beroepsgang gestart. De gebrekkige (of vernietigbare) beschikking krijgt dan toch na verloop van de beroepstermijn formele rechtskracht en kan door het rechtsleven als geldige rechtsgrond voor vanuit bestuursrechtelijk oogpunt geaccordeerd handelen. Dan staat het belang van de (formele) rechtszekerheid (de formele rechtskracht treedt in omwille van de snelle duidelijkheid ten aanzien van de status van het besluit) tegenover het belang van de (materiele) rechtszekerheid (besluiten die - kunnen/gaan - werken in het rechtsverkeer horen ook aan alle daaraan gestelde eisen te voldoen). Naar mijn mening dient dan aan de materiele rechtszekerheid voorrang te worden gegeven. ${ }^{78}$ Duk en Nicolar hebben daarom gepleit voor het uitspreken van een declaratoir door de rechter. ${ }^{79}$

\subsubsection{Formele rechtskracht als hypercyclus in het burgerlijke recht}

Formele rechtskracht van beschikkingen na verloop van beroep(stermijn) is een al langer aangenornen bestuursrechtelijke eigenschap. Door deze eigenschap te introduceren en deze eigenschap te hanteren als instrument ter afbakening van de rechtsmachten van de burgerlijke en de administratieve rechter wordt de eigenschap van beschikkingen - in een ander rechtsgebied getrokken - tot hypercyclus. Het uit de concretisering van administratiefrechtelijke rechtszekerheid geboren instituut van de formele rechtskracht van beschikkingen krijgt aanzien als afbakeningsmethode. A fbakening van de onderscheiden rechtsmachten was all zo oud als het rechtspreken door de rechter(s) en het naast elkaar bestaan van beide rechtsgebieden. Iets wat er al is (de formele rechtskracht van beschikkingen in het bestuursrecht), wordt opnieuw - juridisch - ontdekt en gaat functioneren als ware het iets nieuws (vergelijk het hierboven genoemde voorbeeld van Huls inzake mensenrechtenschendingen), dat moet leiden tot nieuw recht, een nieuwe afbakeningsmethode.

Van belang hierbij is eveneens het autopoietische kenmerk van systemen om ze als autopoietisch gesloten te zien. Autopoietische geslotenheid betekent, als gezegd, dat een systeem informatief (cognitief) open is, maar operationeel gesloten. Informatief bleek het privaatrechtelijke systeem open te zijn (er was oog voor de in het bestuursrecht gehanteerde eigenschap van beschikkingen). Operationeel bleek het echter gesloten; de eigenschap van beschikkingen werd in de eigen termen van het systeem geinterpreteerd. Dat gebeurde met het leerstellige arrest Heesch - Van de Akker, ${ }^{80}$ omdat daarin door de gewone rechter uitvoerig werd aangegeven wat onder de formele rechtskracht van beschikkingen - nu als afbakeningsmechanisme voor de onderscheiden rechtsmachten - moest worden verstaan en hoe de gewone rechter thans moest handelen. In latere jurisprudentie werd deze hypercy-

78. Zoals ook al werd gesteid in mijn noot onder HR 3 november 1995, IB 1996/20 (Petronella-Rotterdan).

79. Vgl W. Duk en P. Nicollai, Nulliteiten in het bestursrecht, in: RM Themis 1993/1, p. 3-31.

80. Vgl. HR 16 mei 1986, AB 1986, 573, m.nt. FHvdB. 
clische formele rechtskracht verder toegelicht, uitgelegd, en toegespitst op de noden van een goed functionerend ontvankelijkheidsprincipe.

Hierboven werd al aangegeven dat autopoietische geslotenheid (operationele geslotenheid) er moet zijn om de eigen eenheid en identiteit te bewaren. Nu we hebben gezien dat de formele rechtskracht zoals de Hoge Raad die in het burgerlijk recht hanteert een andere is als de formele rechtskracht in het bestuursrecht, kunnen we concluderen dat met het binnenhalen van formele rechtskracht in het burgerlijk recht een systeemvreemd element werd binnengehaald, waardoor de operationele geslotenheid geweld werd aangedaan. Formele rechtskracht op die wijze in het burgerlijk recht toegepast, is dan onaanvaardbaar.

Nog hypercyclischer wordt deze formele rechtskracht als deze in verband gebracht wordt met, of inspiratiebron is voor oplossingen in andere aloude vraagstukken zoals bv. de vraag wanneer sprake is van (erkenning van) onrechtmatigheid in het leerstuk van de onrechtmatige overheidsdaad of wragen inzake overheidsaansprakelijkheid voor onrechtmatige beschikkingen ${ }^{81}$ of wanneer het verband gelegd wordt met de activiteiten van de administratieve rechter als deze steeds meer optreedt als schadevergoedingsrechter. ${ }^{82}$ Nieuwe namen voor onderscheidingen ten aanzien van de formele rechtskracht doen opgeld: 'eigenlijke' en 'oneigenlijke" formele rechtskracht. ${ }^{83}$ Daarmee is weer een overstap gemaakt, of wellicht moet ik het benoemen als de creaties voor of de systeem interne aanpassingen tot het mogelijk maken van hypercyclische verbindingen. Dan zijn we aangekomen bij de volgende paragraaf.

\subsubsection{Formele rechtskracht als Hyperzyklische Verknüpfung bij de strafrechter}

Niet alleen de burgerlijke rechter kan gevraagd worden om een oordeel over de formele rechtskracht van een beschikking, ook de strafrechter kan aldus geadieerd worden. Dient de strafrechter zich onbevoegd te verklaren of het OM niet-ontvankelijk te verklaren indien een administratieve rechtsgang (die met voldoende waarborgen is omklleed) gevolgd kan worden? En indien die weg niet is gevolgd, dient de strafrechter dan uit te gaan van de geldigheid (rechtmatigheid, formele rechtskracht) van het besluit analoog aan het handelen van de burgerlijke rechter als geschetst sinds Heesch - Van de Akker?

De vraag stellen, lijkt haar beantwoorden (vergelijk hiervoor hoofdstuk 3). Uiteraard moet de strafrechter zelfstandig de betekenis van de beschikking kunnen interpreteren (of als voorvraag beantwoorden) en zonodig toetsen voordat hij tot strafbaarstelling overgaat.

81. Vgl. T. Hartlief en R.P.J.L. Tjütes, Overheidsaansprakelijkheid, in: NTBR 1994, p. 36 en het daarna werder uitgewerkte R.P.J.L. Tjittes, Herbezinning op de grondslagen van de overheidsaansprakelijkheid, preadvies Vereniging voor burgerlijk recht, Lelystad $\$ 996$.

82. Vgl. W. Konijuenbeli, De administratieve rechter als schadevergoedingsrechter, preadvies Vereniging voor Burgerlijk recht, Lelystad 1996, p. 23.

83. Vgl. M.R. Mok, en R.P.J.L. Tjittes, Formele rechtskracht en overheidstansprakelijkheid ${ }_{\text {in: }}$ RM Themis $1995 / 9$, p. $383-404$. 


\title{
9.5.5 Conclusie. eigen aard van bestunrsrecht, civiel recht en strafrecht
}

Met een beroep op de aard van het strafrecht of de functie van het strafrecht kan ook een geheel andere conclusie worden getrokken. Demeersseman legt nadruk op de materiele autonomie van het strafrecht:

\begin{abstract}
"Doorslaggevend bij de beantwoording van de vrasg of aan het materiéle strafrecht materiêle autonomie toekomt is volgens het daarvoor gestelde criterium, of nen erkent, dat bij het materiele sirafrecht wan een zozeer wan andere rechtsgebjeden afwijkende functie sprake is, dat het hieran niet meer goed zou kunnen beantwoorden, indien men bij de toepassing ervan gebonden zou zijn aan de begrips- en theorieworming (begrippen en normen, zo men wil) vit andere rechtsgebieden. Wanneer we dit criterim nuder onder ogen zien, wordt duidelijk, dat het uit twee componenten is samengesteld. De eerste is de erkerning, dat het materiele strafrecht een eigen, vari andere rechtsgebieden afwijkende functie heeft; de wweede is de erkenning: op grond van deze afwijkende functie, dat deze functie niet goed vervuld zou kunnen worden bij gebondenheid aan theorie- en begripsworming wit andere rechnsgebieden. ${ }^{2.4}$
\end{abstract}

Beide vragen worden bevestigend beantwoord. De eigen functie (of: het eigen doel) van het materièle strafrecht is aldus Demeersseman de leedtoevoegende functie en ook heeft het strafrecht zijn eigen aanpak; kortom, het strafrecht is een eigen (gesloten, wettelijk, ultimum remedium) systeen.

\begin{abstract}
"Welk karakter de strafbepaling ook heeft - sluitstuk of niet - steeds is er o. i. sprake van een eigen strafrechtelijke nomstelling. Zelfs wameer het strafrecht krachi bij zet aan de naleving van nomen uit andere rechtsdisciplines is het niet louter als een accessoir recht te beschouwen. Het is de wetgever zelf namelijk, die bepaalt of en op welke wijze deze normen uit die andere rechtsdisciplines worden overgenomen en in het strafrechtelijke systeem worden gencorporeerd. Er vindt met andere woorden een verstrafrechtelijking plats. Deze eigen strafrechtelijke normstelling nu is o.i. een van de uithingen van de eigen aaripak wan het materietle strafrecht (waarin zich de erkenning openbaart, dat het strafrecht in veel gevallen niet aan zijn doel kan beantwoorden bij gebondenheid aan theorie- en begripsworming uit andere rechisgebieden). ${ }^{85}$
\end{abstract}

Wellicht is het hanteren van de hoofdregell van formele rechtskracht met als doel het vermijden van forumshopping bij de burgerlijke rechter te begrijpen, maar vanuit het strafrecht is forumshoppen nauwelijks - in ieder geval slechts in beperkte mate - mogelijk. ${ }^{8}$ Vanuit de functies van de rechtspraak van verschillende kolommen (bestuurstechtspraak, burgerlijke rechtspraak en strafrechtspraak) is in ieder geval wel aan te geven dat de effecten van ten beschikking (die al of niet formele rechtskracht heeft gekregen) veelsoortig en ongelijksoortig kunnen zijn. Elke rechter dient daar op zijn eigen manier en met zijn taakstelling voor ogen mee om te gaan. Dat betekent dat onrechtmatigheidsoordelen in het bestuursrecilt, in het burgerlijk recht ến in het strafrecht drie eigen-aard-ige en dusdoende verschillende oordelen (ook ten aanzien wan een en hetzelfde handelen) zijn en daarom ook naast elkaar

84. H.A. Demeersseman, De autonomie van het materiele strafrecht, diss., Amhem 1985, p. 610.611.

85. H.A. Demeersseman, De autonomie wan het materiele strafrecht, diss, Amhem 1985, p. 632

86. Vgl. bv. de verwoede pogingen om een rechterlijk oordeel te krijgen door Leenders in $\|$ HR $I I$ oktober 1996, JB 1996/241 m.nt. EwdL (Leenders-Ubbergen). Nadat de begane overtreding geseponeerd was, kon afleen via de mogelijkheid van art. $12 \mathrm{~Sv}$. een strafrechterlijk oordeel witgelokt worden. 
kunnen bestaan. ${ }^{\text {"In }}$ autopoietische terminologie zijn het naast elkaar staande en autopoietisch gesloten systemen. Vrijwarende werking is daarom nimmer vanzelfsprekend. ${ }^{88}$ Van der Burg stelt dan ook: 'in het algerneen verdient $m$.i. de uitleg dat de vergunning niet slaat op het te laste gelegde feit, de voorkeur." ${ }^{\text {st }}$

\subsection{Tenslotte}

Vanuit de theorie van autopoiese kan formele rechtskracht worden beschreven als hypercyclus en ook de analyse als Hyperzyklische Verknupfung blijkt verhelderend. Zo bezien is de theorie met name behulpzaam als analyse-model. In die analyse wordt formele rechtskracht - autopoietisch bezien - als een hypercyclus in het burgerlijke recht binnengehaald, waarbij de operationele geslotenheid geweld wordt aangedaan. De conclusie daarvan is dat deze formele rechtskracht niet dezelfde is als die in het bestuursrecht en daarom ook niet de afbakeningsproblemen van de deelsystemen kan oplossen.

Verheldering is op zichzelf van grote waarde. Als normatieve strategie houd ik twijfels. ${ }^{90}$ Wat kwalijker lijkt aan hypercycli (al of niet verknilpft) is, dat met de variaties (van oorspronkelijke betekenis van begrippen naar - deels - gewijzigde begrippen in andere rechtsgebieden) waarborgen in het gedrang komen. Teubner stelt weliswaar dat waarborgen in de klassieke visie ook in het gedrang zijn, maar vraag is dan wat autopoiese als extra of als oplossing te bieden heeft? Als in het gedrang zijnde waarborgen niet verstevigd worden, maar (slechts) op een andere manier geanalyseerd (en daarmee zichtbaar gemaakt) worden, voegt de theorie van autopoiese niets toe aan de beschermende factoren in het recht.

Twijfel is er ook ten aanzien wan de beschrijving van de werking van het recht. Teubner voert werking van het recht op als paradox. We weten dat we niet weten warom het werkt, maar we weten ook dat men (desondanks) kan handelen, omdat het toch wel werkt. ${ }^{9 !}$ ॥s werking van het recht dus autopoietisch te verklaren, dat wil zeggen als een zichzelf producerend systeem? Hebben we het dan over de werking van rechtsgevolgen of de werking van de rechtshandeling? Is de autopoietische theorie wel zorgvuldig genoeg ten

87. Dit zal nader worden beschouwd in het hoofdstuk waarin de formele rechtskracht wordt geanalyseerd vanuit het spectrale perspectief.

88. Zo oordeelt ook de stratkamer van de Hoge Raad in zijn arrest van 5 februari 1991, AB 1992, 38, alwaar naast een verlaging wan een RWW-uitkering een strafrechtelike veroordeling wordt uitgesproken. Witdrukkelijk steli de A-G in zijn conclusie dat er geen sprake is van een tweede bestraffing in de zin van art 14 lid 7 IVBP; daarin gaat de Hoge Raad mee.

89. F.H. van der Burg onder HR 13 november 1984, AB 1985, 361 (Camperen in Domburg), p. 908.

90. Die twijfels bespeur ik ook bij M. Schreuder-V/asblom in haar oratie Eigenzinnig recht, Deventer 1998, p. $26-29$.

91. Teubner haalt ten anzien hiervan Joerges aan: 'Und Joerges zieht die Konsequenz: "Die Unbestimmtheitsproblematik erweist sich als Paradoxie Man WeiB, daB man nicht WeiB, warum das Recht funktioniert; aber man Weib auch, daB man handeln kann, weil es eben funktioniert". " in: Recht als autopoietische System. Frankfulurt am Main 1989, S. 14. 
aanzien van dit onderscheid? Is de autopoietische theorie niet veeleer een sociologische analyse van het recht dan een juridische analyse van het recht?

Vanuit de transcendentale methode, en in het bijzonder vanuit de daarvan deell uitmakende aspectenleer, zou als kritiek op de autopoietische methode geuit kunnen worden dat in de autopoietische methode het biologische en/of het sociologische aspect wordt verwisseld met het juridische aspect, omdat het gebaseerd is op (en als uitgangspunt heeft genomen) de in de biologie ontdekte zelfproductie en dat heeft toegepast op het samenleven en het recht. Het zou daarom een te eenzijdige en dus gemankeerde theorie zijn. Wanneer immers biologisch en juridisch aspect verwisseld worden, blijft de juridische verklaring van de theorie ontbreken. In het volgende hoofdstuk zal getracht worden om rechtskracht te analyseren vanuit deze transcendentale methode.

Het hypercyclisch verbinden en/of van het ene naar het andere rechtsgebied transporteren wan ideeèn en begrippen is riskant. Vanuit de rechtsvergelijking is al langer benadrukt dat elementen van het ene stelsel niet zomaar overgeplant kunnen worden in andere stelsels. Ook voor de interne rechtsvergelijking gaat dit op. Ook deze kritiek is al eerder geuit; Beurskens noemde de wederkerige rechtsbetrekking een koekoeksei in het nest van het bestuursrecht. ${ }^{93}$

De vraag die aan het eind van dit hoofdstuk misschien nog rest, is of dit hoofdstuk eigenlijk wel opgenomen had moeten worden in deze studie. De theorie blijkt en blijft uitermate schimmig; juridische handen en voeten vinden we nauwelijks. De enige conclusie die overeind blijt is, dat formele reclntskracht in het burgerlijk recht als afbakeningsmethode van rechtsmacht autopoietisch niet kan (want als systeemvreemd element fungeert). Deze conclusie had ook langs een andere weg bereikt kunnen worden, zodat de vraag blijft wat autopoiese toevoegt. Toch kan geconstateerd worden dat Teubners autopoiese regelmatig in het Nederlandse bestuursrecht een rol speelt; auteurs noemen hem en gaan met de autopoiese in gesprek. De wederkerige rechtsbetrekking (of, een subjectiveringstendens) wordt daarmee ook in verband gebracht. Vanuit diezelfde gedachtengang kwam De Jong tot een negatie van rechtskracht; daarom moest ik dit spoor wel volgen.

92. Vgl. Teubner: Om het wat pragmatischer te sitellen. Als we ons bezighouden met bijwoorbeld (...) bestursecht dan gebruiken we theories over (...) statsrecht, over de venliouding tussen staat, matischappij en ind ividu. Deze theoriezn zijn, wanneer je zo vergelijkt met politieke en sociologische theorietn, niet zo complex. $\mathrm{k}$ denk dat beide hierboven beschreven componenten van autopoicse (als analyse edi als normatieve strategie, EvdL) een zeer goed huipmiddel kumen zijn woor wen goede ontwikkeling van deze theorieen zodat ze te gebruiken zijn in de rechtsdoctrine of bij de formulering van overheidsbeleid. ' in: $H$. Stout en J. Stoop, Autopoiese aan de Maas: ofwel instrumentele wetgeving reddeloos verdronken? "een wraaggesprek met $G$. Teubner, Regelmaat $1991-1$, p. 6 .

93. Vgl. W.J.J. Beurskens, De 'wederkerige rechisbetrekking': koekoeksei in het nest van het publiekrecht, in: Eenzijdig en wederkerig? beschowwingen over de wederkerige rechtsbetrekking als basisconcept in het bestuursrecht, E.C.H.J. van der Linden en A.C. Tak (red.), Deventer 1995, p. 23. 


\section{Rechtskracht als geldingsvraagstuk; een analyse vanuit de transcendentale denkkritiek}

\subsection{Inleiding}

Aangezien Van Eikema Hommes de (formele) rechtskracht in de transcendentale denktralitie positioneert als elementair grondbegrip, dat een structuurelement is van de rechtswetenichap, zal deze gedachtengang in het hiernavolgende worden besproken. Zo kan worden snderzocht welke de (nieuwe) betekenis van rechtskracht is, die vanuit deze methode is ontwikkeld. Rechtskracht als elementair grondbegrip betekent gelding; daar ga ik eerst op in. Jok de begrippen formele en materiële rechtskracht worden besproken, waarna de onderling verhouding tussen beide begrippen aan de orde komt. Tenslotte ga ik in op rechtskracht aan te normzijde en de feitelijke zijde van her rechtsaspect.

De transcendentale denkkritiek is in hoge mate ontoegankelijk. Zowel Dooyeweerd als Van Eikema Hommes schrijven vanuit een eigen en uniek begrippenarsenaal. De door hen voorzestane analyse en beschouwing van de rechtswetenschap zijn pas toegankelijk wanneer de lezer zich het imposante begrippenarsenaal eigen maakt. Een uitputtende inleiding en coelichting op de transcendentale denkkritiek zelf zullen hier niet worden gegeven; zij wordt mierna bekend verondersteld.'

De transcendentale denkkritiek heeft drie belangrijke pijlers. De eerste poot is de transzendentale methode zelf, daarnaast zijn de aspectenleer en de verbandenleer van belang. Deze drie pij]ers zijn in de transcendentale denkkritiek - alhoewel los van de transcendentale methode totstandgekomen en er dus wel van te isoleren - met elkaar verbonden en kunnen niet (meer) los van elkaar worden gezien. Via de zogenaamde grensbegrippen en regulatieve ideeën worden de verbindingen gelegd. Samen leiden ze tot een allesomvattende wijsgerige visie op het leven; met andere woorden, de transcendentale denkkritiek beperkt zich niet tot een analyse van het recht (dat is namelijk slechts één aspect).

1. Voor een studie van de transcendentale denkkritiek verwijs ik naar o.a. H.J. Hommes, Enige beschouwingen over Kant's metafysische rechtsleer, in: RM Themis 1963, p. 441 e. $\mathrm{y}_{\text {, }}$ H.J. Hommes, De methodische betekenis wan het rechtsbegrip, oratie, Zwolle $1965 ; \mathrm{HJ}$. van Eikema Hommes, Hoofdlijnen wan de geschiedenis der rechtsfilosofie, Deventer 1972; H.J. van Eikema Hommes, De elementaire grondbegrippen der rechtsw wetenschap, Deventer 1972; HJ. van Eikenta Hommes, be samengestelde grondbegrippen der rechtswetenschap, Zwolle 1976; N.H.M. Roos, Enige opmerkingen over de grondslagenproblematiek in de rechtsfilosow fie van HJ. van Eikema Hommes, in: Tijdschrift voor rechtsfilosofie en rechtstheorie 1980, p. 26 e.v. H.J. wan Eikema Hommes, Inleiding tot de wijsbegeerte van H. Dooyeweerd, Den Haag 1982. 


\subsection{Rechtskracht als elementair grondbegrip: rechtskracht is gelding}

\subsubsection{Inleiding}

In de transcendentale methode wordt rechtskracht gezien als juridische gelding. In die visie zijn rechtskracht van rechtsnormen en gelding wan rechtsnormen gelijk aan elkaar in de zin van het vermogen rechtsfeiten effectief te regelen (rechtskracht is gelding van normen). In zoverre volgt de transcendentale denkkritiek de klassieke, rechtspositivistische benadering (hoofdstuk 8), waarin rechtskracht eveneens op rechtsnormen wordt betrokken. In het bijzonder in Kelsens wisie, wordt rechtskracht gezien als werkzaamheid (effectiviteit) die gelding (geldigheid) vooronderstelt ofwel werkzaamheid (effectiviteit) door middel van gelding (geldigheid). Gelding (geldigheid) van rechtsnormen is bij Kelsen verbonden met een dynamisch rechtsvormingsproces. Merkls rechtskrachtbegrip is opgevat als duur van de gelding en is afgeleid uit het rechtsbegrip; aldus is Merkls rechtsorde-idee statischer dan dat van Kelsen. De transcendentale üteenzetting omtrent de betekenis van rechtskracht van Van Eikema Hommes is steeds in oppositie met deze rechtspositivistische benadering weergegeven. Ook echter de beschrijvingen en definities in het traditionele debat, dat wil zeggen van de minder rechtstheoretisch en rechtsfilosofisch georiënteerden, ontmoeten oppositie van Van Eikema Hommes daar zij - vanuit transcendentalistisch oogpunt bezien - ten onrechte van alleen maar een formele benadering van rechtskracht uitgaan.

\subsubsection{Betekenis rechiskracht}

Van Eikema Hommes acht rechtskracht gelijk aan rechtsgelding, waarbij rechtskracht dus verwant is aan juridische dynamiek en juridische constantie. ${ }^{2}$ Ten aanzien van het onderscheid tussen formele en materiele rechtskracht wordt in het traditionele debat alleen van de formele zijde van rechtskracht uitgegaan.

Jegens welke betekenissen van rechtskracht opponeert Van Eikema Hommes? Dan hebben we het primair over wat Van Eikema Hommes duidt met de civilistische rechtskrachtleer. De betekenis van rechtskracht wordt daar als onaantastbaarheid gedefinieerd; deze visie bleek aantrekkingskracht te hebben op de burgerlijke rechter, die haar hanteerde als instrument têr afbakening van zijn rechtsmacht met die van de bestuursrechter (hoofdstuk 2). Maar ook de bestuursrechter hanteerde de rechtskracht in de zin van rechtens vaststaand (hoofdstuk 4).

In de (door Van Eikema Hommes zo genoemde) publicistische rechtskrachileer werd de rechtskracht van de beschikking vergeleken met en/of gelijkgesteld aan de rechtskracht van de rechterlijke uitspraak, met name het (civiel) wonnis. Zo introduceerde Van der Pot rechtskracht in ons land ${ }^{3}$ en vanuit die optiek onderzocht Donner de consequenties ervan voor het

2. Vgl. H.l. van Eikema Hommes, De elementaire grondbegrippen der rechtswetenschap, Deventer 1972 , hoofdstuk 7, p. 140 e.y.

3. Vgl. C.W. wan der Pot, De rechtskracht der beschikking, in: De vomen van het besturen, in: Nederlands Bestuussecht, Alphen a/d Rijn 1932. 
bestuursrecht. ${ }^{4}$ Rechtskracht was in de publicistische leer onaantastbaarheiden onveranderlijkheid van de beschikking voor ieder ander dan het beschikkingnemende orgaan (formele rechtskracht) en anderzijds ook woor het beschikkingnemende orgaan in de zin van onmogelijkheid tot intrekking of wijziging (materiële rechtskracht). Zo was het de concretisering van het rechtszekerheidsbeginsel: 'Het is het beginsel van de rechtszekerheid-enerzijds in de typische vorm wan het litis finiri oportet, anderzijds in de vorm van de onaantastbaarheid wan verkregen rechten - dat er zich tegen verzet, dat deze laatste, tevens laagste fase in het rechtsvormingsproces opnieuw discutabel wordt gesteld. ${ }^{5}$

Dat die onaantastbaarheid niet absoluut was stond evenwel buiten kijf; de betekenis van rechtskracht was daardoor relatief.

Deze betekenissen van rechtskracht vat Van Eikema Hommes beide samen onder de formele kant van rechtskracht; dat is de formele onveranderlijkheid en onaantastbaarheid van rechtsnormen, die verwant is met de juridische constantie. Van Eikema Hommes erkent dat de formele kant van rechtskracht een rol speelt; het is echter niet de enige betekenis die hij aan rechtskracht geeft. Daarom is het alleen maar van de formele kant van rechtskracht uitgaan een gemankeerde, want te beperkte visie:

\footnotetext{
'Rechtskacht en rechtsgelding zijt identiek en komen aan alle rechtsnormen binnen hun matericel of formeel omgrensde rechtsgebieden toe.

Ofschoon de rechishracht ten nauwste met de dynamische analogieënsfeer in het rechtsaspect verbonden is en daarop rust en dan ook met de relatieve constantie en onveranderlijkheid van rechtsnormen in het dynamisch rechtsvormingsproces samenhangt, mag zij daarmee toch niet worden vereenzelvigd, zoals in de gangbure literatuur vaak gebeurt. Daarin vat men rechtskracht veelal op als formeel-juridische onvercanderlijkheid of onaartastbarheid wan een rechtsnorm.

Dit hangt hijermee samen, dat de rechtskracht van oudsher alleen bij rechterlijke beslissingen in civiele procedures wordt behandeld, waar zij als gezag van gewijsde (anctoritas rei judicatae) optreedt. Dit is de civilistische rechtsknachtleer. ${ }^{: 6}$
}

Daarnaast is er de publicistische rechtskrachtleer. Daar werd rechtskracht van administratieve beschikkingen vergeleken met de rechtskracht van rechterlijke uitspraken. Van Eikema Hommes acht de vereenzelviging, die daarbij vaak plaatsvindt "niet juist.

\begin{abstract}
'De wragg rijst nu of de vereenzelviging van (formele en materiele) rechtskracht van rechterlijke uitspraken en administratieve beschikkingen met hun formecl-juridische onveranderlijkheid, die uitcraard ten relatieve is, juist is. Dit is mi. niet het geval. Strikt genomen ligt de formele onveranderlijkheid van reclitsnomen aan hazn rechtskracht ten grondslag. Anders gezegd: de (formele en materiele) rechtskracht woeit uit de formele onveranderijkheid en onaantastbaarheid der rechisnormen wort. (...) We stuiten hiser op de formele kam van de rechtskracht die haar grondslag alleen de rechswormende wilswertilaring wan een competem rechtswormer als onistaansworm wan rechismormen wind. Op deze formele kant van de rechtskracht zijn zowel de "formele' als de "materiele" rechtskracht in traditionele zin betrokken. Het gaat bij beide immers on de vraag, in hoewerne de ordenende rechtswil van de rechtsvormer, als onistaansworm van recht, kan worden
\end{abstract}

4. Vgl. A.M. Donner, De rechtskracht van administratieve beschikkingen, diss., Alphen a/d Rijn 1941 .

5. H.J. van Eikema Hommes, De elementaire grondbegrippen der rechtswetenschap, Devenger 1972, p. 156.

6. HJ. van Eikema Hommes, De elementaire grondbegrippen der rechiswetenschap, Deventer 1972, p. 155. 
weranderd. Wanneer beide, de fomele en de materiele rechtskracht in traditionele zin op de formele kant van rechtskracht rusten, rijst de vraag of deze onderscheiding, al thans wat de termen "formeel' en "materieel" betreft, well zirvol is. Voor deze vragg is temeer alanleiding, ondat de traditionele onderscheiding bij hogere trappen van rechtswoming in het algemeen niet opgat. Bij wetgeving ontbrekt immers de "materiete" rechskracht, omdat de wetgever te allen tijde gereehtigd moet zijn zijn wetten, wanneer hem dit vit rechtspo* litick oogpunt gewenst woorkont, te weranderen."

\subsubsection{De formele kant van rechtskracht}

De formele kant van rechtskracht is gebaseerd op de formele onveranderlijkheid van ontstaansvormen van rechtsnormen. De formele en materiële rechtskracht in de publicistische zin zijn gebaseerd op deze formele kant wan rechtskracht. Van Eikema Hommes opponeert aldus jegens hen die - naast gelding - werking als rechtskracht definiëren en ook jegens hen die naast formele rechtskracht als onaantastbaarheid jegens anderen dan de rechtsvormer zelf de materiële rechtskracht als onaantastbaarheid jegens de rechtswormer zelf beschouwen. In zijn ogen wordt in die benadering te zeer de nadruk gelegd op de formele zijde van rechtskracht, de formele onveranderlijkheid en onaantastbaarheid van rechtsnormen. Rechtskracht heeft inderdaad verwantschap met juridische dynamiek en constantie (en dus met het subsumptie-mechanisme dat Kelsen in het dynamische principe onderscheidt en dat Van Eikema Hommes de verticale rechtsdynamiek noemt), maar daarmee niet alleen. Omdat de traditionele indeling van formele en materiële rechtskracht uitgaat van de formele zijde van rechtskracht will Van Eikema Hommes in zijn benadering van het rechtskrachtvraagstuk de roll van materiële rechtsbeginselen benadrukken.

Van Eikema Hommes' kritiek bestaat daarin dat de formeel-logische opvatting wordt verabsoluteerd en dusdoende de normatief-juridische zin van de juridische dynamiek en constantie miskent.

\footnotetext{
"Merkls formalistische rechtsopvatting leidt er echter toe, dat de positieve rechtsvorming van alle bovenwillekeurige materiele rechtsbeginselen wordt losgemaakt, ook van de modaaljuridische beginselen der juridische constantie en rechtsdynamiek. De wraag naar de constantie en veranderlijkheid der rechtsnomen wordt een kwestie wan louter wetgeverswillekeur."8
}

Aldus wordt, zo stelt Van Eikema Hommes, de grens tussen praktische rechtsvorming en theoretisch-logisch denken in de rechtswetenschap volledig uitgewist. Het verticale rechtsvormingsproces berust niet louter op logische afleiding uit hogere rechtsnormen, maar ook op materiële rechtsbeginselen, die ook weer verwant zijn met juridische dynamiek en constantie, althans zo stelt Van Eikema Hommes', waardoor we zijn beland bij de materiële kant wan rechtskracht.

7. Hu. van Eikema Hommes, De ellementaire grondbegrippen der rechtswetenschap, Deventer 1972, p. 157

8. H.J. van Eikema Hommes, De elementaire grondbegrippen der rechtswetenschap, Deventer 1972, p. 159.

9. Vgl. HJ. van Eikema Hommes, De elementaire grondbegrippen der rechtswetenschap, Deventer $1972, \mathrm{p}$ 160. 


\title{
10.2.4 De materiële kant van rechtskracht, de rechtsbeginselen
}

De formele zijde van rechtskracht is niet de enige grondslag van rechtskracht. Daarnaast erkent Van Eikema Hommes een andere grondslag, waarin de materiële rechtsbeginselen een rol spelen.

\begin{abstract}
"Asangezien de ordenende rechtswill van een competent rechtswormer als ontstaansboron van rechtenormen niet de enige grondslag is voor het in het leven roepen wan geldend recht, maar daarwoor ook de materiele rechtsbeginselen, die de inhoud der rechtsnormen bepalen, beslissend zijn, kan de formele kant der rechtskrach, die op de relatiewe onveranderlijkheid wan de ontstaanswormen der rechtsnormen berust, niet her gehele vrangstuk der rechtskracht uitmaken, maar zal daarin ook cen materiele kant moeten worden crkend."ilo
\end{abstract}

De inhoud van deze materiële kant van rechtskracht wordt door Van Eikema Hommes voornamelijk geschetst in oppositie met de stellingen van Merkl, die keer op keer als niet alleen puur logisch, maar zelfs als logicistisch worden gediskwalificeerd. De logische afleiding van lagere rechtsnormen uit hogere rechtsnormen wordt door Van Eikema Hommes ontkent. De gedelegeerderechtsvorming komt volgens hem tot stand door afleiding uit hogere materiele rechtsbeginselen. De rechtskracht is daarop rechtstreeks gebaseerd.

"Er is geen sprake van dat het verticale rechtswormingsproces op logische affeiding uit hogere rechtsnormen berust. De gedelegeerde rechisvorming binnen materiele rechtsgebieden is nadere juridische vormgeving aan in de hogere rechtsnom besloten materiele rechtsbeginselen of aan eventueel nieuwe door de rechtsvormer te winden rechtsprincipes. De rechiskracht van rechtsnormen wordt niet door de rechtswetenschap vastgesteld, maar bernst op de rechiswormende arbeid der competente rechtsorganen, die aan boven-willekurige rechisbeginselen positieve worm geven. Niet slechts de formele kant der rechisworming, maar vooral bok de materiele kont der rechtsbeginselen, is beslissend voor de rechtskacht van rechisnormen."

\section{En ook:}

'Die rechtliche Geltung oder Effektivitat der Rechtsnormen ist also nicht nur von dem dynamischen Prozeß der rechtichen Willensbildung durch konpetente Rechtsorgane abhängig, sondern vor allem von den mateniellen, menschlichen Willkur entzogenen Rechisprinzipien, die dem Ithall des gettenden Rechts immerhalb eines materiellen Rechtsgebiets zugrunde liegen. Diese materiellen Rechtsprinzipien gehoren nicht zu dem ganz variablen, von der Willkür des Gesetzgebers ablingigen Inhall der Rechtsnormen, wie es der Rechtspositivismus Jehrt. Sie haben einen tiber-wilkurlichen Inhalt und sind in der modalen Struktur des Rechtsaspekis und den typischen Struknuren (Natur der Sache) der Geselschaftsbeziehungen mach ihrem Rechtsaspekt fundient. (..) In den materiellen Rechtsprinzipien, als aberwillkurlicher Ginundage des Rechtsbildungsprozesses, begegnen wir dem Wermoment (walue, valeur) im Recht. M.E. bestehen keine Uberzeitlichen, in sich ruhenden Werte, aus denem Normen abgeleitet werden konnten., ${ }^{12}$

10. H.J. wan Eikema Hommes, De elementaire grondbegrippen der rechtswetenschap, Dewenter 1972, p. 157158.

11. H.J. wan Eikema Hommes, De elementaire grondbegrippen der rechtswetenschap, Deventer 1972, p. 160.

12. H.J. Hommes, Sein und Sollen im Erfahrumgsbereich des Rechts, in: ARSP $1970 / 6,8.176$ m 177. 
Zo bezien vervullen de beginselen dezelfde rol als de 'Grundnorm", maar zijn ze niet op louter logische wijze het afleidingsmechanisme, maar inhoudelijk, materieel en dus bovenwillekeurig (want onafhankelijk van de wetgever). Overigens doet de verwijzing naar de altijd (van nature) aanwezige, bovenwillekeurige materiêle rechtsbeginselen als oorsprong en hoogste trap wan rechtsvorming vermoeden dat de transcendentale denkkritiek niet meer is dan een variant op het aloude naturrechtdenken. ${ }^{13}$

\title{
10.2.5 Nieuw onderscheid formele en materiele rechtshracht
}

Het onderscheid in formele en materiele rechtskracht is volgens Van Eikema Hommes terug te voeren op enerzijds vormgeving van rechtsnormen (formele rechtskracht) en anderzijds bovenwillekeurige, materiele rechtsbeginselen of rechtsgronden (materièle rechtskracht). Beide gronden van rechtskrachtkunnen niet worden losgekoppeld, ze veronderstellen elkaar:

\begin{abstract}
'Wanneer de onderscheiding tussen 'formele' en 'materiele' rechtskracht in traditionele zin onbevredigend is, hoe dienen we dan de formele en materiele kant in hei probleem van de rechiskracht te zien?

Oms antwoord dat miet slechts voor concrete rechtsnormen met een hoge graad van juridische onaantasitbaarheid, maar voor alle soorten van rechtsnormen moet opgaam, dient aan de modale card van de rechtsnormen te worden ontleend.

We weten (...) dat elke geldende rechtsnorm berust op juridische vormgewing of positivering door competente rechtsorganen aan bovenwillekewrige, wateriële rechtsbeginselen. De materizle rechtsbeginselen wormen de inhoud van het geldende recht, de jurdische vorngeving door competente rechtsorganen via ordenende jur ischin wilsverklaringen (wetgeving, rechtspraak, verlenen van beschikkingen e.d.) verschaft aan de rechtsnormen hum onontbeerlijke, historisch variabele ontstaans- en bestaansvorm. Beide, de formele en de materisle zijde der rechtsnormen veronderstellen elkaar. Het dynamische proces van de juridische vormgeving is angewezen op materiele rechtsbeginselen, en de laatste kunnen hun juridische zin allen (bedloeld is: alleen, EvdL) openbaren bimen het kader van het cerste."14
\end{abstract}

Vervolgens heet de formele kant der rechtskracht formele rechtskracht terwijl de materiële kant der rechtskracht materiële rechtskracht wordt genoemd. Rechtskracht wordt gezien als het vermogen van rechtsnormen om op effectieve wijze rechtsgevolgen aan rechtsfeiten te verbinden, zodat subjectieve rechtsverhoudingen zi.jn geregeld. Formele rechtskracht wordt daarbij gedefinieerd als:

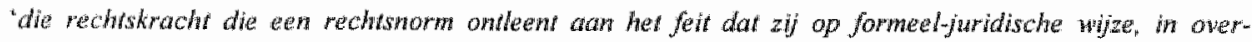
eanstemming met het dacarvoor geldende recht, in de ordemende rechtswil wan een rechusvormer is tot stand gekowen, ondfhonkelijk van de wragg of hatar inhoud just is en beantwoord aan hogere rechtsmormen. 15

13. Zulks valt ook af te leiden uit de dissertatie van H.J. Hommes, Een nieuwe herleving wan het natuurrechl, Zwolle 1961 , i.h.b. p. 204 e.v, wasin owerigens afstand wordt genomen van de traditioneel-metafysische natuurrechtsteer vanwege het dualistisch religieuze grondmotief daarvan. De verwijzing naar beginselen als toetssteen voor het positieve recht staat ook wel bekend als het culturrechtelijk perspectief, dat eveneens een wariant behelst op de natuurrechtsleer; vergelijk: P.B. Cliteur, Conserwatisme en culturrecht, diss., Amsterdam 1989 en ook H. Franken, Inleiden tot de rechtswetenschap Amhem 1995, p. 37-65.

14. H.J. van Eikema Hommes, De elementaire grondbegrippen der rechtswetenschap, Deventer 1972, p. 164.

15. H.J. Van Eikema Hommes, De elementaire grondbegrippen der rechtswetenschap, Deventer 1972, p. 164. 
Formele rechtskracht is in iedere rechtsorde onmisbaar, stelt Van Eikema Hommes, ondat het beginsel der rechtszekerheid eist dat een rechtsnorm die formeel-juist is tot stand gekomen, verbindend is. ${ }^{16}$ Uit deze rechtsgeldigheid vloeit voort een rechtsplicht tot toetsing woor de rechtsorganen die met de toepassing van rechtsnormen zijn belast. $\mathrm{Zij}$ moeten toetsen of de norm inderdaad formeel-juist tot stand is gekomen. ${ }^{17}$

De materiële rechtskracht is op dezelfde wijze afhankelijk van de relatiewe constantie van rechtsbeginselen als de formele rechtskracht afhankelijk is van de relatieve constantie van ontstaanswormen van rechtsnormen.

\begin{abstract}
"Wat de materiële kant van de rechtskracht die we materiele rechtskrachit of maverieel-juridische gelding khnnen noemen betreft, deze vindt zijn grondslag in de bovenwillekeurige, materiele (modale en typische) rechtsbeginselen, die de inhoud van de rechtsnomen bepalen. Deze rechtsbeginselen worden ook wel rechtsgronden genoemd. Daarin komt tot uitdrukking dat ze als juridisch-toereikende gronden wan de materiële rechtsknacht fungeren.

Zaals de formele rechtskracht wan de relatieve constantie en onveranderijkheid der onstanswormen wan rechtsnormen afhankelijk is, zo is de materiele rechiskrach van de relatieve consfantie en onveranderlijkheid der rechtsbeginselen afhamkelijk.

De materiele rechtskracht in de hier bedoelde zin van de gelding, die rechtsnormen aan hun materiele rechisbeginselen ontlenen, komt witerarard in de traditionele rechiskrachtheorietn, die alleen op de formele kant wan lhet rechtskitachtprobleem gericht zijn, niet in het blikweld. ${ }^{18}$
\end{abstract}

\title{
Anders gezegd:
}

'De formele rechiskrach is afhankelijk van de relatieve constantie en dynamiek van de juridische vormgeving. Is een gewone wet op staatsrechtelijk juiste wijze tot stand gekomen en openbaar gematkt, dan ontlenen de daarin gepositiweerde rechtsnomen aan deze ontstansvorm hun formele rechtskracht. Wordt de wet echter na verloop van tijid niet in het dynamisch verticale rechtsvormingsproces opgenomen, dan wordt zij een 'dode letter' en verliest haar rechtskracht. Dit laaiste doet zich altijd voor wanneer de in de wet opgenomen beginselen verouderd of ondeugdelijk zijn. Dan ontvalt aan de rechtsnormen han materiele rechtskracht, die afhankelijk is van de materisle rechtsbeginsellen. Want zoalls de formele teclitskracht in de juridische vormgeving gegrond is, $z O$ is de materiele rechtskracht in de materiele rechtsbeginselen gefundeerd. Maar zoals de materiele rechtskracht onbestaanbaar is zonder de juridische vormgeving door competente rechtsorganen en de daarin gegronde formele rechtskracht, zo kan de formele rechtskrach xich niel handhaven zonder de in de rechtsbeginselen gebaseerde materiele rechtskracht ${ }^{* 19}$

\subsubsection{Betekenis formele en materiële rechiskracht}

Het door Van Eikema Hommes gehanteerde begrip formele rechtskracht betekent dan de eigenschap van normen die ontstaat doordat de norm op correcte wijze door een bevoegd rechtswormer is tot stand gekomen (gelding van de vorm); het is een feitelijk gegeven. Zijn

16. Vgl. HJ. van Eikema Hommes, De elementaire grondbegrippen der rechiswetenschap, Deventer 1972, p. 164.

1.7. Vgl. H.J. van Eikema Hommes, De elementaire grondbegrippen der rechtswetenschap, Deventer 1972, p. 165.

18. HJ. wan Eikema Honnes, De elementaire grondbegrippen der rechtswetenschap, Deventer 1972, p. 165

19. HJ. van Eikema Hommes, Hoofdininen wan de geschiedenis der rechtsfilosofie, Deventer 1972, p. $332-333$. 
begrip materiële rechtskracht betekent dan de eigenschap van normen die ontstaat doordat de norm in overeenstemming is met bovenwillekeurige materiële rechtsbeginselen (gelding van de inhoud). Voor de hypothese van deze studie is wan belang dat de door Van Eikema Hommes gehanteerde definities feit en norm onderscheiden; formele rechtskracht fungeent immers aan de feitelijke zijde van het recht, terwijl materièle rechtskracht aan de normzijde van het recht fungeert.

Toch blijft er onvrede. Het nieuwe begrip materiële rechtskracht is nog steeds vaag; nog steeds is onduidelijk wat de precieze betekenis is van het nieuwe begrip materiêle rechtskracht. Wanneer weten we bijvoorbeeld zeker dat een norm omwille van haar inhoud niet (meer) geldt of nooit heeft gegolden of heeft kunnen gelden (ontbreken materiéle rechtskracht); is deze ontgelding ook van de bovenwillekeurige materiële rechtsbeginselen afhankelijk? Hoe werkt dat dan? De materièle rechtskracht komt niet tot uitdrukking in de traditionele theorieen, maar waar wel? Van Eikema Hommes stelt dat we daarvoor moeten kijken bij 'de materiële geldingstheorieën, die onafhankelijk van de proces- en administratiefrechtelijke rechtskrachttheorieën, ontwikkeld worden. 'Een materiele geldingstheorie zal, wanneer die 'uitgaat wan de wederkerige betrokkenheid van materiële rechtsbeginselen en dynamische juridische vormgeving, een verband tussen haar leer en de formele rechtskracht binnen proces- en administatiefrecht moeten leggen. ${ }^{200} \mathrm{Er}$ is dus werk aan de winkel.

\subsubsection{Verhouding formele en materiele rechtskracht}

De basis van de materiële rechtskracht ligt in de materiële rechtsbeginselen, die fungeren aan de normzijde van het rechtsaspect. Anderzijds is de basis van de formele rechtskracht gelegen in de juridische dynamiek (dynamische rechtsvorming) en constantie (relatieve constantie der juridische ontstaansvormen), die fungeren aan de feitelijke zijde van het rechtsaspect. "Maar zoals normzijde en feitelijke zijde correlaat zijn en wederkerig op elkaar aangewezen, zo zijn materiële rechtsbeginselen en dynamische rechtsvorming wederkerig op elkaar betrokken. En dit brengt mee dat ook formele en materiële rechtskracht op elkaar aangewezen zijn en elkaar veronderstellen." De verhouding tussen formele en materiële rechtskracht is aldus een dynamische verhouding.

Aldus leidt Van Eikema Hommes uit het bestaan van de normzijde en feitelijke zijde van het rechtsaspect het onderscheid tussen formele en materiele rechtskracht af; een onderscheid tussen twee aspecten van rechtskracht die weliswaar een verschillende oorsprong vindem, maar naast elkaar bestaan en naast elkaar moeten worden beschouwd. Ook Steenbeek kwam tot die conclusie. Hij concludeerde dat elke materiële rechtskracht (van de rechtsgevolgen) afhankelijk is wan de formele rechtskracht (van de rechtshandeling). Het omgekeerde is in zijn analyse echter niet het geval, ${ }^{22}$ maar later stelt hij toch dat formele en materiele

20. H. Wan Eikema Hommes, De elementaire grondbegrippen der rechiswetenschap, Deventer 1972, p. 165 166.

21. H. wan Eikema Honmes, De elementaire grondbegrippen der rechtswetenschap, Deventer 1972, p. 167

22. Vgl.J.G. Steenbeck, Rechtshandeling en rechtsgevolg in het administratief recht, diss., Assen 1958, p. 71 
rechtskracht als twee aspecten van rechtskracht plegen te worden onderscheiden. Dat is reden voor de stelling: "Een beschouwing over formele rechtskracht dient reeds om die reden vergezeld te gaan van een beschouwing over materiele rechtskracht." ${ }^{23}$

De onderlinge verhouding van formele en materiele rechtskracht beschouwt Van Eikena Mommes als een dynamische verhouding.

\begin{abstract}
'De materiele rechtskracht veronderstell de formele rechtskrach. Eersi wanneer blijkt dat een rechtsnorm op formeel-juiste wijze (rechtsgeldig) is tot stend gekomen en dus formele rechtskracht bezit, kont de materide rechtskracht aan de onde. In het belang van de rechtszekerheid beginnen we met an te nemen dat een rechtsgeldig tot stand gekomen rechtsnorm verbindend is, nog afgezien van haar inhoud. De vraag naar de rechtsgeldigheid der inhoud en dus natr de materitle rechtskracht komt daama aan bod. Ongekeerd is de formele rechishracht niets zonder de materièle rechtshracht, althans bij rechtsnomen, die nog niet op de laagste trap van rechtswerwerkelijking staan, waarop geen gewone rechismiddelen meer kunnen worden aangewend. Ontbreekt de materiele rechtskracht bij rechtsnomen, omdat de beginselen waarop zij ruster in strijd zijn met die van hogere rechtsnormen binnen dezelfide materiele rechiskring, of valt zij weg omdat de beginselen verouderd zijn of omdat er sprake is van overschijding door de rechtsvormer van materiele competentiegrenzen, dan valt ook de formele rechtskracht weg, hetzij ondat de rechtsnorm nievig wordt verklaard door een daartoe bevoegd orgatan, hetzij omdat zich een contraire indirecte rechtsvorming ontwikkelt, die de formeel gehandhatide rechtsnom tot een "dode letter' maakt. ${ }^{24}$
\end{abstract}

Zodoende kan de verhouding tussen materiële en formele rechtskracht alleen als een dynamische worden opgevat; de transcendentale methode verabsoluteert geen enkel moment op deze dynamische lijn, zoals positivisme en natuurrechtsleer wel doen, aldus Van Eikema Hommes:

\footnotetext{
"Hieruit wolgt dat de verhouding van formele en materiale rechtskracht niet star en eśnwomig mag worden opgevat. Een statische rechtskrachtleer vinden we zowel bij het juridisch positivisme, dat de formele rechtskracht verabsoluteert, als bij de traditionele natuurrechtsleer, die de materiele rechtskracht tot een metafysische gelding per se, onafhankelijk van het dynanisch rechtsvormingsproces verheft.

De verhouding van formele en materiele rechtskracht is een dynamische in hun wederkerige betrokkenheid. Er is bij de uiteinden van de verticale rechtsvormingslad ter, $t$, bij de haogste trap van algemene rechtsworming è bij de laggste trap van concrete rechtsvorming binnen een materieel rechtsgebied een verhouding

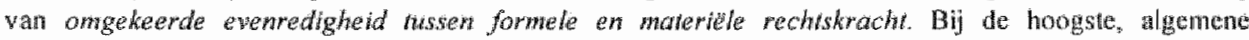
rechtsworming is sprake van een hoge graad wan materiwe rechskracht, terwijl de formele rechtskracht hier cen bijzonder lage graad bezil of zelfs geheel wegvalt bij de largste trap van rechtsvorming is er sprake wan een hoge grad van formele rechtskracht, watartegenower de materielte rechtskracht een bijzonder lage gracad vertoont of zelfs wegvalt

Tussen deze beide uiteinden is er sprake van een spanningswolle verhouding, wambij nu eens de materiete, dan weer de formele rechtskracht het overwicht heeft.

Hivervan latat zich in abstracto weinig zeggen. ${ }^{25}$
}

En met deze laatste constatering, naar mijn mening een volstrekte dooddoener, maakt Van Eikema Hommes zichzelf ongeloofwaardig. Als immers in abstracto weinig te zeggen valt

23. J G. Steenbeek, Rechtskracht, in: NTB 1989/8, p. 265.

24. H.J. van Eikema Hommes, De elementaire grondbegrippen der rechiswetenschap, Deventer 1972, p, 167.

25. H.J. van Eikema Hommes, De elementate grondbegrippen der rechts wetensehap, Deventer 1972, p. 169. 
(hoe zit dat dan in concreto?) van de verhouding van formele en materiele rechtskracht, wordt onduidelijk wat de toevoegende waarde is van het nieuwe begrip materielle rechiskracht en laadt Van Eikema Hommes de verdenking op zich een lege huls te hebben gepresenteerd. In abstracto lijkt immers de nieuwe definitie van materiële rechtskracht ruimte te bieden voor een nieuwe betekenis wan het begrip, maar als daar uiteindelijk toch niets van te zeggen valt, is de nieuwe betekenis niet alleen vaag, maar ook schimmig geworden. Daaraan doet de door Van Eikema Hommes ingebouwde rem niet af: 'Bepalend voor deze dynamische verhouding zal zijn de typische aard der rechtsgebieden, waarin de rechtsnormen gepositiveerd worden, het gewicht van de rechtsbelangen, die daaraan geharmoniseerd worden, maar vooral de trap, waarop de rechtsnormen in de hiërarchische orde der rechtswormingsfasen staan. ${ }^{2 k}$

\subsection{Rechtskracht aan de normzijde en aan de feitelijke zijde van het rechtsaspect: ontrafeling feit en norm}

Van Eikema Hommes verwerpt de tweedeling 'Sollen' en 'Sein', de tweedeling in normen (als waarden) en feiten (als sociale werkelijkheid); de dialectische tweedeling bestaat niet en in plaats daarvan is het beter uit te gaan van de correlatie normzijde en feitelijke zijde van het recht. Van Eikema Hommes omzeilt de stelling dat de tweedeling normzijde en feitelijke zijde van het recht eveneens dialectisch is door in 'zijn' theorie zowel formele als materiële rechtskracht te analyseren vanuit het rechtsaspect. Dat rechtsaspect maakt dat er geen dialectische tweedeling is, maar creëert de correlatie, de wederkerige kruisbestuiving; dan zijn er geen antipolen meer. Het rechtsaspect beschouwt hij als een normatief en objectief eigen-aard-ig aspect van de werkelijkheid. Daarbinnen plaatst hij een normzijde tegenover een feitelijke zijde. Materiële rechtskracht fungeert voornamelijk aan de normzijde van het rechtsaspect. Formele rechtskracht behoort tot de feitelijke zijde van het rechtsaspect.

"Deze dilalectische opvattingen inzake rechtskracht (...) zijn voor ons onaanvaardbaar. In plaats van de dialectische verbinding wan 'Sollen" (normen, waarden) en "Sein' (feiten, sociale werkelijkheid) dienen we uit te gann van de correlatie wan norm en feitelijke zifde in het rechtsaspect. Het rechtsaspect zelf is ook geen dialectische werbinding lussen het 'zedelijke' en het 'sociale', maar bezit in onze tijdelijke ervaringswereld cen onherleidbare eigenaard, met een hamomische, niet in dialectische spanningen uiteenvallende, structurele opbouw. Ongetwiffeld fungeren de materiele rechisbeginselen, die de basis zijn voor de materiele rechtskracht, aan de noryzifde wan het rechtsaspect, terwijl de dynamische rechtsworming met de relatieve constuntie der juridische ontstanswormen, and de fetelijke zijde fungeren, ofschoon zij, als ontstaansvormen van rechusnomen ook en functie aan de normzijde hebben. Maar zoals normzijde en feitelijke zijde correl aat zijn en wederkerig op elkar aangewezen, zo zijn materiele rechtsbeginselen en dynamische rechtsworming wederkerig op elkaar betrokken. En dit brengt mee dat ook formele en materiële rechtskracht op elkaar aangewezen zin en elkar weronderstellen. 27

26. H.J. van Eikema Hommes, De elementaire grondbegrippen der rechtswetenschap, Deventer 1972, p. 169.

27. H.J. wan Eikema Hommes, De elementaire grondbegrippen der rechtswetenschap, Deventer 1972, p. $166-167$. 


\subsection{Tenslotte}

De transcendentale methode imponeert. Dat komt voomamelijk doot de integrale en omvangrijke aanpak. Juist daardoor is de methode ook moeilijk te falsificeren. Toch blijven ook twijfels bestaan. Niet alleen is het goddelijk ijkpunt, als ik zo beknopt mag zijn, niet (meer) van deze tijd, daarnaast - en vooral - is de vanuit logisch standpunt niet houdbare grondslag en eveneens het uitblijven van het duiden van het onherleidbare eigen-aard-ige kernpunt van het rechtsaspect, moeilijk wanneer daarop vervolgens een hele methode, een wijze van analyseren wordt geênt. Overigens ben ik met Langemeijer eens dat het zoeken naar een definitie van recht een nogal ijdele aangelegenheid schijnt, wat ons overigens niet vrijpleit om er maar niet meer naar te zoeken. ${ }^{28}$

Boeiende invalshoeken vanuit de transcendentale methode blijven uiteraard het inzicht van de materiële grondslag van rechtskracht in de rechtsbeginselen en (daarmee samenhangend) de - weliswaar vage maar toch nieuwe -.- definiëring van materiele rechtskracht, al dient daarnaar inderdaad verder onderzoek te worden gedaan. Ook de betrokkenheid van formele en materiële rechtskracht op elkaar, al eerder door Steenbeek benadrukt, wordt uitvoerig onderbouwd. Aldus biedt de transcendentale methode zicht op een verbreding van de analyse van het rechtskrachtbegrip.

28. Vgl. G.E Langemeijer, Inleiding tot de studie van de wijsbegeerte des rechts, Zwwolle 1973, p. 326, die 20 lf als kern van normen ziet de zogenaamde "gulden regel": "dat men eigen en andermans belangen met gelijk gewicht meet." (p. 213) 


\section{Toetsing en de formele en de materiële rechtskracht van besluiten; een analyse vanuit het spectrale perspectief}

\subsection{Inleiding}

Onder de titel 'spectraal recht' gaat een aan de Maastrichtse faculteit ontwikkelde benadering van het recht schuil. Met name Tak en Teunissen zijn er de grondleggers ${ }^{2}$ van en ook Schlössels ${ }^{3}$ valt als daaraan verbonden te kenschetsen. Met de gelijknamige bundel $\mathrm{l}^{4}$ is het culminatiepunt van denken en discussièren bereikt. Aldus kreeg de benadering ook haar benaming.

De spectrale benadering van het recht wordt gekenmerkt door het analyseren van de bevoegdheidsuitoefening als rechtsfeit, dat al naar gelang het rechtsgebied andere (dat wil zeggen anders gekwalificeerde)rechtsgevolgen kan hebben. Aldus waaieren de gevolgen als een spectrum over het hele recht en blijft het feit (met name de bevoegdheidsuitoefening) het beginpunt van de analyse. De spectrale benadering heeft affiniteit met de transcendentale theorie; met name de daar prominente verbandenleer, die ook wel rechtskringenleer wordt genoemd, fungeert als inspiratiebron.

Zoals we hierna nog zullen zien komen in het procedurele de uitgangspunten van de spectrale benadering samen. Het is daarom dat daar de sleutel moet liggen voor het zoeken naar nieuwe inzichten met betrekking tot de betekenis van (formele en materiele) rechtskracht van bestuursbesluiten. Bij de toetsing van bestuursbesluiten door bestuursorganen, bestuursrechter en burgerlijke rechter zal daarom het onderscheid tussen formele en materiële rechtskracht scherp moeten worden.

Volgens de spectrale visie heef de bestuursrechter zowel handhaving van het objectieve recht tot doel als ook het doel dat hij individuele rechtsbescherming wil verlenen. Deze beide doelstellingen geven richting aan zijn toetsing. Bekend is dat de rechter-juist ondat

1. Dit hoofdstuk is een bewerking van mijn geliknamige bijdrage anen de bundel spectral rech? De bevoegdheidsuitoefening door de overheid als rechtsfeit, E. C.H. van der Linden, R. N. Schlossels. R.J.G.H. Seerden (red.), Den Halag 1998, p. 131-163.

2. Vgl. A.Q.C. Tak, Besluten van algemene strekking, in: RM Themis 1980, p. 132-162, Onwetnatig bestum

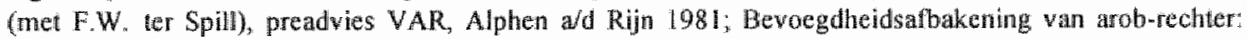
kunsing of gekunsteld?, oratie Mastricht, Deventer 1984; Het Moment X, in: TvO 1990, p, 134-138; De ongewerste discussie, in: Nieuw bestuursprocesrecht, J.J.M. ten Berge a a. (ned.), Deventer 1992, p.67-85 en Naar een invullende rechtsleer, in: Recht en Kritiek 1993, p. 174 191, De overheid in het burgerijik recht, "s-Craventhage 1997; J.M.H.F. Teunissen, Het burgerlijk kleed van de stat, diss, Zwolle 1996.

3. Vgl. RJ.N. Schlossels, Het specialiteitsbeginusel, diss, Den Haag 1998.

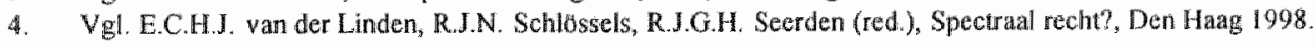


hij deze beide doelstellingen nastreeft - in een dubbele positie verkeert. Wanneet ik vanuit. de spectrale benadering formele en materiële rechtskracht analyseer, doe ik dat vanuit de veronderstelling dat het dubbele in de positie van de toetsende rechter verklaard kan worden. Het resultaat van die analyse zal echter zijn dat toetsing door de rechter van enerzijds de formele rechtskracht en anderzijds de materiele rechtskracht verschillende dicta dient op te leveren.

\subsection{Basisnoties van de spectrale kijk op het recht}

\subsubsection{Loskoppeling feit en gevolg}

Het spectrale perspectief start vanuit de loskoppeling van rechtsfeiten en rechtsgevolgen als gesloten bi-polair systeem. Oorzaken kunnen meerdere en uiteenlopende gevolgen hebben, stelt Tak zodoende. Het door slechts éen feit geactiveerde recht vertoont "als een regenboog een grote mate van verscheidenheid, van nuanceringen, van variaties. Zo bezien kan terecht worden gesproken van spectraal recht'."

Loskoppeling van feiten en gevolgen leidt miet direct tot spectraal recht. Ook in het spectrale perspectief wordt dit erkend. 'Toch is deze typering eigenlijk niet helemaal zuiver; niet het recht is spectraal, maar de door het recht aan het feit verbonden rechtsgevolgen. Het recht is altijd eenduidig; er bestaat maar één recht. Zulks geldt $(\ldots)$ ook voor feiten; $(.$.$) als$ rechtsfeiten evenwel (...) kan één en hetzelfde 'natuurfeit' naar de verschillende gevolgen ervan (...) worden onderscheiden". "Aldus kan eén en hetzelfde feit(encomplex) gelijktijdig in verschillende rechtsgebieden werken. Deze verschillende rechtsgebieden worden doorgaans beheerst door rechtsnormen van geheel eigen aard; de rechtsnormen uit de zgn. rechtsverbanden. Daar kom ik later op terug.

\subsubsection{Toepassing op formele rechtskracht}

Dat rechtsfeiten en rechtsgevolgen losgekoppeld moeten worden, was al herhaaldelijk bepleit door Steenbeek. Hij analyseerde rechtskracht vanuit die stellingname. Formele rechtskracht werd gekoppeld aan de rechtshandeling (als bijzonder rechtsfeit) en materiële rechtskracht werd met de rechtsgevolgen verbonden. Steenbeek verbond deze indeling steeds aan (rechterlijke) toetsing van een rechtshandeling op een tunc-moment (toetsing van de formele rechtskracht) of een nunc-moment (toetsing van de materiële rechtskracht)?

5. A.Q.C. Tak, Dimensies van overheidshandelen in het bijzonder betrokken op de rechtsbescherming, im: Spectraal recht?, Den Haag 1998, p. 3.

6. A.Q.C. Tak. Dimensies van overheidshandelen in het bijzonder betrokken op de techtsbescherming. in: Spectral recht?, Den Hatg 1998, p. 3.

7. Vgl J.G. Steenbeek, Rechtshandeling en rechtsgevolg in het Staats- en administratief reclat, diss., Assen 1958; Rechtskracht, in: NTB 1989/8, p. 265-268; Ex tunc of ex nunc?, in: TvO 1990/8, p. 181-183. 
Laten we het loskoppelen wan feit en gevolg concreet bezien aan de hand van de formele rechtskracht van beschikkingen en de leer die de Hoge Raad in deze heeft ontwikkeld. Aldus analyseren we de formele rechtskracht van beschikkingen vanuit het spectrale perspectief.

In het geschil tussen de gemeente Heesch en M.J. van de Akker was de rechtsvraag waarmee de rechter nu eigenlijk van doen had; was er in casu sprake van een beschikking of van een rechtshandeling naar burgerlijk recht? Om deze vraag te kunnen beantwoorden, dienden feiten gekwalificeerd te worden.

Het geschil spitste zich toe op de vraag of de brief (waarin de akte) een beschikking of een rechtshandeling naar burgerlijk recht was. Was de brief immers op te vatten als beschikking, dan had deze formele rechtskracht gekregen omdat Van de Akker geen administratieve rechtsgang (Arob) had gebruikt. De burgerlijke rechter zou dan van de rechtsgeldigheid van die beschikking zijn uitgegaan. Concreet: Van de Akker kreeg dan niks terug. Was de brief daarentegen op te vatten als rechtshandeling naar burgerlijk recht, dan zou de zaak anders liggen. Wanneer namelijk de onverschuldigdheid van de betaling niet in geschil is (en dat zou het geval zijn in de redenering dat de overeenkomst wegens strijd met artikel 14 Wegenwet nietig zou zijn), gaat de burgerlijke rechter van die onverschuldigdheid als waststaand feit uit. Dan zou er voor Van de Akker nog wel een mogelijkheid tot restitutie in zitten.

Ten aanzien van de vraag of dit feit(encomplex) tegelijkertijd verschillende rechtsgevolgen (in verschillende rechtsgebieden) kan bewerkstelligen, is de kwalificatie beschikking/rechtshandeling naar burgerlijk recht indicatief. Kan derhalve dit feit(encomplex) zowel als beschikking gekwalificeerd worden en tegelijkertijd als rechtshandeling naar burgerlijk recht? Met betrekking tot deze vraag stelde $\mathrm{A}-\mathrm{G}$ Franx het volgende:

\footnotetext{
'Onderdeel 2 van middel II stelt de vraag aan de orde wellk rechtskarakter toekont aan de brief van B en W van 13 juni 1977 met bijlage (...). In dit verband zij opgemerkt, dat een besluit een meervoudig karakter kan hebben: het kan zowel een 'beschikking' zijn als een 'rechtshandeling naar burgerlijk recht', een en ander in de zin van art. 2 Wet Arob. (...) Het toesturen van de brief met bijlage aan Van de Akker laat zich beschouwen als (...) cen samenval van rechtsmonenter:

a. Een aanbod tot het sluten wan een overeenkomst mel een bepalde inhoud (..)

b. Het ter kernis van Van de Akker brengen van een beshit tot:

$1^{\circ}$ het shiten wan bedoelde owereenkomst met hem, en tot

$2^{\circ}$ wergerimg van de gevragde werguning onder een voorwaarde, te wetem dat Van de Akker hiot zou instemmen met het sluiten van die overeenkomst. (...)

Naar mijn mening blijkt van al deze elementen wit het arrest van het hof. Het anbodkarakter (a) komt tot uiing (...) en het tweeledige besluitkarakter (b) komt nar woren (...).

Zou men slechts letten op het onder $a$ bedoelde aanbod, dan zou daarin exa rechishandeling naar burgerlijk recht bul geen 'arobabele' beschikking gezien mogen worden. (...)
}

8. Ik ga hier uit van de casus en rechterlike reactie in het geschil dat bekend statit als Heesth-Van de Akker en warain de Hoge Raad arrest wees op 16 mei 1986, AB 1.986,573 m.nt. FHvdB. Voor een beschrijying hiervan werwijs ik naar hoofdstuk 3 . 
Betrekt men hierbij element b-1", het beslinit yan de gemeente tot het aangaan van een overeenkomst met Van de Akker, dan is het antwoord op de vraag. arobabele beschikking? minder eenwoudig

Aldus gaf de $A-G$ blijk van een spectralle zienswijze ten aanzien van de brief die Van de Akker had ontwangen. De 'samenval van rechtsmomenten' zouden wij immers - in spectrale traditie - kumnen kwalificeren als het samenvallen van verschillende rechtsgewolgen (namelijk rechtsgevolgen uit verschillende rechtsverbanden) na én en hetzelfde feit(encomplex). ${ }^{10}$

(Overigens bood de formulering in artikel 2 Arob van een beschikking nu juist niet de mogelijkheid tot het aannemen van een samenval wan verschillende rechtsgevolgen naar aanleiding van hetzelfde feit(encomplex); daar kon een beschikking juist niet gelijktijdig ook een rechtshandeling naar burgerlijk recht zijn. $)^{n}$

De Hoge Raad komt niet tot het expliciet benoemen en/of overnemen van de door de A-G gekenschetste samenval van rechtsmomenten. Steeds volgt hij de redenering(en) uit de cassatiemiddelen. Wanneer daar gesproken wordt van de beschikking (die formele rechtskracht heeft gekregen) of van de onverschuldigdheid van de betaling, dan beoordeelt hij dat - terecht - en hanteert eveneens die terminologie; nimmer rept hij bv. van 'de beschikking, die ook als overeenkomst kan worden gezien'. De Hoge Raad stelt niet expliciet, dat het in deze casus onmogelijk was om de brief aan te merken als een overeenkomst, maar volgt de A-G, voorzover deze concludeert dat de Hoge Raad de Arob-jurisprudentie moet volgen. De A-G adviseert aldus:

\begin{abstract}
'Aan 'etikettering' als 'beschikking' dan wel als 'rechtshandeling naar burgerlijk recht", in verband met de rechtsmacht van de rechter, valt niet te ontkomen (..). Zulke conflicten ( $=$ jurisdictieconflicten, EvdL) zijn onaangenaam, maar blijkbaar niet altijd te vermijden, met name niet zolang de maatstaven die de burgerlijke en de adminisuratieve rechter aanleggen, niet volledig identiek zijn. Naar die identiteit. dient te worden gestreefd. Dat brengt mee dat de Arob-jurisprudentie door Uw Raad mede in aanmerking genomen en zoveel mogelijk gevolgd noet worden."
\end{abstract}

Dat volgen van de administratieve rechtspraak wordt naar aanleiding van het eerste midde] het meest expliciet door de Hoge Raad verwoord, maar komt eveneens tot uitdrukking in de

9. A-G Franx bij HR 16 mei 1986, AB 1986,573 m.nt FHvdB (Heesch-Van de Akker), p. 1672 .

10. De benadering van de A-G kan worden gekenschetst als een moo voorbeeld van de en-on-benadering, zoals deze tot uitdrukking komt in de bijdrage van $\mathrm{H}$. Nihholt. Het schijngevecht over het rechtskarakger van de exploitatiewerordening, in: Spectraal recht?, Den Hang 1998, p. 189 nt. 87.

11. Dat werd eerder al als een geforceerde voorstelling van zaken gekenschetst. Vgl. A.Q.C. Tak, Bewoegdheidsafbakening wan de Arob-rechter, kunstig of gekunsteld?, oratie Massiricht, Deventer 1984. De benadering van de wetgever zok eveneens kunnen worden gekenschetst als een mooi voorbeeld van de of of-benadering, zoals $\mathrm{H}$. Nijholt die onderscheidt in Het schijngevecht over het rechtskarakter van de exploitatieverordening, in: Spectraal rech?; Den Haag 1998, p. 188 .

12. A.G Franx bij HR 16 mei 1986, AB 1986,573 (Heesch-Van de Akker), m.nt. FHwdB, p. 1671, r.k. Om

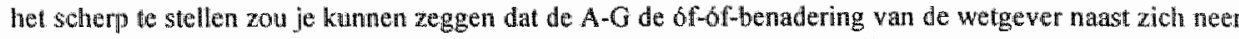
wenst te leggen, maar niet explictet - en in oppositie met de wetgever - wil overgaan tot toepassing van de en-hn-benadering. De Hoge Raad gata in die voorzichtiger benadering mee. 
formulering van de regel van formele rechtskracht naar aanleiding van de middelen II en III, die de A-G kenschetst als motiveringsklachten, die gegrond zijn.

Door aan te nemen dat én feit(encomplex) verschillende rechtsgevolgen in verschillende rechtsgebieden teweeg kan brengen, wordt erkend dat op één feit(encomplex) rechtsnomen uit verschillende rechtsverbanden van toepassing kunnen zijn. Daarmee zijn we beland bij een volgende paragraaf.

\subsection{De verbandenleer}

Voor de verbandenleer is de mens de maat van alle onderscheid. Omdat de mens leeft in relatie tot anderen, verkeert hij in de verschillende samenlevingsverbanden. Deze verbanden kennen elk hun recht van eigen aard. Zo wordt verklaard dat de verschillen in rechtsgebieden zijn ontstaan. In zijn uiteenzetting van de verbandenleer erkent ook Teunissen dit aan de mens toekomende Archimedisch punt. 'De mens fungeert in allerlei sociale betrekkingen van zowel maatschaps- als gemeenschapsaard. Bezien naar het rechtsaspect van deze betrekkingen betekent dit dat hij als rechtssubject fungeert in evenzovele materięle rechtskringen als er maatschaps- of gemeenschapsbetrekkingen zijn waarbinnen hij optreedt. "is

Deze rechtskringen of verbanden staan niet op zichzelf. De mens is tegelijkertijd lid van verschillende verbanden. Dat betekent dat de mens ook steeds en tegelijkertijd te maken heeft met het recht van de verschillende rechtskringen waarvan hij deel uit maakt. In het spectrale perspectief wordt daarom gesteld dat de rechtskringen met elkaar zijn vervlochten. 'Juist omdat de ontstaans(- en bestaans)vormen van positief" recht op zichzelf nog niets prejudiciëren omtrent het materiële ("typische") karakter van het gepositiveerde recht, kunnen in die rechtsvormen verschillende materiële rechtskringen met elkaar vervlochten zijn, steeds met respectering van de eigen rechtssfeer van de onderscheiden rechtskringen. Die rechtsvormen zijn a.h.w. de knooppunten van de vervlechtingen van onderling onherleidbare, materiële rechtskringen." ${ }^{14}$

De basis van de verbandenleer is kortom als volgt. Mensen leven in verbanden. Die verbanden hebben ieder een eigen aard (gezinsverband, verenigingsverband, staatsverband). Die eigen aard ontlenen de verbanden aan het feit dat de individuen die er lid van zijn er een (vanuit de verbandsdoelstellingen bepaald) doelmatig karakter aan hebben gegeven. Individuen zijn steeds van meerdere verbanden lid. Elk verband heeft zijn eigen rechtsstelsel. Elk individu verkeert, naar de verbanden waar hij in verkeert, in verschillende rechtsstelsels.

Wanneer het recht aldus wordt bezien als pluriform, dan staat in het spectrale perspectief de vervlechting voorop van rechtsnormen ten aanzien van eén feit door de verschillende rechtsverbanden heen. "Het ware rechtspluralisme erkent dat de samenleving niet een totaalstructuur is, maar bestaat uit allerlei eigen-geaarde maatschaps-en gemeenschapsverhoudin-

13. J.M.H.F. Teunissen, Het burgerlikk kfeed wan de staat, diss., Zwolle 1996, p. 218 .

14. J.M.F.F. Teunissen, Het burgerlijk kleed van de staat, diss., Zwolle 1996, p. 212. 
gen met eigen interne rechtssferen, hoezeer deze rechtssferen ook extern vervlochten zijn in de integrerende rechtsorde van het burgerlijk recht. En de menselijke rechtssubjectiviteit kan in geen enkele van die rechtskringen geheel opgaan, ótk niet in die van het publiekrecht of het burgerlijk recht. De mens heeft allerlei specifieke juridische functies, al naar gelang de materiêle rechtskring waarin hij fungeert." ${ }^{15}$ Aldus voert de verbandenleer het spectrale perspectief naar een pleidooi woor pluriformiteit in de zin van differentiatie tussen en respect voor de verschillende rechtskringen. Dit pleidooi voor pluriformiteit van het recht en respect voor de rechtskringen vloeit voort uit respect voor de pluriformiteit van de mens (en de aanname van de principiële gelijkwaardigheid van de verschillende mensen).

\subsection{Staatsverband als rechtskring}

Een van de rechtskringen is het staatsverband. De staat is op te vatten als een institutie, een institutaire gemeenschap. De staat is gefundeerd in haar historie, waarvoor als typisch geldt dat de overheid (als gezagsorganisatie) zwaardmacht heeft. Pas wanneer binnen de staat de overheid het heeft gebracht tot een centrale gezagsorganisatie, ontstaat als tegenwicht tevens de erkenning van de individuele vrijheid. Gevolg daarvan is dat de Staat als taak krijgt de toepassing van het beginsel van de verdelende rechtvaardigheid. Het individu heeft daarin politieke rechtssubjectiviteit (opkomst grondrechten, toekenning kiesrecht). Zo ontstaat de publieke rechtsorde. Daarnaast leidt individuele vrijheid tot erkenning van de burgerrechtelijke rechtssubjectiviteit en een private rechtsorde. ${ }^{16}$

Overugens kan hiervoor in de plaats ook gezien worden de realisatie van de materiële gelijkheid, zoals door Simon wordt voorgestaan. ${ }^{17}$ Ook dan staat respect voor de mens en principięle gelijkwaardigheid voor de verschillende mensen voorop, maar wordt eveneens uitdrukking gegeven aan een meer dynamischer, emancipatoir perspectief op het recht. Wellicht is het onderscheid vooral een kwestie wan accentverschil; de opvatting inzake verdelende rechtvaardigheid wloeit als theoretisch uitgangspunt voort uit een analyse van de staat in zijn historisch gegroeide vormen en het uitgangspunt van de materiêle gelijkheid als grondslag van de staat is meer een resultaat van een op de toekomst gerichte visie.

\subsection{Spectratal recht als uitd rukking van de invullende rechtsleer}

De spectrale benadering gaat ervan uit dat de overheid altijd als overheid, en dus publiekrechtelijk handelt. Omdat het (geschreven) publiekrecht in de spectrale benadering als eigenaard-ig instituut wordt geanalyseerd (en daar hiaten kunnen liggen), valt er immers vanuit het burgerlijk recht iets in te vullen in het publiekrecht (zolang men hier tenminste geen rol aanneemt voor het ongeschreven publiekrecht). Het publiekrecht en het privaatrecht zijn verschillend van karakter. De overheid is verplicht tot de behartiging van het algemeen

15. J.M.H.F. Teunissen, Het burgerlijk kleed van de stat, diss., Zwolle 1996, p. 221-222.

16. Vgl. JM.H.F. Teunissen, Het burgerlijk kleed van de staat, diss, Zwolle 1996 ,

17. Vgl. HJ. Simon, Publiekrecht of privaatrecht?, diss., Zwolle 1993 ; een visie waarbij ik mijzelf zeer thuisvoel. 
belang. Daarmee heeft zij definitief een andere taak dan willekeurig welke particulier (die zich overigens algemene belangen best kan aantrekken). De overheid kan optreden met gebruikmaking van burgerlijkrechtelijke instrumenten wanneer zij via de - normale publiekrechtelijke kanalen thet algemeen belang niet kan behartigen. Aldus zal zij - invullend - het burgerlijk recht kunnen hanteren.

\subsection{De overheid in het publiekrecht}

Object van alle recht is voor Tak de mens met zijn particuliere autonomie, want 'zonder de mens en zijn natuurlijke autonomie kennen wij geen recht.' De overheid bezit niet zulk een autonomie; zij is geen mens met menselijke waardigheid en pre-constitutionele bevoegdheden. ' $\mathrm{Zij}$ is juist creatie van de constitutie, een constitutionele creatie en fictie, ten behoeve van de gemeenschap als geheel.' En 'zij ontleent haar bestaan louter aan die gemeenschap'. Daaruit vloeit de overheidstaak ook voort: 'Iedere publiekrechtelijke regeling dient te zijn gekwalificeerd door het leidende - en de overheidstak begrenzende - beginsel van het algemeen belang.' Behartiging van dat algemeen belang is de vervulling van de bestaansreden van de overheid: 'Misschien mag een particulier dat algemeen belang ook niet veronachtzamen, maar alleen de overheid is verplicht om het na te streven, te behartigen: dat is nu eenmaal het kenmerkende van de overheid, en daaraan kan men de overheid herkennen" ${ }^{18}$

\subsubsection{De overheid-invullend - in het burgerlijk recht}

Als de (immer publiekrechtelijk gebonden) overheid in maatschappelijk rechtsverkeer wil treden met andere personen of groepen, ontstal er een probleem. In feite ontstat dit probleem altijd bij maatschappelijk rechtswerkeer van personen of groepen. Daarom is voor dit verkeer een bijzonder systeem vereist. Er moet zodoende een flexibele manier zijn om het onderscheid tussen publiekrecht en burgerlijk recht door de overheid duidelijk te maken. 'Het moet een soepel systeem zijn, (..) als het ware het gemeenschappelijke buizenstelsel, waarin de uitoefening van individuele en groepsbevoegdheden in het externe verkeer plaatsheeft. De diverse bevoegdheden worden er als het ware 'ingevuld'. Om die reden gaven wij aan deze benadering de typering 'invullende rechtsleer' mee. (...) Het zal duidelijk zijn, dat in ons rechtssysteem het Burgerlijk Wetboek deze functie van 'gemeen" schappelijk buizenstelsel' vervult."

\subsubsection{Staatsverband in het burgerlijk recht}

De invullende rechtsleer ziet op het systeem dat het onderlinge verkeer tussen de verbanden beheerst. Het Burgerlijk Wetboek heeft in deze visie twee functies. De eerste, externe, functie is het bieden van (al)gemeen 'burgerlijk' recht (maatschappelijk verkeersrecht voor alle personen en groepen) en de tweede het regelen van bekwaamheid en bevoegdheid van

18. A.Q.C. Tak, De overheid in het burgerlijk recht, "s-Gravenhage 1997, p. 2 I -26.

19. A.Q.C. Tak, De overheid in het burgerlijk recht, "s-Gravenhage 1997 , p. 106. 
particuliere personen, natururlijke zowel als rechtspersonen, het privaatrecht (intem recht; bekwaamheid en bevoegdheid).

"Het Burgerlijk Wetboek is de (al)gemente regeling woor het externe onderlinge maatschappelijke verkeer tussem werbanden, maar tevens woor het interne verkeer binnen de private werbanden. Dat de regeling in het wetboek in het latste geval als "priwaatrecht" wordt aangeduid, valt te begrijpen. Voor het exteme maatselhappelijke verkeer tussen private individuen en werbanden onderling is die typering evenwel minder juist: 20

Het Burgerlijk Wetboek is echter steeds een 'loze huls"; wanneer het staatswerband gebruik makt van het 'gemeenschappelijk buizenstelsel' is dat immers nog steeds te typeren als publiekrechtelijk optreden. Van de 'loze huls'-functie moeten we ons steeds bewust zijn:

${ }^{7}$ Indien al invulling wordt gegeven aan overheidsbevoegdheden met gebruikmaking van de vormen van het Burgerlijk Wetboek, mag zulks nimmer afdoen aian: a. de absolute voorrang van het bijzondere publickrechtelijk mididel als het door de volkswertegenwoordiging eerst aangewezene; $b$. de volledige onderwerping van de BW-vorm aan de publiekrechtelijke desiderata (...) Betekent dit alles, dat de overheid het recht zou moeten worden ontzegd om over goederen te beschilkken, om afspraken te maken met andere overheidslichamen of met particulieren, en om actic te ondememen tegen hen die het algemeen belang bedreigen? Uiteraard niet. Waar het om gaat, is om de duidelijkheid dat als die owerheid gebruikmakt van goederen, afspraken maakt of actie onderneemt tegen onrecht dat het algemeen belang bedreigt, dat zij dan zulks niet doet en niet kam doen als een particulier, doch steeds als owerheid. En dat zij dus geen gebruik maakt of kan maken van privaatrecht, doch steeds wan publiekrecht. ${ }^{21}$

\subsubsection{Verbandenleer en rechterlijke bevoegdheid}

Binnen de verschillende rechtskringen opereren eigen-aardige rechters. Ieder in hun eigen rechtskring oordelen zij naar de maatstawen wan de eigen rechtskring. $\mathrm{Zij}$ hanteren dus een eigenaard-ige toetsing. Het object van toetsing verschilt. De strafrechter toetst de strafwaardigheid van door het OM strafwaardig geacht handelen, de burgerlijke rechter beoordeelt geschillen met betrekking tot eigendom en burgerlijke rechten en plichten en de bestuursrechter toetst of een besluit rechtens correct is tot stand gekomen en op grond daarvan al dan niet voor vernietiging in aanmerking komt.

Elk der rechters hanteert een eigen-aard-ige toetsingsmaatstaf; al toetst elke rechter op de rechtmatigheid, deze houdt steeds een eigen-aard-ig oordeel in. De strafrechter toetst de rechtmatigheid van (direct of indirect) menselijk handelen (wederrechtelijk gedrag). De burgerlijke rechter toetst de rechten en plichten en de rechtmatigheid van handelingen van burgers (jegens de wederpartij). ${ }^{22}$ De bestuursrechter toetst de rechtmatigheid van rechtshandelingen van het bestuur.

20. A.Q.C. Tak, De overheid. in het burgerlijk recht, 's-Gravenhage 1997, p. 111.

21. A.Q.C. Tak, Overheid in het burgerlijk recht, "s-Gravenhage 1997, p. 117.

22. Waarbij ik - gemakshalve - de toetsing wan handelingen van de overheid door de burgerlijke rechter aan dezelfde (genoemde) maststawen hier - nog - maar over éen kam scheer. 
Wanneer het recht van de verbanden verschillend van karakter is; specifieker gezegd, wanneer het publiekrecht apart van karakter is, is het dan niet logisch dit recht steeds door aparte bestuursrechters te laten beoordelen, dus ook in zaken waarbij het Burgerlijk Wetboek invullend is gehanteerd?

\begin{abstract}
"Hoe zou immers die aparte behandeling beter gestalte kunnen krijgen, dan door de behandeling van alle zaken waarin de overheid partij is (dus of dat nu met behulp van de door bijzondere wetten aangereikte wormen of met behulp van aan het Burgerlijk Wetboek ontleende wormgevingen), in handen te stellen wan de typisch op de overheid gerichte nieuwe besturrsrechtelijke kamers van de rechtbanken? De bestuursrechteliike sectoren dus. ${ }^{23}$
\end{abstract}

Het is daarom dat in de rechtsbescherming de spectrale benadering zijn culminatiepunt windt.

\title{
11.5 Toetsing bezien vanuit het spectralle perspectief
}

\subsection{Inleiding}

Centrale notie in de spectrale benadering terzake van de rechtsbescherming is dat duidelijk moet zijn dat toetsing van overheidshandelen en publiekrechtelijk optreden (al of niet met invullende gebruikmaking van het Burgerlijk Wetboek) moet geschieden door rechters die gespecialiseerd zijn in het onderkennen en daarnaar oordelen van het aparte publiekrechtelijke karakter van dergelijke geschillen.

De geschiedenis van de rechtsbescherming in ons land is zeer versnipperd. Allesbepalende ingang voor de rechtsbescherming tegen de overheid is het beschikkingsbegrip, later besluitbegrip, gebleken. De spectrale benadering ontkent dat dit hanteren van het besluitbegrip een gelukkige keuze is. Afbakening van de grens dient niet te zijn de soort handeling, maar de soort rechtsgevolgen. ${ }^{24}$ Aangezien het stelsel van rechtsbescherming wordt geregardeerd door artikel 6 EVRM kan beter daarbij expliciet aansluiting worden gezocht.

Wat houdt bij de spectrale benadering de taak van de rechter eigenlijk in? Wat moet hij eigenli.jk doen, de rechter, de bestuursrechter en de civiele rechter? Wat toetst hij, moet hij toetsen en wat niet? Hoe toetst hij, moet hij toetsen en hoe niet? En zijn rechters de enige instanties die toetsen; hoe zit dat dan met de toetsing in heroverweging, de toetsing door het bestuursorgaan zelf? Toetsing kent vanouds verschillende onderscheidingen. Van belang is nu welke vragen er eigenlijk worden gesteld als we het hebben over die verschillende vormen van toetsing.

\subsubsection{Toetsing: rechtmatigheids-en doelmatigheidstoetsing}

De vraag die hier (vaak) aan de orde is, is de vraag wie er toetst en waarom zo? Is dat het bestuur (en dan hebben we het over volle of beleidstoetsing in heroverweging) of is dat de

23. A.Q.C. Tak, De overheid in het burgerlijk recht, "s-Gravenhage 1997, p. 117.

24. Vgl. A.Q. Tak, De overheid in het burgerlijk recht, "s-Gravenhage 1997, p. 138. 
rechter (en dan hebben we het over de terughoudender rechtmatigheidstoetsing)? In geval van zelf in de zaak voorzien treedt er een vermenging op van het hier bedoelde onderscheid. In de spectrale benadering staat de gedachte voorop dat bestuursorgaan en rechters op definitief verschillende wijze een geschil bezien. Daarbij hoort de gedachte dat zolang het bestuur zelf besluiten toetst, dit een objectieve toetsing moet zijn en zodra de rechter geroepen is een oordeel te geven, de overgang naar een subjectieve toets zou moeten worden gemaakt. Het moment waarop het besluit objectief vaststaat en objectieve toetsing dus niet meer mogelijk moet zijn, duidde Tak als het 'Moment $X$ '. ${ }^{25}$

\begin{abstract}
"Woor een juist begrip van het hier voorgestane systeem zil) vooropgesteld, dat (...) alle handelen van de overheid steeds is gericht op het belang van de gemeenschap (...). leder overheidshandelen wordt daardoor gekenmerkt als onpersoonlijk of «gemeen, gericht "erga omnes"; met als zodanig objectief en algemeen karakter. (...) Juist het onpersoonlijke van de taakuitoefening van de overheid, het verbod van partijbinding, vere ist echter behandeling van personen zonder voorkeur of discriminatie; gezien vanuit de burger toont dit de eis van verdelende rechtwaardigheid, iustitia distributiva. Waar (of, veel beter, woorzover) sprake is van veronachtzaming valn deze eis, wordt het individu nadelig 'gedetermineerd' in 'his civil rights and obligations" en is (dus) rechterlijke rechtsbescherming vereist. Terwijl de objectieve controle op het handelen "als zodanig", in absiracte en algemene zin, vanuit het bestum zelf en vanuit de volkswertegenwoordiging, primair is gericht op beleddsmatigheid en objectieve rechtmatigheid, hoort de rechter zich te concentreren op de subjectieve rechtwaardigheid van de overheidshandeling ten anzien van het individu dat (veel beter weet: voorzover het) zich persoonlijk en bijzonder benadeeld aclint. Daarbij behoort de rechter zich te onthouden van de beleidsmatige controle', ${ }^{26}$
\end{abstract}

\title{
11.5.3 Toetsing: ex tunc en ex nunc
}

Daarnaast is van belang de vraag wat er wanneer wordt getoetst. Is dat het besluit (op het moment dat het werd afgegeven en dan hebben we het over een objectieve toetsing van de on-rechtmatigheid die erga omnes werkt) of is dat het belang (dat betrokkene op het actuele moment inroept, dan hebben we thet over een subjectieve toetsing van de on-rechtmatigheid die inter partes werkt)?

De publiekrechtelijke subjectieve toetsing door de bestuursrechter zal in de spectrale benadering steeds een toets zijn op de 'egalité devant les charges/services publiques'. Hier wreekt zich de versnipperde geschiedenis van de rechtsbescherming. In een spectrale benadering worden objectieve en subjectieve toetsing immers gescheiden, terwijl de geschiedenis een bonte kermis van objectieve en subjectieve toetsing laat zien via het middel van het administratief beroep en de administratieve rechtspraak. Dat de bestuursrechtspraak hier te lande steeds een objectieve toets inhoudt, heeft alles te maken met het hanteren van het beschikkingsbegrip (thans besluitbegrip) als rechtsingang. Dat besluit immers is een objectief 'product' van de overheid met erga omnes-werking. Objectieve toetsing kan logischerwijze- slechts ex tunc, dus ten aanzien van de vraag of dit besluit naar de maatsta-

25. Vgl. A.C. Tak, Het Moment $X$, in: TrO 1990, p. 134-138.

26. A.Q.C. Tak, De overheid in het burgerlijk recht, 's-Gravenhage 1997, p. 176-177. 
ven van objectief publiekrecht op het moment van afgeven rechtmatig in het rechtsleven is gevloeid. Heroverweging (herbeslissing) daarentegen kan uiteraard ex nunc.

\title{
11.5.4 Rechtmatigheidstoetsing ex tunc en doelmatigheidstoetsing ex numc
}

Rechtmatigheidstoetsing door een terughoudende rechter geschiedt steeds ten aanzien van het besluit, met betrekking tot de vraag of dat besluit destijds (op het tunc-moment) rechtmatig effecten in het rechtsleven kon sorteren. Doelmatigheids- of volle toetsing geschiedt doorgaans naar de actuele maatstaven met betrekking tot de vraag of met het besluit de meest optimale effecten gecreeerd zijn.

In beginsel (dat wil zeggen indien niet van schakelbepalingen gebruik wordt gemaakt) toetsen bestuursrechters ex tunc en civiele rechters ex nunc.

\begin{abstract}
"De bijzondere instanties oordelen, anders dan de civiele rechter, ex tunc. Dat wil zeggen dat zij bij hun toetsing van het bestreden besluit of wan de betwiste handeling de feiten en ontstandigheden die zijn ontstann nadat het besluit is genomen of de handeling is gestell, buiten beschouwing laten. Dit is echter niet het geval bij een eventuele herbeslissing, dus indien de bijzondere instantie voor een vernietigde beslissing een nieuwe in de plats stelt (art. 72 lid 4 Awb): 27
\end{abstract}

\subsubsection{Toetsing: abstract en concreet}

Vervolgens dient de vraag hoe en waaraan er wordt getoetst te worden besproken. Is dat toetsing aan de norm zelf (de algemene regeling van de rechtssituatie erga omnes) of is dat aan het effect van de norm (de geconcretiseerde rechtspositie inter partes). Toetsing van effecten van normen wordt wel concrete toetsing genoemd, terwijl de toetsing van de norm (in de regeling) zelf abstracte toetsing heet. ${ }^{28}$

Het zal inmiddels duidelijk zijn dat de abstracte toetsing in de spectrale kijk op het recht niet dient te geschieden door rechters, dus ook niet door de bestuurstechter. In feite is de abstracte toetsing in de spectrale visie een vorm van toetsing die voór het moment $\mathrm{X}$ thuishoort. Daarmee is verbonden de notie dat abstracte toetsing in feite een objectieve toets is. Concrete toetsing door de bestuurstechter zal dan steeds een toetsing inter partes aan de 'egalité devant les charges publiques' inhouden; is kortom een subjectieve toets.

\footnotetext{
'Daarbij behoort de rechter zich te onthouden van de beleidsmatige controle; de abstracte controle hooguit als het ware indirect of als "concrete toetsing" te verrichien (in betekenis beperkt tot het bijzondere gewal) en zich te bedienen van de op geindividualiseerde rechtsbescherming gerichte publiekrechtelijke rechtsnonmen dis zich lenen voor subjectieve en concrete toepassing. ${ }^{29}$
}

27. A.Q.C. Tak, De overheid in het burgerlijk recht, 's-Gravenhage 1997, p. 137; bedoeld is uiteraard art, 72 . vierde lid, van het achiste hoofdstuk van de Awb.

28. Bekend is ook de Durtse terminologie waar abstracte toetsing wel wordt gezien als dat de rechier voldoet aan 'Normgerechtigkeit' en bij concrete toetsing wordt dan gesproken van 'Einzelfallgerechtigkeit'. Vgl. ook: G. Wiarda, Drie typen wan rechtsvinding, Zwolle 1988, p. 33.

29. A.Q.C. Tak, De overheid in het burgerlijk recht, "s-Gravenhage 1997, p. 177 
Ten aanzien van het onderscheid tussen de bestuursrechter en de civiele rechter kan dan aangegeven worden dat het hier niet betreft de toetsing ex tunc (door de bestuursrechter) en toetsing ex nunc (door de civiele rechter), maar wel de daarmee verbonden dicta. Bestuursrechters zijn tot vernietiging (objectief oordeel) bevoegd, civiele rechters niet.

\subsection{Het onderscheid tussen de formele en de materiële rechtskracht vanuit het spectrale perspectief}

\subsubsection{De formele en de materiële rechtskracht}

De spectrale benadering definieert rechtskracht niet expliciet, maar kritiseert de formele rechtskrachtleer in het positieve recht. Er is kritiek op de formele rechtskrachtleer van de burgerlijke rechter in de spectrale benadering. De burgerlijke rechter hanteert formele rechtskracht als ontvankelijkheidsinstrument, dat leidt tot het overnemen van het oordeel van bestuursrechter of bestuur. Dan is de toepassing van formele rechtskracht niet overtuigend: 'overtuigt deze toepassing van de leer niet' en: 'Algemeen gesteld leidt zij tot nauwelijks aanvaardbare consequenties bij (onder meer) onbevoegdheid, schending van fundamentele rechten of (anderszins) dwingende publiekrechtelijke voorschriften. ${ }^{30}$ Laten we een 'spectrale' definitie van formele rechtskracht en materièle rechtskracht afleiden uit de benadering.

Vanuit de spectrale benadering dient onderscheid gemaakt te worden tussen feit en gevolg. Wanneer nu onderscheid wordt aangebracht in de vaststelling van een rechtshandeling (rechtsfeit) en de inhoud daarvan (beoogde rechtsgevolgen) en daaraan het onderscheid tussen de formele en de materiële rechtskracht wordt verbonden, wordt duidelijk dat de vorm van de rechtshandeling (vaststelling) louter formele rechtskracht kan verkrijgen en de inhoud (gevolgen) van de beschikking materiële rechtskracht heeft. De formele rechtskracht behelst dan de vaststelling dat een beschikking in overeenstemming met de daarvoor bestaande eisen is tot stand gekomen en daarom in die vorm vaststaat. De materiêlle rechtskracht geeft dan aan dat bepaalde rechtsgevolgen conform de eisen van positief recht en algemene rechtsbeginselen effectief zijn. Kort beschouwd is de formele rechtskracht gericht op de geldigheid van overheidshandelen en de materielle rechtskracht op de effectiviteit, de werking ervan. Aldus geeft de rechtskracht aan een rechtshandeling een soort van vermoeden van rechtmatigheid; daarbij kan onderscheid worden gemaakt naar de inhoud en omvang van die rechtmatigheid (inzake de totstandkoming en inzake de inhoud, de rechtsgevolgen van de rechtshandeling).

\subsubsection{Verbandenteer en de formele en de materiêle rechtskracht}

De rechtsgevolgen van een in het bestuursrecht genomen rechtshandeling kunnen in de spectrale benadering naar vorm en inhoud in de overige rechtskringen verschillen. Combinatie van het onderscheid in vaststelling (formele rechtskracht) van een rechtshandeling en

30. A,C. Tak, De owerheid in het burgetlijk recht, "smavenhage 1997, p. 181. 
de inhoud, rechtsgevolgen ervan (materiële rechtskracht) met thet feit dat een en thetzelfde feit(encomplex) in verschillende rechtsverbanden rechtsgevolgen kan sorteren, leidt dan tot de constatering dat de vaststelling van een overheids-rechtshandeling (formele rechtskracht) in het bestuursrecht geschiedt, terwijl die vaststelling tegelijkertijd inhoudelijk rechtsgevolgen (materiële rechtskracht) kan hebben in verschillende rechtsgebieden (dat wil zeggen ook in andere rechtsgebieden naast het besturursrecht). Zo bezien kan het vaststellen van een bestuursrechtelijk besluit met formele rechtskracht tegelijkertijd en naast elkaar gevolgen hebben in het bestuursrecht, in het civiel recht en in het strafrecht. Ter illustratie hiervan wil ik het geschil tussen Leenders $B V$ en de gemeente Ubbergen in herinnering roepen. ${ }^{31}$ Leenders BV wilde groente en fruit verkopen vanuit een rijdende winkelwagen in de woonkemen Ubbergen, Beek en Ooy. De gemeente achtte het noodzakelijk dat daartoe een vergunning werd afgegeven, maar Leenders ontkende dat omdat zij meende dat de APV waarop deze beschikking werd gebaseerd onverbindend zou zijn. Na wat brieven over en weer werd een vergunning afgegeven voor verkoop in de woonkern Beek. Leenders wil dan een rechterlijk oordeel over de verbindendheid van de APV en de noodzaak van deze vergunning. Op haar bezwaarschrift zal nimmer een beslissing volgen. Een bestuursrechterlijk oordeel blijft eveneens uit. Leenders lokt een strafrechterlijk oordeel uit door te klagen na een sepot. Het strafrechterlijk oordeel is uiteindelijk dat de APV een te vage basis biedt voor strafverwolging en enige artikelen uit de APV worden buiten toepassing verklaard. Nu wil Leenders schadevergoeding en gaat naar de burgerlijke rechter. Dan stelt de gemeente zich op het standpunt dat de vergunning inmiddels formele rechtskracht heeft verkregen. De rechtbank probeert het met een schikkingscomparitie. Daar stelt de gemeente zich niet werplicht te voelen alsnog te beslissen op het bezwaar. De rechtbank gaat daarin niet mee, maar het hof conformeert zich aan de juistheid van de genomen beschikking. De Hoge Raad laat de beschikking voor wat die is; er is immers een onrechtmatige daad gesteld en die wordt dus beoordeeld. Voor een rechtstreekse toetsing van de APV biedt de Hoge Raad ümmer - nog - een luisterend oor. ${ }^{32}$ Kortom, zo wordt één en hetzelfde feit(encomplex) door de bestuursrechter niet beoordeeld, door de strafrechter beoordeeld als niet strafwaardig en door de burgerlijke rechter beoordeeld in het kader van een actie uit onrechtmatige daad. Zo bezien zijn bestuursrechtelijke gevolgen op te vatten als directe (want in eerste instantie beoogde) gevolgen van de vaststelling van de rechtshandeling en alle andere gevolgen als indirecte (want niet in eerste instantie beoogde) gevolgen.

\subsubsection{Rechterlijke bevoegdheid en de formele en de materielle rechtskracht}

De stelling dat een rechter als rechtsvormer buiten zijn competentiegebied geen formele rechtskracht kan laten ontstaan, kan verklaard worden vanuit de verbandenleer. Wanneer immers in iedere rechtskring eigen-aard-ig recht geldt, is het niet meer dan een logische

31. Vgl. HR 41 oktober 1996, JB 1996/241 m.nt. EvdL (Leenders-Ubbergen).

32. Althans nu rechtstreekse toetsing van een APV door de bestuursrechter niet mogel ijk is dient de burgerlijke rechter (art. 6 EVRM indachtig) rechtsbescherming to bieden. 
gevolgtrekking dat de in zo"n rechtsverband actief opererende rechtsvinder (die een rechter is) dat recht vindt (recht spreekt) naar de maatstaven wan het verband waarin hij actief is. Aldus opgevat is er naast de formele rechtskracht (vaststelling) wan een besluit ook de formele rechtskracht (vaststelling) vain het rechterlijk oordeel inzake dat besluit per rechtskring te onderscheiden. De rechters in hun rechtskringen oordelen op verschillende punten maatstaven, zodat ook hun waststelling (formele rechtskracht) een andere inhoud (materielle rechtskracht) kent per rechtsgebied.

Een bijzondere positie vervult in dit kader de burgerlijke rechter, daar hij eveneens als bestuurs(rest)rechter fungeert. Wanneer de burgerlijke rechter inspringt in het gat dat de administratieve rechtspraak laat liggen, dan doet hij dat niet op de wijze zoals de bestuursrechter dat doet. De burgerlijke rechter springt in dat gat op een wijze en naar de maatstaven van het burgerlijk recht. Van der Hoeven stelt het aldus:

Want al heeft de jurisprudentie van de burgerlijke rechter onmiskenbaar in een leemte voorzien, waarvoor men dankbaar moet zijn, als een gelijkwaardig substituut voor een goede administratieve rechtspraak kan $z \mathrm{ij}$ toch nitet gelden." 33

En ten aanzien van de wens de taakwerdeling tussen burgerlijke en administratieve rechter op een meer harmonische wijze te laten verlopen zei hij later:

'Daarwan is echter niets gekomen en dat heeft er ongetwijfeld toe bijgedragen, dat de burgerlike rechter stap' voor stap het bestuursrechtelijk terrein is gaan verkennen en bezetten met behulp van het privaatrechtelijk begrippenapparast. Voor de theoretische ontwikkeling van het bestuursrecht heeft dit tot gevolg gehad, dat de problemen in niet geringe mate toenamen. Immers, naast problemen, voortwloeiend uit de bestuurstechtelijke vraagstelling op zichzelf, rezen nu ook kwesties die een gevolg waren van de penetratie wan het privatrecht op bestuurlijk terrein. In de latere jaren is, mede door de hoge vlueht die het kort geding voor de president van de rechtbank, 6́k in zaken tegen de overheid, heeft genomen, die penetratie nog belangrijker geworden. De grote betekenis daarvan is, ook door de wetgever, niell steeds onderkend. ${ }^{34}$

Er zijn ook tegenowergestelde geluiden te horen. Zo wordt wel gesteld dat sinds de invoering van de regel van de formele rechtskracht door de burgerlijke rechter en de daaruit voortvloeiende taakverdeling tussen de bestuursrechter en de burgerlijke rechter de oordelen wan deze rechters zijn gaan samenvallen. Scheltema ontwaart drie regels die in de jurisprudentie gehanteerd worden, maar geeft meteen maar even aan dat die jurisprudentie rond die regels toch niet helemaal goed begrepen wordt (Door wie is evenwel niet helemaal duidelijk; door de rechters, welke rechters, hoe blijkt dat dan? In dat geval geldt dan dat de rechters de mouwen kennelijk nog - of weer - moeten opstropen.):

33. J. van der Hoeven, De grenzen van de rechterlike functie in de administratieve rechtspraak, in: RM Themis 1974, p. 660 .

34. J, wan der Hoeven, De drie dimensies van het bestursrecht, VAR-reeks 100, Aphen a/d Rijn 1989, p. 144. 


\begin{abstract}
"Voor een goed begrip van de materie vemeld ik hieronder drie regels uit de jurisprudentio, die ean goede kapstok voor het vraagstuk wormen, maar blijkens de jurisprudentie niet altijd goed begrepen worden. (..) De Hoge $\mathbb{R}$ aad heef de woigende, ten dele unt elkaar voortwoelende, regels ontwikkeld:

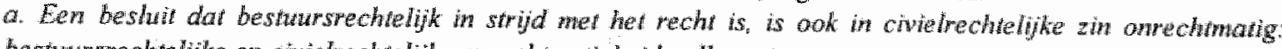

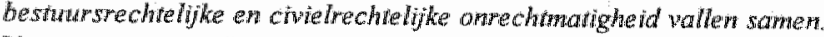

Vroeger was over dit ondenwerp anders geoordeeld. Toen de burgerlijke rechter nog niet rechtstreeks troetste aan de beginselen van behoorlijk bestuur, kon het voorkomer dat een besiut naar bestumrsrechtelijke maatstawen hin strijd met het recht was, maar geen onrechtmatige daad in civielrechtelijke zin vormde. Sinds de burgerlijke rechter overheidsoptreden aok direct toetst aan de beginselen van behoonlijk bestusur, zijn de bestuursrechtelijke er civielrechtelijke toetsingsmaatstaven dezelfde gevorden: er bestat maar sen snort onrechtmatigheid.

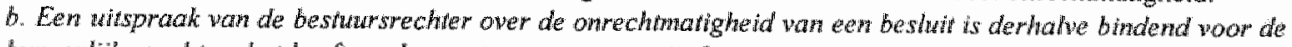
burgerlije rechler: het heeft op dat punt gezag vam gewijsde

(...) Ondat er maar én soort onrechtmatigheid bestaat, betekeni een oordeel van de bestuurstechter over de rechunatigheid van een besiuit dat er een rechtelije uilsprank met gezag wan gewijsde over dat onderwerp bestaat. (...)

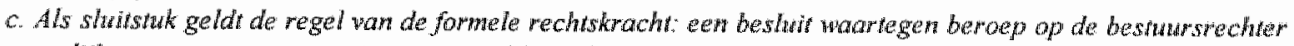
mogelijk was geweest, maor niet is ingesteld, geld bil de burgerlike recher als rechwath

Deze regel is nodig om tot een goede talkverdeling tussen de rechters te komen. Is de bestuurstechtelijke rechts. weg mogelijk, dan moet men die ook gebruiken. Anders zou men achteraf bij de burgerlijke rechter vragen aanhangig kumnen maken die nu juist ter beslissing aan de bestuursrechter zijn opgedragen. Deze regel yoorkomt dus dat de beoogde takverdeling tussen admin istratieve en burgerlijke recher wordt gefrustreerd. ${ }^{35}$
\end{abstract}

\title{
Onduidelijk blijft hoe een goede taakverdeling tussen beide rechters met instandhouding van
}

essentiële verschillen in beider toetsing (in het bijzonder het object van de rechterlijke toetsing) te rijmen valt met deze (de rechter in de mond gelegde) regels. Vandaar ook wellicht dat die verschillen in toetsing worden ontkend. Alledrie de regels behoeven nuancering. Ten aanzien van regel a. wordt uitgegaan van de premisse dat rechters aan hetzelfde recht toetsen. Dat lijkt een open deur. Een open deur evenwel, waarbij over een 'dletail' wordt. lyeengestapt, nl. dat de verschillen in toetsing woort kunnen vloeien uit verschillende voorwerpen van geschil; uit het toetsen van (niet aan) het voorwerp van geschil (aan, inderdaad, het recht). Dat dit verschil in toetsing door de rechters verband houdt met het feit dat zij rechtspreken in verschillende rechtskringen werd vanuit de spectrale visie op het recht werklaard. Uiteraard is in dit verband het institutionele verhaal (welke rechter toetst wat? welke rechter stelt wat vast - formele rechtskracht?) het minst interessant; het moet gaan on de materiele kant van de zaak, van de toetsing (hoe toetst de rechter?).

Met betrekking tot regel $b$. valt op te merken dat het binden van de ene rechter aan het oordeel van de andere ten aanzien van de toetsing van weliswaar hetzelfde feit(encomplex) maar van eveneens verschillende voorwerpen van geschil, berust op een vergelijking van appels met peren. De binding aan een rechterlijk oordeel valt immers in spectraal perspectief

35. Annotator Scheltema onder HR 27 mei 1994, NJ 1997, 158 (Sprangers-Staat), p. $789-790$.

36. In dezelfde zin ook - althans zo begrijp ik hem - Damen als thij stelt: 'Kwesties wan rechumachitwerdeling kunnen juristen ongemeen boeien, maar uiteindelijk maskt het waarschijnijk niet zoveel uit of de administratieve recinter of de burgenijke rechter zich ermee bernoeit. Anders kan dat bij het materiele recht liggen." Zie: $\mathbb{L}$ J.A. Damen, Moet pech weg?, in: Voor risico wan de overheid?, C.P.M. Cleiren e.d. (red.), Roterdam 1996, p. 27. 
te kwalificeren als een gevolg van de vaststelling van een rechterlijk oordeel door anderen (in dit geval door een andere rechter, een rechter wit een andere rechtskring). Die binding heeft betrekking op de inhoud van de uitspraak (met andere woorden, de materiële rechtskracht vanuit de ene rechtskring wordt als vaststaand, als formele rechtskracht in de andere rechtskring gepresenteerd).

Tenslotte ten aanzien van regel $\mathrm{c}$. De formele rechtskracht is als eigenschap vastgeklonken aan het besluit dat als zodanig (erga omnes) identiek naar vorm jegens alle partijen werkt. Soms zijn er verschillende belanghebbenden in een geding (bv. direct- en derde-belanghebbende - zoals in Utrecht-Budinowski en Pejkovski ${ }^{37}$ - of bv. belanghebbende en cessionaris - zoals in Sprangers-Staat ${ }^{38}$ ). Het feit dat rechtskracht vastgeklonken is aan het besluit, heeft voor de verschillende belanghebbenden weinig uit te staan met de toetsing van de persoonlijke positie van belanghebbenden in het kader van een civiele vraag door de burgerlijke rechter en de toepassing van de formele rechtskrachtregel. De formele rechtskracht is immers gekoppeld aan een tunc-moment, terwijl de gevolgen daarvan (de materiele rechtskrachit) altijd naar een nunc-moment worden beoordeeld.

Overigens is het doel wel reeds duidelijk: eenheid van recht dient door de Hoge Raad bewerkstelligd te worden. Ook al is eenheid van recht het doel en gaat men uit van de opvatting dat alleen de cassatierechter daarvoor verantwoordelijk is, dan nog kan slechts ingegaan worden op die eenheid van recht indien vergelijkbare zaken voorwerp van discussie kunnen zijn. Een bestuursrechtelijk besluit (publiekrechtelijke rechtsvaststelling) valt nu eenmaal niet (geheel) samen met de feitelijke, civiele belangpositie van personen. Wat in het ene rechtsgebied geduld moet worden, kan in het andere rechtsgebied juist reden zijn voor compensatie en/of genoegdoening. Wanneer eenheid van rechtsgebieden niet bestaat, is het ook niet zinvol de cassatierechter dat als doel in zijn werkomschrijving vast te leggen; zo'n werkomschrijving maakt trouwens de rechter in een volwassen democratische rechtsstaat zelf wel.

Niet alleen met betrekking tot de toegang tot de rechter is er dusdoende vanuit het spectrale perspectief een argument - in het bijzonder vanuit het idee van rechtspluralisme - te vinden tot veelheid van rechtspraak, maar ook ten aanzien wan de zgn. gebondenheid var de rechter in de ene rechtskring aan het oordeel van een andere rechter in een ander rechtsverband. Ook is hieruit een scepsis af te leiden ten aanzien van de zogenoemde vrijwarende werking van vergunningen. Wanneer de oordelen van rechters uit de verschillende rechtsgebieden immers betrekking hebben op verschillende rechtsvragen is vrijwarende werking een aberratie. Slechts waar oordelen samenvallen (deze zijn denkbaar in thet kader van voorvragen, die een rechter zodoende steeds moet beantwoorden), kan een bepaalde variant op eenheid (een soort van samen-oplopen of samen-rnee-opgaan, die niet hetzelfde is als eenheid) in het blikveld komen. Samenval is nimmer hetzelfde als eenheid. ${ }^{39}$

37. Vgl. HR 8 september 1995, JB 1995/249 (Utrecht-Budinovski en Pejkowski).

38. Vgl. HR 27 mei 1994, RvdW 1994, 121 (Sprangers BV-Staat).

39. Wgl. A.C. Tak, De overheid in het burgerlijk recht, "s-Grawenhage 1997, par. 3.5, p. 174 e.x. 


\subsection{Toetsing van de formele en de materiẻle rechtskracht van besluiten}

\subsection{Inleiding}

Wanneer de formele rechtskracht van besluiten is betrokken op de vaststelling van de rechtshandeling en de materiële rechtskracht is betrokken op de inhoud (de rechtsgevolgen) van de rechtshandeling, kan dit aanleiding zijn voor een verschillende wijze van toetsing van de formele en de materiële rechtskracht van besluiten. Wat leert de spectrale benadering op het recht hierover? Concreet: valt het onderscheid doelmatigheidstoetsing en rechtmatigheidstoetsing samen met toetsing van de materielle en de formele rechtskracht? In gelijke zin: valt het onderscheid tussen ex tunc-toetsing en ex nunc-toetsing samen met toetsing van de formele en de materiële rechtskracht? Of: valt het onderscheid in abstracte en concrete toetsing samen met toetsing aan de formele en de materiële rechtskracht?

\subsubsection{Ex tunc/ex nunc}

Wanneer een oordeel over de vorm van een rechtshandeling gegeven wordt, kan dat tot een geheel ander(sluidend) oordeel (moeten) leiden dan wanneer een oordeel gegeven wordt over de inhoud van een rechtshandeling of de daaruit voortvloeiende rechtsgevolgen. Ook het recht in de en rondom de door de rechtshandeling gecreezerde rechtssituatie is niet stil blijven staan (of hoeft dat niet te zijn).

Het oordeel over de worm van de rechtshandeling (de formele rechtskracht) kan alleen ex tunc gegeven worden. Een ex tunc oordeel gegeven aver de inhoud (over de materiële rechtskracht), terwijl we eigenlijk ook wel weten dat de rechtssituatie voortduurt (dus ook niet meer is zoals die was), is eigenlijk een fictie. Toetsing van de rechtssituatie geschiedt daarom sinds jaar en dag door de executieve zelf (in de vorm van heroverweging) naar de stand wan zaken zoals die op het moment van het beoordelen van het voorgelegde geschil was (een nunc-moment). Aldus kan de inhoud van de rechtshandeling, de gevolgen (de materiële rechtskracht) in overeenstemming worden gebracht met de actuele rechtssituatie (doelmatigheids- of volle toetsing).

Omdat rechters over een dergelijk administratief oordeel oordelen doordat het besluit (de vorm, de formele rechtskracht) aan hen wordt woorgelegd, is hen (slechts) toewertrouwd te oordelen, te controleren of het bestuursorgaan rechtmatig heeft gehandeld. Dat oordeel kan uit de aard der zaak alleen maar gegeven worden over het moment watop het bestuursorgaan handelde; dusdoende is het bestuursrechterlijke oordeel altijd een oordeel ex tunc. Bij het zelf in de zaak voorzien lopen rechter ex tunc-en ex nunc-activiteiten door elkaar. ${ }^{40}$

Zo bezien wordt duidelijk dat er geen principieel verschil bestaat in de formele rechtskracht van een besluit dat niet in rechte is aangevochten en de formele rechtskracht van het besluit dat wel in rechte is aangevochten. ${ }^{41}$ De vaststelling van het besluit door een bestuursorgaan kan door de rechter immers. (slechts) worden bevestigd of ongedaan gemaakt. De rechter

40. Vgl. J.G. Steenbeek, Ex tunc of ex nunc?, in: Tro 1990/8, p. $181 \mathrm{e}$.

4. Anders: M.R. Mok en R.PJ.L. Tjittes, Formele rechtskracht en overtseidsaansprakelijkheid, in: RM Themis $1995 / 9^{*}$ p. 384 , l.k. die spreken van eigenlijke en oneigenlijke fomele rechtskracht. 
voegt - in beginsel ${ }^{42}$ - aan het besluit (met zijn rechtskracht) niets toe. Ook hier zijn wel andere geluiden te horen, $b v$. daar waar gesteld wordt dat een besluit dat niet ter toetsing stond van de bestuursrechter dus (!) geen formele rechtskracht kan krijgen. ${ }^{43}$

\subsubsection{Ex tunclex nunc-toetsing en de burgerlijke rechter}

Laten we de consequenties van verschillende toetswormen in de verschillende rechtskringen - in het bijzonder woor de burgerlijke rechter-eveneens in ogenschouw nemen. Wanneer de burgerlijke rechter om een oordeel wordt gevraagd ten aanzien van een feit(encomplex) dat in de bestuursrechtelijke rechtskring als een besluit/beschikking wordt gekwalificeerd, toetst hij volledig naar de maatstaven van de civiele rechtskring. Hij doet dat ten aanzien van het actuele moment - ex nunc. De burgerlijke rechter zal - wanneer hem een oordeel over een bestuursbesluit wordt gevraagd - in dezelfde dubbele situatie terechtkomen als de bestuursrechter wanneer deze zelf in de zaak voorziet. Er zijn verschillende manieren om dit te vermijden: naast afhouden van oordelen (in de zin van conformeren aan het bestuursrechtelijke oordeel conform de hoofdregel van formele rechtskracht zoals door de Hoge Raad is ontwikkeld) is er de mogelijkheid om louter te beoordelen hoe het feit(encomplex) zich verhoudt tot civiele rechtsmaatstaven.

Een voorbeeld daarvan is te zien in het arrest dat de Hoge Raad wees in het geschil tussen de Staat en Frank Bolsius. ${ }^{44}$ Frank Bolsius aanvaardde elders een werkkring, omdat hij op basis van gedane onjuiste inlichtingen meende dat hij in aanmerking zou komen voor een tegemoetkoming in de verhuiskosten; later volgt de afwijzende beschikking. Hij beriep zich bij de burgerlijke rechter op de onrechtmatigheid van de aan hem gedane en gebleken onjuiste mededelingen. Naast het in een administratieve procedure proberen om de beschikking vernietigd te krijgen (door de bestuursrechter), stond voor hem de mogelijkheid open om het feit(encomplex) civiel te laten toetsen. Dat een besluit overigens formele rechtskracht kan verkrijgen is dan (dat wil zeggen, woor de burgerlijke rechter) irrelevant, omdat Bolsius in de burgerlijke procedure uitging van de rechtsgeldigheid van de beschikking.

Zowel vanuit het loskoppelen van feit en gevolg als vanuit het onderscheiden van rechtskringen kan de 'Bolsius-methode' worden verklaard. Het feit(encomplex) kan in de bestuursrechtelijke rechtskring aanleiding zijn voor de vaststelling van een besluit (dat wil zeggen als publiekrechtelijke rechtshandeling), terwijl datzelfde feit(encomplex) daarnaast en tegelijkertijd gekwalificeerd kan worden als civielrechtelijk relevant (bijvoorbeeld als onrechtmatige daad), omdat het als feitelijk handelen civiele rechtsgevolgen in het leven kan roepen. De burgerlijke rechter heeft dan niet van doen met rechtmatigheidstoetsing van het besluit aan de matstaven van de bestuursrechtelijke rechtskring, met ex tunc-toetsing en

42. De bevoegdheid tot het zelf in de zalk voorzien daargelaten.

43. Vgl. 'De formele rechtskracht wan ewn besluit was hier aan de orde in combinatie met een besluit dat niet ter toetsing stond vas de bestuurstechter, en dus geen formele rechtskracht kan krijgen." Aldus annotator Scheltema onder HR II februari 1994, NJ 1997, 162 (Geleen-S.), p. 822.

44. Vgl. HR 2 februari 1990, AB 1990, $223 \mathrm{~m} . \mathrm{nt}$. G.P. Kleijn (Statat-Bolsius). Een ander voorbeeld zag u al in thet arrest van de Hoge Raad van 11 oktober 1996, JB 1996/241 rn.nt. EvdL (Leenders-Ubbergen). 
met terughoudendheid ten aanzien van de toetsing van het besluit; de burgerlijke rechter toetst dan niet de gerichtheid op bestuursrechtelijke nomen, die bij de publiekrechtelijke rechtsvaststelling wel centraal staat. De Hoge Raad stelt dan ook expliciet dat: "de omstandigheid dat de administratieve rechter door onjuiste of onvolledige inlichtingen opgewekt vertrouwen dat in bepaalde zin zou worden beschikt, onvoldoende heeft geoordeeld on de vervolgens in andere zin genomen beschikking te vernietigen, de burgerlijke rechter niet zonder meer belet te oordelen dat het geven van die inlichtingen onzorgvuldig was en verplicht tot vergoeden van de daardoor veroorzaakte schade. ${ }^{.45}$

\subsubsection{Vernietigen en onverbindendverklarentegenover buiten toepassing verklaren en buiten werking stellen}

Ex tunc-toetsing door de bestuursrechter en ex nunc-toetsing door de burgerlijke rechter komen ook voort uit de wijze waarop zij het recht en het woorliggende geschil beschouwen. Van der Hoeven stelde al eens dat de administratieve rechter het voorliggende geschil beschouwt als een zaak van de objectieve rechtsorde. Het is daarbij duidelijk dat het geschil tussen burgers voor de civiele rechter niet als zodanig (kan) word(t)(en) opgevat. Van der Hoeven zei het aldus:

"De vraag is wooral: welke conceptie heeft de rechter van de relatie tussen bestuur en bestuurde. Men zou, in grote trekken, deze relatie kunnen omschrijven als én die haar oorzaak vindt in een objectieve rechtsorde, waardoor wel de "vrijheid' wan oordeel van het bestuur geheel bepanld is, maar die niet de wrijheid van de bestuurde geheel omvat. De vrijheid van de butger is, althans in onze samenleving, in belangrijke mate een "vrijheid wan"; vrijheid van het bestuur is altijd een "vrijheid tot". (..) De confrontatie tussen de vrijheid van de burger, die zijn eigen vrijheid is, met die van het bestuwr, die een "wrijheid" wan geheel andere orde is en in wezen een verplichting inhoudt, de confrontatie van het belang van de burger, dat zijn eigen belang is, noet bestuursbelangen die nimmer de eigen belangen zijn van de dragers ervan - deze confrontatie is bij het tot stand komen van een bestuurijke beslissing in wezen geen andere, dan bij een beslissing gegeven in administratief geding. De administratieve rechter hanteert in beginsel-binnen bet kader van zijn bevoegdheid - geen andere criteria dan het bestuursorgaan behoort te doen, maar wèl andere dan die, wolke de burger voor zichzelf hanteert. ${ }^{46}$

Is aldus aangegeven dat de bestuursrechter vooral georienteerd is op het objectieve recht, terwijl de burgerlijke rechter vooral de subjectieve rechtsrelaties in ogenschouw neemt, dan volgt de vraag, of deze constatering ook betekenis heeft voor het onderscheid tussen concrete en abstracte toetsing. Het standpunt wan de burgerlijke rechter, in het bijzonder van de Hoge Raad, hierover ligt besloten in zijn stellingen inzake zijn advies over constitutionele

45. HR 2 februari 1990, AB 1990,223 m.nt. G.P. Kleijn (Staat-Bolsius), r.o. 3.3

46. J. Wan der Hoeven, De grenzen wan de rechterlijke functie in de administraticwe rechtspraak, in: RM Themis 1974, p. 671-674. Later - in zijn advies inzake constitutionele toetsing - onderstreept Van der Hoewen nog dat de Raad yan State het beste toegerust is voor objectieve, algemene toetsing wooraf en dat rechtspraak per definitie concreet is; vergelijk: Adwies J. var der Hoeven inzake Constitutionele toetsing, in: NJCM 1992, p. 293-303. 
toetsing. In dat advies geeft de Hoge Raad aan dat zoveel mogelijk concreet getoetst zou moeten worden ${ }^{47}$ In verband met de toetsing aan grondrechten stelt hij:

'Daarbij zal het niet anders kunnem gaan dan om een beoordeling die ruimte latat aan de wetgever, en voorts on correcties op de wettelije regeling die aan de belangen van de burger tegemoet komen, maar die de regeling zelf woor het overige zoveel mogelijk intact laten. 48

Ook overigens wordt gehecht aan het voorkomen van schokken in de rechtsontwikkeling. Concrete toetsing is als zodanig te beschouwen als een 'temperingstechniek', ${ }^{49}$ net als ex nunc bepalen dat een wetsbepaling onverbindend is wegens strijd met de Grondwet. ${ }^{50}$ Vanuit het spectrale denken valt nu de vraag te stellen: is ex tunc-toetsing dan ook abstracte toetsing en ex nunc-toetsing concreet? Wanneer ex tunc-toetsing door de bestuursrechter samenhangt met de heersendle opvatting dat voorliggende geschillen beschouwd moeten worden als vraagstukken wan objectief recht zeker. Als ex nunc-toetsing door de civiele rechter samenhangt met de opvatting dat de subjectieve rechtsrelaties voorwerp zijn van geschil, dan kan ex nunc-toetsing ook gezien worden als concrete toetsing. Het dictum dat tot uitdrukking komt bij deze verschillende zienswijzen (van de voorwerpen van geschil en de wijze waarop daarover adequaat getoetst kan worden), zou dan ook verschillend moeten luiden. Oordelen over de formele rechtskracht, de vaststelling van de publiekrechtelijke rechtshandeling (ex tunc, abstract) zijn oordelen over de objectieve rechtsorde en dienen daarom in "objectieve" bewoordingen gesteld te luiden; vernietigen of onverbindendverklaren. Oordelen over de materiële rechtskracht, de rechtsgevolgen (ex nunc, concreet) zijn oordelen inzake de subjectieve rechtsrelaties van mensen en dienen daarom in 'subjectieve' bewoordingen gesteld te luiden: buiten toepassing laten of buiten werking plaatsen (in dit concrete geval). ${ }^{5 i}$

Met deze constatering zitten we weer middenin het probleem dat een administratieve rechter voelt wanneer hij primair het objectieve recht handhaaft, maar tegellijkertijd ook rechtsbescherming aan de burger wil verlenen. De positie van deze rechter is daarom steeds en noodgedwongen een dubbele. Het zou aanbeveling verdienen om het onderscheid in het voorwerp van geschil en de dicta (resultaten die rechter in het geschil kan bewerkstelligen) daarbij ook in wetgeving steeds duidelijk te hebben. Helaas is de Awb op dit punt verwartend. Zeker nu een steeds groter deel van de besturssrechtspraak wordt uitgeoefend door leden van de gewone rechterlijke macht hadden de implicaties ten aanzien van dit punt uitdrukkelijk verwoord moeten worden in de Awb. Ook Van Male accentueert dit onderscheid waar hij stelt dat wanneer de rechter een regel onverbindend verklaart dit

47. Hetgeen ook overeen komt met de strekking wan art. $12 \mathrm{AB}$.

48. Advies van de Hoge Raad en PG Renmelink inzake Consititutionele toetsing, in: NJCM 1992, p. 248.

49. Vgl. Advies wan de Hoge Raad en PG Remmelink inzake Constitutionele toetsing, in: NJCM 1992, p. 256257.

50. Vgl. Advies van de Hoge Raad en PG Remmelink inzake Constitutionele toetsing, in: NJCM 1992, p. 258

51. Vgl. A.Q.C. Tak, Dimensies van overheidshandelen, in: Spectraal recht, Den Haag 1998, p. 20. 
uitsluitend juridische werking heeft tussen de partijen van het geding waarin getoetst werd. ${ }^{52} \mathrm{Hij}$ zegt eveneens: "Anders dan bij de vernietiging verdwijnt de (door de rechter, EvdL) onrechtmatig gevonden regel niet uit de rechtsorde. Het is darn ook mogelijk en het komt ook een enkele keer voor, hoezeer verwerpelijk dat ook moge zijn, dat het bestuursorgaan de regel blijft toepassen. De praktijk is evenwel dat bestuursorganen in de onverbindendverklaring in een concreet geval aanleiding vinden om de regel niet meer toe te passen, c.q. hem in te trekken of te wijzigen. ${ }^{53}$

Het wermijden van dit soort dubbele posities voor rechters is voor Tak reden om te pleiten voor eern systeem waarbij het contentieux objectif en het contentieux subjectif resoluut van elkaar worden gescheiden. Hij pleit woor een "Europeser" systeem, waarbij hem de Stratsburgse jurisprudentie voor ogen staat. ${ }^{54}$

\subsection{Tenslotte}

De formele rechtskrachtleerzoals de Hoge Raad die heeft ontwikkeld in het burgerlijk recht, verschilt principieel van de formele rechtskracht zoals die in helt bestuursrecht tot uitdrukking is gekomen. In de spectrale benadering van het recht is formele rechtskracht slechts betrokken op de vaststelling van het besluit, terwijl de materiêle rechtskracht op de inhoud, de rechtsgevolgen betrekking heeft. Daarom kan het onderscheid tussen de formele en materiële rechtskracht in de spectrale benadering zichtbaar maken dat verschillende toetsingswijzen bij de bestuursrechter en bij de burgerlijke rechter door elkaar lopen. Voor de toetsing van de formele en de materiële rechtskracht betekent dit dat onderscheid kan worden gemaakt naar toetsing van de vorm van de rechtshandeling (ex tunc) en van de inhoud van de rechtshandeling (ex nunc). De ex tunc-toetsing van de vorm betreft toetsing van de formele rechtskracht (objectieve toetsing) en dient uit te monden in formele dicta, die op de vaststelling van een besluit zijn betrokken, zoals bv. vernietiging en/of onverbindendverklaring. De ex nunc-toetsing van de inhoud van een besluit betreft de toetsing van de materiële rechtskracht (subjectieve toetsing) en dient uit te monden in materiele dicta, die op de werking, de effectiviteit van een besluit, dat wil zeggen de rechtsgevolgen, zijn betrokken, zoals bv. buiten toepassing verklaren of zelf in de zaak voorzien.

Dit onderscheid maken in dicta door het onderscheid in formele en materiele rechtskracht is uiteraard relevant voor de rechtspraktijk. Het vermijden van een dubbele positie voor dle rechter was de belangrijkste drijfweer woor de conclusie dat het bestuursprocesrecht een andere grondslag behoeft. Gesteld kan inmiddels worden dat de analyse vanuit de spectrale benadering een vruchtbare analyse is gebleken.

\$2. Zie ook: F.A.M. Stroink, Atgemeen bestuursrecht, Zwolle 1996, p. 145.

53. R.M. van Male. Gevolgen wan onrechtmatige regelgewing in Nederland, preadvies vereniging woor de vergelijkende studie wan het recht wan Belgie en Nederland, Zwolle 1995, p. 20.

54. Vgl A.Q.C. Tak, De owerheid in het burgerlijk recht, "swGravenhage 1997, p. 173 en p. 184-186. 


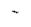




\title{
Hoofdstuk 12
}

\section{Rechtskracht: "de kleren van de Keizer"}

\begin{abstract}
en nog altijd hield dat whieke schonwspel hem bezig: een man in een komer, mel aen boek, lezend zonder de woorden te articuleren.

Die man maakte de siap van het schibffeken naar het begrip rechtstreeks, wet weglating wan hei klankeken: de wreende kunst die hij initieerde, de kunst wan het stillezen, had wonderlike consequenties. Zij zou well jaren later leiden tot de opvating van het boek als een doel op zichzelf nier als een middel tot aen doel."
\end{abstract}

\subsection{Inleiding}

Aan het eind van dit boek gekomen, kunnen we ons afvragen wat we nu geleerd hebben over de betekenis van rechtskracht; zo luidt immers de probleemstelling van deze studie. Dit is ook de plaats waar het "Leitmotiv" van dit boek nog eens gememoriseerd moet worden. Immers, ook aan het eind van deze studie is er weinig eenduidigheid over het begrip rechtskracht; vast staat inmiddels wel dat er niet én rechtskrachtbegrip is, maar dat meerdere betekenissen, benaderingen de ronde doen. De hypothese van dit boek heeft in ieder geval zichtbaar gemaakt dat er verschillende benaderingen zijn.

Er zijn veel verschillende benamingen van rechtskracht en/of rechtsbestendigheid in omloop. We weten inmiddels dat schrijvers die verschillende betekenissen, benamingen van rechtskracht hanteren omdat $z$ ij vanuit verschillende benaderingen opereren. Laten we, bij wijze van samenvatting, deze verschillende betekenissen nog eens voor het voetlicht brengen en daarbij al die benaderingen beschrijven door hun implicaties te duiden van feit, norm en gevolg.

Inmiddels kunnen we wel constateren dat de aanwezigheid van het hanteren van vele en werschillende definities (al komen ze voort uit verschillende benaderingen van het recht) tot verwarring en onduidelijkheid lejdt. Rechtskracht is een begrip waar de rechtspraktijk niet op kan varen; zoals het nu wordt gehanteerd is het onhoudbaar. Het begrip behoeft daardoor een herijking. Die herijking is hier geschied door de begrippen te analyseren vanuit de verschillende benaderingen, niet alleen de positiefrechtelijke, maar ook de historische, de rechtsvergelijkende, de rechtstheoretische en de rechtsfiflosofische. Een herijking van een definitie is nauwelijks volgbaar voor de lezer als die geen 'handen en voeten' krijgt. Die heeft de lezer dan ook gekregen in de vorm van een hypothese. Deze hypothese van het rechtskrachibegrip moest tweeerlei functies kunnen vervullen; enerzijds een definitie aanreiken die 'groot' genoeg is om aan alle benaderingen te kunnen worden gespiegeld (een sleutel) en die anderzijds gehanteerd kan worden als maatstaf (als toetssteen). Deze

1. Dit is de wertaling wan Barber van de Pol wan Borges" De cultus van het boek en andere essays (Otras inquisiciones), Amsterdam 1990, p. 131-132. 
hypothese ligt in het ontrafelen wan de rechtskracht van het feit, van de norm en van het rechtsgevolg. Dit behoeft toelichting.

Steeds wanneer een bevoegdheidsuitoefening plaatswindt worden feiten en hun gevolgen met elkaar in verband gebracht. De norm heeft hiertussen een bemiddelende functie. De norm heeft zowel met het feit als met het gevolg een relatie; daarom spreken we ook van rechtsfeiten en rechtsgevolgen. Een feit is bepaald door tijd. Feiten zijn doorgaans aflopende gebeurtenissen. De gevolgen gaan deel uitmaken van de wereld van het recht. Daarom word: vaak gesproken van een door de bevoegdheidsuitoefening veroorzaakte wijziging in de rechtssituatie. Deze definitie (die door Steenbeek is gegeven) maakt het mogelijk om elke andere definitie of typering van rechtskracht een plaats te geven. De bestuursrechtelijke rechtshandeling kan zo worden beschouwd als het aflopende feit (een bijzonder rechtsfeit in de woorden van Steenbeek) dat rechtsgevolgen in het leven roept. De rechtskracht die verbonden wordt met het plaatsvinden van het rechtsfeit is een aanwijsbare en met een tuncmoment verbonden formele rechtskracht. De rechtskracht die blijft en woortduurt, wordt met het nunc-moment (en de rechtsgevolgen) verbonden en heet materiele rechtskracht. ${ }^{2}$

\subsection{De betekenissen van rechtskracht}

In dit boek is rechtskracht geanalyseerd vanuit verschillende benaderingen. Ik meen dat elk van deze analyses iets toevoegt aan verbetering van het inzicht in de betekenis wan rechtskracht in de publiekrechtelijke, en in het bijzonder bestuursrechtelijke werkelijkheid.

De eerste betekenis van rechtskracht zoals in deze studie werd besproken, is de betekenis die de burgerlijke rechter er aan geeft. Hoe is de burgerlijke rechter ertoe gekomen om de formele rechtskracht van beschikkingen expliciet te definiëren? Welke definitie ontwikkelde hij? Wat was het doel van deze definitie van formele rechtskracht?

Formele rechtskracht wordt door de burgerlijke rechter gehanteerd als een afbakeningsinstrument; het staat in een lange rij van instrumenten ter afbakening van het aloude dilemma. Het nimmer door de wetgever opgeloste verdelingsvraagstuk, kan de burgerlijke rechter nu zelf beslechten. Formele rechtskracht bij de burgerlijke rechter zegt dus ook iets over bevoegdheidsverdeling en competentie.

Oorspronkelijk was de burgerlijke rechter de enige rechter die het handelen van ook de overheid beoordeelde. Dat deed hij dan in het kader van een onrechtmatige daadsvraag, terwijl hij oordeelde over feitelijk handelen, ook in de vorm van bevoegdheidsuitoefening (anders gezegd, gezagsuitoefening) wanneer dat effecten had op de eigendom van burgers. Dit typische overheidshandelenzou door de invoering van administratieve rechtspraak onder de bestuurstechter kunnen komen, maar kwam daar aanvankelijk niet terecht, omdat de afbakening van beide rechtsmachtenniet langs deze scheidslijn verliep. Naar de letter van de

2. Vgl. 1.G. Steenbeek, Rechtshandeling en rechtsgevolg in het Staats-en administratief recht, diss., Assen 1958, p. 69. 
Grondwet valt typisch overheidshandelen dat eigendom of andere burgerlijke rechten en schuldvorderingen raakt immers onder de competentie van de burgerlijke rechter.

De burgerlijke rechter bepaalde zijn competentie vanuit het perspectief van de burger (Guldemond-Noordwijkerhout). De administratieve rechter werd door de wetgever telkens competent verklaard naar object. De invoering van administratieve rechtspraak leverde dus problemen op, doordat de verschillende benaderingswijzen van het objectum litis en het fundamentum petendi, tegenover elkaar kwamen te staan. Niettemin hield verhoogde rechtsbescherming door de bestuursrechter de belofte in voor de burgerlijke rechter dat hij kon terugtreden. De techniek van de niet-ontvankelijkverklaring was het eerste instrument dat gehanteerd werd in deze discussie. De bevoegdheid van de burgerlijke rechter bleef daarbij wel bestaan; de techniek leidde tot niet in behandeling nemen van de raak (niet-ontvankelijkheid betekende dan buiten behandeling laten).

Een andere oplossing bij botsingen met het overheidsgezag wordt gevormd door het besluit met overheidsgezag terzijde te laten ( $V_{\&} D$ en Super Doe-Groningen). Weer een andere methode vornt de niet-toetsbaarheid ofwel de formele rechtskracht. In dat geval is de burgerlijke rechter bevoegd en laat hij de zaak ook niet buiten behandeling; hij doet wel degelijk uitspraak, alleen houdt die uitspraak in dat hij het oordeel van een ander overneemt (Hei- en Boeicop en St. Oedenrode-Driessen).

Zo tracht de burgerlijke rechter zijn rechtsmacht vorm te geven. Waar uiteraard ook de administratieve rechter waakt over zijn bevoegdheid, is een voortdurend spel van aantrekken en afstoten van rechtsmacht gestart op terreinen op het grensgebied van privaat- en publiekrecht. Steeds als duidelijk is of wordt dat de bestuursrechter een terrein definitief afstoot, zal de burgerlijke rechter aanvullen. Is afstoting niet duidelijk, of trekt de bestuursrechter 'opeens' een terrein tot zich, dan treedt de burgerlijke rechter terug. In dat waaierende terrein schrijdt de rechtsbescherming voort.

In zo'n klimaat lijkt formele rechtskracht voor de burgerlijke rechter een aantrekkelijk instrument om adequaat aanvullende rechtspraak te kunnen bieden. De formele rechtskracht, die hier wordt gehanteerd als onaantastbaarheid, lijkt zo'n adequaat instrument. Onaantastbaarheid is immers duidelijk en zeker (want is er of is er niet).

Formele rechtskracht is de meest recente methode in het aloude afbakeningsvraagstuk. Via de band van de onaantastbaarheid (en dat impliceert niet-toetsbaarbeid) kon formele rechtskracht in het civiele gedachtengoed worden binnengehaald. Door het aldus te beschouwen als procesrechtelijk middel leek het de belofte in zich te dragen dat het afbakeningsvraagstuk definitief kon worden opgelost.

In z:jn arrest Heesch-Vande Akker definieert de Hoge Raad formele rechtskracht expliciet. Daardoor is het voor de rechtsvorming een belangrijk arrest. De relevante overwegingen van de Hoge Raad luiden als volgt:

3.3.1 De onder 3.1.5 (: weergave van de oordelen van het hof, EvdL) weergegeven opzet van 's hof's gedachtengang vergt vervolgens beantwoording van de door de middelen II en III aan de orde gestelde vraag of het hof het primaire betoog van de gemeente - kort gezegd: dat de betaling berust op een beschikking wet 
formele rechiskracht hierwoor 3.1 .4 (: weergave van in mechte ingenomen standpunten, EvdL) - terecht heeft verworpen.

3.3.2 Deze wrang moet bevestigend worden beantwoond. Voorop moet worden gesteld dal wanneer tegen een beschikking een met voldoende waarborgen omklode administratiefrechtelike rechtsgang heef opengestaan (zoals die ingevolge de Wet Arob), de burgerlijke rechter, 20 deze beroepsgang niet is gebruikt, itl geval de geldighe id van de beschikking in het woor hem gevoerde geding in geschil is, ervan dient uit te gaan dat die beschilkking zowel wat haar wigze van tot stand komen alls wat haar inthoud betreft in overeenstemning is met de desbetreffende wettelijke voorsehriften en algemene rechtsbeginselen. Dit geldt in beginsel bôk dan, indien dir de burgerlike rechter ertoe zou nopen aan zijn witspraak de rechtsgeldigheid ten grondslag te leggen van een beschikkhing waarvan als waststaand mag worden aangenomen dat $7 i i_{\text {, }}$ às daantegen tijdig admuinstratiefrechielijk beroep zou zijn ingesteld, zou zijn wernietigd. De daaraan verbonden bezwaren kurnen evenwel door bijkomende omstandigheden zo klemmend worden dat op dat beginsel een witzondering moet worden aanvaard. Of voor zulk een uilzondering plats is, hangt bjgevolg af van de bijzonderheden wan het gegewen gewal. ${ }^{3}$

Deze hoofdregel van formele rechtskracht zoals de Hoge Raad die hier heeft geformuleerd bevestigt de geschetste lijn wan het overnemen van het oordeel zoals dat in het bestuursrecht tot stand is gekomen; aldus wordt de afbakening van rechtsmacht vorm gegeven. De hoofdregel betekent dat wordt uitgegaan van de rechtmatigheid (naar totstandkoming en naar inhoud) van het bestuursrechtelijke oordeel. Zo vermijdt de burgerlijke rechter dat hij dat bestuursrechtelijke oordeel moet geven. Maar slechts daar walar de mogelijkheid bestaat dat de burgerlijke rechter treedt in die bestuursrechtelijke rechtsuitleg, haakt hij af. Zo voorkomt de burgerlijke rechter dat hij treedt in de beoordeling die hij aan de bestuursrechter voorbehouden acht.

Waarom is de formeel rechtskrachtige beschikking voor de burgerlijke rechter onaantastbaar? Waarom toetst hij de gerichtheid op de norm, de publiekrechtelijke rechtsvaststelling, de rechtshandeling als rechtshandeling, niet? Een verklaring kan zijn dat dit, de gerichtheid op de norm, een normatief, objectief, oordeel behelst. De burgerlijke rechter is niet gewoon op die wijze te toetsen (en acht zich daarom daartoe niet bevoegd); niet voor niets zegt hij vaak zelf dat de wetgever voor dit oordeel een terzake meer deskundig geachte specifieke rechter heeft aangewezen. Het binnenhalen van het bestuursrechtelijke oordeel, anders gezegd het overnemen wan het oordeel in administrativo inzake de formele rechtskracht van de beschikking, maakt het mogelijk om dat normatieve oordeel verpakt als. 'feit' binnen te halen; vandaar dat dit 'feit' onaantastbaar moet zijn.

Uitzonderingen op de hoofdregel houden toetsing door de burgerlijke rechter in; wat en waardoor beoordeelt hij nu wel? $\mathrm{Nu}$ formele rechtskracht onaantastbaarheid van het bestuursrechtelijke oordeel betekent, zal de rechtmatigheid van het - resterende - feitelijk handelen wel steeds beoordeeld worden door de burgerlijke rechter. Toetsen kan de burgerlijke rechter in die situatie wel, omdat de gerichtheid op rechtsgevolg van de beschikking (de publiekrechtelijke rechtsvaststelling) in die gevallen niet aan de orde is en de beschikking louter als feit, als gegeven een rol speelt. Eigenlijk wordt er in die situatie dus ook niet getoetst, althans niet aan normen van publiekrecht, maar worden - slechts - 'feiten' op 
hun feitelijk karakter beoordeeld; het hangt dus van de inkleding van het inleidende processtuk af of de burgerlijke rechter zal ontvangen en zal toetsen.

Heeft de burgerlijke rechter zich laten inspireren door de bestuursrechter? Hoe wordt daar met (formele) rechtskracht omgegaan? Ook hier is de formele rechtskracht bekend als een ontvankelijkheidsinstrument. Na verloop van de beroepstermijn heeft de beschikking immers formele rechtskracht gekregen. Bestuursrechters hanteren vaak de term rechtens vaststaand of onherroepelijk geworden als synoniem voor deze formele rechtskracht. Deze formele rechtskracht wordt ook wel gezien als onaantastbaarheid ten opzichte van de bestuursrechter of ten opzichte van derde-belanghebbenden.

De materiële rechtskracht, zoals die vaak tegenover deze formele rechtskracht wordt onderscheiden, wordt wel onder de noemer intrekbaarheid of wijziging aangeduid. De schrijvers hebben daarmee doorgaans de onaantastbaarheidjegens het handelende orgaan op het oog. Welke betekenissen hechten auteurs aan formele en materiële rechtskracht?

Voor auteurs als Van der Pot, Donner, maar ook Van Wijk, Stellinga, Van der Burg/Cartigny, De Haan/Drupsteen/Fernhout, De Jong, Konijnenbelt/Van Male betekent formele rechtskracht onaantastbaarheid en materiële rechtskracht intrekking en/of wijziging. Dit definitiepaar is het eerste dat in het bestuursrecht opkomt. De door de burgerlijke rechter gehanteerde formele rechtskracht-onaantastbaarheidkan zodoende gebaseerd zijn op deze in het bestuursrecht gehanteerde.

Dit begrip onaantastbaar lijkt nogal statisch, alsof de beschikking onveranderbare situaties in het rechtsleven roept. Dit probleem werd al door Donner onderkend; hij hanteert daarom als uitersten op een lijn de moeilijke termen starheid en plooibaarheid met betrekking tot rechtskracht. Een bestuursorgaan moet vrij zijn om - weer - wijzigingen aan te brengen in de rechtssituatie (die door de oorspronkelijke beschikking is gecreêerd) maar anderzijds heeft de openbare dienst belang bij duidelijkheid en dus moet een rechtssituatie aanwijsbaar vaststaan.

De vraag moet dan ook anders gesteld worden: formele rechtskracht is onaantastbaarheid van wat? En ook: materiële rechtskracht is intrekking en/of wijziging, maar wat wordt er ingetrokken of gewijzigd? Als vanuit het perspectief van het bovenstaande auteurs hierop antwoord geven, dan zal dat zeker luiden onaantastbaarheid, intrekking of wijziging van het besluit (de beschikking). Zo bezien worden de zaken vertroebeld voor het woetlicht gebracht, immers een besluit als op enig moment vastgesteld is zeker statisch en onaantastbaar, maar de gevolgen die dat besluit heeft bewerkstelligd zijn lang zo onaantastbaar niet. Donner voelde intuitief wel aan dat de materiële rechtskracht (van rechtsgevolgen) zichtbaar wordt bij intrekking en wijziging: starheid is verbonden met een aanwijsbaar moment, terwij] plooibaarheid leidt tot aantasting van de rechtsgevolgen, de rechtssituatie-bijvoorbeeld op basis van actuele maatstaven.

De tweede definitie van rechtskracht die in het bestuursrecht de ronde doet is die van Vegting: duurzaamheid verbonden met juridisch bestaan (formele rechtskracht) en werbonden met - in tijd en naar personen gespreide - effecten (materiële rechtskracht). 
De derde betekenis - van Steenbeek - definieert formele rechtskracht op een - aflopend moment (eigenschap van de rechtshandeling) en materiêle rechtskracht als blijvend (eigenschap van het rechtsgevolg). Feit en gevolg worden aldus expliciet onderscheiden; deze tweedeling in formele en materiële rechtskracht houdt rekening met de verschillende actoren die in het publiekrecht kunnen handelen, maar ook met de factoren tijd en plaats. Feit en gevolg krijgen invulling als vorm en inhoud. Dat deze inhoud (de gevolgen dus) genormeerd wordt door het recht (de bemiddelende functie van normen tussen werkelijkheid en rechtswerkelijkheid) blijft bij Steenbeek onderbelicht.

Het lijkt overigens onwaarschijnlijk dat de burgerlijke rechter een van deze laatste betekenissen van formele rechtskracht als inspiratiebron heeft gebruikt voor zijn eigen definitie van formele rechtskracht als synoniem met onaantastbaarheid.

Niet alleen bestuursrechtelijke auteurs hanteren definities van formele en materiële rechtskracht, ook bestuursorganen en bestuursrechters gebruiken de begrippen. Formele rechtskracht is te beschouwen in een spanningsrelatie tussen bestuursorgaan en bestuursrechter. Dit behoeft toelichting.

Formele rechtskracht vindt zijn rechtvaardiging in het rechtszekerheidsbeginsel. Duidelijk en voorzienbaar moet voor belanghebbende zijn wanneer de beschikking vast staat. De beschikking is als laatste en meest concrete stap het instrument dat de rechtssituatie wijzigt of, met andere woorden, de publiekrechtelijke rechtssituatie normeert. Een wijziging in de rechtssituatie is daarmee steeds objectief en tot een ieder gericht, heeft met andere woorden erga omnes-werking. De rechtssituatie of de inhoud van de gewijzigde rechtssituatie moet dan ook voor ieder kenbaar zijn voordat men er aan gebonden wordt. De voortgang van de openbare samenleving eist dat dat binnen afzienbare tijd gebeurt. Door insteiling van korte beroepstermijnen is dat ook het geval.

Tegelijkertijd moeten bestuursorganen in hun uitoefening van het algemeen belang kunnen "spelen' met bevoegdheden; het al of niet afgeven van beschikkingen, het wijzigen of intrekken van beschikkingen moet met een zekere flexibiliteit kunnen plaatsvinden. Vandaar dat de rechtskracht van beschikkingen, die voor belanghebbenden een duidelijke starheid kan vertonen, voor bestuursorganen een meer flexibele omvang moet hebben. In zo'n situatie staan twee kenmerken van rechtskracht tegenover elkaar. Dan staan enerzijds de erga omnes-werking (die voortvloeit uit de rechtszekerheid) en anderzijds de uitvoering of concretisering van het collectieve algemeen belang (die object is van bevoegdheidsuitDefening door bestuursorganen) tegenover elkaar in een spanningsrelatie.

Het bestaan van een bevoegdheid verleent aan actoren (bestuursorganen) de potentie om rechiskracht aan een rechtshandeling mee te geven. Rechtskracht is zodoende steeds verbonden aan de bevoegdheidsuitoefening. Daardoor ontstaat de situatie dat de bevoegdheidsuitoefening enerzijds (als publiekrechtelijk handelen) objectief is, gericht jegens allen (erga omnes) en anderzijds (als feitelijk handelen) subjectief is, individuen raakt in hun belang (inter partes).

Dit als uitgangspunt nemende kijken we naar de formele rechtskracht van beschikkingen in het administratief recht; duidelijk zal inmiddels zijn dat een onderscheid aangebracht moet worden in perspectief (van bestuursorganen, van rechters, van burgers). Vanuit het perspec- 
tief van het bestuursorgaan staat immers de objectieve gezagsuitoefening altijd voorop; vanuit het perspectief van de rechter de subjectieve bevoegdheidsuitoefening en het belang van individuen. De administratieve rechter heeft het helemaal moeilijk: hij verkeert in een 'dubbele' positie; enerzijds wil hij - als rechter immers - individuele rechtsbescherming verlenen (ingevolge de doelstelling van de Algemene wet bestuursrecht) en anderzijds handhaaft hij het objectieve recht (want zijn rechtsmacht is - ook in de Awb - op besluiten betrokken en vereist een algemene belangenafweging, die kan leiden tot vernietiging). De (materiële) rechtszekerheid gebiedt dat belanghebbenden mogen vertrouwen op beschikkingen met formele rechtskracht. De (formele) rechtszekerheid gebiedt dat er duidelijkheid is ten aanzien van beschikkingen met formele rechtskracht.

Wanneer, dat will zeggen op welke dag, gaat formele rechtskracht in? Ten aanzien van deze vraag spelen twee benaderingen voortdurend door elkaar. Theoretisch gezien kan de beschikking formele rechtskracht verkrijgen ofwel na een correcte afkondiging door het bestuursorgaan ofwel ma ongebruikt verlopen van de beroepstermijn ofwel na verloop van de (gehele) bestuursrechtelijke procedure. Daartussen kunnen in beginsel maanden, zo niet jaren liggen. Vraag is daarmee welk het moment is van de afronding van de competente rechtsvorming. Wanneer het bestuursrecht in een procesrechtelijk vertoog wordt opgevat (het rechtsbeschermingsdenken), zal de formele rechtskracht pas kunnen aanvangen aan het eind van de administratiefrechtelijke procedure of, bij ongebruikt verstrijken van de beroepstermijn, aan het einde van die beroepstermijn. In benaderingen van het bestuursrecht die primair uitgaan van de bevoegdheidsuitoefening (het bevoegdheids- of besluitvormingsdenken) zal het moment van verkrijging van de formele rechtskracht bij het begin wan die procedure liggen. Daarop is als uitzondering te bedenken dat de formele rechtskracht van de bevoegdheidsuitoefening nog niet perfect is zolang de bestuursrechtsgang nog niet volledig is doorlopen. Aldus zal op moment 1. van onderstaand schema de formele rechtskracht zijn ingetreden wanneer men uitgaat wan de bevoegdheidsuitoefening. Dit geldt dan als vaststaand moment, tenzij de uitzondering (uitoefening nog niet perfect) wordt aangenomen, omdat in dat geval het moment van rechtskrachtverkrijging ligt op moment 2 . De uitzondering (uitoefening nog niet perfect) valt dan samen met het moment van rechtskrachtverkrijging in het procesrechtelijke uitgangspunt. Ondertussen kan een civiele procedure starten; dat geschiedt dan op enig moment $y$.

Schematisch gezien:

$\mathbb{1}$

2 (administratieve procedure)

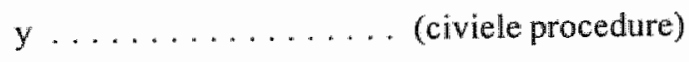

Op moment 1. wordt de beschikking genomen (moment van rechtskrachtverkrijging vanuit het bevoegdheidsdenken). Op moment 2 . is de bestuursrechtelijke procedure volledig doorlopen (moment van rechtskrachtverkrijging vanuit het procesrechtsdenken). Op moment $y$. start (wellicht) de civiele rechtsgang. 
Zoals al is gebleken, kan de invoering van het beginsel van de formele rechtskracht van beschikkingen door de burgerlijke rechter worden beschouwd als het binnenhalen van een instrument ter afbakening van rechtsmachten. Daarbij werd - zoals hier duidelijk is geworden - de formele rechtskracht aanvankelijk wooral benaderd vanuit het procesdenken (als instrument in een rechtsmiddelenstelsel). Deze betekenis is in het bestuursprocesrechi eveneens herkenbaar, al wordt daar doorgaans van een rechtens vaststaand besluit of van onherroepelijkheid van een besluit gesproken. In de bevoegdheidsbenadering is formele rechtskracht een eigenschap van een beschikking die deze heeft op het moment van het nemen van het besluit. Daardoor geeft het bestuursorgaan iets authentieks, een geldigheidstempel mee aan de beschikking. De bevoegdheidsuitoefening als gezagsuitoefening heeft - als product van objectief recht - erga omnes-werking. Deze betekenis van rechtskracht in het bevoegdheidsdenken is eveneens gebleven: de eigenschap van beschikkingen als uitdrukking van de publiekrechtelijke gezagsuitoefening met erga omnes-werking. Twee werschillende betekenissen (beter gezegd karakteristieken) van rechtskracht staan dan tegenover elkaar: onaantastbaarheid aan de rechtshandeling-kant (procesdenken) en erga omnes-werking aan de gevolg-kant (bevoegdheidsdenken).

Conclusie van dit alles is dat we moeten constateren dat de formele rechtskracht in het publiekrecht een uiterst relatieve betekenis heeft. Een uiterst relatieve betekenis is niet hetzelfde als geen betekenis. Het betekent niet dat de formele rechtskracht er niet is, of dat die er niet zou moeten zijn. Het betekent wel dat bestuursorganen en bestuursrechters op verschillende wijze met formele rechtskracht omgaan. Voor bestuursorganen staat daarbij flexibiliteit voorop; zij focussen op de rechtsgevolgen, de materiële rechtskracht, waardoor zij de relativiteit van de betekenis van formele rechtskracht van het besluit - althans voor zichzelf - onderstrepen. Voor de binding van de burgers is formele rechtskracht effectief. Deze nuancering tussen strakke binding voor de burger en relatiewe binding voor zichzelf biedt bestuursorganen juist de hele attractie van rechtskracht. Aldus is rechtsbescherming tegen eenmaal genomen besluiten een betrekkelijke waarborg tegen bestuursmacht. Ook bestuursorganen willen echter zeker zijn dat een eenmaal genomen besluit vaststaat. Dat verklaart eveneens waarom bestuursorganen in procedures wel eens het rechtskarakter van bepaalde handelingen als besluiten (met formele rechtskracht) willen duiden. Daarmee betreden we het terrein van de uitzonderingen op de hoofdregel van formele rechtskracht zoals door de burgerlijke rechter werd mogelijk gemaakt.

Hoe verloopt de verdere ontwikkeling van de formele rechtskracht bij de burgerlijke rechter? Het gevolg van het aannemen van formele rechtskracht door de burgerlijke rechter is dat deze niet zelf (meer) hoeft te toetsen. Hij treedt terug, maar slechts in zoverre als met thet ten tonele voeren van de beschikking de vraag gesteld wordt naar de gerichtheid op de publiekrechtelijke norm, de publiekrechtelijkerechtsvaststelling. Hij neemt dan het bestuursrechtelijke oordeel over.

De belangrijke vragen die hierdoor ontstaan, dat wil zeggen die ontstaan als de burgerlijke rechter formele rechtskracht aanneemt en overgaat tot het overnemen van het bestuursrech- 
telijke oordeel, zijn of hij dat bestuursrechtelijke oordeel compleet overneemt (1) en of hij daarmee ook wel hetzelfde overneemt (2)?

De eerste vraag leidt naar de omvang van formele rechtskracht en in het bijzonder naar de uitzonderingen op formele rechtskracht. De uitzonderingsmogelijkheid op de hoofdregel van formele rechtskracht fungeert als een hardheidsclausule. Dat past geheel in de alomvattende traditie van bevoegdheid van de burgerlijke rechter. Na Heesch-Van de Akker zien we dan ook een lijn in de jurisprudentie met verschillende pogingen om een uitzondering aangenomen te krijgen.

Er zijn bij de burgerlijke rechter uitzonderingen mogelijk op de formele rechtskracht van beschikkingen. Deze uitzonderingen worden aangenomen wanneer er bijzondere omstandigheden zijn die leiden tot klemmende bezwaren tegen het vasthouden aan de hoofdregel. In hoofdlijnen zijn er twee typen uitzonderingen. De eerste wariant is er wanneer er sprake is van 'misleiding' door de overheid. De tweede variant wordt aangenomen als partijen het met elkaar eens zijn over de juridische status (het rechtskarakter) van het voorwerp van geschil; dan is er met andere woorden eenstemmigheid tussen partijen over de (on)rechtmatigheid van de beschikking.

De uitzonderingen zijn aan elkaar tegengesteld. De eerste uitzondering staat in het teken van het perfectioneren, het vervolmaken, het nóg beter tot zijn recht laten komen van de administratieve rechtsbescherming; bij hiaten in de rechtsbescherming is deze uitzondering immers mogelijk. Deze eerste variant, "misleiding" door de overheid als uitzondering op formele rechtskracht, bevestigt het systeem van de administratieve rechtsbescherming.

De tweede uitzondering, partijen zijn het met elkaar eens, staat in het teken van de wilsovereenstemming. Het is een uitzondering waardoor de derde buiten spel kan worden gezet. $Z i j$ staat daarom op gespannen voet met een systeem waarin rechtmatigheidsoordelen in objectieve zin erga omnes worden gegeven (bestuursrecht).

Nadat de uitzonderingsmogelijkheid enigszins in beeld gekomen is, kijken we weer naar de hoofdregel; dan komt de tweede hierboven gestelde vraag in beeld. Als de burgerlijke rechter het bestuursrechtelijke rechtmatigheidsoordeel bindend overneemt, in hoeverre doet hij dat en neemt hij dan well hetzelfde over? Het bestuursrechtelijke oordeel houdt in ieder geval in een oordeel over een rechtssituatie ex tune (feit), dat objectief van aard is (norm) en dat erga omnes-werking heeft (gevolg). Neent de burgerlijke rechter deze "publiekrechtelijke benadering" over?

Een beschikking die niet in rechte is aangevochten wordt rechtsgeldig geacht. Het spiegelbeeld is eveneens waar: de beschikking die (in het bestuursrecht) is vernietigd, levert onrechtmatigheid op. Zo wordt niet-rechtsgeldigheid met civiele onrechtmatigheid vereen zelvigd, zodat vernietiging moet worden begrepen als burgerrechtelijke onrechtmatigheid. Het oordeel van de burgerlijke rechter is een inter partes-oordeel. De onatantastbaarheid van de beschikking met formele rechtskracht is voor hem dan ook niet een eigenschap met erga omnes-werking. Een bestuursrechtelijk vaststaand (feitelijk) gegeven over een beschikking op een bepaald moment (een ex tunc-oordeel) wordt ex nunc gekwalificeerd in het burgerlijk recht. 
Wanneer de burgerlijke rechter het bestuursrechtelijke oordeel overneemt, is dat niet hetzelfde oordeel. De burgerlijke rechter kiest (en dat is terecht) immers steevast voor het verbinden van inter partes-werking (gevolg) aan zijn uitspraken. Ook wordt het oordeel dat bij de burgerlijke rechter een rol speelt (vamuit bestuursrechtelijk oogpunt een ex tunc gegeven) pas actueel op het moment dat de burgerlijke rechter wordt geadieerd, dus ex nunc. Daarmee stelt de burgerlijke rechter een historisch gegeven centraal voor een kwalificatie (een normatief oordeel) nu. Zo bezien neemt de burgerlijke rechter NIETS over, want over dat ex nunc-moment heeft noch het bestuursorgaan noch de bestuursrechter ooit een oordeel gegeven.

Conclusie van dit alles is, dat de burgerlijke rechter appels en peren gelijkschakelt, terwijl de formele rechtskracht van beschikkingen niet het adequate instrument is om rechtsmacht af te bakenen of toetsingswijzen op elkaar af te stemmen. Beter zou het zijn als de burgerlijke rechter dat expliciet had gemaakt; dan zou ook de wetgever de noodzaak van een werkelijk adequate afbakeningswijze eerder aannemen.

Er zijn tekenen dat de strafrechter de definitie van formele rechtskracht van de burgerlijke rechter overneemt; hoe dat moet gebeuren en wat er precies wordt overgenomen is evenwel onduidelijk. In deze benadering van het begrip wordt geijverd voor gelijkstelling van de formele rechtskracht van de burgerlijke rechter en die in strafzaken. Deze gelijkstelling heeft sporen in (bestuursrechtelijke) Wet Mulder-zaken; daar zal de inspiratie zijn opgedaan.

Nadat de historische betekenis van het rechtskrachtbegrip bij de burgerlijke rechter, de bestuursrechter en de strafrechter in kaart was gebracht, werd de vraag naar de vreemde herkomst van het begrip voor het voetlicht geplaatst. De begrippen formele en materielle rechtskracht werden immers in Nederland geïntroduceerd op basis van een vergelijking met het Duitse, civielrechtelijke, Rechtskraftbegrip. De Jong inventariseerde de bronnen hiervan; ik heb zijn uitgezette sporen gevolgd, vervolgd en waar nodig (hiaten) aangevuld.

Wat is de herkomst en oorsprong van het rechtskrachtbegrip? Welk Duits begrip was maatgevend voor de discussie? Waaraan werd het begrip vastgeknoopt; waarvan was het begrip de eigenschap?

De Duitse discussie start bij het begrip 'materielle Rechtskraft' en ziet dat als eigenschap van rechterlijke vonnissen. Eenzelfde materiêle rechtskracht als de civiele uitspraak moest ook de administratieve uitspraak hebben, vond Bernatzik. Vervolgens wordt bij Mayer scherp dat de eigenschap materiële rechtskracht is vastgeknoopt aan het element "Urteil" van die civiele vonnissen. Daarmee is de theoretische overgang naar een eigenschap van ook besluiten van bestuursorganen gezet, omdat ook deze de potentie kunnen hebben om oordelen te geven. Tezner trekt die conclusie expliciet als hij de eigenschap rechtskracht uitbreidt over 'Verwaltungsakte'. De discussie spitst zich daarna toe op de vraag welke beslissingen van bestuursorganen dat constitutieve element, dat 'Urteil', bevatten. Dat 'Urteil' is bij de verschillende typen beschikkingen anders; sommigen zien dat 'Urteil' bij 'Verfügungen' (Beetschen), anderen bij 'Entscheidungen" (Bernatzik), weer anderen helemaal niet of juist bij beide (Tezner, Fleiner, Hemmrich, Jellinek). 
Wat houdt dat element "Urteil" dan eigenlijk in? Het is een procesrechtelijk verschijnsel dat pregnant tot uitdrukking komt bij uitspraken. Als je de beschikking ziet als een publiekrechtelijke rechtsvaststelling, dan bevat deze ook dat element 'Urteil'. Dat nu is precies wat Kormann op het oog had toen hij 'Rechtskraft' als eigenschap van alle publiekrechtelijke rechtshandelingen duidde. De eigenschap rechtskracht is dan verbonden met het constitutieve moment van rechtsvaststelling.

Bematzik heeft voorts de belangrijke wetenschap geleverd dat rechtskracht pas kan ontstaan als er sprake is van bevoegdheden (die hij verbindt met de opkomst van het concept van de rechtsstaat). Wanneer dit wordt verbonden aan het onderscheid tussen bevoegdheidsdenken en procesdenken betekent dat, dat een belangrijk onderscheid kan worden geexpliciteerd. Wolff benoemt dit verschil in rechtskracht voorafgaand aan de aanvang van de bezwaartermijn 'Bestandskraft' en rechtskracht vanaf dat processueel relevante moment 'Rechtskraft'. Dit is een belangrijk onderscheid voor het denken in rechtskracht, want doordat Wolff dat voor de Duitse situatie zo expliciet heeft onderscheiden, is het nu ook beter 'zichtbaar' voor de Nederlandse situatie. Om het onderscheid dit volle accent te geven heb ik voor de term 'Bestandskraft' als equivalent rechtsbestendigheid voorgesteld. Daarnaast is er dan de rechtskracht. Zowel rechtsbestendigheid als rechtskracht kennen een formele en een materiële variant.

Inmiddels weten we dat rechtskracht een eigenschap is. Ook weten we dat de aard van die rechtskracht nog steeds verschillend wordt gezien; zo wordt rechtskracht wel gedefinieerd als inter partes-onaantastbaarheid, als rechtens vaststaand en ook als erga omnes-werking van besluiten.

Bij Kormann zagen we dat rechtskracht als eigenschap werd gezien van alle publiekrechtelijke rechtshandelingen; hij zag kennelijk vergelijkbare, "universele", elementen. Zo werd rechtskracht als eigenschap van alle rechtshandelingen vermengd over de mogelijke dragers. Bij Wolff daarentegen gaat het weer uiteen en worden de onvergelijkbare elementen, de verschillen, weer naar woren gehaald.

Zo is wel de stelling verdedigd dat het constitutieve element doorslaggevend is woor het aannemen van rechtskracht. Zou dit constitutieve element iets 'universeels' vertegenwoordigen (zoals met name Erichsen en Mayer/Kopp uitdrukkelijk stellen), zodat verklaarbaar is dat rechtskracht de eigenschap is van vonnissen én beschikkingen (en van alle overheidsbesluiten)? De introductie van het rechtskrachtbegrip in Nederland is in ieder geval langs deze lijn gelopen; kennelijk is de vergelijkbaarheid op dit punt het duidelijkst. Zo wordt in ieder geval wel de civielrechtelijke oorsprong van het begrip verklaarbaar, althans begrijpelijk.

Verschillende auteurs, die over de betekenis van rechtskracht, formele rechtskracht en materiële rechtskracht schreven, baseerden zich op Kelsen en Merkl. Vegting deed dat expliciet. Steenbeek is niet $z_{0}$ expliciet, maar hij neemt wel uitdrukkelijk de positieve rechtsorde als uitgangspunt van elke studie aan. Zo kwam ik ertoe om het rechtskrachtbegrip te analyseren vanuit de theorie van de rechtspositivisten. Door zich te baseren op (of te laten 
inspireren door) de rechtspositivisten werd een belangrijke theoretische basis gelegd onder het rechtskrachtbegrip. Kreeg het begrip daardoor ook een specifieke betekenis?

Voor de betekenis van rechtskracht bij Kelsen is het onderscheid 'Sein' en 'Sollen' van belang. Normen behoren tot de wereld van het 'Sollen' net zoals dat het geval is voor gelding (geldigheid). Werking (effectiviteit) daarentegen is een kwestie van "Sein". Wanneer nu de betekenis van rechtskracht bij Kelsen kan worden gedefinieerd als werking door middel van gelding, dan is rechtskracht een feitelijk gegeven dat alleen kan bestaan doordat er een normatieve achtergrond is. Dit lijkt - prima facie - sterk op de door Steenbeek gehanteerde definitie: rechtskracht is erkenning door de rechtsorde.

Toch is dit merkwaardig, omdat Kelsen steeds spreekt van werkzaamheid van normen (waar Steenbeek rechtskracht van rechtsfeiten definieert als erkenning door de rechtsorde). Dat impliceert dat Kelsens rechtskracht alleen maar als definitie kan worden gehanteerd in de ziru van werking van de rechtsorde door middel van de gelding ervan; dan immers is het een feitelijk gegeven. Daarmee is blootgelegd dat zowel feit en norm ontrafeld moeten worden op het niveau wan rechtsorde (stelsel, systeem) als op het vlak van de (individuele) norm.

Ook Merkl ziet rechtskracht als werking door middel van gelding. Zijn rechtskrachtbegrip, duurzaamheid (of temporele werking), is een eigenschap van normen.

De rechtspositivisten beschouwen de structuur van een rechtsstelsel louter op formeellogische wijze. Het systeem van de 'reine Rechtslehre" valt aldus te beschouwen als de grammatica van een rechtsstelsel. Een rechtstelsel heeft logica als bouw-basis nodig; in die zin is het een noodzakelijk systeem. Gelede normstelling en hiërarchie van normen als concretiseringen van de 'Stufenbau' zijn niet meer weg te denken in westerse (staats)rechtstelsels. Maar, er zijn ook bezwaren tegen de 'reine Rechtslehre' in te brengen. Het meest genoemde, en meest bezwaarlijke element van hun theorie is ongetwijfeld dat het stelsel "inhoudsloos" is, in die zin dat elke gewenste inhoud via het subsumptie-principe tot recht kan verworden. Kelsen zegt zelf dat 'jeder beliebige Inhalt Recht sein kann'. Dat is onbevredigend, want al is in Kelsens optiek de 'Grundnorm' dan wel niet inhoudsloos, de techniek wan het recht maakt inhoudsloosheid wel degelijk mogelijk. Merkl trekt die lijn dan ook door naar in beginsel onveranderlijkheid van het recht, van een rechtsstelsel, juist omdat het is betrokken op een universele en eeuwig onveranderlijke 'Grundnorm'.

De conclusie moet zijn: wanneer Vegting en Steenbeek leunen op of geïnspireerd zijn door dit rechtspositivistische stelsel, waartegen bezwaren zijn in te brengen (inhoud is irrelevant; elke inhoud kan recht zijn), is het voor de hand liggend dat deze kritiek aanzwelt. Vanuit die aanzwellende kritiek is een nieuwe theorie opgekomen, die andere paradigmata dan het louter formeel-logische perspectief voor het bestuursrecht naar voren wilde schuiven. Dan hebben we het over het betrekkelijk nieuwe, jonge paradigma van de wederkerige rechtsbetrekking in het bestuursrecht, gebaseerd wellicht op de theorie van de autopoiese.

Teubners autopoietische benadering is bijzonder aantrekkelijk, met name omdat de dynamiek en het levend-zijn van recht daar wordt benadrukt. Dat wordt veroorzaakt door de cognitieve (informatieve) openheid van systemen. Systemen zijn echter wel autopoietisch gesloten. Deze autopoietische geslotenheid (dat wil zeggen de operationele geslotenheid) 
van systemen heeft ais ratio het bewaren wan de eigen eenheid en identiteit van het systeem. De formele rechtskracht zoals de burgerlijke rechter die (geinspireerd door het in het bestuursrecht bestaande begrip) heeft binnengehaald ter afbakening van zijn rechtsmacht met die van de bestuursrechter, doet deze autopoietische geslotenheid geweld aan. Dat geldt eveneens voor het hanteren wan het door de burgerlijke rechter gedefinieerde formele rechtskrachtbegrip door de strafrechter.

Aan de transcendentalistische benadering is de naam van Van Eikema Hommes verbonden. Van Eikema Hommes verwerpt de tweedeling 'Sollen' en 'Sein', de tweedeling in normen (als waarden) en feiten (als sociale werkelijkheid); de dialectische tweedeling bestaat niet en in plaats daarvan is het beter uit te gaan van de correlatie normzijde en feitelijke zijde van het recht. Van Eikema Hommes omzeilt de stelling dat de tweedeling normzijde en feitelijke zijde van het recht eveneens dialectisch is door in 'zijn' theorie zowel formele als materiele rechtskracht te analyseren vanuit het rechtsaspect. Dat rechtsaspect maakt dat er geen dialectische tweedeling is, maar creèert de correlatie, de wederkerige kruisbestuiving; dan zijn er geen antipolen meer. Het rechtsaspect beschouwt hij ais een normatief en objectief eigen-aard-ig aspect van de werkelijkheid. Daarbinnen plaatst hij een normzijde tegenover een feitelijke zijde. Materiële rechtskracht fungeert voornamelijk aan de normzijde van het rechtsaspect. Formele rechtskracht behoort tot de feitelijke zijde van het rechtsaspect.

Formele rechtskracht is de eigenschap van normen die ontstaat doordat de norm op een correcte wijze door een bevoegd rechtsvormer is tot stand gekomen (gelding van de vorm); het is een feitelijk gegeven. Materiële rechtskracht betekent do eigenschap van normen die ontstaat doordat de norm in overeenstemming is met bovenwillekeurige materiële rechtsbeginselen (gelding van de inhoud).

In de spectrale benadering wordt voomamelijk aansluiting gezocht bij het concrete positief recht. De rol van rechtskracht wordt daarin geduid, maar het begrip wordt niet expliciet gedefinieerd. De spectrale benadering leidt tot een pleidooi voor het maken van onderscheid in toetsing van rechtshandeling naar moment van toetsen (ex nunc en ex tunc), naar het object van toetsen (feit in concrete toetsing of norm in abstracte toetsing) en naar de aard van toetsing (objectief in de vorm van controle en subjectief in de vorm van reclitsbescherming).

\subsection{Rechtskracht: 'De kleren van de Keizer'}

Het is tijd voor mijn eigen visie. Twee stellingen en daarmee verband houdend twee karakteriseringen van het begrip rechtskracht blijven daarbij overeind: rechtskracht is erkenning (paragraaf 4) en rechtskracht is 'illusie' (paragraf 5), kortom, rechtskracht is 'Kleren van de Keizer". 
Naar aanleiding van een dissertatie 4 over artikel 53 van onze Grondwet van 1848 meende ik de essentie van rechtskracht te herkennen. Het in de Grondwet neergelegde beginsel van de democratische rechtsstaat: "De Koning is onschendbaar, de ministers zijn verantwoordelijk", werd door Krol geanalyseerd. Een nieuwe gedachte was de aandacht voor de koningsmythe: de koning wil wel goed, maar hij wordt geadviseerd door kwaadwillende raadslieden/ministers. De koningsmythe werd op veel plaatsen herkend: tussen koning en ministers, tussen president en adviseurs; tussen dictator en handlangers, tussen minister en diens ambtenaren; kortom, de koningsmythe gaat over macht. Wie is de machtige? Degene die met rituelen omhangen is of diens raadgever? Degene die het lint doorknipt of zijn dienaar? Degene die de massa's toespreekt of zijn propaganda-maker? Degene die (formeel) beleid uitvoert of degene uit wiens koker dat belleid komt?

Wat is nu de essentie van rechtskracht? Is rechtskracht 'De kleren van de Keizer?" ? Is rechtskracht dan niets, kale naaktheid, een transparant gewaad, een luchtballonnetje, een lege dop, een aanname, een fictie? Maar, al was de Keizer dan wel naakt, hij had toch nuet niets aan. Hij droeg een fictie, hij was omhuld met de een of andere uitdrukkingsvorm van intelligentie (in de koningsmythe: rechtvaardigheid), hij was behangen met een idee Rechtskracht is een fictie, rechtskracht is het mechanisme van omzetting van macht in rechtvaardigheid, rechtskracht is kracht van recht, rechtskracht is de vertaalslag wan de rechtsidee naar de werking van die rechtsidee, rechtskracht is die eigenschap van publiekrechtelijke rechtsfeiten, die de overgang van feit naar (publiek-)recht markeert.

Wanneer rechtskracht wordt bezien als ijkpunt van de overgang van feit naar (publiek)recht, kan de stelling worden staande gehouden dat rechtskracht steeds, bij elke publiekrechtelijke rechtsfiguur, kortom, 'universeel' aanwezig is. Aldus is de titel van deze studic tot stand gekomen; de kleren van de Keizer waren weliswaar onzichtbaar, maar ze waren er wel. Deze aanwezigheid van de kleren staat voor de stelling dat rechtskracht in het publiekrecht altijd aanwezig is.

\subsection{Rechtskracht is erkenning}

Ook Steenbeek dacht dat rechtskracht steeds aanwezig is, want hij vat de essentie van rechtskracht samen als erkenning door de rechtsorde. Recht zijn, zo verdedigde hij, is rechtskracht hebben.

De vraag die daarmee gesteld is, luidt als rechtskracht erkenning is door de rechtsorde, van wat is dat dan erkenning; wat wordt waarom erkend? Daarop kan geantwoord worden dait rechtskracht erkenning is van de relevantie van feiten voor normen, zodat gevolgen actief kunnen worden bewerkstelligd.

4. Vgl. Cl.B. Krol, Als de Koning dit eens wist ...!, diss., Antwerpen 1994.

5. De vergellijking is uiteraard gebaseerd op het bekende sprookje "De nieuwe kleren van de Keizer" van H.C. Andersen, vele versies. 


\subsection{Rechtskracht is "illusie"}

Rechtskracht als erkenning is een altijd aanwezig fenomeen. Dat maakt het wluchtig, onzichtbaar. Zo bezien is het begrip toch moeilijk te vatten. Dit whuchtig typeren in juridisch jargon, het "onzichtbare" benoemen, kan met behulp van de abstractie fictie. Dan is rechtskracht een fictie, een 'illusie'. Ook daarom is rechtskracht de kleren van de Keizer, want al even onzichtbaar als die kleren. De tweede stelling van deze studie betreft dit "onzichtbare" dat kennelijk aan rechtskracht kleeft. Dit behoeft toelichting.

Het beschouwen van rechtskracht als altijd aanwezige fictie ontstond doordat ik een beschouwing las over stillevens. ${ }^{6}$ Ook rechtskracht zag ik toen als $20^{3} n$ momentopname van het alledaagse in het recht. Net als stillevens moest rechtskracht iets weergeven dat zich normaliter aan het oog, aan de waarneming onttrekt. Altijd aanwezig is rechtskracht, net zoals de gebruikswoorwerpen die vaak in stillevens zijn afgebeeld. Toch is de ene vork de andere niet, en dat geldt eveneens voor voedsel, fruitschalen, borden of planten. En stillevens zijn van alle tijden. Evenals het verschijnsel rechtskracht geeft het stilleven die ene interpretatie van het leven van alledag weer. Zo is rechtskracht als de momentopname van het rechtsleven vanuit de perspectieven van verschillende actoren, beschouwers van het recht even veelzijdig als stillevens dat zijn. Hoe moest ik het stilleven, rechtskracht, lezen? Is het een uitingsvorm van rhopografie (beelden van alledaagsheid, het triviale) of van megalografie (beelden van het verhevene)? Hoe realistisch zijn stillevens of simuleren ze een werkelijkheid?

De Romeinse stillevens, de zogenaamde xenia, dragen sporen van zowel deze vragen van representatie, maar gaan ook over kwesties van macht (klassenverschillen, de macht over de natuur en de zeggenschap over de representatie). Laat ik hier een uitstapje maken naar deze stillevens. Daarna zal ik het verband leggen met rechtskracht.

De Romeinse xenia vormen een categorie van afbeeldingen in villa"s, die als stillevens avant la lettre kunnen worden beschouwd. Soms zijn het afbeeldingen van voedsel, soms van gebouwen. Ze verbeelden echter allemaal illusies. De waarde van het stilleven zit hem dan niet in de realistische afbeelding van een tuin op de muur waarachterzich de tuin inderdaad bevindt, maar het scheppen van de illusie dat men zowel binnen als buiten is, want ook binnen is de om de ruimte heenliggende tuin waarneembaar. Op die wijze kon het verwende publiek geamuseerd worden. Realisme is woor de Romeinse schilders een methode geweest om illusies, bijvoorbeeld van ruimteloosheid of tijdloosheid, op te wekken. Bekend is Plinius' verhaal van de wedstrijd tussen Parrhasius en Zeuxis. ${ }^{7}$ In de kunstgeschiedenis kent

6. It heb gebruik gemaakt van de vertaling door Mieke Bal en Gineke von den Heuvel van Norman Bryson, Het ongeziene in beeld, vier essays over het stilleven, Amsterdam 1993; oorspronkelijke titel Looking at the Overlooked: Four Essays on Still Life Painting.

7. Voor de liefhebber: "descendisse hic in certamen cum Zeuxide traditur at, cum ille detullisser uyas pictas tanto successu, ut in sceanam aves advolarent, ipse detulisse linteum picum ita veritate repraesentata, ut Zeuxis alitum iudicio fumens flagitaret tandem remoto linteo ostendi picturam atque intellecto errore concederet paiman ingenwo pudore, quoniam ipse volucres fefelliset, Parrhasius autem se artificem." uit: $\mathbb{C}$. 
het werhaal zijn plek als parabel van realisme. Beide schilders trachten naar beste kunnen een woorstelling te maken. Zeuxis liet een schilderij zien van wat druiven, dat zo natuurgetrouw was dat vogels tegen de muur van het toneel vlogen. Parrhasius liet een schilderij zien van een gordijn en dat was zo realistisch geschilderd, dat Zeuxis uitriep dat zijn rivaal het gordijn maar eens moest opentrekken om zijn schilderij te laten zien. Toen Zeuxis doorhad dat hij fout zat, gaf hij de prijs aan Parrhasius, terwijl hij toegaf dat hij alleen maar de vogels had bedrogen, maar dat Parrhasius hem, een schilder, voor de gek had gehouden. Bryson benadrukt de plaats van de wedstrijd: op het toneel, in het theater. Zeuxis' druiven maken dat de vogels komen aanvliegen. Vliegen ze tegen het geschilderde vlak? Nee, Plinius spreekt hier van het vliegen van de wogels tegen de muur van het toneel. Daaruit concludeert Bryson dat Zeuxis' schilderij een voorbeeld is van het genre scenografie, schilderwerk voor het toneel. Het gordijn kent ook zo'n boodschap: zou het schilderij verborgen zijn achter een gordijn? Anderzijds, de afscherming door middel van een gordijn is op zichzelf al een theatraal gebaar. Dubbel theatraal wordt het als de onthulling van de afbeelding van de neponthulling plaatsvindt in een theater.

\footnotetext{
"Wat opvalt is dat in beide delen van het verhaal het idee van het toncelmatige aanwezig is en dat de relatie iussen de schilderkunst en het theater wordt benadrukt. Het gaat hier zonder meer over illusionisme, maar dan wel een zeer speciaal soort illusionisme. We hebben niet te maken met regelrechte imitatie, waarin een echt voorwerp $a$ is uitgebeeld in afbeelding b: chte druiven aan de ene kant, het schilderij aan de andere kant. Nee, het verhal brengt de imitatie eerder op een hoger plan, een soort imitatie in het kwadrat. Stel je de wlucht vogels woor, die op Zeuxis' afbeellding afkomt. De reis begint in de lucht, in de natuurlijke wereld, en we mogen ammemen dat de warneming van de vogels zelf is opgevat als pre-cultureel en pre-symbolisch (daarom is Zeuxis' prestatie zo indrukwekkend). Vervolgens verlaten de vogels die pre-culturele zone en konen de ruimte van het theater binmen. Er heeft een verschuiving plaatsgevonden wan het ene soort ruimte naar het andere, een overgang van een naluurlijke rumte buten de representatie naar een culturele ruimte waarin de representatie is gehuisvest. Daarna overschrijden de wogels nog een grens, en wliegen het gebied wan het toneel zelf binnen (iw sceanawy); hier zijn de condities van de echte wereld, in dit geval de wereld van de zaal, opgeschort en krijgt de rumte wan de fictie de overhand. Tenslotie wiegen de vogels tegen het geschilderde oppervlak van het achterdoek aan. Hier legt de wereld van het toneel het af tegen de wereld die in het geschilderde beeld wordt getoond, een ruimte die bimnen de fictieve toneeliruimte nog weer fictiever is, zodus een toncelstuk in een toneelstuk.

De abeeldugen die Plinius besclirijli maken in feite deel wit vay een uiterst gecompliceerd spel van verschuivingen Iussen verschillende ontologische niveaus, die van elkaar worden gescheilden door nawwheurig bepalbare grenzen of drempels. Een eerste drempel scheidt de natuur (oningevuld, asymbolisch) van de whesmene zone van de cultuur (architectutr). Een tweede drempel binnen de architectuur van het theater scheid: de zaal van het toneel. Een laatste drempel brengt en scheiding aan tussen de ruimte van het toncel an de ruimte binnen bet beeld. Het verloop wan het verhaal bestaat uit teen snelle beweging dwars door een reeks in elkaar geschoven ruimtes, die door hun specifieke relatie ten opzichte van illusie en werkelibkheid van elkatar te onderscheiden zijn. De iwee opmerkelijke "stillevens" van Zeuxis en Parhasius zijn binnen dit traject geconstrueerd. Als de anekdote alleen maar ging over levenseclutheid, dan zou deze ingewikkelde, opeenvolgende reeks drempels overbodig zijn. Maar juist die ingewikkeldheid is de inzet van het verhal. ${ }^{8}$
}

Plini Secundi, Naturalis Historiae, Libri XXXV, 65-66. Ik heb gebruik gemaakt van de Engelse vertaling van H. Racklam, London 1995, cen reprint van de eerste druk uit 1952, p. 308-31.1.

8. Norman Bryson, Het ongeziene in beeld vier essays over het stilleven, Amsterdam 1993, p. $31-32$. 
Hoe zil het met de opvolgende reeks van drempels ten aanzien van de 'illusie' wan de ingewiikkelde rechtskracht, van het op enig moment aanwijsbaar kunnen constateren dat een besluit rechtens correct is tot stand gekomen en in het rechtsleven kan werken; de rechtskracht, die weergeeft de dan vaststaande conformiteit met het recht? De eerste drempel is van de alledaagse werkelijkheid naar de werkelijkheid van het recht. De tweede drempel is de toegang tot het 'huis der rechten', dat wil zeggen tot de in het geval van rechtskracht publiekrechtelijke rechtsvormers (wetgever, bestuursorgaan en rechter). $\mathrm{Zij}_{\mathrm{ij}}$ geven rechtskracht mee aan rechtshandelingen (rechtsbestendigheid). Deze rechtskracht markeert vervolgens "wat rechtens is" (rechtskracht). Rechtskracht na de derde drempel, dus als momentopname van 'wat rechtens is' vooronderstelt die verschillende stappen van de gewone werkelijkheid naar die abstracte, niet fysiek tastbare aanname. Rechtskracht als eigenschap is dan het eindpunt in de verschillende fasen, die samen maken dat recht werkt. Vandaar dat rechtskracht een fictie, of een opeenvolgende reeks 'illusies' is, in het theater dat recht heet.

Wanneer rechtskracht beschouwd kan worden als een opeenvolgende reeks 'illusies' in het rechtsleven, is in ieder geval al verklaard waar die complexiteit van het leerstuk vandaan komt. Ook juristen zoeken naar theater/amusement. In dat licht valt ook Donners uitspraak over een complexe casus te plaatsen: "De zaak was intussen van academisch belang geworden ... (...) Voor juristen was het geval een 'roomtaartje' maar de onderwijzeres zal het hare wel hebben gedacht van de rechtsbescherming."

De drempels tussen natuurlijke fysieke waarneming en de overgang naar het theater, de 'illusie' worden achtereenvolgens genomen. Ook voor rechtskracht zijn deze overgangen te duiden. Rechtskracht is niet zomaar kracht (want blote macht), maar kracht van recht. Rechtskracht kan pas bestaan als er bevoegdheden zijn (aldus Bernatzik), dus na het ontstaan en tot ontwikkeling komen van het concept van de rechtsstaat. Rechtskracht heeft zijn oorsprong in het civiele recht, maar heeft eveneens zijn plaats in het publiekrecht. Rechtskracht blijkt de erkenning van het feit dat rechtsfeiten dragers zijn van rechtskracht; zo markeert rechtskracht de overgang van feit naar (publiek-)recht. Rechtsvormers in het publiekrecht kunnen een eigenschap aan hun handelingen meegeven en aldus belichaamt rechtskracht de vertaalslag van de rechtsidee naar de werking (effectiviteit) van het publiekrecht.

In de gedragswetenschappen worden overgangen van en naar belangrijke levensfasen wel aangeduid als 'rites de passage'. Overgang van kindertijd naar pubertijd of volwassenheid, ouderdom en dood zijn "rite de passage". ${ }^{10}$ Rechtskracht als eigenschap van een rechtshandeling en met zijn connotatieve verwijzingen naar de rechtsidee is in het rechtsleven op te vatten als de uitdrukkingsvorm van zo'n 'rite de passage'.

9. A.M. Donner, Nedertands bestuursrecht, algemeen deel, Alphen a/d Rijn 1987, p. 261.

10. Een bekend voorbeeld wan $z 0^{\circ} n$ "rite de passage" is te zien in de film Halfaoune, wastin een Marokkaanse jongen het badhus wordt uitgezet ondat hij een vrouw begluurt, die zich ontkleedt. Hij wordt het badhuis uitgegooid omdat zijn kindertijd (en dus het baden met de wrouwen) voorbij is. 
Rechtskracht is 'illusie', omdat het als een Droste-cacaodoos steeds opnieuw, in een nieuwe laag, verschijnt. Een rechtshandeling kan weliswaar na verloop van de beroepstermijn de zogenoemde onaantastbare formele rechtskracht krijgen (het aanwijsbare moment van rechtskikracht), maar de rechtssituatie alls geheel kan aan wijziging onderhevig zijn. Formele rechtskracht als aanwijsbaar moment geeft daarom slechts schijnzekerheid. De betekenis ervan mag dan ook niet worden overschat. Tegelijkertijd is het een belang wan openbare orde dat aanwijsbaar is dat een rechtshandeling (met formele rechtsbestendigheid) op enig moment rechtens vaststaat of vaststaand is geworden. Het openbaar bestuur zou stuurloos worden zonder die aanwijsbare momenten. Aanwijsbare momenten hebben een verwijsfunctie. Het bestutur, de direct-belanghebbende en ook diens buurman kan bijvoorbeeld opvolgende buren voorhouden destijds een vaststaande beschikking te hebben gekregen. Daardoor verloopt het samenleven gestructureerd. Ook voor de rechterlijke macht is aanwijsbaarheid van wat rechtens is (al is het een fictie) van eminent belang, omdat anders nimmer een oordeel over de rechtmatigheid van het handelen van het bestuur gegeven kan worden. Formele momenten, niet alleen als historisch feit, maar als gegeven waarnaar kan worden verwezen, geven richting aan zo'n rechtmatigheidsoordeel. Of, om met Steenbeek te spreken: 'ze legitimeren'.

Rechtskracht is 'illusie', omdat het zo elastisch is. Omdat het rechtsleven veelzijdigheid van vormen verlangt, zal de rechtsbestendigheid en de rechtskracht als eigenschap van de rechtshandeling (die de uitdrukkingsvorm is van de regulering van het rechtsleven) met die veelzijdigheid meebewegen. W at dan (materieel gezien) rechtens vaststaand is, wordt steeds met een op de concrete situatie passende worm (formeel) meegegeven.

Rechtskracht is 'illusie', omdat het 'uniwerseel' is; alle rechtshandelingen hebben iets van rechtskracht als eigenschap. Dat maakte rechtskracht 'universeel'. Recht geldt en recht werkt, dat is steeds bij elke rechtshandeling aan te wijzen. Rechtshandelingen bevestigen keer op keer dat recht geldt en dat recht werkt. Rechtskracht markeert dat voor die concrete rechtshandelingen. Soms is de vorm moeilijker te duiden, soms is het overduidelijk. Soms is rechtskracht als 'Kleren van de Keizer' een ondoorzichtig gewaad, soms lijken de patronen van de stof duidelijk te zien. Maar rechtskracht bestaat, dat is inmiddels duidelijk!

Dit woord illusie, behoeft toelichting, want de lezer kan het wellicht opvatten als waandenkbeeld of als iets dat niet bestaat. Zo bedoel ik het niet. Veeleer heb ik de illusie zelf op het oog. Alweer een voorbeeld. Wanneer de toeschouwer op het podium ziet dat de illusionist een dame doorzaagt, weet hij dat zij niet zal sterven. Dat immers zou, behalve een onsmakelijk tafereel, maken dat u als toeschouwer zich zou afwenden van het gebeurde en (en dat zou verstandig zijn) aangifte zou gaan doen op het politiebureau. De toeschouwer weet dat er iets is dat hij niet ziet. Juist daarom gaat het bij de illusie, of misschien moet ik wat oneerbiedig zeggen, bij het 'goocheltrucje'. Want omdat de toeschouwer weet dat de doorgezaagde dame straks zal 'herrijzen', is het leuk, amuseert hij zich en is de illusie entertainment. Daarom is voor rechtskracht de parallel met de Romeinse schilderijen zo cruciaal. Juist omdat het afbeelden van de tuin op de blinde muur (waarachter de tuin daadwerkelijk ligt), de illusie oplevert. Zo'n verwijzing maakt dat de toeschouwer zich tijdloos, ruimteloos waant. Ook voor rechtskracht geldt dat juist het weten dat het er is, 
terwijl het - prima facie - onzichtbaar is, nu juist de attractie van de eigenschap is. Dit is dan ook de inhoud van de eigenschap rechtskracht. Ik vermoed dat daaron rechiskracht ook werkt.

\subsection{Rechtskacht als middel of als doel?}

Nu rest mij nog een vraag: is rechtskracht voornamelijk te zien als middel en niet als doel op zichzelf (dat gemaakt wordit door zichzelf)? Hoe bewust zijn we ons van rechtskracht? Voor de beantwoording van deze vraag wordt een parallel getrokken met taal als middel en als doel.

Usseling verdedigt de stelling dat filosofie bestaat in teksten.

"Of men het erkent of niet, de filosofie bestaat nu eenmaal, zij het dan niet uitsluitend maar wel allereerst, in een netwerk wan teksten die op de een of andere manier naar elkaar verwijzen en op elkaar alangewezen zijn." ${ }^{31}$

Door middel van lezen en schrijven is de filosoof bezig met zijn beroep.

"Een filosoof zonder bibliotheek en zonder boeken is naw welijks woorstelbaar."

De sinoloog Kien, in Canetti's. Het martyrium ${ }^{13}$, is in een voortdurend gesprek met zujn boekenkast. Wanneer het op werkelijk, reêl contact met andere mensen aankomt - in zijn geval spreekt hij alleen met zijn huishoudster en latere echtgenote - vat hij de bedoelingen van zijn gespreksgenote volslagen verkeerd op; hij is geen sociaal (communicerend) wezen meer. Het gebrek aan communicatie drijf witeindelijk tot wanhoop. Zijn einde vindt de geleerde Kien in zijn brandende bibliotheek.

Taal louter als doel zien, valt aldus te kenschetsen als gemankeerd; taal dient vooral ter communicatie. Wanneer taal zijn mogelijkheid to communicatie mist en (wanneer het louter en alleen) dient als doel in zichzelf, dan keert zij tegen zichzelf. Taal is naast doel vooral midde!.

Juristen beschouwen taal als een middel. ${ }^{14}$ Zo dichtte Van Wassenaer van Catwijck:

11. S. IIsseling, Boeken-wijsheid, Fülosofische notities over boeken, lezers en schrijvers, Kampen 1995, p. II.

12. S. Jsseling, Boeken-wijsheid, Filosofische notities over boeken, lezers en schrivers, Kampen 1095, p. 34.

13. Vgl. Elias Canetti, Het martyrium (oorspr. Die Blendung, 1935), vertaald in her Nedlerlands door Jacques Hamelink, Amsterdam 1990.

4. Er zijn natuurlijk ook uitzonderingen, waarbji de rechtstaal wel als doel wordt gezien, zoals bijwoorbecld in G.C.JI. van den Bergh, Themis en de muzen: de functie van gebonden vormen in het recht, diss., Hathem 1964 of de verrukkelijke Vertefling wan een merkwardige straftzaak, De gelaarsde kat door $\mathbb{G}$. W. wan Viersen Trip, ; en wie herinnert zich miet het door platsing in het leerboek van O.K. Brahn, woor Juristen beroemd geworden: 'De schrijfmachine mijment gekkepraat. Lees maar, er stadit niet wat er statat." van de hand van M. Nijhof, Awater. 
"Verstaanbaar recht in een versteanbare tad:

Het was eens en het blijfl nog vele eeuwen zowel sprookje als na te jagen ideaal. ${ }^{15}$

Taal is voor de jurist zijn gereedschapskist. Het is het instrument waarmee het recht beschreven (dat is: na analyse verklaard) wordt. Het beschrijwen van een begrip is daarom essentieel. De beschrijving van een begrip markeert de overgang van (de fysieke) werkelljkheid naar (het) recht. De rechtstaal immers is niet blanco; omdat in het recht al allerlei begrippen en definities bestaan, gaat het beschrijven van een (nieuw) begrip al van die institutionele (rechts)werkelijkheid uit.

Tegelijkertijd worden juridische begrippen, wanneer zij eenmaal in het recht functioneren, woortdurend opnieuw geïnterpreteerd en daardoor in hun werking opgerekt of juist ingekrompen. Het verbinden van een bepaalde betekenis aan een feit-en-begrip-substraat heet in het juridisch jargon kwalificatie. Kwalificatie van feiten uit de werkelijkheid als zijnde herkenbaar in die begrippen speelt een belangrijke rol bij het afbakenen van de werking van een begrip. ${ }^{16}$ Of dit steeds opnieuw interpreteren en daardoor creëeren van nieuwe begrippen 'uit zichzelf' ontstaat, lijkt betwijfelbaar. Is het niet veeleer de zucht naar theater, de behoefte aan taal als doel die ook juristen kennen, waardoor steeds wordt gezocht naar de overgangen van zijn en schijn? In een interactionistisch perspectief op het recht is taal niet alleen een middel voor de jurist, maar wordt ook (een beetje) doel, want markeert de overgang van de werkelijkheid naar de rechtswerkelijkheid. Taal als doel, recht als doel, als (zelf)creator van juridische begrippen, vormt aldus een 'rite de passage'.

De overgang van werkelijkheid naar recht is een overgang van zijn en schijn, van mimesis; een overgang van herhalende verplaatsing, zoals IJsseling dat vaststelt.

'Hetzelfde verschijnt op een andere plats wasurdoor het nooili zonder meer hetzelfde is. Deze herhalende verm platsing is het wezen van de mimesis, en het is daardoor dat steeds nieuwe betekenissen kunnen ontstalan." 17

De bedenker van deze mimesis, Plato, streefde naar uitbanning van deze herhalende verplaatsingen: het ideaal is de Idee zoveel mogelijk te benaderen in een functionele zin. Kunstenaars als opwekkers van illusies, afbeeldingen van afbeeldingen zijn daarbij uit den boze. Plato zegt: "... kunstenaars: het is een pest, alles wat die mensen maken, een groot gevaar voor de geest van iedereen die ermee in aanraking komt ${ }^{18}$ Daarmee vertegenwoor-

15. A.J.O. Baron van Wassenaer van Catwijek, Recht en taal, sprookje en ideaal, in: Meesterlijke taal, over taal en taalgebruik in het recht, uitgegeven ter gelegenheid van het achtste lustrum van de Jonge Balie Utrecht, Zwolle 1988, p. 153.

16. Hierop bouwt WJ. Witteween voort in zijn dissertatie De retorjek in het recht, Ower retorica en interpretatie, staatsrecht en democratie, Zwolle $1988 \mathrm{en}$ ook in De taal van de wetgever, De wet moet spreken, maar hov?, in: Meesterlijke taal, over taal en taalgebruik in het recht, uitgegeven ter gelegenheid wan het achtste lustrum van de Jonge Balie Utrecht, Zwolle 1988, p. 3-19.

17. S. Usseling, Boeken-wijsheid, Filosotische notities over boeken, lezers en schrijvers, Kampen 1995, p. 41 (cursivering van Samuel Usseling).

18. Dit is de vertaling van Gerard Koolschijn wan Plato's Politeia, Constitutie, Amsterdam 1997, p. 245. 
digt Plato een standpunt dat als 'realistisch' gekenschetst moet worden. Zeuxis" druiven of Parrhasius" gordijn worden door hem beschouwd als afbeeldingen van de door de vakman afgebeelde vormen van een type, de Idee (die louter de schepper kan hebben gemaakt). Kunst is verwerpelijk in Plato"s ogen omdat het meerdere stappen van de Idee afstaat, dan het product van ambachtslieden. Is het recht voor Plato daarmee ook alleen het zijn, zonder schijn; met andere woorden ontkent Plato, of zou Plato willen ontkennen dat ficties, illusies in het recht bestaan? Is Plato's realisme een pleidooi voor staatsraison avant a lettre?

Bestaat het recht zonder illusies, of juist dankzij ficties? De overgang van werkelijkheid naar recht is een bijzondere, want in de juridische werkelijkheid heerst weer schijn en zijn. Zo stelt Steenbeek:

\footnotetext{
"... biedt het verschijnsel van de terugwerkende kracht een merkwaardig voorbeeld hoezeer ons rechtsstelsel berust op zuiver abstracte constructies. Het gaat toch tegen alle fysieke mogelijkheden in on datgene, dat tevoren zús was, achteraf van het begin af aan de gestalte van zó te geven. Men kan achteraf niet met redeligkheid volhouden, dat een driedimensionaal lichaam, dat als bal in de speelgoedwinkel lag, toch als kubus daar heeft gelegen. Als het een bal was, was het geen kubus, en daarmede kan elke discussie op dit plan worden gestaakt. In deze fysieke wereld kan het zelfs moeilijk zijn woor het vervolg van een ball eer kubus te maken.

In de wereld van de juridische werkelijkheid kan een dergelijk terugwerkend procểdé echter wel plaats winden wen men behoeft daar niet eens de fictie te hulp te roepen. (...)

In de abstracte wereld van de rechtswerkelijkheid is zoiets mogelijk. ${ }^{19}$
}

Ficties zijn uitermate effectief hebben we gezien. Zijn we ons dan ook bewust van de effectiviteit van rechtskracht? Wat is de opzet of is er wel opzet achter rechtskracht? Toulmin geeft aan dat er voor het bereiken van volledig bewustzijn uberhaupt al verschillende stappen zijn geweest. "Sommige van die stappen zijn zeer recent gezet. Augustinus vertelt bijvoorbeeld hoe Sint-Ambrosius wan Milaan gezeten op de treden van de kathedraal, de bijbel of het misboek zo snel las dat de mensen die hem zagen lezen concludeerden dat hij een tovenaar moest zijn. En dat was hij omdat hij in zichzelf las, zonder, zoals men toen deed, de woorden met de lippen te vormen, ook al werden ze niet uitgesproken. Zo moet het ook toegegaan zijn in trappistenkloosters; de monniken lazen zo stil dat anderen hen niet konden horen. Misschien lazen ze ook wel hardop, maar waar het om ging was dat ze niet met elkaar communiceerden. Ieder moest voor zichzelf de mis zeggen, ona fhankelijk van de anderen. ${ }^{20}$

Rechtskracht is ingelezen in het (publiek-)recht zelf. Het wordt tijd dat wij ons daarvan bewust worden. De parallel met de overgang van werkelijkheid naar rechtswerkelijkheid legt bloot dat rechtskracht in het publiekrecht steeds aanwezig is, want al was de keizer dan wel naakt, hij had toch niet niets aan. Daarbij is vastgesteld dat rechtskracht geen doel op

19. J.G. Steenbeek, rechtshandeling en rechtsgevolg in het staats-en administratief recht, diss., Assen 1958, p. $56-57$

20. Stephen Toulmin, Descartes, Descartes..., in: Een schitterend ongeluk, vraaggesprekken met Wimi Kayzer, Ansterdarn/Antwerpen 1995, p. 279. 
zichzelf is, maar slechts een middel (een eigenschap) voor een doel: de rechtmatige en doelmatige functionering van het publiekrecht.

\subsection{Conclusie}

Ik kom tot een afronding. Wat heeft dit boek nu duidelijk gemaakt? Op de eerste plaats dat er grote spraakverwarring heerst. In de inleiding heb ik als 'Leitmotiv' van dit boek naar voren gebracht dat er geen duidelijkheid is over de betekenis wan het begrip rechtskracht. Ik gaf aan dat er wellicht niet sprake is van één begrip rechtskracht, maar van vele begrippen rechtskracht en van vele verschillende begrippen rechtskracht. Vervolgens heb ik deze verschillende begrippen rechtskracht, die de ronde doen omdat ze vanuit verschullende benaderingen van thet recht zijn ontstaan, de revue laten passeren. Al deze benaderingen dragen een kern van waarheid in zich. Toch moeten we ons ervan bewust zijn dat we steeds vanuit én benadering, vanuit een bepaald perspectief naar het begrip rechtskracht kijken. Als we dat eenmaal geaccepteerd hebben moeten we vervolgens ons er van bewust worden vanuit welke benadering, welk perspectief we naar het begrip kijken. Pas als we weten welke bril we hanteren, weten we waar we het over hebben. Dat legt de spraakverwarring bloot en komt de duidelijkheid van de discussie ten goede.

Steenbeek verzuchtte in 1989 dat er ook toen geen sprake was 'van communis opinio over de inhoud van dit begrip' en hij riep op: 'wij moeten het met elkaar eens worden over de inhoud van dit begrip'. ${ }^{21}$ In dit boek zijn de 'roots" van het begrip in kaart gebracht. Het vormt zodoende een eindpunt en een beginpunt. Een eindpunt is het boek wanneer vanuit eén benadering een definitie van het begrip wordt gehanteerd; de verschillende begrippen staan naast elkaar. Aldus is het boek een ijkpunt. Het beginpunt is het boek omdat wij nu voldoende materiaal hebben om het ook met elkaar eens te gaan worden. De discussie zal van karakter gaan veranderen; overleg en afstemming maakt plaats voor polariseren (vanuit de dogmatiek). We kunnen nu achterhalen wie wat wanneer over de inloud van het begrip heeft gezegd, zodat het discours zich kan bewegen in de richting van een discussie over war we nu naar toe willen.

Deze studie heeft eveneens duidelijk gemaakt dat de in het huidige positief recht gehanteerde definitie van formele rechtskracht te beperkt is. Het is maar eén benadering en definitie van het begrip tussen vele andere. Vooral de vergelijking met in Duitsland gebruikelijke definities heeft zichtbaar gemaakt dat er meer onder de zon is dan alleen het ontvankelijkheidsinstrument formele rechtskracht in de zin van onaantastbaarheid in rechte. Naast dit denken vanuit het processuele (contentieus recht) is er - alhoewel minder expliciet zichtbaar - ook het denken vanuit de bevoegdheidsuitoefening (alhoewel de besluitvorming op zichzelf ook een proces is, is het ook een ander soort proces - niet op tegenspraak, noncontentieus van karakter). Beide benaderingswijzen leiden tot verschillende waardering van feiten en gevolgen; ook de normering van de bevoegdheidsuitoefening verschilt van die van 
het processuele. De belangrijkste aanbeveling die hieruit voortvloeit is de door mij voorgestelde aanvulling met het begrip rechtsbestendigheid. De rechtsbestendigheid komt voort uit het denken vanuit de bevoegdheidsuitoefening. Dan bestaat naast de rechtsbestendigheid de rechtskracht, die voortkomt uit het procesdenken. Ik heb me laten inspireren door de hiervoor in Duitsland gehanteerde begrippen 'Bestandskraft' en 'Rechtskraft". Deze kunnen beide weer worden ingedeeld in een formele en een materiêle variant.

Het breekpunt tussen rechtsbestendigheid en rechtskracht ligt bij de aanvang van de bezwaarfase. Vóor dat moment spreken we van rechtsbestendigheid; daarna van rechtskracht. De fase van rechtsbestendigheid is de fase tot de contentieuse fase. De bekendmaking van het besluit speelt in deze fase ook nog een rol, omdat de bekendmaking niet jegens elke belanghebbende op dezelfde wijze (noch op hetzelfde moment) hoeft te geschieden. De fase wan de rechtskracht begint met de contentieuze fase, die in beginsel minimaal de beroepstermijn beslaat, maar ook jarenlang kan duren.

Formele rechtsbestendigheid ('formelle Bestandskraft') ontstaat op het moment van het officieel nemen van het besluit; het is het moment waarop de overheid het geldigheidstem. pel aan het besluit meegeeft. Dat moment van formele rechtsbestendigheid hebben wordt gerespecteerd. Het tenietdoen (ex tunc) komt in drie gevallen voor: 1. het exceptionele ex tunc opheffen door het bestuur zelf (als buitengewoon rechtsmiddel); 2 . in spontane vernietiging en 3 . door een bestuursrechtelijke vernietigingsuitspraak.

Materiële rechtsbestendigheid ('materielle Bestandskraft') is dan het vermogen (of de potentie) om het formeel rechtsbestendige besluit actief rechtsgevolgen in het rechtsleven te laten creëeren. Het is op een nunc-moment betrokken.

Formele rechtskracht ('formelle Rechtskraft') is de rechtsbestendigheid in rechte; in bezwaar en in beroep. Het is de procesrechtelijke onaantastbaarheid die ingaat na het onbenut verstrijken van de beroepstermijn en op een tunc-moment is betrokken. Alle ontvankelijkheidskwesties hebben hier mee van doen.

Materiële rechtskracht ('materielle Rechtskraft') is dan het vermogen (of de potentie) die in het proces moet worden aangenomen, dat dit besluit op rechtens correcte wijze rechtsgevolgen in het leven heeft geroepen.

Welke vragen worden eigenlijk gesteld als we het hebben over formele en materiele rechtsbestendigheid en formele en materiële rechtskracht?

Daarmee kom ik op een ander onderscheid, dat eveneens in Duitsland (met name door lpsen) werd gemaakt, het onderscheid in de "allseitige" rechtskracht van "beschikkingen", die nog in de besluitvormingsfase (nog vóor de contentieuze fase) verkeren ('Bestandskraft" of rechtsbestendigheid) en in de 'inter partes'-rechtskracht van beschikkingen die all in de contentieuze fase zijn beland ('Rechtskraft' of rechtskracht). Is er onderscheid tussen deze "allseitige" rechtsbestendigheid (de 'Bestandskraft' met erga omnes-werking, als voortkomend uit een bevoegdheidsbenadering van het bestuursrecht) en de meer relationele rechtskracht (de 'Rechtskraft' met inter partes-werking als voortkomend uit een procesrechtelijke benadering van het bestuursrecht)? 
En daarop weer doordenkend, heeft dit onderscheid in rechtsbestendigheid('Bestandskraft') en rechtskracht ('Rechtskraft') te maken met de plaats of de functie van de drager van de rechtskracht? Zou de plaats die rechtshandelingen hebben in de rechtsstaat een verklaring kunnen verlenen woor eventuele verschillen in de rechtskracht wan ce verschillende typen rechtshandelingen? Zijn er verschillen in de rechtskracht wan rechtshandelingen van de onderscheiden delen van de trias politica? Welke verschillen zouden door de functies van de onderscheiden machten veroorzaakt kunnen worden? Moet geconcludeerd worden dat rechtskracht de eigenschap is van rechtsfeiten of rechtshandelingen uit eén bepaalde functie? Een aantal factoren veroorzaakt verschil in de rechtskracht van vonnis, uitspraak, beschikking in de besluitvormingsfase, beschikking in de contentieuze fase, besluit van algemene strekking en wet. Deze factoren zijn aangeduid als antinomieën: de benadering van het bevoegdheidsdenken (executieve) tegenover die van het procesdenken (rechtspraak); de rechtsbestendigheid ('Bestandskraft') tegenover de rechtskracht ('Rechtskraft'); de erga omnes-werking versus de inter partes-werking. Ook wordt hier well gerept van de karakterisering van de rechtssituatie en/of de rechtsverhouding als objectief danwel als subjectief. Deze factoren zijn beschouwd aan de hand wan de verschillende rechtsfiguren. Om dat te doen, is aangesloten bij de wijze van onderscheiden zoals dat in Duitsland tot uitdrukking komt in het begrippenpaar 'Bestandskraft' en 'Rechtskraft'. In de door Wolff gekozen benadering, wordt onderscheid gemaakt tussen enerzijds bewoegdheidsdenken (rechtsbestendigheid of 'Bestandskraft') en anderzijds procesdenken (rechtskracht of 'Rechtskraft'). Steenbeek het ontrafelt feit (de formele variant, die er op een bepaald, aflopend tuncmoment is), norm en gevolg (de materiele variant, die er steeds is, blijft en daarom op een nunc-moment is betrokken). De koppeling van deze benaderingen is de benadering die in deze studie steeds is gevolgd. Vanuit deze systematische benaderingswijze kan de rechtsbestendigheid en de rechtskracht van elke rechtsfiguur worden geanalyseerd. Dat is tot op heden in Nederland niet gebeurd.

Wat wordt zichtbaar als de hypothese van deze studie wordt gehanteerd als maatstaf voor de verschillen in rechtsbestendigheid en rechtskracht van uiteenlopende dragers? Belangrijkste constatering lijkt dat de materièle rechtsbestendigheid en materiële rechtskracht voor hun inhoud afhankelijk zijn van de drager (hetgeen voortvloeit uit de functie van de rechtsfiguur). Laten we deze verschillen nog eens bezien.

Het eerste dat opvalt is dat bij de vraag of aan "wetten" (algemeen verbindende voorschriften) rechtskracht toekomt in feite de vraag gesteld wordt of normen drager kunnen zijn van rechtskracht; dat is opvallend omdat in deze studie formele rechtskracht steeds wordt gezien als eigenschap van feiten, terwijl materiele rechtskracht eigenschap van gevolgen is. Normen verlenen aan feiten weliswaar hun gevolgen, of beter gezegd bemiddelen bij het verlenen van (dan rechts)gevolgen aan feiten, maar zijn zelf niet drager van rechtskracht.

Bij deze en andere besluiten van algemene strekking (bundel beschikkingen, plan, beleidsregel) ligt de vraag of zij drager kunnen zijn van rechtskracht wel open zodra het feit en het gevolg in beeld komen; dan is de norm niet de drager van rechtskracht. Steeds zal dan gekeken kunnen worden naar het feitelijke moment (vaststelling van een 'wet', beschikking, plan, beleidsregel is een aanwijsbaar moment), waaraan formele rechtsbestendigheid 
gemakkelijk kan worden verbonden. Hetzelfde geldt woor de overeenkomst tussen bestuursorganen; wanneer het moment van vaststelling van het contract als aanwijsbaar en aflopend feitelijk moment formele rechtsbestendigheidverlangt, zal de inhoud, de rechtsgevolgen (dat wil zeggen de verbintenis) materièle rechtsbestendigheid verlangen.

De uitspraak van de administratieve rechter en het vonnis van een burgerlijke rechter zijn beide te beschouwen als een rechtsfeit; in zoverre kumnen zij beide formele rechtskracht hebben. Het gevolg van beide rechterlijke uitspraken (administratief zowel als burgerlijk) is binding van partijen aan die uitspraak; deze binding is voorwerp van materiele rechtskracht (want het rechtsgevolg van het feitelijke doen van de rechterijike uitspraak). De uitspraak wan de administratieve rechter is echter ex tunc gegeven ten aanzien van een objectiefrechtelijk besluit en in zoverre bevat zij dus niet alleen de subjectieve inter partes bindende rechtsgevolgen van een rechterlijke uitspraak, maar ook een objectief en dus erga omnes bindend oordeel over een besluit.

De rechtsbestendigheid van iedere beschikking vór de contentieuze fase (de rechtsbestendigheid of 'Bestandskraft') wordt eveneens gekenmerkt door deze objectieve erga omnes-werking, terwijl de rechtskracht in de contentieuze fase (de rechtskracht of 'Rechtskraft') juist de inter partes-werking benadrukt.

Als conclusie kan gelden dat er grote verwarring, onduidelijkheid, heerst in de discussie over welke rechtsfiguren als dragers van welke eigenschap aangemerkt kunnen worden. Dat komt doordat steeds met een andere bril naar het probleem wordt gekeken. Als men zich bewust is met welke bril er gekeken wordt, is het heel goed mogelijk om met de verschillende begrippen (formele en materiële rechtsbestendigheid en formele en materiële rechtskracht) om te kunnen springen.

Wanneer we spreken van rechtsbestendigheid hebben we het over de vraag naar de bevoegdheid: is hier een geldige rechtshandeling tot stand gekomen? Rechtsbestendigheid betreft de rechtshandeling als publiekrechtelijke rechtsvaststelling. Is zij geldig, is zij een rechtshandeling, is die onherroepelijk, is het mogelijk om haar nog in te trekken? Al deze wragen houden verband met bevoegdheid.

De formele variant van rechtsbestendigheid moet aanwijsbaar zijn; is met andere woorden verbonden met een feit. Is de bevoegde handeling op de juiste wijze tot stand gebracht? Immers, als er geen bevoegdheid is, is de handeling rechtens non-existent; is sprake van een nulliteit. Daarom is de formele rechtsbestendigheid op het tunc-moment betrokken.

De materiële variant van rechtsbestendigheid is de gevolgen-kant. Is de bevoegde handeling conform de specialiteit van de bevoegdheid gegeven? Is de gelijkheid in acht genomen, is willekeur afwezig; met andere woorden hier heersen de algemene beginselen van behoorlijk bestuur. Deze moeten wel vanuit het perspectief van het bestuursorgaan worden benaderd. Dat betekent dat het bij de materièle rechtsbestendigheid er om gaat of de rechtsgevolgen van het besluit kumnen worden gewijzigd of ingetrokken. Hier gaat het ook om herhaalde aanvraag-situaties en de precedentwerking van een besluit voor andere belanghebbenden. Bij rechtskracht staat de vraag naar de rechtsbescherming centraal. Rechtskracht betreft de rechtshandeling als processueel relevant gegeven; met andere woorden de aantastbaarheid. 
Ook hier is de formelle variant, de formele rechtskracht, op een tunc-moment betrokken. Te denken valt aan vragen inzake de beroepstermijn, de ontvankelijkheid.

De materiële rechtskracht is weer verbonden met de gevolgen, een nunc-moment. Dan hebben we het eveneens over herziening door de rechter, die (zo blijkt nu) onderscheiden moet worden van de herhaalde aanvraag-situatie(omdat die de materiele rechtsbestendigheid betreft).

Welke vuistregels kunnen tot slot aan de rechtspraktijk worden aangereikt om met rechtskracht te kunnen omgaan? Ik zie er drie:

1. onderscheiden van feit en gevolg;

2. onderscheiden van het feit naar karakter;

3. onderscheiden van het feit naar het moment.

Laat ik deze vuistregels toepassen op een woorbeeld. Stel, er is een aanvraag voor een bouwvergunning. De vergunning wordt verleend. Het huis wordt gebouwd. De aanvrager woont in het huis. Jaren later - het onderhoud heeft niet meer plaatsgevonden - is het huis niet meer conform de eisen van het Bouwbesluit en de Woningwet; het is verkrot.

Regel 1 onderscheidt feit en gevolg. Het feit is de vergunningverlening (destijds; ex tunc). Gevolg daarvan was dat het gebouwde conform het recht, kortom legaal gebouwd mocht worden. Is er formele rechtsbestendigheid? Ja, want het besluitvormingsproces heeft geleid tot een normconforme bevoegdheidsuitoefening ten bewijze waarvan belanghebbende een vergunning mocht ontvangen. Er is eveneens materiële rechtsbestendigheid; de vergunning heeft tot gevolg gehad dat gebouwd mocht worden. Is er formele rechtskracht? Omdat de beroepstermijn is verstreken, kunnen we concluderen dat de vergunning formele rechtskracht heeft gekregen. De materiële rechtskracht is daardoor niet ter discussie kunnen komen.

Ondat het pand inmiddels een krot is, kan het nu (ex nunc) eigenlijk niet meer bewoond worden. Het bestuursorgaan kan de gevolgen (dat wil zeggen de materiële rechtsbestendigheid) willen wijzigen (ofwel ambtshalve, ofwel na daartoe te zijn ingelicht door derden); dat eist een doelmatige taakuitoefening en daartoe dienen bevoegdheden. In zo'n situatie is een nieuw besluit vereist; dat eist de rechtsbescherming. De bouwvergunning houdt evenwel haar formele rechtsbestendigheid; deze heef als het ware eeuwigheidswaarde, en blifft steeds als verwijsbaar moment, als feit in de geschiedenis bestaan. Dit feit kan slechts ongedaan gemaakt worden als het bestuursorgaan het ex tunc intrekt of als het getroffen wordt door spontane vernietiging of het ex tunc wordt vernietigd in beroep bij de administratieve rechter. Daarmee zien we iets opvallends: de bestuursrechter die een beroep gegrond acht en vernietigt, neemt ex tunc alle rechtsgevolgen uit het rechtsleven doordat het feit wordt doorgestreept. Dat heeft te maken met vuistregel 2. Rechtsbescherming is enerzijds gericht op individuele, subjectieve rechtsposities, maar kan in Nederland slechts toepassing vinden via controle van het objectieve besluit. Het feit is - in de zin van aanjager van de norm - immers veroorzaker van gevolgen. Zo handhaaft de bestuursrechter zowel het objectieve recht als verleent hij rechtsbescherming. Het zou aanbevelenswaardig zijn als de 
rechters deze twee taken explicieter zouden maken. Controle is vanouds aan feiten gebonden (want betreft het objectieve, algemene belang), terwijl rechtsbescherming gericht is op de gevolgen (want betreft het subjectieve belang). De bestuursrechter laveert tussen beide taken. Wanneer beide verschillen explicieter zouden worden gemaakt (door de wetgever), zou ook voor de leek (die immers zelf zijn weg moet zoeken in rechtsbeschermingsland) beter kenbaar zijn wat hij wel en wat hij niet kan verwachten bij het bestuur en bij de rechter.

In deze studie heb ik trachten aan te geven wat ik onder rechtskracht versta. Daarbij heb ik de betekenissen van rechtskracht, de verschillende benaderingen van het begrip, proberen te integreren (te synthetiseren) in een nieuw rechtskrachtbegrip dat ruinte geeft aan de verschillende uitwerkingen van de eigenschap rechtskracht voor zijn verschillende dragers. Daarbij is getracht zoveel mogelijk aansluiting te zoeken bij de discussie zoals die met betrekking tot de rechtskracht van beschikkingen bestaat. De als resultaat van deze studie door mij werdedigde begrippen formele en materiele rechtsbestendigheid naast formele en materiële rechtskracht onderstrepen het onderscheid in feiten, normen en gevolgen en geven ze structuur, dus kenbaarheid en rechtszekerheid aan het recht. Dat is winst, al blijft het begrip rechtskracht als algemene notie nog steeds de kleren van de Keizer. 


\section{Samenvatting}

Vanuit verschillende invalshoeken werd in dit boek de (formele en materiele) rechtskracht van bestursbesluiten benaderd. Wat kan de lezer zoal aantreffen? De formele rechtskracht is hier te lande niet gecodificeerd, maar komt in de jurisprudentie wel (veelvuldig) woor. Een analyse daarvan treft $u$ in dit boek aan. De wijze waarop de formele en materiele rechtskracht hun plaats vinden in het Duitse debat wordt ook besproken, evenais de implicaties van de in Duitsland gemaakte onderscheidingen voor ons land. Daarnaast komt het onderscheid tussen formele en materiële rechtskracht aan de orde. De betekenis van traditionele onderscheidingen (zoals toetsing ex nunc en ex tunc, rechtmatigheids- en doelmatigheidstoetsing, werking erga omnes en werking inter partes, objectieve en relatieve toetsing, eenzijdigheid en wederkerigheid, non-contentieuze en contentieuze fase of feit, norm en gewolg) voor rechtskracht wordt onderzocht. Hoe is dit boek opgebouwd?

In deze studie werd een poging ondernomen om de betekenis van de rechtskracht van bestuursbesluiten voor de publiekrechtelijke en in het bijzonder voor de bestuursrechtelijke werkelijkheid te inventariseren en helder te krijgen.

De eerste betekenis van rechtskracht zoals in deze studie is besproken, is de betekenis die de burgerlijke rechter er aan geeft. Formele rechtskracht wordt door de burgerlijke rechter gehanteerd als afbakeningsinstrument van zijn rechtsmacht met die van de bestuursrechter. Het betekent dan inter partes-onaantastbaarheid, zodat bij aanwezigheid van formele rechtskracht de burgerlijke rechter niet tot zelfstandig toetsen overgaat. De burgerlijke rechter neemt dan het bestuursrechtelijke oordeel over.

De burgerlijke rechter heeft zich laten inspireren door de bestuurstechter bij zijn definitie van formele rechtskracht als inter partes-onaantastbaarheid. De bestuursrechter zal immers eveneens niet ontvangen bij aanwezigheid van formele rechtskracht. Behalve dat formele rechtskracht in het bestuursrecht in een benadering vanuit het processuele (procesdenken) aldus beschouwd wordt als ontvankelijkheidsinstrument is er ook een betekenis die uitgaat van het denken vanuit de bevoegdheidsuitoefening. In deze bevoegdheidsbenadering is formele rechtskracht een eigenschap van een beschikking die deze heeft op het moment van het nemen van een beshuit. Daardoor geeft het bestuursorgaan iets authentieks, een geldigheidsstempel mee aan de beschikking. Deze bewoegdheidsuitoefeningals gezagsuitoefening heeft - als product van objectief recht - erga omnes-werking.

Een andere definitie van rechtskracht die in het bestuurstecht de ronde doet is duurzaamheid. Enerzijds is deze duurzaamheid verbonden met het juridisch bestaan (formele rechtskracht) en anderzijds is deze verbonden met - in tijd en naar personen gespreide - effecten (materiële rechtskracht).

Weer een andere betekenis van rechtskracht definieert formele rechtskracht op een - aflopend - moment (eigenschap van de rechtshandeling) en materiele rechtskracht als blijvend (eigenschap van het rechtsgevolg). 
Deze laatste twee betekenissen zijn niet door de burgerlijke rechter als inspiratiebron gebruikt voor zijn eigen definitie van formele rechtskracht als synoniem met onaantastbaarheid.

In dit boek is de vraag gesteld of de burgerlijke rechter wanneer hij het bestuursrechtelijke oordeel overneemt, of hij dat compleet overneemt (1) en of hij daarmee ook wel hetzelfde overneent (2)?

De eerste vraag leidt maar de omvang van formele rechtskracht en in het bijzonder naar de uitzonderingen op formele rechtskracht. De uitzonderingsmogelijkheid op de hoofdregel van formele rechtskracht fungeert als een hardheidsclausule.

De tweede vraag concentreert op het verschil in bestuursrechtelijke en burgerrechtelijke oordelen. Het bestuursrechtelijke oordeel houdt in een oordeel over een rechtssituatie ex tunc (feit), dat objectief van aard is (norm) en dat erga omnes-werking heeft (gevolg). Neemt de burgerlijke rechter deze 'publiekrechtelijke benadering' over? Het antwoord is dat de burgerlijke rechter niet hetzelfde oordeel overneemt. Een bestuursrechtelijk vaststaand gegeven over een beschikking op een bepaald moment (een ex tunc-oordeel) wordt ex nunc gekwalificeerd in het burgerlijk recht. De burgerlijke rechter kiest (en dat is terecht) steevast voor het verbinden van inter partes-werking (gevolg) aan zijn uitspraken.

Nadat de historische betekenis(sen) van rechtskracht in kaart is gebracht, werd de vraag naar de vreemde herkomst van het begrip voor het voetlicht geplaatst. Naast het begrip 'Rechtskraft' dat voortkomt uit het procesdenken onderscheidt met in Duitsland het begrip 'Bestandskraft' dat voortkomt uit het bevoegdheidsdenken. Deze begrippen worden beide weer ingedecld in een formele en een materiële variant.

Ondat we in Nederland geen equivalent kennen wan het begrip 'Bestandskraft', maar wel met de daarmee verband houdende problematiek worden geconfronteerd, heb ik het begrip rechts bestendigheid voorgesteld.

Naast rechtsbestendigheid is er dan rechtskracht. Rechtsbestendigheid is er vón de contentieuze fase. Wanneer deze contentieuze fase aanvangt, spreken we van rechtskracht.

De vraag waarvan rechtskracht eigenlijk de eigenschap is, werd daarna bestudeerd. Vanuit systematische wijze werd de rechtsbestendigheid en de rechtskracht van verschillende rechtsfiguren geanalyseerd. Als conclusie kan gelden dat er grote verwarring, onduidelijkheid, heerst in de discussie over welke rechtsfiguren als drager van welke eigenschap aangemerkt kunnen worden. Dat komt doordat steeds met een andere bril naar het probleem wordt gekeken. Als men zich bewust is met welke bril er gekeken wordt, is het heel goed mogelijk om met de verschillende begrippen (formele en materiële rechtsbestendigheid en formele en materiele rechtskracht) om te kunnen gaan.

In de analyses vanuit de rechtstheorie en rechtsfilosofie werden de mogelijke achtergronden van het leerstuk besproken. De rechtskracht van bestuursbesluiten werd zowel als rechtspositivistisch, als autopoietisch, als transcendentaalen als spectraal vraagstuk geanalyseerd. Elke benadering bracht eigen invalshoeken die leidden tot soms meer en soms minder nuttige inzichten in het leerstuk. 
Ten aanzien van de vraag hoe of door wie recht 'gemaakt' wordt antwoorden de rechtspositivisten dat recht door mensen is gemaakt, de autopoieten dat recht door het recht zelf is gemaakt, de transcendentalisten dat recht door God is gemaakt en in de spectrale theorie is recht gemaakt door mensen in hum verband en is het in de loop van de geschiedenis gestalte gegeven. Hoe dat recht er dan uit kan zien, wordt ook verschillend opgevat. De rechtspositivisten zeggen dat recht alles zijn kan, dat wil zeggen elke inhoud kan hebben. De autopoieten gaan ervan uit dat de bouwstenen van nu vorm geven aan nieuwe oplossingen woor het recht van morgen. De transcendentalisten steillen voorop dat recht maar één aspect wan het leven is; de inhoud ervan heeft relaties met alle andere aspecten en is zodoende athankelijk van de verbanden waarin men verkeert bepaald (vorm gegeven); geloof is de allesbepalende creator van de inhoud van het recht. Hoe het recht er uit ziet is in de spectrale theorie een, volledig aan de menselijke (gelijk)waardigheid ten dienste staand, gegeven.

Zowel rechtspositivisten als transcendentalisten beschouwen rechtskracht als een vorm van rechtsgelding van normen. Dat is opvallend, want in deze studie is de eigenschap steeds benaderd als verbonden met een feit.

Teubners autopoietische benadering leert dat autopoietische geslotenheid de eenheid en eigenheid van een systeem garandeert. Zo bezien doet het hanteren van formele rechtskracht door de burgerlijke rechter deze autopoietische geslotenheid geweld aan.

In Van Eikema Hommes' transcendentalistischebenadering wordt een poging gedaan tot het opnieuw definiëren van formele en materiële rechtskracht. Formele rechtskracht is de eigenschap van normen die ontstaat doordat de norm op een correcte wijze door een bevoegd rechtsvormer is tot stand gekomen (gelding van de vorm). Materielle rechtskracht betekent de eigenschap van normen die ontstaat doordat de norm in overeenstemming is met de bovenwillekeurige materiële rechtsbeginselen (gelding van de inhoud).

In mijn eigen visie blijven na beschouwing van rechtskracht vanuit deze verschillende perspectieven twee centrale stellingen owereind. Allereerst is rechtskracht erkenning: rechtskracht is altijd in het publiekrecht aanwezig, ook al is het onzichtbaar. Rechtskracht hebben is immers de erkenning dat er recht is. Ten tweede is rechtskracht als onzichtbaar, maar altijd aanwezig fenomeen vluchtig. Vluchtig typeren in juridische termen komt het dichtst bij het karakteriseren van rechtskracht als een 'illusie", een fictie. Juist ondat rechtskracht als altijd aanwezige eigenschap van rechtsfeiten zo 'onzichtbaar' is, blijft het mysterieus, moeilijk grijpbaar, elastisch, flexibel. Beide stellingen culmineren in de metafoor wan rechtskracht als de kleren van de Keizer uit het sprookje, want al was de Keizer dan well nakt, hij had toch niet niets aan... 


\section{Summary}

This book examines the concept of substantive and formal (procedural) legal force of administrative decisions from different perspectives. Formal legal force has not been codified in the Netherlands. However, it frequently features in case law, an analysis of which is made in this book. The author discusses the discourse on formal and substantive legal force as developed in Germany and the implications for the Netherlands of the distinctions which have been made in Germany. In addition, she deals with the differences between formal and substantive legal force. The author examines the meaning of the traditional distinctions relating to legal force, such as testing ex tunc and ex nunc, the lawfulness and 'best solution' tests, the erga-ommes effect, the inter-partes effect, objective and subjective testing, unilaterality and reciprocity, the non-contentious and contentious stage, or act, norm and legal effect.

An attempt is made in this book to make an inventory of and to clarify the different meanings of the legal force of administrative decisions in the public-law domain, especially in administrative law. The meaning of legal force first discussed in this dissertation is the meaning created by the civil judge. Formal legal force is employed by the civil judge as a tool for distinguishing his own jurisdiction from that of the administrative judge. Legal force here stands for inter-partes inviolability, which prevents the civil judge from applying his own test in cases of formal legal force. In such cases, the civil judge will adopt the administrative judgment.

In defining formal legal force as inter-partes inviolability, the civil judge has been inspired by the administrative judge. The latter will also not admit the case in the event of formal legal force. In addition to the fact that formal legal force under administrative law is viewed as a tool to assess admissibility -a procedural approach-, there is also the meaning which came about as a result of approaching it in terms of exercise of administrative authority. In this competence approach, formal legal force is a feature of decision at the moment that decision was taken, by which the administrative authority confers authenticity, renders validity, to the administrative decision. This exercise of administrative power in the form of exercise of authority has an erga-omnes effect, since it is a product of objective law.

Another definition of legal force, which circulates in administrative law, is continuity. In the case of formal legal force, continuity is linked to legal reality and in the case of substantive legal force it is linked to legal effects, dispersed over time and persons.

Yet another meaning of legal force defines formal legal force as finite (feature of rechtshandeling [an act having the legal effect intended by the parties]) and substantive legal force as permanent (feature of legal effect).

The latter two meanings have not been used by the civil judge as a source of inspiration for his own definition of formal legal force as synonymous to inviolability. The author poses the question as to whether the civil judge, in adopting the judgment of the administrative judge, (1) does so in full and (2) whether he renders the same judgment. 
The first question leads us to the scope of formal legal force and in particular to the exceptions to legal force. The exceptions to the principal rule of formall legall force serve as a hardship clause.

The second question focuses on the difference between civil and administrative judgments. A judgment rendered by an administrative judge is an assessment of the legal reality ex tunc (act), which is objective in nature (norm) and which has an erga-omnes effect (legal effect). Does the civil judge adopt this public-law approach? The answer is that he does not. A fact established in public law about an administrative decision at a specific moment in the past (an ex-tunc judgment) is assessed ex nunc in private law. The civil judge will consistently, and rightly so, opt for the inter-partes effect (legal effect) of his decisions.

After having mapped out the historical definitions of legal force, the author highlights the foreign origins of the concept. In addition to the concept of 'Rechtskrafi', which developed from the procedural approach, the concept of 'Bestandskraft' is distinguished, which derives from the competence approach. Both concepts consist of a formal and a substantive variety. No equivalent exists in the Netherlands of the concept of 'Bestandskraft'. However, the relevant problems do occur there, which has caused the author to propose the term "rechisbestendigheid" (a time-honoured quality). In addition to rechtsbestendigheid, there is legal force (rechtskracht); where rechtsbestendigheid is a pre-contentious concept, rechtskracht pertains to the contentious phase.

She proceeds by investigating the question of legal force as a feature. The rechtsbestendig. heid and legall force of various legal concepts are analyzed from a systematic angle. One conclusion may be that there is great confusion and a lack of clarity as to what legal concepts possess what features. This is the result of the fact that the matter is viewed differently by different people. If one is aware of the specific angle from which the problem is viewed, then is it very well possible to deal with the concepts of formal and substantive rechtsbestendigheid and formal and substantive legal force.

In her analyses based on legal theory and legal philosophy, the author discusses the theories on which the doctrine may be based. The legal force of administrative decisions is analyzed as a legal positiwist, an autopoietic, a transcendental and a 'spectral' issue. Each approach provides its own perspective, which yields a number of useful and a not so useful insights into the doctrine.

The legal positivists' answer to the question as to how law originates or who creates it, is that law is man-made. The autopoi-ites entertain the view that law creates itself (autopoiesis), whereas the transcendental ists believe that God creates the law. In spectral theory, law is created by humans within their particular circles and shaped by history. The face of law is therefore also a matter of opinion. Legal positivists propose that law can be anything, that is to say, it can have any content. Autopoi-ites assume that the building blocks of current law form new solutions for future law. Transcendentalists presume that law is but one aspect of life; its content relates to all of life's other aspects. Thus, it depends on the circles in which 
humans exist. Faith is the all-ordaining creator of the content of law. In spectral theory, law is a given fully subservient to human dignity and equality.

Both the legal positivists and the transcendentalists view legal force as a form of validity of norms. This is remarkable, because in this dissertation this feature thas been consistently approached in connection with 'act'.

Teubner's autopoietic approach teaches us that the autopoietic cocoon protects the unity and individuality of the system. From this perspective, the civil judge's use of formal legal force upsets the autopoietic cocoon. In the transcendentalist approach of van Eikema-Hommes, an attempt is made to redefine formal and substantive legal force. In this approach, formal legal force is a norm feature, which comes about as a result of the norm having been correctly created by the competent lawmaker (force of form). Substantive legal force is then a norm feature, which comes into existence because the norm conforms with the non-fortuitous, substantive legal principles (force of content).

After having studied legal force from these different angles, the author submits that two central propositions remain. First, legal force is the result of acknowledgement: legal force is always, be it not visibly, present in public law. Force of law follows from acknowledgment of law. Second, legall force, the invisible, ever-present phenomenon, is elusive. Characterizing 'elusive' in legal terms is almost like saying legal force is an illusion, fiction. Precisely because of the invisibility of legal force, the ever-present feature of rechtsfeiten (acts having legal effect), it remains mysterious, elusive, resilient and flexible. Both propositions culminate in the metaphor of legal force as the Emperor's clothes. The Emperor may be naked, he is not without array... 


\section{Bijlage}

\section{Verwaltungsverfahrensgesetz \\ (VwVFG)}

Vom 25 Mai 1976 (BGBII S. 1253)

(BGBI. III 201-6)

\section{Abschnitt 2 \\ Bestandskraft des Verwaltungsaktes}

\section{$\$ 43$ Wirksamkeit des Verwaltungsaktes}

(1) Ein Verwaltungsakt wird gegenüber demjenigen, für den er bestimmt ist oder der von ihm betroffen wird, in dem Zeitpunkı wirksam, in dem er ihm bekanntgegeben wird. Der Verwaltungsakt wird mit dem Inhalt wirksam, mit dem er bekanntgegeben wird.

(2) Ein Verwaltungsakt bleibt wirksam, solange und soweit es nicht zurückgenommen, widerrufen, anderweitig aufgehoben oder durch Zeitablauf oder auf andere Weise erledigt ist.

(3) Ein nichtiger Verwaltungsakt ist unwirksam.

\section{$\$ 44$ Nichtigkeit des Verwaltungsaktes}

(1) Ein Verwaltungsakt ist nichtig, soweit er an einem besonders schwerwiegenden Fehler leidet und dies bei verständiger Würdigung aller in Betracht kommenden Umstände offenkundig ist.

(2) Ohne Rücksicht auf das Vorliegen der Voraussetzungen des Absatzes 1 ist ein Verwaltungsakt nichtig,

1. der schriftlich erlassen worden ist, die erlassende Behörde aber nicht erkennen läßt;

2. der nach einer Rechtsvorschrift nur durch die Aushändigung einer Urkunde erlassen werden kann, aber dieser Form nicht genügt;

3. den eine Behörde außerhalb ihrer durch \& 3 Abs. 1 Nr. 1 begründeten Zuständigkeit erlassen hat; ohne dazu ermächtigt zu sein;

4. den aus tatsächlichen Gründen niemand ausführen kann;

5. der die Begehung einer rechtswidrigen Tat verlangt, die einen Strat- oder Bußgeldtatbestand verwirklich:;

6. der gegen die guten Sitten verstößt.

(3) Ein Verwaltungsakt ist nicht schon deshalb nichtig, weil

1. Vorschriften über die örtliche Zuständigkeit nicht eingehalten worden sind, außser wenn nein Fall des Absatzes $2 \mathrm{Nr} .3$ vorliegt;

2. eine nach $\$ 20$ Abs. 1 Satz 1 Nr. 2 bis 6 ausgeschlossene Person mitgewirkt hat;

3. ein durch Rechtsvorschrift zur Mitwirkung berufener Ausschuß den für den Erlaß des Verwaltungsaktes vorgeschriebenen Beschluß nicht gefaßt hat oder nicht beschluffähig war;

4. die nach einer Rechtsworschrift erforderliche Mitwirkung einer anderen Behörde unterblieben ist.

(4) Betrifft die Nichtigkeit nur einen Teil des Verwaltungsaktes, so ist er im ganzen nichtig, wenn der nichtige Teil so wesentlich ist, daß die Behörde den Verwaltungsakt ohne den nichtigen Teil nicht erlassen hätte.

(5) Die Behorde kann die Nichtigkeit jederzeit von Amts wegen feststellen; auf Antrag ist sie festzustellen, wenn der Antragsteller hieran ein berechtigtes Interesse hat. 


\section{Heilung won Verfahrens- und Formfehlern}

(1) Eine Verletzung von Verfahrens- oder Formvorschriften, die nicht den Verwaltungsakt nach 44 nichtig macht, ist unbeachtlich, wenn

1. der für den Erlaß des Verwaltungsaktes erforderliche Antrag nachträglich gestellit wird;

2. die erforderliche Begründung nachträglich gegeben wird;

3. die erforderliche Anhiorung eines Beteiligten nachgeholt wird;

4. der BeschluB eines Ausschusses, dessen Mitwirkung fïr den ErlaB des Verwaltungsaktes erforderlich ist, nachtratich gefaßt wird;

5. die erforderliche Mitwirkung einer anderen Behörde nachgeholt wird.

(2) Handlungen des Absatzes $1 \mathrm{Nr} 2$ bis 5 düren nur bis zum Abschluß eines Vorverfahrens oder, falls ein Vorvertahren nicht stattfindet, bis zur Erhebung der verwaltungsgerichtlichen Klage nachgehoit werden.

(3) Fehlt einem Verwaltungsakt die erforderliche Begründung oder ist die erforderliche Anhörung eines Beteiligten vor Erlaß des Verwaltungsaktes unterblieben und ist dadurch die rechtzeitige Anfechtung des Verwaltungsaktes versäumt worden, so gill die Versäumung der Rechtsbehelfsfrist als nicht verschuldet. Das fü die Wiedereinsetzungsfrist nach $\$ 32$ Abs. 2 maßgebende Ereignis tritt im Zeitpunkt der Nachholung der unterlassenen Verfahrenshandlung ein.

\section{\$46 Folgen von Verfahrens- und Formfehlern}

Die Aufhebung eines Verwaltungsaktes, der nicht nach 44 nichtig ist, kann nicht allein deshalb beansprucht werden, weil er unter Verletzung von Vorschriften über das Verfahren, die Form oder die obrtliche Zuständigkeit zustande gekommen ist, wenn keine andere Entscheidung in der Sache hätte getroffen werden können.

\section{$\$ 47$ Undeutung eines fehlerhaften Verwaltungsaktes}

(1) Ein fehlerhafter Verwaltungsakt kann in einen anderen Verwaltungsakt umgedeutet werden, wenn er auf das gleiche Ziel gerichtet ist, von der erlassenden Behörde in der geschehenen Verfahrensweise und Form rechtmäßig hätte erlassen werden körnen und wenn die Voraussetzungen für dessen Erlaß erfüllt sind.

(2) Absatz 1 gilt nicht, wemn der Verwaltungsakt, in den der fehlerhafte Verwaltungsakt umzudeuten wäre, der erkenmbaren Absicht der erlassenden Behörde widerspräche oder seine Rechtsfolgen für den Betroffenen ungünstiger wären als die des fehlerhaften Verwaltungsaktes. Eine Umdeutung ist ferner unzulassig, wenn der fehlerhafte Verwaltungsakt nicht zurückgenommen werden dürfte.

(3) Eine Entscheidurig, die nur als gesetzlich gebundene Entscheidung ergehen kann, kann nicht in eire Ermessensentscheidung umgedeutet werden.

(4) 828 ist entsprechend anzuwenden.

\section{\$48 Rucknahme eines rechtswidrigen Verwaltumgsaktes}

(1) Ein rechtswidriger Verwaltungsakt kann, auch nachdem er unanfechtbar geworden ist, ganz oder tei weise mit Wirkung für die Zukunft oder für die Vergangenheit zurückgenommen werden. Ein Verwaltungsakt, der ein Recht oder einen rechtlich erheblichen Vorteil begründet oder bestätigt hat (begünstigender Verwaltungsakt), darf nur unter den Einschränkungen der Absätze 2 bis 4 zurückgenormmen werden.

(2) Ein rechtswidriger Verwaltungsalkt, der eine einmalige oder laufende Geldleistung oder teilbare Sachleistung gewährt oder hierfur Voraussetzung ist, darf nicht zurückgenommen werden, soweit der Begünstigte auf den Bestand des Verwaltungsaktes vertraut hat und sein Vertrauen unter Abwägung 
mit dem öffentlichen Interesse an einer Rücknahme schutzwüdig ist. Das Vertuaten ist in der Regel schutzwưrdig, wenn der Begünstigte gewährte Luistungen verbraucht oder eine Vermögungsdisposition getroffen hat, die er nicht mehr oder nur unter unzumutbaren Nachteilen rückgangig machen kann. Auf Vertrauen kann sich der Begünstigte nicht berufen, wenn er

1. den Verwaltungsakt durch arglistige Täuschung, Drohung oder Bestechung erwirkt hat;

2. den Verwaltungsakt durch Angaben erwirkt hat, die in wesentlicher Beziehung unitichtig oder unvollständig waren;

3. die Rechtswidrigkeit des Verwaltungsaktes kannte oder infolge grober Fahrlässigkeit nicht kannte.

In den Fallen des Satzes 3 wird der Verwaltungsakt in der Regel mit Wükung für die Vergangenheit zurückgenommen. Soweit der Verwaltungsakt zurückgenommen worden ist, sind bereits gewalle Leistungen zu erstatten. Für der Erstattung gelten die Vorschriften des Bürgerlichen Gesetzbuches uber die Herausgabe einer ungerechtfertigten Bereicherung entsprechend. Auf den Wegfall der Bereicherung kann sich der erstattungspflichtige bei Vorliegen der Voraussetzungen des Satzes 3 micht berufen, soweit er die Umstände kannte oder infolge grober Fahrlässigkeit niclat kannte, die die Rechtswidrigkeit des Verwaltungsaktes begründet haben. Die zu erstattende Leistung soll durch die Behörde zugleich mit der Rücknahme des Verwaltungsaktes festgesetzi werden.

(3) Wird ein rechtswidriger Verwaltungsakt, der nicht unter Absatz 2 fätlt, zurückgenommen, so hat die Behörde dem Betroffenen auf Antrag den Vermögensnachteil auszugleichen, den dieser dadurch erleidet, dal er auf den Bestand des Verwaltungsaktes vertraut hat, soweit sein Vertrauen unter Abwågung mit dem öfentlichen Interesse schutzwürdig ist. Absatz 2 Satz 3 ist anzuwenden. Der Vermögensnachteil ist jedoch nïht über den Betrag des Interesses hinaus zu ersetzen, das der Betroffene an dem Bestand des Verwaltungsaktes hat. Der auszugleichende Vermögensnachteil wird durch die Behörde festgesetzt. Der Anspruch kann nur innerhalb eines Jahres geltend gemacht werden, die Frist beginnt, sobald die Behörde den Betroffenen auf sie hingewiesen hat.

(4) Erhält die Behörde von Tatsachen Kenntnis, wellche die Rücknahme eines rechtswidrigen Verwaltungsaktes rechtfertigen, so ist die Rücknahme nur innerhalb eines Jahres seit dem Zeitpunkt der Kenntnisnahme zulässig. Dies gilt nicht im falle des Absatzes 2 Satz $3 \mathrm{Nr}$. 1.

(5) Über die Rücknahme entscheidet nach Unanfechtbarkeit des Verwaltungsaktes die nach $\$ 3$ zuständige Behörde; dies gilt auch dann, wenn der zurückzunehmende Verwaltungsakt von einer anderen Behörde erlassen worden ist.

(6) Für Streitigkeiten über die nach Absatz 2 zu erstattende Leistung und den nach Absatz 3 auszugleichenden Vermögensnachteil ist der Verwaltungsrechtsweg gegeben, sofern nicht eine Entschädigung wegen enteignungsgleichen Eingriffs in Betracht kommt.

\section{Widerruf eines rechtmäßigen Verwaltungsaktes}

(1) Ein rechtmäßBiger nicht begünstigender Verwalungsakt kann, auch nachdem er unanfechtbar geworden ist, ganz oder teilweise mit Wirkung für die Zukunft widerrufen werden, auBer wenn eibn Verwaltungsakt gleichen Inhalts erneut erlassen werden mübte oder aus anderen Grinden ein Widerruf unzulässig ist.

(2) Ein rechtmäßiger begünstigender Verwaltungsakt darf, auch nachdem er unanfechtbar geworden ist, ganz oder teilweise mit Wirkung für die Zukunft nur widerrufen werden,

1. Wenn der Widerruf durch Rechtsvorschrift zugelassen oder im Verwaltungsakt vorbehalten ist;

2. wenn mit dem Verwaltungsakt eine Auflage verbunden ist und der Begünstigte diese nicht odler nicht innerhalb einer inm gesetzen Frist erfült hat; 
3. wenn die Behơde auf Grund nachträglich eingetretener Tatsachen berechigt wäre, den Verwaltungsakt nicht zu erlassen, und wenn ohne den Widerruf das offentiche Interesse gefahrder Whirde;

4. wenn die Behörde auf Grund einer geänderten Rechtsvorschrift berechtigt wàre, den Verwaltungsakt nicht zu erlassen, soweit der Begünstigte won der Vergünstigung noch keinen gebrauch gemacht oder auf Grund des Verwaltungsaktes noch keine Leistungen empfangen hat, und wenn ohne den Widerruf das offientliche Interesse gefahrdet würde;

5. um schwere Nacheile fü das Gemeinwohl zu verhüten oder zu beseitigen.

$84 \mathrm{Abs} .4$ gill entsprechend.

(3) Der widerrufene Verwalltungsakt wird mit dem Wirksamwerden des Widerrufs unwirksam, wenn die Behónde keinen späteren Zeitpunkt bestimmt.

(4) Uber den Widerruf entscheidet nach Unanfechtbarkeit des Verwaltungsaktes die nach $\$ 3$ zuständige Behörde; dies gilt auch dann, wenn der zu widertufende Verwaltungsakt von einer anderen Behörde erlassen worden ist.

(5) Wird ein begunstigender Verwaltungsakt in den Fällen des Absatzes 2 Wr. 3 bis 5 widerrufen, so hat die Behörde den Betroffenen auf Antrag für den Vermögensnachteil zu entschädigen, den dieser dadurch erleidlet, dafs er auf den Bestand des Verwaltungsaktes vertraut hat, soweit seim Vertrauen schutzwürdig ist. $\$ 48$ Abs. 3 Saltz 3 bis 5 gilt entsprechend. Für Streitigkenten über die Entschädigung ist der ordentliche Rechtsweg gegeben.

\section{Rucknahme und Widerruf im Rechtsbehelfsverfahren}

348 Abs. 1 Satz 2, Abs. 2 bis 4 und Abs. 6 sowie $\$ 49$ Abs, 2, 3 und 5 gelten nicht, wenn ein begünstigender Verwaltungsakt, der von einem Dritten angefochten worden ist, whrend des Vorverfahrens oder während des verwaltungsgerichtichen Verfahrens aufgehoben wird, soweit dadurch dem Widerspruch oder der Klage abgeholfen wird.

\section{\$1 Wiederanfigreifen des Verfahrens}

(1) Die Behörde hat auf Antrag des Betroffenen über die Aufhebung oder Änderung eines unanfechtbaren Verwaltungsaktes zu entscheiden, wenn

1. sich die dem Verwaltungsakt zugrunde liegende Sach-oder Rechtslage nachträglich zugunsten des Betroffenen geảndert hat;

2. neue Beweismiltel vorliegen, die eine dem Betroffenen gunstigere Entscheidung herbeigefuhrt haben würden;

3. Wiederaufnahmegrïnde entsprechend \&580 der Zivilprozeßordnung gegeben sind.

(2) Der Antrag ist nur zulässig, wenn der Betroffene ohne grobes Verschulden auBerstande war, den Grund für das Wideraufgreifen in dem früheren Verfahren, insbesondere durch Rechtsbehelf, geltend zu macher.

(3) Der Antrag mub binnen drei Monaten gestellt werden. Die Frist beginnt mit dem Tage, an dem der Betroffene von dem Grund für das Wiederaufgreifen Kerntmis erhalten hat.

(4) Uber den Antrag entscheidet die nach \$ 3 zustandige Behörde; dies gilt auch dann, wenn der Verwaltungsakt, dessen Aufhebung oder Änderung begehrt wird, von einer anderen Behörde erlassen worden ist.

(5) Die Vorschriften des $\$ 4$ Abs. 1 und des 49 Abs. 1 bleiben unberührt. 


\section{\$5 Rückgabe von Urkunden und Sachen}

Ist ein Verwaltungsakt unanfechtbar widerrufen oder zurückgenommen oder ist seüne Wirksankeit aus einem anderen Grund nicht oder nicht mehr gegeben, so kann die Behörde die auf Grund dieses Verwaltungsaktes erteilten Urkunden oder Sachen, die zum Nachweis der Rechte aus dem Verwaltungsakt oder zu deren Ausübung bestimmt sind, zurückfordern. Der Inhaber und, sofern er nicht der Besitzer ist, auch der Besitzer dieser Urkunden oder Sachen sind zu ihrer Herausgabe verpflichtet. Der Inhaber oder der Besitzer kann jedoch verlangen, dafl ihm die Urkunden oder Sachen wieder ausgehändigt werden, nachdem sie vor der Behörde als ungültig gekennzeichnet sind; dies gilt nicht bei Sachen, bei denen eine solche Kennzeichnung nicht oder nicht mit der erforderlichen Offensichtlichkeit oder Dauerhaftigkeit möglich ist. 
Verwaltungsgerichtsordnung

(VwGO)

Vom 21. Januar 1960 (BGBI. IS. 17)

In der Fassung der Bekanntmachung wom 19. März 1991 (BGB1. I S. 686)

(BGBI. III 340-1)

\section{\$121 [Wirkung rechtskräftiger Urteile]}

Rechtskräftige Urteile binden, soweit über den Streitgegenstand entschieden worden ist,

1. die Beteiligten und ihre Reclitsnachfolger und

2. irm Fall des $\$ 65 \mathrm{Abs}$. 3 die Personem, die einen Antrag auf Beiladung nicht oder nicht fristgemäB gestellt haben. 


\section{Lijst van geraadpleegde literatuur}

\section{$A B A R$}

Rapport wan de Commissie Algemene Bepalingen wan Administratief recht, $4 \mathrm{e}$ druk. Aphen a/d Rijn 1980; een herdruk van 1973 met een supplement uit 1976 ABAR

Rapport van de Commissie Algemene Bepalingen van Administratief recht. 5e druk. Alphen a/d Rijn 1984

Achterberg, $\mathbb{N}$.

Allgemeines Verwaltungsrecht, Heidelberg, 2. Aufl. 1986

Adoll, $H_{-}-\mathrm{P}$.

Verwaltungsverfahrensrech: Rücknahme und Widerruf von Verwaltungsakten, in: IA 1988, 12 , \$. $625-627$

Akkermans-Wijn, J.C.E.

Contracten met de overheid, diss., Nijmegen 1989

Allewijin, D.

Het nieuwe besturursprocesrecht, VAR-preadvies 112, Alphen a/d Rijn 1994 Allewijn, D.

Artikel 8:2 Awb; een woorlopig blijuende uitzondering, in: NJB 1998/17, p. 787-788 Andersen, $P$.

Ungültige Verwaltungsakte mit besondere Berücksichtigung der Ungültigkeitsgründe,

Mannheim/Berlin/Leipzig 1927

Angeren, van, J.A.M.

De gewone rechter en de administratieve rechtsgangen, diss., Deventer 1968

Angeren, van, J.A.M.

De aanwullende functie van de gewone rechtsprak ten opzichte van andere rechtsgangen, in:

RM Themis 1991, p. 3-23

Artzt, M.

Zur Problematiek der Rücknahme des Widerspruchs nach Erlaß des Widerspruchsbescheids im

Klageverfahren, in: NVwZ 1995, 7, S. 666-668

Badura, $P$.

Gestaltungsfreiheit und Beurteilungsspielraum der Verwaltung, bestehend aufgrund und nach

Mafgabe des Gesetzes, in: Wege zum Rechtsstaat, Festschrift für Otto Bachof zum 70. Geburts-

tag, hrsg. G. Pütner, München 1984, S. 169-189

Banda, P.H.

Administratief procestecht in vergelijkend perspectief, Een rechtsvergelijkende studie naar de invlloed van de functie van het beroep op de rechter bij de regeling van thet administratieve procesrecht, diss., Zwolle 1989

Baring

Die "Rechtskraft" der Verwaltungsakte, in: NJW 1952, 28, S. 1053-1076 $\mathbb{B a x}, \mathrm{C} . J$.

Legitimatie, in: Algenene Begrippen Staatsrecht, o.r.v. Holterman, e.a. Z Zwolle 1991,

p. $259-277$ 
Beetschen, B.

Die matericlle Rechiskraft der Verwaltungsverfügungen, Zurich 1923

Benda, E.

Zur gesellschaftlichen Akzeptanz werwaltungs- und verfassungsrechticher Entscheidungen, in: Dow $1983,7, S .305-310$

Berge, ten, I.B.I.M.

Botkbeschouwing: C.P.J. Goorden, Rechtsbevoegdheid in het bestuurstecht, in: RM Themis $1993, p \cdot 282-285$

Berge, ten, J.B.J.M. en A.Q.C. Tak

Nederlands administratief procesrecht, deel 1, Zwolle 1983

Berge, ten, J.B.J.M. en A.Q.C. Tak

Hoofdiynen wan het Nederlands diministratief procesrecht, Zwolle 1990

Berge, ten, J.B.J.M.

Bescherming tegen de overheid, Zwolle 1995

Bergh, van den, G.C.II.

Themis en de muzen: de functie van gebonden vormen in het recht, diss., Haarlem 1964

Bernatzik, E.

Rechtsprechung und materielle Rechtskraft, Neudruck der Ausgabe Wien 1886, Aalen 1964

Beseler, H.-F.

Die Rechtskraft der Verwaltungsakte, Diss., Münster 1960

Beumer, E.J.

Rapport van de Commissie Beumer, Nietigheid en vernietigbarheid van beschikkingen,

VAR-geschrift XI, 1944

Biehler, G.

Zur Bindungswirkung von Urteilen des Bundeswerfassungsgerichts, in: DVBI. 1991 ,

S. 1.237-1239

Bitter, C.M. en M.B. de Witte-van den Haak

Beslissen op bezwaarschrift, un: Overheid en nieuw Bestuursrecht, o.r.Y. G.R.J. de Groot, Den Haag 1993 , p. $29-43$

Bitter, C.M. en A.A. van Rossum

Formele rechtskracht en onverbindendheid van wetgeving (HR 16 oktober 1992, AB 1993, 40), in: NTB $93 / 6$, p. $206-211$

Bolit, H.

Bentderingen in het bestuarstecht, in: Aantrekkelike gedachten, Beschouwingen over de $\mathrm{Awb}$,

o.r.V. J.L.Boxum, Deventer 1993, p. 141-161

Bok, A.J.

Rechterlijke toetsing van regelgeving, diss., Deventer 1991

Bok, A.J.

Rechtsbescherming in Frankrijk en Duitsland, Deventer 1992

Bok, A.J.

Algemene wet bestuurstechi en Verwaltungsverfahrensgesetz, in: Aantrekkelijke gedachten,

Beschouwingen over de Awb, o.r.v. J.L. Boxum e.a., Deventer 1993, p. $211-223$

Borges, II.L.

De cultus van het boek en andere essays (Oras inquicisiones), vertaald door Barber van de Pol, Amsterdam 1990 
Braams, A.C.M. Woorbereiding wan bestuiten, in: Overheid en nieuw bestaurstectit, o.r.v. G.R.J. de Groot, Den
Haag 1993, p. 17-29

Bradley. A.W.

Administrative Justice and the Binding Effect of Official Acts, in: Current Legal problems $1981, \mathrm{vol} .34, \mathrm{p} .1-24$

Braun, J.

Die prajudizielle Wirkung bestandskraftiger Verwaltungsakte; Ein Beitrag zur Auseinandersezung um Notwendigkeit und Grenzen der materieller Bestandskraft belaster Verwaltungsakte, Frankfurt am Maim/Bern, 1980

Breitkopf, $K$.

Rücknahme und Widerruf von Verwaltungsakten mit Dawerwirkung unter besonderer

Berücksichtigung des Wiederaufgreifens des Verwaltungsverfallrens in Recht der Sozial-

versicherung und der Kriegsopferversorgung, Diss., Bochum 1980

Brenninkmeijer, A.F.M.

De toegang tot de rechter, Een onderzoek naar de betekenis van ana hankelijke rechtspraak in een democratische rechtsstaat, diss., Zwolle 1987

Brenninkmeijer, A.F.M.

Spanmend bestuursprocesrecht, in: NJB 1994, p. 12-19

Brenninkmejjer, A.F.M.

In memoriam 2 RO, in: NJB 1994, p. 59

Brenninkmejer, A.F.M. en J. Vranken

Harmonisatie van burgerlijke en bestuursprocesrecht, in: WPNR 1992, no. 6074, p. 1003-1018 Brohm, W.

Rechtsgrundsätze für normersezzende Absprachen, in: DôV 1992, 23, \$. 1025-1035

Bronnenmeyer, $\mathrm{H}$.

Der Widerruf rechtsmäßiger begünstigender Verwaltungsakte nach \& 49 VwVfG, Berlin 1994 Bruijn, de, J.A., e.a.

Grote projecten, Besluitworming \& management, Alphen a/d Rijn 1996

Bryson, $\mathbb{N}$.

Het ongeziene in beeld, vier essays over bet stilleven, Amsterdam 1993 (oorspr. titel: Looking at the Overlooked: Four Essays on Still Life Painting)

Büchner, $V$.

Die Bestandskraft verwaltungsrechtlichet Verträge, Diss., Düsseldorf 1979

Bull, H.P.

Allgemeines Verwaltungstecht, Heidelberg, 4. Auft.

Bullinger, $M$.

Zur Bestandskraft belastender Verwaltungsakte, in: $5 Z$, 1963, 15, S. 466-470

Burg, van der, F.H.

Formele recheskracht, wertrouwensbeginselen en derde-beroep, in: Een stellig annotator,

Opstellen aangeboden aan J.R. Stellinga, Zwolle 1982, p. 1.21

Burg, van der, F.H., G.J.M. Cartigny, G. Overkleefi-Verburg, Rechtsbescherming tegen de overheid, Nijmegen 1985

Buruma, Y. en E.J. Daalder

Formele rechtskracht in het strafrecht, in: RMThemis 1994/7, p. 320-335 
Canetri, $\mathbb{E}$.

Het martyrim (oorsp. Die Blendung, 1935), vertaald in het Nederlands door Jacques

Hamelink, Amsterdam 1990

Cliteur, P.B.

Conservatisme en culturrecht, diss., Amsterdam 1989

Clwysenaer, I.L.H.

De toetsing van administratieve beschikkingen door de strafrechter, in: NJB 1970, p. $1000-1007$

Coester, $\mathbb{R}$.

Die Rechtskraft der Staatsakte, München und Leipzïg 1927

Daalder, E.J.

Praktisch procederen, in: Overheid en nieuw bestuursrecht, o.r.v. G.R.J. de Groot, Den Halg 1993, p. 43-53

Damen, L, J.A.

Maar lyet recht dat kan werkeren, in: Gem.st. 6509, nr. 1

Damen, L.J.A.

Bestaat de Awb-mens, in: Aantrekkelijke gedachten, Beschouwingen over de Awb, o.r.v. J.L. Boxum e.a., Deventer 1993, p. 109-131

Dames, L.J.A.

Kan de ministerrad besluten nemen?, in: AA 1996/45, p. 47-53

Damen, L.J.A.

Moet pech weg?, in: Voor risico van de overheid?, C.P.M. Cleiren e.a. (red.), Rotterdam $1996,1996, \mathrm{p} .17-43$

Demeersseman, H.A.

De autonomie van het materiële strafrecht, diss., Arnhem 1985

Domke, U.

Rechtsfragen der Bestandskraft von Verwaltungsakten, Diss., Mamheim 1989

Donner, A.M.

De rechtskracht van administratieve beschikkingen, diss. Alphen a/d Rijn 1941

Donner, A.M.

Administratief-rechtelijke nulliteiten, in: Bestuurswetenschappen 1946, p. 4-24

Donner, A.M.

Bestendig en wederkerig, over het verband van staat en staatsrecht, oratie $R$ UG, Zwolle 1979

Domer, A.M.

De rechtskracht van administratieve beschikkingen, (interview) in: AA 1985, p. 678-681

Donner, A.M.

Nederlands Bestuursrecht, Algemeen deel, Alphen a/d Rujn 1987

Donner, A.M.

De machten en de rechterlijke macht, in: $\mathbb{R M}$ Themis $1989 / 9$, p. $428-438$

Donner, A.M.

Staat en/of samenleving, in: NTB 90/1, p. 14-18

Dorn, $M$.

Möglichkeiten der Verånderung bestandskräftiger Zuwendungsbescheide, in: Dö 1988, 1 ,

S. $7-16$ 
Dritel, van, J.M.C.

De ministeriële verordening, diss., Zwolle 1956

Drion, $y$.

Administratie contra rechter tot de intrekking van het Conflictenbeshit, diss ., "S-Gravenhage 1950

Drupsteen, Th.G.

Frank Bolsius: administratieve en civiele rechtsgang, in: $\mathrm{A} A 1990,7 / 8, \mathrm{p} .459465$

Duk, W. en P. Nicolai

Nulliteiten in het bestuursrecht, RM Themis 1993, p. 3-31

Eikema Hommes, van, H.J.

Enige beschouwingen over Kant's metafysische rechisleer, in: RMThemis 1963, p. 441 e.v.

Eikema Hommes, van, H.J.

De methodische betekenis wan het rechtsbegrip, oratie, Zwolle 1965

Eikema Hommes, van, H.J.

Sein und Sollen im Erfahrungsbereich des Rechts, in: ARSP 1970/6, S. 155-186

Eikema Hommes, van, H.J.

Hoofdlijnen der geschiedenis der rechtsfillosofie, Deventer 1972

Eikema Hommes, van, H.J.

De elementaire grondbegrippen der rechtswetenschap, Deventer 1972

Eikema Hommes, van, H.J.

De samengestelde grondbegrippen der rechtswetenschap, Zwolle 1976

Eikema Hommes, wan, $\mathbb{H} . J$.

Inleiding tot de wijsbegeerte wan H. Dooyeweerd, Den Haag 1982

Erasmus, D.

Lof der zotheid, in de vertaling van P.G. Witsen Geysbeek, Amsterdam 1828, eveneens J.M.

Vermeer-Pardoen, Utrecht 1992 (Stultitiae Laus, 1511)

Erichsen, $H_{-}-\mathrm{U}$, und U. Knoke

Bestandskraft von Verwaltungsakten, in: NVwZ 1983, 4, S. 185-192

Erichsen, H.-U., (hrsg.)

Algemeines Verwaltungsrecht, Berlin/New York, 10. Aufl. 1995

Faber, $\mathrm{H}$.

Verwaltungsrecht, Tübingen, 4. Auf1. 1995

Filener, $F$.

Uber die Umbildung zivilrechtliche Institute durch das öffentliche Recht, Academische

Antritustede, Tubingen 1906

Fleiner, $F$.

Institutionen des Deutschen Verwaltungsrechts. 8. Aufl. "Tubingen 1928

Foerste, $U$.

Zur Rechtskrati in Ausgleichszusammenhängen, in: ZZP 1995, 2, S. 167-193

Forsthoff, E.

Lehrbuch des Verwaltungsrechts 1,1966

Frank, $\mathbb{N}$.

Zur Durchsetzung verwaltungsrechtlicher Entscheidungen, in: Stat und Recht 1981, 11 ,

S. $1025-1033$ 
Franke, K.G.W.

Die Rechtskraft der Steuerwerwaltungsakte, Diss., Münster 1962

Franken, $\mathrm{H}$.

InLeiden tot de rechtswetenschap, Arnhem 1995, p. 37-65 Franz, F.

Die Biestandskrafi der Verwaltungsakte, in: Die Deutsche Richterzeitung 1964, 42, S. 339-343

Greifeld, A.

Abschied von der reformatio in peius im Widerspnuchswerfahren der VwGO?, in: NVwZ 1983, $12,5,725-727$

Gribrian, J.L.M.

De wederkerige rechtsbetrekking als nieuw paradigma?, in: R\&R 1993/2, p. 87-96 Gusy, C.

Bestandskraft und Konkurentenklage, in: Gewerbearchiv 1988, 10, S. 322-328

Haan, de, P. en Th.G. Drupsteen, R. Fernhout

Bestuursrecht in de sociale rechtsstaat, deel 1, Ontwikkeling, Organisatie, Instrumentarium,

Deventer 1996

Haan, de, P. en Th.G. Drupsteen, R. Fernhout

Bestuursrecht in de sociale rechtsstaat, deel 2, Bestururshandelingen en warborgen, Deventer 1986

Harries, $H$.

Verwaltungsentscheidung und Rechtsverhältnis, in: NJW 1984, 39, S. 2190-2194

Hartlief, T. en R.P.J.L. Tjittes

Overheidsaansprakelijkheid, in: NTBR 1994 , p. 36

Hemmrich, $\mathbb{H}$.

Die Rechtskraft der verwaltungsgerichtlichen Entscheidungen und der Verwaltungsakte, Diss., Köln 1929

Hendriks, L.E.M.

Techniek en normstelling in het milieustrafrecht, diss., Zwolle 1994

Hennekens, H.Ph,J.A.M.

De Hoge Rad en de formele rechtskracht, in: Gem.st. 6962, nr, 1, p. 149-155

Herzberg, J.

Zoals, Amsterdam 1993

Hijma, Jac. en M.M. Othof

Compendium van het Nederlands vermogensrecht, Leidraad voor het nieuwe BW, Deventer

$1996, \mathrm{nr}, 96$

Hirsch Ballin, E.M.H.

Wederkerig bestuursrecht, in: RMThemis $1989 / 1$, p. $1-4$

Hoeven, wan der, I.

De grenzen van de rechterlijke functie in de administratieve rechtspraak, in: RMThemis 1974,

p. 658-679

Hoeven, van der, J.

De drie dimensies van het bestuursrecht, Alphen a/d Rjn 1989

Hoeven, vander, $J$.

Advies inzake Constitutionele toetsing, in: NJCM 1992, p. 292-303 
Holterman, Th.

Constanten in het publiekrecht; Zwolle 1995

Horn, T.

Folgenbeseitigung bei aufgehobenem Verwaltungsakt mit Dritwirkung, in: DoV 1989, 22,

S. $976-986$

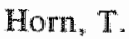

Der Aufhebungsanspruch beim Verwaltungsakt mit Drittwinkung, DoV $1990,20, S .864-872$ Huart, F.J.A.

Taak en methode bij de uitoefening van het administratief recht, oratie UWA, Amhem 1930 Hufen, $F$.

Heilung und Unbeachtlichkeit grundrechtsrelevanter Verfahrensfehler? in: NJW 1982, 39, S.

$2160-2169$

Hufen, $F$.

Zur Systematik der Folgen von Verfahrensfehlern - eine Bestandsaufnahme nach zehn Jahren VwVFG, DVBI. 1988, 2, S. 69-77

Huls, N.J.H. en H.D. Stout (red.)

Reflecties op reflexief recht, Zwolle 1992

Ibler, $\mathrm{M}$.

Kann der Widerruf eines Verwaltungsakis widerruten werdem?, in: NVwZ 1993, 5, S, 451-454 Usseling, $\mathrm{S}$.

Boeken-wijsheid, Filosofische notities over boeken, lezers en schrijvers, Kampen 1995 Ipsen, $\mathrm{H}$.

Widerruf gültiger Verwaltumgsakte, Hambutg 1932

Ipsen, J.

Rechtsfolgen der Verfassungswidrigkeit von Norm und Einzelakt, Hab.Schr. Göttingen, BadenBaden 1980

Ipsen, $J$.

Verbindlichkeit, Bestandskraft und Bindungswirkung von Verwaltungsakten, Versuch einer begrifflicher Klärung, in: Die Verwaltung, Zeitschrift für Verwaltungswissenschaft, 1984,

p. $169-195$

Jachnanu, $M$.

Die Bindungswitkung normkonkretisierender Verwaltungsvorschriften, in: Die Verwaltung $1995,1,5.17-33$

Jellinek, W.

Gesetz, Gesetzesanwendung und Zweckmassigkeitserwägung. Tübingen 1913

Jellinek. W.

Verwaltungsrecht, Offenburg, 3. Aufl. 1948

Jesch, $\mathrm{D}$.

Die Bindung des Zivilrichters an werwaltungsakte, Diss., Tübingen 1956

Jeromin, C.M.

Die Bestandskraft von Verwaltungsakten im AmtshaftungsprozeB, in: $N$ WZ 1991, 6,

S. $543-545$

Jong, de, JP.

Bestuursrecht van vreemde herkomst, diss., Zwolle 1988 
Jurgens, E.C.M.

Beroep tegen algemeen verbindende voorschriften, coreferaat voor de Vereniging voor Wetgeving en wetgevingsbeleid, Alphen a/d Rijn 1996

Kelsen, H.

Reine Rechtslehre, Wien 1960

Kelsen, $\boldsymbol{H}$.

Allgemeine Theorie der Normen, Wien 1979

Kemper, G. H.

Rechtsfragen zum Anwendungsbereich des $\$ 51 \mathrm{VwVfG}$, unter besonderer Berücksichtigung des Asylverfahrens, in: NVwZ 1985, 12, S. 872-880

Klappstein, W.

Rechtseinheit und Rechtsvielfalt im Verwaltungsrecht; Dargestellt am Beispiel der Bestandskraft von Verwaltungsakten nach dem Allgemeinen und dem Besonderen Verwaltungsrecht. Diss... Heidelberg 1994

Klein, K.H./Czajka, D.

Gutachten und Urteil im Verwaltungsproze:B, München, 4. Aufl. 1987

Kluth, W.

Rechtsfragen der werwaltungsrechtlichen Willenserklärung; Auslegung, Bindung, Widerruf, Anfechtung, in: NVwZ 1990, 7, S. 608-614

Knoke, U.

Rechtsfragen der Rücknahme von Verwaltungsakten; Zur Dogmatik und Kritik der

Rücknahmebestimmungen der Verwaltungsverfahrensgesetze, Berlin 1989, Zugl. Diss. Münster 1987

Knöpfle, $\mathbb{F}$.

"Tatbestands-" und "Feststellungswirkung" als Grundlage der Verbindlichkeit von gerichtlichen Entscheidungen und Verwaltungsakten, in: Bay VBI. 1982, 8, S. 225-230

Kollmann, A.

Zur Bindungswirkung von Verwaltungsakten, in: DöV 1990, 5, S. 189-196

Konijnenbelt, W.

De administratieve rechter als schadevergoedingsrechter, preadvies Vereniging voor burgerlijk recht, Lelystad 1996

Kopp, F.

Uber die Grenzen der verwaltungsgerichtlichen Rechtskontrolle im Wirtschaftsrecht, in:

WiVerw 1982, 1, S. 1-22

Kopp, F.

Bericht über die Verhandlungen der Abteilung VerwaltungsprozeBrecht des 54. Deutschen Juristentags in: BayVBI. 1982, 22, S. 682-686

Kopp, F.

Die Bestandskraft von Verwallungsakten, in: DVB\#. 1983, S. 392-400

Kopp, F.

Friedrich Schoch: Vorläufiger Rechtsschutz und Risikoverteilung im Verwaltungsrecht, in: $A$ ö $\mathbb{R}$ 1989, S. $509-512$

Kopp, F.

Die Ausschlußfrist des $\$ 48 \mathrm{Abs} .4 \mathrm{VwVfG}$ nach rechtskräftiger Aufhebung eines Rücknahmebescheids, in: DVBI. 1990, S. 663-665 
Kopp, F.J.

Vorlâufiges Verwaltungsverfahren und vorläufiger Verwaltungsakt, Frankfurt an Main Berlin/Bern/New York/Paris/Wien 1992, Zugleich: Diss. Berlin

Kopp: J.

Verwaltungsakte unter Vorbehalt und sonstige vorliafige Verwaltungsakte, in: DVB1. 1989, S. $238-242$

Kopp, F.O.JKopp, J.

Grenzen der Rechtskraftwirkung won Urteilew aufgrund von Anfechtungsklagen, in: NVwZ 1994,1, S. 1-6

Kormann, $\mathrm{K}$.

System der rechtsgeschäfilichen Staatsakte, Berlin 1910

Krause, P.

Rechtsformen des Verwaltungshandelns, Hab.Schr. Universitä des Saarlandes, Berlin 1974 Krebs, W.

Zur Wirksamheit und Geltung von Verwaltungsakten, in: Verwaltungsarchiv 1977, S. 285-291

Krol, Ch.B.

Als de Koning dit eens wist ...., diss., Antwerpen 1994

Langemeijer, G.E.

Ons oordeel over wat recht moet zijn, oratie Leiden, Zwolle 1946

Langemeijer, G.E.

Inleiding tot de studie van de wijsbegeerte des rechts, Zwolle 1973

Laubinger, H. - W.

Die Anfechtbarkeit von Nebenbestimmungen, in: Verwaltungsarchiv 1981,3, S. 345-368

Lauwaars, R.H.

Rechtmatigheid en rechtskracht wan gemeenschapsbesluiten, diss., Leiden 1970

Linden, wan der, E.C.H.J. en A.Q.C. Tak (red.)

Eenzijdig en wederkerig?, Beschouwingen over de wederkerige rechtsbetrekking als basis-

concept in het bestuursuecht, Deventer 1995

Linden, van der, E.C.H.J.

Enige opmerkingen omtrent de betekenis en rechtskracht van bestuursrechtelijke uitspraken naar aanleiding van CRvB 26 juni 1997, in: JB $1997 / 210$

Linden, van der, E.C.H.J.

De formele rechtskracht werkt ook jegens derden, in: Uitspraak 1998/1, p. 25 -32

Linden, van der, E.C.H.J., R.J.N. Schlössels en R.J.G.H. Seerden (red.)

Spectraal recht?, Den Haag 1998

Loening, E.

Die Rechtskraft verwaltungsgerichtlicher Urteile, in: Verwaltungsarchiv 1899 . S. 1-91

Losch, B.

Der vorsorgliche Verwaltungsakt, in: NVWZ 1995, 3, 5. 235-239

Lubberdink, H.G.

Beroep tegen algemeen verbindende voorschriften, preadvies voor de Vereniging voor

Wetgeving en wetgevingsbeleid, Alphen a/d Rijn 1996

Lücke, J.

Vorläufige Staatsakte; Auslegung, rechtsfortbildung und Verfassung am Beispiel worläufiger

Gesetze, Urteile, Beschüsse und Verwaltungsakte, Tubingen 1991 


\section{Lützenkirchen, $J$.}

Ein Vergleich zwischen dem Verfahren der Freiwilligen Gerichtsbarkeit und dem allgemeinen Verwaltungsverfahren, diss., Münster 1967

Maanen, van, G.E.

De wonderbaarlijke geschiedenis van de onrechtmatige overheidsdaad in de $19 \mathrm{e}$ en $20 \mathrm{e}$ euw, Nijinegen 1996

Male, van, R.M.

Rechter en bestuurswetgeving, diss., Zwolle 1988

Malle, van, R.M.

Onvoltooid recht, over rechtsbetrekking, bestuursrecht en bestuursprocesrecht, oratie EUR, Zwolle 1993

Male, $\operatorname{van}$, R.M.

Gevolgen van onrechtmatige regelgeving in Nederland, preadvies Vereniging voor de vergelijkende studie van het recht van België en Nederlland, Zwolle 1995

Marcic, R.

Merkls ontologische Theorie der Rechtskraft, ein vergessenens, doch höchst aktuelles Lehrstück aus des Jubilars Gesamtwerk, in: Festschrift für Adolf Merkl, Imboden e.a., München-Salzburg 1970, S. 223-247

Martens, J.

Die Rechtsprechung zum Verwaltungsverfahrensrecht, in: NVwZ 1982, 9, S. 480-487. Martens, J.

Die Rechtsprechung zum Verwaltungsverfahrensrecht, in: NVwZ 1983, 12, S. 7-724

Martensen, J.

Persönlichkeitsrecht und Anhörung des Bürgers vor dem Erlaß belastender Verwaltungsakte, un:

Dô 1995, 13, S. 538-545

Mayer, F./Kopp, F.

Allgemeines Verwaltungsrecht, Stuttgart/München/Hannover, 5. Aufl. 1985

Mayer, $\mathrm{O}$.

Deutsches Verwaltungsrecht, Erster Band, 3. Aufl., München und Leipzig 1924

Mayer, 0 .

Zur Lehre von der materiellen Rechtskraft in Verwaltungssachen, Archiv für öffentliches Recht, 1907

Maurer, H.

Bestandskraft für Satzungen?, in: Wege zum Rechtsstaat ${ }_{\text {}}$ Festschrift für Otto Bachof zum 70.

Geburtstag, hrsg. von G. Püttner, München 1984, S. 215-243

Maurer, $\mathrm{H}$.

Allgemeines Verwaltungsrecht, München 1994

Menger, C. $\mathrm{F}$.

Rechtskraft bei vorlaüfigem Rechtsschutz?, in: Recht und Staat im sozialen Wandel, Festschrift für H.U. Scupin zum 80. Geburtstag, hrsg. von N. Achterberg, W. Krawietz, D. Wyduckel, Berlin 1.983, S. $847-860$

Merkl, A.

Die Lehre von der Rechtskraft entwickelt aus dem Rechtsbegriff, Wien 1923

Merkl, A.

Allgemeines Verwaltungsrecht, Wien und Berlin 1927 
Merten, D.

Bestandskraft yon Verwaltungsakten, in: NJW 1983, 36, S. 1993-1998

Merten, D.

Bestandskraft von Verwaltungsakten, in: Dokumentation zum Siebten Deutschen Verwaluungsrichtertag 1983, hrsg. vom Bund Deutscher Verwaltungsrichter. Stuttgart/Munchen/Hannover 1983 , S. 99-101

Meyer, H./Borgs-Maciejewski, H.

Kommentar zum Verwalnungsverfahrensgesetz, Frankfurt am Main, 2. Aufl. 1982

Michicls, F.C.M.A.

De Arob-beschikking, diss., 's-Gravenhage 1987

Mok, M.R. en R.P.J.G. Tjittes

Formele rechtskracht en overheidsaansprakelijkheid, in: RMThemis 1995, p. 383-404

Mulert, $\mathbb{M}$.

Die Rücknahme unanfechtbarer belastender Verwaltungsakte, Diss., Münster 1970

Neerhof, R., R. Schlösles en M. de Werd

Bestuur in geding, in. JB 1997/280

Nicolail, P., B.K. Olivier, L.J.A. Damen, H. Troostwijk

Bestuursrecht, Amsterdam 1994

Nicolaï, P., B.K. Olivier, I.C. van der Vlies, L.J.A. Damen, B.J. Schueler

Bestuursrecht, Amsterdam 1997

Okhuizen, E.C.G.

De leer van de formele rechtskracht en de nasleep van het St. Oedenrode-arrest: een uitgemakte zaak?, in: Weekblad Fiscaal Recht 1997/6271, p. 1753-1769

Oliver, D.

Void and Voidable in Administrative Law: A Problem of Legal Recognition, in: Current Legal Problems 1981, vol.34., p. 43.63

Oomen, $\mathrm{C}$.

Ongemotiveerde aanvallen op het uitwegwergumingenstelsel, in: Gem.st. 6404 en 6405 , nrs. 1 Ossenbühl, F.

Verwaltungswerfahren zwischen Verwaltungseffizienz und Rechtsschutzauftrag, in: NVwZ $1982,8, \mathrm{~S}, 465-472$

Ossenbühl, F.

Eine Fehlerquellelehre für untergesetzliche Nomen, in: Dokumentation zum achten Deutschen Verwaltungsrichtertag 1986, hrsg. vom Bund Detutscher Verwaltungsrichter, Stutt-

gart/München/Hannover 1987, S. 112-132

Ortloff, $K .-M$.

Zur Bindungswirkung des baurechtichen Vorbescheids bei nachfolgender Änderung der Sachoder Rechtsiage, in: NVwZ 1983, 11, S. 705-709

Peters, A.A.G.

Het rechtskarakter van het strafrecht, oratie RUU, Deventer 1972

Plato

Politeia, Constitutie, vertaling van Gerard Koolschijn, Ansterdam 1997 
Plini Secundi

Naturalis Histotiae, Libri XXXV, 65-66 (in de vertaling van H. Rackham, herdruk London 1995)

Polak, J.E.M.

Rechtstreeks beroep tegen algemeen werbindende voorschriften en beleidsregels bij de bestuursrechter: voorlopig van de baan?, in: Trema 1997/8, p. 269 e.v.

Pöppinghaus, $\mathrm{K}$.

Das System des Widerrufs von Werwaltungsakten, Diss., Münster 1959

Pot, wan der, C.W.

De vormen wan het besturen, in: Nederlands Bestwursrecht, Alphen a/d Rijn 1932

Randak, M.

Bindungswirkungen von Verwaltungsakten, in: JuS 1992,1, S. 33-39

Redeker, $\mathrm{K}$.

Entwicklungen und Probleme verwaltungsrechtlicher Rechtsprechung, in: Recht und Staat im sozialen Wandel, Festschrift für H.U. Scupin zum 80. Geburtstag "hrsg. von N. Achterberg, W. Krawietz, D. Wyduckel, Berlin 1983, S. 861-879

Redeker, K./Oerizen, von, H.-J.

Verwaltungsgerichtsordnung, Kommentar, Stuttgart/Berlin/Köln, 11. Aufl. 1993

Rernmelink, $\mathrm{J}$.

Advies van de Hoge Raad en Procureur-Generaal inzake Constitutionele toetsing, in: NJCM 1992, p. 243-259

Renck, L.

Verwaltungsaktswirkungen, Rechtsmittelwirkungen und worläufiger Rechtsschutz, in: Bay VBI. $1994,6,5,161-167$

Renck, L.

Zur Dogmatik des Rechtsschutzes unmittelbar gegen Normen, in: BayVBI. 1994, 15, S. $457-459$

Rennert, $\mathrm{K}$.

Rechtskraftprobleme im Verhältnis von Art. 16 Abs. 2 Satz 2 GG und $\$ 51$ Abs. 1 AuslG, in: VBIBW 1993, 8, S. 281-286

Rogier, L.J.J.

De Algemene wet bestuursrecht en strafrecht, Deventer 1995

Roos, N.H.M.

Enige opmerkingen over de grondslagenproblematiek in de rechtsfilosofie van H.If. van Eikema Hommes, in: Tijdschrift voor Rechtsfilosofie en rechtstheorie 1980, p. 26 e.w.

Rupp, H.H.

Bemerkungen zum werfahrensfehlerhaften Verwaltungsakt, in: Wege zum Rechtsstaat, Festschrift für Otto Bachof zum 70. Geburtstag, hrsg. von G. Püttner, München 1984, S. $151-168$

Saladin, P.

Die sogenannte Nichtigkeit von Verfügungen, un: Festschrift für Ulrich Häfelin zum 65.

Geburtstag, Zürich 1989 , S. 539-556 
Samighausen, W.

Widerruf anfgrund rechtswidriger Widerrufsworbehalte nach $49 \mathrm{II} \mathrm{Nr}, 1 \mathrm{Alt}, 2 \mathrm{VwVF}$, in:

NVWZ 1995, 6, S. 563-567

Sauer, $\mathrm{H}$.

Die Bestandskraft won Verwaltungsakten, in: DÖV 1971,5, S. $150-158$

Schack, $\mathrm{H}$.

Drittwirkung der Rechtskraft, in: NJW 1988, 14, S. 865-873

Schafer, A.

Dì Beseitigung begünstigender Verwalungsakte durch die Erlassbehörde, Diss., München 1966

Schelterma, M. en H. Lubberdink

Administratieve rechtsgangen, Algemeen deel, (losbladig)

Scheltema, M. en $W$. Konijnenbelt

De rechtsverwerking in het administratieve recht, VAR-preadviezen nr. LXXIV, Groningen 1975

Scheltema, $M$.

Van rechtsbescherming naar een volwaardig bestuursrecht, in: NJB 1996/33, p. 1356 e.v. Schenke, W.-R.

Das Verwaltungsverfahren zwischen Verwaltungseffizienz und Rechtsschutzauftrag, in: VBIBW $1982,10, \$ .313-326$

Schenke, W.-R.

Probleme der Bestandskraft von Verwallungsakten, in: DÖV 1983, 8, S. 320-332

Schenke, W.-R.

Der verfahrensfehlerhafte Verwaltungsakt gemäß \& $46 \mathrm{VwVfG}, \mathrm{Dob} 1986,8,5.305-321$

Schenke, W.-R.

Die Umdeutung won Verwaltungsakten, in: DVB1. 1987, 13, S. $641-654$

Schenke, W.-R.

Widerruf oder Rücknahme rechtswidrig gewordener Verwallungsakte?, in: Bay VBI. 1990, 4, S.

$107-110$

Schiedeck, E.

Die Nichtigkeit won Verwaltungsakten nach 44 Absatz 1 VwVfG, Diss., Regensburg 1993 Schindler, $\mathbb{R}$.

Abschaffung der Rechtskraft durch die Gerichtshofe des offentlichen Rechts?, in: ZfVB 1989,6,

S. 596-601

Schlössels, R.J.N.

Het specialiteîtsbeginsel, diss., Den Hag 1998

Schmidt, W.

Das Wiederaudgreifen des Verwaltungsverfahrens - Zur Dogmatik des \$ 51 VwVrG, Diss.,

Nürnberg 1982

Schmidt-Alimann, E.

Die Lehre von den Rechtsformen des Verwaltungshandelns, in: DVBL. 1989, S. 533-54

Schoch, F.K.

Die Frist zur Rücknahme begünstigender Verwaltungsakte nach 848 IV VwVFG, in: NVwZ $1985,12, \mathrm{~S} .880-885$

Schreuder-Vlasblom, M.

Eigenzinnig recht, oratie, Deventer 1998 
Schueler, B.J.

Schadevergoeding onder de Algemene wet bestuursrecht, Deventer 1997

Seibert, M. J.

Die Bindungswirkung von verwaltungsakten, Baden-Baden 1989, Zugl: Diss. Bonn 1988

Selmer, P.

Zum Widerruf von Verwaltungsakten, in: Lüneburger Symposion für Hans Peter Ipsen zur

Feier des 80. Geburtstags, hrsg. G. Nicolaysen, H. Qauritsch, Baden-Baden 1988, S. 23-30

Simon, H.J.

Publiekrecht of privatrecht? , diss., Zwolle 1993

Simon, H.J.

Handleiding Awb-praktijk, "s-Gravenhage 1995

Simon, H.J.

De Hoge Raad, de Awb en de toegang tot de rechter, in: JB 1996/123

Simon, H.I.

Handboek bestuurs(proces)recht wolgens de Awb, 's-Gravenhage 1997

Simon, H.J.

Straatsburg bezien vanuit het Nederlandse bestuursrecht, in: JB 1997/261

Sommermann, $\mathbb{K}_{\text {n."P. }}$.

Ulrich Knoke: Rechtsfragen der Rücknahme von Verwaltungsakten, in: AöR 1992, S. 142-143

Spill, ter, F.W. en A.Q.C. Tak

Onwetmatig bestuur, VAR-preadvies, Alphen a/d Rijn 1981

Stadie, $\mathrm{H}$.

Rechtsnachfolge in Verwaltungsrecht, in: DVBL. 1990, S. 501-508

Steenbeek, J.G.

Rechtshandeling en rechtsgevolg in het staats- en administratief recht, diss., Assen 1958

Steenbeek, J.G.

Wet Arob, 's-Gravenhage 1976

Steenbeek, J.G.

Reclutskracht, in: NTB 1889/8, p. 265 e.v.

Steenbeek, J.G.

Ex tunc of ex nunc?, in: Two 1990/8, p. 181-183

Stellinga, I.R.

Nietigheid van administratiefrechtelijke beschikkingen, in: Gemeentebestuur 1940, p. $363-373$ Stellinga, I.R.

Systematische Staatsrechtsstudie, dièsrede voor de Rijksbelastingacademie te Rotterdam 16

oktober 1946, "s-Gravenhage 1946

Stellinga, I.R.

Grondtrekken wan het Nederlands Administratiefrecht, Zwolle 1951

Stellinga, J.R.

Grondtrekken wan het Nederlands Administratiefrecht, Zwolle 1973

Stelliga, J.R.

De nietigheid van reclltswege op de terugtocht, in: TwO 1978/15, p. 332 e.v.

Storz, W.

Die Rücknahme begünstigender Verwaltungsakte wegen ursprünglicher Fehlerhaftigkeit, Diss.,

Tubingen 1963 
Stout, H. en J. Stoop

Het falen wan de wet, Een inleiding tot het autopoietisch denken van Gunther Teubner, in:

Regelmaat 1991-1, p. 2-4

Stout, $\mathbb{H}$. en J. Stoop

Autopoiese aan de Maas, ofwel: instrumentele wetgeving reddeloos verdronken, in: Regelmaat $1991-1$, p. $5-9$

Stroink, F.A.M.

Boekbeschouwing over C.P.J. Goorden Rechtsbevoegdheid in het bestuursrecht, in: NTB 1990 , p. 295 e.v.

Stroink, F.A.M.

Rechterlijke organisatie en rechtspraak in beweging, Zwolle 1993

Stroink, F.A.M.

Algemeen bestuursrecht, Zwolle 1996

Stroink, F.A.M.

Kern van de bestuursrechtspraak, "s-Gravenhage 1997

Stroink, F.A.M.

Complexe besluitvorming: een opgave voor burger, bestuur en rechter, VAR-preadvies 120 ,

Alphen a/d Rijn 1998

Tak, A.Q.C.

Beslluiten van algemene strekking, in: RMThemis 1980, p. 132-162

Tak, A.Q.C. en J.B.J.M. ten Berge

Nederlands administratief procesrecht, deel 2, Zwolle 1983

Tak, A.Q.C.

Bevoegdheidsafbakening van de Arob-rechter, kunstig of gekunsteld?, oratie RL, Deventer 1984 Tak, A.Q.C.

Het moment X, in: TrO 1990 , p. 134-138

Tak, A.Q.C.

De ongewenste discussie, in: Nieuw bestuursprocesrecht, J.B.J.M. ten Berge e.a. (red.),

Deventer 1992

Tak, A.Q.C.

Naar een invullende rechtsleer, in: Recht en Kritiek 1993, p. 174-191

Tak, A.Q.C.

Hoofdlijnen van het Nederiands bestuursprocesrecht, Zwolle 1995

Tak, A.Q.C.

De overheid in het burgerlijk recht, "s-Gravenhage 1997

Teubner, G.

Introduction to Autopoietic Law, in: Autopoietic Law: A New Approach to Law and Society,

Berlin and New York 1988, p. 1-12

Teubner, G.

Recht als autopoietisches System, Frankfuhrt am Main 1989

Teunissen, J.M.H.F.

Het burgerlijk kleed wan de staat, diss., Zwolle 1996

Teunissen, J.M.H.F.

Bestuurlijk oordeel als rechtshandeling, in: Gem.st. 7077, nr. 1, p. 309-31.5 
Tezner, 1 .

Das Rechtskiftproblem in Verwaltungsrechte, in: Verwalungsarchiv $1911, \mathrm{~S} .128-166$,

$442-545$ und $1912, S .102-138$

Tjittes, R.P.J.L.

Herbezinning op de grondsllagen van de overheidsaansprakelijkheid, preadvies Vereniging voor

Burgerljk recht, Lelystad 1996

Toulmin; $\mathbf{S}$.,

Descartes, Descartes..., in: Een schitterend ongeluk, vraaggesprekken met Wim Kayzer,

Amsterdam/Antwerpen 1995, p. 257-303

Vegting: W. G.

Het algemeen Nederlands administratiefrecht, eerste deel, Alphen a/d Rijn 1954

Verheij, $N$.

Bewoegdheidsverdeling tussen burgerlijke en bestuurs rechter, preadvies nr. 50 voor de

Nederlandse Vereniging voor Rechtsvergelijking, Deventer 1994

Versteden, C.J.N.

De sloop wan het uitwegverguningenstelsel en de exploitatieverordeningsmethode, in: Gem.st.

6628 en 6629, nrs. 1

Versteden, C.J.N.

Uitwegvergunningenstelsels en financiële woorwaarden in soorten, in: Gem.st. 6708, 6709 en

6710 nrs. 1

Versteeg, A.J.H.W.M.

Verdeling van rechtsmacht, diss., Deventer 1987

Viersen Trip, van, G.W.

De gelaarsde kat, Vertelling ener merkwaardige strafzaak, Ars Aequi Antiqua 1977

Volkmann, J.

Die Problematik der Rechtskraft sozialwersicherungsuechtlicher Verwaltungsakte, Diss., Köln 1966

Wallerath, $M$.

Allgemeines Verwaltungsrecht, Siegburg, 3. Aufl. 1985

Walter de Bruijn, A.

Terugvorderingsacties in uitwegvergunningenzaken, in: Bouwrecht 1984, p. $779-789$

Wassenaer van Catwijck, Baron van, A.J.O.

Recht en taal, sprookje en ideaal, in: Meesterlijke talal, over taal en aalgebruik in het recht, uitgegeven ter gelegenheid van het achttste lustrum van de Jonge Balie Utrecht, Zwolle 1988

Wattel $\mathrm{P}$.

Relativering vain formele rechtskracht en een omgekeerde tweewegenleer, in: Weekblad Fiscaal

Recht 1991/5947, p. 123-129

Weides, $P$.

Zur Anwendbarkeit der Rücknahmefrist des 48 Abs. 4 Satz 1 VwVfG bei Rechtsanwendungs-

fehlern der Behörde, in: DöV 1985, 3, S. 91-97

Weides, $P$.

Die Jahresfrist für Rücknahme und Widerruf von begünstigenden Verwaltungsakten, in: $D o ̈ V$ 1985,11, S. $431-437$ 
Wel, van der, D.

Administratiefrechtelijke nulliteiten, diss, Arnhem 1951

Wiarda, GJ.

Drie typen wan rechtsvinding, $Z$ Zwolle 1988

Wiederin, $\mathbb{E}_{\text {. }}$

Gilt die lex-posterior-Regel zwischen Bescheiden?, in: ZfV 1992, 3, \$. 249-256

Wijk, van, H.D.

Hoofdstukken van administratief recht, Groningen/s-Gravenhage 1968

Wijk, van, H.D., W. Konijnenbelt, R.M. van Male.

Hoofustukken van administratief recht, Utrecht 1997

Witteveen, W.d.

De retoriek in thet recht, oratie, Z Zwolle 1988

Witteveen, W.J.

De geordende wereld wan het recht, Amsterdam 1996

Wolff, H.J.

Verwaltungsrecht I, 1.Aufl. 1956

Wolff, H.J./Bachof, O.

Verwaltungsrecht I, München, 10. Auft. 1994

Zonderland, $\mathrm{P}$.

Het kort geding in het bijzonder tegen de overheid, Zwolle 1972 


\section{Jurisprudentieregister}

\section{Hoge Raad}

HR 29 mei 1896, W.6817 (Vrouwe Elske) 21,42

HR 21 april 1898, W.7116 (Rhedense koe)

HR 5 december 1904, W.8252 (Scheveningse pier)

HR 20 december 1907 , W.8641

HR 19 juni 1908, W. 8722

HR 31 december 1915, NJ 1916, 407 (Guldemond-Noordwijkerhout)

HR 13 november 1941, NJ 1942, 172 (Staat-Bonneveld)

HR 24 maart 1950, NJ 1950,662

(Vereniging Centrale Veiling Goeree en Overflakkee-Bedrijfschap Groenten en Fruit)

HR 22 februari 1957, NJ 1957, 310 (Schellen en deuropeners)

HR 26 januari 1964, NJ 1965, 2 m.nt. Scholten (Willemse-Bedrijfsvereniging)

HR 23 november 1965, NJ 1966, 331 m.nt. Van Berckel

HR 2 februari 1966, NJ 1966, 415 m.nt. Polak (Hoogeloon)

$48,49,54,56,61,66$

HR 28 november 1967, NJ 1968, 143 (Weertse caféhouder)

HR 26 maart 1971, NJ 1971, 434 (Elslooër verkiezingsafspraak)

HR 9 november 1973, NJ 1974, 91 m.nt. Prins (Limmen-J.N. Houtkoop)

HR 19 november 1977, AB 1978, $243 \mathrm{~m}$.nt. Stellinga (Semper Crescendo)

HR 25 november 1977 , AB 1978, I m.nt. Stellinga

(Loosdrechts Plassenschap-Nagtegaal en Bavelaar)

HR 2 februari 1979, NJ 1979, 581 m.nt. Brunner

(NV Van Wijk en Heringa-BV Van der Linden \& Zonen)

HR 11 december 1981, NJ 1983,320 m.nt. JAB (Ameland-De Boer)

30,31

HR 18 juni 1982, NJ 1983, 723 m.nt. CJHB (Plas-Valburg)

HR 24 januari 1984, AB 1984, 399 m.nt. Van Eijden (St. Oedenrode-Driessen BV) $39,43,55$

HR 13 november 1984, AB 1985, $361 \mathrm{~m}$.nt FHvdB (Camperen in Domburg)

HR 22 november 1985, AB 1986, $245 \mathrm{~m} . n$. Van Ballegooij

(V\&D en Super Doe-Groningen)

HR 9 mei 1986, AB 1986, 429 m.nt. Van der Burg (Staat-Van Gelder NV)

HR 16 mei 1986, AB 1986, 573 m.nt. Van der Burg; NJ 1986, 723 m.nt. Scheltema;

RwdW 1986, 109; AA 1986 m.nt. Hennekens, p. 642. Bouwrecht 1986, p. 775

m.nt. Koeman; tB/S 1986, Burgerlijke rechter, 3 m.nt. Tak; AB-Klassiek, Deventer

1997, nr. 22 m.nt. Ten Berge; Gem.st. 6842/3, p. 339 m.nt. Konijnenbelt.

(Heesch-Van de Akker)

$17,30,40,45$ e.v., 109 e.v., $116,117,211,231,254$

HR 30 januari 1987, AB 1988, 43 m.nt. PvB (Nibourg BV-Zuidwolde)

120,128

HR 6 februari 1987, AB 1987, 272 m.nt. FHvdB ("s-Gravenhage-Aral NV)

HR 10 februari 1987, NJ 1987, 662 m.nt. "tH 
HR 11 nowember $1988, \mathrm{AB} 1989,81 \mathrm{~m} . \mathrm{nt}$. FHvdB

(Ekro BV Vee- en Vleeshandel-Staat)

112,116

HR 14 april 1989, AB 1989, m.nt. Klejis-Wijmobel (Benckiser)

HR 2 februari 1990, AB 1990, $223 \mathrm{~m}$.nt Kleijn (Staat-Bolsius)

$118,246,247$

HR 23 februari 1990 , NJ 1991, 574 m.ni. CIHB

(Central Beheer Schadeverzekering-Bedriffswereniging Metaalnijverlheid)

HR 19 oktober 1990, NJ 1994, 138 m. nt. MS

(Noord-Brabunt-Stichting Brabantse Milieufederatie)

119,122

HR 18 januari 1991, AB 1991, $241 \mathrm{~m}$.nt. FHwdB (Leffers-Staat)

HR 5 februari 1991, $A B 1992,38$

120

HR 31 mei 1991, AB 1992, 290 m.nt. FHvdB (Van Gog-Nederweert)

HR 8 juli 1992. NJ 1993, 180

102,103

HR 16 oktober 1992, AB 1993,40 m.nt. FHvdB (Vulhop-Amsterdam)

HR 23 oktober 1992, NJ 1993, 640 m.nt. MS (K-Bedrijfsvereniging Bouwnijverheid)

HR 10 november 1992, NJ 1993, $181 \mathrm{~m}$ nt. MS

103

HR 13 november 1992, NJ 1993, 639 m.nt. MS (Lanser BV-Haarlemmermeer)

112,118

HR 18 december 1992, NJ 1994, 139 m.nt. MS en CJHB

(Kuunders-Stichting Natuur en Milieu)

HR 14 mei 1993, AB 1993, 503 m.nt. FHvdB

(Het Land Aruba-Playa Liquor \& Bottling Company NV)

HR 18 juni 1993, AB 1993, $504 \mathrm{~m}$.nt. FHvdB (St. Oedenrode-Van Aerle)

113,116

HR 1 juli 1993, NJ 1995, 150 m.nt. CJHB (Staat-Stichting NCB)

114,116

120

103

HR 15 juli 1993, NJ 1994, 524 m.nt. MS

102,106

HR 11 januari 1994, M en R 1994, aft.7/8, nr. 85 m.nt. Hendriks

246

HR 11 februari 1994, RvdW 1994, 47 (Geleen-S.)

25

HR 18 februari 1994, RvdW 1994, 58 (Staat-Kabayel)

HR 27 mei 1994, RvdW 1994, 121 (Sprangers-Staa)

HR 7 oktober 1994, AB 1996, 125 m.nt. Roozendaal (Staat-Van Benten)

$126-128,243,244$

HR 28 oktober 1994, NJ 1995, 139 m.nt. MS (Talma Rustoord-Friesland)

118

121

HR 21 maart 1995, NJ 1995, 694 m.nt. MS

103

HR 7 april 1995, AB 1995, 441 m.nt. Drupsteen (Smit-Staat)

123

HR 21 april 1995, NJ 1995, 437 (Kakkenberg-Kakkenberg)

123,124

HR 23 mei 1995, NJ 1995, 695 m.nt. MS

104

HR 2 juni 1995, AB 1995, 542 m.nt. Drupsteen

(Aharchi-Bedrijfsvereniging voor Tabak)

118

HR 6 juni 1995, NJ 1995, 696 ni.nt. MS

HR 20 juni 1995, DD 1995, 397

105

HR 27 juni 1995, NJ 1995, 722

107

HR 17 juli 1995, NJ 1995, 697 m.nt. MS

HR 8 september 1995, JB 1995/249 (Utrecht-Budinovski en Pejkovski)

125,244

HR 3 november 1995, JB 1996/20 m.nt. EvdL (Petronella BV-Rotterdam)

HR 8 december 1995, JB 1996/60 m.nt. EvdL.

(Bedrijfsvereniging Metalindustrie-Heijboer)

$\mathbb{1 2 0}$

HR 13 febuari 1996, DD 1996,206

105

HR 15 maart $1996, A B$ 1996, 234 m.nt. Drupsteen (Zuidhorn-Erven Staal) 
HR 27 marart 1996, JB $1996 / 124$ m.nt. HJS

HR 11 oktober 1996,JB 1996/241 m.nt. EvdL (Leenders BV-Ubbergen)

$213,241,246$

HR 15 november 1996, JB 1997/21 m.nt. EvdL (Kruit en Warrink-Zuidwolde)

HR 16 mei 1997, JB $1997 / 148$ m.nt. HJS (Dircks c.s.-Peters-Dircks)

125,126

HR 5 september 1997, RvdW 1997, 164 (vof Schut-Provincie Utrecht)

HR 19 juni 1998, NJB 1998/27, nr. 128C (Kaveka-Apeldoorm)

120,124

\section{Gerechtshof}

Hof Leeuwarden 22 februari 1984, NJ 1985,27

Hof 's-Hertogenbosch 7 maart 1984, Bouwrecht 1984, p. 834

Hof' 's-Gravenhage 23 februari 1989, NJ 1990, 595 (EKOM BV-Rotterdam)

\section{Rechtbank}

Rb. Dordrecht 28 januari 1966, NJ 1968, 156 (Heukelemse hinderwetovertreder)

Rb. Rotterdam 18 april 1994, JB $1994 / 118$

Rb. Assen 19 april 1994 , NJ 1995,36

(Stichting anti-vuilwerbranding Drenthe-Staat)

Rb. Utrecht 24 augustus 1994, JB 1995/3 m.nt. EwdL

$\mathrm{Rb}$. 's-Gravenhage 16 november 1994 , JB $1994 / 311 \mathrm{~m}$.nt. EvdL

Rb. "s-Hertogenbosch 23 november 1995 , JB $1996 / 28 \mathrm{~m}$.nt. EvdL en RS

Rb. Roermond 30 november $1995, J B 1996 / 4$ m.nt. EvdL

Rb. Breda 27 februari 1996, Nieuwsbrief Awb/Justex (ongepubliceerd)

Rb. Utrecht 10 mei $1996, J B 1996 / 195$ m.nt. EvdL

Rb. Rotterdam 27 mei 1997, JB 1997/185 m.nt. EvdL

Rb. Zutphen 19 december 1997 , JB $1998 / 45$ m.nt. EvdL

Pres. b. Utrecht 14 juni 1994, JB $1996 / 23$ m.nt. EvdL

Pres. rb. Amsterdarn 2 februari 1996, JB 1996/145 m. nt. EvdL

Pres. en rb. Den Haag 21 november 1997, JB $1997 / 292$ m.nt. EvdL

\section{CRvB}

CRvB 4 december 1987, AB 1988,298 m.nt. JHS 
CRvB 1 juni 1989, AB 1989, 436 m.nt. HH

CRvB 6 december 1990, AB 1991, $150 \mathrm{~m}$.nt. HH

CRvB 31 januari 1991, AB 1991, 291 m.nt. HH

CRvB 2 mei $1991, A B 1992,22$ m.nt. HH

CRvB 27 april 1992, AB 1992, 688 m.nt. HH

CRvB 14 mei 1992, AB 1992, $420 \mathrm{~m}$.nt. HH

94

CRvB 10 juni 1992, AB 1992,570 m.nit WASD

CRvB 2 maart 1993, AB 1993, 421

CRvB 21 april 1994, AB 1994, 476 m.nt. HH

CRvB 28 nowember 1995 , Gem.st. 7039 , nr. 7 en JB 1996/33

CRvB $\ 4$ mei 1996 , JB 1996/142 m.nt. EvdL

CRvB 26 juni 1997, JB 1997/219 m.nt. EvdL

\section{$\mathrm{ABR}$}

ABR 21 oktober 1996, JB 1996/232 m.nt. HJS

ABR 21 juli 1997, Gem.st. 7078, nr. 8 m.nt. J.M.H.F. Teunissen (Niedorp) 166

ABR 15 september 1997, JB 1997/252 m.nt. EvdL 162

ABR 15 januari 1998, JB 1998/36 m.nt. EvdL 40

ABR 15 jamuari 1998, JB $1998 / 51 \mathrm{~m}$.nt. EvdL 40

\section{ARRS}

ARRS 1 september 1977, AB 1977, 366 (Maastricht I)

$48,49,51-53$

ARRS 27 maart 1981, AB 1981, 323 (Maastricht II)

ARRS 11 december 1986, Gem.st. 6851, nr. 10 m.nt. J.M.H.F. Teunissen (Waalre) 46

ARRS 7 april 1990, AB 1991,122 m.nt. PvB $\quad 88$

ARRS 2 september 1991, AB 1992,77

ARRS 16 oktober 1992, AB 1993, 328 m.nt. PvB

\section{Vx ARRS}

Vz. ARRS 12 aktober 1990, AB 1991, 120 m.nt. PvB

Vz. ARRS 8 maart 1991, AB 1992, 167

Vz. ARRS 13 januari 1993, AB 1993, 236

\section{AGB}

AGB 20 december 1991, AB 1992, 294 m.nt. FM 90

AGB 8 april 1991, AB 1991, 426 m.nt. PJS 93

AGB 22 april 1993, AB 1993, 387 m.nt. FM 90 
CBB

CBB 16 maart 1990, AB 1990, 362

CBB 12 september 1990, AB 1991, 441

CBB 10 november 1994 , JB 1994/317

Vz. CBB

Vz. CBB 8 november 1990, AB 1991, 289

CBStufi

CBStufi 2 januari 1995, JB 1995/38

KB

KB 29 oktober 1969, Stb. 488, AB 1970, p. 43 (Nijmegen I)

KB 20 januari 1970, AB 1971, 153 (Nijmegen II) 51

KB 29 oktober 1975, no. 23, Stb. 600, Bouwrecht 1976, (p. 25), nr. 5 (Soest)

Gemeenschappelijk Hof van Justitie van de Nederlandse Antillen en Aruba

Gem HvJ NA en Aruba 21 september 1993, Burgerlijke Zaken 1993, no. 280 (hoofdistuk $5, \S 1$ ) 


\section{Trefwoordenregister}

autopoietische geslotenheid

'Bestandskraft";

$6.3 .2,7.4$

van 'Wet'

7.4 .6

van "Verwaltungstechtich Wertrag"

7.4 .7

bevoegdheidsbenadlering/bevoegdheidsdenken

burgerinke rechter:

bewoegdheid van de

ontwankelijkheid bij de

toetsing door de

ex tunc

erga omnes

elementair grondbegrip

feitelijke zijde van het recht

formele rechtskracht;

bestuursrechter

burgerlijke rechter

herkomst en oorsprong in Nederland

hoofdregel

strafrechter

toetsing

uitzondering op

groot project

hypercyclus;

recht als

materiele rechtskracht;

$4.2,6.2,6.3,10.2 .4,10.2 .7,11.6,11.7,12.7$

nomzigde van het recht

ontrafeling feit, norm en gevolg

h. $1,2.2 .4,2.3 .3,2.4 .3,3.2 .5,3.3 .2,3.4 .5$,

procesdenken/processuele benadering

rechtsaspect

rechbeschermingsbenadering/procesdenken 
rechtskracht;

administratieve rechter

besluit van algemene strekking (bas)

duur van de gelding

eigenschap

erkenning

feitelijke zijde

formele kant van

10.2 .3

geldingsvraagstuk

h. 8, h. 10

herkomst en oorsprong in Duitsland

"illusie"

kleren van de Keizer

$12.3,12.4,12.5$

materiële kant van

10.2 .4

middel

12.6

normzijide

rechtsbestendigheid

10.3

rechtsfeiten

rechtshandelingen

uitspraak

$6.3 .3,6.5,7.4,12.7$
7.4 .9

7.4 .8

7.4 .3

universeel element

verschillen

vonnis

"Rechuskraft"

reflexief recht

9.3 .1

repeterend besluit

"Sollen und Seim"

spectraal recht;

toetsing

verbandenlleer

toetsing;

abstract

11.5 .5

concreet

doelmatigheid

$11.5 .2,11.5 .4$

ex nunc

ex tunc

rechtmatigheid

transcendentaal;

h. 10

denkkritiek

uitwegvergunning 
wedlerkerige rechtsbetrekking

zelfproductie van het positieve recht

9.3 


\section{Curriculum vitae}

Eveline van der Linden werd geboren op 24 oktober 1964 te Heerlen waar zij ook het Bernardinuscollege bezocht. Vanaf 1982 doorliep zij de Nieuwe Lerarenopleiding in Sittard en behaalde zij onderwijsbevoegdheden voor de vakken Nederlands en Geschiedenis. In 1987 begon zij de opleiding Nederlands Recht aan de Maastrichtse Faculteit. In 1991 studeerde zij af. Vervolgens ging zij doceren aan het Instituut voor Staats- en Bestuursrecht van de Rijksuniversiteit Utrecht. Zij keerde in 1993 als aio terug naar haar eigen alma mater. $\mathrm{Zij}$ is actief in de vrouwenbeweging, onder andere als Centraal Bestuurder van de Vrouwenbond FNV. Thans is zij als universitair docent Staats- en Bestuursrecht verbonden aan de Vakgroep Publiekrecht van de Universiteit Maastricht. 